\title{
How India Clothed the World
}




\title{
Global Economic History Series
}

\author{
Series Editors \\ Maarten Prak, Utrecht University \\ Jan Luiten van Zanden, Utrecht University
}

\begin{abstract}
Editorial Board
Gareth Austin, Graduate Institute of International and Development Studies, Geneva

Şevket Pamuk, Boğazici University, Istanbul Kenneth L. Pomeranz, University of Chicago

Tirthankar Roy, London School of Economics and Political Science

Peer H.H. Vries, University of Vienna
\end{abstract}

VOLUME 4

The Titles published in this series are listed at brill.com/gehs 


\title{
How India Clothed the World
}

\section{The World of South Asian Textiles, 1500-1850}

\author{
Edited by \\ Giorgio Riello \\ Tirthankar Roy
}

With the collaboration of Om Prakash and Kaoru Sugihara

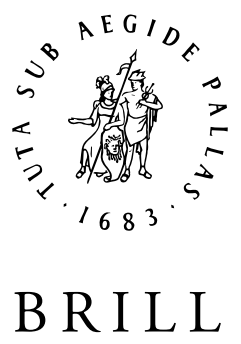


This is an open access title distributed under the terms of the CC BY-NC-ND 4.0 license, which permits any non-commercial use, distribution, and reproduction in any medium, provided no alterations are made and the original author(s) and source are credited. Further information and the complete license text can be found at https://creativecommons.org/licenses/by-nc-nd/4.0/

The terms of the cc license apply only to the original material. The use of material from other sources (indicated by a reference) such as diagrams, illustrations, photos and text samples may require further permission from the respective copyright holder. working with Knowledge Unlatched. More information about the initiative can be found at www.knowledgeunlatched.org.

Originally published in 2009 under ISBN 978-90-04-17653-9 (hardback). The paperback contains minor corrections.

Cover illustration: Cloth merchant seated in his shop selling to a costumer. Opaque watercolour, India, c. 1800. Reproduced by kind permission of the British Library.

This book is printed on acid-free paper.

Library of Congress Cataloging-in-Publication Data

How India clothed the world : the world of South Asian textiles, 1500-1850 / edited by Giorgio Riello, Tirthankar Roy, with the collaboration of Om Prakash and Kaoru Sugihara.

p. cm. -- (Global economic history series ; 4)

Includes bibliographical references and index.

ISBN 978-90-04-17653-9 (hardback : alk. paper) 1. Textile fabrics--India--History.

2. Textile industry--India. I. Riello, Giorgio. II. Roy, Tirthankar.

TS1403.H688 2009

$382 ' .4567700954--\mathrm{dc} 22$

2009022322

ISSN 1872-5155

ISBN 978-90-04-25531-9 (paperback)

ISBN 978-90-47-42997-5 (e-book)

Copyright 2009 by Giorgio Riello and Tirthankar Roy. Published by Koninklijke Brill NV, Leiden, The Netherlands.

Koninklijke Brill NV incorporates the imprints Brill, Hotei Publishing,

IDC Publishers, Martinus Nijhoff Publishers and VSP.

All rights reserved. No part of this publication may be reproduced, translated, stored in a retrieval system, or transmitted in any form or by any means, electronic, mechanical, photocopying, recording or otherwise, without prior written permission from the publisher.

Authorization to photocopy items for internal or personal use is granted by Koninklijke Brill NV provided that the appropriate fees are paid directly to The Copyright Clearance Center, 222 Rosewood Drive, Suite 910, Danvers, MA 01923, USA.

Fees are subject to change. 


\section{CONTENTS}

List of Figures and Maps ................................................................ ix

Colour Plates ......................................................................... xiii

List of Tables ......................................................................... xxix

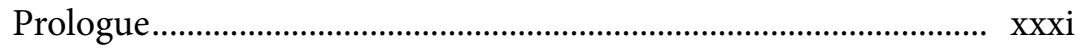

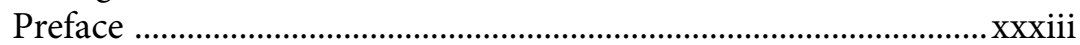

Introduction: The World of South Asian Textiles, 1500-1850 ..... $\quad 1$ Giorgio Riello and Tirthankar Roy

PART I

REGIONS OF EXCHANGE: TEXTILES IN THE INDIAN OCEAN AND BEYOND

Southeast Asian Consumption of Indian and British Cotton Cloth, 1600-1850 Anthony Reid

Cloths of a New Fashion: Indian Ocean Networks of Exchange and Cloth Zones of Contact in Africa and India in the Eighteenth and Nineteenth Centuries.

Pedro Machado

English versus Indian Cotton Textiles: The Impact of Imports on Cotton Textile Production in West Africa.

Joseph E. Inikori

British Exports of Raw Cotton from India to China during the Late Eighteenth and Early Nineteenth Centuries.

H. V. Bowen

The Resurgence of Intra-Asian Trade, 1800-1850

Kaoru Sugihara 
PART II

REGIONS OF PRODUCTION: TEXTILES IN SOUTH ASIA

The Textile Industry and the Economy of South India, 1500-1800

David Washbrook

Four Centuries of Decline? Understanding the Changing

Structure of the South Indian Textile Industry ......

Ian C. Wendt

From Market-Determined to Coercion-Based: Textile

Manufacturing in Eighteenth-Century Bengal

Om Prakash

The Political Economy of Textiles in Western India: Weavers, Merchants and the Transition to a Colonial Economy Lakshmi Subramanian

Competition and Control in the Market for Textiles:

Indian Weavers and the English East India Company in the

Eighteenth Century 281 Bishnupriya Gupta

PART III

REGIONS OF CHANGE: INDIAN TEXTILES AND EUROPEAN DEVELOPMENT

The Indian Apprenticeship: The Trade of Indian Textiles and the Making of European Cottons 309

Giorgio Riello

The French Connection: Indian Cottons and Their Early Modern Technology

George Bryan Souza

Fashioning Global Trade: Indian Textiles, Gender Meanings and European Consumers, 1500-1800

Beverly Lemire 
Quality, Cotton and the Global Luxury Trade

Maxine Berg

Historical Issues of Deindustrialization in

Nineteenth-Century South India

Prasannan Parthasarathi

Glossary

437

Bibliography

443

Notes on Contributors

473

Index

477 
$-978-90-47-42997-5$ 


\section{LIST OF FIGURES AND MAPS}

Colour plates of figures marked by an asterisk can be found on pp. xiii-xxviii

\section{Figures}

I.1. ${ }^{*}$ Chart of the Indian Ocean in a portolano

by Joan Martines of Messina, 1578

I.2. ${ }^{\star}$ Ceremonial cloth, produced in Gujarat in India

for export to the Indonesian market, c. 1470-1550

I.3. ${ }^{\star}$ Fort of St. George on the Coromandel Coast, Madras, mid-eighteenth century

1.1. ${ }^{*}$ Baju jacket tailored from Coromandel Coast cloth in Sumatra, late-eighteenth century

4.1. British imports of raw cotton into Canton from India, 1785-1833

5.1. Intra-Asian trade

5.2. India's exports, $1750-1850$.

5.3. India's imports, $1750-1850$

5.4. India's exports to China, 1813-50

5.5. The opium triangle, 1840

5.6. Intra-Asian trade, 1840

5.7. Trade of Bengal, 1811

5.8. Trade of Bengal, 1840

5.9. Trade of Bombay, 1811

5.10. Trade of Bombay, 1840

5.11. Trade of Madras, 1811

5.12. Trade of Madras, 1840

5.13. Trade of Penang-Singapore, 1828

5.14. Trade of Singapore, 1840

5.15. Imports and exports of cotton goods of India, 1834-41

7.1. ${ }^{\star}$ Two women ginning cotton; man carding cotton, opaque watercolour. India, 1850-60.

9.1. Indian Weaver, engraving from Pierre Sonnerat's Voyage aux Indes Orientales (1782) 
10.1. Regional textile prices, $1664-1764$...................................... 290

10.2. Prices of longcloth at Cuddalore, 1698-1786 ..................... 290

10.3. Textile prices in Coromandel, 1674-1752 ......................... 291

10.4. Prices of different varieties of textiles in Bengal, 1753-1800

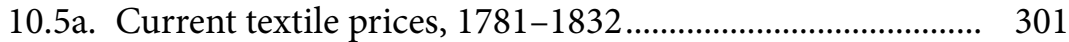

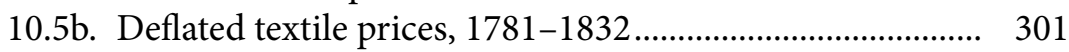

10.6. Textile prices in Amsterdam, 1642-1783 ........................... 302

10.7. The EIC and the market for textiles

A. Monopsony B. Perfect competition

11.1. ${ }^{\star}$ Cotton coverlet embroidered in Hufley, India for the European market, c. 1600

11.2. Textiles imported from Asia into Europe by the EIC and VOC, 1665-1834

11.3. Cotton textiles as percentage of all commodities traded by the VOC (1700-1789) and the EIC (1665-1834)

11.4. Typology of cotton cloth imported by the EIC, 1630-1759

11.5. ${ }^{\star}$ Resist- and mordant-dyed furnishing(?) cotton fabric produced in the Coromandel Coast, c. 1715-25 338

11.6. ${ }^{*}$ Palampore produced on the Coromandel Coast of India, c. 1740

11.7. ${ }^{\star}$ Motif of a cotton banyan produced on the Coromandel Coast, c. 1750-75.

11.8. Indian chintz, painted cotton, produced on the Coromandel Coast, c. 1730 .

11.9. ${ }^{*}$ Block-printed cotton textile, printed possibly in England or the Netherlands, c. 1690-1700

11.10.*"Livre d'Echantillons", second half of the eighteenth century

11.11. Cotton and linen prices in London, 1660-1760 .

$12.1{ }^{\star} \mathrm{A}$ dyer dipping cloth in a red dye. From the manuscript of 'Tashrih al-aqvam', India, early-nineteenth century.......

13.1. *"Hommes en Robe de Chambre" in Nicholas Bonnart, Recueil des modes de la cour de France (Paris, 1676).

13.2. "Magazin des Robes de Chambre" ....................................... 380

13.3. ${ }^{\star}$ Banyan

13.4. ${ }^{\star}$ A portrait of Brook Taylor, painted by Louis

Goupy, c. 1720 . 
14.1. ${ }^{*}$ Dye recipe book with printed cotton samples, $1824 \ldots \ldots \ldots \ldots . \quad 413$

15.1. Trade in yarn and cloth, Madras Presidency, 1855-82 ...... 431

$$
\text { Maps }
$$

I.1. The Indian Ocean in the early modern period

1.1. The eastern part of the Indian Ocean and Southeast Asia in the early modern period

2.1. The western part of the Indian Ocean in the early modern period

3.1. Western Africa in the sixteenth to eighteenth centuries

3.2. Interregional trade routes linking the Gold Coast to the Savannah Interior

5.1. India, Southeast Asia and China, 1784-1826 142

9.1. Western India in the eighteenth century 256 
$-978-90-47-42997-5$ 


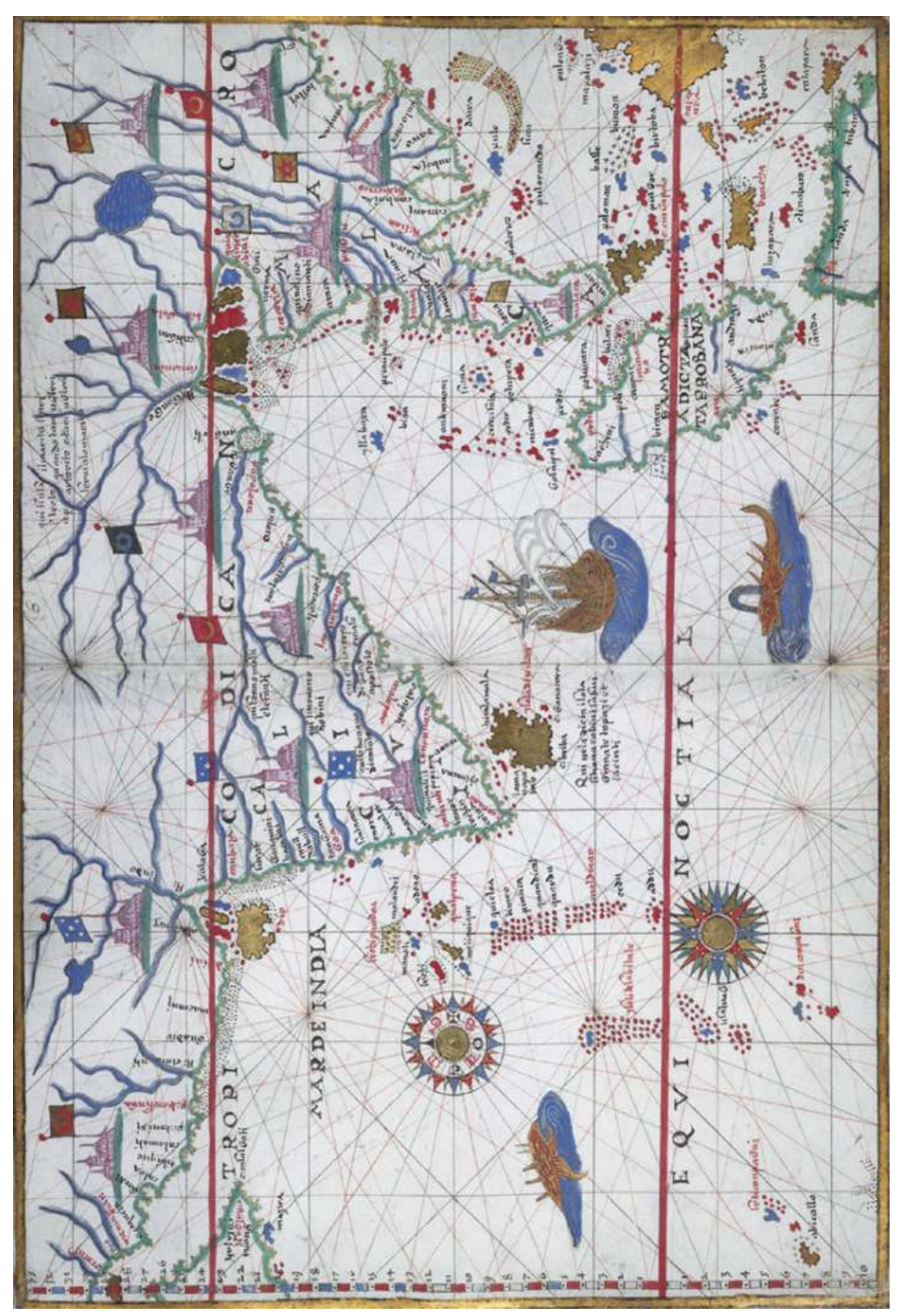

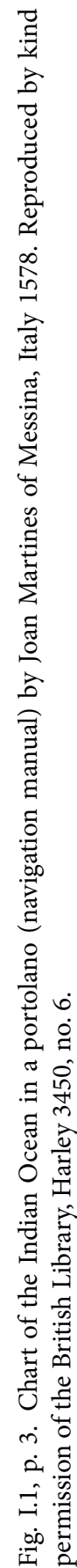



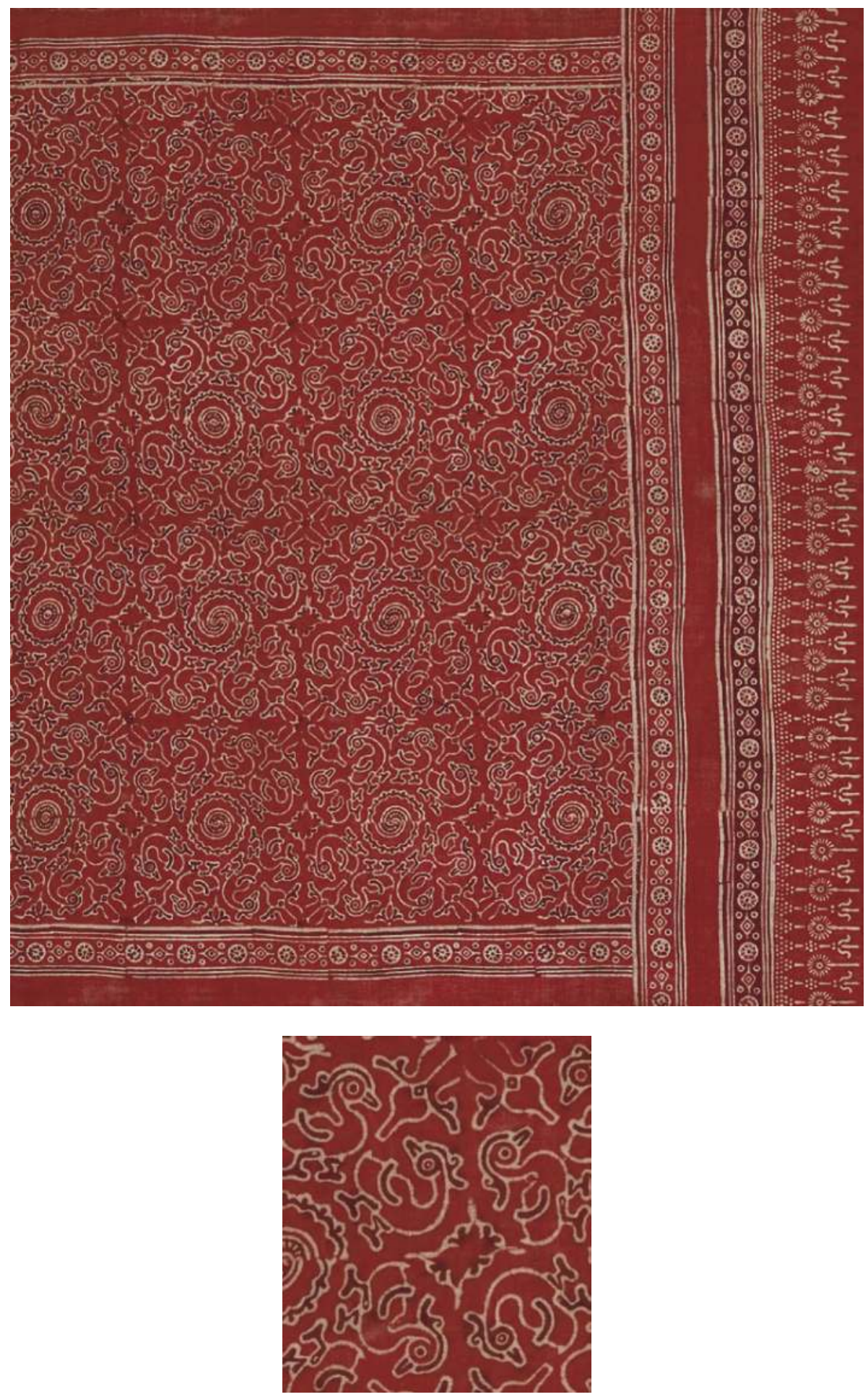

Fig. I.2, p. 5. Cotton, block-printed mordant-dyed ceremonial cloth, produced in Gujarat in India for export to the Indonesian market, c. 1470-1550. Victoria and Albert Museum, IS.94-1993. 


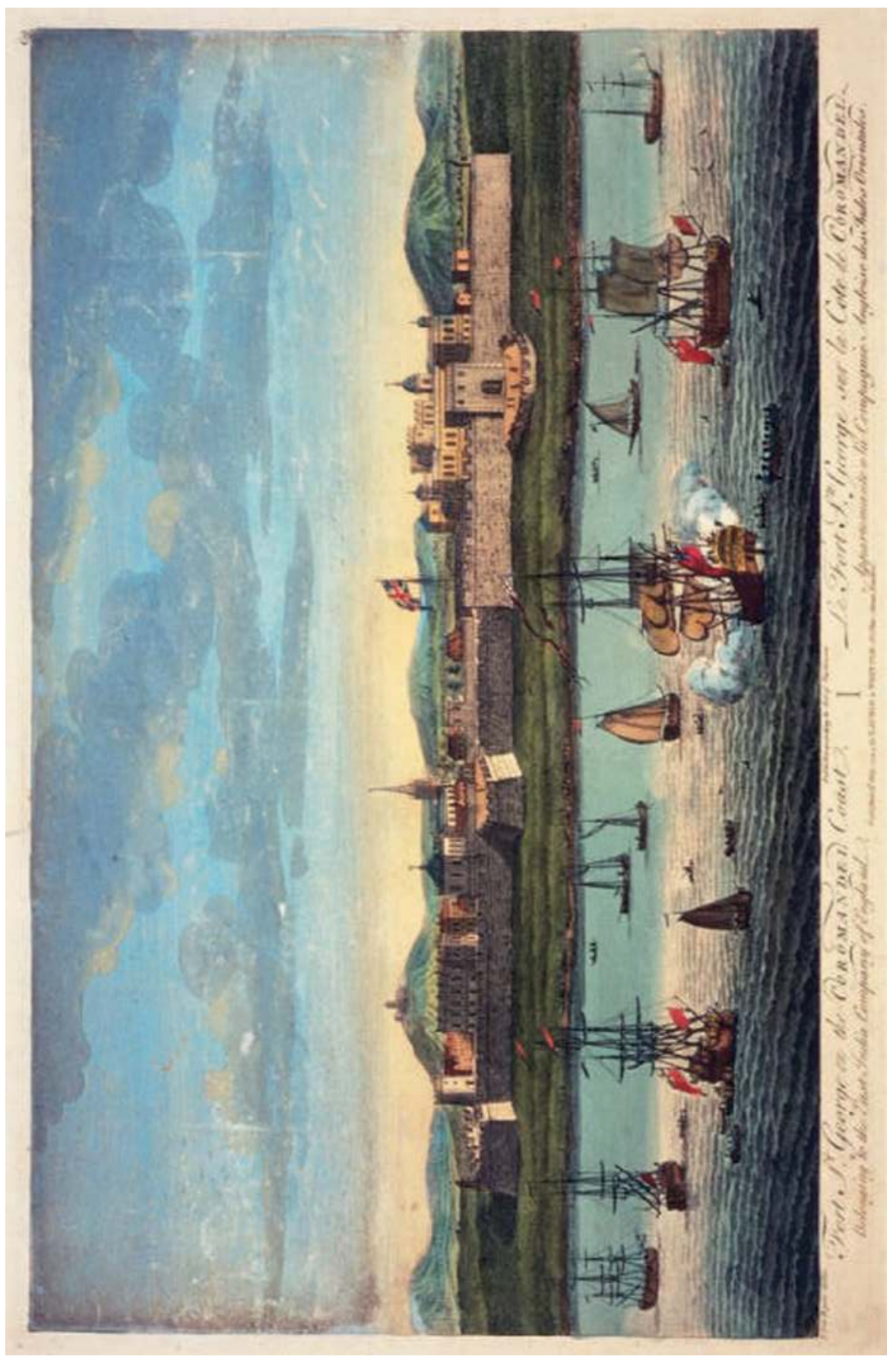

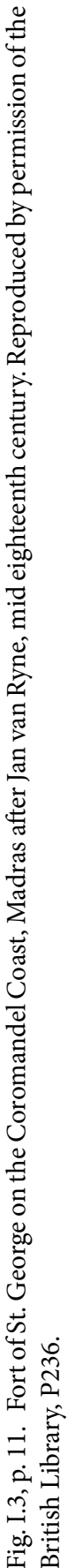



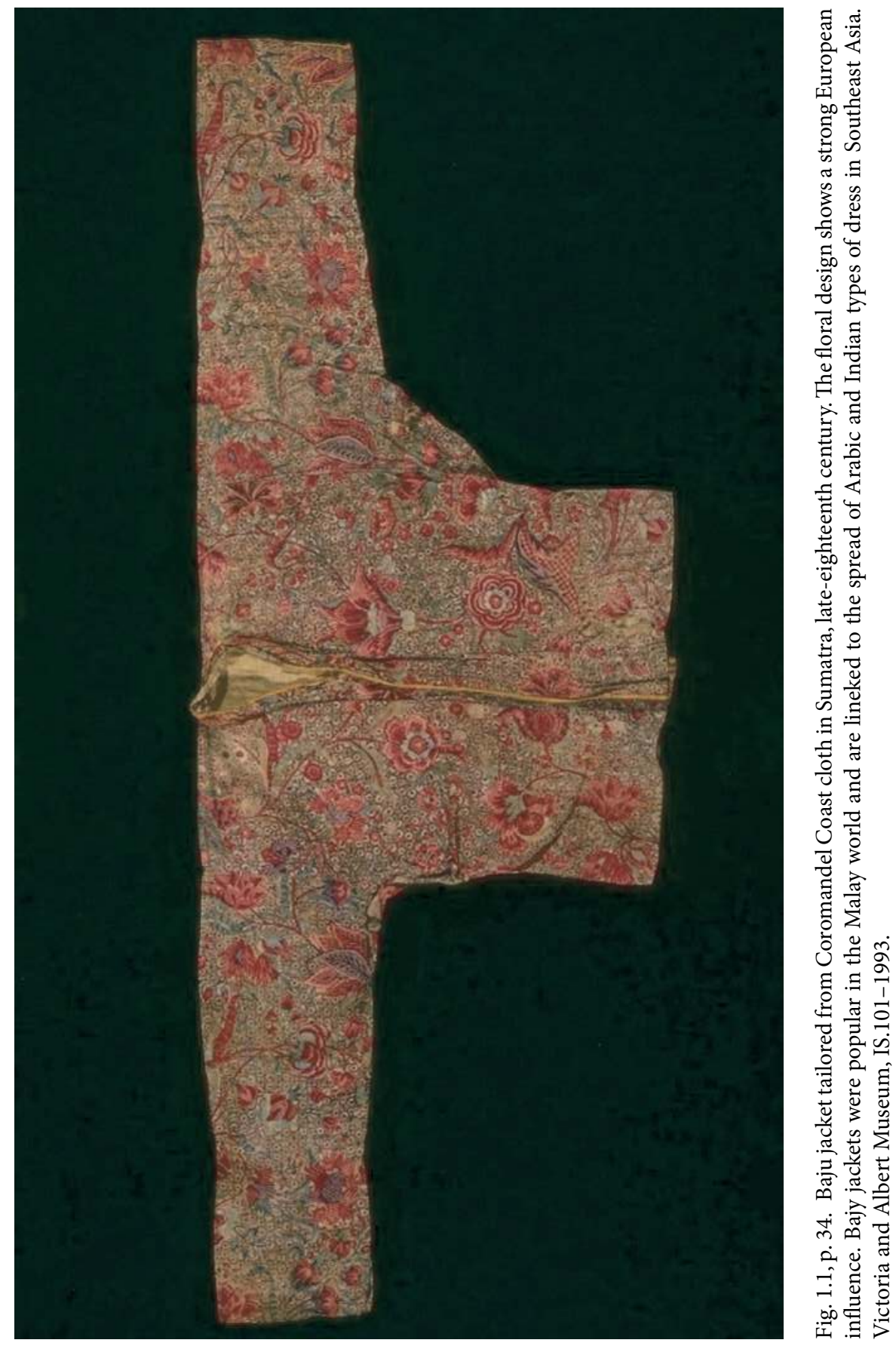


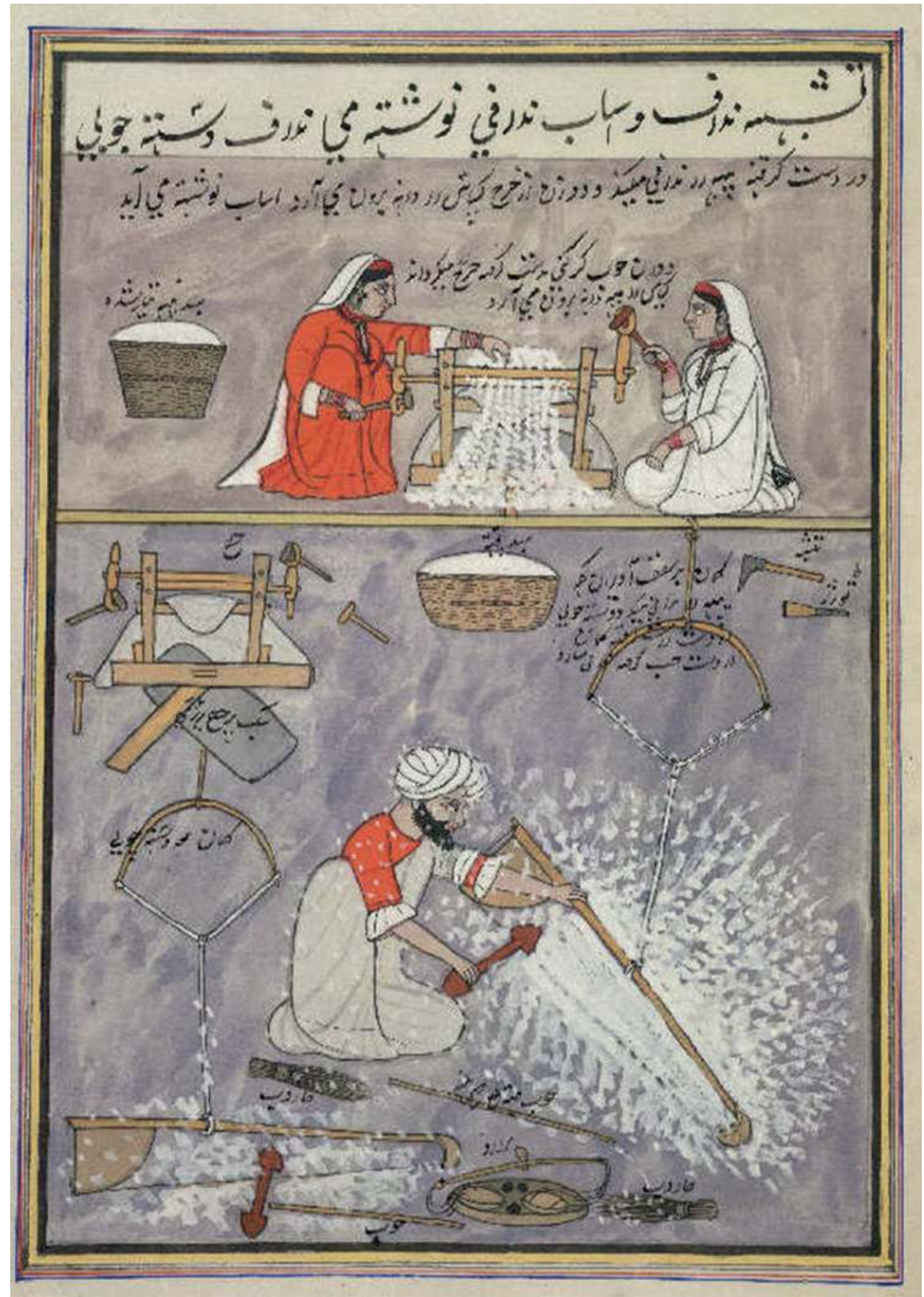

Fig. 7.1, p. 207. Two women ginning cotton; man carding cotton, opaque watercolour. India, 185060. Reproduced by kind permission of the British Library. 


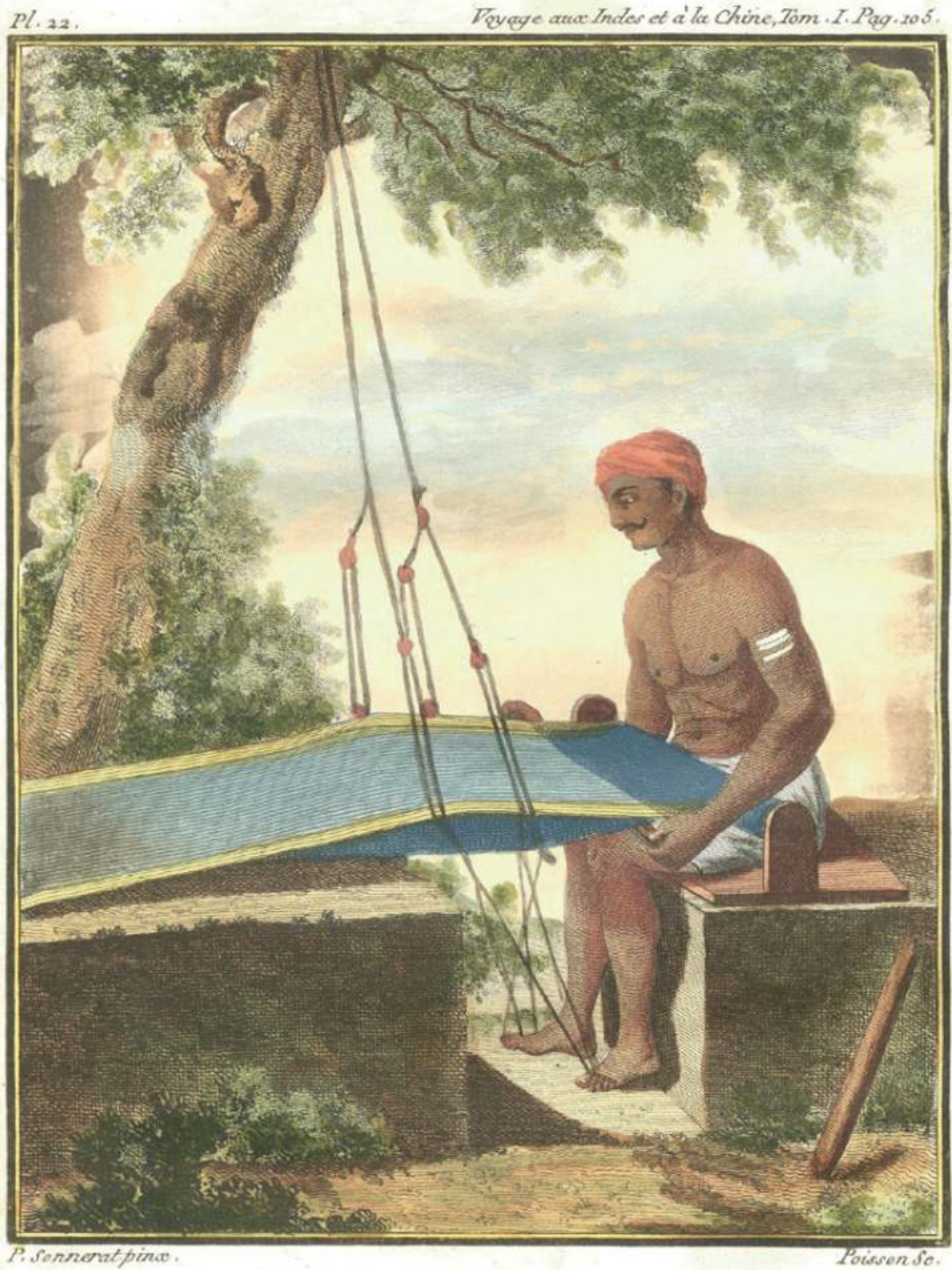

TISSERAN

Fig. 9.1, p. 258. Indian Weaver, engraving from Pierre Sonnerat's Voyage aux Indes Orientales et a la Chine, fait par ordre du roi, depuis 1774, jusqu'en 1781 (1782). 

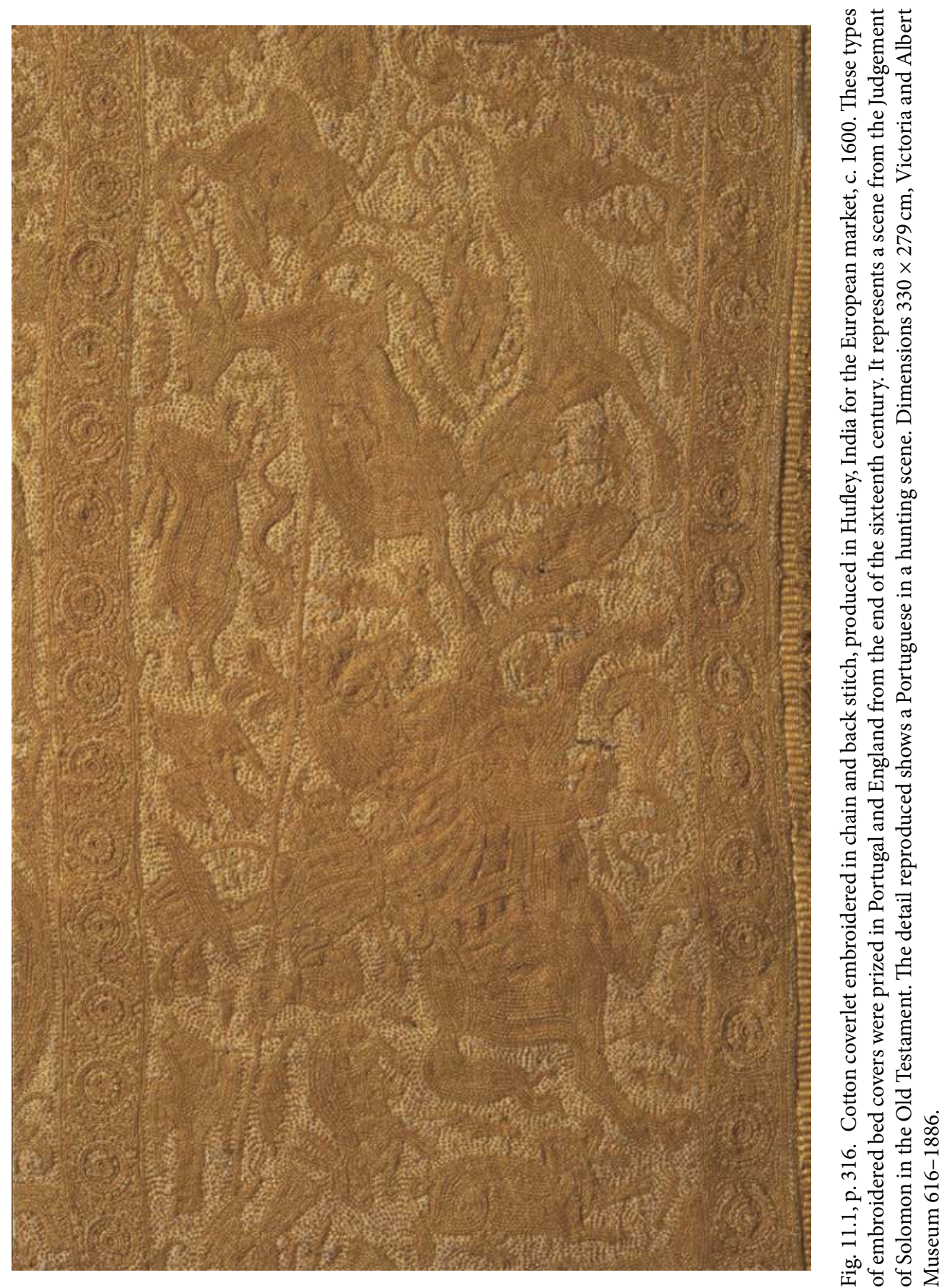


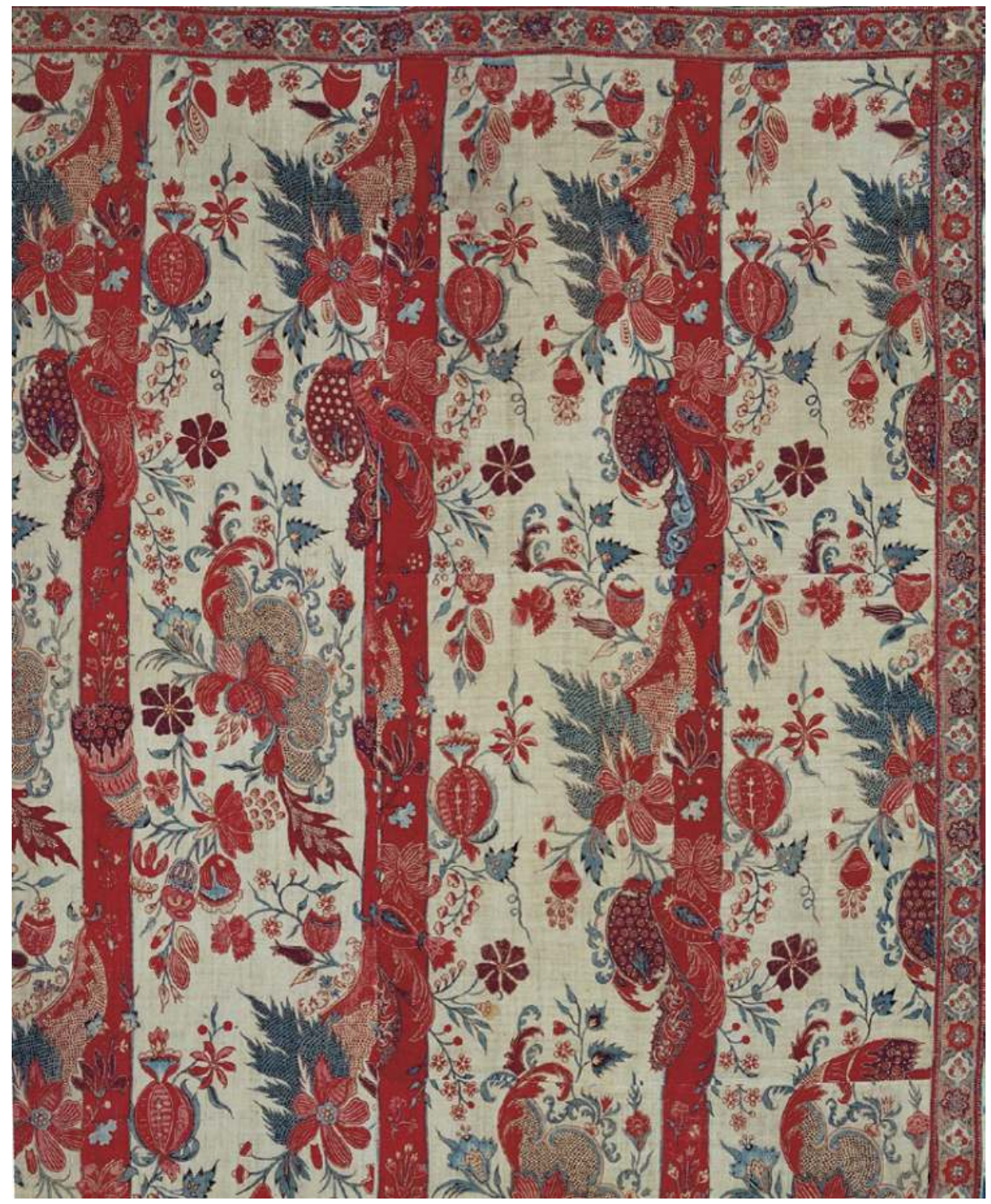

Fig. 11.5, p. 338. Resist- and mordant-dyed furnishing(?) cotton fabric produced in the Coromandel Coast, c. 1715-25. The motif is strongly influenced by French woven silks popular at the time, especially 'bizarre' silks with linear designs, fruit and exotic objects. Dimensions $218 \times 148 \mathrm{~cm}$. Victoria and Albert Museum, 342.B.1898. 


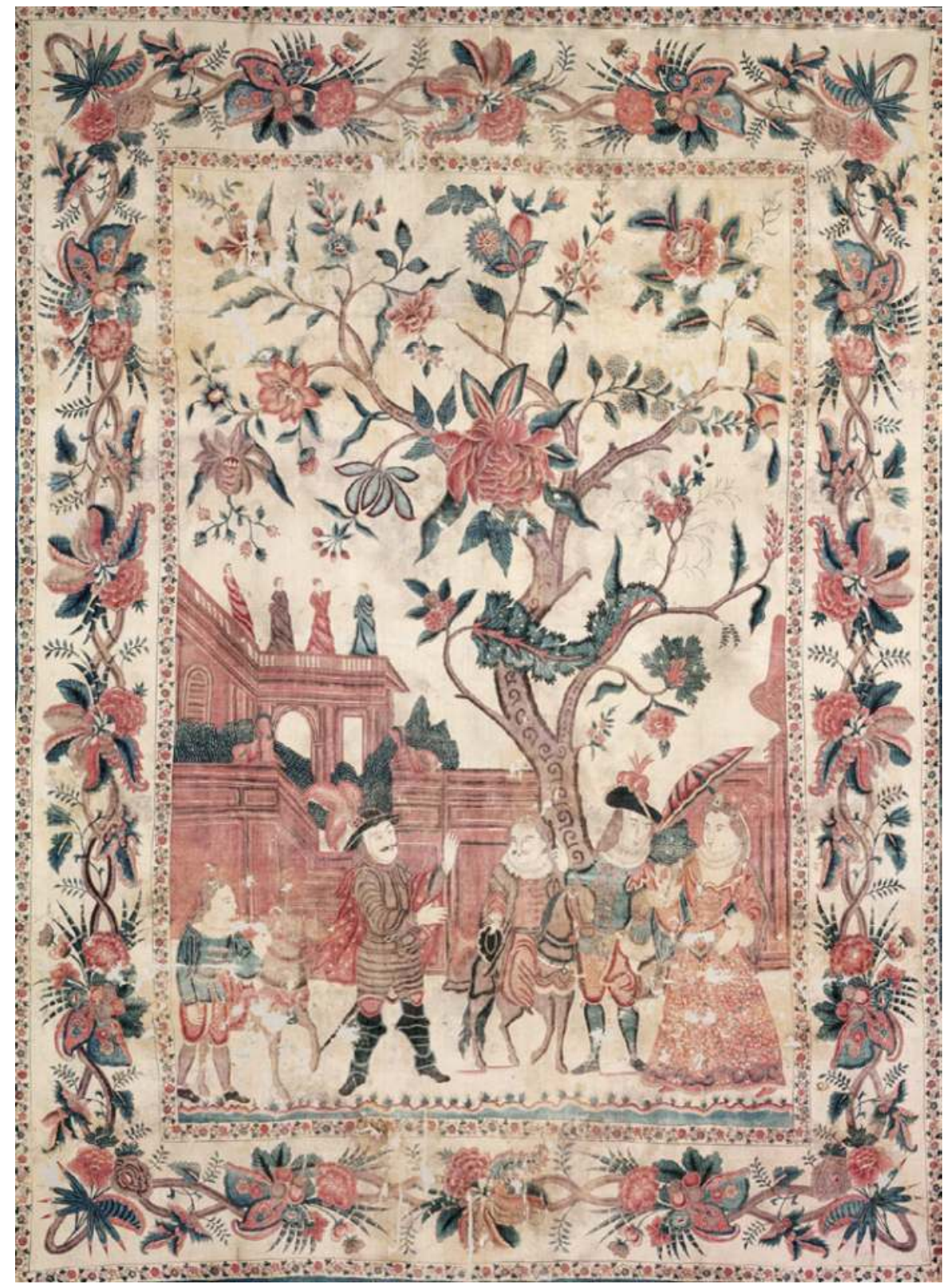

Fig. 11.6, p. 339. Palampore produced on the Coromandel Coast of India, c. 1740. Victoria and Albert Museum, IS.118-1950. The design is based on a print by J. B. H. Bonnart illustrating an episode from Don Quixote. The tree in the original print has been transformed into the exotic flowering tree typical of export chintzes of the period. 


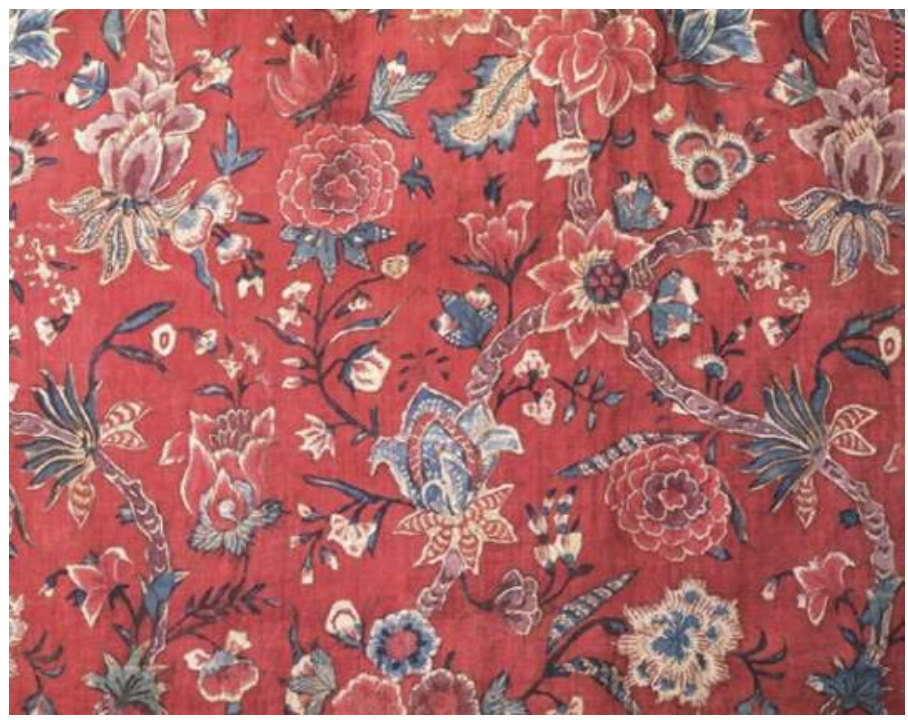

Fig. 11.7, p. 340. Motif of a cotton banyan. Red background. Cotton, painted and dyed, with printed cotton lining produced on the Coromandel Coast, c. 1750-75. Victoria and Albert Museum, T.215-1992. Although the motif suggests that the cloth was produced for the European market and the garment was in all probability tailored in the Netherlands or in England, dark red backgrounds were not particularly popular in Europe, although they might have been see as appropriate for men's garments.

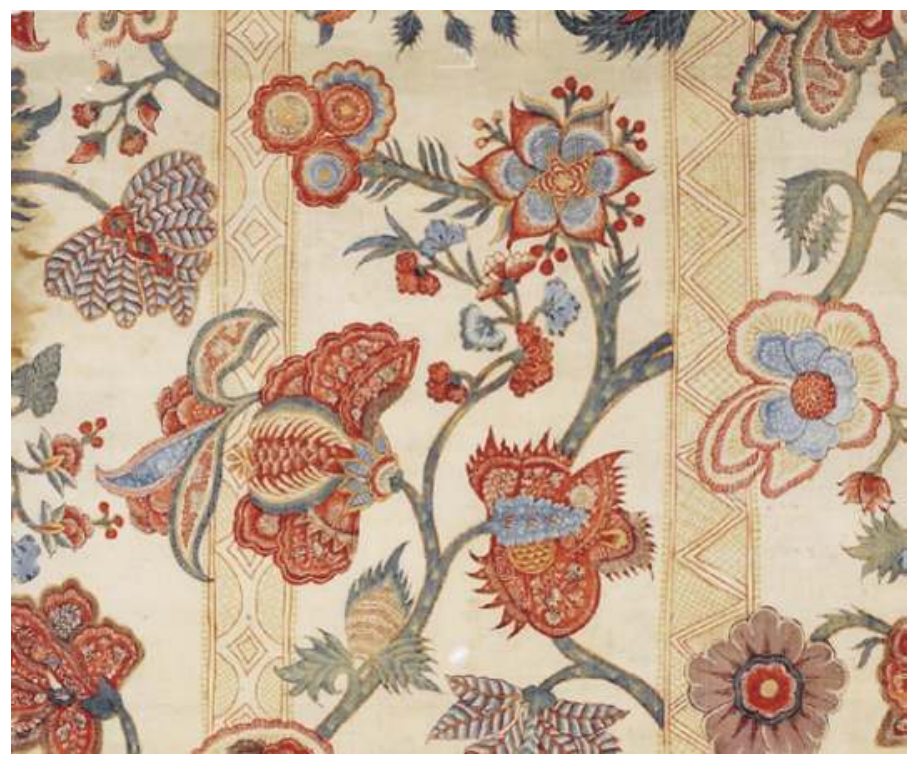

Fig. 11.8, p. 341. Indian chintz, painted cotton, for the European market with light background. Produced on the Coromandel Coast, c. 1730. Courtesy of the Musée de l'Impression sur l'Etoffe, Mulhouse, 858.141.1. 


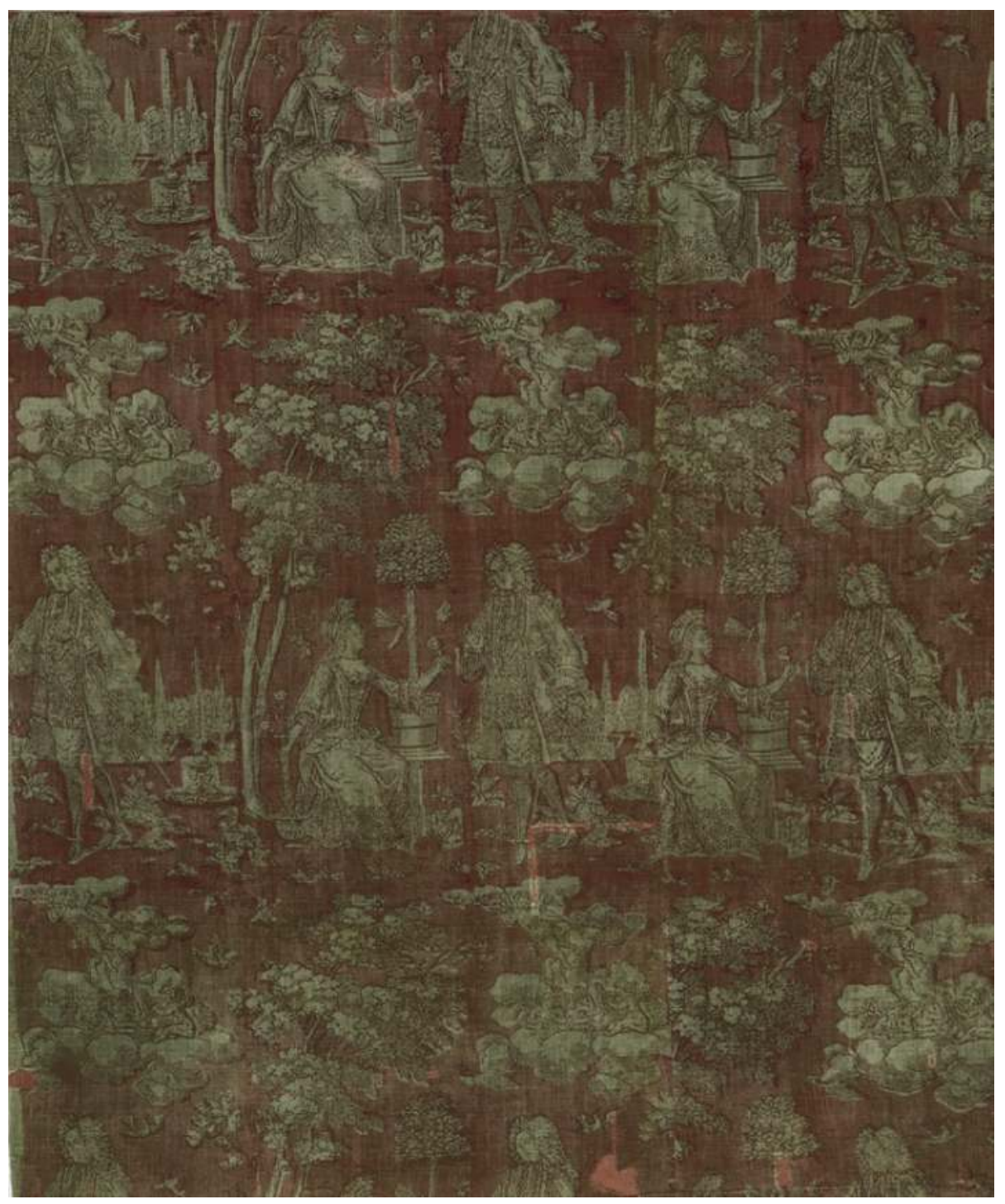

Fig. 11.9, p. 342. Block-printed cotton textile, printed possibly in England or the Netherlands, c. 1690-1700. The white cotton cloth was in all probability imported by the VOC or the EIC and printed by the newly-established European cotton printing industry. One can notice the low level of precision in the print and the use of a dark red background. Dimensions: $99.5 \times 82 \mathrm{~cm}$. Victoria and Albert Museum, T.12.1884. 


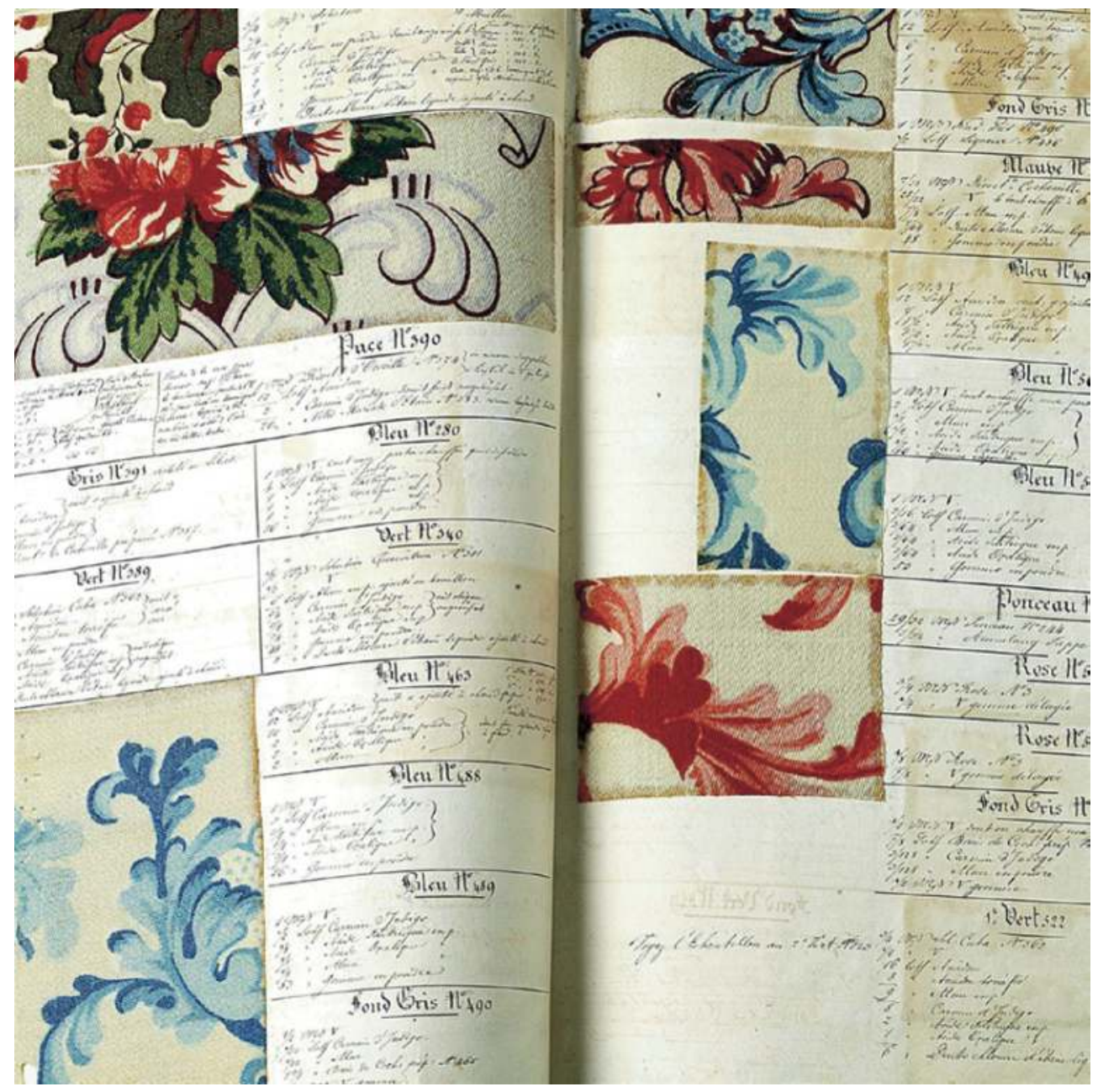

Fig. 11.10, p. 343. "Livre d'Echantillons" showing the variety of textiles produced by a French cotton printing firm in the second half of the eighteenth century, including blue design on white background and polychrome printing. The qualitative difference with the types of cottons produced three generations earlier (illustration 12.6) is evident. Courtesy of the Musée de l'Impression sur l'Etoffe, Mulhouse, Archive. 


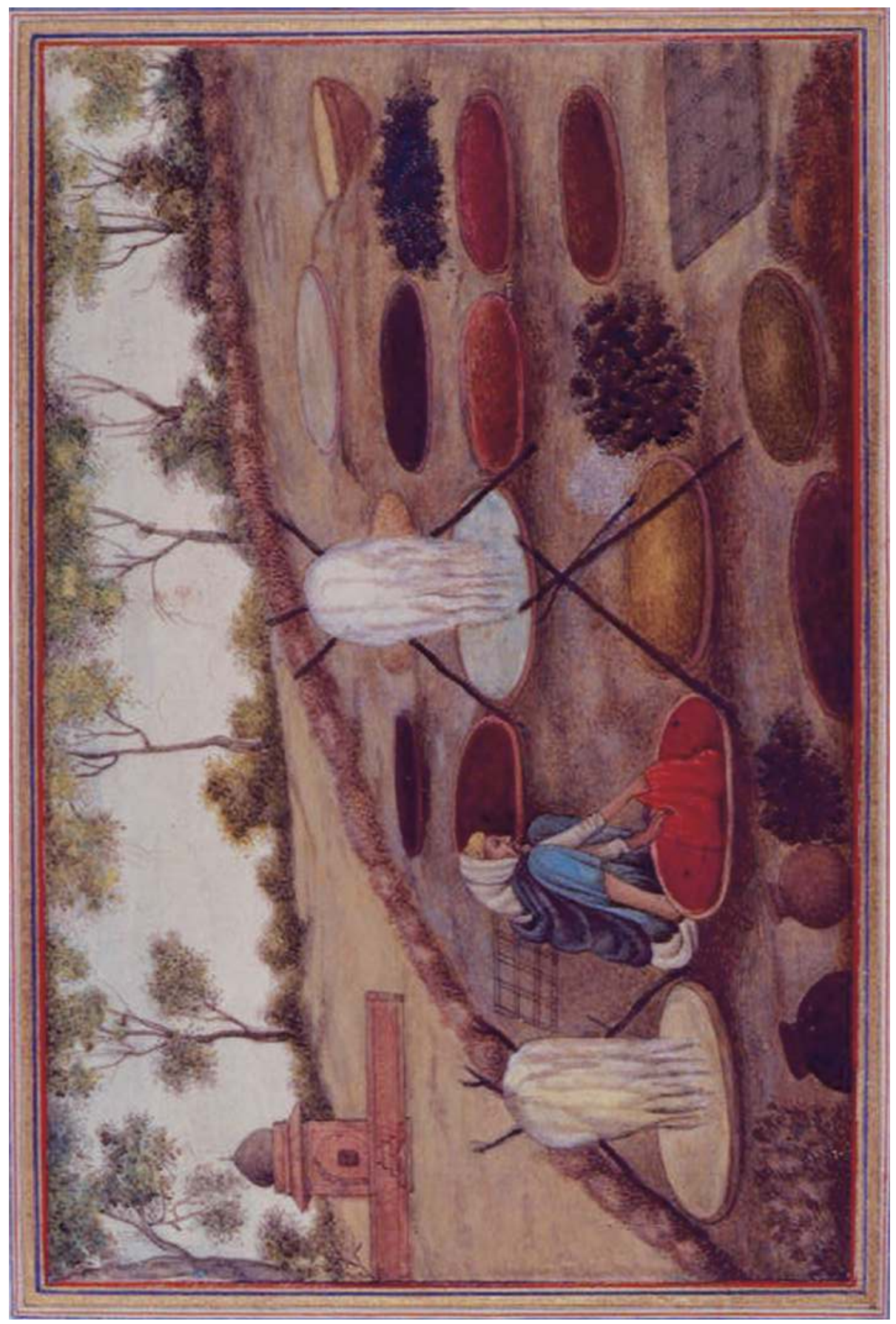

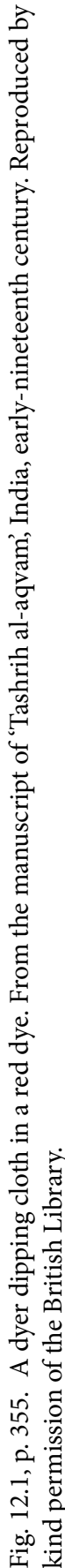




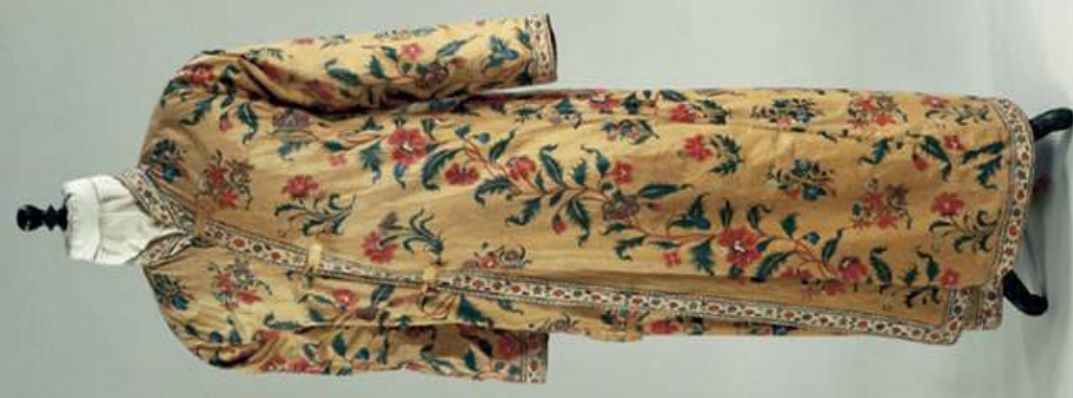

年

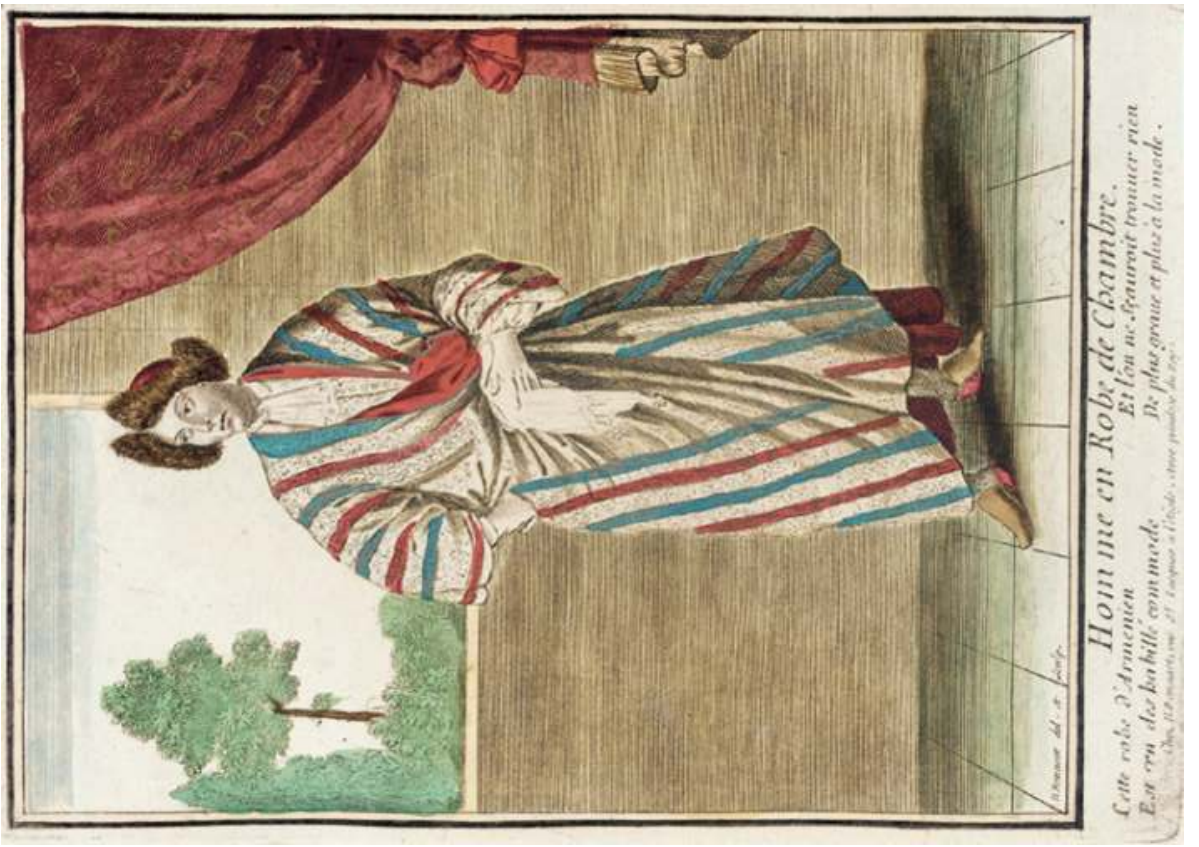

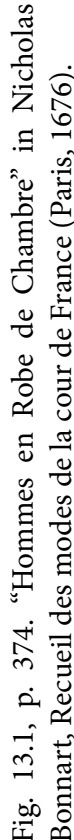




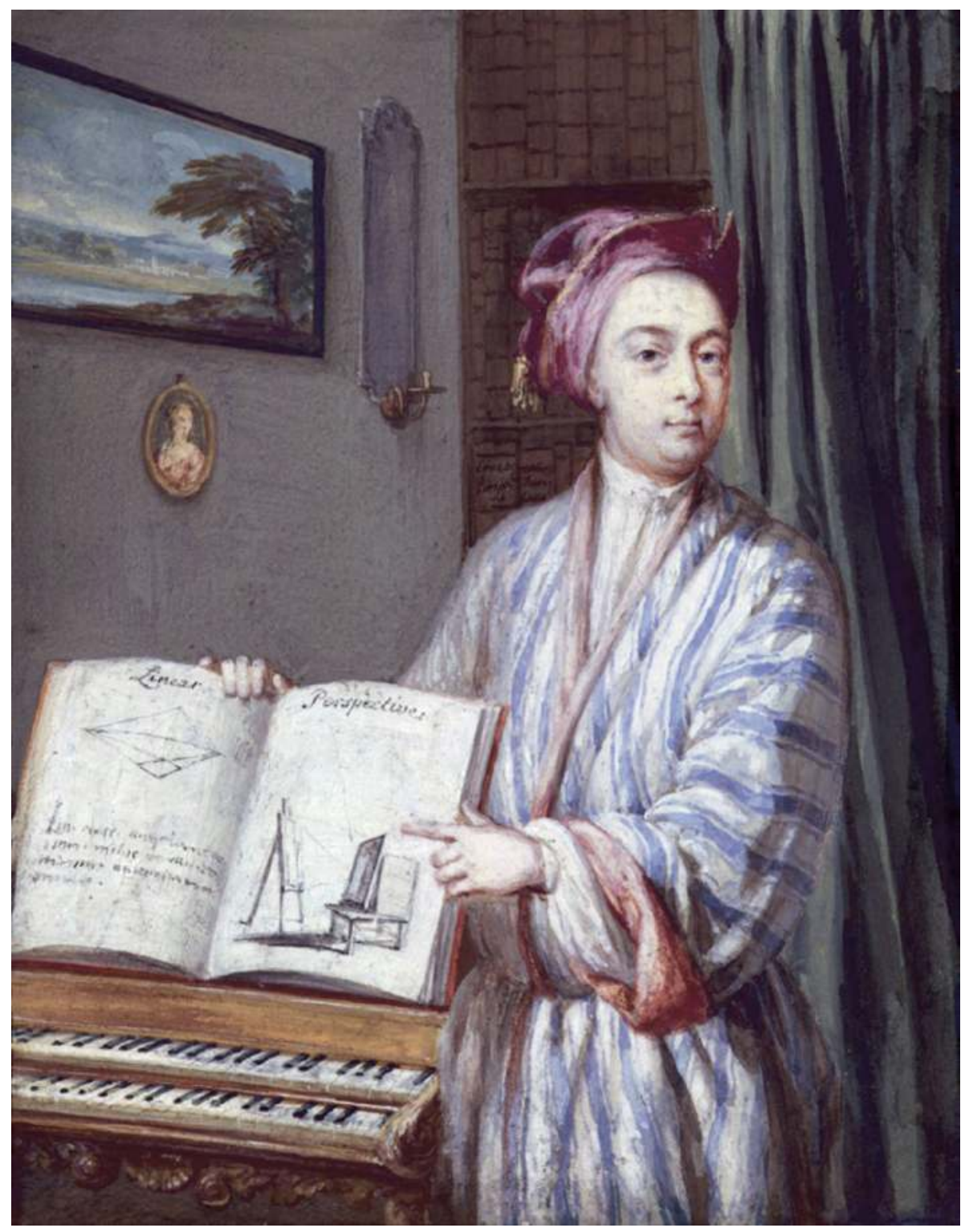

Fig. 13.4, p. 388. A portrait of Brook Taylor, mathematician wearing a blue and white striped (cotton?) banyan, lined with pink fabric. Painted by Louis Goupy, c. 1720. National Portrait Gallery, London NPG 1920. 


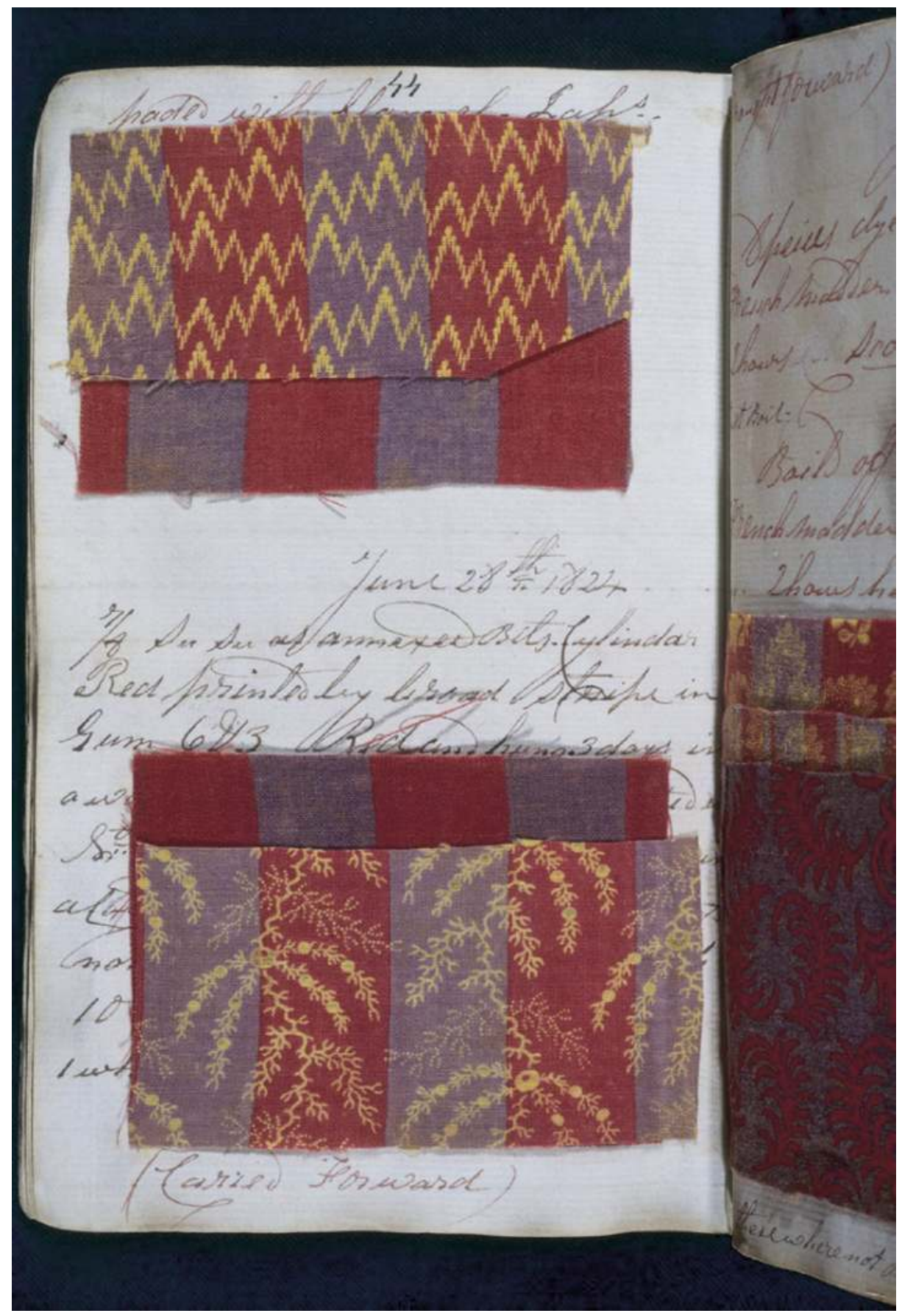

Fig. 14.1, p. 413. Dye recipe book with printed cotton samples. Probably Henry Fielding Bros., 1824. Books like this show the attention given to colouring agents and desing in the production of cottons. Victoria and Albert Museum, T.12-1956. 


\section{LIST OF TABLES}

1.1. Southeast Asian textile imports from India, 1500-1829 ..... 35

1.2. Value of European and Indian cloth exports from Singapore to Southeast Asia (Malay Archipelago, Siam and Cochin-China), 1828-66

1.3. Growth of European cloth exports through Singapore to selected Southeast Asian markets, 1823-66 ...................... 48

3.1. Imports from Britain into the Bight of Biafra, 1661-93 ...... 102

3.2. Imports from Britain into the Bight of Biafra, 1701-90 ...... 103

3.3. Imports from Britain into the Bights of Benin and Biafra, 1828-50

3.4. Competing exports of English and Indian cottons to Western Africa, 1751-1850

3.5. Official and declared values of British cotton textiles imported from Britain into the African coast, 1827-49

3.6. Direct barter exchange of imported goods for 73 captives sold by the Bonny Trader, Allison, to a British slave ship in 1791-92

5.1. Regional composition of exports from major Asian ports, 1840

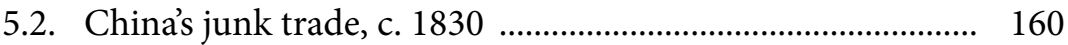

5.3. Commodity composition of Singapore's trade, $1840 \ldots \ldots \ldots . . . . .162$

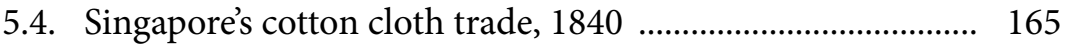

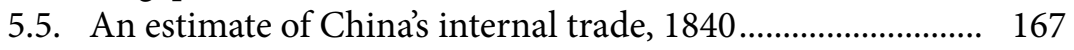

7.1. The structure of the early modern South Indian textile industry, 1650-1800

7.2. Summary of the structure of the early modern South Indian textile industry.

7.3. Labour, income and gender in textile-producing households in early modern South India

8.1. Textiles manufactured in the Aurungs of Haripal and Dhaniakhali, 1767.

8.2. Breakdown of the cost of specific varieties of Bengal textiles manufactured in the Aurungs of Haripal and Dhaniakhali, 1767. 
8.3. Time taken to weave one piece of textile per loom at the Haripal and Dhaniakhali aurungs, 1767.

8.4. Number of looms at work in the aurungs of Chandrakona etc., 1767

8.5. Textiles contracted for by the English East India Company together with their prices at the aurungs of Chandrakona, Khirpai and Radhanagar etc., 1767

8.6. Distribution of English East India Company contracts at Chandrakona etc. among different paikars, 1767 .

10.1. Percentage shares of different categories of textiles traded by the Dutch and English East India Companies, 1730-59

10.2a. Indian exports of textiles to Europe by the VOC and EIC, 1665-1759

10.2b. Indian exports of cotton textiles, 1790-1859.

10.3. A comparative statement of the profit and loss on the following goods sold at outcry the 15 May 1776.

10.4. Difference in company's price and the price acceptable to the weaver.

11.1. Types of cotton textiles imported into Europe by the EIC, 1660-1759

15.1. Earnings in the mid-eighteenth century Britain, South India and Bengal

15.2. Daily grain wages in eighteenth-century South India ..... 421

15.3. Comparative prices of English and Indian cotton yarns, 1812 and 1830

15.4. Weaving costs for longcloth at Ingeram, 1790

15.5. Spinning and weaving costs for longcloth at Vizagapatnam, 1790.

15.6. Cloth and yarn trade in South India (Madras Presidency), 1855-1882 (in rupees). 


\section{PROLOGUE}

The task of a Prologue for a collection of fine scholarly essays on 'The World of South Asian Textiles, 1500-1850' is first to refer briefly to the multilayered contexts that gave rise to their publication. Secondly it should signal their wider significance and deeper meaning for readers who are neither specialists on the history of South Asia, nor familiar with the case (so convincingly and eloquently advanced by this academic enterprise) for representing the production, sale and consumption of Indian cotton textiles as a prime example and paradigm for the study of the long-run development of industries and industrialization on a global scale.

The key word in the book's title is 'World', which signifies that the authors of its interrelated chapters and the convenors of the conference at Pune where they were originally presented are collaborators in an intellectual project to restore global perspectives for the study of history as that discipline is currently pursued at universities in every part of the world.

Historians recognize that the leitmotif of our times, accelerated globalization, has been intensively analysed by their a-historical colleagues in the social sciences. Many are becoming aware of a demand and an intellectual need to bring historical perspectives and methods into current academic and wider political debates concerned with the range and significance of the challenges flowing from globalization for the welfare of humanity as a whole. They have been proselytizing to a conservative profession bunkered in national archives or pursuing selfreferential postmodern agendas to re-orient their research and teaching to reveal the long histories of transcontinental geopolitical, cultural and economic connexions and thereby expose the significance of the global in the local and the local in the global to enable reflexion and further analysis.

This collection does just that and meets all the criteria for scholarly history. It engages with a familiar and traditional metanarrative concerned with material progress, specified here as the question of when, where and why did economic divergence between the occident and the orient occur, by proceeding to investigate why a famous transnational industry, cotton textiles, diffused and relocated its centre of production from east to west. 
The editors and authors are to be congratulated for participating in an all too rare endeavour in academic collaboration, remaining aware of the metanarrative that they were all addressing in their individual ways, while continuing to respect the need for evidence and intellectual rigour that are the hallmarks of modern histories written with greater facility to deal with events and problems that are confined in scale, scope and chronology.

Logistically speaking credit and appreciation for the publication of this innovative exercise in collaborative history on this scale must be gratefully accorded to the Trustees of the Leverhulme Foundation who in 2003 funded a three programme of conferences, visiting fellowships and research designed to address the foundational metanarrative for global economic history namely Adam Smith's famous problem about the wealth and poverty of nations. That programme or network in global economic history (GEHN) involved academics trained in 5 disciplines from 46 universities across Eurasia who had embraced the aspiration to construct economic histories that dealt with problems of material life, progress and decline upon a global scale.

The editors and Brill are to be congratulated for publishing the second of GEHN's volumes of contributions to a field of history that is now gathering momentum and confidence. Several more are scheduled to follow and will aptly be published in Chinese as well as English.

Patrick O'Brien, Centennial Professor of Economic History at the London School of Economics and Convenor of the Network in Global Economic History (2003-2006). 


\section{PREFACE}

This book is a product of the Global Economic History Network (GEHN), an international partnership of scholars, centred at the London School of Economics from 2003 to 2007, and funded by the Leverhulme Trust. The GEHN, established to 'promote research, teaching and co-operation in the innovatory and rising field of global economic history', sponsored a series of international conferences and workshops on themes that lend themselves to long chronological and wide geographical perspectives. Not surprisingly, three of these conferences addressed textile history, cloth being a particularly good window into circulation over time and in geographical space of goods, skills, knowledge, consumption, and capital. A common theme through these colloquia was the important role that the South Asia region had played throughout history in the making of these global exchanges.

Several of the essays in this volume were first presented at the GEHN conference held in Pune, India, in December 2005 which dealt largely but not exclusively with the Indian Ocean trade and regions around the Indian Ocean. These were complemented by papers presented at other GEHN conferences held in Padua, Italy, and at the Fondation des Treilles in Aix-en-Provence.

At the outset we would like to thank Patrick O'Brien for his intellectual leadership throughout the duration of GEHN, and especially for his contribution to the organization and planning of the Pune workshop. Tracy Keefe, who supervised GEHN administration in London, played an important part in the organization of the conference and made a challenging task easy for the local hosts. We would also like to thank all participants in the workshop who contributed to what turned out to be a hugely stimulating and energetic conversation, especially, Gareth Austin, Willaim Clarence-Smith, Dennis Flynn, Kayoko Fujita, Sakis Gekas, Neeraj Hatekar, Douglas Haynes, Hui Kian Kwee, Ruby Maloni, Nobuko Nagasaki, Jan Parmentier, Indrajit Ray, and Harriet Zurndorfer.

Former students of Gokhale Institute of Politics and Economics provided crucial logistical support. We would like to mention and thank Vijay Bhumre, S. Chandrasekhar, Debopam Chaudhuri, Rajesh Danane, S. Darshan, Aparajita Das, Milind Desai, Amrita Gangatrikar, Nachiket 
Gosavi, Vibha Iyer, Ravi Kiran, Abodh Kumar, Chandan Kumar, Divya Kumar, Sandeep Kumar, James Lama, Madhurima Malladeb, Sanjay, and especially, Niranjana Sreenivasan and Shaista Dhanda.

The completion of this volume would have been impossible without the valid assistance of Richard Butler, Andrew Littlejohns, Loraine Long and Raffaella Masé. We would also like to thank the Leverhulme Trust, the Pasold Research Fund, the University of Warwick, and the Global History and Culture Centre at the University of Warwick for supporting the publication of this volume.

In an informal exchange, Gareth Austin described the scope of the workshop in words that appear as the title of the present volume.

Giorgio Riello and Tirthankar Roy May 2009 


\title{
INTRODUCTION: THE WORLD OF SOUTH ASIAN TEXTILES, 1500-1850
}

\author{
Giorgio Riello and Tirthankar Roy ${ }^{1}$
}

\section{Indian Textiles, Indian Ocean and the World Economy}

In 1500 cotton textiles were the centre of the manufacturing life of the Indian subcontinent and the foundation of a wide-ranging trade that spread from India via land and sea to as far as Indonesia and Japan in the east and Saudi Arabia, Ethiopia, Egypt and West Africa in the west (Map I.1). ${ }^{2}$ Various types of textiles, and in particular cotton textiles, were traded by Indian merchants in exchange for a variety of commodities ranging from spices and foodstuffs to specie and luxuries. The regions of Gujarat in western India, Coromandel in its southern part and later Bengal in the east were among the most thriving centres of manufacturing within a well articulated system of exchange.

Europeans could just marvel at the scale, sophistication and articulation of such trade. John Huyghen van Linschoten noted in his Voyage to the East Indies (1598) a "great traffique into Bengala, Pegu, Sian, and Malacca, and also to India", adding that "there is excellent faire linnen of Cotton made in Negapatan, Saint Thomas, and Masulepatan, of all colours, and woven with divers sorts of loome workes and figures, verie fine and cunningly wrought, which is much worne in India, and better esteemed then silke, for that is higher prised than silke, because of the finenes and cunning workmanship".

\footnotetext{
${ }^{1}$ We would like to thank Maxine Berg, Patrick O’Brien and Prasannan Parthasarathi for their comments and suggestions. Any remaining errors are ours.

${ }^{2}$ For a comprehensive overview of trade in the Indian Ocean before the colonial period see Om Prakash, The New Cambridge History of India; Vol. II.5. European Commercial Enterprise in Pre-colonial India (Cambridge: Cambridge University Press, 1998), in particular ch. 1.

${ }^{3}$ John H. van Linschoten, The Voyage of John Huyghen van Linschoten to the East Indies: from the old English translation of 1598, ed. Arthur Coke Burnell and P. A. Tiele (London: Hakluyt Society, 1885), vol. 1, p. 91. By India Linschoten intends Goa and the Malabar Coast.
} 


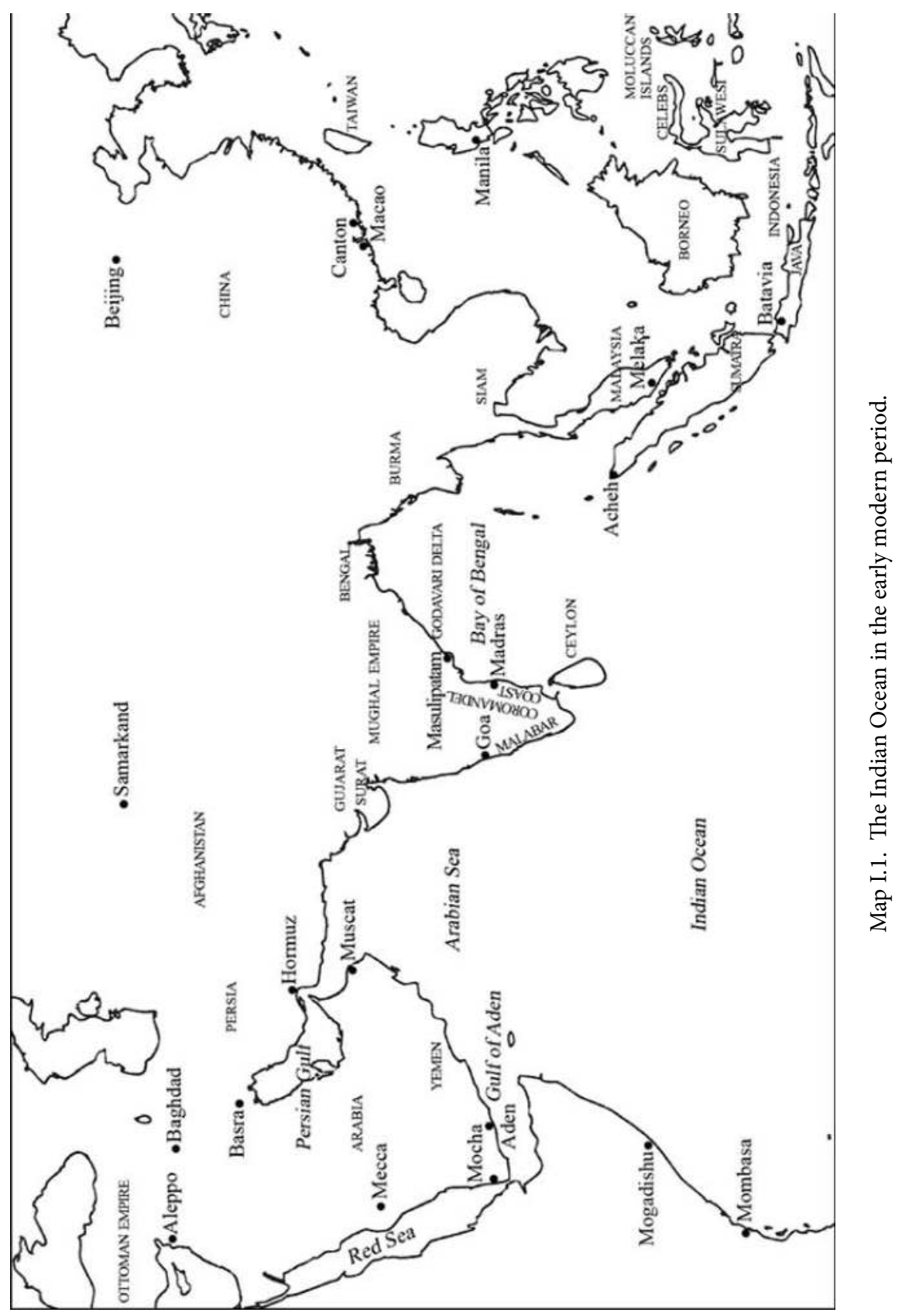




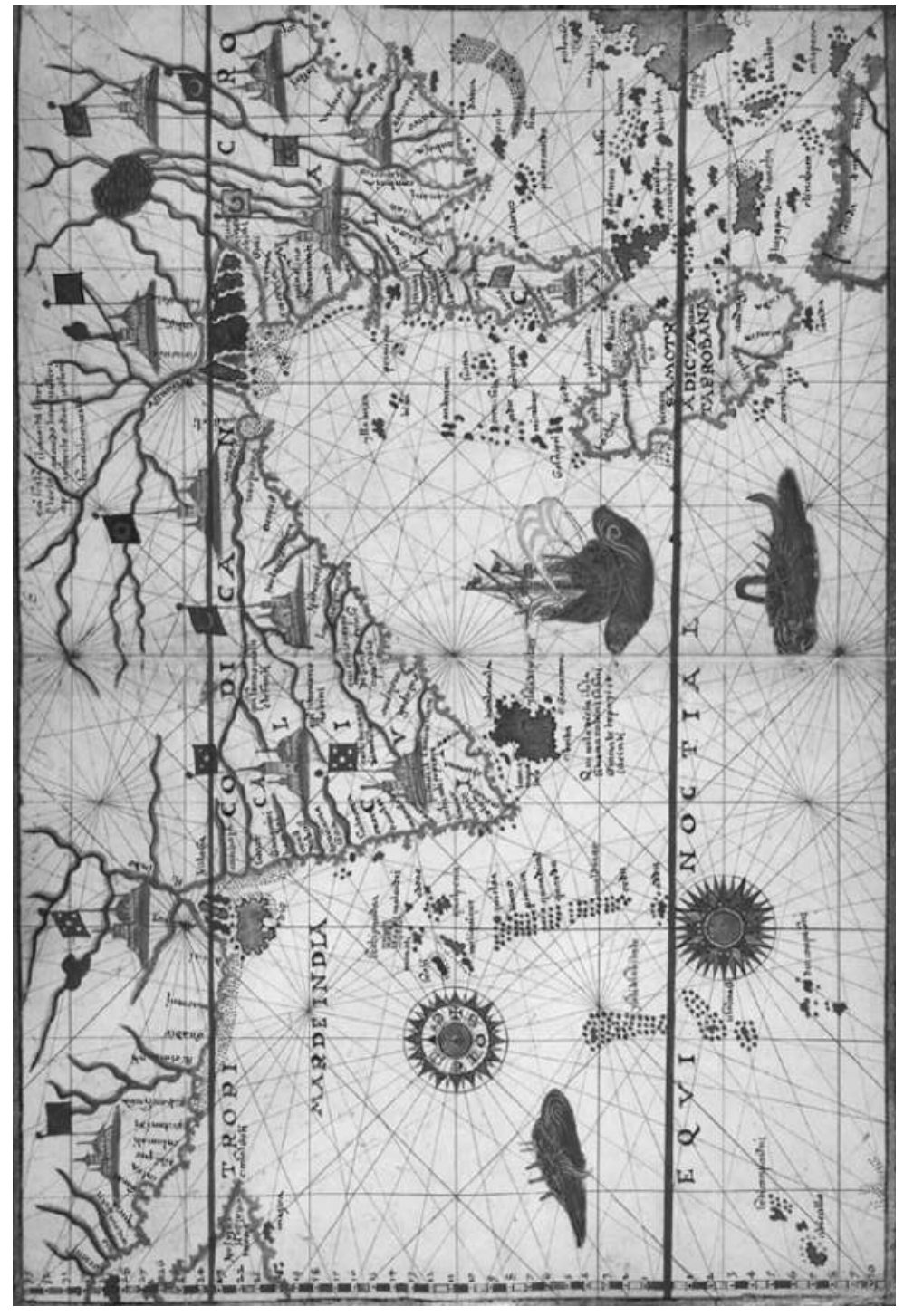

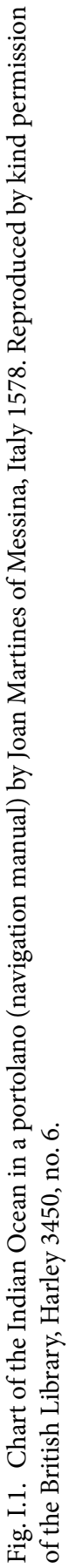


The complexity and the high degree of penetration of Indian cotton textiles in the consumer economies of most countries facing the Indian Ocean can be fully understood by considering the artefact-based analysis carried out in recent years by Ruth Barnes at the Ashmolean Museum, Oxford. Her research has uncovered Indian textiles in fourteenth-century Egypt similar in design to Indian cottons found in Southeast Asia (Fig. I.1). ${ }^{4}$ Such textiles were traded directly by Indian merchants, or through intermediaries and reached parts of Eurasia little known to Indians. By the early seventeenth century great quantities of textiles were sold regularly in Bandar Addas by Indian merchants and moved via land and sea to Persia, Baghdad and Basra where they changed hands again and reached Constantinople via Syria. ${ }^{5}$ The caravan trade carried Indian textiles to Ethiopia, especially cheap striped textiles, along with silver and gold, and embroidered luxury cloth as regal gifts. ${ }^{6}$ As early as the fourteenth century, East Africa exchanged primary products for Asian manufactured goods, cottons, other fine textiles, beads, copperware, Islamic earthenware, glass and Chinese porcelain. ${ }^{7}$ Considerable quantities of Asian textiles also arrived in Congo as luxury cloths designed in rich and colourful ways. ${ }^{8}$

Southeast Asia was another key market for Indian textiles. When Portuguese traders arrived in the area in the early sixteenth century, Gujarati merchants dominated the trade with Melaka from the port of Cambay. Commercial links between South Asia and Southeast Asia were so strong that according to the Portuguese Tomé Pires, Melaka could not "live without Cambay, nor Cambay without Malacca". 9 Melaka

\footnotetext{
${ }^{4}$ Ruth Barnes, Indian Block-Printed Textiles in Egypt. The Newberry Collection in the Ashmolean Museum, Oxford (Oxford: Clarendon Press, 1997), pp. 8-9.

${ }^{5}$ William Foster (ed.), The English Factories in India. A Calendar of Documents in the India Office, British Museum and Public Record Office. (Oxford: Oxford University Press, 1906-27), vol. 4, pp. 124-25. See also R.W. Ferrier, "The Trade between India and the Persian Gulf and the East India Company in the 17th Century", Bengal Past and Present, 89, 1 (1970), pp. 189-98.

${ }^{6}$ Shri Pramod Sangar, "Export of Indian textiles to Middle East and Africa in the Seventeenth Century", Journal of Historical Research, 17, 1 (1974), p. 5.

7 Neville H. Chittick, "East African Trade with the Orient", in Donald S. Richards, (ed.), Islam and the Trade of Asia. A Colloquium (Oxford: Bruno Cassirer, 1970), p. 103.

${ }^{8}$ John Thornton, Africa and Africans in the Making of the Atlantic World, 1400-1680 (Cambridge: Cambridge University Press, 1992), pp. 49 and 51.

9 Tomé Pires, The Suma Oriental of Tome Pires: An Account of the East, from the Red Sea to Japan, written in Malacca and India in 1512-15, ed. Armando Cortesao (London: The Hakluyt Society, 1944), vol. 1, p. 45.
} 


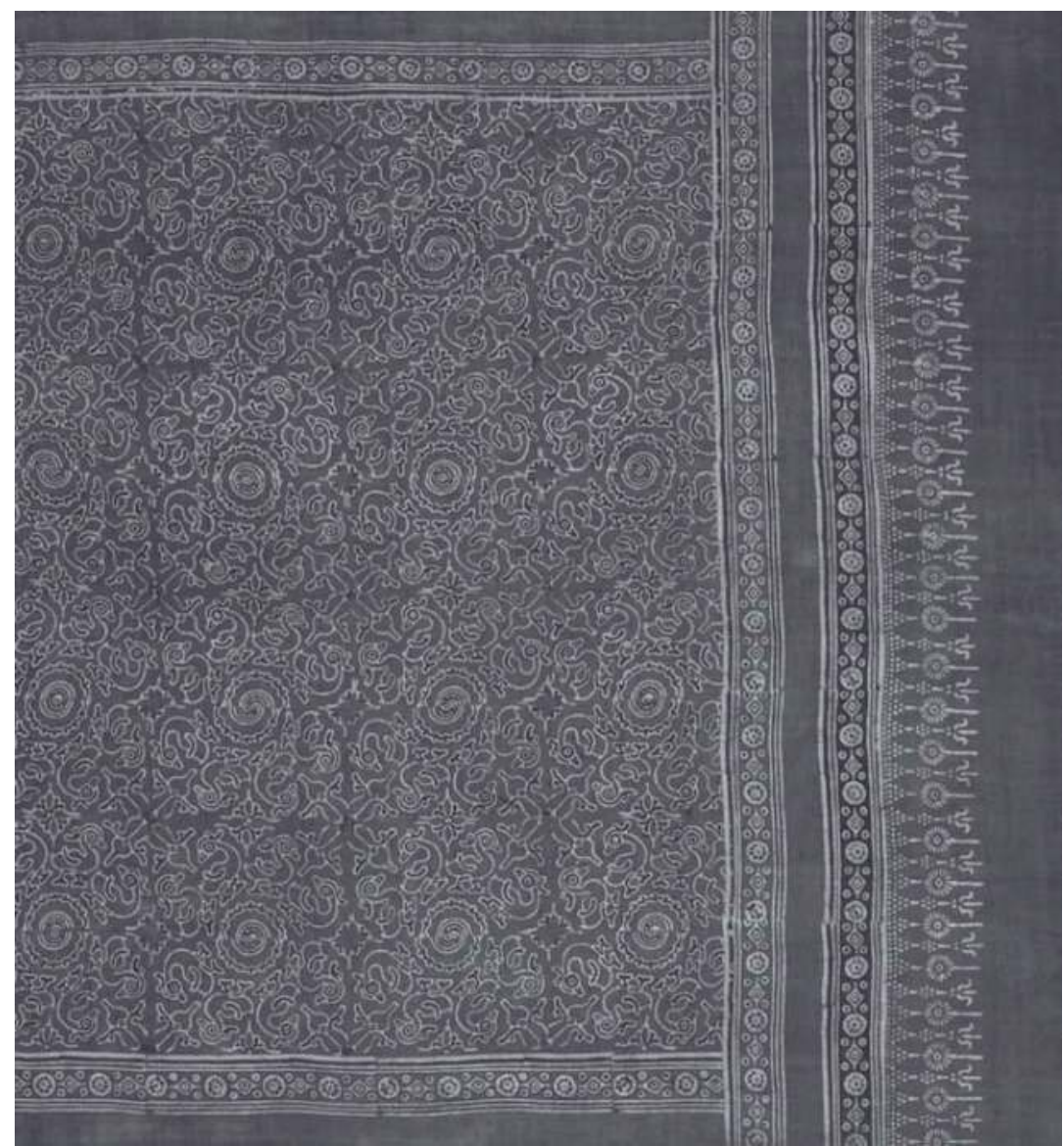

Fig. I.2. Cotton, block-printed mordant-dyed ceremonial cloth, produced in Gujarat in India for export to the Indonesian market, c. 1470-1550. Victoria and Albert Museum, IS.94-1993.

imported rice, sugar, fish and conserves as well as textiles in exchange for pepper, camphor, spices, sandalwood, Chinese porcelain, silk and metals. ${ }^{10}$ Textiles were key in such a pattern of intra-Asian trade. Javanese and Malays, for instance, would not accept any other product, apart from textiles in exchange for foodstuffs and spices. ${ }^{11}$ Burma

${ }^{10}$ Marie Antoinette Petronella Meilink-Roelofsz, Asian Trade and European Influence in the Indonesian Archipelago: Between 1500 and About 1630 (The Hague: M. Nijhoff, 1962), p. 68.

${ }^{11}$ Ibid., p. 189. 
exchanged rice and silver (from Pegu) for the textiles traded by Bengali merchants. ${ }^{12}$ Furthermore an overland caravan trade connected India with continental Asia. In the 1660s, 25-30,000 camel loads of cotton material from India reached Persia every year. ${ }^{13}$ Cotton Textiles changed hands several times and reached central Asia, the Ottoman Empire, Eastern Europe and China.

With the rise of Europe as a new market for textiles from the early seventeenth century, littoral South Asia played an increasing role in global maritime trade. However, the major regions of supply for cotton textiles did not change: Gujarat, Bengal and Coromandel continued to be the main suppliers of textiles to world trade, though the relative importance of these regions changed, with Bengal emerging as most important among these producing regions. Similar changes occurred in the direction of export, participants, and business organization. For example, the pivotal position of Gujarat and Gujarati merchants in the Indian Ocean had been largely mediated by the demand for Indian cloth in Africa, whereas the dominance of the EIC and private traders working under the Company's implicit (and at times clandestine) guarantee was connected with Bengal's export trade to Europe. By 1700, Indian Ocean trade was firmly Indo-European in character and the pre-eminent article of trade was cotton textiles, displacing rice and spices that had ruled earlier networks of transaction in the Ocean. Whereas these earlier networks tended to be segmented and particularly focused on Asia, cloth created a truly global network. In the late-eighteenth century, South Asia accounted for approximately a quarter of the world's textile output and almost certainly a larger percentage of the world's seaborne trade in textiles. India clothed the world.

\footnotetext{
12 Sanjay Subrahmanyam, "Notes on the Sixteenth Century Bengal Trade", Indian Economic and Social History Review, 24, 3 (1987), pp. 267-71; Ashin Das Gupta, "Gujarati Merchants and the Red Sea Trade, 1700-1725", in Blair B. Kling, and M. N. Pearson (eds.), The Age of Partnership: Europeans in Asia before Domination (Honolulu: The University of Hawaii, 1979), pp. 123-58.

${ }^{13}$ Scott C. Levi, The Indian Diaspora in Central Asia and Its Trade, 1550-1900 (Leiden: Brill, 2002), pp. 30-1. See also Id., "India, Russia and the eighteenth-century transformation of the central Asian caravan trade", Journal of the Economic and Social History of the Orient, 42, 4 (1999), pp. 519-48. Also on overland trade, see the important collection, Sushil Chaudhury, Michel Morineau (eds.), Merchants, Companies and Trade: Europe and Asia in the Early Modern Era (Cambridge: Cambridge University Press, 1999).
} 


\section{Historical Perspectives on the Indian Ocean and Trade}

Historical scholarship on the early modern Asian trading world has explored the pivotal role of Indian cotton textiles within this world. Breaking away from an earlier practice of treating Asian trade as a subplot in the story of European expansion, or to use J.C. van Leur's words, of observing Asia 'from the deck of a ship', from the 1960s, contributors to this literature sought to establish the Indian Ocean littoral from the beginning of the Christian era to the eighteenth century as a world with its own distinct historiography. Central to this project was a shared understanding that, well before the Europeans began to control Asian trade and directed it to serve European consumption, they had utilized commodities, routes, and systems long established within intra-Asian trade. This scholarly enterprise, aided and constrained at the same time by its dependence on the archives of the chartered companies, has progressed along several roads.

The earliest strand is represented by the pioneering series of 'company studies' by Charles Boxer, Holden Furber, and Tapan Raychaudhuri. ${ }^{14}$ Soon after these works appeared, and in some cases even before them, historians branched off from the Ocean and the Companies into regions, entrepreneurs, cities, events, peoples and personalities, and territorial politics. ${ }^{15}$ The need to create an integrated account tying

${ }^{14}$ Holden Furber, John Company at Work (Cambridge, MA: Harvard University Press, 1948); Tapan Raychaudhuri, Jan Company in Coromandel, 1600-90: A Study in the Interrelations of European Commerce and Traditional Economies (The Hague, Martunus Nijhoff, 1962); Charles R. Boxer, The Portuguese Seaborne Empire, 1415-1825 (London: Hutchinson, 1969).

${ }^{15}$ On merchant enterprise, see especially Ashin Das Gupta, The World of the Indian Ocean Merchant, 1500-1800: Collected Essays of Ashin Das Gupta (Delhi: Oxford University Press, 2001); Denys Lombard and Jean Aubin (eds.), Asian Merchants and Businessmen in the Indian Ocean and the China Sea (New Delhi: Oxford University Press, 2000); and Ashin Das Gupta and Michael N. Pearson (eds.), India and the Indian Ocean (Calcutta: Oxford University Press, 1987). On trade and manufacture in the major regions, see especially Surendra Gopal, Commerce and Crafts in Gujarat, 16th and 17th Centuries: A Study in the Impact of European Expansion on a Pre-capitalist Economy (New Delhi: People's Publishing House, 1975); Sinnappah Arasaratnam, Merchants, Companies and Commerce on the Coromandel Coast, 1650-1740 (Delhi: Oxford University Press, 1986); Om Prakash, The Dutch East India Company and the Economy of Bengal, 1630-1720 (Princeton: Princeton University Press, 1985), Sanjay Subrahmanyam, The Political Economy of Commerce: Southern India, 1500-1650 (Cambridge: Cambridge University Press, 1990); and Anthony Reid, Southeast Asia in the Age of Commerce, 1450-1680, Volume One: The Lands below the Winds (New Haven and London: Yale University Press, 1984). On territorial politics and the relationship 
the coast to the interior, land and sea, trade and production, and linking the subsidiary commercial spheres in East Africa, the Arab World, India, China, Japan, Indonesia, and continental Australasia, led to bold attempts to seek commonalities that gave the seafaring economy and society a unifying character, one quite distinct from that of the interior regions less dependent on the sea. Inspired by the work of Fernand Braudel on the Mediterranean, and those by Wilhelm Heyd and Henri Pirenne before him, K.N. Chaudhuri and Kenneth Macpherson set out to search for the common preoccupations that seemed to define the unity of the Indian Ocean. ${ }^{16}$ Both historians emphasize the enclosed nature of the Indian Ocean by comparison with the Pacific or even the Atlantic, the Asian landmass being never too far away from the major East-West routes. Both authors emphasize the influence of the monsoon winds in setting the rhythm of trade and production almost throughout the region, and the waning of that influence from the nineteenth century. And both stress the role of trade as a channel of communication of ideas, cultures, technologies, and religions, the 'invisible cargoes' delivered and consumed along with commodities.

Through these works, a rich narrative history of the Indian Ocean has taken shape in the last thirty-odd years. And yet, if global historians today try to fit this history of the Ocean with themes that interest them, the meaning of that narrative could become open to question. The significance of the Indian Ocean and Indian textiles for global history is open to interpretation in at least three distinct contexts:

1. First, the significance of Indian textiles in structuring socio-economic and political relationships within the non-European world is a key subject of recent analyses. This problem is touched upon in several of the essays in this volume when questioning in what ways the trade

between processes of state formation and maritime trade in early modern South Asia, see Christopher A. Bayly, Rulers, Townsmen and Bazaars: North Indian Society in the Age of British Expansion, 1770-1870 (Delhi and Oxford: Oxford University Press, 1983) and Peter J. Marshall, Bengal: The British Bridgehead. Eastern India 1740-1828 (Cambridge: Cambridge University Press, 1987). On port cities, see Lakshmi Subramanian, Indigenous Capital and Imperial Expansion: Bombay, Surat and the West Coast (Delhi and Oxford: Oxford University Press, 1996).

${ }^{16}$ K.N. Chaudhuri, Asia before Europe: Economy and Civilisation of the Indian Ocean from the Rise of Islam to 1750 (Cambridge: Cambridge University Press, 1991); Kenneth McPherson, The Indian Ocean: A History of People and the Sea (Delhi and Oxford: Oxford University Press, 1998). 
of textiles impacted on cultures and economies across and beyond the Indian Ocean.

2. Second, the significance of Indian textiles within the phenomenon that economic historians call 'the rise of the west' continues to be a subject of intense debate. Essays in this volume critically rely on the vast scholarship that has explored how trade impacted upon WestEuropean society in the wake of industrialization by using geographical models based on core-periphery systems.

3. And finally, the new discourse on the rise of Europe in relation to the relative decline of Asia from the eighteenth century, or more familiarly today, 'the great divergence', invites us to reconsider what, if any, lessons the Indian Ocean narrative carries for divergence.

\section{The Meanings of Trade: Relational Spaces}

The early modern period structured its geographies around networks based on connections, with emporia, producing regions and mobile merchants operating across vast spaces. Cottons were central to this world: they formed long-distance commercial relationships across the Indian Ocean. Cotton textiles were perhaps the most global among the various manufactured and non-manufactured commodities entering long-distance trade in the period between 1500 and $1800 .{ }^{17}$ This explains why cotton textiles have been at the centre of historians' attention especially when discussing trade in the Indian Ocean and, more recently, when debating the challenges and limitations of early modern globalization. ${ }^{18}$

The space of the people that purchased Indian cloth was a relational space that dramatically changed during the period here considered.

\footnotetext{
${ }^{17}$ See for instance Maxine Berg, "In Pursuit of Luxury: Global History and British Consumer Goods in the Eighteenth Century", Past and Present, 182 (2004), pp. 85-142; Giorgio Riello, "The Globalization of Cotton Textiles: Indian Cottons, Europe and the Atlantic World, 1600-1850", in Giorgio Riello and Prasannan Parthasarathi (eds.), The Spinning World: A Global History of Cotton Textiles, 1200-1850 (Oxford: Oxford University Press, 2009), pp. 261-87.

${ }^{18}$ Jan de Vries, "Connecting Europe and Asia: A Quantitative analysis of the Caperoute Trade, 1497-1795", in Dennis O'Flynn, Arturo Giràldez and Richard von Glahn (eds.), Global Connections and Monetary History, 1470-1800 (Aldershot: Ashgate, 2003), pp. 35-106; Pieter Emmer, "The Myth of Early Globalization: the Atlantic Economy, 1500-1800", European Review, 9, 1 (2003), pp. 37-47.
} 
By relational space we mean locales that were particularly exposed to influences coming in from overseas. Firstly, the period saw a dramatic change in the relationship between India and Europe largely through extension of contact and exchange centred in the Indian Ocean. What direction did the change take? And why did the relationship have to change in this way? Secondly, the space changed in time with the emergence of new trading communities, the expansion of emporia such as Madras, Melaka, Manila or Batavia and the constant reconfiguration of the links forming such networks (Fig. I.2). The Indian Ocean was quintessentially a 'space of flux' and a 'space in flux'. Can we discern an order in this flux?

Indian cloth was one of the agents lubricating the wheels of commerce in the early modern world, and forging closer economic, social and cultural contact between Europe, Africa, and Asia. And yet, the reasons offered to explain why Indian cottons might be in high demand in the regions around the Indian Ocean and beyond, could be quite diverse. Indian cloth functioned, among the many, as currency in Africa, as a wage good in Southeast Asia, and as a fashion article in Europe. As currency, cloth secured the provisioning of other valuable commodities, such as ivory, slaves, or gum. Guinea cloth, for example, was an indigo-dyed cloth with which initially the French paid for their imports of gum from West Africa. The trade in Indian cloth was large; it complemented - and at times displaced - local cloth, and in this specific exchange, Guinea cloth was the main form of payment, eventually turning into a currency. Ironically, the gum it purchased was needed for mordanting in Europe, a process that helped European calico printing withstand Indian competition. Nevertheless, the attempts by French manufacturers to break into the India trade failed because Indian Guinea cloth was both distinctive as cloth, and a unit of account, a function especially evident during military campaigns. Likewise, in the last quarter of the eighteenth century, there was concern in Portuguese East Africa that Gujarati cloth drove up the price of ivory. Precisely because of the function of Indian cloth as currency, local and imported textiles did not necessarily compete but served different functions and often existed side by side, as Pedro Machado's work on Portuguese East Africa shows. ${ }^{19}$ In Europe, fine Indian cotton and silk cloth created a different kind of market. We see in this demand not only an attempt by

\footnotetext{
19 See Pedro Machado's paper in this volume.
} 

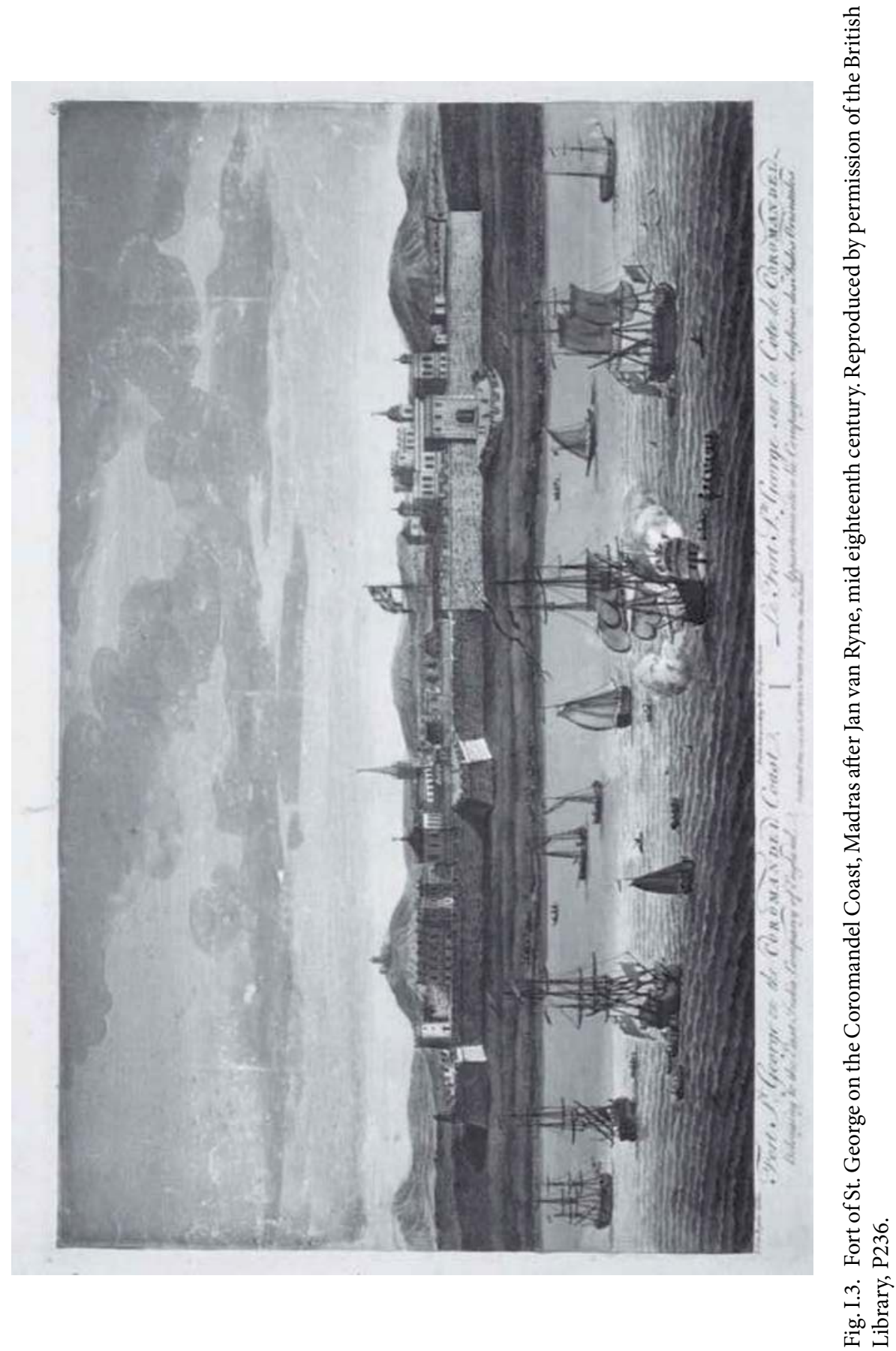
the cultural and social elite to 'distinguish' themselves or mark out a cultural space through the use of new and luxurious articles of consumption: as Lemire suggests, Indian cotton textiles helped to create in Europe a new middle-class and bourgeois notion of fashion. ${ }^{20}$ Once again import substitution was attempted, but these attempts dealt with complex notions of consumption including quality, design, shape, and colour, as well as just cost.

In those areas where Indian cloth also functioned as an article of consumption, its import had different consequences. Import encouraged import-substitution and simultaneously devitalized and revived segments of indigenous manufacturing traditions as illustrated in the papers on the textile trade to Southeast Asia, Europe and Africa. Whereas some kinds of design-intensive cloths were incorporated into elite consumption in these regions - indeed even marked out the ruling classes apart from the populace - in the case of others, import-substitution was relatively easy and occurred frequently between older indigenous textile traditions. The substitution of previously imported goods with indigenous ones as one of the catalysts of economic growth is a model embraced by economists in the 1960s in development theory and readily accepted by historians to explain the economic developments of specific segments of the economy (especially in the production of consumer goods) in different times and periods. But the omnipresence of import-substitution processes occurring in different parts of the early modern world, ranging from Africa to Indonesia to Europe, diminish its explanatory power. ${ }^{21}$ And even the extension of the concept to include the relevance of exporting markets for the rising areas of substitution - what Joseph Inikori has defined as a re-export substitution model - though helpful, does not allow the creation of a comprehensive narrative of economic change. ${ }^{22}$ The importance of import and reexport substitution is particularly evident in current interpretations of European economic growth or, to be more precise, of its process of industrialization. ${ }^{23}$

${ }^{20}$ See Lemire's paper in this volume and Beverly Lemire and Giorgio Riello, "East and West: Textiles and Fashion in Early Modern Europe", Journal of Social History, 41, 4 (2008), pp. 887-916.

${ }_{21}$ Riello, "Globalisation of Cotton Textiles".

${ }^{22}$ See in particular Joseph E. Inikori, Africans and the Industrial Revolution in England: A Study of International Trade and Economic Development (Cambridge: Cambridge University Press, 2002).

${ }^{23}$ Maxine Berg, "Asian Luxuries and the Making of the European Consumer Revolution", in Maxine Berg and Elizabeth Eger (eds.), Luxury in the Eighteenth Century: 


\section{The Meanings of Trade: Indian Ocean as a Space System}

The themes of import-substitution and industrialization bring us closer to that of the origins of modern world economic inequality: what part, if any, did the Indian Ocean play in that process? The basic narrative of cotton textile manufacturing in the Indian subcontinent in the early modern period rests on the assumption that the story of manufacturing and trade of textiles is linked to the history of economic decline for the Indian subcontinent as a whole, which is located especially in the eighteenth century, though south Asian historians disagree on its chronology, causes and intensity. ${ }^{24}$ By the middle of the nineteenth century, when we conclude our analysis, India was no longer the world producer of cotton textiles. It was Britain that clothed the world. This did not just happen because of an expansion of the trade in cotton textiles beyond the Indian Ocean, but also because of a shift of the centre of manufacturing from India to England.

Already in 1934, van Leur had advanced an influential interpretation of Asian economies that projected early modern Asia as equal in many essential respects to early modern Europe, with the difference that trade tended to be socially and politically marginal within Asia. The argument contained a hint of the divergence that was to come, rooted in the relative positions of commerce within the larger regional economies. While the van Leur thesis, that Asian trade could be characterized as 'peddler' trade, was criticized by later authors, the latter still needed to offer an explanation for the relative decline of Indian seafarers in competition with the English and the Dutch. This was a problem that interested Ashin Das Gupta particularly, who framed his argument in terms of merchant organization. Das Gupta's critique of the van Leur thesis took place within a context of comparative business institutions. Yet, its relevance to the divergence discourse is unmistakable. Within the mainstream theory of economic history, later inequality tends to be explained by differences in institutional quality, rather the particularities of European institutions. The significance of Das Gupta's intervention on the theme of European seafarers' ascendance in the Indian waters is that it potentially integrates these two themes, trade and institutional quality, together. ${ }^{25}$

Debates, Desires and Delectable Goods (London: Palgrave, 2003), pp. 228-44; Id., "In Pursuit of Luxury".

${ }^{24}$ See in particular Ian Wendt's paper in this volume.

25 Ashin Das Gupta, World of the Indian Ocean Merchant, passim. 
A more influential form of Europe-Asia comparison is offered by the world systems school, which focuses attention upon positions of regions within a global trading system. An enterprise such as the present volume would connect easily to the world systems approach, which has taught us to think of the early modern world as a field of evolving relationships and exchanges rather than as a field divided into discrete nation states and their respective spheres of control. ${ }^{26}$ Extensive commodity trade conducted in capitalist markets has been around from times earlier than nations, and whereas regional states did in the past compete for control over long-distance trade, networks of trade did not ever possess one political centre. The world systems approach problematizes these worldwide and long-lasting networks by shifting the unit of economic-historical analysis from states to territorial divisions of labour. Although not units of analysis, states are important actors, for it is ultimately unequal power that maintains the system. Strong states and strong regions in core areas keep a surplus extraction and transfer-processes going.

The world systems school, despite numerous variations between major contributors and everlasting imprecision over time and space in defining the modern world system, is based on the fundamental idea that a world system is characterized by one international division of labour and that regions tend to become locked into their respective roles in this division of labour. The Indian Ocean trading world, according to this interpretation, was incorporated within the Europe-centred trading world from the eighteenth century, as the latter itself spread out partly in response to crisis at home. India and much of the littoral regions and their hinterlands were incorporated in the nineteenth century world system as 'periphery', meaning suppliers of labour- and land-intensive goods and importer of industrial goods.

However, as an explanatory model of the origins of inequality, the world systems approach is less than convincing. The notion that roles in Europe-Asia trade had been in some sense predetermined in favour of Europe recently came under attack from Andre Gunder Frank. ${ }^{27}$ Frank, himself a major architect of the argument that Europe's supremacy owed more to trade sustained by power than to exceptional local

\footnotetext{
${ }^{26}$ Immanuel Wallerstein, The Capitalist World-Economy: Essays (Cambridge: Cambridge University Press, 1979).

27 André Gunder Frank, ReOrient: Global Economy in the Asian Age (Berkeley and Los Angeles: University of California Press, 1998).
} 
characteristics, made a strong case that the particular advantage Europe enjoyed in an initially Asia-centric trading world was access to silver plundered from the Americas and armed ships. ${ }^{28}$ Directly or indirectly, the essays in this volume are influenced by the vision of a world defined by intersecting paths along which commodities, materials, and specie flow. And yet, the essays in this volume stop short of defining this world as a 'system'.

The difference is apparent in two respects. First, there is avoidance of conceptualizing network relations as necessarily hierarchical. Although many of the essays refer to India as a 'core' or manufacturing powerhouse within the Indian Ocean, this volume is wary of accepting a neoWallersteinian model based on core and peripheries, for, the so-called periphery had active agency in redefining the roles of all players in the manufacturing and trade of textiles across and beyond the Indian Ocean. Moreover, recent trade history shows that the spatial boundaries of the Indian Ocean remained fluid. The inclusion of China and West Africa shows how the conceptual perimeter of the Indian Ocean went well beyond its physical nature and included world areas that were connected to, but were not geographically part of, the Indian Ocean. Second, the contributions in this volume reassess the role that politically-sustained unequal exchange played in early modern trade. Instead of adopting a plainly political approach, the essays most directly concerned with the question of origins of modern world inequality also consider the role of markets, knowledge, and resource endowments to be important ones. In a large measure this openness on linking trade patterns with world inequality reflects the current state of the global history discourse, which itself has moved away from unequal exchange. This brings us to the theme that has become known as the problem of divergence.

\section{The Meaning of Trade: The Indian Ocean and 'Divergence'}

All essays in this volume refer to the 'age of Indian decline' and 'age of European ascendancy' by drawing on three established images or models. The first is the imperialism model that sees the decline of India

\footnotetext{
${ }^{28}$ Frank added two further theses to this formulation. First, when this cheap source of purchasing power dried up, Europe was forced to find commodities for payment, and invented machinery. Second, the capital needed for industrial investment came from primitive accumulation or a colonial form of plunder.
} 
as a manufacturing crisis. The interference of the Portuguese, and later the English (EIC), Dutch (VOC) and to a lesser extent other European chartered companies in the intra-Asian (the so-called 'country trade') and intercontinental trade was perhaps not as deleterious as previously thought. It was a second phase of European interference, this time based on a more direct control of the productive structures of textile manufacturing in India, as considered by Om Prakash and Bishnupriya Gupta in this volume, that produced profound repercussions on the ability of the system to successfully reproduce itself over time.

A second model, based on issues of industrialization, shifts our attention away from India and towards Europe. This model does not explain Indian economic decline directly but invokes instead a truncated narrative rather narrowly focused on England in the few decades following the middle of the eighteenth century. The 'triumphal' industrialization of North Western Europe is mostly solved by drawing on endogenous causes and in particular the role of technological invention. It argues that the loss of Indian primacy had little to do with India or its political situation but was the result of European achievements in the shape of new organization of labour and new technologies.

For a long time these two models operated on different geographical and conceptual planes. The last decade has seen a revision of this disjuncture in response to a third model: the so-called great divergence model. Kenneth Pomeranz asks historians to look beyond the divisions of Europe and Asia and towards a reciprocal perspective that attempts to comprehend the dynamics of change of a landmass called Eurasia. His study of China and Western Europe has coined the expression 'Great divergence' that encapsulates a change whose agency does not reside in either Asia or Europe. ${ }^{29}$

This volume is not a straightforward application of the great divergence paradigm to India and Europe.$^{30}$ However, its presence is necessary to contextualise several essays focusing on Europe and Britain in a volume that proclaims to be about India and the Indian Ocean. What connects these essays and Pomeranz's model is neither the relevance of contingencies or conjunctures, nor the basic questions asked, but a

${ }^{29}$ Kenneth Pomeranz, The Great Divergence: China, Europe and the Making of the Modern World Economy (Princeton: Princeton University Press, 2000).

${ }^{30}$ This is a topic more widely considered by Parthasarathi in his forthcoming book. Prasannan Parthasarathi, Why Europe Grew Rich and Asia Did Not (Cambridge: Cambridge University Press, forthcoming). 
shared belief in the pan-continental nature of the problem at stake. All essays in this volume embrace a global vision of trade, commodities, oceans, and regions. In order to explain the rise (or decline) of cotton textile manufacturing and trade in South Asia, it is not sufficient to contextualise it within the geographic parameters of the Indian ocean, or even to include casual references to Europe, Thailand, China or West Africa. This volume reflects instead on the global nature of textiles and, in the attempt to provide some explanations, questions the established assumptions put forward by narratives based on 'miracles' and 'disasters'.

It is relevant to notice how Pomeranz has invited Europeanists, as well as Sinologists, South Asianists and global historians to think 'systematically' about how Europe's history of industrialization fits within a global canvas of events that include contingencies and historical conjunctures. Pomeranz's explanation of the different paths of economic development of China and Europe rests on the importance of two key factors: coal (and more broadly the importance of natural endowments) and colonies (broadly conceived as 'favourite markets'). These allowed the north-western part of Europe to start a process of continuative economic growth not to be experienced in places like China or India for at least another century.

Divergence has shifted the explanation of a supposedly European exceptionalism (or better to say exceptional economic performances) away from a set of cultural variables that traditional historical models had favoured starting with Weber and reaching the present-day as in the works of Eric Jones and David Landes. Europe's entrance into the industrial age is no longer seen as a quintessentially 'European' problem.

Whilst this book might agree with Pomeranz that a divergence between Europe and Asia came into being, it argues that this was neither 'great' nor 'late. The European 'take off' in the production and trade of cotton textiles is shown to be the result of a long, arduous and not always successful process that entailed not just the successful deployment of factors of production, but also the putting in place of complex mechanisms of knowledge transfer, assessment of quality, fashionability, etc. India's 'decline' was similarly a protracted event whose explanation involves politics, technology and trade.

India in the nineteenth century has been seen as a 'victim' of the newly established European cotton textile industry. Yet, to see in this episode of decline a decisive historical discontinuity would be to underestimate two very important forms of path dependence that Indian 
textiles generated. In the nineteenth century and during the Industrial Revolution, a part of the Asian manufacturing tradition above described was destroyed, although a great deal survived too to provide an impetus for an indigenous industrialization somewhat later. ${ }^{31}$ The other form of path dependence is more familiar to students of Indian political history. Europeans came to India as traders, and erected trading stations and forts in coastal regions, later to be used as 'bridgeheads' of British colonialism in South Asia. Did cloth exports have a role to play in political transition? From the seventeenth to the eighteenth century, the Indian Ocean trade moved from competition to greater concentration and control in the hands of merchants directly or indirectly backed up by political and military power. The key point of transition was the Battle of Plassey in 1757 which gave the English EIC enormous bargaining power with the Mughal authority. Textile history scholarship has noted that thereafter, Company merchants used their authority to coerce weavers, what Prasannan Parthasarathi calls "an interlocking of colonial authority and dominant Indian groups [that] may explain the resilience of colonialism in India". ${ }^{2}$

If in these accounts, politics induced changes in trade systems, it seems worthwhile to ask whether or not problems of running the IndoEuropean trade systems also had an effect in shaping the desire for political control over trade, as hinted by Bishnupriya Gupta's paper in this book. Historians note almost without exception that the relationship between the English or the Dutch merchant, the Indian intermediary, and the weavers, tended to be deeply and persistently disputatious. ${ }^{33}$

${ }^{31}$ For reinterpretations of crafts history along these lines, see Roy, Traditional Industry in the Economy of Colonial India, Cambridge: Cambridge University Press, 1999; 'Acceptance of Innovations in Early Twentieth Century Indian Weaving', Economic History Review, 55(3), 2002, 507-532; and Douglas Haynes, 'The Logic of the Artisan Firm in a Capitalist Economy: Handloom Weavers and Technological Change in Western India 1880-1947' in B. Stein and S. Subrahmanyam, eds., Institutions and Economic Change in South Asia, Delhi: Oxford University Press, 1996; 'Artisan ClothProducers and the Emergence of Powerloom Manufacture in Western India 1920-50, Past and Present, 172, 2001, 170-198.

32 Parthasarathi, The Transition to a Colonial Economy: Weavers, Merchants and Kings in South India 1720-1800 (Cambridge: Cambridge University Press, 2001), p. 6.

${ }_{33}$ Om Prakash, in this volume, calls this a shift "from market-determined to coercion-based" exchange. See also for a similar argument in the context of Bengal, Hameeda Hossain, The Company Weavers of Bengal: The East India Company and the Organisation of Textile Production in Bengal 1750-1813 (Delhi and Oxford: Oxford University Press, 1989); and of Madras, Parthasarathi, Transition to a Colonial Economy. 
The source of these conflicts was pervasive asymmetric information and the extreme difficulty of enforcing contracts in the absence of welldeveloped commercial law or, in some cases, because of the weakness of the territorial authority that might enforce such laws. The Europeans routinely relied on indigenous systems of informal control, for example by contracting with the headman of weaving communities, in order to ensure contract enforcement. But such a system was hardly an adequate substitute for a legal regime, for the headman system also gave rise to abuses of power.

The colloquia on textiles that produced the present volume were, thus, driven by a need to connect the Indian Ocean and Indian textiles more closely with contemporary global history. How is this task addressed in the book?

\section{How India Clothed the World}

Seen together, and despite differences in the narrative content and regional focus between the essays, three areas of emphasis clearly emerge in this collection. We call them 'regions of exchange', 'regions of production', and 'regions of change'.

\section{(i) Regions of Exchange}

The first of the three parts in which this book is divided looks at nonwestern markets for Indian cloth, in effect tying Indian textiles with Asian and African producers and consumers. Indian cloth was received in markets that were physically and culturally worlds apart. This section focuses on processes and outcomes of economic and cultural interaction rather than on classic merchant-dominated narratives of trade. The essays included in this section emphasise the role played by the so-called 'receiving regions' in their 'commodification' of imported goods and its interconnexions to productive structures. The interplay between intra- and inter-regional competition was as important in determining the success of Indian textiles as advantages in the manufacturing and distribution of these commodities.

Reid shows that Indian cotton cloth was the key with which successive traders from 'above the winds' unlocked the markets for tropical products of Southeast Asia. The Europeans who entered the Indian Ocean in search of spices similarly used cloth purchases in India to trade against spices. In the later seventeenth and eighteenth centuries, 
however, this trade stagnated under quasi-monopoly conditions, while India found new markets for its cloth in Europe. Southeast Asians, less able to afford the higher priced Indian textiles, increased their own production in the eighteenth century. In the great revolution of 17901820, however, British manufactured cloth began its spectacular career as a cheaper replacement for Indian cloth, and took over one Southeast Asian market after another. The paper traces these changes from the viewpoint of the Southeast Asian consumer.

Pedro Machado's paper moves from the wider political economy governing exchange in the Indian Ocean to considering the role of merchants. His chapter sees the Indian Ocean as constituted by distinct regions that contained networks of exchange catering for specific markets, but also overlapped and intersected in complex webs of economic and cultural relationships to create an integrated 'inter-regional arena'. He explores the particularities that structured the chains of relation connecting Gujarat in north-western India to Mozambique and East Central Africa between the second half of the eighteenth and first half of the nineteenth century. Although the place of Gujarat has been correctly regarded as central in the history of nineteenth-century western Indian Ocean commercial systems, that of East Africa has tended to be marginalised. His paper emphasises instead the importance of uncovering links of connection for developing an understanding of the dynamics that shaped relationships in this oceanic space.

Inikori considers the relationship between local manufacturing and international trade. There is evidence, the chapter argues, that cotton cloth was an important part of the long-distance trade of West Africa's sub-regions for centuries before the arrival of European traders on the Atlantic coast in the mid-fifteenth century. The early European traders followed the existing pattern of West Africa's inter-regional trade and became carriers of West Africa's cotton cloths from production regions to markets in other regions. Given this long history of cotton cloth production, it is surprising that the cotton textile industry did not develop to the point of proto-industrial organization anywhere in West Africa by the mid-nineteenth century. Inikori's paper argues that imported textiles exchanged bartered for slaves forcefully procured in the hinterland had adverse effects on inter-regional trade and the growth of the market economy and were the main factors inhibiting the economic growth of Africa and the production of textiles.

Shifting to the opposite end of the 'relational' space of the Indian Ocean, China, Huw Bowen examines the role of cotton in cementing 
the multinational operations of the EIC. Bowen investigates the role of European commercial and political power in shaping new forms of interactions and connections across the sphere of the Indian Ocean. In the late eighteenth century large amounts of raw cotton began to be exported from India to China, thereby enabling the Chinese cotton industry to survive a period of acute agricultural crisis and dislocation. At the heart of this paper lies a discussion of how British imperial expansion on the subcontinent acted as a catalyst for this process as the Company began to use the trade in raw cotton as a means of transferring funds from India to Canton for the purpose of financing the growing tea trade, thereby facilitating the flow of 'tribute' from Asia to London.

Kaoru Sugihara extends the intra-Asian trade story beyond the eighteenth century and beyond Indian cotton textiles. His contribution helps us rethink traditional chronologies that depict trade within the Indian Ocean as entering a phase of contraction in the early nineteenth century to coincide with the rise of a new Euro-centred system of industrial production of textiles. Sugihara's paper reconstructs trade statistics to argue that there was a growth of intra-Asian trade during the first half of the nineteenth century, and that its size was at least comparable to Asia's long-distance trade (the sum of exports and imports) with the West. At this time the restrictions imposed by Dutch and English East India Companies and the Qing Government were gradually removed, which provided country traders and Asian merchants with great opportunities for local and regional trade. The growth of intra-regional trade became partly self-generating, and created a new Asian international market for necessities such as grains, other foodstuffs and cotton cloth, going well beyond the intent of colonial rule and the need for long-distance trade settlement. The opium trade, though crucial for the opening of China to the West, represented a limited aspect of this resurgence.

The essays included in this section propose a narrative or commercial, social and cultural contact through the media of textiles that transcends classic interpretations based on the dominance of a manufacturing core (India) over consumer markets across the Indian Ocean, continental Asia and Africa. They show the complexity of commercial relationships, but also the effects and responses on indigenous economies in places as different as Southeast Asia, West and East Africa. All essays here included suggest a more active role of what where once called 'peripheral' regions not just in controlling the flow of commodities 
that they received, as well as their quality and value, but also in developing their own autonomous production through continuous processes of import substitution. The world of trade of the Indian Ocean was based on a web of connections with continuous stimuli and responses linking disparate parts of the globe. This system, as Sugihara argues, was not shadowed by the arrival of European traders but continued to prosper and develop well into the nineteenth century, thus suggesting that the classic narrative of the demise of Indian textile production is in need of serious revision.

\section{(ii) Regions of Production: India and the Problem of Decline}

The second part of this volume deals with production and exchange of textiles within the major regions in the Indian subcontinent, and discusses how much and how profoundly commerce connected with the regional manufacturing economies of South Asia. Five essays position Indian textile manufacturing within an altogether broader conceptual and historical context. Agency is taken as a key factor in unravelling the notion and creation of a comparative advantage beyond the proximate determinants of prices and quantities. This shift in focus highlights the central importance of political transformation in understanding the changing international competitiveness of Indian textiles.

David Washbrook contextualises the link between textile trade and patterns of economic growth in South India. The southern peninsula of India participated strongly in the expansion of global textile trade in the early modern period. However, few attempts have been made to assess the impact of this trade on the local economy. Washbrook explores these issues by drawing on theories of early modern growth and argues that, while there was a positive response to the trade in terms of the expansion of textile and ancillary forms of production, no lasting basis for economic growth was established. Rather, problems of food supply and of political insecurity were exacerbated by the extension of trading networks. After a period of steady expansion to the end of the seventeenth century, the southern textile industry experienced increasing difficulties during the eighteenth century.

Ian Wendt contextualises previous contributions within their wider historiographical contexts. Generations of historians have been at pains to argue both that textile industry in South Asia made major contributions to the world economy and that it suffered massive decline 
in the face of European corporate and colonial exploitation. Wendt's chapter examines the structure of the early modern South Indian textile industry in its broadest dimensions - from cotton fibres to commerce in finished cloth. Complex forms of specialization, credit relations and production relations enabled the South Indian textile industry to thrive. His chapter appraises in particular disruptions and continuities in the Indian handicraft textile industry: the elimination of female, agrarian and part-time labour, in contrast with the remarkable persistence of handloom weavers and textile merchants. Wendt argues that 'de-industrialization' in South Asia can be better characterized as the de-agrarianization, masculinization and professionalization of the textile industry.

The larger context of political and economic change that accompanied early colonial rule in India forms the backdrop to the papers contributed by Om Prakash and Lakshmi Subramanian. Prakash analyses the changes in the structure of textile manufacturing and procurement in Bengal in the second half of the eighteenth century as a result of the assumption of political authority in the region by the English East India Company. Prakash argues that a market-based system was replaced by one embedded in coercion of local merchants as well as artisans. Consequently, the established picture of a ruined textile industry in Bengal seems to be in need of substantive revision.

Complementing Prakash's analysis, Subramanian concentrates upon the nature of relations between labour and capital in the half century of transition to colonial rule, to identify the strategies that both Indian producers, middlemen and traders deployed to deal with the changing political situation. Revisionist historiography on the eighteenth century has tended to foreground the merchant-financier in the political economy of the successor states. The experience of the merchant groups in Western India endorses this position - here, intermediary merchants and brokers were able for some time to resist the attempts of the EIC to introduce structural adjustments in the existing system of textile procurement and commerce. This did not, however, mean that merchants and manufacturers were operating from positions of great advantage: the prevailing conditions of political insecurity, shortage of money, rising prices of yarn owing to erratic supplies, combined with the company's policy of trying to restrict the mobility of weavers constituted very major problems that found reflection in business failures, resistance and desertion by weavers. What little remained of their bargaining power depended upon the extent of the Company's power in the region. 
Once this changed, and Surat was annexed, politics entered the equation leaving merchants, bankers and artisans exposed to the full weight of the Company's hegemony.

This part concludes with a paper by Bishnupriya Gupta exploring the eighteenth-century change in the textile trade between India and Europe. The historical literature notes that the decline in the last decades of the century coincided with the political domination of the Indian subcontinent by the EIC. The literature has seen political factors as central to the decline. As the EIC, the argument goes, acquired revenue rights in Bengal and gained control over the political and legal structure, the exploitation of weavers increased and consequently there was a squeeze on the price paid to the producers. Disputing this supply-side story, Gupta argues that the Company's agents were less able to impose their command over the market than has been previously suggested. The EIC had limited capacity to impose contract compliance and was a price taker in the world market for textiles. The absence of an increasing trend in textile prices in the European market from the middle of the eighteenth century and the eventual decline in nominal and real terms can explain the failure on the part of the EIC to increase procurement prices.

\section{(iii) Regions of Change: The New European Markets}

The final part of this book considers the 'extension' of trade in cotton textiles to Europe in the seventeenth and eighteenth centuries. Scholarship has been slow to consider the role of Indian textiles in what is still portrayed a 'European' story of industrialization and economic development based on the manufacturing of cotton textiles through the adoption of new technology. This group of papers challenges several aspects of such an accepted view by offering a more balanced perspective of the relationship between Indian and European cotton manufacturing. Papers tackle the issue of the transfer of technological, productive, and material knowledge between India and Europe. They address this important and complex issue by drawing on topics as different as concepts quality, information, fashion and manufacturing skills.

Giorgio Riello seeks to contextualize the trade of textiles between Europe and Asia by analyzing its quantitative, as well as the qualitative impact on the European economy. The records of the English, Dutch, French, Portuguese and Swedish East India companies provide precious information about the import of Asian textiles into Europe. His paper shows how, contrary to what is suggested by most literature on 
the so-called English 'calico craze', cottons entering Britain were largely white and unprinted. He argues that more importance should be given to the European chartered companies' strategies of 'learning' from Asian producers and traders: the 200-year period during which Europeans engaged in the trade of textiles within and beyond the Indian Ocean served as an 'apprenticeship' and should be seen as a necessary, although not sufficient, condition for their eventual engagement in the production of such products at home and their trade within the Atlantic Ocean. The 'European ascendancy', if one wishes to still call it so, can no longer be explained in isolation and must recognise and analyse its profound linkages with the history of trade and production within the Indian Ocean.

George Souza develops the analysis of knowledge transfer between Asia and Europe by considering the importance of dyeing materials and the technical expertise of printing on textiles. Rather than unilaterally embracing Europe's industrial divergence as the linchpin to explain the different economic trajectories of Europe and Asia in the eighteenth and nineteenth centuries, Souza argues that technical convergence was necessary. In order to develop an indigenous cotton textile industry, European textile manufactures had to converge through the acquisition and incorporation of new materials and superior technical knowledge and practice from other parts of the globe. Asia, America, and Africa were the potential sources of supply of new raw materials and India and China, in particular, were the potential sources of technical knowledge in the area of textile production. Souza's paper examines the comparative superiority of Indian cotton technology. It isolates one example of Indian cotton textile production and compares it with an equivalent cotton textile produced contemporaneously in France. It determines how, for what reasons and which aspects of Indian cotton textile production technology were investigated by the French.

Indian textiles did not just provide commercial, material and technical exemplars. Beverly Lemire argues that they were also key elements in shaping new notions of fashionability and taste in Europe. But commerce and fashion were complemented by new concepts of quality both for product and manufacturing processes in Europe. By 1500, the traffic in vibrant printed textiles linked together disparate regions of the world. Indian cottons were unmatched by other fibres in terms of cost and quality, providing a key medium for the global circulation of print imagery. The appetite for these textiles made India the source of the most significant global consumer commodity before 
industrialization. Lemire's paper examines cotton's role in global trade by exploring our understanding of fashion in economic history and by analysing the long-term influence of Indian cottons on European markets and society, leading to the development of a fashion system.

Maxine Berg investigates the connections between the global luxury trade and the invention of quality consumer goods in eighteenthcentury Europe, and especially Britain. In her paper, she argues that the trade in Chinese and Indian export-ware stimulated both product and process innovation in Europe. Quality was the key priority of the major textile inventions of the period, as it was for improvements in earthenware, glass and metal ornaments. Asian export commodities provided models of product-type and large-scale production; metropolitan market institutions selling Asian luxuries also shaped markets for new British consumer goods. Cotton textiles, especially muslins and printed calicoes, are examples of a what Berg calls a 'quality road to industrialization' that characterized vast parts of British manufacturing innovation in the eighteenth century.

Prasannan Parthasarathi's concluding paper takes us back to India in the late-eighteenth and early-nineteenth century. Parthasarathi argues that, for the entire duration of the eighteenth century, the wages andstandards of living of Indian weavers were not inferior to those of their European counterparts. The strong manufacturing position of India ensured prosperous conditions and a degree of independence that was not enjoyed by textiles workers in many parts of Europe. This reassessment of the relative position of labour in the Indian subcontinent is used as the background for the analysis of the issue of decline of textile manufacturing in India vis-à-vis the industrialization of Europe. Parthasarathi argues that indeed in many areas of India textile spinning and weaving declined, but that it was mostly the female workforce employed in spinning to be affected in the early part of the century by the import of large quantities of cheap (but good quality) yarn from England. He argues for a more nuanced understanding of decline in which the loss of international markets for Indian textiles in the first half of the nineteenth century is distinct from the success of British wares on Indian markets in the second half of the century.

\section{Conclusion}

The book hopes to meet two goals. The first of the two aims is to provide both scholars and students with a comprehensive introduction to the 
key issues characterising the story of cotton textiles in the Indian Ocean. It does so by drawing on the categories and conceptual vocabulary of global history and on its recent theoretical formulations.

The second objective of the book is to address a historiographical agenda discussed in more detail in the second and the third sections of this chapter. The idea is to revisit the Indian Ocean and Indian textiles in search of new meanings. The idea of the present volume, and the symposia that it follows, is to unpack these two boxes, already familiar to specialist historians, and to re-examine the contents of these boxes, in the light of new themes in global history. Three themes in particular receive emphasis in this chapter: intermediation in knowledge, the need to build a Europe-Asia connected narrative on divergence, and the need to explore relational spaces armed with a wider range of examples than is possible within region-centred stories.

The book proposes a notion of the Indian Ocean formed by fluxes (material, but also webs of power, skills, fashion, etc.) that transcends the traditional geographic boundaries of the Indian Ocean as a maritime space. Central to the theme of this book is an assessment of the relative decline of Indian textile production and trade vis-à-vis the process of economic transformation that characterised European industrialization from the second half of the eighteenth century. Several of the papers here included provide a reading that challenges established interpretations and show the diverse and sometimes persistent role of India's manufacturing on world history - a position that seems more consistent with the present-day economic resurgence of South Asia than one of decay and decline. 
$-978-90-47-42997-5$ 
PART I

REGIONS OF EXCHANGE: TEXTILES IN THE INDIAN OCEAN AND BEYOND 
$-978-90-47-42997-5$ 


\title{
SOUTHEAST ASIAN CONSUMPTION OF INDIAN AND BRITISH COTTON CLOTH, 1600-1850
}

\author{
Anthony Reid
}

\section{The Importance of Cotton Cloth}

It was Indian cloth, more than any other single article of import, which opened up Southeast Asia to the long-distance trade over the past millennium. The local trade was of course more ancient and always more substantial in terms of bulk. Rice, dried and pickled fish, salt, earthenware and metal tools were traded between upland and lowland communities from very early times. But long-distance traders sought some of the unique products of Southeast Asia - spices such as cloves, mace and nutmeg, birds of paradise, aromatic woods and resins such as camphor and sandalwood, tin, and above all gold. To persuade people to accumulate such goods for sale there was nothing so useful as high-quality cloth. Indian merchants learned to bring cloth with them to Southeast Asia, and in time Southeast Asians in turn sought out such cloth by taking their own cargoes of tropical and forest produce to India.

It was not that Southeast Asians could not produce their own cotton cloth. Cotton was grown from at least the thirteenth century in those parts of Southeast Asia that had a marked dry season - Luzon, central Vietnam, eastern Cambodia, east Java and central Burma (Map 1.1). Chinese sources note cotton as one of the exports from all these places to China. ${ }^{1}$ The biggest such source, the dry zone of central Burma, was supplying about 1,000 tons a year of raw cotton to Yunnan by $1600{ }^{2}$ Bali, Sumbawa and South Sulawesi exported cotton and cotton cloth in more limited Archipelago circles. Specialist weaving centres were established in urban centres and in those dry areas where agriculture was least rewarding.

\footnotetext{
1 Anthony Reid, Southeast Asia in the Age of Commerce, c.1450-1680 (New Haven: Yale University Press, 1988-93), vol. 1, pp. 90-92.

${ }^{2}$ Victor Lieberman, Strange Parallels: Southeast Asia in Global Context, c.800-1830 (Cambridge: Cambridge University Press, 2003), vol. 1, p. 145.
} 


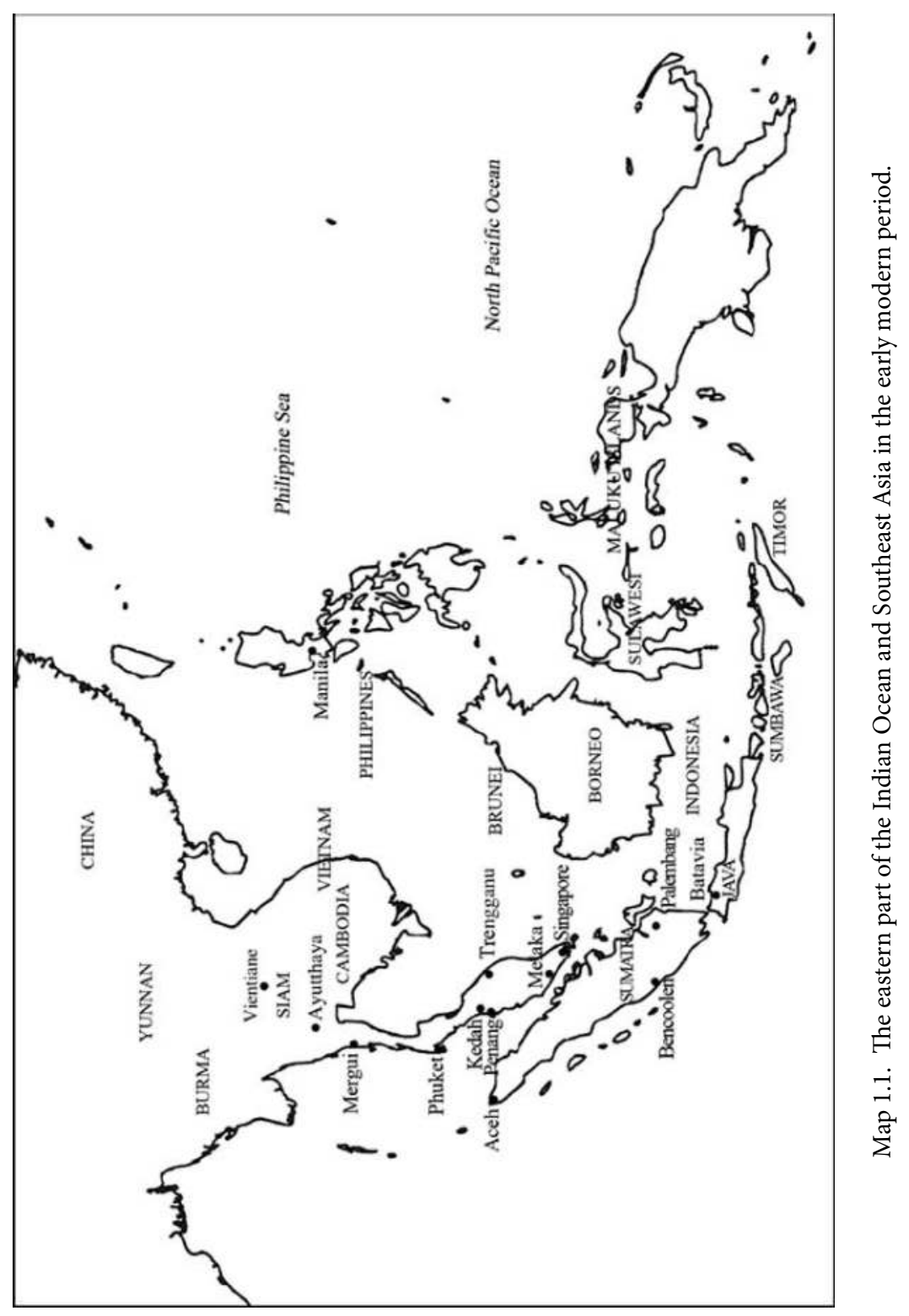


Yet the quality and relative affordability of Indian cloth was a huge incentive towards preferring the imported variety. Dressing the body, and often also the place of dwelling or feasting, in rich impressive cloth was a crucial part of the status game of most Southeast Asian societies. Observers from the sixteenth century noticed how little of their wealth Southeast Asians put into houses and other fixed property, and how much into items of dress and bodily decoration. ${ }^{3}$ In arguing for the importance of the cloth trade in Java after the British conquest, Raffles asserted: "the lower classes of people, unlike those of Hindustan, are accustomed to wear clothing". ${ }^{4}$ Indian cloths established their reputation by the brilliance of the colours, fixed by mordants not available to Southeast Asians (Fig. 1.1). The larger scale and more developed commercialism of Indian production eventually also made Indian cotton cloth cheaper than local products in international markets such as Melaka, Aceh, Banten and Ayutthaya. ${ }^{5}$ By contrast, in Southeast Asia spinning and weaving was largely still a household activity, exclusively performed by women on backstrap looms, and therefore unable to match the productivity of Indian wooden looms. Moreover cotton could not be grown in the year-round wet centre of Southeast Asia Sumatra, the Peninsula, western Java and Borneo - so that these areas were particularly reliant on cotton cloth imports.

These factors make it likely that coloured cotton textiles were prominent in the goods brought to Southeast Asian ports from the time India and Southeast Asia began interacting intensively by sea around the fifth century. By the sixteenth century - when more adequate evidence survives - it was a very large trade. Gujarat, Bengal and the Coromandel coast were all shipping a great variety of cotton cloths to the markets of lower Burma (Pegu), Tenasserim (for the cross-Peninsula trade to Siam and Indochina), Melaka, Sumatra and Java. Tomé Pires estimated that before the Portuguese conquest in 1511, Melaka received each year about five vessels each from Gujarat and South India, and several from Bengal, all laden with cloth for Southeast Asian markets. In addition, a lively trade was carried separately to Pasai in Sumatra

\footnotetext{
${ }^{3}$ Reid, Southeast Asia in the Age of Commerce, vol. 1, pp. 85-88.

${ }^{4}$ Raffles's memo, dated January 1813. Cit. in Harold R. C. Wright, East Indian Economic Problems of the Age of Cornwallis and Raffles (London: Luzac, 1961), p. 228.

${ }^{5}$ K. N. Chaudhuri, "The Structure of Indian Textile Industry in the Seventeenth and Eighteenth Centuries", in Tirthankar Roy (ed.), Cloth and Commerce: Textiles in Colonial India (New Delhi: Sage, 1996), pp. 33-36.
} 


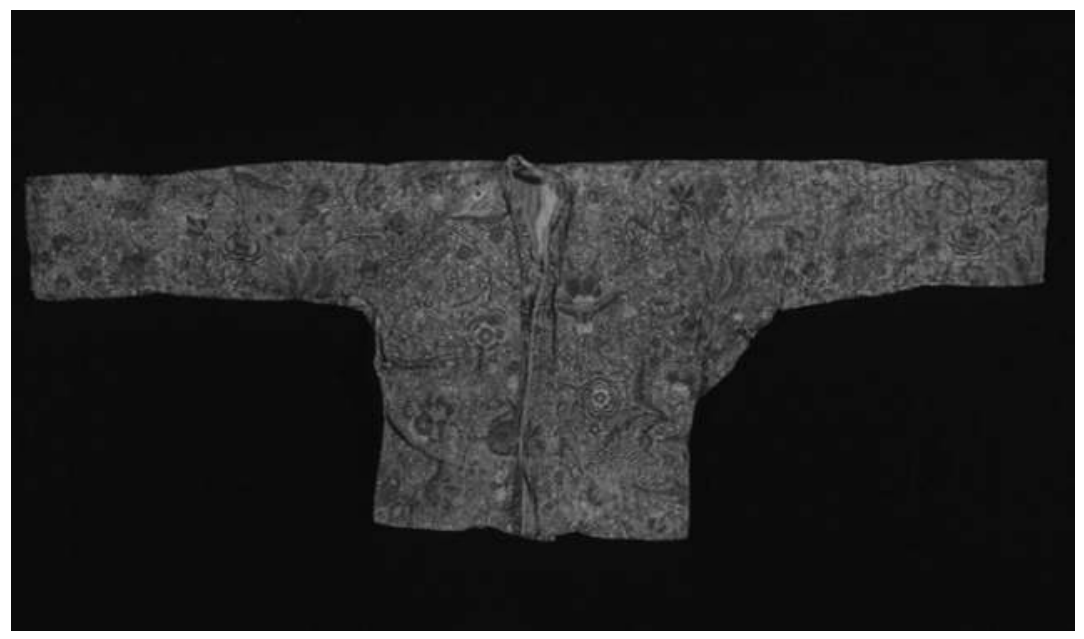

Fig. 1.1. Baju (jacket) tailored from Coromandel Coast cloth in Sumatra, lateeighteenth century. The floral design shows a strong European influence. Baju were popular in the Malay world and are linked to the spread of Arabic and Indian types of dress in Southeast Asia. Victoria and Albert Museum, IS.101-1993.

and Mergui and Tenasserim on the mainland. My crude estimates based on Pires' figures suggest that circa 600,000 Spanish dollars (SP\$) worth of Indian cotton cloth was then flowing to Southeast Asia every year (Table 1.1). ${ }^{6}$

\section{The Age of Commerce}

The long sixteenth century was one of rapid expansion in the seaborne trade to and through Southeast Asia, as European, Chinese and Japanese traders joined the Indian and Southeast Asian shippers in increasingly fierce competition. The prices as well as the quantities of Southeast Asian pepper, clove, nutmeg and cinnamon increased, and in return increasing amounts of Indian cloth were consumed. Each new wave of Europeans learned that in order to acquire the pepper and spices they wanted from Southeast Asia, they had first to stock up on Indian textiles.

${ }^{6}$ These figures are drawn from Tomé Pires, The Suma Oriental of Tomé Pires: An Account of the East, from the Red Sea to Japan, Written in Malacca and India in 1512-15, ed. Armando Cortesão (London: Hakluyt Society Publications, 1944), as summarized in Reid, Southeast Asia in the Age of Commerce, vol. 2, pp. 26-28. 
Table 1.1. Southeast Asian textile imports from India, 1500-1829

\begin{tabular}{|c|c|c|c|c|c|c|}
\hline & \multicolumn{2}{|c|}{ From Coromandel } & \multicolumn{2}{|c|}{ From all of India } & \multicolumn{2}{|c|}{$\begin{array}{l}\text { Estimated Southeast } \\
\text { Asia imports }\end{array}$} \\
\hline & $\begin{array}{l}\text { Thousand } \\
\text { pieces }\end{array}$ & $\begin{array}{l}\text { Thousand } \\
\text { Spanish } \\
\text { dollars }\end{array}$ & $\begin{array}{l}\text { Thousand } \\
\text { pieces }\end{array}$ & $\begin{array}{l}\text { Thousand } \\
\text { Spanish } \\
\text { dollars }\end{array}$ & $\begin{array}{l}\text { Thousand } \\
\text { pieces }\end{array}$ & $\begin{array}{l}\text { Thousand } \\
\text { Spanish } \\
\text { dollars }\end{array}$ \\
\hline \multicolumn{7}{|l|}{1510 to } \\
\hline Melaka & & 175 & & 460 & & 600 \\
\hline \multicolumn{7}{|l|}{ c. 1600} \\
\hline estimate & 410 & 430 & 900 & 940 & 900 & 940 \\
\hline $1641 \mathrm{VOC}$ & 357 & 143 & 440 & 440 & 1760 & 1760 \\
\hline 1686-7 VOC & 458 & 331 & 485 & 359 & 1455 & 1077 \\
\hline $1703-5$ VOC & 130 & 212 & 223 & 416 & 446 & 832 \\
\hline 1723-5 VOC & 112 & 228 & 196 & 471 & 392 & 942 \\
\hline 1757-9 VOC & 137 & 318 & 272 & 620 & 544 & 1240 \\
\hline 1770-1 VOC & 76 & 133 & 102 & 193 & 510 & 965 \\
\hline 1811 Madras & 412 & 597 & & & & \\
\hline \multicolumn{7}{|l|}{$1821-2$} \\
\hline Madras & 761 & 959 & & & & \\
\hline \multicolumn{7}{|l|}{$1828-9$} \\
\hline Singapore & & & & $616(861)$ & & $3080(4305)$ \\
\hline
\end{tabular}

Sources: For 1600 the estimates (for Southeast Asia as a whole) are based on increases in shipping of factors of roughly 2 for Gujarat, 1.5 for Bengal and 2.5 for Coromandel. These are converted to pieces (of an average 11.5 metres) according to the formula of Laarhoven. I am assuming (crudely) that the Portuguese cruzado in which these estimates were made was equivalent to a Spanish real (dollar). VOC imports for the (chiefly Archipelago) Southeast Asia market are taken from the careful calculations of Ruurdje Laarhoven, summarized in Ruurdje Laarhoven, "The Power of Cloth: The Textile Trade of the Dutch East India Company (VOC) 1600-1780" (Unpublished Ph.D. Thesis, Australian National University, 1994), p. 286. Estimates in the final column for total Southeast Asian imports are based on assumptions that the VOC occupied a quarter of the Southeast Asian market in 1641, a third in 1686-7, half in 1703-60, and a fifth in 1770-71 when India-based country traders were making gains. Anthony Reid, Southeast Asia in the Age of Commerce, c.1450-1680 (New Haven: Yale University Press, 1993), vol. 2, pp. 27-31; Anthony Reid, "A New Phase of Commercial Expansion in Southeast Asia," in Anthony Reid (ed.), The Last Stand of Asian Autonomies: Responses to Modernity in the Diverse States of Southeast Asia and Korea, 1750-1900 (Basingstoke: Macmillan, 1997), pp. 76-7. Figures for 1811-22 are the recorded exports of Madras to the eastward, sometimes itemized as Aceh, Penang, Java, Manila or 'Malay ports', for which I am indebted to Tamara Hudec, personal communication. The 1828-9 figure is the export of Indian cloth (total cloth in brackets) to Southeast Asian destinations, chiefly the Indonesian Archipelago and Siam; from Lin Ken Wong, "The Trade of Singapore, 1819-69", Journal of the Malaysian Branch of the Royal Asiatic Society, 33, 4 (1960), pp. 259-64 (see also Table 1.2). I have estimated the Singapore share of the Southeast Asian textile market as $20 \%$ in $1828-9$. Italic figures represent estimates. 
As explained by one experienced Portuguese to the neophyte Frenchman, Beaulieu:

It was necessarily appropriate that they have a post in Acheh, but there was no meaning to having one here, if one didn't have any in Surat, because reals [Spanish dollars] and other French goods are not proper for this place, and one would be losing coming directly from France to here to buy pepper, instead of passing through Surat. ${ }^{7}$

Arriving only in 1596, Dutch merchants were quicker than most to learn the secrets of the cloth trade as the key to unlocking Indonesia's spices. In a 1602 survey of the market of Banda, at the time the conduit for eastern Indonesian spices, Augustijn Stalpaert described 21 types of cloth that had to be acquired from the Coromandel Coast, eight obtained from Gujarat and six from Bengal. He calculated that 70,000 pieces of cloth could be sold in Banda for the Maluku markets every year, 85 percent of which was Indian and the remainder Indonesian. ${ }^{8}$

I have argued elsewhere that this competitive commercial interaction reached its high point in the period $1620-50$. After this period, a certain 'crisis' set in which reduced the returns to Southeast Asians of their exports, and eventually also reduced the quantities being traded. The final column of Table 1.1 shows my estimates of overall Southeast Asian imports, based on the known VOC shipments and an estimate of the extent of VOC market share at different periods. The figure of SP $\$ 1,760,000$ for the estimated value of imports in 1641 represents the Southeast Asian consumption of imported textiles at this peak period. What this meant in terms of actual consumption is extremely difficult to calculate. As Ruurdje Laarhoven makes clear, the size of a piece of cloth differed greatly depending on the type of cloth and its supplier. Prices also diverged very widely.

If I press this quantifying tendency to the limit, it is not in any false belief in accuracy, but rather to refute the assumption often made that this pre-industrial trade was only in 'luxuries' for an elite. During this

7 Beaulieu, in Aceh in 1630s, as translated by Denys Lombard, "The Indian World as seen from Acheh in the Seventeenth Century", in Om Prakash and Denys Lombard (eds.), Commerce and Culture in the Bay of Bengal, 1500-1800 (New Delhi: Manohar, 1999), p. 190.

${ }^{8}$ Ruurdje Laarhoven, "The Power of Cloth: The Textile Trade of the Dutch East India Company (VOC) 1600-1780" (Unpublished Ph.D. Thesis, Australian National University, 1994), pp. 49-51. Stalpaert's memo is reproduced in full as appendix 3 of G. P. Rouffaer and H. H. Juynboll, De Batikkunst in Nederlandsch-Indië en haar geschiedenis (Utrecht: Oosthoek, 1914). 
peak period, more than 1.7 million pieces were imported from India for the Southeast Asian markets every year. If Ruurdje Laarhoven's calculations are correct that an average 'piece' might have been 11.5 square metres in area, this would mean about 20 million square metres of cloth were imported each year. ${ }^{9}$ This represents about one square metre for each Southeast Asian. If the cloth was spread around equally, which of course it was not, each Southeast Asian could have purchased enough Indian cloth for a single wrap-around garment of sarung type every two or three years. ${ }^{10}$

No doubt the remotest and poorest parts of the region were not affected at all by Indian cloth. The large commercial cities, where perhaps one million of the Southeast Asian population lived, were disproportionately likely to buy Indian cloth rather than to buy or produce their own. Yet this amount of cloth cannot have been restricted to the cities or the elites. A Dutch envoy who made the arduous journey up the Mekong to the Lao capital of Vientiane to spy out commercial possibilities in 1642 reported that 40,000 'pieces' of Indian cloth reached that city for the Lao market every year. ${ }^{11}$ There can have been few more difficult markets to reach. Since the Mekong was not navigable between Laos and Cambodia, this cloth was brought to the Siamese capital of Ayutthaya by sea, or a mixture of sea and the painful transit of the Peninsula from Tennasserim, and then hauled on bullock-carts for the 400 miles across the plain and low hills:

Since they go in great caravans of 60 to 100 carts [for security], if one of them breaks down the whole train is held up; also in the hot sun the buffaloes pull very badly, as well as other obstacles; so that five months is needed for the journey [Ayutthaya to Vientiane]; on the return since they have less heavy loads they do it in three months. ${ }^{12}$

Inland communities in Sumatra, Timor and Sulawesi were also reached by these cloths, as was upper Burma, a thousand kilometres up the Irrawaddy. Local habits of producing at home for local consumption certainly must have continued, and some centres of production for sale

\footnotetext{
9 Laarhoven, “The Power of Cloth", p. 39.

${ }_{10}$ Reid, Southeast Asia in the Age of Commerce, vol. 2, p. 31.

${ }_{11}$ Ibid., p. 57.

${ }^{12}$ Gerrit Wusthoff (1642), in Hendrik Muller (ed.), De Oost-Indische Compagnie in Cambodia en Laos: Verzameling van bescheiden van 1636 tot 1670 (The Hague: Linschoten-Vereniging, 1917), p. 196. See also Reid, Southeast Asia in the Age of Commerce, vol. 2, p. 61 .
} 
did withstand the competition of imports. But the major textile items actually traded over significant distances in Southeast Asia in this peak period were Indian.

Decline of Indian Imports and the Rise of Indigenous Substitutes, $1660-1780$

The 1660s were a moment of profound crisis generated by a variety of different causes - warfare, a global decline in the availability of silver, climatic difficulties, and Dutch monopoly pressure. Only the VOC with its monopolistic structure was able to continue to thrive, although on a reduced scale compared with previous decades. Dutch monopolies had been established first in the buying areas, starting with the nutmeg and mace of Banda (1621), then the cloves of Maluku more broadly (complete by the 1650s), and finally and less successfully the widely dispersed pepper-growing areas. The Dutch monopoly of the vital supply of Indian cloth was never so complete, as demonstrated by the fact that they had to pay progressively higher prices for their Indian cloth. Laarhoven has been able to show that the average buying price of cloth by the VOC was 1.8 guilders per piece in the period 1619-23, 3.75 guilders in 1652-3, 4.66 in 1703-5 and 6.01 in 1723-4. ${ }^{13}$

Even though the Dutch Company was not affected as much as other traders by the crisis of the mid-seventeenth century, its sale of textiles to Southeast Asia decreased substantially. If we disregard the exceptional years 1683-5, when the VOC bought record amounts of Coromandel cloth in a vain attempt to monopolise supply and break the spirit of its rivals, the amount of cloth the VOC shipped from Coromandel to Batavia dropped steadily from a peak of two million guilders worth each year in the 1660 s, to less than 800,000 guilders in the late 1680s. The longer-term downward trend of the eighteenth century is shown in Table 1.1. ${ }^{14}$

If the Dutch suffered a downturn after the 1660s, most of their competitors in the trade to Southeast Asia were far more seriously affected. The English, Danish and French companies were excluded from the Archipelago ports controlled by the Dutch, but continued to carry significant amounts of cloth to non-Dutch ports, notably those of

${ }^{13}$ Laarhoven, "Power of Cloth", pp. 297-99.

${ }^{14}$ Reid, Southeast Asia in the Age of Commerce, vol. 2, p. 30. 
Burma, Siam, Aceh, Johor, Trengganu and Brunei. Masulipatnam and Negapatnam, which had sent 13 and 10 ships respectively carrying cloth to Southeast Asian ports in 1624, sent only a half-dozen each a decade later and had largely dropped out of the contest by the 1650s. The Gujarati vessels that had played a major role in Southeast Asia in the sixteenth century had dropped out of the trade altogether by 1700 . Chulia merchants survived in the Southeast Asian cloth trade by using smaller vessels, trading out of San Thome, Cuddalore, Porto Novo and Alambaran to ports such as Aceh, Junkceylon (Phuket), Kedah and Mergui. By establishing good relations with French, English and Portuguese country traders on the one hand and the courts of Aceh, Kedah and southern Siam on the other, they were able to trade even when their ships were outclassed. Although making the case for continuity of Coromandel cloth trading to Southeast Asia, Battacharya concludes that the biggest Chulia merchants like Sayyid Pillai Marakkayar, who died in 1755 with a fortune of 130,000 pagodas derived from trade with Aceh, Pegu, Melaka, Kedah and Junkceylon, were "perhaps not more than the shadows of the seventeenth century shipping magnates of Masulipatnam and Surat". ${ }^{15}$ Like the Bugis in the Archipelago, they filled the lower niches in the trade system as the high points were increasingly occupied by Europeans.

The failure to sell cloth in the previous quantities was explained by a chorus of Dutch merchants as based purely on the impoverishment of the former buyers. "The Javanese", one noted, "having become poor and indigent as a result of the endless wars and upheavals, have been forced to resort, more than they otherwise would, to weaving their cloths themselves, not only for their own use, but to sell to those in other places" ${ }^{16}$ Another Dutch account stressed in 1693 that "the Javanese and most eastern people" had been wealthy enough in earlier times to buy Indian textiles for their daily use, but the recent impoverishment had meant that these "have become limited to the use of the wealthy". ${ }^{17}$ Since only the VOC supplied the most expensive Gujarati

${ }^{15}$ Bhaswati Bhattacharya, "The Chulia Merchants of Southern Coromandel in the Eighteenth Century: A Case for Continuity", in Prakash and Lombard (eds.), Commerce and Culture in the Bay of Bengal, pp. 304 and 285-305.

${ }_{16}$ VOC, Letter Home of 1684, and other sources cited in Reid, Southeast Asia in the Age of Commerce, vol. 2, pp. 301-302.

${ }_{17}$ VOC, Letter Home of 8 December 1693, in W. Ph. Coolhaas (ed.), Generale Missiven van Gouverneurs-Generaal en Raden aan Heren XVII der Verenigde Oostindische Compagnie; Vol. 5 (1686-1697) (The Hague: Nijhoff, 1975), p. 639. 
silk patolas, at prices much higher than before, these became ritual heirlooms in parts of eastern Indonesia. ${ }^{18}$

For local cloth production, therefore, the late seventeenth century is one of important new beginnings. The origins of the Javanese resistdyeing process known as batik are not well understood, though the earliest written mention of the word is in a Dutch document of the 1660s. Production certainly expanded at the end of the seventeenth century, and in consequence new production techniques such as the canting (from the tool to apply wax-resist to the cloth) should probably be ascribed to this period, possibly a process of hybridisation with techniques brought from China, where wax-resist dyeing of batik type has a longer confirmed history. Laarhoven argues that both Indian weavers and Chinese traders resident in Java must have been involved. ${ }^{19}$ For the first time we find Javanese cloth appearing in the markets of South Sumatra to replace the Indian. ${ }^{20}$ Similarly, the production of South Sulawesi checked cloth, especially in otherwise dry and unproductive Selayar, expanded to supply the markets of eastern Indonesia. This became one of the key items of trade of the Bugis sailors who travelled as far as the Peninsula and Cambodia with it. Local domestic production, which had continued throughout the boom in Indian cloth, also expanded to fill the market sector. Alfons van der Kraan, portraying the scene in Java just before the transformation wrought by industrial production in the early nineteenth century, could say that Javanese "satisfied by far the greater part of their cotton cloth requirements through a domestic textile industry, an industry which involved cotton growing, spinning, weaving and dyeing.". ${ }^{21}$

This pattern was however one of low labour efficiency in international terms. Although the backstrap loom and the spinning wheel did spread widely throughout Southeast Asia, the system was designed to absorb the time of household women, and not in most cases to produce competitively for the market. In eighteenth-century Java it was believed to take a woman a month to spin a pound of cotton thread. Weaving

\footnotetext{
18 Robyn Maxwell, Textiles of Southeast Asia: Tradition, Trade and Transformation (Melbourne: Oxford University Press, 1990), pp. 355-60.

19 Laarhoven, "Power of Cloth", pp. 407-12.

20 Barbara Andaya, "The Cloth Trade in Jambi and Palembang Society during the Seventeenth and Eighteenth Centuries", Indonesia, 48 (1989), pp. 38-40.

${ }^{21}$ Alfons van der Kraan, Contest for the Java Cotton Trade, 1811-40: An Episode in Anglo-Dutch Rivalry (Hull: Center for Southeast Asian Studies, University of Hull, 1998), p. 4.
} 
was also slow on a backstrap loom, and its narrowness meant that two bands had to be sewn together to produce cloths similar to those produced by the Indians on a wood-frame loom. ${ }^{22}$

Free Trade and Commercial Upturn, 1790-1840

The Australian National University's Southeast Asian Economic History Project sought to develop a long-term time series for key Southeast Asian exports, which might help to compensate for the paucity of internal data to measure trends in the wider economy of the region. The data collected showed the exports of sugar (from Java, the Philippines and Thailand) taking off from about 1780, pepper (chiefly Sumatra) from about 1790, and coffee (Sumatra, Java, Peninsula) from 1800, after a century of negligible growth. It was estimated that the returns to Southeast Asia from these three crops totalled about SP $\$ 1.2 \mathrm{~m}$ in the 1780 s, doubling to $\$ 2.3 \mathrm{~m}$ in the early $1800 \mathrm{~s}$, and then soaring up to $\$ 6.7 \mathrm{~m}$ in the $1820 \mathrm{~s}$ and $\$ 22 \mathrm{~m}$ in the $1840 \mathrm{~s} .{ }^{23}$ While almost half of the last-mentioned figure was the product of the Dutch-controlled cultivation system in Java, the remainder was spread widely around the islands. The pepper and most of the coffee were smallholder crops outside colonial control, most of it shipped off by private American, French, Indian and Chinese vessels rather than those of the former colonial monopolists.

This rapid growth in the value of exports was at a higher rate than had occurred since the early seventeenth century. Only in the late twentieth century did higher export growth rates become common. We are entitled therefore to see the turn of the century as a markedly expansionary period resulting from the freeing up of trade, collapse of company monopolies, and smallholder expansion of pepper and coffee. One of the effects was a similar increase in demand for imports, of which cotton cloth was again the single most important item. Table 1.1 shows that the amounts of Indian cotton cloth shipped to Southeast Asia from Madras alone in 1821-22 - 721,000 pieces at a value of almost a million Spanish dollars - surpassed even the seventeenth

\footnotetext{
${ }^{22}$ Reid, Southeast Asia in the Age of Commerce, vol. 1, pp. 93-94.

${ }^{23}$ David Bulbeck, Anthony Reid, Lay-Cheng Tan and Yiqi Wu, Southeast Asian Exports since the 14th Century: Cloves, Pepper, Coffee and Sugar (Singapore: ISEAS for ECHOSEA 1998).
} 
century peak levels of Dutch imports to Batavia from the whole of India. Because of the shift to more expensive cloths, the increase was even greater in value than in quantity. Aceh also increased in importance as a destination for Indian cloth after $1766 .{ }^{24}$ Table 1.1 shows that the long decreasing phase in Indian exports to Southeast Asia ended around 1760, starting to grow again after that date and reaching unprecedented levels in the booming 1820s.

This however was a difficult period for the Indian cloth industry, seemingly suffering the problems of long-term monopolistic supply arrangements, whereby the producers were closely tied to the English and Dutch company buyers from whom they expected advances before producing. They were not well equipped to expand rapidly to fill a rise in Southeast Asian demand, and the British seemed more inclined to debate the 'protection' of Indian peasant producers from competition than to stimulate more capital-intensive production methods. ${ }^{25}$ The monopolistic approach of the East India Company ensured that Indian production remained relatively stagnant at a time when revolutionary changes were affecting the technology of cotton spinning and weaving.

It is worth quoting here the searing attack of an ardent free-market advocate, John Crawfurd, on the monopolies of the East India Company. As British Resident of Singapore in the 1820s Crawfurd had witnessed that "the most remarkable example we have of the success of free trade is exhibited in the little settlement of Singapore, a barren islet". ${ }^{26} \mathrm{He}$ pointed out that in 1818, less than ten years after the establishment of this base for free trade, its exports had reached $£ 1,387,201$, more than the value of all the East India Company's exports from Britain to India and China combined. ${ }^{27}$ Crawfurd was absolutely convinced that the reason India's trade and production had stagnated in comparison with that of Europe, the Americas and China was that,

For a full century at least, reason, common sense, and the principles of science, have been alike set at defiance to serve the purposes of a party; set at defiance, as experience has amply attested, for the virtual purpose of obstructing the commerce of England, and arresting the progress of improvement in India... We were told, in a tone of oracular authority,

${ }^{24}$ Wright, East Indian Economic Problems, p. 249.

${ }^{25}$ Ibid., pp. 192-223.

${ }^{26}$ John Crawfurd, A View of the Present State and Future Prospects of the Free Trade and Colonization of India (London: James Ridgeway, 2nd edn. 1829), p. 6.

27 Ibid., p. 6. 
and on the alleged experience of two centuries, that the trade between Great Britain and India was wholly incapable of extension; that we could furnish nothing new that the Hindoos wanted, nor the Hindoos produce any thing new which we required... in short that the Indians, hating change of every description, were enamoured of monopoly and all its consequences. $^{28}$

Crawfurd's onslaught on monopoly is fatally marred to contemporary ears by a racist tendency to attribute some of the failures of Indian production to "the slovenliness and ignorance of a semi-barbarous people", because he wanted to make the case for allowing European enterprise to galvanise the market in India. ${ }^{29}$ Yet he also asked how Indian agrarian production could be improved when "from 50 to 60 , and even 70 per cent. of the gross produce of the soil" was taken by the Company in taxation from poor peasants with little capital. ${ }^{30} \mathrm{He}$ produced impressive evidence of how the production of cotton, sugar, tobacco, pepper and iron had stagnated, grown uncompetitive, and declined in India as a result of the monopolies, at a time when more productive crop types and methods were introduced to the West Indies, Southeast Asia and the Americas enabling them to far surpass India in productivity. His argument for admitting European enterprise was racist incidentally rather than in essence. He argued that Indian prejudice and opposition to change had been outrageously exaggerated by the upholders of monopoly. ${ }^{31}$ He pointed to the saner and more productive interaction of conquering Muslims in India and Manchus in China, who were not foolish enough to think as the English Company did that if they allowed their entrepreneurs to follow the conquest they would end up dispossessing the locals, provoking them into rebellion, or worst of all, civilising them. The Company's parliamentary defenders argued, he said, that:

If we govern them well, these Indians will become wise and enlightenedrebel against us, expel us the country, and establish a native government. By way of corollary to these ominous and terrible objections, it is directly or indirectly insinuated that the East India Company is the fittest of all human instruments for governing the Indians... from all which it necessarily follows, that there is no governing India unless the administration monopolizes its commerce. ${ }^{32}$

${ }^{28}$ Crawfurd, View of the Present State, pp. 1-2.

${ }^{29}$ Ibid., p. 17.

${ }^{30}$ Ibid., p. 30.

31 Ibid., pp. 58-101.

32 Ibid., pp. 40-43. 
In the case of manufactured cotton cloth Crawfurd may be considered a visionary. He was outraged that nothing had been done to improve cotton production in India for three hundred years, while the United States, Brazil and Egypt had all soared ahead, reducing East India Company production to a mere 7 percent of British imports. ${ }^{33}$ As he saw it the export of manufactured cloth was "nearly altogether in the hands of the private trader, and so it advances from year to year", with the Company's role so lethargic as to be swiftly rendered irrelevant. Nevertheless the booming exports of 1828 had still produced only enough manufactured cloth to provide three-tenths of a yard for every inhabitant of India, two tenths for those of Southeast Asia, Persia and Arabia, and one tenth for those of China. He looked forward to a trade which would clothe the peoples of Asia with cheap British cloth to everybody's benefit. ${ }^{34}$

\section{Expansion of British Cloth from 1810}

Following the invention of Samuel Crompton's mule in 1779, the labour input needed to produce high-quality yarn from raw cotton in the British factories had by 1795 dropped to less than a hundredth of that of the older manual system. Between 1780 and 1810, British cotton cloth and yarn exports expanded more than 50 -fold in value, to nearly $£ 19$ million per year, while the ever-cheaper prices at which this cloth was sold meant that the quantities exported increased more than 200fold. The exports went initially overwhelmingly to Europe, but from 1806, when Napoleon launched his Continental blockade to exclude British trade, new markets began to be sought in the Americas, Africa and Asia. ${ }^{35}$

British manufactured cloth was relatively slow to reach Southeast Asia. The British ports of Penang (from 1786) and Bencoolen were established importers of Indian cottons, but this trade was in the hands of India-based merchants, both British country traders and Chulias, who did not hasten to shift their purchasing from Indian to British suppliers. The East India Company's exports to Asia were initially concentrated on India itself. The Company's agents in Penang as late as 1806

33 Ibid., pp. 24-25.

34 Ibid., pp. 6-8.

35 Van der Kraan, Contest for the Java Cotton Trade, pp. 8-10. 
believed that British woollens had more potential than cottons, since they were valued by upland peoples in Burma and Siam while the cotton market was well served by India. In a memo reviewing Penang's role in selling British manufactures, however, the Governor of Penang did point out that British chintzes "of a pattern suited to the Malays... of a dark ground and large figured pattern" would sell well in Penang to visiting Malay, Bugis and Acehnese vessels. ${ }^{36}$

Nevertheless the first substantial consignment of British chintzes to Penang in 1810, still much less than the quantities of woollens at a mere 1,300 pieces, was considered to exceed the demand. The patterns and colours were still not suitable to satisfy Indonesian customers who were used to the fine Indian cloths. Moreover, as Raffles pointed out the following year, "the vend of the British chintzes to the eastward is materially checked from the circumstances of several of their principal colours yielding on first washing". ${ }^{37}$ The British conquest of Java a few months later raised expectations for sales, but nevertheless the quantities of "Indian calicoes printed in England" sent out in the first two East India Company ships destined for Java were small, and sold poorly. Those intended to be of 'Bugis' patterns were "too narrow for sarongs and not fit for any other part of the native dress". ${ }^{38}$

No doubt it was the monopolistic habits of the Company itself that limited the success of this trade. Even John Crawfurd, later the great upholder of free trade and the role of Chinese intermediaries in it, became involved in his role as Resident at the court of Jogjakarta in a scheme which foisted British cloth on Javanese landholders. Some of the poor farmers expected to pay for this cloth fled the district rather than face the pressure from the government and Chinese hierarchy through which the cloth was 'sold'. ${ }^{39}$

Raffles fortunately did not favour a Company monopoly of trade in Java, and it would have been impossible to impose anywhere else. It was independent traders at both ends of the trade system who created the effective trade in British cloth to Southeast Asia, once the Java trade was declared open in 1814. Merchants based in Batavia, and China traders returning to Britain through Southeast Asia, carried the

\footnotetext{
36 Cited in Wright, East Indian Economic Problems, p. 224.

37 Raffles report to Governor-General from Malacca, 10 February 1811, cited in Ibid., p. 226.

38 Report from Batavia February 1813, cited in Ibid., p. 229.

39 Ibid., pp. 231-33.
} 
desired patterns to Britain, while the cotton traders of London followed up by sending their own agents to the East to collect details of the demand. In 1815 some Java-based merchants made direct contact with Lancashire manufacturers, while in 1819 some of those manufacturers themselves sent agents to Java. Between 1814 and 1819, Semarang's imports of British cloth to supply central Java leapt from 1,000 to 15,000 pieces. Crawfurd could write in 1820 that "The consequence of the influx of British goods has already been the entire superseding of all the finer Indian cloths formerly consumed. The only Indian cotton goods now imported are a few coarse cloths, blue and white... in which the labour of manufacture bears but a small proportion to the raw material".40

Because of its larger exposure to western trade than the rest of Southeast Asia, Java was the first to succumb in this way to European manufactured cloth. The return of Java to Dutch rule in 1816 initially did nothing to slow the flow of British cloth. By 1823 Britain controlled the Java market for imported cloth, supplying 97 percent of the total imports of cotton cloth, in excess of SP\$1.3 million in value. ${ }^{41}$ About half of this amount was brightly coloured chintzes in floral patterns already made popular by the Indian trade: "The favourite colours are red and green, and next to these yellow and brown. In short, the colours should be as bright as possible, and the pattern should occupy as much as possible of the ground". ${ }^{42}$ These were worn as coats or gowns (baju), whereas for the sarung covering the lower body, "none of our manufactures are exactly suitable". ${ }^{43}$ Almost half the British import was therefore of white cambrics, which the Javanese used as the cloth on which to draw their wax-resist (batik) patterns. ${ }^{44}$ From this point on, the primary role of the Javanese textile industry became the production of batik from European-produced plain cloth.

Elsewhere in Southeast Asia the victory of European cloth was slower coming. Singapore was relatively receptive to European cloth by comparison even with Penang, which continued older connections with the Coromandel producers for much longer. Not until 1846 did Penang

${ }^{40}$ John Crawfurd, History of the Indian Archipelago (Edinburgh: Constable, 1820), vol. 3, pp. 502-03.

${ }^{41}$ Van der Kraan, Contest for the Cotton Trade, p. 13, and Table 3.

${ }^{42}$ Crawfurd, History, vol. 3, p. 503.

${ }^{43}$ Ibid.

${ }^{44}$ Ibid., vol. 3, p. 504. 
establish a direct import of British cloth, for which its needs in the Sumatra trade had been met from Singapore. ${ }^{45}$ Even Singapore's cloth trade was more than 70\% Indian as late as 1828 (Table 1.2). The bulk of this cloth was exported to the Archipelago by small Bugis and Malay vessels which would formerly have had to pick up their Indian cloth supplies at Dutch ports, or Aceh, Riau or Kedah. In 1828-9 these vessels took SP\$109,077 worth of Indian cloth from Singapore to Borneo, $\$ 65,351$ to Sulawesi (Celebes) and $\$ 96,678$ to Sumatra, all far in excess of the amounts of British cloth. Even to Java, which received the bulk of its imports of British cloth directly from Europe, Singapore exported through these small vessels only $\$ 22,686$ of European cloth but $\$ 157,151$ of Indian cloth. ${ }^{46}$

Thereafter the change was very rapid (Table 1.2). By 1835-6 Singapore's European cloth exports had more than doubled to constitute 55 percent of the cloth traded, while the Indian cloth trade declined inexorably, to less that 30 percent in $1840-1,15$ percent in $1848-9$ and just 2.6 percent in 1865-6. Even the Archipelago destinations which had been most committed to the familiar Indian cloths were all (except Java) importing larger quantities of European cloth from Singapore by

Table 1.2. Value of European and Indian cloth exports from Singapore to Southeast Asia (Malay Archipelago, Siam and Cochin-China), 1828-66 (in Spanish dollars)

\begin{tabular}{lrrrc}
\hline Year & European & Indian & \multicolumn{1}{l}{ Total } & $\begin{array}{c}\text { European } \\
\text { percentage }\end{array}$ \\
\hline $1828-9$ & 244,776 & 616,510 & 861,286 & 28.4 \\
$1835-6$ & 562,957 & 457,583 & $1,020,540$ & 55.2 \\
$1840-1$ & 618,114 & 234,333 & 852,447 & 72.5 \\
$1843-4$ & 530,723 & 156,995 & 687,718 & 77.2 \\
$1845-6$ & 895,307 & 234,996 & $1,130,303$ & 79.2 \\
$1848-9$ & 666,082 & 103,189 & 769,271 & 86.6 \\
$1855-6$ & $1,031,265$ & 114,783 & $1,146,048$ & 90.0 \\
$1865-6$ & $4,015,535$ & 107,660 & $4,123,195$ & 97.4 \\
\hline
\end{tabular}

Source: Lin Ken Wong, “The Trade of Singapore, 1819-69”, Journal of the Malaysian Branch of the Royal Asiatic Society, 33, 4 (1960), pp. 259-64.

${ }^{45}$ Lin Ken Wong, “The Trade of Singapore, 1819-69", Journal of the Malaysian Branch of the Royal Asiatic Society, 33, 4 (1960), p. 81.

${ }^{46}$ Ibid., p. 259. 
1841-2. The rapid expansion in the consumption of British cloth in different markets is apparent from Table 1.3.

Java was the exception for reasons that have been made clear by Alfons van der Kraan. In the early years after the British occupation, European ships continued to take British cloth directly to Java, leaving Singapore only as the resort for Malay and Bugis vessels bringing in Indian cloth. When the vast size (3.3 million guilders) of the import trade in British cloth became clear to Dutch policy-makers in 1823, they decided to develop a textile industry that would cut the British out of the Java trade. This was done by stimulating the textile industry of Belgium (at the time part of the United Kingdom of the Netherlands),

Table 1.3. Growth of European cloth exports through Singapore to selected Southeast Asian markets, 1823-66 (in thousand Spanish dollars value)

\begin{tabular}{llcrrrrr}
\hline Year & $\begin{array}{l}\text { Dutch } \\
\text { Indies }^{*}\end{array}$ & Sumatra $^{* *}$ Borneo Celebes Peninsula Siam Vietnam \\
\hline 1823 & $(1,386)$ & & & & & & \\
$1828-9$ & $29(2,037)$ & 20 & 3.8 & 3.8 & 10 & 86 & 0.6 \\
$1835-6$ & $35(2,455)$ & 157 & 9 & 9 & 15 & 58 & 0.9 \\
$1840-1$ & $8(5,197)$ & 272 & 51 & 51 & 60 & 107 & 19 \\
$1844-5$ & 33 & 220 & 87 & 87 & 46 & 126 & 19 \\
$1848-9$ & 63 & 173 & 107 & 58 & 52 & 169 & 36 \\
$1855-6$ & 24 & 262 & 236 & 168 & 99 & 315 & 254 \\
$1862-3$ & & & & & & 362 & 687 \\
$1865-6$ & 524 & 927 & 328 & 171 & 121 & 1,072 & 859 \\
\hline
\end{tabular}

* In an attempt to cover the ports subject to Dutch differential tariffs, I have combined here the entries in the British record for Java, Neighbouring Isles, and Rhio (Riau Archipelago). In the years before 1844 Singapore cloth exports to Java were very low, as European cloth was generally shipped directly to Batavia. The figures in brackets are those for total cloth imports into Java (from van der Kraan), converted on the basis that 2.5 guilders are one Spanish dollar.

** This is the combination of the Singapore export category Sumatra with the categories Penang and Malacca (combined after 1847). The bulk of the cloth sent to Penang was for the northern Sumatra trade in this period, though provision of the tin-mining frontiers of Phuket and Perak is also a factor in the 1860s. Singapore exports to Malacca were very modest, and some of it was also destined for Sumatra.

Sources: Calculated from tables in Lin Ken Wong, "The Trade of Singapore, 1819-69", Journal of the Malaysian Branch of the Royal Asiatic Society, 33, 4 (1960), pp. 259-65. Figures in brackets calculated from tables in Alfons van der Kraan, Contest for the Java Cotton Trade, 1811-40: An Episode in Anglo-Dutch Rivalry (Hull: Center for Southeast Asian Studies, University of Hull, 1998). 
and imposing high duties against foreign textile imports, in open violation of the 1824 Anglo-Dutch Treaty. Since the free port of Singapore was seen as particularly threatening to Dutch control of commerce, British goods coming in from Singapore had to pay 10 percent additional duty above the discrimination already practiced on direct imports. By these means the British share of European cotton goods imported into Java was cut down from 96 percent in 1823 to 30 percent in 1829 while the Belgian industry grew rapidly to take the lion's share. ${ }^{47}$

British dismay over this development was one of the reasons why Britain changed its policy over the United Netherlands, and allowed the secession of the pro-French southern Netherlands from the Union in 1830. With the loss of its industrial base, Holland could no longer keep out British manufactures, which three years later in 1833 returned to dominate the Java market. ${ }^{48}$ The Netherlands resolved to build its own industry producing textiles for the Java market, and to entrust the matter to the state trading company, NHM, which also had the monopoly of shipping the products of the cultivation system in Java to the Netherlands.

Relations with Britain were now deemed too important to again flaunt the 1824 Treaty, which had established that the Netherlands should charge tariffs on British ships no higher than twice those on Dutch ships. In 1835 a tariff of 12.5 percent was for the first time imposed on Dutch manufactures, so that 25 percent could be charged on British goods. But at the same time the Government signed a secret arrangement with the NHM to give the proceeds of the 12.5 percent duty back to the Company, which would use it to encourage and subsidize the infant Dutch textile industry. By these means the Netherlands again moved ahead of Britain in supplying the Java market in 1836, and by 1840 it was providing 68 percent of the cloth imports, against Britain's 30 percent. The intermediary role of Singapore as a source of European cloth was virtually eliminated by a draconian tariff of 70 percent on goods of European origin transhipping in that port, which explains why Singapore's supplies of cloth to Java continued to be almost entirely Indian in origin. ${ }^{49}$ The Java market for European cloth

\footnotetext{
47 Van der Kraan, Contest, pp. 13-24; Wong, “Trade of Singapore”, pp. 40-42.

48 Van der Kraan, Contest, pp. 24-25.

49 Wong, "Trade of Singapore”, pp. 46-49.
} 
had by 1840 expanded to nearly 13 million guilders or SP $\$ 5 \mathrm{~m} .{ }^{50}$ This made Java the largest foreign cloth market in Southeast Asia, and ensured that the great majority of Javanese were dressed in cloths of European manufacture.

The Mainland states of Southeast Asia had also imported Indian cloth since the sixteenth century, and similarly seen some diminution of the flow in the 'long eighteenth century'. Francis Light estimated the consumption of Indian textiles in Siam in 1789 at only SP\$60-80,000 a year, mostly reaching the Chaophraya valley and the capital after portages across the Peninsula from ports such as Tenasserim, Junkceylon (Phuket) and Kedah..$^{51}$ This certainly picked up during the commercial upturn described above, since by 1821 Penang alone was sending over SP $\$ 200,000$ worth of Indian cloth to Siam by these Peninsula routes as well as by sea. ${ }^{52}$ In the 1820 s Singapore took over the trade by sea, as the Bangkok-based Chinese junks journeyed no further than Singapore for their supplies of cloth and other articles of import. In 1828-9 the SP $\$ 174,507$ worth of textiles shipped from Singapore to Siam had a slightly larger share of Indian than European cloths, but thereafter the European cloth expanded rapidly while the Indian share faltered to be less than 10 percent by 1841 (Table 1.3). ${ }^{53}$ The million dollars worth of British cloth exported by this route in 1865 represented the bulk of Siam's cloth imports, though the Chulias and Penang supplied a declining trickle across the more arduous Peninsula routes. Singapore constituted 43 percent of Siam's import trade in 1857 and 60 percent in 1866, and most of the remainder was with China. ${ }^{54}$ Lancashire had by then come to supply most of Siam's clothing needs, albeit to a lesser extent than Java.

Vietnam before the French conquest was much less inclined to succumb to cloth from the west, manufactured or not. Its model of dress was China, and Chinese silks had dominated its textile imports for centuries. Vietnam opened its southern ports to western trade in 1821, but as with the Siamese case, it was Vietnamese 'topes' and Chinese

${ }^{50}$ Van der Kraan, Contest, pp. 52-53.

51 "A brief account of the several countries surrounding Prince of Wales's Island with their production. Received from Francis Light" (1789), in H. P. Clodd, Malaya's First British Pioneer: The Life of Francis Light (London: Luzac, 1948), Appendix II, p. 156.

${ }_{52}$ Wong, "Trade of Singapore", p. 135.

53 Ibid., p. 264.

${ }^{54}$ Ibid., p. 152. 
junks that almost exclusively operated the trade from Singapore. The import trade was not seen as a means to clothe the poor, as elsewhere, but to provide the needs of the elite and the state. Hence British woollens were at first of greater interest than cottons for the traders, and for the royal mission sent to Singapore in 1825 , notably to furnish protective clothing for the army ${ }^{55}$ Indian cloth imports were nil in most years, while the import of European cloth rose only to SP $\$ 157,784$ in 185758 , the last year before French intervention in the south. That intervention, which had taken over the southern provinces around Saigon by 1867, enormously boosted the import of European cloth manufactures from Singapore. These were worth SP $\$ 682,532$ in $1862-3$ and SP $\$ 858,628$ in $1865-66 .{ }^{56}$ Though a five-fold increase over the 1850 s, this still represented a significantly lower rate of consumption than in Siam or the Archipelago.

\section{Conclusion}

Much work remains to be done on the impact of this revolution in consumption patterns in Southeast Asia, as in other parts of the world. It transformed within a generation the indigenous textile industry from a subsistence cottage industry to provide the poor, to a craft production for elite consumption and for special occasions. The cheapness of the new cloths ensured that the everyday clothing of Southeast Asia came to be produced in the factories of Lancashire.

${ }_{55}$ Ibid., pp. 154-58.

56 Ibid., p. 263. 
$-978-90-47-42997-5$ 


\title{
CLOTHS OF A NEW FASHION: INDIAN OCEAN NETWORKS OF EXCHANGE AND CLOTH ZONES OF CONTACT IN AFRICA AND INDIA IN THE EIGHTEENTH AND NINETEENTH CENTURIES ${ }^{1}$
}

\author{
Pedro Machado
}

\section{Introduction}

Over the past two decades there has been a perceptible growth in interest in the history of the Indian Ocean as an arena of integrated economic, political and cultural interaction. Despite some differences, historians appear to be in general agreement that the 'essential' unity of the Indian Ocean was determined and maintained by the ebb and flow of intersecting social and cultural circuits of maritime exchange. They see the Indian Ocean as constituted by distinct regions that, while they may have contained particular networks and circuits of exchange that catered for particular markets, overlapped and intersected in complex webs of economic and cultural relationships to create an integrated 'inter-regional arena' (Map 2.1). ${ }^{2}$

At the centre of these circuits of exchange, which connected South Asia to spheres beyond the subcontinent, were textiles. For centuries, the Indian subcontinent had produced and supplied textiles of varying quality and size to markets that stretched beyond the Indian Ocean, from north-western Europe and West Africa, to the eastern

1 This chapter has benefited from discussions at the GEHN Conference on "Meanings of Trade: Textiles in the Early Modern World", Pune, December 2005, especially the comments of W. G. Clarence-Smith, Prasannan Parthasarathi, and Lakshmi Subramanian. I thank also Om Prakash and Krista Maglen for their close reading of a longer and more unwieldy version. Any remaining errors are mine alone.

${ }^{2}$ Frank Broeze (ed.), Brides of the Sea: Port Cities of Asia from the 16th-20th Centuries (Sydney: New South Wales University Press, 1989), pp. 3, 21, quoted in Michael Pearson, The Indian Ocean (London and New York: Routledge, 2003), p. 13; Sugata Bose, "Space and Time on the Indian Ocean Rim", in Leila Tarazi Fawaz and C. A. Bayly (eds.), Modernity \& Culture: From the Mediterranean to the Indian Ocean (New York: Columbia University Press, 2002) p. 368; Id., A Hundred Horizons: The Indian Ocean in the Age of Global Empire (Cambridge, Ma.: Harvard University Press, 2006). 


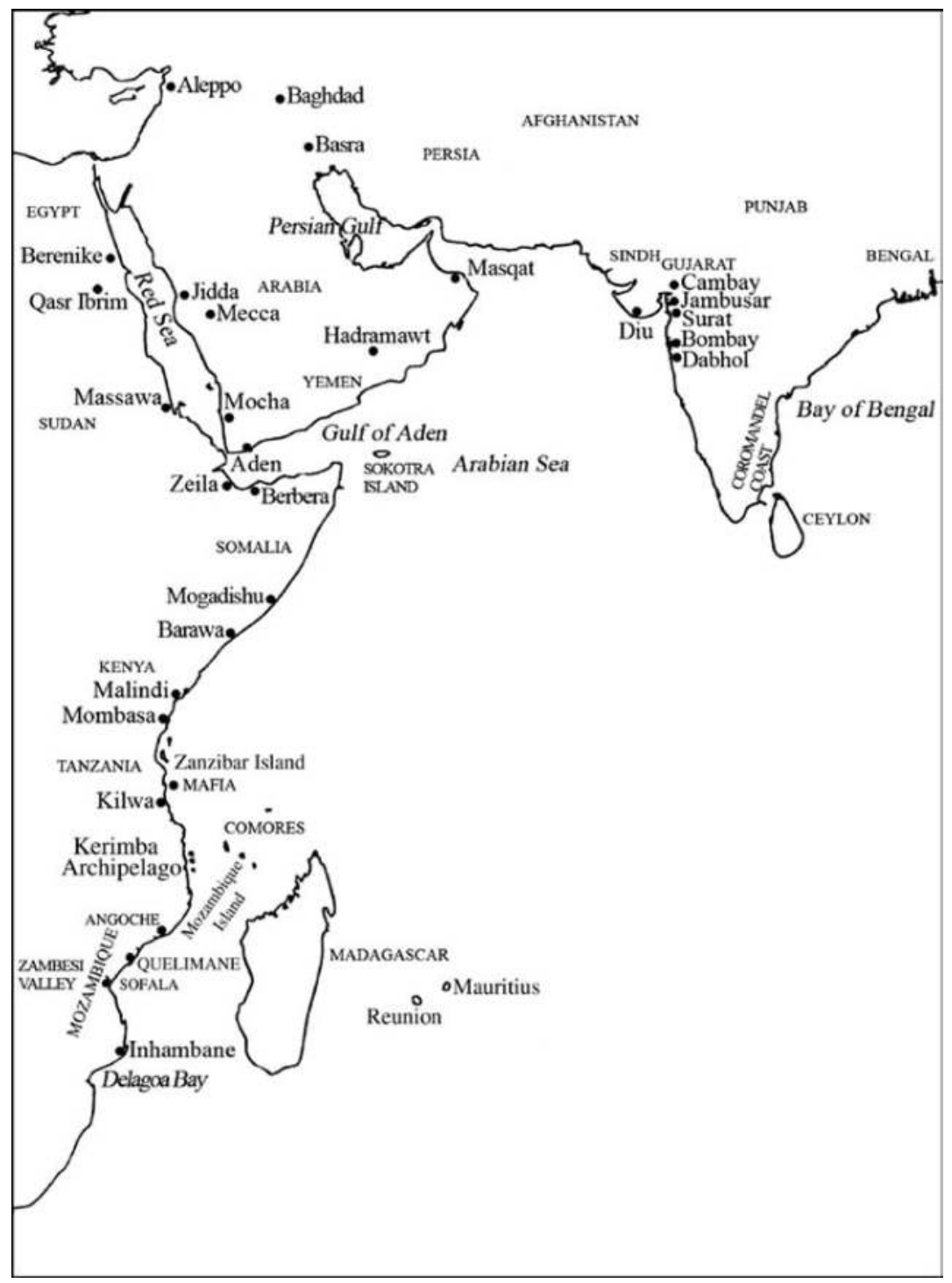

Map 2.1. The western part of the Indian Ocean in the early modern period. 
Mediterranean, Southeast Asia and the Americas. This global flow of textiles was sustained by high productivity and low prices, and in turn fuelled by consumerism. ${ }^{3}$ Within the region of the western Indian Ocean, a stream of textiles linked South Asia to East, East-Central and South-East Africa, bringing African consumers into relation with South Asian producers in intimate and complex 'connected histories'. This intra-regional engagement, linking Indian weavers with African consumers, was mediated in critical ways by networks of Indian mercantile groups, chief among them the Gujarati Vāniyā, whose presence in the Indian Ocean was of longstanding duration.

In this chapter I explore the particularities that structured the chains of relation connecting Gujarat in northwestern India to East-Central and South-East Africa between the second half of the eighteenth and first half of the nineteenth century. Gujarat has been identified as "a land of the Indian Ocean as well as of India" which occupied until the nineteenth century a central place in western Indian Ocean commercial systems. ${ }^{5}$ By contrast, the place of Africa has tended to be marginalised in general accounts of the history of the Indian Ocean. Regarded as being of limited importance to the structure and dynamics of oceanic exchange, East, East-Central and other coastal Africans often warrant only passing mention. This chapter suggests that one way to redress this partial view of western Indian Ocean history and bring Africans into the narrative is to explore the interrelation between EastCentral and South-East Africa, and Gujarat and western India as regions with connected Indian Ocean histories. ${ }^{6}$ I thus emphasise the importance of uncovering links of trans-local connection for developing a better understanding of the dynamics that shaped relationships in this oceanic space.

This chapter considers the place of Gujarati Vāniyā networks operating from the territories of Diu in Kathiawar (western Gujarat), and to

\footnotetext{
3 Prasannan Parthasarathi, "Global Trade and Textile Workers, 1650-2000" (Unpublished paper presented at "Globalization and Trade Conference", International Institute of Social History, November 2004).

${ }^{4}$ David Ludden, "Presidential Address: Maps in the Mind and the Mobility of Asia", Journal of Asian Studies, 62, 4 (2003), p. 1068.

${ }^{5}$ Sanjay Subrahmanyam has recently referred to Gujarat as the "linchpin" of western Indian Ocean trade. See Sanjay Subrahmanyam, "Of Imârat and Tijârat", Comparative Studies in Society and History, 37, 4 (1995), pp. 750-80.

${ }^{6}$ I have drawn inspiration here from Sanjay Subrahmanyam, Explorations in Connected History (New Delhi: Oxford University Press, 2005).
} 
a lesser extent Daman located south of Surat, in the chains that connected African consumers and Indian producers. ${ }^{7}$ It was the embeddedness of Gujarati merchants in local, regional and international networks in both India and Africa - underpinned by the circulation of financial, social and cultural capital - that was key to their success. ${ }^{8}$ Gujarati merchants (both Hindu and Muslim) had been prominent in the Indian Ocean for centuries, and though their relative importance changed over time, they played one of the most important integrative roles in the economy and culture of the ocean as mediators of crosscultural and cross-regional contact. ${ }^{9}$

The period from the 1750 s to the 1840 s is seen as a moment of 'reconfiguration' for the Indian Ocean networks and the role of India within them due to the encroachment of Empire. I argue, however, that rather than collapsing under the weight of colonial might, South Asian social and economic networks negotiated the process of imperial reach and were successful in maintaining their engagement across and between competing imperial spaces in the ocean. Far from being marginalised, these already existing networks of circulation remained instrumental in connecting local and regional systems in South Asia and, more broadly, structure global systems of material, cultural and social exchange. ${ }^{10}$

Gujarati merchants enjoyed a comparative advantage over European merchants and states, as well as 'Swahili' and 'Arab' merchants because of the tightly-controlled hold they exercised over the importation into EastCentral and South-East Africa of cotton textiles produced in western India. These textiles were in great demand as exchange commodities

\footnotetext{
7 Vāniyā are Hindu and Jain merchant communities. For a fuller discussion of the term see Pedro Machado, "Gujarati Indian Merchant Networks in Mozambique, 1777c.1830" (Unpublished PhD Thesis, School of Oriental and African Studies, University of London, 2005), ch. 2.

${ }^{8}$ I borrow this formulation from Amira K. Bennison's discussion of Islamic brotherhoods in "Muslim Universalism and Western Globalization", in A.G. Hopkins (ed.), Globalization in World History (London: Pimlico, 2002), pp. 74-97.

9 An overview of the place of South Asian and Gujarati merchant networks is provided in Machado, "Gujarati", ch. 2; Bose, "Space”, p. 374 and Id., Hundred Horizons; Philip D. Curtin, Cross-cultural Trade in World History (Cambridge: Cambridge University Press, 1984); Claude Markovits, The Global World of Indian Merchants, 1750-1947 (Cambridge: Cambridge University Press, 2000). By the eighteenth century this role was increasingly confined to the western Indian Ocean for reasons I discuss in "Gujarati."

${ }_{10}$ The notion of circulation, useful for understanding how a merchant network operated, is borrowed from Markovits, Global World.
} 
in the African trade of the interior and were regarded as the "currency that is accepted in ports". ${ }^{11}$ Gujarati textiles had a critical function in African material exchange and relations because of their use as primary measures of value for which ivory, slaves and other commodities were exchanged across the Indian Ocean in areas that effectively constituted cloth currency zones of contact. ${ }^{12}$ This function was the result of the particular social, cultural, political and symbolic meanings which cloth attained through complex processes of domestication. In their journey from a weaver's loom in India to the hands of a local ruler, trader or patron-client in Africa, a piece of cloth underwent a transformation as it became inscribed with meanings that reflected local articulations of taste.

I address the question of African consumerism and the broader processes it affected across the Indian Ocean. A central argument is that demand was shaped by the local particularities of African consumer tastes and, as such, dictated the varieties of textiles that entered the East-Central and South-East African markets. ${ }^{13}$ Thus, far from being marginalised in this commercial nexus, African consumers were able to negotiate the terms of trade and their engagement in relations of exchange of which they formed an integral part.

African demand had an influence beyond the continent as it stimulated production in a specific locale in Gujarat, Jambusar, where the bulk of the western Indian textiles for the African markets were manufactured. In order to remain competitive, the Vāniyā needed to supply this market with textiles which were in demand or in fashion. They thus had to ensure that information on the types of cotton textiles which were sought in each trading season was always kept up-to-date. In identifying the influence of African consumer taste, this chapter contributes to the growing appreciation that Africans, historically 'under-considered populations' in narratives of regional and global interconnectivity, exerted leverage in defining material relationships through processes shaped by 'direct reciprocities', a view that is

${ }^{11}$ Arquivo Hístorico Ultramarino (hereafter AHU), Moç., Cx 46 Doc 31, de Albuquerque to Crown, 12 August 1783.

${ }_{12}$ Richard Roberts, "Guinee Cloth", Cahiers études africaines, 32, 4 (1992), pp. 597-627; Machado, "Gujarati”.

${ }^{13}$ A similar point has been recently argued by Carolyn Keyes Adenaike for West Africa. See Carolyn Keyes, "West African Textiles, 1500-1800", in Maureen Fennell Mazzaoui (ed.), Textiles (Aldershot: Varorium, 1998), pp. 251-61. 
challenging conceptions of seemingly marginal actors as ineffective in influencing larger frameworks of economic exchange. ${ }^{14}$

Equally important, the capacity of the Vāniyā to supply this market relied on regular access to centres of textile production in western India to which information on textile types could be transmitted annually. Far from exercising control over the supply and production of textiles for the African markets, however, Indian merchant procurement of these supplies was secured through middlemen with whom they agreed oral contracts on an annual basis. Merchants thus had to negotiate contracts regularly with brokers who were ultimately responsible for acquiring textiles from weavers, and for providing the merchants with their export cargoes. The trade in Indian textiles thus depended on the dynamics of the interrelation between both demand and supply. In order to trade successfully, Gujarati merchants needed to balance the intricacies of these economic factors through networks of information and agents in both spheres of their operations in the Indian Ocean. It is here argued that it was the ability of these merchants to connect both ends of this transoceanic commercial nexus which gave them the advantage over competitors.

\section{India, Cloth and the Indian Ocean}

For centuries cotton and silk textiles produced in India were used in commercial exchanges throughout the Indian Ocean and beyond. Among the greatest strengths of the Indian textile industry was its specialisation in serving distinct networks of long-distance trade, its adaptability and its capacity for product differentiation. These resulted in the creation of extensive regional markets that made the Indian textile sector unique among Asian manufacturing industries. ${ }^{15}$ The main production areas which specialised in the manufacture of cotton textiles for export were located in Gujarat, the Coromandel coast, Bengal,

14 Jeremy Prestholdt, "On the Global Repercussions of East African Consumerism", American Historical Review, 109, 3 (2004), pp. 755-81; Id., Domesticating the World: African Consumerism and the Genealogies of Globalization (Berkeley: University of California Press, 2008).

${ }^{15}$ Roy, "Introduction", in Ibid., pp. 11-32; Chaudhuri, The Trading World of Asia and the English East India Company 1660-1760 (Cambridge: Cambridge University Press, 1978), p. 205; R. J. Barendse, "Reflections on the Arabian Seas in the Eighteenth Century", Itinerario, 25, 1 (2001), pp. 25-49; Pearson, Port Cities. 
the Punjab and Sind. ${ }^{16}$ Gujarati textiles were traded extensively to Southeast Asian markets, but it was to the western Indian Ocean that the bulk of its cotton textiles were sent, particularly to the markets of the Red Sea and Persian Gulf, and to a lesser degree those of East Africa.

The technical advantages enjoyed by Indian handicraft production (such as the development of multiple shafts and peddles which allowed weavers to maximise productive capacity), coupled with the availability of relatively inexpensive dyes such as indigo, and skilled labour engaged in all the stages of textile production from cotton growing to the spinning of thread, printing and weaving, resulted in an extremely efficient and highly competitive industry with which no other region could compete in terms of price or quality until the development of machineproduction in Europe in the latter half of the eighteenth century. ${ }^{17}$

When the Portuguese arrived on the East African coast in the late fifteenth century, they soon established how far participation in coastal trade relied on Gujarati textiles. These textiles served a critical and widespread function as currency in a largely non-monetized world. But cloth was not used solely for its exchange value: it also had 'use value,' "as a means of bestowing moral and social qualities, of marking both high and low status". ${ }^{18}$ The conspicuous consumption of textiles was as important as their political use in rituals of exchange which fostered and underpinned ties between people. Cloth givers could, for instance, ensure that receivers were committed "to loyalty and obligations in future", 19 and rulers legitimized the power of successors or regional chiefs in investiture ceremonies by using selectively chosen imported textiles. Africans used imported and local textiles in ways which were socially, politically, economically and symbolically sophisticated.

${ }^{16}$ K. N. Chaudhuri, "The Structure of Indian Textile Industry in the Seventeenth and Eighteenth Centuries", in Tirthankar Roy (ed.), Cloth and Commerce (New Delhi: Sage, 1996), pp. 40-4. See also Tapan Raychaudhuri and Irfan Habib (eds.), The Cambridge Economic History of India; Vol. I. 1200-1750 (Cambridge: Cambridge University Press, 1982), p. 270.

${ }^{17}$ Lotika Varadarajan, "Syncretic Symbolism and Textiles: Indo-Thai Expressions", in Om Prakash and Denys Lombard (eds.), Commerce and Culture in the Bay of Bengal 1500-1800 (New Delhi: Manohar 1999), pp. 361-82; Pearson, Merchants, pp. 97-98.

${ }_{18}$ Mark Horton and John Middleton, The Swahili (Oxford: Blackwell, 2001), pp. 111-12.

19 Annette B. Weiner and Jane Schneider, "Introduction", in Annette B. Weiner and Jane Schneider (eds.), Cloth and Human Experience (Washington \& London: Smithsonian Institution Press, 1989), p. 3; Richard Roberts, Two Worlds of Cotton (Stanford: Stanford University Press, 1996). 
This should not obscure the widespread African textile production that existed on the coast, islands and interior of East Africa. There was a vibrant weaving industry before the sixteenth century which served local demand, and textile production took place in many East African towns between Mogadishu in the north and Sofala in the south. Cotton was grown at Kilwa, and artisans in Sofala, Angoche and the Kerimba archipelago were known to weave cotton textiles which were used in local and long-distance trade..$^{20}$ In South-East Africa local hand-woven cotton cloth was worn by women in the Delagoa Bay area. ${ }^{21}$ It is within the broader context of local textile production that we need to place Indian imports and see them as supplementing local supplies in this early period. ${ }^{22}$ Still, there can be little doubt that Indian textiles were regarded as integral to the nexus of the East African textile trade which stretched from the northern coast down to the Zambezi Valley where they were consumed in their original state (i.e. the design was not altered in any way) by consumers who could afford the foreign imports. ${ }^{23}$ From the coast, they were then sent directly into the interior.

Although East Africa was not the largest export market for Gujarati textiles in this period, the greatest number going to West Asian markets, the way this trade operated provides an illuminating example of the particular desirability of Indian textiles, and the ability of Indian merchants and producers to maintain supply. The acknowledgement that at least until the first quarter of the nineteenth century, if not later, indigenous merchants controlled the majority of textile exports from India - and that consumer tastes in Indian Ocean markets were important for Indian labour and its productive capacity - is one which will gain greater acceptance as historians come to appreciate more fully the true place of respective mercantile interests in the subcontinent's textile trade.

${ }^{20}$ Pearson, Port Cities, p. 122; Prestholdt, "As Artistry Permits and Custom May Ordain", Program of African Studies Working Papers (Northwestern University), 3 (1998), p. 26; A. Rita-Ferreira, African Kingdoms and Alien Settlements in Central Mozambique (c. 15th-17th Cent.) (Coimbra: Departamento de Antropologia, Universidade de Coimbra, 1999), pp. 116-19.

${ }_{21}$ Patricia Davison and Patrick Harries, "Cotton Weaving in South-East Africa: Its History and Technology", in Dale Idiens and K.G. Ponting (eds.), Textiles of Africa (Bath: Pasold Research Fund, 1980), pp. 175-92.

22 Pearson, Port Cities, pp. 124-25.

${ }^{23}$ Prestholdt, "As Artistry Permits". 


\section{Contours of African Consumerism}

The dominance of Gujarati textiles in the import trade of East and East-Central Africa continued into the eighteenth century as, particularly the latter area, became commercially important for the Portuguese possessions in western India after the Portuguese had suffered significant territorial losses to the Dutch in the Indian Ocean. ${ }^{24}$ For Gujarati Vāniyā merchants this provided the possibility to expand their textile exports to a region where demand for Indian manufactures had grown once supplies through the northern East African coast no longer fed the African markets. It also enabled Gujaratis to secure their control over the carrying trade in these manufactures. Although in previous centuries Indian textiles had been overwhelmingly procured by Gujarati merchants, they were sent for the most part to East-Central and South-East Africa on Portuguese (Crown) vessels due to regulations aimed at monopolising cross-oceanic trade. From the eighteenth century this changed markedly. In the context of a shift in state policy away from mercantilist underpinnings to one that increasingly favoured a free trade regime, the Vāniyā assumed complete control over the direct shipment of textiles to Africa, and thus were able to command a powerful presence in its economy in an openly competitive environment.

Evidence relating to textile exports to East-Central and South-East Africa improve considerably from the 1750 s as Portuguese State efforts to quantify this trade demanded more detailed records. Imports of textiles, at this time under State contract, into Sena (in the Zambezi Valley) alone, to which the greatest number of textiles were sent, amounted to 120-160,000 pieces per year, ${ }^{25}$ while imports for the rest of the territory were estimated to amount to c. 80,000 pieces (200 bares). However, it has been suggested that in a year like 1753, when "the introduction of free trade goods in the Rivers of Sena (Zambezi Valley) in relation to Crown goods was considerably higher", the numbers of textiles that

${ }^{24}$ Pearson, "Indians in East Africa", in Rudrangshu Mukherjee and Lakshmi Subramanian (eds.), Politics and Trade in the Indian Ocean World (Delhi: Oxford University Press, 1998), p. 242.

25 "Pieces" was the name given to bundles of cloths brought to Mozambique Island; however, pieces were sorted and arranged into bars of 400 cloths and it was these that were "the currency of the land". So, the number of "pieces" discussed here actually represented a far higher number of cloths which were eventually transported into the African interior. 
entered East-Central Africa from India reached an estimated half a million pieces. ${ }^{26}$ With the opening of trade to Crown subjects in the 1750 s, the import of Gujarati textiles may have risen to between $800,000-1,000,000$ pieces annually. ${ }^{27}$ Although probably an overestimate, an increase in the number of textiles brought to the coast is discernible from around this time. It is more likely that annual imports of Indian textiles stood at 300,000-500,000 pieces from the middle of the century. ${ }^{28}$ Their supply depended on Vāniyā merchants - either active in Gujarat or on Mozambique Island (which served as an entrepôt through which textiles entered the African interior) - to such an extent that a Portuguese official was led to comment that "when these [Indians] fail [in their textile imports] will be when there is no longer any cotton in the world". ${ }^{29}$

Using this evidence it is possible to assess the quantitative impact which the Portuguese changes to the customs regime in 1786 had on exports. ${ }^{30}$ The average number of pieces exported in 1787-89 was just over 381,000 , confirming estimates that place the trade of textiles through the island-entrepôt at around 360-400,000 pieces per year to the end of the century. ${ }^{31}$ Exports from Daman, a secondary port through which Jambusar textiles were shipped to Africa, are difficult to ascertain before the nineteenth century, but shipping lists

${ }^{26}$ Alexandre Lobato, Evolução Administrativa e Economica de Moçambique 1752-63 (Lisbon: Agência Geral do Ultramar, 1957), p. 258. This is drawn from "Oficio de 20 de Novembro de 1753..." published in Memoria e Documentos acerca dos Direitos de Portugal aos Territorios de Machona e Nyassa (Lisbon: Imprensa Nacional, 1890), pp. 166-67.

${ }_{27}$ Fritz Hoppe, A África Oriental Portuguesa no Tempo do Marquês de Pombal (1750-77) (Lisbon: Agência-Geral do Ultramar, 1970), p. 219.

${ }_{28}$ This is most clearly seen in extant textile export lists, which show that between 1780 and 1784 a total of approximately 1,800,000 pieces of assorted textiles were sent to Africa, most of which were supplied through Diu. These figures have been calculated from tables contained in Historical Archives of Goa (thereafter HAG), CD 999, "Mappa Geral ... 1780, 1781, 1782, e 1784", n.d. See also CD 1003, Indian merchants to Governor, 25 April 1788; and Lobato, Evolução.

${ }^{29}$ AHU, Moç., Cx 29 Doc 56, Pereira do Lago to Crown, 12 August 1769.

${ }^{30}$ Reform of Portuguese imperial commerce was a feature of the second half of the eighteenth century. The changes introduced to import and export tariffs in the 1780s went further than previous efforts, and reflected the desire of the Portuguese State to establish liberalized commercial conditions in the Portuguese Asian empire, and thus stimulate trade and consequently increase revenue. For details see Machado, "Gujarati".

${ }^{31}$ HAG, CD 1001, “Mappa...”, 16 June 1789. There was a drop in exports towards the end of the century that was likely related to French corsair activity in the Mozambique Channel. For details see Machado, "Gujarati”. 
for the end of the century suggest that they were likely to be up to 200,000 pieces a year. ${ }^{32}$

The large numbers of Gujarati cotton textiles which began entering African markets in the final quarter of the eighteenth century became of growing concern to the Portuguese authorities, who sought to achieve full regulatory control over the trade throughout the territory. Besides attempting to control textile imports from India, the Portuguese also sought to exert control over their distribution with a view to determining price and thus to curbing inflationary pressures that they deemed to have been caused by unrestricted textile importation. The latter had already become a matter of grave concern in the 1760s, leading the Governor-General Pereira do Lago to complain bitterly about the 'damage' being done to trade by the "free introduction of cloths into the interior". His logic was that if it were possible to prohibit merchants from sending textiles into the interior, then African traders would be forced to travel and bring their goods to towns and fairs where exchange could be better regulated, and Crown profits more securely obtained..$^{33}$ The attention of Portuguese officers began to focus increasingly - particularly from the 1770s - on Gujarati merchant networks as they were the importers of the vast bulk of textiles that entered East-Central and South-East Africa. The Portuguese were concerned with maintaining exchange price levels as stable as possible between imported Gujarati cotton cloths and ivory ${ }^{34}$ However, despite their attempts to control the entry of piecegoods into Africa, and also the free movement of the Vāniyā and their African agents in the African interior, the Portuguese were unable to stop variable exchange rates outside Mozambique Island. ${ }^{35}$

Consumer demand for Gujarati cloths was high throughout EastCentral and South-East Africa, and the market was able to absorb large imports especially in the final quarter of the eighteenth century. Textile demand alone from the Portuguese factories of Quelimane, Sena and

32 HAG, CDm 1057, da Costa, Caetano Coutinho, Javer Khushal et. al to Governor, ant. 21 April 1784. On shipping lists see, for example, AHU, Moç., Cx 69 Doc 95, “Carga..., March 1794; Cx 73 Doc 34, “Carga..., 11 March 1796.

${ }_{33}$ AHU, Moç., Cx 25 Doc 91, de Mello to Juiz Ordinario, 4 December 1765.

34 This relationship was expressed in the bar de fato, a standardised measure of weight. The bar was approximately equal to 248 kilograms on Mozambique Island and to 294 kilograms in the Zambesi Valley.

35 AHU, Moç., Cx 86 Doc 29, da Cunha to Souza Coutinho, 9 October 1800. For further details, including accusations that Gujaratis were importing "falsified" cloths (textiles that did not conform to official size and quality specifications), see Machado, "Gujarati". 
Tete in the early 1780 s stood on overage at $80-100,000$ pieces a year, or 200,000 if one includes private Portuguese trade. ${ }^{36}$ Despite occasional and ill-informed protestations that the African market was small, ${ }^{37}$ officials in Mozambique agreed (mostly reluctantly) over the extent to which Gujarati textiles were needed for purposes ranging from acquiring cloths for sagoates, ${ }^{38}$ to payment of garrisons whose soldiers could not trade for even the most basic provisions without cloth. ${ }^{39}$ Indeed, officials openly admitted that Gujarati textiles were the 'currency' of the region. The Portuguese complaints about markets being 'flooded' with cotton cloths reflects a poor understanding of consumer demand, or frustration at how distribution networks had been disturbed, rather than simple oversupply. ${ }^{40}$ Their complaints reveal a concern about price stability caused by the difficulties faced by both official and private traders in an open market. They were unable to compete with Gujarati merchants without the imposition of monopoly trading practices, or without measures to restrict Indian trade, such as prohibiting the contact of merchants with - and movement in - the African interior. ${ }^{41}$ Vāniyā merchants were the commercial lifeblood of the economy of Mozambique and, as they provided an invaluable contribution to Portuguese Royal income through customs payments, any attempts to control or undermine their trade were likely to fail.

Further, the Vāniyā possessed a well-developed understanding of the nuances of demand in the African textile market. This was gained primarily through sustained contact with local agents and traders in

${ }^{36}$ AHU, Códice 1345, fl. 77, "Portaria..., 13 May 1782; AHU, Moç., Cx 36 Doc 3, "Mappa...", n.d. [but 1781]. For cloths ordered by the factories of Sena, Inhambane and Lourenço Marques in 1786, see Cx 52 Doc 93, "Fato...”, 30 October 1786.

${ }^{37}$ See, for example, AHU, Moç., Cx 75 Doc 61, de Souza to Tenente General, 22 October 1796.

38 These were tribute payments made to African rulers in order to be allowed to trade in or through a particular area. See, for example, AHU, Moç., Cx 33 Doc 27, Tenente General to Governor-General, 8 March 1780; Cx 38 Doc 59, Melo e Castro to Tenente General, 6 June 1782.

${ }^{39}$ It was estimated in 1778 that "for the annual payment of the garrisons of the entire territory" it was necessary to spend 100,000 cruzados "for the purchase of cloths from Asia on account of the Royal Treasury". See Montaury, "Moçambique, Ilhas Querimbas ... c. 1788", in António Alberto de Andrade, Relações de Moçambique Setecentista (Lisbon: Agência Geral do Ultramar, 1955), p. 346.

40 AHU, Moç., Cx 38 Doc 14, "Memoria...", 24 January 1782; Cx 55 Doc 35, Mello e Castro to Governor-General, 27 September 1787; Cx 30 Doc 68, "Oficio...", 10 August 1772; Cx 42 Doc 44, Ferreira Nobre to Governor-General, 7 June 1783.

${ }^{41}$ Restrictions had been placed on Indian movement and trade earlier but these intensified in the 1780s for reasons discussed in Machado, "Gujarati". 
both Makuana ${ }^{42}$ to which the Vāniyā had been trading for much of the eighteenth century and in Sena in the Zambesi Valley where from the late 1770 s they established a presence. ${ }^{43}$ Gujarati merchants were careful therefore to ensure that the makeup of their textile piecegood imports corresponded to demand in a particular season and/or region. Valuable information about tastes was relayed to them by these knowledgeable agents who were important figures in the chains of relation linking intraregional exchange and local consumers. ${ }^{44}$ Similar to caravan leaders in the later nineteenth-century East African interior, ${ }^{45}$ the patamares and vashambadzi maintained direct contact with consumers and thus developed indepth knowledge of the contingencies of local demand. The information they collected in the interior, including an understanding of the complexities of exchange equivalencies, was critical not only to the success of their own trade but also to that of the Vāniyā who sought, therefore, to maintain direct contact with African agents. The Vāniyā appear to have understood well how indispensable this contact was for them, as demonstrated starkly in the following Portuguese commentary from 1781:

... [Indian merchants] compete ... to give cabayas that are in fashion, toucas ... ordering them especially from Diu with new designs that are communicated to their partners in the monsoons, from which we can see that the Africans, seeing these painted cloths of a new fashion, every year hurry to the [Indian merchants] and not to any Christian [merchants], and when one [Christian] by chance does appear he leaves disappointed and will certainly not return on another occasion. ${ }^{46}$

The Portuguese suggested that Gujaratis were unfairly 'creating' demand through the introduction of 'new cloths' but while this may

${ }^{42}$ Called patamares or mercadores volantes, these were African mixed-race trading agents commonly of slave status who traded on the mainland opposite Mozambique Island.

${ }_{43}$ These were the vashambadzi (sing. mushambadzi), i.e. 'professionalised' caravan leaders also of slave status who were responsible for organising trade caravans into the interior of the Zambesi Valley.

${ }_{44}$ AHU, Moç., Cx 36 Doc 35, Pereira Nobre, de Menezes, et. al to Senado da Camara, 14 July 1781.

${ }^{45}$ Jonathan Glassman, Feasts and Riot (Portsmouth, NH: Heinemann, 1995); Stephen J. Rockel, Carriers of Culture: Labor on the Road in Nineteenth-Century East Africa (Portsmouth, NH: Heinemann, 2006); Prestholdt, "Global Repercussions"; Id., Domesticating the World.

${ }^{46}$ AHU, Códice 1345, fl., 44v, "Resposta..., 2 July 1781. See also Cx 36 Doc 35, Punji Velji, Laxmichand Motichand et alt. to Juiz Ordinario, 3 August 1781. The emphasis is mine. 
contain some truth, it is also an admission of being unable to compete with either the distribution networks which the Indians had in place or the knowledge they possessed of the market. The latter was particularly indispensable because consumer tastes were not uniform throughout the territory in which Gujarati textiles were distributed. For example, at the Manyika fair of Masekesa (located south-west of Sena on the Zambesi River) it was noted with some surprise how cloths which were in demand a few years earlier no longer found a market:

... previously the best cloths were capotins and ardians, which generated a great deal of profit because they were not discounted and were cheaper, and now at this fair nothing is sold other than zuartes and some dotins, which are good quality cloths, that is, the mossambazes [mushambadzi] do not want to take any other quality cloth ... [because it] serves for [the acquisition of] provisions only... ${ }^{47}$

Regional differences also meant that merchants who attempted to supply cloths had to possess a good knowledge of the market. The following relates to the Delagoa Bay area and underlines the importance of being keenly aware of changes in interior markets:

... an abundance of cloths caused the Africans to not want half ardians in exchange for provisions which are needed by the army, and only serve for the ivory trade in the Rivers [Zambesia] ... it is damaging that the esteem for the other cloths has been lost... ${ }^{48}$

Clearly, merchants had to be aware of fluctuations in consumer tastes, and failure to supply the required cloths to the market could be disastrous.

Reflecting a lack of understanding of how demand changed among African consumers, and exposing racist perceptions of Africans as willing to accept any article of foreign production, the Portuguese labelled their tastes as 'fickle' and subject to random change. ${ }^{49}$ While this kind of perception was common among other Europeans in different parts of Africa, it is not the case that Africans blindly accepted any commodity on offer. The Vāniyā unfailingly understood very early on that commercial success depended in large part to being attuned to the changing regional differences of textile demand in East-Central and South-East Africa. Because they did not venture into interior markets, critical

47 AHU, Moç., Cx 69 Doc 22, de Almeida to Governor-General, 26 October 1794.

48 AHU, Moç., Cx 64 Doc 19, de Mattos to Governor-General, 12 May 1793.

49 AHU, Moç., Cx 40 Doc 9, Coelho to da Fonseca, 21 October 1782. 
information was provided to them as noted earlier by the patamares and vashambadzi, with whom the Vāniyā maintained contact on a regular basis. The Portuguese attempted to undermine this system by restricting Vāniyā movement from Mozambique Island, particularly in the late 1770s and 1780s, but were unsuccessful because of the pressures which the Indians exerted on the authorities when such policies were pursued. ${ }^{50}$

A growing realisation that consumer demand and tastes - at least as much as if not more than production - played a critical role in determining commercial transactions between foreign merchants and African consumers has recently prompted historians to consider the precise extent to which these influenced precolonial African economic exchange. For example, Joe Miller has shown how African demand for Indian textiles shaped Portuguese and Brazilian trade between the 1770 s and the first quarter of the nineteenth century. He observes that: "imports are likely to prove more momentous for Africa's history than its better publicised exports, since what Africa received from abroad enabled people there to consolidate old, or to develop new, production techniques and productive relations". ${ }^{51}$ This scholarship has alerted historians to the important role played by consumer tastes in shaping African precolonial commercial exchanges. Yet, despite the importance of this work and the shift of focus it proposes, it has not adequately traced out the repercussions of African demand on the structures of material exchange and/or production. As a result, it has failed to recognise how Africans influenced the broader parameters of the processes in which they were embedded as integral actors. Recently, however, there have been signs that this may be changing, particularly through work that has analysed the 'repercussions' of nineteenthcentury East African demand in places as far as Massachusetts and Bombay. ${ }^{52}$ In placing African demand in East-Central and South-East Africa within a broader Indian Ocean context, this chapter contributes to this changing perspective on the role of Africans in the global economy.

\footnotetext{
${ }^{50}$ Details can be found in Machado, "Gujarati".

${ }^{51}$ Joseph C. Miller, "Imports at Luanda, Angola 1785-1823", in Gerhard Liesegang et alt. (eds.), Figuring African Trade (Berlin: Dietrich Reimer Verlag, 1986), p. 164. This line of enquiry was further developed in Way of Death (Madison: The University of Wisconsin Press, 1988).

52 Prestholdt, "Global Repercussions"; Id., Domesticating the World.
} 


\section{Of Many Hues}

The complexities of African consumer tastes are best seen in the vast array of textiles which were imported from Diu (and to a lesser extent Daman), and which recall the range of textiles that Richard Burton noted and described in Zanzibar in the 1850s. ${ }^{53}$ While a comparable list does not exist for East-Central and South-East Africa, it is possible from the lists of cloths located in the sources to identify some of them reasonably accurately. ${ }^{54}$ These, however, represent only a small proportion of the textiles which were supplied by the Vāniyā to African markets. A number of the cloths appear to have been traded across large areas of East-Central and South-East Africa, such as capotins (blue and white chequered or striped cloths), canequins (coarse indigodyed blue or black calicoes), and the highly valued samateres (narrow white cotton cloths) and zuartes (indigo-dyed cloths) ${ }^{55}$

Local contingencies in consumer tastes were influenced, in part, by the way cloth was used. ${ }^{56}$ In Manyika, for example, zuartes and dotins (strong, coarse cotton cloths) were in great demand. ${ }^{57}$ Others textiles sent to the Masekesa trading fair included samateres, savagagins and "primarily the Dotins ... that are accepted in all the lands of Manica..." Cured savagagins were worn by the royalty and nobility, while samateres were used for sacrificial ceremonies "performed in order to appease the Vadzimu [an ancestral spirit]" and to denote mourning. ${ }^{58}$ It is clear, however, that from the 1780s, zuartes had increasingly become the most sought-after cloths as revealed in the cases of vashambadzi refusing to accept any other textiles. ${ }^{59}$ In the Rozvi empire,

${ }^{53}$ Richard Burton, The Lake Regions of Central Africa (London: Longman, Green, Longman and Roberts, 1860), vol. 2, Appendix I, "Commerce, Imports and Exports", pp. 387-419.

${ }^{54}$ Lists of cloths were found in the documentation located at the AHU, Caixas de Moçambique and Códices, and at the HAG, CD and CDm and AD \& ADm. We should note that Lobato, História, Vol. 2, pp. 328-29 also provides a list of a number of these cloths but does not attempt to describe them or trace their distribution.

55 A. C. P. Gamitto, King Kazembe (Lisbon: Junta de Investigações do Ultramar, 1960), vol. 2, Appendix I, B, “Table showing the types of cotton cloth...”, p. 198.

56 This was noted years ago in John Irwin and Paul R. Schwartz, Studies in IndoEuropean Textile History (Ahmedabad: Calico Museum, 1966).

${ }_{57}$ H. H. K. Bhila, Trade and Politics in a Shona Kingdom (Essex: Longman, 1982), p. 131.

${ }_{58}$ Manoel Galvão da Silva, "Diario...", 14 November 1788, in Luis Fernando de Carvalho Dias, Fontes para a Historia, Geografia e Comercio de Moçambique (sec. XVIII) (Lisbon: Junta de Investigações do Ultramar, 1954), p. 328; Bhila, Trade, p. 131.

59 AHU, Moç., Cx 69 Doc 22, de Almeida to Governor-General, 26 October 1794. 
Gujarati textiles were sent by the emperor as part of the regalia at the investiture of new provincial chiefs. Cloths were also given as presents to the mhondoro, the Mutapa spirit medium, while rulers who regularly brought tribute to the Zimbabwe were rewarded with cloth. ${ }^{60}$ A further example shows how in Sofala, canequims, samateres, capotins, ardians and cutonias (a striped cloth of mixed silk and cotton weave) were regularly traded but that, in a development similar to that in Manyika, zuartes became the most in demand. ${ }^{61}$ Doutins and capotins were actively traded as cloths worn exclusively by the elites as markers of distinction and connection to a global trading world. Further south, in Delagoa Bay, economic expansion by the end of the eighteenth century also provided a fillip for the demand for various Gujarati textiles. ${ }^{62}$

It is important to note that, despite the circulation of Indian textiles, local African textiles continued to be manufactured and traded in at least two locales. Most well known are the machiras of the Zambesi and Shire region, about which S. I. Mudenge has argued that "throughout the history of their relations with coastal traders until the twentieth century, the Shona never replaced their indigenous products for imported ones. The animal skins and the roughly woven machira cloth both saw the dawn of the twentieth century".63 Machiras were traded extensively on prazos ${ }^{64}$ and were popular among the Nsenga Chewa, southern Lunda and Karanga-related peoples. ${ }^{65}$ They were also traded

${ }^{60}$ S. I. Mudenge, A Political History of Munhumutapa (Harare: Zimbabwe Publishing Co., 1986), p. 185.

${ }^{61}$ João Julião da Silva, "Memoria...", in José Fialho Feliciano and Victor Hugo Nicolau (eds.), Memórias de Sofala (Lisbon: Comissão Nacional para as Comemorações dos Descobrimentos Portugueses, 1998), pp. 144-45. We should point out that the editors of this collection of documents suggest that da Silva was writing after 1838 and had therefore constructed his narrative retroactively.

${ }^{62}$ Malyn Newitt, A History of Mozambique (Bloomington and Indianapolis: Indiana University Press, 1995), p. 159. See also: Benigna de Jesus Lurdina Mateus Lisboa Zimba, "Overseas Trade, Regional Politics, and Gender Roles: Southern Mozambique, ca. 1720 to ca. 1830" (Unpublished PhD Thesis, University of Michigan, 1999), p. 328; Alan Smith, "The Struggle for Control of Southern Mozambique, 1720-1835" (Unpublished PhD Thesis, University of California, Los Angeles, 1970), p. 164; "Plano e relação da Bahia ...", in Caetano Montez, Descobrimento e Fundação de Lourenço Marques, 1500-1800 (Lourenço Marques: Minerva Central Editora, 1948), p. 172.

${ }_{63}^{63}$ Mudenge, Political History, p. 187.

${ }^{64}$ Inheritable Portuguese Crown estates leased to Portuguese settlers in the Zambezi Valley.

${ }^{65}$ Allen F. Isaacman, Mozambique. The Africanization of a European Institution (Madison: The University of Wisconsin Press, 1972), pp. 66 and 73. 
at Masekesa and throughout the Shire Valley. ${ }^{66}$ Although there can be little doubt that Indian cloths were more prestigious, machiras remained well into the twentieth century a staple commodity thanks to their durability and range of uses.

Locally-grown cotton was also woven in Sofala. Production of cloths called gondos continued well into the nineteenth century, and they were traded to Zambesia where they were used for making sails. ${ }^{67}$ Machiras and gondos confirm that the trade in African textiles was not incompatible with the import of Gujarati textiles: they complemented one another because they did not compete for the same market. Ultimately, local contingencies such as the uses to which cloths were put, and how they were integrated into local systems of consumption determined whether local textile production was or was not undermined by imports. Indian cloths had a variety of meanings for local consumers, from their prestige value as visible reminders of a person's place in society, to their social uses in initiation and investiture ceremonies. Cloths were also offered as gifts to rulers to allow merchants to conduct trade in their lands, were accumulated as a reflection of a ruler's wealth and were used to pay troops. ${ }^{68}$

\section{Networks of Supply: Gujarat}

The importance of African consumer tastes in affecting textile exports from western India is clear. Success in the textile trade depended on a clear understanding of which types of cloths were in demand in the African interior, and providing these accordingly. Of equal importance to the success of this trade was the regular and efficient procurement of textiles in the interior of Gujarat. Without a regular supply of appropriate textiles for the African trade, the Vāniyā would have been unable to satisfy consumer demand, and consequently would have been severely

\footnotetext{
${ }^{66}$ Newitt, History, p. 214; Alpers, Ivory, p. 86.

67 da Silva, "Memoria", p. 99; Gerhard Liesegang (ed.), "Resposta das Questoens sobre os Cafres" ou Notícias Etnográficas sobre Sofala do Fim do Século XVIII (Lisbon: Junta de Investigações do Ultramar/Centro de Estudos de Antropologia Cultural, 1966), p. 23. Cotton and bark cloth production between the Limpopo and Rovuma Rivers survived into the twentieth century, for which see Liesegang, "A First Look at the Import and Export Trade of Mozambique, 1800-1914", in Liesegang et. al., Figuring, pp. 452-523.

68 See, for example, Biblioteca da Ajuda, 54-XIII-3 (3), Barbosa, "Analyse Estatistica", 30 December 1821, for cloths being sent to Zambesia as payment for troops.
} 
restricted in their trade with the African interior. As a small and infertile island, Diu was a poor and unproductive area which had to rely for its textile supplies on mainland western Gujarat. ${ }^{69}$ Its position at the southern tip of the peninsula of Kathiawar (Saurashtra), close to Gujarati production centres, however, meant Diu was potentially wellplaced to take advantage of this vast hinterland for its textile supplies. Effectively, it functioned as an entrepôt through which flows of goods from Africa and India intersected and were redirected.

The analysis of the importation of Indian textiles into Africa has paid little or no attention to issues of supply and production in India. ${ }^{70}$ This has generated an incomplete appreciation of the extent to which Indian weavers and people beyond South Asia were intimately connected through the mediating role of Gujarati merchant networks. A more rounded account needs to incorporate South Asia into the discussion and thus highlight the connections that - through histories of circulation - tied Africa and the Indian subcontinent. This chapter provides only cursory details on production in South Asia as it focuses primarily on textile procurement in India for the East-Central and South-East African markets. ${ }^{71}$

It has been widely recognised that textile manufacturing in India differed across the producing regions. In Bengal and the Coromandel, for example, the textile industry was found both in town and country. ${ }^{72}$ By contrast, in the Punjab and Gujarat weavers were located in urban centres or close to the main cities. Cities such as Surat served as a market for small weaving towns which were located a short distance away. Other major textile centres of Gujarat were all urban. There were certain advantages for producers in being located in or near an urban centre, not least of which was the concentration of large populations with regular consumption needs. Other no less important considerations were

\footnotetext{
${ }^{69}$ Pearson, "Brokers in Western Indian Port Cities", Modern Asian Studies, 22, 3 (1988), p. 467.

${ }^{70}$ There are notable exceptions here: Roberts, “Guinée Cloth"; Pearson, Port Cities; Prestholdt, "East African Consumerism"; Id., Domesticating the World.

${ }^{71}$ Further details, especially on production, can be found in Machado, "Gujarati".

72 There is evidence from Dutch records for the northern Coromandel suggesting however that weavers were entirely dispersed in 'industrial villages' scattered throughout coastal districts. Om Prakash, European Commercial Enterprise in Pre-colonial India (Cambridge: Cambridge University Press, 1998), pp. 163-64; Joseph J. Brennig, "Textile Producers and Production in Late Seventeenth Century Coromandel", in Sanjay Subrahmanyam (ed.), Merchants, Markets and the State in Early Modern India (Delhi: Oxford University Press, 1990), pp. 66-89.
} 
proximity to sources of raw cotton, skilled, semi-skilled and unskilled labour, and a supply of good-quality water essential for dying. ${ }^{73}$

There is much evidence to show that Indian weavers were able to adjust their production effectively to respond to changing consumer tastes in the vastly different Indian Ocean markets. Export production was therefore characterised by a high degree of specialisation based on product differentiation as well as market orientation. ${ }^{74}$ Thus, weavers in Bengal produced textiles for West Asian markets, while those in the Coromandel supplied the Southeast Asian markets. The capacity of weavers to adjust their production to conform to the tastes of purchasers in distant markets is perhaps nowhere more clearly seen than in the case of Gujarat, where weavers "had fully adopted their manufacturing techniques and the fabrics to suit the needs of ... buyers".75

Production for African markets was equally specialised. What is striking, however, is that in the eighteenth and nineteenth centuries production was not dispersed across Gujarat, but it was concentrated almost exclusively in a single locale. Jambusar was a weaving and cotton and indigo producing centre located south-east of Cambay, across the Mahi River and approximately 50 miles south-west of Baroda in the "great Cotton district" of western India. ${ }^{76}$ Weavers in Jambusar manufactured textiles exclusively for African consumers, and did so according to the particular specifications which Gujarati merchants provided annually to them through middlemen. This chapter suggests that because of the large volume of textiles produced for the African markets, Jambusar's existence as a prosperous weaving and manufacturing centre depended to a large extent on the demands of African consumer tastes. It confirms K. N. Chaudhuri's position, when he observes that "one of the best indicators of a region's industrial ties to a particular market area is the degree to which producers [are able to] adjust their products to consumer tastes". ${ }^{77}$ Over the course of the eighteenth century (if not earlier), weavers in Jambusar and African consumers were brought into a relational trans-oceanic material dynamic defined by the particularities of taste and fashion.

${ }^{73}$ Chaudhuri, "Structure", pp. 39 and 44.

${ }^{74}$ Ibid., pp. 40-41.

75 Ibid., p. 42. The emphasis is mine.

${ }^{76}$ John Briggs, The Cities of Gujarashtra: Their Topography and History Illustrated, in the Journal of a Recent Tour, with Accompanying Documents (Bombay: Times' Press, 1849), p. 148.

77 Chaudhuri, "Structure", p. 42. 
The eighteenth century was one of prosperity for Jambusar for two related reasons. The first concerned commercial policies adopted by the Marathas who controlled the area. Maratha potentates appear to have been aware of the value of production and commerce for the prosperity of their regimes, and were therefore eager to provide or maintain favourable conditions to this end. This is one of the reasons why trade grew over the period from the 1740 s to the $1820 \mathrm{~s}^{78}$ The second reason contributing to the prosperity of Jambusar was the decline of production in Cambay. In the 1740s the Marathas had declared freedom of trade both in Cambay and in its parganas (local districts) but the latter benefited from this measure much more than Cambay that was at the time suffering unstable political and social conditions. Indeed, production in the qasbas (markets) of Cambay declined considerably in the following years and, along with it, the revenue of the Nawab.

By contrast, cotton production and trade in the parganas increased significantly as artisans and workers left the qasbas and city of Cambay for nearby towns. One of the towns to which artisans migrated and which saw a growth in its production was Jambusar, which according to Aniruddha Ray "began to prosper not only as a wholesale mart but also as a trading center that took away much of Cambay's resources" ${ }^{79}$ The migration of weavers away from cities which Maratha rule had destroyed in the early eighteenth century, such as "beleaguered" Ahmedabad, may also have benefited Jambusar. ${ }^{80}$ Production remained buoyant into the nineteenth century, and "a great trade was carried on from Jambusar in cotton piece-goods with Bombay and other places". ${ }^{81}$ What has been mostly overlooked is the importance of African consumer demand on the growth of the productive capacity of weaver households in Jambusar.

Gujarati merchants acquired textiles for the African markets through a system of advances which rested on (verbal) agreements between

\footnotetext{
${ }^{78}$ Sumit Guha, "Potentates, Traders and Peasants: Western India, c.1700-1870", in Burton Stein and Sanjay Subrahmanyam (eds.), Institutions and Economic Change in South Asia (Oxford: Oxford University Press, 1996), pp. 71-84.

${ }^{79}$ Aniruddha Ray, "Malet Collection on Cambay (Gujarat) at the End of the 18th Century", in Ernestine Carreira (ed.), Sources européennes sur le Gujarat (Paris: Société d"Histoire de" Orient and L'armattan, 1998), p. 22.

${ }^{80}$ Chaudhuri, Trading World, p. 310.

${ }^{81}$ William Milburn, Oriental Commerce London: Black, Parry \& Co., 1813), vol. 1, p. 156. See also Gazetteer of the Bombay Presidency, vol. II: Gujarat: Surat and Broach (Bombay: Government Central Press, 1877), pp. 563-65.
} 
contracting merchants and their brokers on the number and types of textiles which were required for the trading season. Prices for the different types and qualities of textiles were also agreed with the broker. Brokers (who could work for a number of merchants) took the merchants' orders to Jambusar and presented the details to further intermediaries who dealt directly with the weavers. Brokers were not just working as agents, but were known to purchase textiles from weavers to sell to merchants. ${ }^{82} \mathrm{~A}$ broker might have dealt directly with weavers in Jambusar but there is evidence to suggest that most commonly he did not. This is in keeping with commercial practices in other parts of India where brokers tended not to deal with producers but with their representatives, such as headweavers in the South Indian case. ${ }^{83}$

The broker also arranged for the finishing of the textiles which was generally not the responsibility of the weaver. In a few cases this may have been done in Diu and Daman, where by the second decade of the nineteenth century there were "painters" and "printers".${ }^{84}$ Sinnapah Arasaratnam has pointed to the complex social structure of weaving villages that prevented direct contact between weavers and brokers, and thereby offered weavers some protection. As found throughout India, advances to weavers in Jambusar were made in cash and the money was used to purchase necessary raw materials such as yarn. Weavers could refuse to honour their agreements with brokers, in many cases returning the advance if a higher offer was made. ${ }^{85}$ There are examples where weavers failed to return advances and placed brokers and merchants in awkward positions, without much chance for redress.

This procurement system worked well for the merchants, the brokers and the weavers who produced the textiles for the export market. Gujarati merchants, removed from production centres, were supplied with the types and quantities of textiles needed for their trade on a

${ }^{82}$ HAG, CDm 1068, “Representação...”, 30 May 1821. This was a widespread practice which is confirmed in evidence for Southeastern India. See Sinnapah Arasaratnam, "Weavers, Merchants and Company", Indian Economic and Social History Review, 17, 3 (1978), p. 267.

${ }^{83}$ For a discussion of headweavers, see Arasaratnam, "Weavers"; Parthasarathi, The Transition to a Colonial Economy (Cambridge: Cambridge University Press, 2001), p. 86.

${ }^{84}$ HAG, AD 4955; MR 193A, fl 496, “Mappa...”, 14 Oct 1814; MR 169C, fl. 567, "Mappa...", 31 Dec 1818.

${ }^{85}$ Arasaratnam, "Weavers". 
regular basis. Weavers were provided with the capital for their work, given access to export markets and were protected from market fluctuations. The brokers benefited from the money and credit arrangements that were made with merchants for their purchases. ${ }^{86}$ However, relationships between merchants and brokers were not always without conflict. ${ }^{87}$ The broker was probably a widely disliked figure among merchants, despite the critical role he occupied in the procurement of textiles for the export trade. Merchants were acutely aware that they relied on him for their supplies, yet felt that such a reliance could be against their interests.

Although it is not certain when the Vāniyā first established procurement from Jambusar, evidence suggests that by the early 1730s its artisans were already producing textiles specifically for the East-Central and South-East African markets. ${ }^{88}$ By the mid-eighteenth century they concentrated their procurement there to the almost complete exclusion of other weaving centres in Gujarat. Indeed, between 85 and 95 percent of all textiles exported to Africa on Indian vessels were manufactured in Jambusar. ${ }^{89}$ It is likely that this represented a high proportion of Jambusar's productive capacity and thus gave work to much of the town's spinners and weavers. In 1800, Gujarati merchants committed a sum as large as Rs. 400,000 for the purchase of Jambusar textiles expressly for East-Central and South-East African markets. ${ }^{90}$ This is an indication of the scale of resources that the Vanniya could mobilize. At the same time, it underlines how the livelihoods of weaving households, merchant families and brokers were sustained by their interrelation with African consumers. In turn, it highlights how consumer tastes affected seemingly distant economic processes, and unmasks the importance of African consumer tastes for the vitality of one of Gujarat's

${ }^{86}$ Chaudhuri, Trading World, pp. 254-62; Parthasarathi, Transition, pp. 22-3; Arasaratnam, "Weavers".

${ }_{87}$ See, for example, HAG, CDm 1067, Testimony of Panachand Jalalchand, 30 May 1821; “Rellação...", n.d. [but 1821]; Governor of Daman to Viceroy, June 1821; CDm 1063, Panachand Jalalchand to Viceroy, 13 June 1821.

${ }^{88}$ Aniruddha Ray, "Cambay and its Hinterland: Early Eighteenth Century", in Indu Banga (ed.), Ports and Their Hinterlands in India (1700-1950) (New Delhi: Manohar Publications, 1992), pp. 140-41.

${ }^{89}$ HAG, AD 4952-68 and CD 995-1012; CDm 1055-68.

${ }^{90}$ Maharashtra State Archives, Commercial Department Diary of the Bombay Government No. 27 of 1800, Petition of the Contracting Brokers, p. 510ff, quoted in Lakshmi Subramanian, "Power and the Weave", in Mukherjee and Subramanian, Politics, p. 74 . 
centres of cloth production. The relational dynamic produced by these mutually constituting - and thus connected - histories allows us to place Africa and South Asia within a broader Indian Ocean history of which they formed an integral part.

Portuguese efforts to establish textile production in their Indian territories began in the eighteenth and continued into the nineteenth century as they responded to the aggressive procurement practices of the English East India Company in western India in general, and in Surat in particular. Gujarati support of the Portuguese aims was, despite occasional appearances to the contrary, never truly forthcoming. The reasons were many and related most of all to the investment of the Vāniyā in an efficient procurement system centred on Jambusar. ${ }^{91}$ This was in keeping with how coastal exporting towns and cities were connected to the textile-producing interior of Gujarat. While it was not the case that Gujarati merchants ignored all the opportunities created by the Portuguese state, they were too firmly established within the Gujarat textile economy and marketing structure to consider patronage from the Portuguese. ${ }^{92}$ In short, Indian merchants judged the Portuguese proposals to develop textile manufacturing in either Diu or Daman as not holding advantages which superseded those of their already existing (and independent) system of procurement. The risks involved in fully supporting the actions of a financially and politically weak state were too high. This is why, at least in their African trade, merchants continued to operate without direct access to weavers and through the intermediary function of brokers.

As a result, throughout the first quarter of the nineteenth century piecegoods for the African markets continued to be produced overwhelmingly in Jambusar. ${ }^{93}$ The sustained dominance of Jambusar textiles in African markets - and the capacity of the Vāniyā to supply these - is truly remarkable. Textiles from Surat and Bombay were exported through Diu to Africa into the mid-to late 1810s, along with manufactures from Bhavnagar, but these remained limited until the 1830s. ${ }^{94}$ The second remarkable feature of this trade is that the Vāniyā

${ }^{91}$ For further details see Machado, "Gujarati".

92 This point draws on Raj Chandavarkar, The Origins of Industrial Capitalism in India (New York: Cambridge University Press, 1994), pp. 56-7.

${ }_{93}$ AHU, Moç., Cx 92 Doc 53, "Carga...”, 19 January 1802; Cx 97 Doc 25, “Carga...”, 12 January 1803; Cx 148 Doc 32, "Carga..., 3 February 1815. See also See HAG, AD 4952-4956; and Registos Gerais..., Bando, 11 December 1809.

${ }^{94}$ See, for example, HAG, AD 4967-69. 
continued to acquire textiles from Jambusar in a period of increasing British penetration into western India. Although the establishment of control over Surat was a protracted affair, and the extension of British rule into other parts of Gujarat was only complete in the second decade of the nineteenth century, from the last quarter of the eighteenth century the British had developed a keen interest in the Gujarati market for raw cotton, primarily for its China trade. ${ }^{95}$ Raw cotton from Jambusar thus found its way to the coast, although this does not appear to have disrupted artisanal production in the city, and certainly not that serving the East-Central and South-East African markets.

\section{Slave Trading and 'Foreign' Competition}

The years following the early 1790s saw exports of textiles from Diu to the markets of East-Central and South-East Africa drop to 150,000250,000 pieces per year. This was due to the heightened danger of attack from French corsairs, which in turn resulted in a drop in the number of Indian vessels arriving at the coast. This situation may have persisted into the first few years of the nineteenth century after which the number of palas (Indian sailing vessels) arriving in Africa rose to between two and four a year. The return of these vessels and their textile cargoes was - it is important to stress - also related to the growth of the African slave trade. Its growing dominance in the economy of Mozambique did not marginalise the Vāniyā networks which adapted their trade accordingly, and exported a greater number of African slaves to western India for which there was a small but significant market. ${ }^{96}$ Their primary interest remained in ivory, which was of great cultural and social value to South Asian elites and broader populations throughout western and northern India; but their shift into slave trading reflected their responsiveness to the vagaries of changing conditions of trade.

The adaptive capacity of the Vāniyā rested also in Indian textiles continuing to be used in the purchase of slaves, just as they had been

${ }_{95}$ Pamela Nightingale, Trade and Empire in Western India 1784-1806 (Cambridge: Cambridge University Press, 1970); Subramanian, Indigenous Capital and Imperial Expansion (Delhi: Oxford University Press, 1996); Bayly, Indian Society and the Making of the British Empire (Cambridge: Cambridge University Press, 1988), ch. 2.

${ }_{96}$ Machado, "Gujarati", ch. 6. See also Id., "A Forgotten Corner of the Indian Ocean", in Gwyn Campbell (ed.), The Structure of Slavery in Indian Ocean Africa and Asia (London: Frank Cass, 2004), pp. 17-32. 
used for the purchase of ivory. Although imported firearms were used in exchange for slaves from the middle of the eighteenth century, and increasingly in the nineteenth century, ${ }^{97}$ the use of cloths as exchange media was not displaced. Nor was its desirability among African consumers diminished, as suggested by a well-informed contemporary author who noted that in Quelimane, an important gateway into the Zambesi Valley and slave trading centre, just the opposite was true. ${ }^{98}$ Clearly, the exchange of slaves and textiles was intimately connected, as demonstrated by the fact that many Gujarati merchants prominently involved in the slave trade were also among the largest exporters of textiles from Diu to Africa. ${ }^{99}$ This helps explain why over the period 1804-10, textile exports from Diu alone totalled around 1,853,000 pieces; it is likely demand remained high in the following decade. Corresponding increases in the importation of Indian cotton textiles as a result of increased slave trading was by this time not uncommon in the South-Weast Indian Ocean. ${ }^{100}$ Throughout the 1820s reasonably complete records show that textile exports from Diu were fairly stable, although they were lower than in previous years. ${ }^{101}$ This may reflect the adverse effects which increased slaving was having on Vāniyā commerce in East-Central and South-East Africa. ${ }^{102}$

Although quantitative evidence does not exist for either the volume or value of textile exports from Diu after 1831, the slowdown in textile

\footnotetext{
${ }_{97}$ For details see Alpers, Ivory, pp. 14, 96-7, 110-11, 152, 195, 198.

98 Vasconcellos e Cirne, Memoria sobre a Provincia de Moçambique (ed. José Capela) (Maputo: Arquivo Histórico de Moçambique, 1990), p. 24.

${ }^{99}$ Further details can be found in Machado, "Gujarati".

100 For example, see Pier Larson, History and Memory in the Age of Enslavement: : Becoming Merina in Highland Madagascar, 1770-1822 (Portsmouth, NH: Heinemann, 2000), pp. 127-28; and M. Morice, "Observation on the list of Trade Goods from Another Point of View", in G. S. P. Freeman-Grenville (eds.), The French at Kilwa Island (Oxford: Clarendon Press, 1965), pp. 144-45.

101 For example, three Vāniyā vessels arriving at Mozambique Island in 1820 were reported to have carried cargoes with a combined total of just over 179,000 pieces, a figure supported by other examples. Machado, "Gujarati”; Biblioteca da Ajuda, 54-XIII3 (3), Barbosa, "Analyse Estatistica", 30 December 1821; Gonçalo de Magalhães Teixeira Pinto, Memoria sobre as Possessoẽs Portuguezas na Asia, escriptas no anno de 1823 (Nova Goa: Imprensa Nacional, 1859), pp. 30-32.

102 There was a sharp increase in textile exports in 1829 , but this may have been the result of heightened demand from slavers who increased their purchases of slaves before the 1830 treaty, which banned imports into Brazil. The Vāniyā continued to trade in cloths with the Makua in Makuana in these years, but records for 1831 show a marked decrease in Indian exports. AHU, Códice 1425, fl. 13v, "Para o Cheque de Sancul", 22 April 1831.
} 
exports from Jambusar was likely also to have been caused by disruptions to the slave trade by increased British anti-slaving patrols in the western Indian Ocean. However, it was not only the ending of the slave trade that undermined textile exports. Equally significant in the decline of the Gujarati textile trade for the African markets was the increasing competition of 'foreign' textiles. For instance, an informed official wrote that he thought it "necessary that the Governors of those territories [Diu and Daman] promote improvement in manufactures through their possible means in order that the Africans lose completely their love for English trade goods [from India] ... to which they are growing accustomed, and which are a thousand times better" ${ }^{103}$ Implicit in this statement was the knowledge that the decision by the Portuguese Crown in 1810 to allow the "entry of English cotton goods ... made Indian manufactures disappear..." ${ }^{104}$ This resulted from the AngloPortuguese Treaty of Commerce and Navigation that ultimately undermined Portuguese trade in the nineteenth century. Although concern was clearly mounting over the importation of textiles from England and from English ports from the early 1810s, it does not seem that their entry into the region severely undermined the trade of the Vāniyā until later in the century. ${ }^{105}$

What the Vāniyā did consider a grave danger to their textile exports and to their primacy in East-Central and Southeast Africa from around the mid-1810s was the entry of other 'foreign' textiles into the market. These appeared to be textiles that came from other parts of Kathiawar, especially from Bhavnagar but also from Surat and Bengal, that were under the control of South Asian merchant networks. Given the focus of much of the work on South Asian textiles on production for the European markets, scholars have tended to overlook the competition that existed among different producing regions and/or exporting merchants in South Asia for markets within the Indian Ocean. This appears to have been the case with the growing competition from Bhavnagar

103 AHU, Moç., Cx 153 Doc 113, Cavalcanti de Albuquerque to Marquez de Aguiar, 26 June 1817. For details of English trade in southern Mozambique, see David William Hedges, "Trade and Politics in Southern Mozambique and Zululand in the Eighteenth and Nineteenth Centuries" (Unpublished PhD Thesis, School of Oriental and African Studies, University of London, 1978).

104 Arquivo Nacional da Torre do Tombo, JC, Maço 62, Cx 202, 9 September 1815.

${ }^{105}$ For the effects of the Anglo-Portuguese Treaty, and of British industrial production on Portugal and the Portuguese empire in this period, see Rudy Bauss, "A Legacy of British Free Trade Policies", Calcutta Historical Journal, 6, 2 (1982), pp. 81-115. 
on Jambusar, and the threat later posed by Mandvi in Kachchh and by other South Asian merchant networks (most especially the Bhātiyā). For instance, in 1816 a vessel from Bhavnagar departed for Mozambique with textiles "suitable for the consumption of that part of Africa". The threat these textiles could pose to Diu and Daman worried officials so much that in 1817 they communicated the information directly to the exiled Portuguese Crown in Rio. ${ }^{106}$

It is not surprising that Bhavnagar textile exports troubled the Vāniyā merchants because they were sent expressely to Mozambique for the purchase of slaves. From the 1810s Bhavnagar seems to have become the second most important supplier of textiles for the Mozambique trade after Jambusar, and we know of a few cases of Vāniyā merchants buying their textiles in Bhavnagar. Notwithstanding the potential of Bhavnagar for serving as an alternative source of supply, it appears that the Vāniyā were unable to exploit it fully. They were not as powerful there as they were in Jambusar and therefore had to compete with other merchant groups to secure textile supplies. Moreover, it could be the case that the Vāniyā were too heavily invested in the procurement network centred on Jambusar to have exploited other sources of supply.

Concerns were expressed not only by the Vāniyā, but also by Portuguese officials, who were aware that textiles exported from ports outside their administration meant a reduction in custom duties and hence income. ${ }^{107}$ There were further laments in 1817 in Mozambique from the Vāniyā against the entry of 'foreign textiles' which resulted in their cloths "not enjoying the trade they needed". ${ }^{108}$ It is not entirely clear why the Vāniyā were unable to resist the competition of 'foreign textiles' in Mozambique, a market in which they had valuable experience. Nor is it clear how these textiles came to conform to the specificities of African consumer tastes that had been so ably satisfied by Jambusar cloth. A possible explanation might be found in the famines that affected Gujarat - in particular the severe ones in 1811 and $1813 .{ }^{109}$ These could have disrupted Vāniyā textile supplies from Jambusar and allowed the entry into Mozambique of textiles from Kachchh and elsewhere in India. However, extant documentation does not point to

106 HAG, CDm 1065, Castro e Almeida to Gomes Loureiro, 16 February 1817.

107 HAG, MR 193A, fl. 1378, Merchants to de Azevedo, 31 December 1814.

108 HAG, CM 1447, Palha to Governor, 28 July 1817.

109 Abdul Sheriff, Slaves, Spices \& Ivory (London: James Currey, 1987), pp. 84-85. 
a disruption in supplies from Jambusar in famine years. It is, therefore, difficult to understand why the Vāniyā were unable to resist the entry of these foreign textiles into the Mozambique market.

The Portuguese authorities, always keen to blame Indian merchants for any downturn, believed that the Vāniyā had brought this situation on themselves because they had "sent for the consumption of this captaincy falsified trade goods and of such poor quality that not even the Africans want them". ${ }^{110}$ Considering the Vāniyās knowledge of African consumer tastes, and their long years spent supplying these markets, it is extremely unlikely that this would have been the case. Moreover, the Portuguese accusations appear to be overstated as figures show the continued demand for Jambusar textiles in Africa into the 1830s. Vāniyā concerns about the intrusion of foreign textiles into the African markets were however not totally misplaced. Indian merchants realised the scale of this problem in the 1820s. ${ }^{111}$ They underlined how foreign textiles were 'hurting' their trade in India and Mozambique, and they wanted them to be banned from entering Portuguese territories. ${ }^{112}$

A significant downturn, resulting from the arrival of textiles from locales other than Diu or Daman, is discernible from the 1830s. The clearest demonstration of this is to be found with the cargo of an Indian vessel which, perhaps for the first time, arrived at Mozambique Island without a single consignment of cotton piecegoods. ${ }^{113}$ Of course, this may have been an exception, but the evidence presented above, the drop in value of piecegood exports from Jambusar to Diu and Daman, ${ }^{114}$ and the complaints of the marked fall in exports, all point to the start of a terminal decline in the textile export trade, which continued throughout the 1830 s and early 1840 s. ${ }^{115}$

\footnotetext{
110 AHU, Moç., Cx 154 Doc 105, Abreu e Menezes to Conde de Baia, 25 September 1817.

111 For details see Machado, "Gujarati".

${ }_{112}$ HAG, CDm 1066, Indian merchants of Daman to Castelão, 14 November 1823.

113 Francisco Santana, (ed.), Documentação Avulsa Moçambicana do Arquivo Histórico Ultramarino (Lisbon: Centro de Estudos Históricos Ultramarinos, 1964-74), vol. 3, p. 695.

114 British Library, Oriental \& India Office Collections, P/419, Bombay Commerce, vols. 56-66. These records provide only "official" trade and therefore underestimate the real value of this trade. Indeed, the figures suggest higher values. They do, nonetheless, confirm a trend, namely the fall in the value of the trade that reflected the challenges I have been discussing.

115 See, for example, HAG, CD 1012, "Mapa...", 10 Feburary 1831; CD 997, de Macedo to Ferreira Pestana, 5 July 1845. Further details can be found in Bauss, "Legacy".
} 
The effects of the entry of foreign textiles into African markets were exacerbated by the sharp decline in the slave trade and the arrival of other 'foreign' textiles in the 1840s and 1850s. American textiles, in particular, were fast conquering the market. As the Portuguese Carlos José Caldeira wrote in the early 1850s:

Americans dominate the trade of the entire coast, they trade to the ports or at times unload easily as contraband at any place they regard as convenient the goods [which are] suitable for exchanges with Africans, such as cloths. They [Americans] introduce better and cheaper cotton goods than those from Diu, Daman... which until now were used for this commerce, and which they [American textiles] are forcing out of the market ... ${ }^{116}$

As a result, they were "establishing among the Africans a taste for finer and better patterned cloths, with grave damage to the manufactures of Diu and Daman, which were sustained by this commerce, the principal resource of those establishments". ${ }^{117}$ This signalled the start of the challenge of machine-produced textiles for Indian handicrafts in the Indian Ocean and beyond.

English manufactures appear also at this time to have been squeezing the textile exports of the Vāniyā out of their African markets. Although this threat had been felt in the 1810s, it was in the 1840s and 1850 s that the full force of their impact became evident. A. C. P. Gamitto, writing in 1832, remarked how the standard bale of cloths in the Zambesi Valley consisted of seven different varieties of Indian manufactured cloths; but by the time of his departure from Mozambique in 1853, he noted how cotton textiles of English and American manufacture "are preferred to the Indian weaves". ${ }^{118}$ Whereas at the start of the nineteenth century piecegoods exported from Diu and Daman had constituted approximately 90 percent of Mozambique's textile imports, by the mid-1850s they represented only about 25 percent and declined further later in the century. ${ }^{119}$ Quite how this reversal took place and how it affects our understanding of consumer dynamics in African

116 Carlos José Caldeira, Apontamentos d"uma Viagem de Lisboa a China e da China a Lisboa, Tomo Segundo (Lisbon: J. P. M. Lavado, 1853), p. 105. The emphasis is mine.

117 Ibid.

118 Gamitto, King Kazembe, Vol. 2, p. 197; David Livingstone also noted the decline in Missionary Travels and Researches in South Africa (New York: Harper, 1858), p. 680, quoted in Alpers, Ivory, p. 233.

119 HAG, AD, 4952-53; Caldeira, Apontamentos, pp. 105-6; Liesegang, "Import", p. 457. 
markets and of South Asian competition in the Indian Ocean, awaits further enquiry.

At the same time as machine-produced cotton textiles were undermining Indian weaves, the position of the Vāniyā was being further challenged by Bhātiyā merchants from Kachchh (especially Mandvi) whose presence on the Mozambique coast became noticeable from the 1820 s and 1830s. By the 1840s they were prominent in the import and export trades. ${ }^{120}$ It therefore appears that the Indian cloths which Gamitto wrote about in the 1830s were possibly imports from Kachchh, rather than from Diu and Daman. These Kachchhi goods were also challenged by the machine-produced American and English cotton textiles but appear to have been successful in meeting this challenge for a short time for reasons which remain unclear.

\section{Conclusion}

I have sought to examine the dynamic linkages in the chains of connection between western India and East-Central and Southeast Africa in the eighteenth and nineteenth centuries. I have done so by considering, primarily, the role played by a particular Gujarati merchant network of the western Indian Ocean, the Vāniyā, in mediating material exchange structured around the consumption and production of Indian textiles. It was the networks of circulation of groups like the Vāniyā both within Gujarat and across the Indian Ocean to Africa that bound Indian weavers and weaving households, brokers and merchant networks in the interior of Gujarat, and African consumers of cloths along the coasts and interiors of East Central and South-East Africa together in an intimate cross-oceanic embrace. The discussion offered here thus points to the importance of the binding modalities of consumer tastes in affecting intra-regional exchange, and helps further to challenge the view of Africans as marginal actors in the economy of the western Indian Ocean.

This chapter also suggests that historians need to pay far greater attention to the resourcefulness and dynamism of indigenous merchant networks and their capital in exploiting markets in the Indian Ocean, and to the survival of Indian handicraft textile production in

120 Caldeira, Apontamentos, pp. 106-7. 
the face of intensified competition from factory production in the nineteenth century. ${ }^{121}$ While there can be little doubt that India lost export markets in the nineteenth century, it appears to be a gradual and differentiated process which accelerated only from the 1830s. The vitality of Indian Ocean markets - particularly those in Africa - up to this period and their importance to the export production of particular areas in Gujarat, has been greatly underestimated by scholars who have emphasised instead the textile export trade to European markets. ${ }^{122}$ While the latter may have been dominated by European capital, the acknowledgement that until the middle of the nineteenth century and beyond, as some new work is beginning to suggest - it was South Asian merchants who controlled the majority of textiles exports from India, is an idea that is gaining greater acceptance among historians.

Indeed, as scholars begin to challenge accounts of globalization that posit a singular historical trajectory, it is becoming increasingly evident that the histories of circulation and mobility in places such as South Asia offer insight into the multiple ways in which indigenous actors were not marginal but integral to this process and affected it in multiple ways. By examining the processes that brought South Asia into relation with other spaces in the Indian Ocean - and the mobile groups that mediated these processes - we are able to locate these within the larger framework of the globalizing connections of the eighteenth and nineteenth centuries. ${ }^{123}$ We are able also to contribute in significant ways to the ever-growing challenge to the limiting perspectives of the Area Studies paradigm and national history writing. ${ }^{124}$

${ }^{121}$ For the impact of Lancashire factory-produced cotton goods, for example, see B.R. Tomlinson, The Economy of Modern India, 1860-1970 (Cambridge: Cambridge University Press, 1993), ch. 3.

122 But see Pedro Machado, "Awash in a Sea of Cloth: Gujarat, Africa and the Western Indian Ocean, 1300-1800", in Giorgio Riello and Prasannan Parthasarathi (eds.), The Spinning World: A Global History of Cotton Textiles, 1200-1850 (Oxford: Oxford University Press, 2009), pp. 161-79 for a change of perspective.

${ }^{123}$ And well into the twentieth century as suggested by Bose's Hundred Horizons.

124 This is not to say that alternative approaches are without problems. For a discussion of some of the challenges, see the recent American Historical Review, "Conversation: On Transnational History", 111, 5 (2006). 


\title{
ENGLISH VERSUS INDIAN COTTON TEXTILES: THE IMPACT OF IMPORTS ON COTTON TEXTILE PRODUCTION IN WEST AFRICA ${ }^{1}$
}

\author{
Joseph E. Inikori
}

\section{Introduction}

The development of manufacturing in pre-colonial West Africa remains largely understudied. This is mainly because quantitative evidence on manufacturing activity in the region during the period is not readily available. The problem is compounded by the limited number of trained economic historians researching in the field. Thus, much of the evidence that can be found in the archives and other sources is yet to be systematically collected and studied. Given this state of affairs, it is no surprise that there is hardly an elaborate empirical study of the impact of imported manufactures on the development of manufacturing during the era of the Atlantic slave trade. Yet, general statements on the subject are not wanting. The received wisdom appears to be that imported manufactures had no adverse impact on the development of manufacturing in the region during the period. John Fage provided the lead when he argued that imports of European manufactures stimulated increased "African production and economic activity generally", and that "the increase in imports of Indian, European or American cloth meant that more people could afford to clothe themselves rather than that local manufacture ceased (or, so far as there is evidence, declined)". My objection to the argument was similarly general. I stressed that it was an inappropriate application of Ricardo's static comparative advantage principle to issues of structural transformation and general economic development. "There is no historical example", I added, "of

1 An earlier version of the paper was presented at the GEHN Conference on "Cotton Textiles as a Global Industry, 1200-1850", University of Padua, Italy, 17-19 November 2005. I would like to thank the participants for their comments, and particularly Suraiya Faroqhi who acted as discussant.

${ }^{2}$ John D. Fage, A History of Africa (London: Hutchinson 1978), pp. 272-73. 
an economy in which the technology and organization of industrial production were transformed during a period of uncontrolled importation of cheap foreign manufactures". ${ }^{3}$

Over the past several decades the Fage argument, in one form or another, has been presented repeatedly in the literature with no empirical evidence to support it. David Eltis and Lawrence Jennings asserted in 1988 that trade with the Atlantic world made no difference to the history of Western Africa in the period 1600-1860, and that imported manufactures had no adverse impact on local industries. ${ }^{4}$ John Thornton argued in 1992 that manufactures imported into Africa by European traders were luxury products that did not affect adversely the development of manufacturing in Africa. ${ }^{5}$ Somewhat more cautiously, Herbert Klein disputes the argument of "some scholars that the East Indian cotton goods were a determent to the local textile industry in many parts of West Africa", noting that "in all regions of Africa, local artisanal textile production continued into the postslave-trade era, which suggests that local cloth was probably quite competitive with European imports at the lower end of the scale, at least until the British were able to introduce their coarser cloths in the late nineteenth century on a massive scale". ${ }^{6}$ More recently, Ralph Austen and Dennis Cordell have argued that although Africa traded with Europe after 1500, African economies were much less radically transformed than those in the Americas and Asia, because African economies were largely protected by the physical environment against direct competition with European economies, "except in the southern regions where whites settled". Austen and Cordell believe that "This absence of direct competition allowed continued

${ }^{3}$ Joseph E. Inikori, "Introduction", in Joseph E. Inikori (ed.), Forced Migration: The impact of the export slave trade on African societies (London and New York: Hutchinson and Africana, 1982), p. 55.

${ }^{4}$ David Eltis and Lawrence C. Jennings, "The Trade between Western Africa and the Atlantic World in the Pre-colonial era", The American Historical Review, 93, 4 (1988), pp. 936-59. See also David Eltis, "Trade between Western Africa and the Atlantic World Before 1870: Estimates of Trends in Value, Composition and Direction", Research in Economic History, 12 (1989), where Eltis argues that imported textiles and other consumer manufactures did not breach the economic self-sufficiency of Africans. p. 231.

${ }^{5}$ John Thornton, Africa and Africans in the making of the Atlantic world, 1400-1680 (Cambridge: Cambridge University Press, 1992), pp. 44-53.

${ }^{6}$ Herbert S. Klein, The Atlantic Slave Trade (Cambridge: Cambridge University Press, 1999), p. 124. 
growth in the early modern period, but may be linked to the major crises of the modern period"?

These general claims are difficult to prove or disprove, because there are no detailed empirical studies of manufacturing activity in precolonial West Africa. However, reasonable inferences can be drawn from a combination of import statistics and the available evidence on the history of cotton textile production and inter-regional trade in West Africa during the period 1200-1850. To avoid confusion, the issue for investigation needs to be clearly stated. The question is not whether cotton textile production of any form declined or disappeared totally from all or most parts of West Africa during the period as a result of the adverse impact of imports. The question is whether the development of the industry was adversely affected by the import of textiles in exchange for captives. Again, we have to be precise when we talk about development. To say that industrial development or general economic development was retarded by the import of manufactures in exchange for captives does not imply that West Africa would have achieved an industrial revolution during the period in the absence of the Atlantic slave trade. ${ }^{8}$ Industrial development or general economic development is a long-term process with observable manifestations or elements, some measurable and others not. An industrial revolution is the end product of a successfully completed industrialization process. But between handicraft production of manufactures - or peasants' craft - and mechanized, factory production of manufactures there are several observable intermediate points in the industrialization process where progress can be assessed. Some of these have measurable characteristics. One such point that has gained widespread observation and treatment in the literature on industrialization is proto-industrialization. This level of industrial development is characterized, in the main, by the transformation of previously independent, small-scale producers of manufactures into semi-wage workers by merchant capitalists who take

\footnotetext{
7 Ralph A. Austen and Dennis D. Cordell, "Trade, Transportation, and Expanding Economic Networks: Saharan Caravan Commerce in the era of European Expansion, 1500-1900", in Alusine Jalloh and Toyin Falola (eds.), Black Business and Economic Power (Rochester: University of Rochester Press, 2002), p. 108.

${ }^{8}$ David Eltis, The Rise of African Slavery in the Americas (Cambridge: Cambridge University Press, 2000), p. 163, where Eltis attributes to me an argument totally alien to my work. See my review of the book, American Historical Review, 106, 5 (2001), p. 1753; Anthony G. Hopkins, An Economic History of West Africa (Harlow, Essex: Longman, 1973), p. 119.
} 
over the supply of raw materials (and also tools in many instances), the organization of production, and the marketing of the final product in distant markets (including overseas markets). The producers working at home receive payment on a contracted piece rate. While critics of the concept have demonstrated historically that not all regions that achieved proto-industrialization went on to achieve full industrialization or an industrial revolution, ${ }^{9}$ there can be no doubt that protoindustrialization is an important measure of progress in the process of industrial development.

The discussion of industrial progress in West Africa during the period in question centres on the evidence concerning this important measure. Specifically, the paper focuses on the extent to which protoindustrial production developed in cotton textile production in West Africa during the period and examines the role of textile imports exchanged for captives. This role is analyzed in the light of the competition between East India and English cottons both in England and in West Africa. ${ }^{10}$ Because proto-industrialization, by definition, is a product of commerce and enlarged markets for manufactures, factors promoting and those limiting the growth and development of commerce and the market economy in West Africa feature prominently in the paper. The point about the exchange of imported manufactures for captives needs to be stressed. By and large, the imported manufactures were not exchanged for other goods produced in West Africa - the victim populations did not receive anything in return for the people they had expended resources to raise from conception to productive age. The overall growth of the level of production and trade over time, given economies operating under conditions of unlimited supply of agricultural land, was, therefore, held back. The impact assessment

9 Sidney Pollard, Peaceful Conquest: The Industrialization of Europe 1760-1970 (Oxford: Oxford University Press, 1981), pp. 14-20; Donald. C. Coleman, "ProtoIndustrialization: A Concept too Many", Economic History Review, 36, 3 (1983) pp. 435-48; Brian Short, "The De-Industrialisation Process: A Case Study of the Weald, 1600-1850", in Pat Hudson (ed.), Regions and Industries: A Perspective on the Industrial Revolution in Britain (Cambridge: Cambridge University Press, 1989) pp. 156-74; Frank Perlin, "Proto-Industrialization and Pre-Colonial South Asia", Past and Present, 98 (1983), pp. 30-95. For the historical development of the concept, see Franklin Mendels, "Proto-industrialisation: Theory and Reality, General Report", Eighth International Economic History Congress, Budapest, 1982, "A" Themes (Budapest: Akadémiai Kiadó, 1982), pp. 69-107.

${ }^{10}$ It should be noted that while British traders dominated imports into West Africa during the period of study, similar manufactures were also brought by other traders in Europe and in the Americas. 
must, it follows, go beyond the usual analysis of the impact of imported manufactures on the development of manufacturing. It must probe in addition the impact on overall growth of production, local and interregional specialization, and the development of domestic markets for manufactures and other goods.

\section{Cotton Production and Market Development in the Pre-European Period}

Cotton textile production in West Africa dates back to medieval times and beyond. Several parts of the region, from the Igbo heartland in the east to Senegambia in the west and the interior savannah, were involved in cotton manufacturing from very early times. A combination of factors - easy access to raw cotton, population density, access to markets, the general state of crafts development, and technology - contributed to the growth and spatial distribution of the industry over time. The amount of information available on individual production areas may not correspond to the relative quantitative and qualitative importance of the areas; it may just be by accident that research has concentrated on specific periods and localities. However, taking the evidence on the earlier periods together with the more plentiful evidence for the nineteenth and early twentieth century, we can identify the most important production areas and the factors explaining their development over time.

The northern Igbo area, the northernmost part of southeastern Nigeria in the savannah belt, often called the Igbo heartland because it is the earliest settled part of Igboland, ${ }^{11}$ is one of the best known early cotton textile producing areas in West Africa. Conditions favouring the growth of craft manufacturing developed relatively early in the area. It possessed iron ore and coal, and iron smelting began in the area no later than the eighth century BC. ${ }^{12}$ In addition, it was the main beneficiary of the agricultural prosperity in Igboland fostered by the Nri hegemony present from the ninth to the fifteenth century. ${ }^{13}$ This led to

${ }^{11}$ A. E. Afigbo, "The Spell of Oral History: A Case Study of Northern Igboland", History in Africa, 33 (2006), pp. 39-52.

${ }_{12}$ Ibid., p. 39.

${ }_{13}$ Kenneth Onwuka Dike and Felicia Ekejiuba, The Aro of South-eastern Nigeria, 1650-1980: A Study of Socio-Economic Formation and Transformation in Nigeria (Ibadan: University Press, 1990), pp. 109 and 115. 

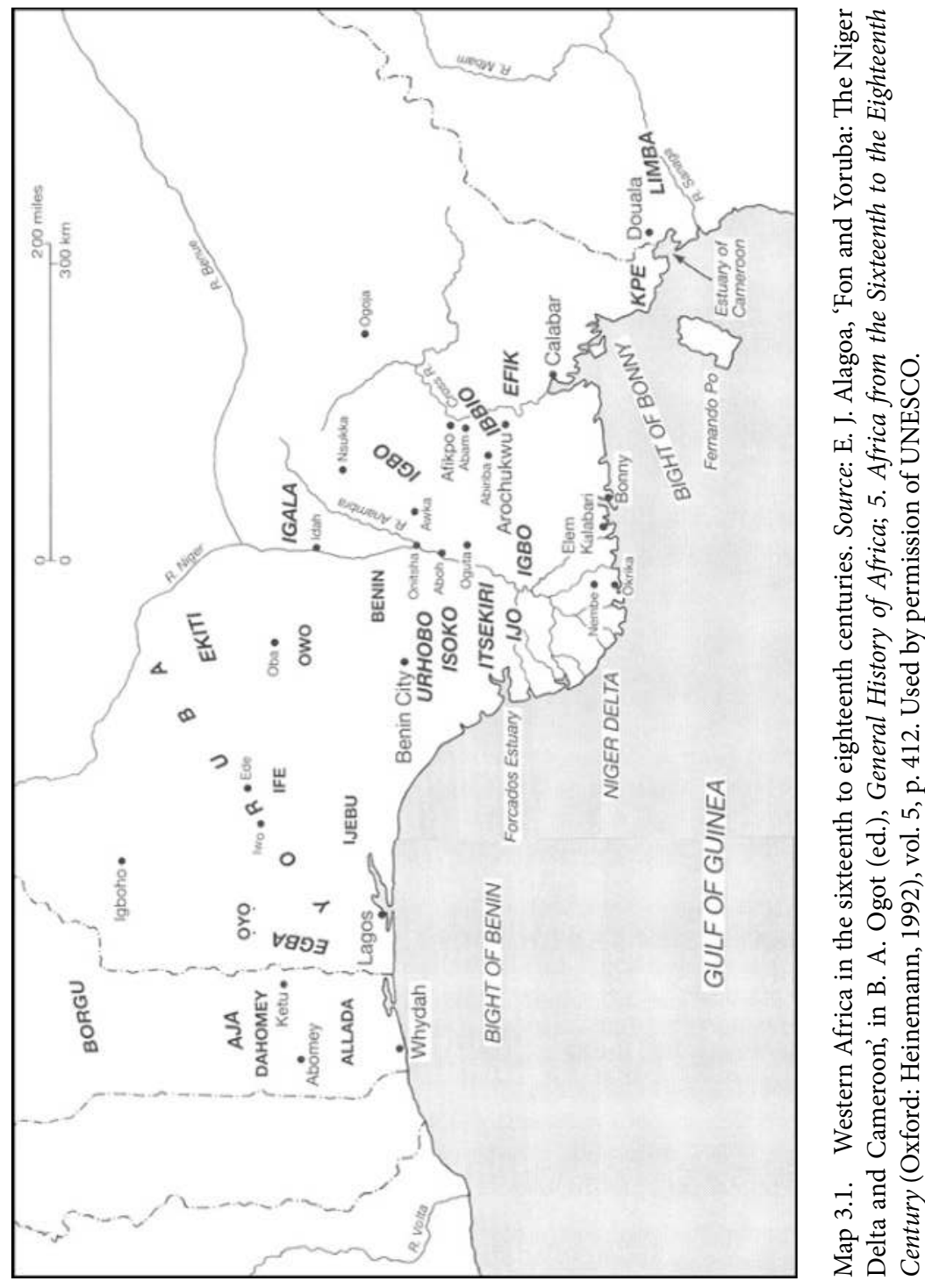
a high population density that resulted in a low land to population ratio in the area. As Dike and Ekejiuba put it:

The cumulative effects of the agricultural revolution and its concomitant prosperity, the dependence on palm oil and root crops, and the long period of peace associated with the Nri hegemony seem to have given rise to a demographic explosion. The resulting disequilibrium between the limited resources and demography naturally was first felt in the primary centres of Igbo settlement, the central uplands (agbaenu) with their light acidic and easily leached soils (Aniocha). The disequilibrium generated gradual shifts of population towards the fertile but heavily forested lowlands and river valleys which had been demographically and agriculturally of marginal importance. ${ }^{14}$

These conditions match very well several of the factors economic historians generally employ to explain the growth of proto-industrialization. Hence, northern Igboland was the earliest centre of manufacturing and trade in southeastern Nigeria. The Awka Igbo developed their iron and copper metalworking activities and trade between the ninth and fifteenth century. The Anam and Nsukka Igbo developed their cotton textile production during the same period. ${ }^{15}$ Thurstan Shaw's archaeological excavations in Igbo-Ukwu, a few miles from Awka, provide a wealth of information on craft manufacturing in northern Igboland between the ninth and fifteenth century. ${ }^{16}$ The extensive range of materials discovered, dated to between the ninth and fifteenth century $\mathrm{AD}$, includes cloths, whose yarn quality and woven pattern indicate remarkable technical skills on the part of the craftsman. ${ }^{17}$

${ }^{14}$ Ibid., p. 115. See also Afigbo, "Spell of Oral History", p. 39.

15 A. E. Afigbo, "Pre-colonial Trade Links Between Southeastern Nigeria and the Benue Valley", Journal of African Studies, 4, 2 (1977), pp. 128-29.

16 Thurstan Shaw, Igbo-Ukwu: An Account of Archaeological Discoveries in Eastern Nigeria (Evanston:Northwestern UniversityPress, 1970); ThurstanShaw, "Archaeological Discoveries: The Example of Igbo-Ukwu", in Thurstan Shaw (ed.), Discovering Nigeria's Past (Ibadan: Oxford University Press, 1975), pp. 47-57.

17 David Northrup, Trade Without Rulers: Pre-Colonial Economic Development in South-Eastern Nigeria (Oxford: Clarendon Press, 1978), pp. 17-20. Although the IgboUkwu cloths were not made of cotton fibres, the skill of the artisans exhibited by the quality of the yarns and of the woven cloths indicates clearly the general degree of sophistication of cloth production in northern Igboland before the Atlantic slave trade era (1650-1850). See Thurstan Shaw, Unearthing Igbo-Ukwu: Archaeological discoveries in eastern Nigeria (Ibadan: Oxford University Press, 1977), p. 82, where Shaw says: "The fibres of the textiles have been microscopically examined, but there has been no success in identifying them, except to say that they are not cotton". Figure 7.1 on p. 83 shows a piece of the Igbo-Ukwu cloths. 
Other early cotton textile production areas on the Atlantic coast and the immediate hinterland in West Africa, about which there is some evidence, include the Benin kingdom in southwest Nigeria, Allada in the modern Republic of Benin, the Ivory Coast (quaqua cloth), the upper Guinea coast, and places around the Senegal River valley. ${ }^{18}$ For all of these areas it is not clear from the evidence whether they actually produced the cloth associated with them by the reporting observers or it was brought from other places in West Africa's hinterland and sold by them. For example, as will be shown later, there was considerable trade in cotton cloths between Benin and its northern neighbours, especially the Nupe and northeastern Yoruba. ${ }^{19}$ Benin also traded with the cloth-producing northern Igbo through the Aboh entrepot on the River Niger. ${ }^{20}$ Some or all of the cotton cloths sold in Allada may also have been imported from the Yoruba hinterland.

The evidence suggests, however, that the main centres of cotton textile production in West Africa before the growth of seaborne trade with Europeans were in the savannah interior, where the medieval empires with their commercial and Islamic learning cities - were located. Political and demographic factors interacted to create favourable conditions for the development of trade and manufacturing in the region. From the thirteenth to the fifteenth century, the bulk of West Africa's population and the major centres of high population density were in the savannah interior, especially the Niger Bend. Several cities in the interior savannah - Niani, Timbuktu, Jenne, Gao, etc. - had populations ranging from 30,000 to 100,000 between the fourteenth and sixteenth century. ${ }^{21}$ Population concentration, political organization,

${ }^{18}$ Colleen E. Kriger, Cloth in West African History (Lanham, MD: Altamira Press, 2006); Colleen Kriger, “'Guinea Cloth': Production and Consumption of Cotton Textiles in West Africa before and during the Atlantic Slave Trade" (Paper presented at the Conference, "Cotton Textile as a Global Industry", University of Padua, Italy, 17-19 November, 2005).

19 A. F. C. Ryder, "Dutch Trade on the Nigerian Coast During the Seventeenth Century", Journal of the Historical Society of Nigeria, 3, 2 (1965), pp. 203-204; S. A. Akintoye, "The North-Eastern Yoruba Districts and the Benin Kingdom", Journal of the Historical Society of Nigeria, 4, 4 (1965), pp. 544-46.

20 Afigbo, "Precolonial Trade Links", p. 124. Northrup speculates on the converse, the possibility that "the Igbo-Ukwu textiles were imports from Benin, whose cloths they so closely resemble, yet there is no reason to think that Benin made all of its own cloth or had a monopoly on the trade". Northrup, Trade Without Rulers, p. 17. It is now sufficiently well established that the Igbo-Ukwu cloths were produced by the northern Igbo.

${ }^{21}$ Djibril Tamsir Niane, "Mali and the Second Mandingo Expansion", in Djibril Tamsir Niane (ed.), General History of Africa, IV: Africa from the Twelfth to the Sixteenth 
relatively low cost of transportation in the open savannah and along the Niger and other rivers, and their greater links to the early centres of world trade located in the Mediterranean meant that the major societies in the interior savannah were relatively more commercially and industrially developed in the fifteenth century than those located between them and the Atlantic. No precise dates can be stated for the beginning of cotton cloths production in the region. The available evidence makes it clear, however, that cotton cloths production was widespread in the West African savannah by the fourteenth century. ${ }^{22}$ Arabic sources show that cloth strips were used as currencies all over the region by the fourteenth century. ${ }^{23}$

Spatial distribution of craft manufacturing, differing levels of sociopolitical development across space, regional pattern of demographic change, and geographical distribution of natural resources all combined to encourage the development of inter-regional and local trade in West Africa from medieval times to the fifteenth century. At the centre of this trade was the exchange of manufactures (including cotton cloth) produced in one part of West Africa for agricultural and other goods produced in other parts of the region. As mentioned earlier, the Niger bend (that area of the River Niger from the modern city of Segu to where the river enters modern Nigeria) was an early centre of population concentration, socio-political development, manufacturing, and commerce. It, therefore, played a leading role in the development of long-distance trade in West Africa during this period. The state of Kanem-Borno (in the Lake Chad region) and the Hausa city-states in modern northern Nigeria also played major roles in the trade.

On the Atlantic coast and the immediate hinterland, an extremely important point of the trade was the Gold Coast (modern southern Ghana). This is one of the areas in West Africa where there is no evidence of early cotton cloth production. The evidence is strong that it

Century (London, Berkeley and Paris: Henemann, University of California Press and Unesco, 1984), p. 156; S. M. Cissoko, "The Songhay from the 12th to the 16th century", in ibid., p. 206; John O. Hunwick, Timbuktu and the Songhay Empire: Al-Sadi"s Ta"rikh al-sudan down to 1613 and other Contemporary Documents (Leiden: Brill, 1999), pp. xxiv-xxv, xlix.

${ }^{22}$ Colleen Kriger, "Textile Production in the Lower Niger Basin: New Evidence from the 1841 Niger Expedition Collection", Textile History, 21, 1 (1990), pp. 31-56; Id., "Textile Production and Gender in the Sokoto Caliphate", Journal of African History, 34, 3 (1993), pp. 361-401; Id., “'Guinea Cloth'”.

${ }^{23}$ Id., "Textile Production in the Lower Niger Basin", p. 39. 

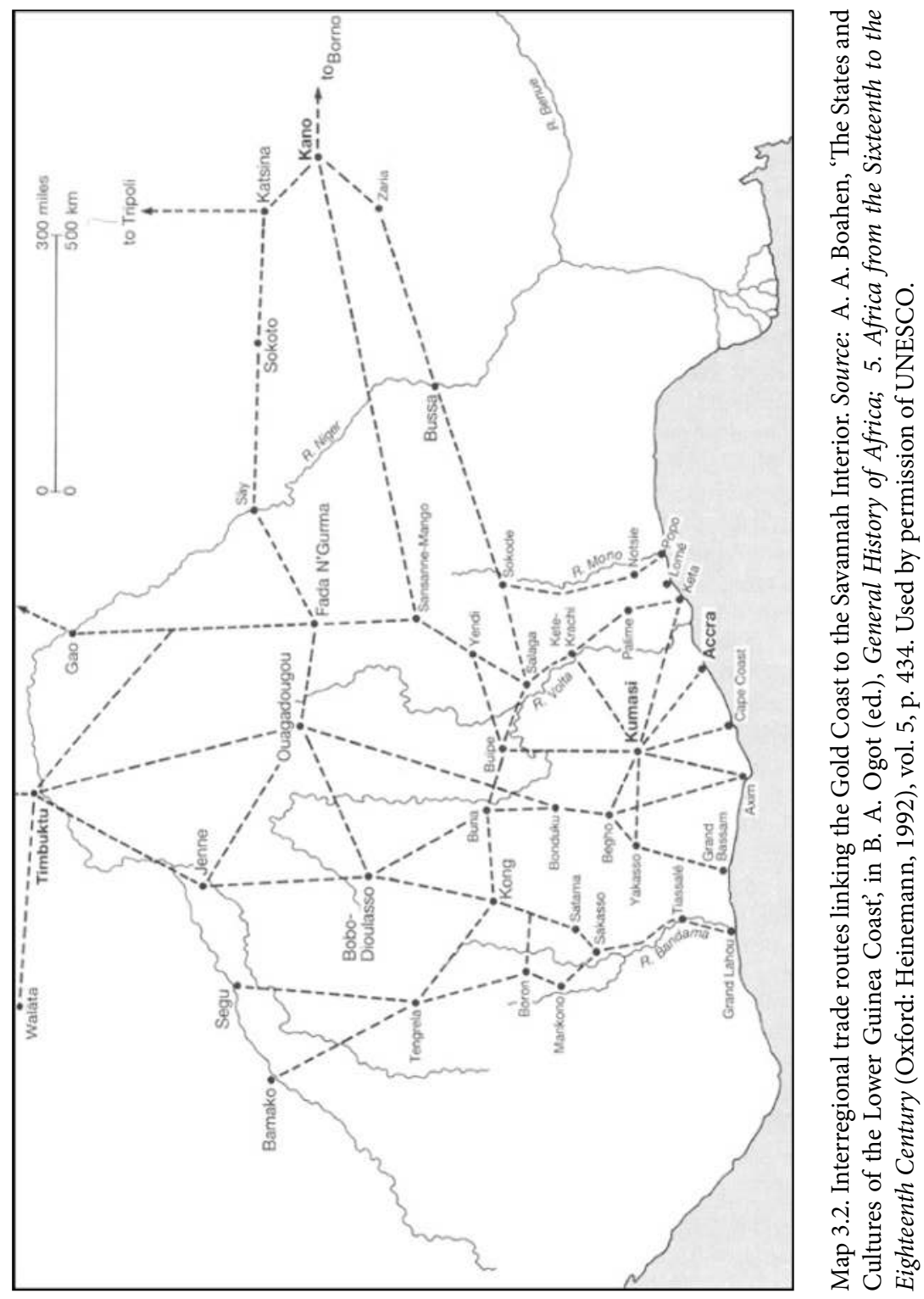
was a major importer of cotton cloths from other parts of West Africa from medieval times. But the Gold Coast produced two commodities that were central to the long-distance trade of West Africa during the period - gold and kola nuts. The latter became a major product in West Africa's long-distance trade as the ruling elite and a large proportion of the ordinary people in the savannah states increasingly became Muslims, kola nuts being the only stimulant Islam allows adherents to consume. The Gold Coast was the main producer of kola nuts for several centuries up to the nineteenth. ${ }^{24}$ The Gold Coast was also the main gold producer in West Africa in the centuries preceding Portuguese explorations. When the demand for gold increased in Europe in the fourteenth century, the merchants of the Niger bend played the role of middlemen in the export of gold from the Gold Coast to Europe through North African and Middle Eastern merchants.

The growth of the trade in gold and kola nuts linked the Gold Coast firmly to the economies of the West African savannah, with a direct trade route connecting the Niger bend commercial city of Jenne to Begho, the gold and kola nut entrepot on the edge of the Akan forest in what would later become the metropolitan area of the Asante empire. The commercial importance of Begho led to its colonization by Niger bend traders from Jenne in the late fourteenth century. ${ }^{25}$ Other members of the Niger bend trading diaspora, who had moved to Hausaland (in modern northern Nigeria), developed in the fifteenth century another trade route linking the Gold Coast to Hausaland, supplying the Hausa city-states with gold and kola nuts. ${ }^{26}$ In exchange for its gold and kola nuts, the Gold Coast received from the Niger bend and Hausaland a variety of manufactured goods which included cotton cloths and leather goods. European textiles and Asian goods (especially cowries) carried to the Niger bend by North African and Middle Eastern traders were among the goods exported to the Gold Coast by the Niger bend traders. But most of the manufactures that the gold and kola nut producers received from the savannah were produced by craftsmen in the Niger bend and Hausaland. The evidence suggests a gradually evolving inter-regional division of labour between

\footnotetext{
24 Paul E. Lovejoy, Caravans of Kola: The Hausa Kola Trade, 1700-1900 (Zaria: Ahmadu Bello University Press, 1980).

${ }^{25}$ Ivor Wilks, "A Medieval Trade Route from the Niger to the Gulf of Guinea", Journal of African History, 3, 2 (1962), pp. 337-38.

${ }_{26}$ Hunwick, Timbuktu and the Songhay Empire, p. xxix.
} 
the Gold Coast and various manufacturing areas in West Africa in the fourteenth and fifteenth centuries. ${ }^{27}$

A similar trend can be observed in the Benin trading area of southwest Nigeria and the Igbo heartland in southeastern Nigeria. The evidence shows the Benin kingdom had been heavily involved in trade with its hinterlands for several centuries before it came into contact with European traders in the late fifteenth century. There is clear evidence that the trade was very important to the kingdom's ruling elite, including the Oba of Benin himself. ${ }^{28}$ For our present purpose Benin trade with northeastern Yoruba country and Nupe, which developed from very early times, is of particular interest. Yoruba areas connected to Benin by this trade to its northeastern hinterland included Owo, Okeluse, Akure, Ilesha, Ife, the Ife trading centre of Apomu (where Benin, Ijebu, Oyo, Ife, and Ekiti traders gathered to trade), Akoko, Ekiti, and Iyagba. The trade with Nupe went through the northeastern Yoruba country. ${ }^{29}$ The evidence suggests some element of specialization was involved in the trade. Before European traders were involved in Benin's trade with its hinterland in the early sixteenth century, Benin traders exported brass utensils and iron implements (all made in Benin), salt and coral beads. ${ }^{30}$

The northeastern Yoruba and Nupe appear to have specialized in cotton cloths production. The most important Benin imports from these places were cotton cloths. Spinning, dyeing and weaving of cotton cloths was a very important industry for the women in Ekiti, Akoko, and Igbomina. They produced three types of cloth: a two-strip cloth (each strip about two yards by one yard) called $i k e j i$, produced mainly for personal consumption by the producers (not marketed); a threestrip cloth (each strip about three yards by two feet) called iketa; and a four-strip cloth (also about three yards by two feet, each strip) called ikerin. The latter two types were made specifically for the market. The evidence suggests that the ikerin cloth was consciously designed for the

\footnotetext{
${ }^{27}$ Mahdi Adamu, The Hausa Factor in West African History (Zaria: Ahmadu Bello University Press, 1978), p. 11.

${ }_{28}$ Akintoye, "The North-Eastern Yoruba Districts", pp. 544-45.

${ }^{29}$ Ibid., p. 544.

30 The salt and beads were probably also produced in Benin. White salt is called unweriaka (Benin salt) by the Urhobo people, Benin's neighbours in the Niger Delta. According to the Yoruba historian, Dr. Akintoye, the Benin are reputed among the Ekiti "to have been very good blacksmiths in the distant past". Akintoye, "The North-Eastern Yoruba", p. 545.
} 
Benin market; the producers referred to it as aso-Ado - meaning 'Benin cloth' or 'cloth for Benin' ${ }^{31}$ It is pertinent to note that a European observer, Barbot, is reported to have said in the early eighteenth century that two types of native cloths were bought in Benin:

The first was the type called 'Benin cloth', made up of 'four bands, striped blue and white, an ell and a half long .... and called by the Blacks Mouponoqua'; the second the blue narrow cloth 'Ambafis', which was 'much inferior to the former in every way'... Barbot's sources had it that 'both sorts (were) made in the inland country'. This hinterland obviously comprised the large territory extending as far northeast as the Nupe country on the Niger and as far west as Ijebu. ${ }^{32}$

Developments in northern Igboland (the Igbo heartland) between the ninth and fifteenth century also encouraged the growth of interregional and local trade in southeastern Nigeria. The growth of population in northern Igboland during the period put pressure on the land. One response to this development was migration. The other was to move away from land intensive to labour intensive activities - manufacturing and trade. Such a shift was aided by the availability of natural resources such as iron ore, coal, and raw cotton, and growing markets for manufactures in regions with a relative surplus of land (the Cross River valley and others) and Atlantic coastal regions rich in salt and fish. The metal products and cotton cloths of the northern Igbo were traded to these regions. Northern Igboland was also linked to the western Igbo entrepot of Aboh on the River Niger where traders from Igala and other northern savannah communities, the Atlantic coast and other parts of southeastern Nigeria, and the Benin kingdom met regularly to exchange goods. ${ }^{33}$ The Igbo-Ukwu materials (mentioned earlier), especially the locally made brass ware, suggest that northern Igbo was linked to the long-distance trade conducted between the copper producers in the southern Sahara and the savannah commercial centres. Similar to the evidence about the Gold Coast and Benin discussed earlier, the

\footnotetext{
31 Akintoye, “The North-Eastern Yoruba”, p. 546.

${ }^{32}$ Ibid., p. 545, citing John Barbot, Description of the Coast of North and South Guinea (London, 1732), pp. 357-61.

33 Afigbo, "Pre-colonial Trade Links", pp. 124-30; E. J. Alagoa, "Long-Distance Trade and States in the Niger Delta", Journal of African History, 11, 3 (1970), pp. 323-25; David Northrup, "The Growth of Trade Among the Igbo before 1800", Journal of African History, 13, 2 (1972), pp. 217-36; A. J. H. Latham, "Currency, Credit and Capitalism on the Cross River in the Pre-colonial Era", Journal of African History, 12, 4 (1971), pp. 599-605; Dike and Ikejiuba, The Aro of South-eastern Nigeria, pp. 114-15.
} 
indication here is that a gradual process of inter-regional specialization was in progress and inter-regional and local trade was pushing forward a commercialising process and the development of market economies in the major sub-regions of southeastern Nigeria in the decades preceding the arrival of European traders on the Atlantic coast. ${ }^{34}$

\section{Early European Trade, the Market Economy and Cotton Production}

The evidence suggests that the early European traders, who purchased mostly products derived from West Africa's natural resources, continued and/or extended the pre-existing pattern of trade on the West African Atlantic coast. There have been efforts to determine the pattern and magnitude of coastal trade among the West African communities along the Atlantic coast in pre-European times. ${ }^{35}$ The evidence is good enough to permit a writer to say that an established coastal trade route linked southeastern Nigeria all the way down to the Gold Coast before the arrival of European traders in the region in the late fifteenth century. ${ }^{36}$ The early European traders operated as carriers in the preexisting regional trade in cotton textiles. The Portuguese had started the carrying trade in the fifteenth century, establishing a factory in the Benin kingdom in 1487 largely for the purpose of buying what the Europeans called 'Benin cotton cloth' and exporting it to the Gold Coast. The Dutch and other Europeans continued the carrying trade. In 1633-34 the Dutch alone imported about 12,641 pieces of Benin cloth into the Gold Coast; another 16,000 pieces in 1644-46. Other

${ }^{34}$ Joseph E. Inikori, "Transatlantic Slaving and Market Development in the Atlantic World: West Africa, 1450-1850", in David Eltis and Stanley L. Engerman (eds.), The Cambridge World History of Slavery, Vol. 3: AD 1420-AD 1804 (Cambridge: Cambridge University Press, forthcoming); Marion Johnson, "The Cowrie Currencies of West Africa: Part I", Journal of African History, 11, 1 (1970), pp. 17-49; Marion Johnson, "The Cowrie Currencies of West Africa: Part II", Journal of African History, 11, 3 (1970), pp. 331-53.

35 Alagoa, "Long-Distance Trade"; Robin Law, "Trade and Politics behind the Slave Coast: The Lagoon Traffic and the Rise of Lagos, 1500-1800", Journal of African History, 24, 3 (1983), pp. 321-48; Wilks, "Medieval Trade Route", p. 339; John D. Fage, "Some Remarks on Beads and Trade in Lower Guinea in the 16th and 17th Centuries", Journal of African History, 3, 2 (1962), pp. 343-44.

${ }_{36}$ Northrup, Trade without Rulers, p. 22. On the strength of the evidence on which this point is based, Northrup says: "The proof of the existence of such an inter-coastal trade is admittedly not conclusive, but it is suggestive enough to have won the support of two specialists in Gold Coast history" (referring to Ivor Wilks and John Fage, fn. 34 above). 
cotton imports were brought from Allada in the modern Republic of Benin and from the Ivory Coast. ${ }^{37}$ According to Ryder, the English traders exported from Benin to the Gold Coast "at least as many" cotton cloths as the Dutch did during the same period. ${ }^{38}$

All or most of the cloth exported from Benin to the Gold Coast came from the same regions (northeastern Yoruba country and Nupe) with which Benin had traded metal products in exchange for cotton cloths for several centuries preceding the arrival of the European traders as we showed earlier. The European sources testify consistently that the cloths came from hinterland kingdoms, some about "three hundred or more miles inland". ${ }^{39}$ The European cotton cloth carrying trade from Benin in the sixteenth and seventeenth centuries was extensive. The volume and complexity of the trade induced innovations in its organization. As Ryder put it: "Besides intensifying long-distance trade within the Benin region, the great demand for cloth also helped to develop the system of "trust", or credit-trading, as a characteristic feature of European commerce in Benin".40 Apparently because the Portuguese did not have necessary goods to exchange for the cotton cloths in the early years of the trade, the Oba of Benin in the sixteenth century extended credit to the European traders between voyages. With the expansion of the trade in the seventeenth century and the takeover by the Dutch and the English traders, the extension of credit moved in the opposite direction. A sort of quasi putting-out system developed. Because the Benin traders could not stock enough cloths for the European traders to purchase immediately on arrival, they were granted credit in goods by the European traders. They carried the goods to the hinterland where the cotton cloths were produced; "and with these goods they have the cloth made in five or, at the most, six months" ${ }^{41}$ It is not known whether the Benin traders were directly involved in the designing of the cloths and the organization of their production. But all

${ }^{37}$ Kwame Yeboa Daaku, Trade and Politics on the Gold Coast, 1600-1720: A Study of the African Reaction to European Trade (Oxford: Clarendon Press, 1970), p. 24; Marion Johnson, "Technology, Competition, and African Crafts", in Clive Dewey and Anthony G. Hopkins (eds.), The Imperial Impact: Studies in the Economic History of Africa and India (London: The Athlone Press, 1978), pp. 262-63.

38 Ryder, "Dutch Trade", p. 203.

39 Ibid., p. 203.

${ }^{40}$ Ibid., pp. 203-204.

${ }^{41}$ Ibid., p. 204, citing Father Monteleone (Archivio della Sacra Congregazione di Propanganda Fide, Rome, Scritture Riferite nei Congressi, Africa, Angola, Congo e Senegal, vol. 2, f. 585, Thome, 24 May 1692). 
the evidence points to a quasi proto-industrial form of production. It is significant that the producers in northeastern Yoruba country called the cloths aso-Ado (Benin cloth or cloth for Benin) as stated earlier.

The predominance of African products - gold, cotton cloths, pepper, ivory, and others - in the first two centuries (the mid-fifteenth to the mid-seventeenth century) of European commercial enterprise in West Africa reinforced the ongoing development of long-distance and local trade, the commercialising process, and the growth and geographical spread of the market economy in West Africa. For the sake of brevity, the case of the Gold Coast (modern southern Ghana) may be taken for illustration. As we have seen, in the decades preceding the arrival of the European traders, the region was a major point in the growing longdistance trade in West Africa because of its gold and kola nuts. From the mid-fifteenth century, a seaborne trade in gold by the Europeans was added to the overland exports of gold and kola nuts. The multiplier effects of this expanded export trade in products gave a fillip to the ongoing development of a market economy in the region. Evidence from research shows that the period from the mid-fifteenth to the midsixteenth century was characterized by population growth, increases in the number of urban centres and in their absolute sizes, the movement of manufacturing from rural areas to the towns, and division of labour between town and country. ${ }^{42}$ The growth of the domestic market which followed these developments created market incentives for wealthy Asante merchants who had accumulated considerable wealth from the gold and kola nut trades to invest their profits in forest clearing to create farmlands in the sixteenth and early seventeenth centuries. ${ }^{43}$ The extent of commercialisation of the Gold Coast economy during the period is indicated by the gradual emergence of a land market. For example, the land on which Kumasi was later built was purchased at that time for the gold equivalent of $£ 270$ (sterling), a very large sum in those days. ${ }^{44}$

It is reasonable to infer that early European trade in African products (gold, hides and skins, and pepper in the region from Senegambia

${ }^{42}$ Ray A. Kea, Settlements, Trade, and Polities in the Seventeenth-Century Gold Coast (Baltimore: Johns Hopkins University Press, 1982), pp. 11, 85-91.

${ }^{43}$ Ivor Wilks, "Land, Labour, Capital and the Forest Kingdom of Asante: A Model of Early Change", in J. Friedman and Michael John Rowlands (eds.), The Evolution of Social Systems (London: Duckworth, 1977), pp. 487-534; Kea, Settlement, Trade, and Polities, pp. 85-91; Ivor Wilks, Forests of Gold: Essays on the Akan Kingdom of Asante (Athens: Ohio University Press, 1993).

${ }^{44}$ Kea, Settlement, Trade, and Polities, p. 90; Inikori, "Transatlantic Slaving", fn. 45. 
to the Ivory Coast, cotton cloths and pepper in the Benin trading area) generated similar effects in other parts of West Africa. The earlier evidence on cloth export from Benin certainly points in that direction.

\section{Insights from Changing Commodity Composition of Imports from Europe}

Long-run changes in the structure of merchandise imports into West Africa from Europe, from the early decades of the trade to the midnineteenth century, offer a window into the impact of the Atlantic slave trade on economies and societies in the region. Because West African sub-regions started intensive trading with the Europeans at different points in time, the early decades of the trade constitute different periods for the sub-regions. By the last quarter of the seventeenth century, the Gold Coast had been heavily involved in trading with the Europeans for about two hundred years, while intensive European trading in the Bight of Biafra (southeastern Nigeria) had started just a few decades earlier. We have, therefore, taken commodity composition of English imports into the latter region in the middle decades of the seventeenth century as suggestive of the structure of early merchandise imports for all sub-regions.

Consistent with the evidence showing European traders' distribution of local cotton textiles in the early decades of their trade in West Africa, British trade records show very few textiles imported from England in those decades. Between 1661 and 1681, textiles were at most 1.6 percent of the total value of imports into the region from England (Table 3.1). The most important import into southeastern Nigeria in these early decades was commodity currency, copper rods weighing about one pound each, reflecting the ongoing expansion of interregional and local trade discussed earlier. The commodity currency was used only in domestic exchanges. Export and import trade with the Europeans was strictly by barter. Iron bars employed in the manufacture of iron products by the Awka and other metal workers of the Igbo heartland were the other important product in these decades. All this is consistent with the earlier discussion concerning the continuation and further extension of the pre-contact growth of market production, specialization, and trade in the early decades of European commercial enterprise in West Africa.

The currently available seventeenth-century evidence for the Dahomean coast (modern southern Republic of Benin, which is part of 
Table 3.1. Imports from Britain into the Bight of Biafra: 1661-93 (in $£$ sterling and percentage)

\begin{tabular}{|c|c|c|c|c|c|c|c|}
\hline & $\begin{array}{l}\text { Currency } \\
\text { (copper rods; } \\
\text { manilas; } \\
\text { cowries) (\%) }\end{array}$ & $\begin{array}{l}\text { Iron } \\
\text { bars } \\
(\%)\end{array}$ & $\begin{array}{l}\text { Firearms } \\
(\%)\end{array}$ & $\begin{array}{l}\text { Textiles } \\
(\%)\end{array}$ & $\begin{array}{l}\text { Other } \\
\text { commo- } \\
\text { dities } \\
(\%)\end{array}$ & $\begin{array}{l}\text { Total } \\
\text { value } \\
\text { (in } \mathfrak{E})\end{array}$ & $\begin{array}{l}\text { Number } \\
\text { of } \\
\text { cargos }\end{array}$ \\
\hline 1661 & 67.6 & 9.4 & 6.7 & 1.6 & 14.6 & 889 & 1 \\
\hline 1662 & 69.4 & 9.7 & 6.9 & 1.6 & 12.5 & 866 & 1 \\
\hline 1680 & 38.1 & 56.1 & 0.0 & 0.7 & 5.0 & 4,157 & 7 \\
\hline 1681 & 44.2 & 45.9 & 0.0 & 0.0 & 10.1 & 6,673 & 9 \\
\hline 1684 & 64.9 & 21.5 & 0.0 & 7.9 & 5.8 & 2,822 & 3 \\
\hline 1690 and 1692 & 30.6 & 35.4 & 0.0 & 10.7 & 23.3 & 2,598 & 3 \\
\hline 1693 & 35.7 & 25.5 & 0.0 & 14.6 & 24.3 & 926 & 1 \\
\hline
\end{tabular}

Sources: The National Archives, Kew, T 70/1221, T 70/309, T 70/911, T 70/914A, $\mathrm{T} 70 / 916, \mathrm{~T} 70 / 917, \mathrm{~T} 70 / 919$, $\mathrm{T} 70 / 924$. The cargoes represent only a small part of the actual total for each year.

the Bight of Benin), though somewhat later than that for southeastern Nigeria, points in the same direction. Textile imports were already large in the 1680s and 1690s - 28.4 percent of total imports in 1681 and 32 percent in the early $1690 \mathrm{~s}$. But the most important imports were cowries, the currency for domestic exchanges in the area. They comprised 59.2 percent of the total value of imports in 1681; by the early 1690 s they still made up 38.6 percent. ${ }^{45}$ The earliest figures for imports into the Gold Coast are taken from a Portuguese account ledger for 1529$1531 .{ }^{46}$ Computed in terms of the gold value of each item, metalware (mostly brass manillas weighing about $1.3 \mathrm{lbs}$ each, pans for washing gold, large cooking pots, brass shaving bowls, and brass chamberpots) made up 50 percent of the total, cloth 25 percent, slaves imported from other parts of West Africa 19 percent, beads 3 percent, and other small items 3 percent. ${ }^{47}$ The import of labour into the Gold Coast at this time should be noted. The imported labour was used largely in forest clearing by the Asante entrepreneurs discussed earlier.

Again, the Dahomean and Gold Coast imports in the early decades of seaborne trade with the Europeans all indicate sustained expansion

\footnotetext{
${ }^{45}$ Ibid.

${ }^{46}$ John Vogt, "Portuguese Gold Trade: An Account Ledger from Elmina, 1529-1531", Transactions of the Historical Society of Ghana, 14, 1 (1973), pp. 93-103.

${ }^{47}$ Ibid., pp. 93-94.
} 
of market production and the growth of internal trade. The limited import of firearms in these early decades, as the evidence shows, suggests the prevalence of relatively peaceful conditions conducive to the growth of long-distance and local trade at the time. From the late seventeenth century, all this changed. Two important changes set others in motion. First, the rapid growth of American demand for slave labour changed decisively European traders' demand from West African products to captives to be sold in the Americas. Second, the imports brought by the European traders to pay for the captives became largely finished consumer manufactures, dominated from the eighteenth century by cotton textiles from India and England. As the forceful procurement of captives directly and indirectly generated widespread socio-political conflict in the largely politically fragmented territories, demand for firearms grew over time and firearms became the other major import treated by some analysts as producer goods because of their employment in wars and raids that generated captives sold for export. ${ }^{48}$ Imports into the Bight of Biafra (southeastern Nigeria) illustrate the change (Table 3.2). The import of textiles and firearms grew over the eighteenth century. In the 1790s they comprised about three-quarters of the total value of imports. Currency imports declined drastically indicating the contraction of inter-regional trade. Similarly, relatively few iron bars

Table 3.2. Imports from Britain into the Bight of Biafra: 1701-90 (in $£$ sterling and percentage)

\begin{tabular}{|c|c|c|c|c|c|c|c|}
\hline & $\begin{array}{l}\text { Currency } \\
\text { (copper rods; } \\
\text { manilas; } \\
\text { cowries) (\%) }\end{array}$ & $\begin{array}{l}\text { Iron } \\
\text { bars } \\
(\%)\end{array}$ & $\begin{array}{l}\text { Firearms } \\
(\%)\end{array}$ & $\begin{array}{l}\text { Textiles } \\
(\%)\end{array}$ & $\begin{array}{l}\text { Other } \\
\text { commodities } \\
(\%)\end{array}$ & $\begin{array}{l}\text { Total } \\
\text { value } \\
(\text { in } \mathfrak{E})\end{array}$ & $\begin{array}{l}\text { Number } \\
\text { of cargos }\end{array}$ \\
\hline 1701 & 29.9 & 35.5 & 3.2 & 9.3 & 22.1 & 2,602 & 2 \\
\hline 1724 & 33.2 & 0.0 & 7.6 & 30.3 & 28.9 & 937 & 1 \\
\hline 1790 & 6.3 & 10.0 & 39.7 & 37.9 & 6.2 & 8310 (a) & 1 \\
\hline 1791 & 2.9 & 2.8 & 27.0 & 46.6 & 20.7 & 7,326 & 1 \\
\hline
\end{tabular}

(a) The 1790 total cargo values are shown in bars in the source.

Sources: The National Archives, Kew, T 70/1221, T 70/309, T 70/911, T 70/914A, T 70/916, T 70/917, T 70/919, T 70/924, C 107/5, C 107/6.

${ }^{48}$ Henry A. Gemery and Jan S. Hogendorn, "Technological Change, Slavery, and the Slave Trade", in Dewey and Hopkins (eds.), The Imperial Impact, pp. 243-58. 
were being imported, again, signalling the decline of manufacturing for inter-regional exchange in the Igbo heartland.

Currently available evidence for the Dahomean trading area and the Gold Coast in the late seventeenth and early eighteenth century shows a more or less similar pattern. Textile imports into Dahomey increased from 38.1 percent of the total value of imports in 1701 to 66.1 percent in 1724; currency imports (cowries) declined from the 59.2 percent in 1681 to 22.1 percent in 1724 , with firearms at 8.9 percent. One cargo of goods worth $£ 13,626$ (sterling), shipped to the Gold Coast in 1684 by the English Royal African Company, was made up of 78.9 percent textiles (European and Asian) and 7.6 percent firearms; there were no cowries at all and hardly any intermediate goods. ${ }^{49}$ Early in the nineteenth century, the pattern changed in terms of currency import into the Gold Coast, where effective British naval patrol virtually terminated Atlantic slave exports shortly after British abolition in 1807. Large quantities of currency (cowries) were now being imported as product exports (seaborne and overland to the savannah territories) increased..$^{50}$ But in the Bights of Benin and Biafra, where significant captive exports continued throughout the first half of the nineteenth century, the pattern remained virtually unchanged (Table 3.3). ${ }^{51}$

Table 3.3. Imports from Britain into the Bights of Benin and Biafra: 1828-50 (selected items in $£$ sterling and percentage)

\begin{tabular}{lcccccr}
\hline & $\begin{array}{c}\text { Currency } \\
\text { (cowries) }(\%)\end{array}$ & $\begin{array}{c}\text { All metals } \\
(\%)\end{array}$ & $\begin{array}{l}\text { Firearms } \\
(\%)\end{array}$ & $\begin{array}{l}\text { Textiles } \\
(\%)\end{array}$ & $\begin{array}{l}\text { Alcohol } \\
(\%)\end{array}$ & $\begin{array}{l}\text { Total value } \\
\text { (in } £)\end{array}$ \\
\hline $1828-30$ & 0.1 & 5.3 & 32.8 & 26.8 & 14.4 & 387,257 \\
$1832-43$ & 1.7 & 3.1 & 21.5 & 34.4 & 15.5 & $3,277,546$ \\
$1845-50$ & 1.2 & 5.0 & 15.7 & 32.0 & 21.0 & $3,024,691$ \\
\hline
\end{tabular}

Sources: The National Archives, Kew, Cust. 8/25-8/71; Cust. 10/18-Cust. 10/41.

${ }^{49}$ Inikori, “Transatlantic Slaving”.

${ }^{50}$ Ibid.

${ }^{51}$ By this time the British government had abolished the Atlantic slave trade for its nationals, but other European nations and their offshoots in the Americas were still carrying on the trade. The Yoruba wars at this time made the Bight of Benin a major slave-trading region, with the port of Lagos as its headquarters. Slave exports continued to flourish in the Bight of Biafra up to the 1830s when it began to decline. In contrast, slave exports from the Gold Coast had been reduced to a minimum by this time. The African region specified in the records is "the West Coast of Africa from the Volta to the Cape of Good Hope, both exclusive". For all practical purposes, however, 


\section{Impact of Imported Cottons Exchanged for Captives}

As captive exports to the Americas expanded from the late seventeenth century, West Africa became a major market for Indian and European cotton textiles. The direct exchange of the imported textiles for export captives (the barter system of trade) had far-reaching effects on the growth and development of cotton textile production in West Africa. The rest of the paper attempts to show that in the main production areas it prevented the growth of demand and output to a point where merchants found it worthwhile to superimpose on the producers the proto-industrial form of production organization and marketing. To prove this proposition we must take into account the direct competitive effects of the imports and the effects of the forceful procurement of captives for export on the growth of inter-regional trade and specialization, the spread of the market economy, and the expansion of the internal market for manufactures in general and for local cotton textiles in particular. ${ }^{52}$

By the second half of the eighteenth century West Africa had become a major export market for English and East India cottons. Producers in Lancashire struggled long and hard to take over the market from Indian cottons and effectively succeeded in doing so in the first half of the nineteenth century. Table 3.4 shows the competing exports of English and East India cottons from England to Western Africa from the mideighteenth to the mid-nineteenth century. The competition between Indian and English cottons was about even in the 1750s and 1760s. But in the 1770s, Indian cottons had a clear edge. In the last two decades of the eighteenth century the English industry, especially the export sector concentrated in Lancashire, adopted revolutionary new technologies. In spite of that Indian cottons expanded their share of the West African market in the 1790s. Evidence shows that the gains made by Indian cottons in this decade did not result from a relative decline in demand for English cottons in West Africa. On the contrary, Lancashire manufacturers were unable to meet soaring export orders from the

the imports went virtually to southern Nigeria. Places beyond southern Cameroon were hardly involved. That is the justification for using Bights of Benin and Biafra in the Table.

${ }_{52}$ As stated in fn. 10 above, we must bear in mind that, in terms of the overall magnitude of these exchanges, other traders from Europe and the Americas also imported similar cotton textiles exchanged for captives. 
Table 3.4. Competing exports of English and Indian cottons to Western Africa: $1751-1850$ (decennial totals)

\begin{tabular}{lcc}
\hline Period & East India Cottons & English Cottons \\
\cline { 2 - 2 } & value in $£$ & value in $£$ \\
\hline $1751-1760$ & 436,802 & 406,254 \\
$1761-1770$ & 798,955 & 898,921 \\
$1771-1780$ & 993,251 & 636,456 \\
$1781-1790$ & $1,457,298$ & $1,407,583$ \\
$1791-1800$ & $2,865,340$ & $1,987,565$ \\
$1801-1807$ & $2,202,400$ & $2,136,109$ \\
\hline & quantity in yards & quantity in yards \\
\hline $1827-1830$ & $2,835,500$ & $6,915,577$ \\
$1831-1840$ & $4,536,200$ & $59,295,855$ \\
$1841-1850$ & $4,776,590$ & $107,675,091$ \\
\hline
\end{tabular}

* From 1827 to 1850 the English cottons are shown in yards in the customs ledgers, while the East India cottons are shown in pieces. The conversion of the Indian cottons to yards is based on information taken from the records of Thomas Lumley \& Co. of London, slave merchants and dealers in East India goods (The National Archives, Kew, C114/154). The computation from this source gives 10 yards per piece, average. Figures for English cottons are not available for 1844.

Sources: Computed from Joseph E. Inikori, Africans and the Industrial Revolution in England: A Study in International Trade and Economic Development (Cambridge: Cambridge University Press, 2002), Table 9.8, p. 444.

British slave traders during the period. This may have been due to the shortage of skilled workers to operate the new machines. ${ }^{53}$

In the first half of the nineteenth century things changed drastically. Indian cotton imports increased from approximately 4.5 million yards in 1831-1840 to 4.8 million yards in 1841-1850, while English cotton imports grew from 59.3 million yards to 107.7 million yards (even with no figures for 1844) during the same period. A major factor in the competitive edge of English cottons in the first half of the nineteenth century was a drastic reduction of their prices. Table 3.5 compares the official values of British cotton textiles imported in 1827-1849 into the West African coast from the River Volta (eastern end of the Gold Coast) to southeastern Nigeria, based on constant prices established at the

${ }^{53}$ Joseph E. Inikori, Africans and the Industrial Revolution in England: A Study in International Trade and Economic Development (Cambridge: Cambridge University Press, 2002), pp. 443-46. 
beginning of the eighteenth century, with the declared values based on current prices at the time. As can be seen from the table, the current price values were 43.2 percent of the constant price values in 1827-29; they declined continuously and were only 19.9 percent by $1847-49$. It is, therefore, no surprise that the English cottons captured a greatly enlarged share of the West African market in the first half of the nineteenth century.

This competition between English and Indian cottons offers a window on the impact of imported textiles exchanged for captives on the development of cotton textile production in West Africa between 1650 and 1850. It should be noted that large-scale imports of Indian cottons into England by the English East India Company began in the midseventeenth century. The quantity ordered by the company grew from an annual average of 174,000 pieces in 1661-64 to approximately 2.4 million in $1681-83 .{ }^{54}$ This rapid growth was not just the result of new

Table 3.5. Official and declared values of British cotton textiles imported from Britain into the African coast from the River Volta to the Cape of Good Hope: $1827-49$

\begin{tabular}{|c|c|c|c|}
\hline & $\begin{array}{l}\text { Official value } \\
\text { (constant prices } \\
\text { in } £ \text { ) }\end{array}$ & 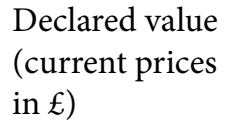 & $\begin{array}{l}\text { Declared value as a } \\
\% \text { of official value }\end{array}$ \\
\hline $1827-29$ & 97,462 & 42,127 & 43.2 \\
\hline $1830-32$ & 228,368 & 88,528 & 38.8 \\
\hline $1833-35$ & 406,945 & 135,912 & 33.4 \\
\hline $1836-38$ & 573,235 & 185,893 & 32.4 \\
\hline $1839-41$ & $1,050,850$ & 314,706 & 30.0 \\
\hline $1842-44$ & $1,302,709^{*}$ & $315,588^{*}$ & 24.2 \\
\hline $1845-47$ & $1,281,662$ & 311,194 & 24.3 \\
\hline $1847-49$ & $1,568,677$ & 312,786 & 19.9 \\
\hline
\end{tabular}

* These figures are for 1842 and 1843; there are no figures for 1844 in the customs ledgers.

Sources: The National Archives, Kew, Customs 8/25 - Customs 8/69. See also Joseph E. Inikori, "West Africa's Seaborne Trade, 1750-1850: Volume, Structure and Implications", in Gerhard Liesegang, Helma Pasch and Adan Jones (eds.), Figuring African Trade: Proceedings of the Symposium on the Quantification and Structure of the Import and Export and Long Distance Trade in Africa, 1800-1913 (Berlin: D. Reimer, 1986), Table III.5, p. 71.

\footnotetext{
${ }^{54}$ Ibid., Table 9.5, p. 430.
} 
demand in England; a significant portion of the domestic market for English woollen and silk was taken away by the new product. This is why woollen and silk manufacturers put pressure on British legislators to restrict the import of cotton textiles. The legislators obliged, only to pave the way for the development of a domestic cotton textile industry behind import control. It was from the protected domestic market that the new industry launched its battle with the Indian cottons in West Africa. It is significant that before this encounter British woollens and European linens were being imported into Western Africa, especially the Gold Coast, in considerable quantities. The cargo shipped by the Royal African Company to the Gold Coast in 1684, mentioned earlier, contained textiles valued at $£ 10,740$ (sterling f.o.b.) made up largely of European linen and British woollen textiles, ${ }^{55}$ a reflection of the dominance of European linens and British woollens in the textiles shipped to West Africa in the late seventeenth century. Initially, the imported Indian and English cottons had to take away much of the West African market from the linens and woollens, just as they were doing in Europe.

There is clear evidence that by the late seventeenth and early eighteenth century these imported European woollens and linens had replaced in Gold Coast markets local cotton cloths previously imported from Benin, Allada, and the Ivory Coast. ${ }^{56}$ The loss of the Gold Coast market was clearly a damaging blow to cotton cloth producers in northeastern Yoruba country and Nupe who were the suppliers of the cotton cloths that Benin traders sold to the Europeans for export to the Gold Coast. As we noted earlier, the Benin hinterland suppliers were already in a quasi proto-industrial relationship with the Benin traders at the time. Together with other effects of the growth of captive procurement for export, the loss of this important long-distance market precluded further progress toward full-scale proto-industrial production of cotton cloths in these areas. The same point applies more or less to producers in Hausaland and the Niger Bend for whom the Gold Coast had been a major export market.

The point to stress, however, is that if the imported woollens which were unable to compete with Indian cottons in England had this impact on the local cotton trade on the Gold Coast, it is reasonable to infer that

55 Inikori, "Transatlantic Slaving and Market Development".

${ }^{56}$ Daaku, Trade and Politics, p. 24; John Kofy Fynn, Asante and its neighbours 17001807 (Evanston, Ill.: Northwestern University Press, 1971), pp. 11-12. 
Indian cottons and their English rivals had even greater adverse impact in the second half of the eighteenth century, and even more so in the first half of the nineteenth, for the reasons already shown in the preceding paragraphs. Furthermore, the fact that with all the technological innovations of the late eighteenth century, induced in part by the competition, the English cottons still had to share the West African market more or less equally with the Indian cottons, before they pulled away decisively in the first half of the nineteenth century, is a clear indication of the competitive strength of the Indian cottons which producers in West Africa (especially those on the coast and the immediate Atlantic hinterland) were unlikely to match. This point is supported by one piece of indirect evidence. While the correspondence of the English cotton manufacturers with the British slave traders shows a sustained preoccupation with their competition with Indian cottons in West Africa, there is not a single mention of competition with local producers in West Africa in the eighteenth century. There are many references to raw cotton production and efforts to encourage large scale production for export to Europe. ${ }^{57}$ But there is no indication at all that local cotton textile producers presented any competition in the West African market. A report made from Keta (in Anlo, just east of the Volta River) by a Dutch official in 1718 is revealing:

I found here at Quita a large number of children and men constantly busy spinning cotton on little sticks of about a foot length. I wanted to buy some, as they said that they collected this cotton in order to maintain their children. They were prepared to sell, but they asked not less than three strings of cowries for one ball of cotton which does not weigh more than about half a pound, which would mean paying about as much as at home [Holland]. When I proposed to buy a big quantity of about hundred pounds for 20 Angels, they just laughed at me ... I am sure that if the Negroes did their best to make cotton plantations, they could gain a lot from it; but these people think only in a day-to-day manner, and never think of tomorrow. ${ }^{58}$

The indication here is that raw cotton was expensive because of the underdevelopment of commercial production of raw materials. The

${ }^{57}$ Dutch documents translated by Van Dantzig contain many references to raw cotton production, especially in the Bight of Benin: A. van Dantzig (ed.), The Dutch and the Guinea Coast, 1674-1742: A Collection of Documents from the General State Archive at The Hague, Compiled and Translated (Accra: GAAS, 1978). The English documents contain similar information.

${ }^{58}$ Ibid., p. 206. 
Dutch official must have thought it to be a lack of foresight. But it was, in reality, rational economic behaviour in a context of limited market opportunities for the productive employment of resources. It is significant, however, that there is no mention of a competing cotton textile industry. The same thing is true of the British documents.

The direct barter exchange of imported cotton textiles and other manufactures for captives in the area of Bonny (southeastern Nigeria), may be employed to illustrate how the exchange operated to retard the development of cotton textile manufacturing in West Africa during the period. As Table 3.6 shows, a total of 637 pieces of ten different types of cotton textiles, English and Indian, were included in assortments of imported goods exchanged in barter for 73 captives sold by a Bonny

Table 3.6. Direct barter exchange of imported goods for 73 captives sold by the Bonny Trader, Allison, to a British slave ship in 1791-92

\begin{tabular}{lc}
\hline English and Indian cotton textiles & Number of pieces \\
\hline Chintz & 85 \\
Blue Bafts & 72 \\
White Bafts & 25 \\
Chelloes & 33 \\
Half Pollicels & 25 \\
Photaes & 104 \\
Niccanees & 61 \\
Cushtaes & 47 \\
India Romals & 132 \\
Manchester Romals & 53 \\
Total cottons & 637 \\
\hline Other Commodities & In number \\
\hline Neptunes (Brass Pans) & 86 \\
Iron Bars & 229 \\
Copper Bars & 119.5 \\
Guns & 383 \\
Gun-Powder (Kegs) & 1,197 \\
\hline Sources \& &
\end{tabular}

Sources \& Notes: Computed from Joseph E. Inikori, "The Development of Entrepreneurship in Africa: Southeastern Nigeria during the Era of the Trans-Atlantic Slave Trade", in Alusine Jalloh and Toyin Falola (eds.), Black Business and Economic Power (Rochester, N.Y.: University of Rochester Press 2002), Appendix III, pp. 36-7. Some minor items, such as beads, hats, caps, knives, cutlasses, etc., included in the assortment of goods exchanged for the 73 captives in a total of 15 separate transactions, have been left out in this table. 
trader to a British slave ship in 1791-92. This is approximately nine pieces per captive sold for export. Very few of the goods exchanged for the captives went beyond the middlemen cities on the coast and their immediate hinterlands. The victim populations in the interior, where the captives were forcefully taken, received nothing in return other than the disruption of their economies and societies. It is significant that the table shows an average of 5.2 guns and 16.4 kegs of gunpowder also exchanged for each of the 73 captives sold. The coastal societies and their immediate hinterlands now had little need for the manufactures (cotton cloths in particular) from the interior as they did in pre-contact times and shortly after. Given the tens of thousands of captives sold for export annually in the eighteenth and early nineteenth centuries, they must have been filled with imported textiles and other manufactures..$^{59}$

As the widespread socio-political conflict engendered by the violent procurement of captives for export disrupted the flow of inter-regional trade and raised transaction costs, traders and state functionaries in the coastal cities and their immediate hinterlands could not rely on the flow of trade to supply even their subsistence needs. Hence, the traders retained some of the captives they bought, the state kept some of the prisoners taken in wars, and the warriors and raiders held on to some of their captives - they all employed these retained captives in agriculture to provide the food they needed. ${ }^{60}$ The dependent populations that grew up in southeastern Nigeria (like the rest of Atlantic Africa) ${ }^{61}$ during the Atlantic slave trade era were concentrated in the middlemen coastal cities and their immediate hinterlands, and the holding elites were involved in the captive export process either as traders, state functionaries, warriors, or raiders. ${ }^{62}$ These coastal cities and their immediate hinterlands thus evolved over time into typical parasitic enclave economies with little productive, but largely disruptive, links to the victim populations and their economies and societies in the interior.

\footnotetext{
59 Modern research puts total transatlantic export of captives from Africa at a minimum of 12 million, concentrated largely in the period 1750-1850. Southeastern Nigeria was a leading export region between 1750 and 1830 .

${ }^{60}$ Latham, "Currency, Credit and Capitalism"; Joseph E. Inikori, "Export Versus Domestic Demand: The Determinants of Sex Ratios in the Transatlantic Slave Trade", Research in Economic History, 14 (1992), pp. 111-59.

${ }^{61}$ Patrick Manning, Slavery and African Life: Occidental, Oriental, and African Slave Trades (Cambridge: Cambridge University Press, 1990).

${ }^{62}$ Inikori, "Export Versus Domestic Demand".
} 
For much of the eighteenth century and the early nineteenth, therefore, the growing inter-regional trade that had connected the densely populated Igbo heartland to the Cross River valley and the Atlantic coast, in which manufactures from northern Igboland were exchanged for agricultural and aquatic products shown previously in the paper, was disrupted and severely constricted. Captives from the populous Igbo heartland now flowed to the coast in place of the earlier manufactures. The combined effects of socio-political conflict and population loss ultimately held back the growth of trade and specialization, the commercialising process, and the development and geographical spread of the market economy in northern Igboland, all of which retarded further development of manufacturing (including cotton textiles) in the area. The evidence presented in the paper makes it clear enough that this experience was shared by other major areas of cotton cloths production in West Africa during the period.

\section{Conclusion}

John Iliffe's investigation concerning the level of capitalist development in West Africa by the mid-nineteenth century provides an appropriate backdrop against which to conclude this paper. In his investigation Iliffe employs the general conception of capitalism as a system of production in which free wage labour is the dominant form of the labour process. He takes proto-industrialization, with its merchant control of the production and marketing process through the putting-out system, as the closest to capitalist manufacturing in the industrialization process before the mechanization and factory organization of manufacturing. ${ }^{63}$ In all of West Africa he finds no evidence of proto-industrialization in cotton spinning or weaving. Only in dyeing is there some such evidence (oral) concerning the industry in Kano, but not in the coastal and forest regions to the south ${ }^{64}$ - there was no proto-industrial production of cottons and other manufactures in northern Igboland and northeastern Yoruba country, areas whose great potential for protoindustrialization was discussed extensively in the paper. As Iliffe puts it, "There is no significant written evidence from the nineteenth-century

${ }^{63}$ John Iliffe, The Emergence of African Capitalism (Minneapolis: University of Minnesota Press, 1983).

${ }^{64}$ Ibid., pp. 6-15. 
West African savannah of any trend towards what in Europe is now called proto-industrialisation". But oral evidence collected in the 1970s shows that in the nineteenth century "Kano's cloth merchants began to buy unfinished cloth from the weavers and put it out for processing by dyers and beaters in return for what was in effect a wage. The merchant then received the cloth back for marketing; his signature on the bale acted as a trademark". ${ }^{65}$ This paper has argued that the non-development of proto-industrialization in West Africa's cotton industry by the mid-nineteenth century is attributable largely to the sale of imported textiles in exchange for captives in the region between 1650 and 1850.

Iliffe's findings on the non-development of proto-industrialization in West Africa by the mid-nineteenth century testify to the retardation of market development in the region between 1650 and 1850, the causes of which we have demonstrated in the paper. Proto-industrialization, by definition, was a function of the growth of markets for manufactures. As Peter Kriedte noted more than two decades ago, "The world market which was slowly coming into existence acted as the engine of proto-industrial growth".66 That the region in West Africa that came closest to a full-scale proto-industrialization - the Kano emirate in modern Northern Nigeria - is located in the interior savannah (far removed from the Atlantic coast) is instructive. ${ }^{67}$ Its industry developed behind natural protection by distance from the chaos of the Atlantic slave trade and the direct adverse impact of imported textiles. Even so, Kano's industrial development was adversely affected by the slave trade and the import of textiles into regions that would have otherwise been major markets for Kano's products. This is particularly true of the Gold Coast, as indicated by its inter-regional trade and its specialisation during the period 1200-1600. The Kano industry, like the more successful Lancashire industry, was export-oriented ${ }^{68}$ Under the conditions which prevailed in West Africa between 1650 and 1850, Kano's potential export markets remained severely constricted and largely out of reach. And following British colonization of Nigeria, and

65 Ibid., p. 10.

${ }^{66}$ Peter Kriedte, Peasants, Landlords and Merchant Capitalists: Europe and the World Economy, 1500-1800 (Leamington Spa, Warwickshire: Berg, 1983), p. 13.

${ }^{67}$ Philip James Shea, "The Development of an Export Oriented Dyed Cloth Industry in Kano Emirate in the Nineteenth Century" (Unpublished Ph.D. Thesis, University of Wisconsin, Madison, 1975); Philip James Shea, "Economies of Scale and the Indigo Dyeing Industry of Pre-Colonial Kano", Kano Studies, 1, 2 (1974), pp. 55-61.

68 Shea, "Development"; Id., "Economies of Scale". 
the extension of the railways to Kano in 1911, imported European textiles began to chop away even the home market in the Kano emirate. It was estimated in 1916 that European cottons worth $£ 500,000$ were imported into Kano in one year. ${ }^{69}$ More empirical research may unearth further evidence in the future. But there can be little doubt that imported European and Asian textiles exchanged for export captives in West Africa between 1650 and 1850 inhibited the growth of trade, the commercialising process, and the growth of demand for local cotton cloths to a point where merchants thought it worth their while to superimpose on the producers proto-industrial organization of cotton textiles production and marketing in the region during the period.

69 Shea, "Development", p. 87. Shea noted that the Kano industry at this time also faced the problem of raw cotton exports from Nigeria to Britain "which must have pushed up the cost of producing cloth". 


\title{
BRITISH EXPORTS OF RAW COTTON FROM INDIA TO CHINA DURING THE LATE EIGHTEENTH AND EARLY NINETEENTH CENTURIES ${ }^{1}$
}

\author{
H. V. Bowen
}

The [Chinese] people are remarkable for industry and perseverance: they are largely engaged in the manufacture of cotton goods; and although the cotton shrub has long been cultivated in China, the extent of their consumption obliges them to import much of the raw material. It is the raw produce generally which meets with the best market in China. ${ }^{2}$

\section{Introduction}

In the five decades or so after 1760 , but especially in the years after 1785, exports of raw cotton from British India to China increased to such an extent that in 1805 consignments amounting to an unprecedented 55.3 million lbs were shipped into the southern port city of Canton. ${ }^{3}$ The establishment of this major commodity flow added an important integrative element into the increasingly multi-centred Asian cotton textile industry, and its quantitative significance may be

${ }^{1}$ A preliminary draft of this paper was presented at the Global Economic History Network conference on cotton textiles held at the University of Padua in November 2005. I am grateful to the participants who made many helpful comments and suggestions, and especially to Harriet Zurndorfer for her detailed commentary on the paper. I also wish to thank Li Bozhong, George Bryan Souza, and Paul Van Dyke for clarifying several points about the importation of Indian cotton into China; and the last-named has also been most generous in sharing his unrivalled detailed knowledge of trading activity at the port of Canton. The research upon which this essay is based was conducted during my tenure of a Research Fellowship (RES-000-27-0108) awarded by the Economic and Social Research Council of Great Britain.

${ }^{2}$ Peter Auber, China. An Outline of its Government, Laws, and Policy: and of the British and Foreign Embassies to, and Intercourse with, that Empire (London: Parbury Allen \& Co., 1834), p. 93.

3 This figure is calculated from data in Hosea B. Morse, The Chronicles of the East India Company Trading to China, 1635-1834 (Oxford: Clarendon Press, 1926-29), vol. 3, p. 2. Morse noted the import of 414,208 piculs of cotton in 1805 ( 1 picul $=133.5 \mathrm{lbs}$ ). Over 98 per cent of this cotton was carried on British-owned ships. 
compared to that of the retained imports of 'wool cotton' into Great Britain which in the same year stood at 58.9 million lbs. ${ }^{4}$ The extent of this importation of large quantities of raw cotton into China during this period has not always been acknowledged by global economic historians, ${ }^{5}$ but just as the burgeoning British cotton industry was dependent upon overseas sources of raw materials so too many Chinese weavers and spinners came to rely upon supplies of cotton delivered across long-distance transoceanic commodity chains. The crucial difference, of course, was that Britain did not grow cotton of its own whereas for many centuries cotton had loomed large within the Chinese agricultural sector. But as far as China was concerned, external supplies were in many ways no less essential to the cotton industry because ecological constraints caused marked fluctuations in the output of different cotton-growing regions during the mid- to late-eighteenth century, and this recast if not severed altogether some of the traditional supply linkages that existed between growers and weavers. ${ }^{6}$

While China's degree of dependence upon external supply was never as complete or long-lasting as that of Britain, large-scale imports of raw cotton nevertheless served in the short term to sustain cotton textile production through a difficult period of agricultural dislocation. As a result, the output of the cotton manufacturing sector was able to meet the consumption needs of a growing local population as well as the steadily expanding overseas demand for the cheap, robust, and usually cream-coloured cloths known to the British as 'nankeens.' It must be

${ }^{4}$ Elizabeth B. Schumpeter, English Overseas Trade Statistics, 1697-1808 (Oxford: Oxford University Press, 1960), p. 62.

${ }^{5}$ See, for example, Kenneth Pomeranz, The Great Divergence. China, Europe, and the Making of the Modern World Economy (Princeton: Princeton University Press, 2000), p. 227. When comparing constraints on textile production and shortages of cotton fibre in Europe and China, Pomeranz writes that "The big difference for Europe, of course, was that beginning in the late eighteenth century it would massively increase its imports of fiber ..." . As has been pointed out, however, this overlooks the fact that China did exactly the same in order to ease pressures on its land. See Prasannan Parthasarathi, "The Great Divergence", Past and Present, 176 (2002), pp. 282-83.

6 There is only limited and patchy data on Chinese cotton growing during the late eighteenth century, but for shortages of fibre and estimates of long-term trends in different regions see Pomeranz, Great Divergence, pp. 132-42, 227, 323-26, 334-37. For the general background see also Kang Chao, The Development of Cotton Textile Production in China (Cambridge, Ma: Harvard University Press, 1977).

${ }^{7}$ Much of the nankeen cloth imported into Britain appears to have been off-white in colour, even though the use of red and yellow thread produced a wide range of white, yellow, and pink cloths. The nankeen cloth sold in Britain was used in the manufacture 
stressed that this is not to suggest that raw cotton imported from India was simply later re-exported from Canton to Europe in the form of nankeen cloth manufactured in Jiangnan in the Yangzi River delta, because most Indian cotton seems to have been retained in and around the southern province of Guangdong where it was used for the production of yarn, thread, and cloth destined for the domestic market. ${ }^{8}$ Nonetheless, it is evident that the large quantities of raw cotton imported from India did ultimately enable the Chinese textile manufacturing sector to sustain diverse forms of output directed towards different expanding markets at home and abroad.

\section{Agents of Commercial Expansion and Integration}

The matching of supplies from one part of the world to demand in another has never happened by chance, and entrepreneurs of one type or another have usually acted as the necessary agents of integration whose information, skills, and resources have established transoceanic trading links. This was indeed the case in the trade in raw cotton between India and China, but other influences were brought to bear upon the evolving commercial systems that facilitated increasing flows between the Indian cotton-growing regions and the port city of Canton. These additional influences were generated by the East India Company's

\footnotetext{
of trousers, breeches, waistcoats and other such items. Consignments to London by the East India Company increased from 11,000 pieces a year during the 1760s to a peak of 185,000 pieces a year during the first decade of the nineteenth century. Figures derived from British Library, London, India Office Records (hereafter BL, IOR), Commerce Journals, L/AG/1/6, vols. 15, 16, 23, 24. Further exports to London were to be found in the licensed private cargoes belonging to the commanders and officers of the Company's East Indiamen, and for such purposes each ship was permitted to carry 2,000 pieces of nankeen. There was, of course, also an illicit trade in nankeens.

${ }^{8}$ From time to time, the East India Company imported small quantities of 'Canton' cloth into London. It is not yet possible to be absolutely precise about where Indian raw cotton actually went after it entered China and most scholarly comment on the matter is based upon speculation rather than firm evidence. See, for example, Robert B. Marks, Tigers, Rice, Silks, and Silt: Environment and Economy in Late-Imperial South China (Cambridge: Cambridge University Press, 1998), p. 178. It does seem likely, however, that at least some of the cotton imported from India was carried out of Guangdong province by the large number of coolies who made return journeys to the inland teagrowing regions after delivering their consignments of tea to the port of Canton (private communication from Paul Van Dyke). Clearly there is a need for a study of the major distribution networks for Indian cotton that were established in China during the late eighteenth century.
} 
military and political expansion on the Indian subcontinent, a wideranging process which saw intra-Asian trade, or the 'country trade' as it was known by contemporaries, being used to serve the wider needs of British imperial finance and remittance. Thus, while it is certainly true to say that much of the trade in raw cotton was conducted on a day-today basis by private individuals, the overall development of the trade during the late-eighteenth century was driven by the imperatives of the East India Company's emerging colonial regime as well as by the changing pace and direction of British territorial expansion. This was first evident during the 1770s and 1780s as the needs of the Company led to the consolidation and growth of a pre-existing commodity chain that extended from the cotton-growing regions of Gujarat through the ports of Surat and Bombay to Canton. It was then also evident after 1800 when supplies from Bombay faltered and a second major chain was established from the northern province of Awadh and its surrounding territories through Calcutta to Canton. Later, after 1810, a third chain came into being between the Coromandel region of South India and China, via Madras, but for the period under review it was the Britishcontrolled port cities of Bombay and Calcutta that acted as the main linchpins in the trade in raw cotton. The initial growth of exports from the two ports occurred at different times, but it was the simultaneous and extensive involvement of Bombay and Calcutta in the trade in raw cotton after 1800 which ensured that, ultimately, the powerful external influences exerted by Chinese demand were felt on the coasts and in the hinterlands of both western and eastern India.

After the conquest of Bengal and the acquisition of extensive tax revenues between 1757 and 1765 , the export of raw cotton to China increasingly came to be regarded as central to the East India Company's entire system for remitting monies from India to Britain through Canton and its rapidly expanding tea trade with London. ${ }^{9}$ One of the Company's primary annual objectives came to be the regular provision of the substantial liquid funds that were needed by their supercargoes at Canton for the purchase of the large quantities of tea that were in high demand in Britain, Europe, and the Atlantic world. It was to be raw cotton together with illegal shipments of opium that helped to

${ }^{9}$ For a succinct overview of how the 'country trade' between India and China became the 'keystone' of the whole structure of Company trade and finance see Michael Greenberg, British Trade and the Opening of China, 1800-42 (Cambridge: Cambridge University Press, 1951), pp. 5-17. 
generate these funds. Consequently, exports of cotton from India to China can be seen to have increased more or less in line with the expansion of the tea trade between Canton and London, ${ }^{10}$ and this interconnected growth served profoundly to alter long-established patterns of trade both within and beyond the Indian Ocean region. The British were not simply engaged in bilateral trade between India and China and, as Ashin Das Gupta put it, the particular form taken by their commercial expansion enabled them to break out "from the folds of the Indian structure [of overseas trade]". ${ }^{11}$ In Das Gupta's view, the British "transformed the commerce of the Indian Ocean during the later eighteenth century" by "linking the Europe trade with the trade of the Indian Ocean", so much so that "the distinction between the two trades begins to break down". The trade in raw cotton lay at the very heart of this wide-ranging process of transformation, and the spin-off effects were felt right across the trading world of Asia.

\section{Exports of Raw Cotton during the Pre-colonial Era}

In much of what follows it will be evident that the volume of British trade between India and China was greatly enhanced during and after the 1760s, but it must be stressed that this trade was built upon foundations laid down in earlier years. The monopolist Company had not itself actively participated in the country trade to any great extent since the 1670s, when it had made commercial concessions to licensed British private traders, although Company ships plying the trade routes from London to China still made voyages via the subcontinent. Indeed, it appears that it was a Company ship, Catharine, that carried the first trial consignment of Indian raw cotton to China, when it sailed from Surat to Amoy in $1704 .{ }^{12}$ In the years that followed, however, the presence of East Indiamen on that route was very limited because the Company favoured 'direct' voyages to China from London, and it was

${ }^{10}$ See Earl H. Pritchard, The Crucial Years of Early Anglo-Chinese Relations, 17501800. Research Studies of the State College of Washington (Washington: Pullman, 1936), vol. 4 , pp. 145-46.

11 Ashin Das Gupta, "India and the Indian Ocean in the Eighteenth Century", in Uma Das Gupta (ed.), The World of the Indian Ocean Merchant, 1500-1800: Collected Essays of Ashin Das Gupta (New Delhi: Oxford University Press, 2001), p. 214.

${ }_{12}$ Morse, Chronicles, vol. 1, pp. 130 and 132. The original intention had been to sell the cotton at Malacca, but this did not happen. For outline details of the voyage of Catharine, see Anthony Farrington (ed.), Catalogue of East India Company Ships' Journals and Logs (London: British Library, 1999), p. 111. 
only after 1740 that Company vessels from London began regularly to make voyages to India and then on to China. ${ }^{13}$ During the early decades of the eighteenth century British sailings between the Subcontinent to Canton were more commonly undertaken by country ships belonging to licensed private merchants and sea captains.

It was the enterprise of private traders that more firmly established the trade in raw cotton which was exchanged for white sugar and sugar candy, and as early as 1713 some British merchants were claiming that cotton "never fails to yield a profittable account" in Canton. ${ }^{14}$ Farmers in the southern provinces of Guangdong and Fujian had already found it more worthwhile to grow tea and sugar for export than to engage in the cultivation of cotton, and they had first turned to cotton imported from northern and central China to support domestic cloth production. Now, however, Indian cotton offered them a cheaper alternative, as provided by Muslim private traders from Surat. Yet, Chinese demand for direct imports of Indian cotton appears to have been limited as far as the British were concerned, and where evidence of cargo composition has survived (albeit only for Company ships), it points to pepper and sandalwood being the commodities that were exported from India in the greatest quantities. ${ }^{15}$ Indeed, as late as 1767 , it was reported from Canton that "Cotton, pepper and sandalwood are always staple commodities here", which indicates that raw cotton was not yet established as the primary commodity exported by the Company from India. ${ }^{16}$ Moreover, the raw cotton from Gujarat that was imported into Canton by the Company during the 1750s and 1760s was not only dispatched from Bombay but was also transhipped via Calcutta and Madras, and

${ }_{13} 32$ such voyages were made during the 1740 s and 56 in the following decade. These figures have been calculated from information in Ibid., passim.

${ }^{14}$ Owners of Amity (Madras) to William Aislabie in Bombay, 8 October 1713, in Sir Richard Carnac Temple, Lavinia M. Anstey, and Bernard P. Scattergood (eds.), The Scattergoods and the East India Company: Being a Selection from the Private Letters and Business Correspondence of John Scattergood, East India Merchant 1681-1723 (Bombay, 1921-33; reprinted Harpenden: D. J. Jeffrey, 1935), p. 116. For the important and longlasting interconnections between the trades in Indian raw cotton and Chinese sugar see Sucheta Mazumdar, Sugar and Society in China. Peasants, Technology, and the World Market (Cambridge, Ma.: Harvard University Press, 1998), pp. 100-109. In addition to sugar, by the beginning of the nineteenth century imports of commodities to Bombay from Canton included piece goods, musk, raw silk, tutenague, and alum. See, for example, BL, IOR, P/419/40: Bombay Commercial Report, 1802/3 (no pagination).

${ }_{15}$ Morse, Chronicles, vol. 1, pp. 238, 265 and 283.

${ }^{16}$ BL, IOR, R/10/6: Canton factory letter book, 1763-9, f. 179: Letter to Bombay, 25 Nov. 1767. 
this points to the fact that no one port in British India had yet achieved a clear-cut ascendancy in the intra-Asian cotton trade. ${ }^{17}$

Of course, any narrow focus on the British must acknowledge that they did not establish entirely new commercial connections within the trading world of Asia, and during the first half of the eighteenth century they certainly did not monopolise the export of raw cotton from India. Rather, they infiltrated pre-existing systems and operated alongside the representatives of many other mercantile communities as well as rival European trading organisations, most notably the Dutch East India Company. It is known, for example, that a few Gujarati merchants were present in China as early as the beginning of the sixteenth century, ${ }^{18}$ and by the end of the seventeenth century a small handful of vessels from Surat were being sent to Manila and Canton for the first time. ${ }^{19}$ Early direct trade between India and China was hindered by a number of political and technical obstructions, but some Indian commodities nevertheless found their way to China through entrepôts such as those in Indonesia and at Melaka. ${ }^{20}$ Marks has recently pointed to the importance of the substantial quantities of Indian raw cotton that were imported into China through the high-volume junk trade conducted after 1685 with the Nanyang, the countries bordering the South China sea. ${ }^{21}$ This trade in raw cotton, with the India-Nanyang leg operated by Portuguese and Indian merchants, formed part of a complex Indian Ocean trading world that predated the arrival of the British. Its existence suggests that at least to some small degree the Asian cotton industry was already on its way to integration by 1700 . Moreover, as has recently been pointed out, Muslim traders continued to maintain a presence at Canton even during the period of British domination of the trade between India and China. ${ }^{22}$

17 There are no aggregate statistics detailing the volume and distribution of annual exports of cotton from India to China during the 1760s, but some details of various individual consignments from Bombay, Calcutta, and Madras are to be found in BL, India Office Records, R/10/6: Canton factory letter book, 1763-69, passim.

${ }_{18}$ K. N. Chaudhuri, The Trading World of Asia and the English East India Company, 1660-1760 (Cambridge: Cambridge University Press, 1978), p. 197. For the overall structure of intra-Asian trade see pp. 191-213.

19 Das Gupta, "India and the Indian Ocean", p. 192. For early Muslim private traders at Canton see Carl T. Smith and Paul A. Van Dyke, "Muslims in the Pearl River Delta, 1700 to 1930", Review of Culture (International Edition), 10 (2004), pp. 6-15.

${ }^{20}$ Ashin Das Gupta, "Indian Merchants and Trade in the Indian Ocean", in Das Gupta (ed.), World of the Indian Ocean Merchant, pp. 61-63.

${ }_{21}^{21}$ Marks, Tigers, Rice, Silks, and Silt, pp. 163-76.

22 Smith and Van Dyke, "Muslims in the Pearl River Delta". 


\section{Tea, Tribute, and the Trade in Raw Cotton}

There can be no doubt that it was the British who eventually marshalled the resources and skills of many far-flung actors in order to take the integration of the Asian cotton industry to an altogether higher level. They did so after 1765 when the East India Company's acquisition of territorial revenues in Bengal completely altered the Company's commercial raison d'etre, and served to recast trading operations as an elaborate remittance mechanism, designed to transfer financial resources from India to Britain. As Edmund Burke put it, the Company's entire trade was transformed into a "vehicle for tribute". ${ }^{23}$ As part of this process, more Company ships were dispatched from London to China, both directly and via Indian ports, in order to facilitate the growth of the tea trade. Consequently, 71 East Indiamen voyaged to Canton via the subcontinent during the 1760s. At first the Company's directors hoped simply to ship large amounts of Indian specie to China, but when this proved to be unsustainable, attention turned instead to the trade in commodities for which there was known demand at Canton, especially raw cotton. Unable to purchase substantial quantities of any commodity on its own account because of acute financial difficulties born out of spiralling military and civil expenditure in India, the Company fell back on its associated communities of licensed private traders by encouraging them to deposit into the Canton treasury any funds generated by the sale of Indian commodities. In return, traders were granted bills or certificates redeemable in India or London at competitive rates of exchange, and this placed considerable sums at the disposal of the Company's supercargoes. ${ }^{24}$

The extent of this dependence on the private sector was considerable and exports on the Company's own account represented less than 4.5 percent of total British exports of Indian raw cotton to China between 1774 and $1785 .{ }^{25}$ From time-to-time, the Company did try to

${ }^{23}$ Quoted in H.V. Bowen, The Business of Empire: The East India Company and Imperial Britain, 1756-1833 (Cambridge: Cambridge University Press, 2006), p. 228. For a discussion of what Burke condemned as the 'revolution' that occurred in Company trade after 1765 see ch. 8 .

${ }^{24}$ For the case of Calcutta merchants trading to Canton see P. J. Marshall, East Indian Fortunes: The British in Bengal in the Eighteenth Century (Oxford: Clarendon Press, 1976), pp. 97-99.

${ }^{25}$ Calculation based on the figures contained in the briefing paper prepared for the government minister Henry Dundas by the senior Company official, William Wright, in May 1786. BL, IOR, H/340, pp. 331-32. 
re-establish itself in the country trade, and indeed in 1786 the directors sanctioned the export of bullion to Bombay which was intended specifically for the purchase of 500 tons of raw cotton to be shipped to Canton on the Company's own account. ${ }^{26}$ But fragile corporate finances continued to dictate that the commercial operations underpinning what became known as the 'country supply' of the Canton treasury were formally subcontracted to small coteries of private merchants in Bombay, Calcutta, and Madras, ${ }^{27}$ as well as to the commanders and officers of East Indiamen who were permitted to carry their own freight-free consignments of cotton on Company ships. One of the many consequences of these practices was an increase in the number of British country vessels dedicated to the shipment of raw cotton, and they began steadily to capture the trade between India and China, so that between 1774 and 1785 almost 60 per cent of all of the cotton imported into Canton from British India arrived in privately owned British ships. ${ }^{28}$

As Britain's intra-Asian cotton trade expanded, there was also a marked structural shift within that trade so that after 1785 the volume of raw cotton shipped from Bombay eclipsed exports from other ports, and accordingly there was a considerable increase in the size of Bombay's private 'country fleet'. ${ }^{29}$ The internal problems and other trading priorities of Calcutta and Madras contributed to this restructuring of cotton exports, and, although Bombay suffered from its own acute

${ }^{26} \mathrm{BL}, \mathrm{IOR}, \mathrm{L} / \mathrm{P} \& \mathrm{~S} / 1 / 9$, ff.143-4. For the thinking behind this decision see the commercial letter of the directors to the Bombay Council, 8 Nov. 1786; ibid., E/4/1004, pp. 31-39.

${ }^{27}$ For details of the agreement struck between the Company's Council at Madras and Thomas Ferguson in 1778 see Morse, Chronicles, vol. 2, p. 31.

${ }^{28} \mathrm{BL}, \mathrm{IOR}, \mathrm{H} / 340$, p. 331. Most of the rest of the imports arrived on Company ships, either as private or Company consignments, and comparatively small amounts of cotton were carried into Canton on Danish, Dutch, French, Prussian, and Spanish vessels. American ships carrying Indian cotton into Canton made their first appearance in 1788 , the first American vessel having arrived in 1784 . As has recently been pointed out, there is a need for some caution when interpreting trade data generated by the East India Company's supercargoes at Canton, because some commercial activity did not capture their attention and thus has not been incorporated into the official record. See Paul A. Van Dyke, The Canton Trade. Life and Enterprise on the China Coast, 1700-1845 (Hong Kong: Hong Kong University Press, 2005), passim. Nevertheless, it seems undeniable that among European traders at Canton the British rose to a position of supremacy by 1784 and then strengthened that position thereafter.

${ }^{29}$ For a detailed study of the involvement of the Bombay country fleet in the shipment of raw cotton to Canton see Anne Bulley, The Bombay Country Ships, 1790-1833 (Richmond: Curzon, 2000), pp. 101-23. 
financial difficulties, it also became evident that direct bulk shipments of cotton from the west coast of India were finding particular favour with Chinese purchasers. At first Bombay predominantly exported Surat cotton, especially the fine, medium-staple, variety grown in the Broach district; but cotton grown further to the north of Gujarat began to rise to prominence during the $1790 \mathrm{~s}^{30}$ In 1787 the Bombay merchants reported that the "Hong merchants [of Canton] confess that cotton from hence, even when they give what we deem a high price, is much cheaper than their own, and that on trial it is found to be of a quality fit for their every purpose". ${ }^{31}$

Price as well as acceptable quality evidently combined to stimulate increased Chinese interest in supplies of raw materials from western India and, as Lord Macartney observed a few years later during his famous embassy to Beijing, cotton from Bombay quickly became one of the "necessaries" of China, "being preferable to silk for common use, as a cheaper and pleasanter wear". ${ }^{32}$ Prices for domestically grown cotton had risen sharply during the early 1780 s as acute food shortages caused more agricultural acreage to be converted to grain production, and dislocations occurred within traditional domestic supply routes, especially in the north of China. As a result, Indian raw cotton proved to be significantly cheaper, despite the addition of freight, packing, and transaction charges, so much so that in 1793-4 Macartney found that, at 10 to 12 taels per picul, Indian cotton was 3 to 5 taels per picul cheaper than

\footnotetext{
${ }^{30}$ For a description of the variety of coloured cottons grown in the different soils of Broach see the manuscript extracts from Dr Hove's Journal [relating to cotton and cotton production], "Notes on a Tour of the Cotton districts of Broach, November December 1787". BL, IOR, H/374, pp. 606-37. At Dowlah Hove noted a garden with trees which produced a yellow dye which "when combined with that of the seeds, becomes near the nankin colour of China, and the colour is lasting. As they export this dye to China with a great advantage, it leads me to suppose that the Chinese dye their nankin with the extract of this shrub" (p. 617). If this was indeed the case, his remarks demonstrate that Gujurati producers were becoming attuned to the needs of a fardistant textile market. A more extensive version of Hove's journal was later published in Anton Pantaleon Hove, Tours for Scientific and Economic Research, made in GuzeratKattiwar, and the Conkuns, in 1787-88, by Dr. Hove. Published ... under the Care of Alexander Gibson (Bombay: Bombay Education Society Press, 1855).

${ }_{31}$ BL, IOR, P/414/47 (1787), p. 67: Bombay merchants to the Bombay Council, 11 May 1787.

${ }^{32}$ George Macartney, An Embassy to China, being the Journal kept by Lord Macartney during his Embassy to the Emperor Ch'ien-lung 1793-94, ed. J. L. Cranmer-Byng (London: Longmans, 1962), p. 261. On the Macartney Embassy see Maxine Berg, "Britain, Industry and Perceptions of China: Matthew Boulton, 'Useful Knowledge' and the Macartney Embassy to China, 1792-94", Journal of Global History, 1, 2 (2006), pp. 269-88.
} 
"the native cotton of China". ${ }^{33}$ At a later period, Indian raw cotton still remained cheaper than Jiangan cotton by around 1 tael per picul. ${ }^{34}$

Increased levels of Chinese demand for Bombay cotton occurred during the mid-1780s, just at the very moment that the East India Company was seeking additional funds at Canton to expand yet further its tea trade. This was a fortuitous set of circumstances for those already engaged in the intra-Asian cotton trade, and in 1787 the leading members of the British and Parsi merchant communities in Bombay reported to local Company officials that "from the ample supply the Chinese merchants had received from hence for the two years last past, they [the Chinese] would now be inclined to relinquish the growth of this commodity to convert their cotton grounds into Batty [rice] fields and to depend on Bombay for a future regular supply" ${ }^{35}$ Lest the officials did not fully understand the wider implications of developments in Canton, the merchants spelled out the substantial benefits that would accrue to the Company as well as to the merchants themselves: "Should the Chinese convert their cotton plantations into Batty grounds, which the threatened famine of last year may incline them to do in order to guard against so dire a calamity in future, we say should this take place what an increase in shipping would be required at this place, what a field would open for the industry of merchants, and what an advantage to the Honourable Company, which from this source would have immense sums paid annually into its Treasury at Canton for bills on the Hon. Court of Directors [in London]".36

In the short term, these optimistic assessments of the Bombay merchants were borne out by a surge in the export of raw cotton from India to China. During the 1760s only a few thousand bales of Indian cotton had ever been shipped into Canton in any one year, but the number of bales exported from the west coast rose through 40,000 in 1785 to over 60,000 a year at times during the late 1780 s and early 1790 s. ${ }^{37}$ Whereas cotton had once been only one of several staple commodities shipped to China from India, by 1792 it accounted for around 80 per cent of

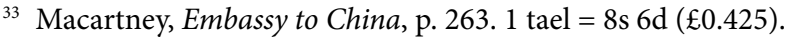

${ }^{34}$ Mazumdar, Sugar and Society, p. 105.

${ }^{35} \mathrm{BL}, \mathrm{IOR}, \mathrm{P} / 414 / 47$, p. 67: Bombay merchants to the Bombay Council, 11 May

${ }^{36}$ Ibid.

37 Ibid., p. 124 (proceedings of 27 Dec. 1786). Bales are an imprecise unit of measure, and these figures are only illustrative of a general trend. Before 1788 a standard Bombay bale was calculated to be of 35,429 cubic feet; thereafter 32,612 cubic feet.
} 1787. 
both the volume and value of the cargoes legally imported into Canton on board twenty British country ships, ${ }^{38}$ although of course with illicit (and therefore unquantifiable) opium added into the equation, raw cotton takes its place as one of two major commodity flows between India and China during the late eighteenth century. Moreover, during the same period Britons, or Britons in partnership with Indian merchants, came to dominate the trade in raw cotton. After 1785 they imported upwards of 95 percent of the commodities shipped into Canton directly from India, and there were only episodic interventions from American merchants. The trade had become regular, large scale, and fully embedded within the Company's wider system of trade and finance. As such, it played a key role in the rapid expansion of the Company's tea trade after 1784 when William Pitt the Younger's sharp reduction of import duties in Britain prompted a near trebling of the volume of tea sold in London, from 5.9 million lbs in 1783 to 16.7 million lbs in $1790 .{ }^{39}$ Quite simply, without the growth of the trade in raw cotton from Bombay to Canton the Company would have been unable to generate the annual financial resources that were needed to meet rapidly escalating demand for cheaper tea in Britain.

\section{Bombay and the Trade in Raw Cotton}

Consignments from Bombay almost completely dominated exports of raw cotton from India to China during the last decade or so of the eighteenth century. Some substantial consignments of cotton were sent to Canton from Madras as late as $1784,{ }^{40}$ but thereafter Bombay established a firm grip on the trade. With the exception of a small consignment of 705 bales shipped to Canton from Calcutta in $1797 / 8,{ }^{41}$ there is little evidence of exports of raw cotton from either Calcutta or Madras at this time. But any confidence that the Bombay merchants

\footnotetext{
${ }^{38}$ Calculated from Morse, Chronicles, vol. 2, p. 201. The other commodities were tin, pepper, sandal wood, elephants' teeth, and bees' wax.

British Parliamentary Papers (hereafter BPP), 1812-13, vol. 8, p. 233. In a concerted attempt to defeat smugglers, Pitt's famous Commutation Act cut the duties on tea from 119 to $12 \frac{1}{2}$ percent. For a forensic study of the Company's tea trade see Hoh-cheung and Lorna H. Mui, The Management of Monopoly: A Study of the English East India Company's Conduct of its Tea Trade, 1784-1833 (Vancouver: University of British Columbia Press, 1984).

${ }^{40}$ For details of 1,770 bales of cotton shipped by Sir George Ramsay on four Company ships, see Madras to Canton, 31 July 1784. BL, India Office Records, Canton Consultations, G/12/79, p. 65 .

${ }^{41}$ BPP, 735-II (1831-2), vol. 10, part 2, p. 853.
} 
might have entertained about their dominant position proved to be short lived. As Figure 4.1 indicates, although there were occasional sharp annual fluctuations in the volume of British exports of cotton to Canton, notably between 1791-3 and 1802-4, Chinese demand very clearly sustained and then increased the overall volume of raw cotton flows into the nineteenth century. Yet because this figure is based upon aggregated data derived from Canton records relating to imports of cotton from all ports in British India it masks important post- 1800 developments which saw the supremacy of Bombay challenged vigorously by cotton exported from Calcutta. Unfortunately the Company's commercial records do not enable full annual comparisons of exports from different Indian ports to be made for any period before the 1830s, but a snapshot of the trade in raw cotton to Canton in 1805 suggests that, in terms of value, exports from Bombay and Surat then accounted for 68.5 per cent of the total, those from Calcutta 30.4 per cent, with the small remainder being taken up by shipments from Madras. ${ }^{42}$

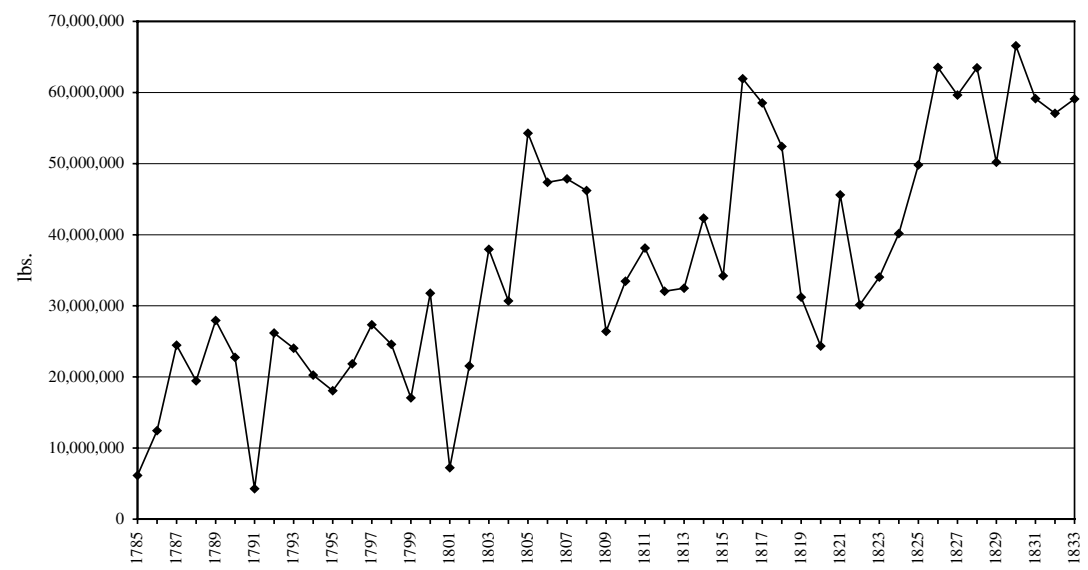

Fig. 4.1. British imports of raw cotton into Canton from India, 1785-1833 (in lbs.). Source: Hosea B. Morse, The Chronicles of the East India Company Trading to China, 1635-1834 (Oxford, 1926-9), vols. 2, 3 and 4, passim. Conversion into pounds: 1 picul $=133.5 \mathrm{lbs}$.

${ }^{42}$ William Milburn, Oriental Commerce; Containing a Geographical Description of the Principal Places in the East Indies, China, and Japan ... (London: Black and Co., 1813), vol. 1, p. 217; and vol. 2, pp. 45, 147. Quite full data is available for the volume of annual exports of cotton from Calcutta to Canton (BPP, 735-II (1831-2), vol. 10, part 2 , p. 853) but officials in London noted that annual returns compiled in Bombay and Madras did not contain similar information for those ports. Ibid., p. 840. 
To many people, the erosion of Bombay's position of supremacy in the export of raw cotton from India to China was wholly unexpected and it caused some to fear for the future of the west coast trade. In 1805 one Bombay official reported to London that "It has already been rumoured that the Bengal cotton trade is likely soon to rival, and indeed to ruin, the Bombay cotton trade"; although he himself was more circumspect in his assessment when he predicted that while competition between the two ports might well reduce the price of cotton in Canton it was unlikely to cause the complete destruction of either one trade or the other. ${ }^{43}$ In explaining this unanticipated turn of events it can be seen that, as in earlier years, the interplay of commercial and imperial factors bore very heavily upon the development of the export trade in raw cotton, and quite different effects were felt on the western and eastern sides of the subcontinent.

As far as the raw cotton traders of Bombay were concerned, their early nineteenth century problems stemmed from the fact that, despite the achievement of impressive growth rates, they had never been able properly to regulate and stabilise the flow of the commodity into and out of their port. ${ }^{44}$ Indeed, the commodity chain that extended from Gujarat through Bombay to Canton was at many points characterised by chronic inefficiencies which created considerable risks for all participants, be they British, Indian, or Chinese, and this meant that the trade was often referred to as being highly speculative in nature. At times the links in the chain proved to be very weak indeed, and before 1800 very little could be done to strengthen them. Not only was the entire private trade in raw cotton founded upon credit and bills advanced to British merchants by local Indian financiers, ${ }^{45}$ but the East India Company and its associates were also heavily dependent upon a large and diverse host of agents, intermediaries, and contractors who acted on their behalf. The raw cotton passed through many hands en route to Canton, and in effect direct British supervision could only be exerted over its cleaning and processing in Bombay, and its subsequent shipment to Canton.

${ }^{43}$ BL, IOR, P/419/42: Bombay Commercial Report 1804/5 (no pagination).

${ }_{44}$ On the transportation of raw cotton to Bombay see Bulley, Bombay Country Ships, pp. 103-4.

${ }_{45}$ For contemporary comment on this see Lakshmi Subramanian, "A Trial in Transition: Courts, Merchants and Identities in Western India, circa 1800", Indian Economic and Social History Review, 41, 3 (2004), p. 278. More generally on this theme see Id., Indigenous Capital and Imperial Expansion: Bombay, Surat and the West Coast (Delhi: Oxford University Press, 1996). 
Crucially, the production and procurement of the cotton was undertaken by others, as was its eventual sale and distribution in China.

The cotton exported from Bombay was grown in areas to the north of the port that lay well beyond the sphere of British military and political influence, and conditions were far from stable within the Maratha Confederacy where warfare, politics, and internecine administrative strife all had the capacity to disrupt production and supply. Moreover, Bombay merchants were at the mercy of the local dealers in Surat, Cambay, and elsewhere who procured raw cotton from the growers. The dealers often acted in combinations which created inflationary pressures, ${ }^{46}$ and at times they could sharply force up prices with damaging effects in Canton, as happened in 1802. An equally persistent problem was that the dealers also stubbornly resisted British efforts to impose stricter degrees of quality control over the consignments of raw cotton dispatched to Bombay. Bales routinely contained a very high content of water, rubbish, and, above all, seed; and this led to endless protests about the deliberate wetting and adulteration of whole consignments. In 1787, it was reported that not one of the thousands of bales of Broach and Jamboseer cotton sent by the dealers of Surat had arrived in Bombay in a marketable state, and seeds were found to account for between one-quarter and one-third of the weight of every bale. ${ }^{47}$ This was an acute problem in view of the fact that it took forty people a whole day to clean one dry bale, and throughout the period the letters of the Company and private merchants were littered with complaints about the dirty nature, adulteration, and generally poor quality of cotton. There is much evidence that the Company imported all manner of machinery into Bombay in order to achieve better cleaning, screwing, and packing of cotton, ${ }^{48}$ and it seems that there was some overall improvement in processing techniques. But although a report from Bombay in 1804 suggested that "the productive labour of this settlement add ninety rupees of value to the value of each candy [of cotton] exported to China", ${ }^{49}$ the serious problem of "foul cotton" never altogether disappeared.

\footnotetext{
${ }^{46}$ On price rises during the late 1790s see Pamela Nightingale, Trade and Empire in Western India, 1784-1806 (Cambridge: Cambridge University Press, 1970), p. 188.

${ }^{47}$ BL, IOR, P/414/47, part II, p.66: Cotton merchants to the Bombay Council, 17 May 1787.

${ }^{48}$ See the examples in $\mathrm{BL}, \mathrm{IOR}, \mathrm{H} / 374$, passim.

49 BL, IOR, P/419/41: Bombay Commercial Report 1803/4, par. 17.
} 
Finally, the Bombay merchants were very much at the mercy of the elements. Heavier than usual rains in the growing regions could wash away crops but, more specifically, sailing times to Canton were always dictated by the arrival of the monsoon. Ships for Canton had to leave Bombay before 30 May each year, or they would 'miss the season', and this introduced an acute organisational pressure because the crop gathered in the north during January and February had to be transported by sea to Bombay before it was prepared and packed prior to stowing on board either the Company's East Indiamen or the privately owned ships of the Bombay country fleet. Much depended upon the cotton arriving in Bombay in good time, but the ships from the north were repeatedly delayed by bad weather, piracy, or a failure of the dealers to assemble cargoes according to schedule. At worst, a combination of factors could result in little or no cotton being received at all, and, unsurprisingly, the private merchant community increasingly pressed the Company to establish greater influence, and ultimately direct control, over the cotton-producing regions.

The private merchants and Company officials of Bombay were thus confronted by a range of local organisational and logistical problems related to the supply of raw cotton to the port, but their difficulties were made considerably worse by the fact that they knew very little indeed about fluctuating patterns of demand and consumption in China. Imperial edict had restricted the trade of the British and other foreigners (apart from the Russians and Japanese) to the port of Canton, and since 1757 all commercial transactions had been conducted through the small group of Hong merchants. ${ }^{50}$ Sino-European tensions could result in the temporary cessation of trade, as happened in $1777 .{ }^{51}$ More generally, the merchants of British India had little if any direct contact with Chinese dealers in raw cotton because they were obliged to rely on the intermediation of the members of the Co-Hong. It is not known to what extent the Hong merchants were direct participants in the trade, but they seem to have been unable to gauge accurately the strength of annual local demand for cotton imports from India. At times some of them were caught with very

${ }^{50}$ For a recent detailed study that throws much new light on the conduct and organisation of trade in Canton see Van Dyke, Canton Trade. For a uniquely detailed contemporary description of the transactions conducted between the officers of a Bombay country ship and Chinese officials and merchants see Bulley, Bombay Country Ships, pp. 106-8.

${ }_{51}$ Morse, Chronicles, vol. 2, p. 24. 
large stocks of imported Indian cotton on their hands, and this caused, or contributed to, their bankruptcy. ${ }^{52}$

In view of this, it proved difficult, if not impossible, for the Company's supercargoes to estimate correctly the number of bales required in Canton each year, and this further complicated matters for those trying to procure appropriate levels of supply in India. As one frustrated official in Calcutta was to write in 1806, "It appears to be strange yet it is not less true that persons concerned in a particular branch of trade should have so imperfect an idea of the nature and extent of it as the European merchants at Canton appear to have of the Cotton trade at Canton carried on between this port and Bombay with China...." ${ }^{53} \mathrm{He}$ went on to write that "The merchants at Canton attribute their want of information ... to their extremely confined situation and the want of a freer communication with the interior of the country which prevents their obtaining knowledge of such circumstances as are likely to increase or lessen the value of any article in the market, and often times in attempting to form a judgement for the guidance of their friends [in India], they have found their opinion erroneous". ${ }^{44}$ By the time these words were written, the cotton merchants of Bombay had already been dealing with this acute problem for more than twenty years.

\section{Bengal's Challenge to Bombay}

It was against this unstable and unsatisfactory commercial background that several circumstances combined to strike a heavy blow against Bombay's pre-eminent position in the raw cotton trade. First, in 1800 the quality of the Company's cotton dispatched from Bombay was so poor that the supercargoes at Canton were obliged to cut the sale price by 5 tales per picul, or more than a third. ${ }^{55}$ Then atrocious weather

${ }^{52}$ Weng Eang Cheong, The Hong Merchants of Canton. Chinese Merchants in Sino-Western trade (Richmond: Curzon, 1997), p. 285. The trading activities of Hong merchants have been reconstructed in great detail in a series of case-studies undertaken by Paul Van Dyke. See Paul A. Van Dyke, "The Yan Family: Merchants of Canton, 1734-80s", Review of Culture (International Edition), 9 (2004), pp. 30-85; Id., "The Ye Merchants of Canton, 1720-1804", Review of Culture (International Edition), 13 (2005), pp. 6-47; Id., "Cai and Qui Enterprises: Merchants of Canton, 1730-84", Review of Culture (International Edition), 15 (2005), pp. 60-101.

${ }_{53}$ BL, IOR, P/174/16: Bengal Commercial Report 1804/5, paragraph 81.

${ }^{54}$ Ibid., par. 82.

${ }_{55}$ BL, IOR, H/374, p. 96: The directors to Bombay, 24 June 1803. 
conditions washed away the cotton crop of Gujarat on two occasions, which caused the total number of bales imported into Bombay to fall from 100,000 in the $1799-1800$ season to only 10,825 between September 1800 and May $1801 .^{56}$

Into the breach stepped Bengal merchants who were now much better placed than ever before to make good any shortfall in shipments to Canton. At the end of the 1780s there had been reports from the great inland mart at Mirzapur that speculative purchasers had been intending to purchase cotton for the China market, ${ }^{57}$ but nothing seems to have come of this. Within a decade or so, however, constraints on the production and supply were being eased to such an extent that whereas the first bulk exports of 'Bengal Cotton' to Canton amounted to just over 8,000 bales in $1802 / 3$, the number of bales exported rose sharply to over 46,000 the following year. ${ }^{58}$

Again, the influence of British imperial policy was felt on the development of the trade in raw cotton because an important supply-side factor underpinning the sharp increase in exports from Calcutta was to be found in the Marquess of Wellesley's annexation in 1801 of parts of Awadh, including the cotton-producing districts of Etawah, Currak, and Khorah. In subsequent years there were rapid extensions of the acreage devoted to cotton cultivation in Awadh itself as well in the adjacent territory of Bundelkhand and other parts of central India, and this greatly increased the amount of cotton that passed through the entrepôt of Mirzapur before it was sent down the rivers Ganges and Hughli to Calcutta. ${ }^{59}$ To be sure, large quantities of raw cotton had found their way into Bengal and its neighbouring provinces in earlier years, but these were deemed barely sufficient to meet the needs of local manufacturers, and it was only after 1801 that Calcutta was able to obtain the level of imports that were necessary to supply external markets to any great degree. As one expert observer of the commercial scene wrote, "On the acquisition of the Ceded provinces, a new article of commerce presented itself for export from Bengal to China, vizt.

${ }^{56}$ BL, IOR, H/476, p. 141: John Duncan to David Scott, 17 May 1801.

57 C. A. Bayly, Rulers, Townsmen and Bazaars. North Indian Society in the Age of British Expansion, 1770-1870 (Cambridge: Cambridge University Press, 1983), p. 244.

${ }^{58}$ BPP, 735-II (1831-2), vol. 10, part 2, p. 853.

${ }^{59}$ For the combination of factors that served to encourage cotton cultivation in Bundelkhand and central India after 1800 see Bayly, Rulers, pp. 244-45, and for the merchant supply and transport networks that fed into Mirzapur and then established the onward connections to Calcutta see ibid., pp. 246-53. 
Cotton".60 The imperial and commercial motivations that lay behind Wellesley's actions have been robustly debated by P.J. Marshall and Rudrangshu Mukherjee, ${ }^{61}$ but, whether or not one believes that a desire to secure cotton for export to Canton (or indeed anywhere else) was a primary motivation behind British policy, it is undeniable that expansion into Awadh was very timely for the British because it opened up new sources of supply for China at the very moment that the Bombay trade in raw cotton was faltering so badly.

The re-entry of Calcutta into the China trade was swift and vigorous and, although less than twenty per cent of the cotton imported from the "upper provinces" in 1805 was sent on to Canton, ${ }^{62}$ the increase of cotton exports added an important new dimension to the commercial and shipping activities of the port. With almost 60,000 bales of cotton being consigned to Canton in 1806, there was a need for more of the port's country fleet to be devoted to the trade. Only a handful of British ships had been dispatched from Calcutta to Canton during the 1790s, and none at all sailed there in 1800/1 and 1801/2. Numbers rose very sharply thereafter, however, and in 1806/7 thirty-five British ships with a combined tonnage over 16,000 tons were sent to Canton, and these cotton-carrying vessels represented almost one-fifth of all clearances from the port. In the years that followed, the combined tonnage of the Calcutta cotton ships destined for Canton was only occasionally greater than that of the ships dispatched from Bombay and Surat. Nevertheless, this tonnage represented a significant proportion of all British shipping cleared from Indian ports to China, standing at an overall 33.8 per cent between 1810 and 1830, and, although Bombay as a port was always much more strongly wedded to the cotton trade, the Calcutta-Canton maritime connection ensured that there were now two main channels through which raw cotton could be taken to China. ${ }^{63}$

${ }^{60}$ BL, IOR, P/174/14: Bengal Commercial report, 1802/3, f. 20 v.

61 P. J. Marshall, "Economic and Political Expansion: the case of Oudh", Modern Asian Studies, 9 (1975), pp. 465-82; Rudrangshu Mukherjee, "Trade and Empire in Awadh, 1765-1804", Past and Present, 94 (1982), pp. 85-102; P. J. Marshall, "Debate: Early British Imperialism in India", Past and Present, 106 (1985), pp. 164-69; Rudrangshu Mukherjee, "A Rejoinder", Past and Present, 106 (1985), pp. 169-73.

62 Marshall, "Debate”, p. 168, footnote 9.

63 Average annual British shipping clearances from Indian ports to Canton between 1810 and 1830 were distributed in the following way: Bombay and Surat, 17,247 tons (58.8\%); Calcutta 10,643 tons (33.8\%); Madras 3,566 tons (11.4\%). Calculated from BPP, 735-II (1831-2), vol. 10, part 2, pp. 792-93, 816-17, 834-35. 
Large shipments of raw cotton from Calcutta to Canton during the first decade of the nineteenth century ensured that there was never a complete breakdown in the supply from India to China, and it is evident that the merchants of Calcutta were able to meet shortages in the Chinese market at an appropriate moment in time. But the fact that this proved to be no short-term measure arose from the fact that, initially at least, the raw cotton produced in northern and central India generated rather fewer of the logistical and processing problems that had long bedevilled the British trade on the west coast. Calcutta merchants learned directly from the experience of their Bombay counterparts ${ }^{64}$ and they quickly appreciated that their cotton was destined for the manufacture of cheap cloth and everyday clothing, which meant that its quality did not have to be of the very finest grade. Being of shorter staple, it is likely that the cotton shipped out of Calcutta was also used for purposes other than spinning and weaving, being especially appropriate for the padding of jackets and quilts. Following on from this, those in Bengal recognised that what really mattered to Chinese manufacturers was that imported cotton was clean and free of seed. In this matter, they were able to benefit from the actions and inspections of up-country agents and the Company's local commercial residents whose supervision ensured that, in the short term at least, a much greater degree of quality control was imposed upon the procurement and transportation process. Raw cotton arrived in Calcutta in a much better state than the consignments that had been passing through Bombay and, because this created fewer processing and packing problems, it was calculated that Bengal cotton would only be slightly more expensive than that imported into Canton from Bombay. Moreover, it was estimated that in the long run this price differential might well disappear altogether. Such was the confidence of some Company officials in Calcutta about the trade in raw cotton that one of them wrote in September 1805 that "The Bombay trade must gradually decline and the traders in this article on the Malabar Coast [sic] must eventually give way to their formidable competitors in Bengal..." ${ }^{65}$ Indeed such was the growing strength of the competition from Bengal that by 1805 the ever-adaptable Parsi merchants of

${ }^{64}$ See BL, IOR, P/174/15: Bengal Commercial Report, 1803/4, par. 73-81. In the main, this paragraph is based upon this source.

${ }^{65}$ Ibid., par. 77. 
Bombay were already beginning to purchase consignments of raw cotton in Calcutta for shipment to Canton. ${ }^{66}$

\section{The Recovery of Bombay}

Although many observers believed that the writing was on the wall for exports of raw cotton from western India to Canton, there was in fact no slide into ruin. As we have seen, Bombay retained a major share in the trade, and a number of factors contributed to this somewhat unexpected recovery of fortunes. Most important of all, the supply of cotton into Bombay was secured and then regulated by the establishment of direct British control over Surat and the cottongrowing districts of Gujarat, Cutch, and Kathiawar between 1800 and 1806. As Pamela Nightingale has shown in great detail, the long-run frustrations of the Bombay commercial community interacted with other imperial impulses, and these led to decisive interventions being made in support of both the cotton trade and wider British strategic interests. The Company's forces were deployed to undertake the necessary expansion, and successive seizures and treaties saw key ports and territories wrested away from local rulers and brought firmly into the British orbit. ${ }^{67}$

This powerful interaction between imperial and commercial policy had the effect of increasing the number of supply lines of raw cotton that ran into Bombay. For some years Bombay had long been breaking away from complete dependence on raw cotton shipments from the port of Surat, and by 1804/5 only 10.4 per cent of total imports were derived from that source. Now, 65.1 per cent of imports came from the northern ports of Gujarat, that is, from ports around the Gulf of Cambay; while the remainder arrived from ports in and around the Gulf of Cutch. ${ }^{68}$ The flows of cotton along these various different routes was by no means steady, and they often fluctuated markedly from year

${ }^{66}$ BL, IOR, P/174/16: Bengal Commercial Report 1804/5, par. 83. On the later Parsi community in Canton see Guo Deyan, "The study of Parsee Merchants in Canton, Hong Kong, and Macao", Review of Culture. (International Edition), 8 (2003), pp. 51-69; Carl T. Smith, "Parsee Merchants in the Pearl River Delta", Review of Culture (International Edition), 10 (2004), pp. 6-15; Madhavi Thampi, 'Parsis in the China trade', Review of Culture (International Edition), 10 (2004), pp. 16-25.

${ }^{67}$ Nightingale, Trade and Empire, pp. 128-235.

${ }^{68}$ BL, IOR, P/419/42: Bombay Commercial Report, 1804/5 (no pagination). 
to year, but the existence of alternative commercial connections across the region helped to reduce the restrictive effects of bottlenecks within the supply system.

Bombay merchants also found that, contrary to expectations, they retained an important advantage over their rivals in Calcutta because they were able to ensure that any supplies of new season cotton they sent to Canton arrived much earlier than shipments dispatched from Bengal. As noted earlier, ships intending to sail directly to Canton had to leave Bombay by the end of May, but by contrast it was reported that "not a single" importation of cotton was ever made into Calcutta from the north before 1 July in any year because of the rain-affected state of river navigation. ${ }^{69}$ The outcome was that the season was "far advanced" before the merchants could load a single bale on to the China ships, and such unavoidable delays caused increased freight and insurance charges as well as the subsequent late arrival of cargoes in Canton. This increased risks for those in Calcutta and ensured that, contrary to expectations, Bombay cotton proved to be slightly cheaper than that from Bengal. ${ }^{70}$

Finally, any early comparative advantage that Bengal cotton enjoyed in terms of its quality does not seem to have lasted for more than a few years. Whereas the British on the west coast of India managed to exert a closer degree of control over the production and transportation of raw cotton, there continued to be a great number of links in the supply chains that extended from northern and central India down to Calcutta. For a host of reasons, the British were unable to reduce their dependence upon intermediary agents and one consequence of this was that Bengal cotton began to acquire a reputation for poor quality. ${ }^{71}$ As one observer, Dr. Nathaniel Wallick, commented in 1832, there were "imperfections in every stage in the cultivation, the cleaning, and the conveying" of the cotton that was destined for export from Bengal. Wallick was particularly critical of the fact that cotton often lay exposed to the weather on open boats for four or five months, causing it to arrive in Calcutta in a "dirty and filthy state", and his general

\footnotetext{
69 BL, IOR, P/174/15: Bengal Commercial Report, 1803/4, par. 78.

${ }^{70}$ BL, IOR, P/174/16: Bengal Commercial Report, 1804/5, par. 81-2.

${ }^{71}$ On this and related themes see Bayly, Rulers, Townsmen, and Bazaars, pp. 252-62.
} 
remarks carried a very strong echo of those that had been made in Bombay thirty years earlier. ${ }^{72}$

\section{Conclusion}

Between 1802 and 1807 consignments from Bombay and Bengal combined to supply the Chinese market with unprecedented amounts of raw cotton, but thereafter the trade moved through a cycle of depression and recovery. Analysis of these movements lies beyond the scope of this essay, as does explanation of the subsequent long-term decline in exports of raw cotton from India to China, although it seems clear that the fitful recovery of internal production and supply systems together with growing imports of cheap yarn and twist from Britain exerted a succession of ever-harder squeezes on Indian raw cotton during the $1820 \mathrm{~s}$ and $1830 \mathrm{~s}^{73}$ In the half-century before 1810 , however, the military and political activities of the East India Company had interacted directly and indirectly with the actions of private merchant communities in India to establish, develop, and diversify a high-volume bulk trade in raw cotton between the subcontinent and Canton. In expanding the trade, the narrow aim of the Company was always to fund tea procurement, but there were many spin-off effects from this imperialcommercial strategy. Most notably, although the supply chains and networks that underpinned the trade in raw cotton were never particularly efficient or well regulated, they did help to smooth out some of the ecological and economic difficulties encountered by China during the late eighteenth century. British imperial expansion on the subcontinent had released powerful integrative forces within the trading world of Asia and beyond, and the effects were keenly felt within the Chinese textile industry.

\footnotetext{
72 Evidence presented to the House of Commons on 14 Aug. 1832: BPP, 735-II (1831-32), vol. 10, part 2, pp. 200-1.

${ }^{73}$ Greenberg, British Trade, pp. 89-103.
} 
$-978-90-47-42997-5$ 
THE RESURGENCE OF INTRA-ASIAN TRADE, 1800-1850 ${ }^{1}$

\author{
Kaoru Sugihara
}

\title{
Introduction
}

This paper considers a set of trade statistics, mostly taken from British sources, to argue that there was a growth of intra-Asian trade during the first half of the nineteenth century, and that the size of this trade was probably comparable to Asia's long-distance trade (exports and imports) with the West.

The traditional historiography emphasises the central importance of India's exports - particularly of opium - to China for the growth of intra-Asian trade and the opening of East Asia into the international economy. In simplified terms, prime movers of this trade were British private traders and those economic actors who supported a triangular settlement mechanism (or mechanisms, if we consider also the role of American merchants) through which remittances of the British in India would be made easier. Merchants engaging in the Chinese tea trade and British exporters to India were also among the beneficiaries of what was called the 'opium triangle'. Furthermore, two opium wars forced China to open its ports to foreign trade, allow the British to develop Hong Kong as an entrepot, and eventually led to the conclusions of a series of commercial treaties between Western powers and China, Japan and Korea. These treaties not only denied tariff autonomy for East Asian countries, but included the most-favoured-nation clause - which proved to be an effective device, when combined with the lack of tariff autonomy - for the purpose of Western powers penetrating into East Asian markets. The treaty port system, under which Western

\footnotetext{
${ }^{1}$ Earlier versions of this paper were presented at the summer symposium for the Socio-Economic History Society of Japan, held at Osaka in August 2005, and at the GEHN conference at Pune in December 2005. I wish to thank the participants of the two meetings, especially Sayako Kanda, Huw Bowen and Om Prakash, for their comments and encouragement.
} 
merchants conducted trade with the provision of extraterritorial rights, became the main mechanism for connecting East Asia to international commerce during the second half of the nineteenth century.

In this view, there was a sharp discontinuity in Asian trade history around the middle of the nineteenth century. The first fifty years are characterised as a period of Western, mainly British, expansion of trade and territorial control in South and Southeast Asia with little impact on East Asian commerce, while the next fifty years saw, along with Western colonialism, Asia's full response to Western impact, in the forms of the growth of intra-Asian trade, the integration of Chinese internal commerce into the Asian international economy and Japan's industrialization. $^{2}$ What was happening to intra-Asian trade between 1800 and 1850, apart from the opium triangle, and how it affected the course of Asian trade history, has not been clearly brought into the picture.

Meanwhile, there have been suggestions of the resurgence of Asian trade since the late eighteenth century. Referring to Southeast Asia, Reid argues that, although there had been a tendency to assume that trade had been relatively inactive between the end of the 'age of commerce' in the second half of the seventeenth century and the growth of export economies in the late-nineteenth century, there was in fact an expansion of trade from 1760 to $1840 .^{3}$ Individual studies on India's internal, coastal and regional trade also point to increased activities of regional commerce in the late eighteenth and the early nineteenth centuries. ${ }^{4}$ There were also signs of increased junk trade along the Chinese coast

${ }^{2}$ In my previous work, I have followed this view myself. See, for example: Kaoru Sugihara, Ajiakan Boeki no Keisei to Kozo (Kyoto: Mineruva Shobou, 1996); and Id., Japan, China and the Growth of the Asian International Economy, 1850-1949 (Oxford: Oxford University Press, 2005).

3 Anthony Reid, "A New Phase of Commercial Expansion in Southeast Asia, 17601840", in Anthony Reid (ed.), The Last Stand of Asian Autonomies: Responses to Modernity in the Diverse States of Southeast Asia and Korea, 1750-1900 (Basingstoke: Macmillan, 1997), pp. 57-82; Id., "Introduction: Four Key Exports and the Trade Cycle of Southeast Asia", in David Bulbeck, Anthony Reid, Lay Cheng Tan and Yiqi Wu (comp.), Southeast Asian Exports since the 14th Century: Cloves, Pepper, Coffee and Sugar (Leiden: KITLV Press, 1998), pp. 1-16.

${ }_{4}^{4}$ Earl H. Pritchard, The Crucial Years of Early Anglo-Chinese Relations 1750-1800 (New York, [1936] 1970); Pritchard, Earl H., "Private Trade between England and China in the Eighteenth Century (1680-1833)", Journal of the Economic and Social History of the Orient, 1 (1958), pp. 108-44; Sinnappah Arasaratnam, "Coromandel"s Bay of Bengal Trade, 1740-1800", in Om Prakash and Denys Lombard (eds.), Commerce and Culture in the Bay of Bengal, 1500-1800 (New Delhi, 1999), pp. 307-28; Sayako Miki, "Merchants, Markets and the Monopoly of the East India Company: The Salt Trade in Bengal under Colonial Control, c.1790-1826" (Unpublished Ph.D. Thesis, School of Oriental and African Studies, University of London, 2005). 
and Southeast Asia, stimulated by British trade expansion, especially after the 1820 s. ${ }^{5}$ No one, however, attempted to grasp the size and structure of intra-Asian trade, and to understand its significance for the course of Asian economic development on a regional scale.

This paper suggests that there was a broad regime shift from mercantilism to forced free trade in South and Southeast Asia, which allowed the entry of not only Western private traders but Asian merchants to seize trade opportunities. These opportunities were often created by increased demand arising from the growth of long-distance trade and availability of improved ships and ports. Therefore, the growth of intra-Asian trade in this period was a result of Asia's response to Western expansion. In this respect it resembles the pattern, which has been recognized on a much larger scale in the second half of the century. The growth of intra-Asian trade under the regime of forced free trade was arguably a feature running through the 'long nineteenth century'.

\section{The Availability of Trade Statistics}

This paper defines intra-Asian trade as trade between six major Asian ports or regions and their trade with other Asian ports. Map 5.1 shows major countries and ports involved, while attempting to map out some of the territorial shifts during the late eighteenth and the early nineteenth centuries at the same time. Figure 5.1 was drawn with the situation around 1840 in mind, and shows the basis of our calculation: intra-Asian trade is a sum of all fluxes here presented.

The intention here is not to pick up every recorded statistic, but to select figures likely to represent the magnitude of regional, rather than local, trade, i.e. trade between two distinct local economies. All territorial boundaries, as well as the area covered by the English East India Company, are disregarded for this purpose. ${ }^{6}$ Thus the coastal trade between Bengal and Bombay is included, together with trade between

${ }^{5}$ Ei Murakami, "Binetsu Enganmin no Katsudo to Shincho: 19 seiki Zenhan no Ahen Boeki Katsudo o Chushinni" ["Activities of Merchants and Fishermen of Fujian and Guandong and the Qing Government: With Special Reference to Opium Trade in the First Half of the Nineteenth Century"], Toho Gakuho, 75 (2003), pp. 201-71.

${ }^{6}$ My previous work on intra-Asian trade for the period from 1880 to 1939 , referred to in note 2 , was based primarily on country-based statistics. Therefore the definition of intra-Asian trade there differs from the one adopted in this paper. However, some attempts have been made to appreciate the significance of the port-based trade 


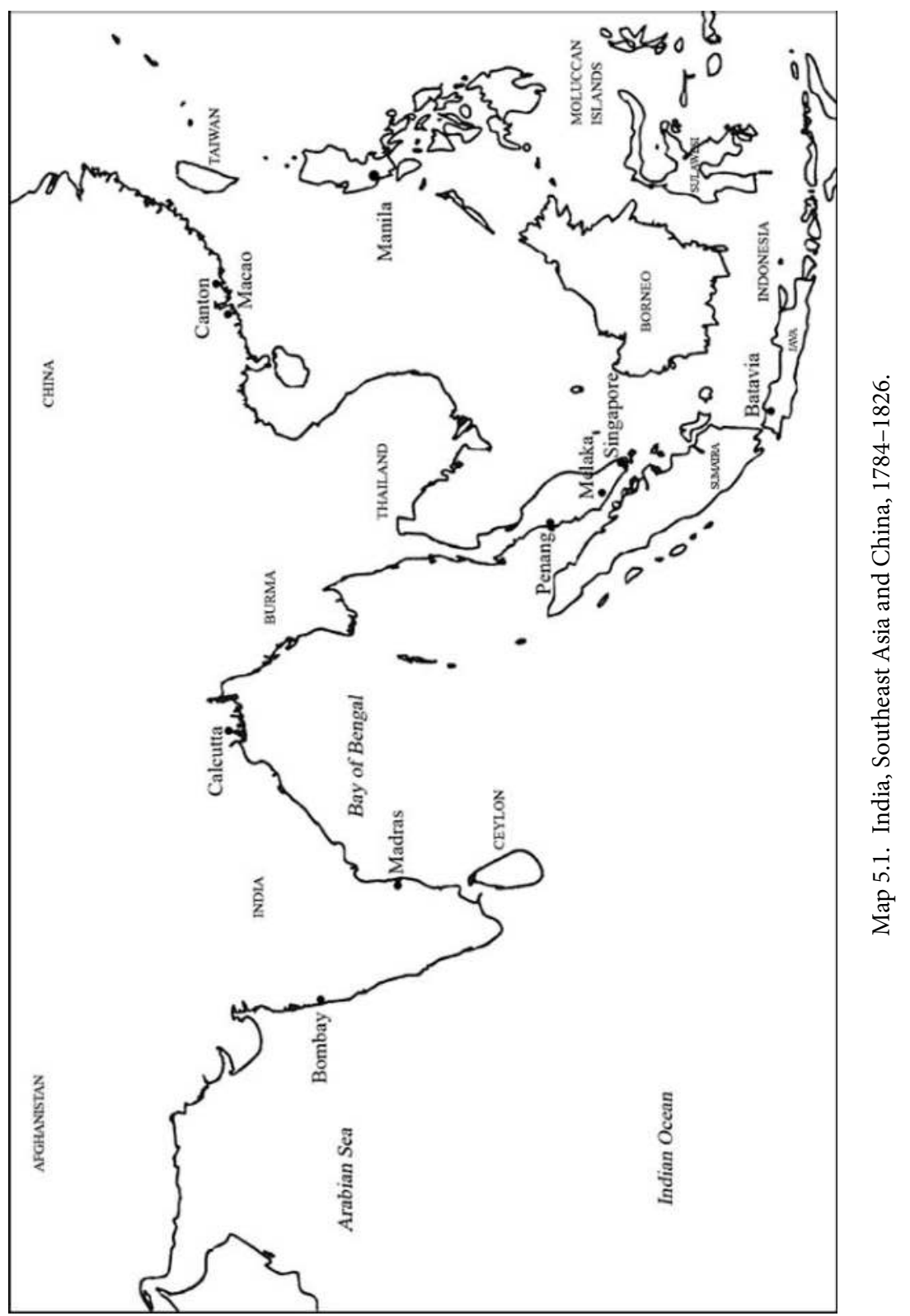




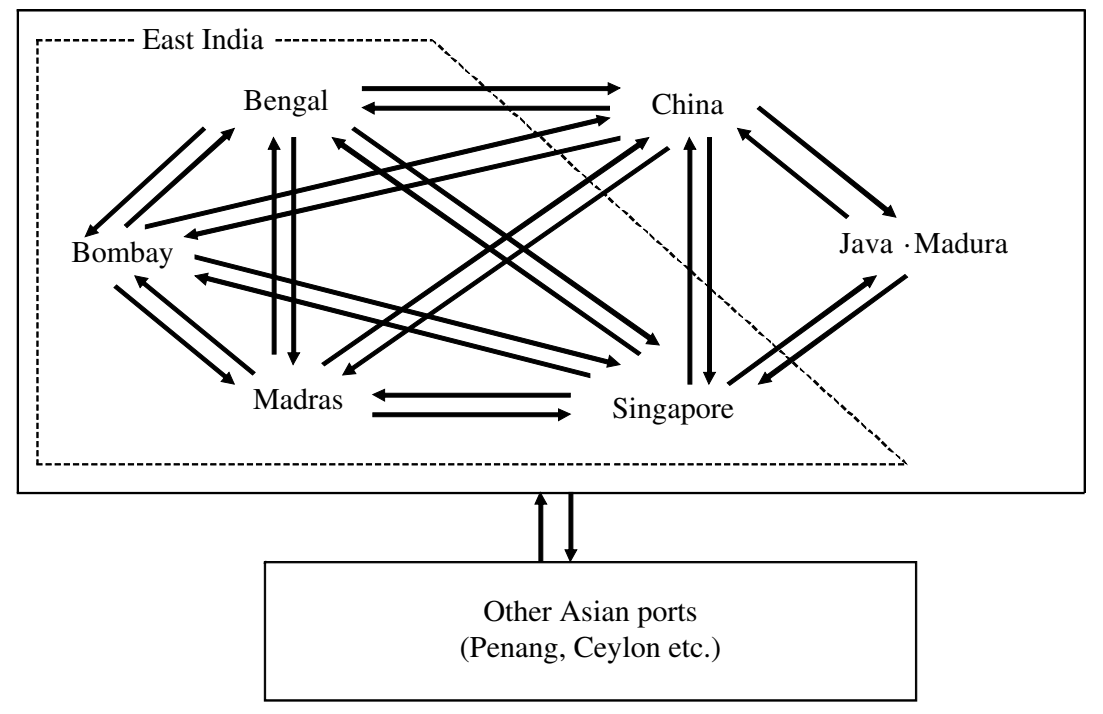

Fig. 5.1. Intra-Asian Trade.

Bengal and China, for example. We also use the trade statistics of 'Java and Madura', recorded by the Dutch. Thus each of the six main entities in the main box of the chart has different qualities: while Bengal (effectively Calcutta), Bombay, Singapore, China (effectively Canton and later Hong Kong) mostly refer to the trade of the main port, 'Madras' and 'Java and Madura' include trade of several smaller ports in addition to that of the main port. Trade between Madras and neighbouring ports and trade inside the 'Java and Madura' region are excluded from the calculation, as it is either likely to be mainly local trade or its inclusion would result in severe double counting. Trade between 'Java and Madura' and the Outer Islands, internal trade of India, and coastal trade within Indian presidencies, sometimes qualify as regional trade, and are excluded from the present calculation. However, they will be

statistics and the interpretation drawn from them, with regard to the late nineteenth and the early twentieth centuries. See Kaoru Sugihara, "Indo Kindaishi ni okeru Enkakuchi Boeki to Chiiki Koeki, 1868-1938 nen”, Toyo Bunka, 82 (2002), pp. 1-46 Kazuko Furuta, "Kobe Seen as Part of the Shanghai Trading Network: The Role of Chinese Merchants in the Re-export of Cotton Manufactures to Japan", in Kaoru Sugihara (ed.), Japan, China and the Growth of the Asian International Economy, 18501949 (Oxford: Oxford University Press, 2005), pp. 23-48; and Hajime Kose, "Foreign Trade, Internal Trade and Industrialization: A Statistical Analysis of Regional Commodity Flows in China, 1914-31", in Ibid., pp. 193-213. 
considered for a more broadly based estimation in the latter part of this paper. The figures for China are supplemented by the statistics from the other five areas as the figures for Canton recorded by Morse may not be as comprehensive as other statistics.

The coverage of intra-Asian trade thus defined goes a long way towards estimating the total sum, since all the trade between the six main areas and other ports are included in the calculation. ${ }^{7}$ To do this, while we use only export figures to calculate trade between the main areas, we need to use both export and import figures for obtaining the sum of trade between the main areas and other ports. We therefore need to convert import values to an export-price basis, so 7 percent of import values, as an approximate percentage, represents the difference between F.O.B. (Free on Board) and C.I.F. (Cost, Insurance, and Freight) values. The only other recorded regional trade that is not included here is trade between other Asian ports, for example, trade between Ceylon and Penang. Since the trade of Ceylon (or Penang) with the six main entities is included, the value of trade that is not included is relatively small. A substantial trade India conducted with the Middle East and East Africa is captured in our calculation from the Indian side.

The next section reviews well-known country-based statistics, to confirm some of the conventional wisdom. The following section presents the structure and growth of intra-Asian trade as defined in this paper, referring to the years of 1811 and 1840. A major omission in this calculation is Chinese junk trade, which is outside the coverage of Morse's statistics. Judging from various British reports, its size, while it has never been estimated in a systematic fashion, is clearly substantial, and it operated within Southeast Asia as well. ${ }^{8}$ While some of them were captured in Singapore and Dutch statistics in our calculation above, there is a strong probability that a large proportion of junk trade between Chinese ports, between China and Southeast Asia, and in Southeast Asia (especially centring around Siam and Cochin-China), existed outside it. Of course many junks engaged in local trade, but a

\footnotetext{
7 Except for what Morse omitted for Canton trade with ports other than the main areas here considered.

8 Anthony Reid, "Chinese Trade and Southeast Asian Economic Expansion in the Later Eighteenth and Early Nineteenth Centuries: An Overview", in Nola Cooke and Li Tana (eds.), Water Frontier: Commerce and the Chinese in the Lower Mekong Region, 1750-1880 (London: Lowman and Littlefield, 2004), pp. 21-34.
} 
substantial amount of junk trade connected distant ports of China, in the same way as intra-European sea- and river-borne trade did, which is often included in world trade statistics. ${ }^{9}$ Junks connecting Chinese ports to Southeast Asian ports or ports of different Southeast Asian countries were clearly intra-Asian trade. We will consider this issue at the end of the fourth section, to arrive at a more broadly based estimation of intra-Asian trade.

The fifth section focuses on the commodity composition, which can be discerned from the available statistics, with special attention to cotton cloth trade. The final section brings in further elements, such as China's internal (land) trade and India's land trade in order to speculate on the magnitude of Asian and intra-Asian trade around 1840. It suggests that Asia's share in world trade was large enough to justify the notion that Asia's response to Western impact was a major force in the growth of world trade in the long nineteenth century.

\section{Western Impact and Opium Trade}

Figures 5.2 and 5.3 are preliminary summaries of available figures of India's exports and imports. They were obtained from British Parliamentary Papers without an examination of original sources, and they are in need of a more precise interpretation. The series marked as 'A' and 'B' in these figures do not include trade conducted by Western ships other than the British and the Dutch. The series marked as ' $\mathrm{C}$ ' includes both company trade and private trade. From the 1780s, it differs widely from ' $\mathrm{B}$ ', but it is difficult to gauge what proportion of private trade was included in these statistics. ${ }^{10}$ After 1793 private trade was further distinguished into 'privilege trade', which was carried out by private individuals, and 'private trade', which was conducted by commanders and officers of the East India Company, and we have

\footnotetext{
9 Paul Bairoch estimated that Europe's share in world trade in 1830 was $67 \%$. Paul Bairoch, "European Foreign Trade in the XIX Century: The Development of the Value and Volume of Exports (Preliminary Results)", Journal of European Economic History, 2,1 (1973), p. 13; and that $72 \%$ of that trade (that is $48 \%$ of world trade) was intraEuropean trade. Id., "Geographical Structure and Trade Balance of European Foreign Trade from 1800 to 1970", Journal of European Economic History, 3, 1 (1974), p. 560.

${ }_{10}$ Pritchard, Crucial Years of Early Anglo-Chinese Relations. For the difficulties of distinguishing smuggling see Mutsuki Matsumoto, "Bengaru ni okeru Ejenshi Hausu no Keisei: Igirisu-kei Shiteki Shihon no Keisei Katei to Higashi Indo Kaisha, 17571800-nen", Keizaigaku Ronso, 32 (1983), pp. 156-218.
} 


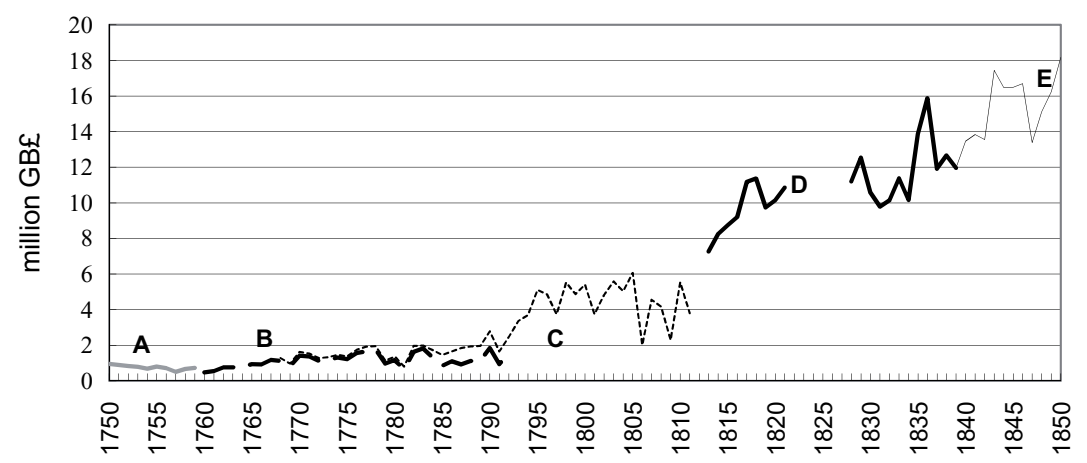

Fig. 5.2. India’s exports, $1750-1850$ (in million GBE). Sources and notes: Line A. K. N. Chaudhuri, The Trading World of Asia and the English East India Company 1660-1760 (Cambridge: Cambridge University Press, 1978); J. R. Bruijn, F. S. Gaastra and Ivo Schoffer, Dutch-Asiatic Shipping in the 17th and the 18th Centuries; 3. Homeward-bound Voyages from Asia and the Cape to the Netherlands (1597-1795) (The Hague: Martinus Nijhoff, 1979).

Line B. BPP, 1812-13 (78) VIII; Bruijn, Gaastra and Schoffer, Dutch-Asiatic Shipping; 3. Homeward-bound Voyages.

Line C. BPP, 1847-48 (974) LXI; BPP, 1812-13 (78) VIII.

Line D. BPP, 1821 (476) VII; George Alexander Prinsep, "Remarks on the External Commerce and Exchanges of Bengal, with Appendix of Accounts and Estimates" [1823], in K. N. Chaudhuri (ed.), The Economic Development of India under the East India Company, 1814-58 (Cambridge: Cambridge University Press, 1971).

Line E. Annual Statement. Annual Statement of the Trade and Navigation of British India, 1873-74 (Calcutta: Statistical Department, 1874).

$\mathrm{A}$ and $\mathrm{B}$ are the sums of exports by the English East India Company and the Danish East India Company. C includes private trade. The data for 1812-13 was lost.

information on them. We have a reasonably good set of data after $1813,{ }^{11}$ a period when the Company's trade became rapidly insignificant. By the end of the 1840s most of the relevant statistics became available in annual publications.

In spite of the problems of interpretation of these data, however, it should be clear that India's trade substantially increased during the first half of the nineteenth century. There were short-term

${ }^{11}$ Some technical problems relating to the compilation of statistics are discussed in George Alexander Prinsep, "Remarks on the External Commerce and Exchanges of Bengal, with Appendix of Accounts and Estimates [1823]", in K. N. Chaudhuri (ed.), The Economic Development of India under the East India Company, 1814-58 (Cambridge: Cambridge University Press, 1971), pp. 51-167. They are taken into account in the figures prepared by Chaudhuri in the same volume. I have essentially accepted their revisions, with very minor adjustments. 


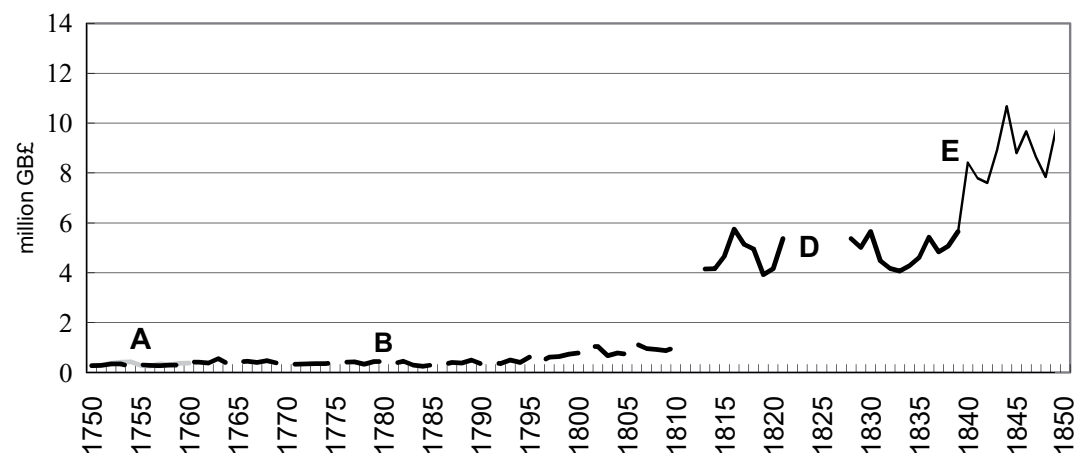

Fig. 5.3. India’s imports, $1750-1850$ (in million GBE). Sources: See same line numbers (A, B, D, and F) in Figure 5.2. The data are subject to the same limitations of similar data in Table 5.2.

fluctuations, but the upward trend in value terms continued decade by decade, including the period (especially the 1830s), which is normally regarded as a period of depression. ${ }^{12}$ There was no evidence of inflationary trend in any case ${ }^{13}$ so the increase of trade was most probably a real one.

It also seems reasonable to assume that the progressive easing of the English East India Company's monopoly and privileges in 1793, 1813 and 1833 greatly facilitated this increase. The 1793 Act required that the Company provide at least 3,000 tons of cargo space a year in Company ships for private trade. As a result, out of 54,000 tons allotted for the private trade for the nineteen years from 1793 to $1812,21,806$ tons worth of $£ 24,585,673$ sterling were used by private merchants for 'privilege trade, while commanders and officers of the East India Company engaged in 'private trade' to the value of $£ 8,543,027$ sterling. ${ }^{14}$ Together, they made up a little less than 40 percent of Britain's imports from India. The 1813 Act basically allowed private individuals to trade freely, except for the China trade. Moreover they were not allowed to

${ }_{12}$ P. J. Thomas and B. Natarajan, "Economic Depression in the Madras Presidency (1825-54)", Economic History Review, 7, 1 (1936), pp. 67-75; David Washbrook, "Economic Depression and the Making of Traditional Society in Colonial India", Transactions of the Royal Historical Society, 3 (1993), pp. 237-63.

${ }_{13}$ Asiya Siddiqi, "Introduction", in Asiya Siddiqi (ed.), Trade and Finance in Colonial India, 1750-1860 (Delhi: Oxford University Press, 1995), pp. 1-60.

${ }_{14}$ British Parliamentary Papers (hereafter BPP), 1812-13 (78) VIII: "Report from the Committee of Correspondence to the Court of Directors of the East India Company on Trade with the East Indies and China". 
trade in vessels under 350 tons burden. The 1833 Act terminated all trading privileges enjoyed by the Company. ${ }^{15}$

How did the relative importance of India and China in British trade change in the first half of the nineteenth century? While imports from China became as significant for Britain as from India at the end of the eighteenth century, India became rather more important during the next half century. British exports to India were far more important than those to China throughout the period. These figures confirm the orthodox view that British exports to India were the driving force behind the entire process of expansion of British trade in Asia. There were however some important developments: by the 1800s American and European Continental traders were conducting trade in India, and British private traders began to demand a more substantial freedom of trade; secondly, after the establishment of Singapore in 1819 and the conclusion of the Anglo-Dutch treaty of 1824, Britain secured a safe route to China, crossing the Straits of Melaka; ${ }^{16}$ and finally, the Singapore-Canton route became the dominant route for exporting Oriental and Western produce to China. ${ }^{17}$

The other side of this British success was the fate of Dutch trade coordinated by the Dutch East India Company (VOC). ${ }^{18}$ After the VOC's trade ceased in the 1790s, the early nineteenth century was marked by the Anglo-Dutch rivalry and wars, especially in Southeast Asia, ${ }^{19}$ and it took a while for the Dutch to resume trade..$^{20}$ The trade of Java and Madura stagnated during the 1820s, before starting to grow rapidly again in the 1830s. If we exclude their trade with the Outer Islands, an

15 BPP, 1847-48 (974) LXI: "Commercial Tariffs and Regulations, Resources and Trade of the several States of Europe and America, together with the Commercial Treaties between England and Foreign Countries: Part XXII; India, Ceylon, and other Oriental Countries", pp. 95-123; Anthony Webster, "The Political Economy of Trade Liberalization: the East India Company Charter Act of 1813", Economic History Review, 43, 3 (1990), pp. 404-19.

${ }^{16}$ Id., Gentlemen Capitalists: British Imperialism in South East Asia, 1770-1890 (London: I. B. Tauris, 1998), ch. 4; Lin Ken Wong, "The Strategic Significance of Singapore in Modern History", in Ernest C. T. Chew and Edwin Lee (eds.), A History of Singapore (Singapore: Oxford University Press, 1991), pp. 17-35.

17 Murakami, "Binetsu Enganmin no Katsudo to Shincho".

${ }_{18}$ For the contrasting trends in the trade of the two companies see: Om Prakash, The

New Cambridge History of India; Vol. II.5. European Commercial Enterprise in Precolonial India (Cambridge: Cambridge University Press, 1998), ch. 7.

${ }_{19}$ Nicholas Tarling, Anglo-Dutch Rivalry in the Malay World, 1780-1824 (Sydney: Halsted Press, 1962); Wong, "Strategic Significance of Singapore".

20 W. L. Korthals Altes, Changing Economy in Indonesia; Vol. 12A. General Trade Statistics, 1822-1940 (Amsterdam: Royal Tropical Institute, 1991), pp. 12-13. 
overwhelming proportion of their expansion came from trade with the West, mostly with the Netherlands. The country probably became the second largest trading partner of Asia's long-distance trade during the second quarter of the nineteenth century, though still a distant second after Britain.

By contrast, India's exports to China were as large, and increased as rapidly, as India's exports to Britain. ${ }^{21}$ Most of this trade was carried out by British private (country) traders, ${ }^{22}$ while American and Continental merchants played a relatively small role in the growth of intra-Asian trade after the late $1810 \mathrm{~s}^{23}$ Though dominated by opium, cotton and other Oriental produce also took up a significant proportion of this trade (Figure 5.4). ${ }^{24}$

The opium triangle thus created is expressed in Figure 5.5, referring to the year 1840. It highlights the most important links between long-distance trade and intra-Asian trade. As is well known, this very large triangular settlement mechanism came about largely to overcome the lack of British remittance facilities. Together with the British encouragement of opium production and trade, ${ }^{25}$ this gave a distinct impression that intra-Asian trade was artificially created by Britain, in an environment where there was little dynamism or force for change within Asian commerce.

This paper argues against such a notion. Figure 5.6 is a matching diagram, created from our statistics, also referring to 1840 . It shows that India's exports to China, depicted in the opium triangle, were only a part, though an important part, of the more complex intra-Asian trading network, the majority of which had little to do with opium ${ }^{26}$ or the settlement mechanism created by the British. We will therefore look

${ }^{21}$ BPP, 1859 (38 Sess.2) XXIII: "Returns relating to the Trade of India and China from 1814 to 1858 ".

${ }^{22}$ Hosea Ballou Morse, The Chronicles of the East India Company Trading to China, 1635-1834, 5 vols. (Oxford: Clarendon Press, 1926-29).

${ }^{23}$ For their involvement in the earlier period see: BPP 1812-13 (171) VIII: "Extracts from Reports on External Commerce in Bengal, relating to Private Trade", p. v.

${ }^{24}$ For an earlier period see: Pritchard, Crucial Years of Early Anglo-Chinese Relations; and Tan Chung, "The British-China-India Trade Triangle (1771-1840)", Indian Economic and Social History Review, 11, 4 (1974), pp. 411-431.

${ }^{25}$ Michael Greenberg, British Trade and the Opening of China, 1800-1842 (New York, 1951); Yuzo Kato, "Shokuminchi Indo no Ahen Seisan, 1773-1830-nen", Toyo Bunka, 83 (1981), pp. 53-109.

${ }^{26}$ Trocki and Rush remind us that opium was not just a product imposed on Asia by Britain, but became an integral part of Southeast Asian societies during the nineteenth century. It is therefore possible to interpret at least part of the opium trade in the 


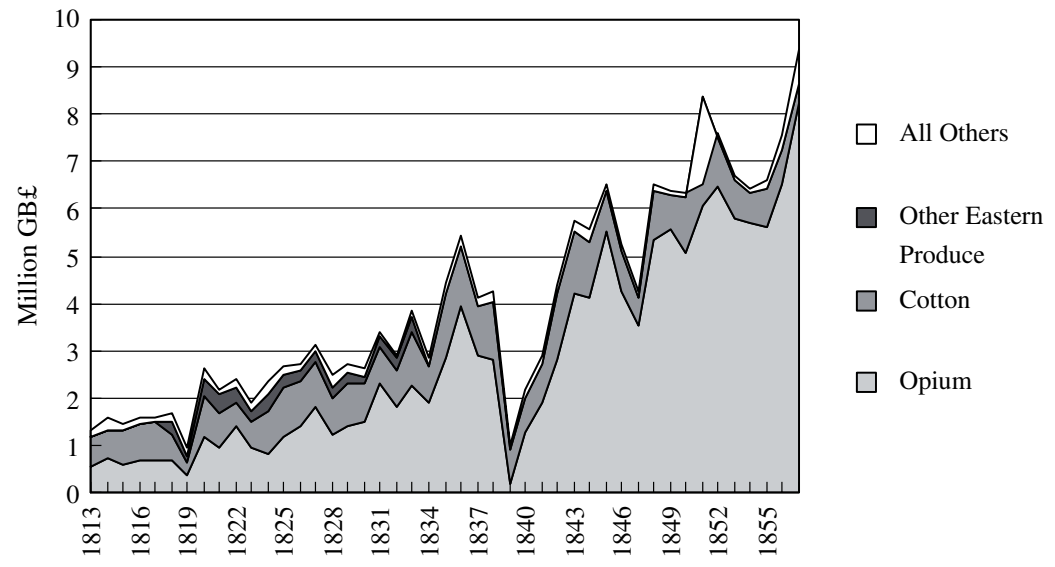

Fig. 5.4. India's exports to China, 1813-50 (in million GBE). Sources: BPP, 1859 (38 Sess.2) XXIII: 'Returns Relating to the Trade of India and China from 1814 to 1858 '. For 1818-33, the amount of 'Other Eastern Produce' was estimated by using the proportion of imports of opium as from Hosea Ballou Morse, The Chronicles of the East India Company Trading to China, 1635-1834, 5 vols. (Oxford: Clarendon Press, 1926-29), vols. 3 and 4.

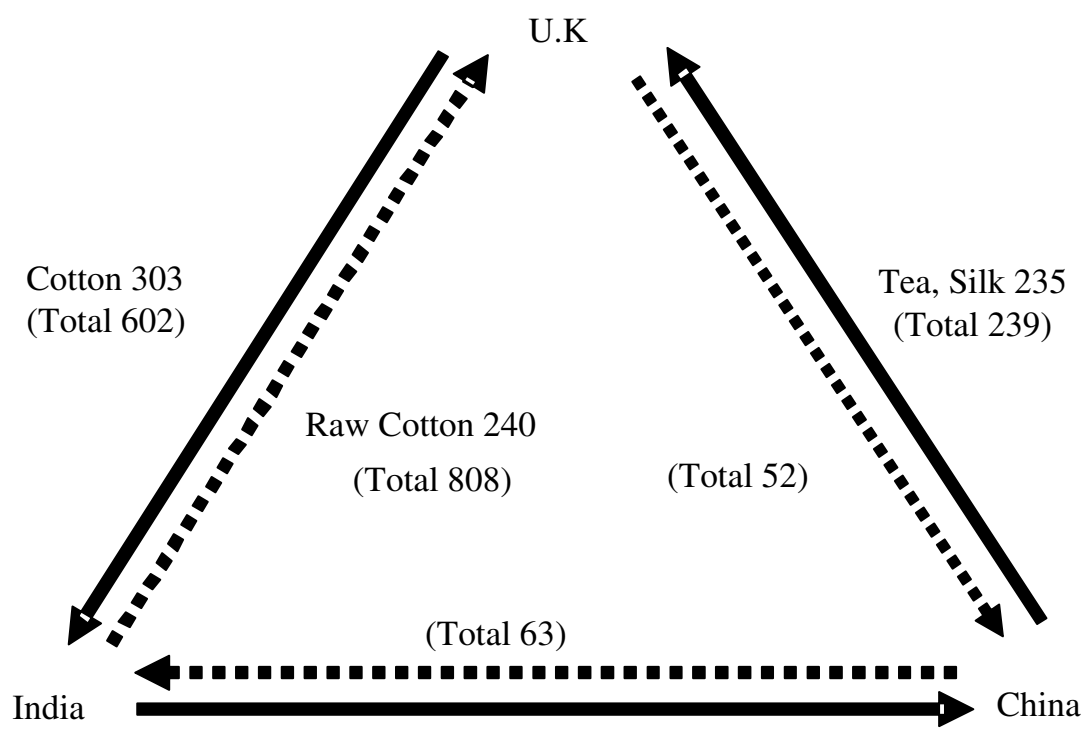

Opium 127

(Total 218)

Fig. 5.5. The opium triangle, 1840 (in 10,000 GBE). Sources: BPP, 1859 (38 Sess.2) XXIII: 'Returns Relating to the Trade of India and China from 1814 to 1858'. The United Kingdom had a trade deficit with India, but had a large current amount surplus consisting of home charges and interest payments. 


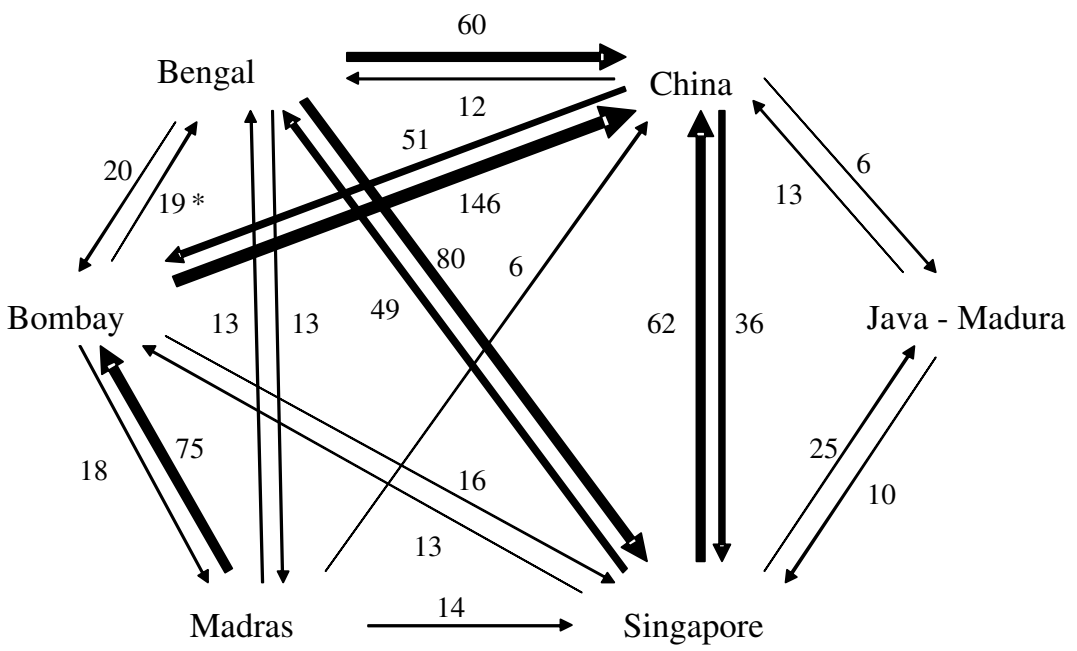

Fig. 5.6. Intra-Asian trade, 1840 (in 10,000 GBE or 100,000 Co. Rupees). Sources and Notes: based on figures 5.1, 5.3 and 5.9; W. L. Korthals Altes, Changing Economy in Indonesia; Vol. 12A. General Trade Statistics, 1822-1940 (Amsterdam: Royal Tropical Institute, 1991). The Bombay export figure was $£ 80,000$. The sum of $£ 190,000$ probably included exports from the Malabar Coast.

at the growth of intra-Asian trade from the regional point of view in the rest of the paper.

\section{Structure and Trends of Intra-Asian Trade}

This section considers the structure of intra-Asian trade and its links with long-distance trade and analyses the possible ways in which intra-Asian trade grew between 1811 and $1840 .{ }^{27}$ The three main Indian ports display differing ways in which long-distance and intra-Asian trade came to be linked to each other (Figures 5.7 to 5.12). By 1811 Bengal was already deeply integrated into long-distance trade, exporting

first half of the nineteenth century as Asia's response, rather than as a direct result of Western impact. If this is the case, it would reinforce our basic argument that the majority of intra-Asian trade was generated by the response of Asian merchants and producers. Carl A. Trocki, Opium and Empire: Chinese Society in Colonial Singapore, 1800-1910 (Ithaca: Cornell University Press, 1990); James R. Rush, Opium to Java: Revenue Farming and Chinese Enterprise in Colonial Indonesia, 1860-1910 (Ithaca: Cornell University Press, 1990).

${ }^{27}$ The choice of these dates is an arbitrary one, and is mainly based on the ready access to statistics across countries and regions. The year 1811 refers to June 1811 to April 1812, due to administrative change, but the value of trade in this "year" does not appear to have been smaller than usual (twelve-months) years. 


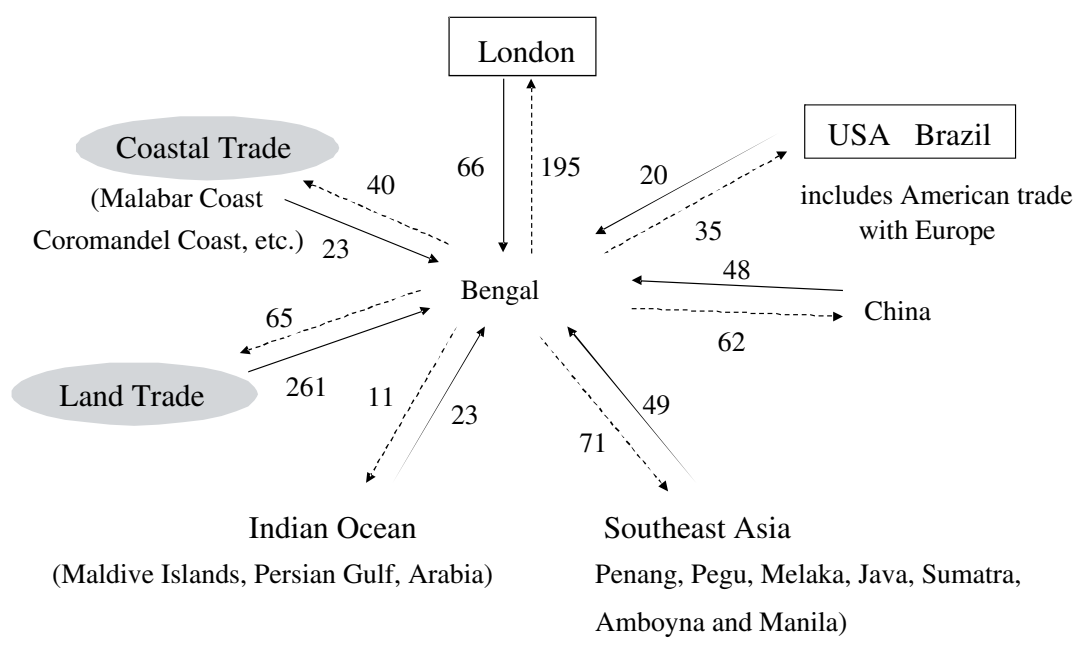

Fig. 5.7. Trade of Bengal, 1811 (in 100,000 Sicca Rupees = GB£12,500). Source: BPP, 1813-14 (46) IX: 'Reports on External Commerce in Bengal, Madras, and Bombay, relating to Private Trade'. It includes East India Company trade.

substantial volumes of indigo and silk to Britain and generating a large trade surplus. ${ }^{28}$ Such surplus was even greater when one considers that Bengal also engaged in booming trade with other parts of India, Southeast Asia and China. The bulk of these surpluses must have been sent to Britain. By 1840 the significance of this structure became paramount not only for Bengal, but also for the British presence in Asia. With the expansion of British power and its stronger hold on local economies, exports to Britain and opium exports to China and Singapore continued to increase. The only major change of this pattern of trade in the early nineteenth century was the increase of cotton textiles imported from Britain. By the mid-century Bengal became a typical export economy specialised in the production and export of primary products.

In 1811 Bombay was far less connected to London than Bengal. It enjoyed a sizable export trade with other parts of India, and was a major trading centre of the Indian Ocean with limited contacts with Britain. By 1840, however, this situation had changed dramatically: Bombay was now closely integrated into the international economy,

${ }^{28}$ Nariaki Nakazato, "Bengaru Ai-ikki o megutte (1): Igirisu Shokuminchi-shugi to Bengaru Nomin”, Toyo Bunka Kenkyusho Kiyo, 83 (1981), pp. 61-151. 


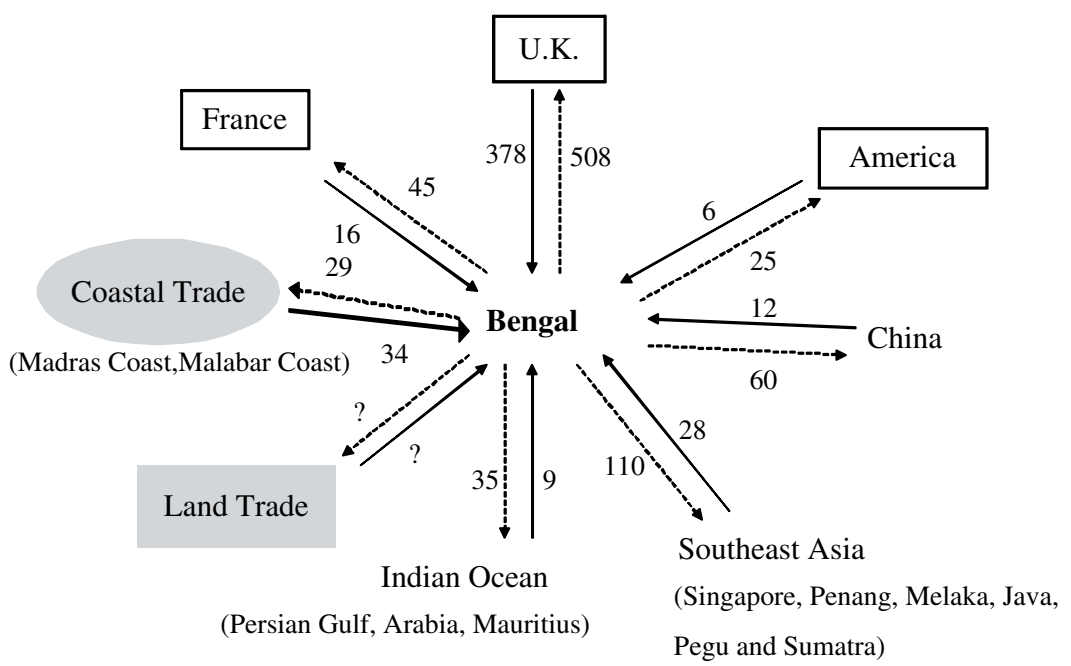

Fig. 5.8. Trade of Bengal, 1840 (in 100,000 Co. Rupees $=£ 10,000$ ). Sources: Bengal. Commercial Annual for the Years 1840-41 and 1841-42, Calcutta.

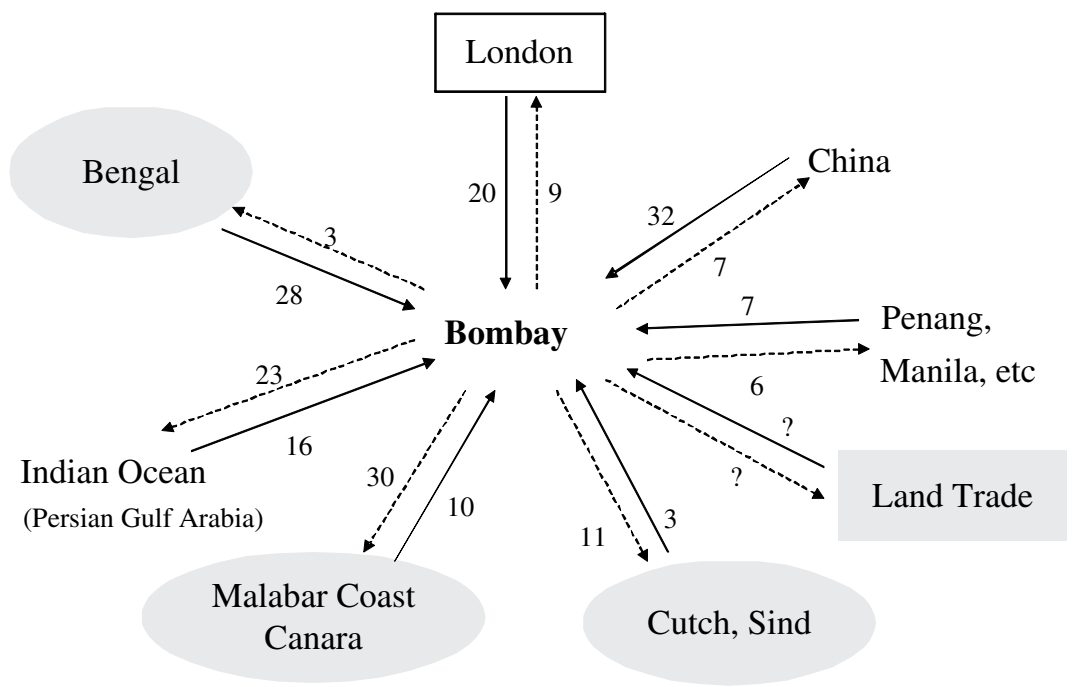

Fig. 5.9. Trade of Bombay, 1811 (in 100,000 Co. Rupees $=£ 10,000$ ). Source: BPP, $1813-$ 14 (46) IX: 'Reports on External Commerce in Bengal, Madras, and Bombay, Relating to Private Trade'. Private trade only. 


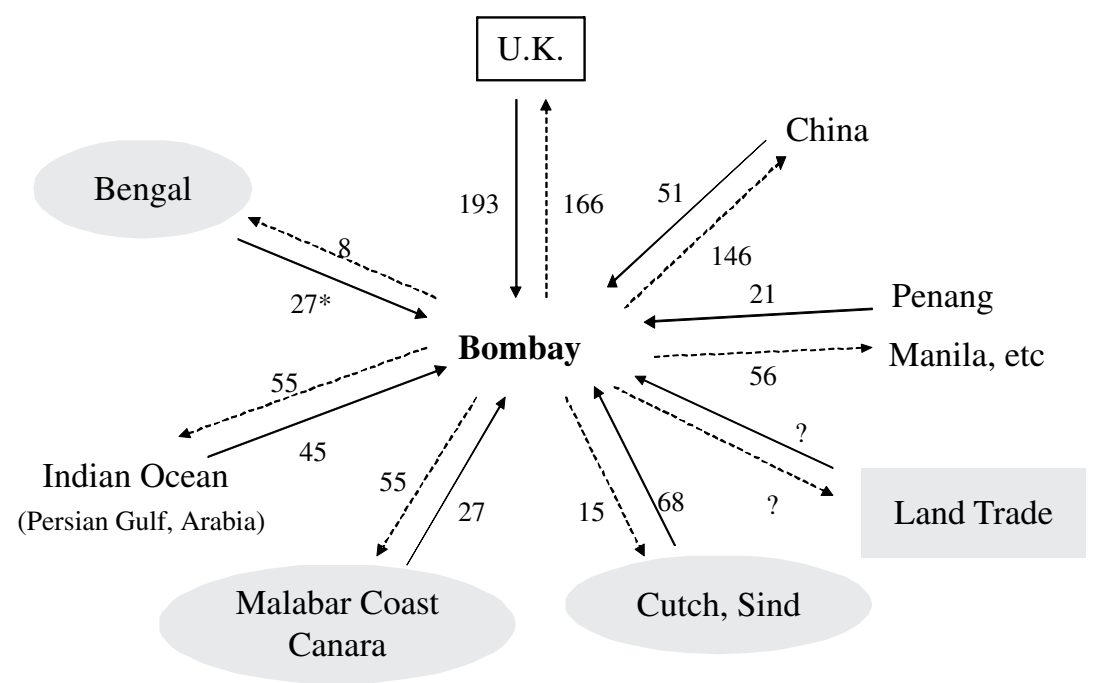

Fig. 5.10. Trade of Bombay, 1840 (in 100,000 Co. Rupees $=£ 10,000$ ). Source: BPP, 1847-48 (974) LXI: 'Commercial Tariffs and Regulations, Resources and Trade of the Several States of Europe and America .... The Bengal export figure was $£ 200,000$.

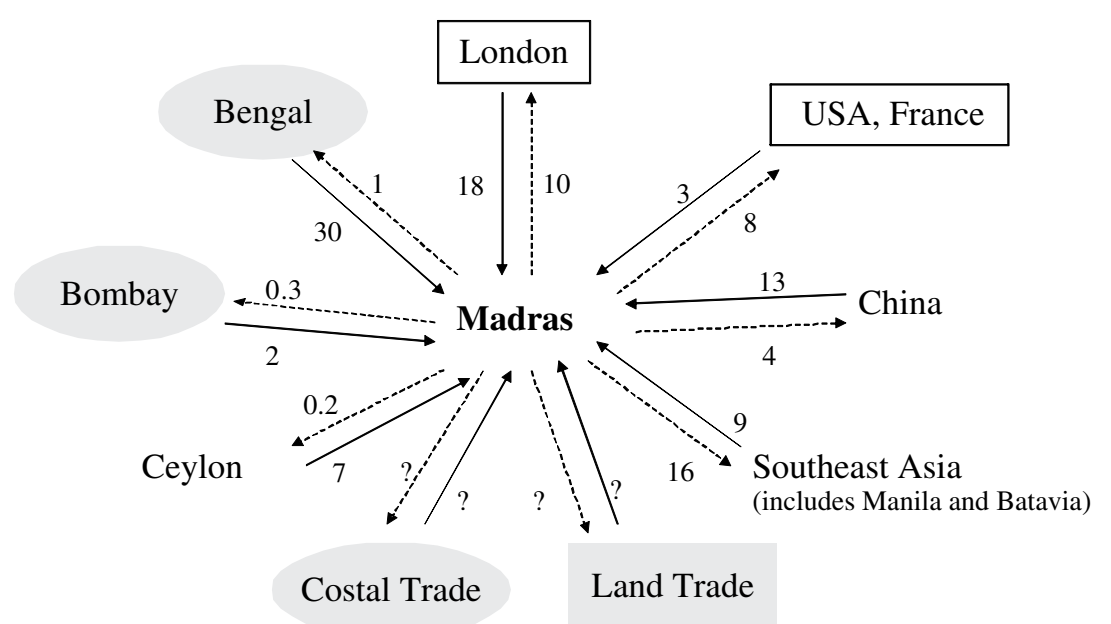

Fig. 5.11. Trade of Madras, 1811 (in 100,000 Co. Rupees $=£ 10,000$ ). Source: BPP, 1813-14 (46) IX: 'Reports on External Commerce in Bengal, Madras, and Bombay, Relating to Private Trade’. Private trade of Fort S. George only. Other ports traded mainly with non-European ports. 


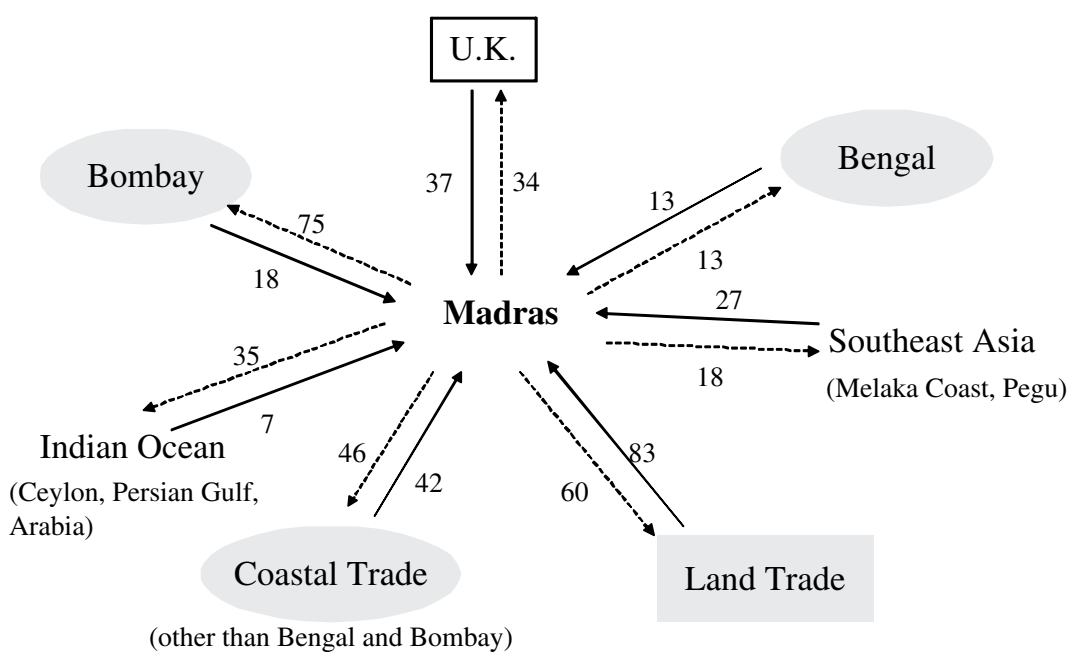

Fig. 5.12. Trade of Madras, 1840 (in 100,000 Co. Rupees $=£ 10,000$ ). Source: Madras. Tabular Statement of the External and Internal Commerce of the Madras Territories during the Year 1841-42, Madras.

through its exports to and imports from Britain, and through opium exports to China. Nevertheless, Bombay's trade position in Asia, especially in the western part of the Indian Ocean, remained strong. There was no sign of decline in regional trade and relatively little change in its composition.

In 1811, Madras too was very much a centre of intra-Asian trade, with links to Bengal, Southeast Asia and China, in addition to Britain. Its connections with Southeast Asia and Ceylon were stronger than Bombay's. Significantly, the local and regional character of the Madras trade was preserved throughout the period. Long-distance trade was ancillary, rather than the main contributor to Madras trade in $1840 .{ }^{29}$

Until the 1820s Penang acted as a centre of long-distance and regional trade in the Bay of Bengal. ${ }^{30}$ Figure 5.13, however, suggests that by 1828 Singapore took over much of this role, especially with regard to long-distance trade and the China trade. Even so, at this time Penang remained more important than Singapore in its trade with Southeast

${ }^{29}$ For a useful background see: A. Sarada Raju, Economic Conditions in the Madras Presidency, 1800-1850 (Madras: University of Madras, 1941).

${ }^{30}$ For a story of Penang up to 1819 see: K. C. Tregonning, The British in Malaya: The First Forty Years 1786-1826 (Tucson, Az.: University of Arizona Press, 1965), ch. 8. Penang's role in the 1820s, however, is not made explicit there. See also Nordin Hussin, Trade and Society: Dutch Melaka and English Penang, 1780-1830 (Singapore: NUS Press, 2007). 


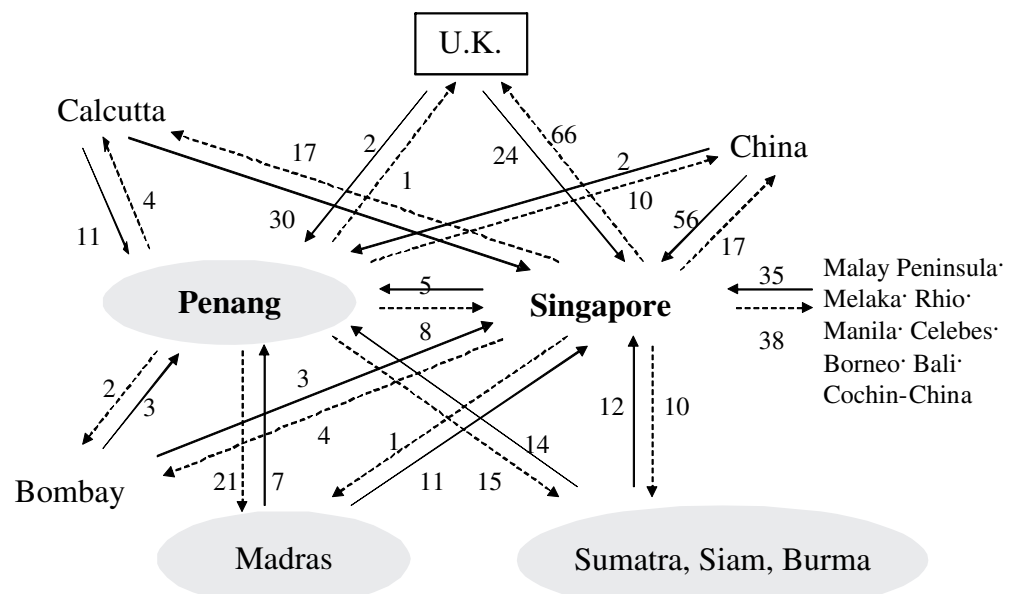

Fig. 5.13. Trade of Penang-Singapore, 1828 (in 100,000 Sicca Rupees $=£ 12,500$ ). Sources: BPP, 1847-48 (974) LXI: 'Commercial Tariffs and Regulations, Resources and Trade of the Several States of Europe and America ...; Lin Ken Wong, "The Trade of Singapore, 1819-69", Journal of the Malaysian Branch of the Royal Asiatic Society, 33, 4 (1960), pp. 1-315; Singapore. Tabular Statement of the Commerce and Shipping of Singapore during the Years 1840-41, 1841-42, 1842-43, and 1843-44, Singapore. Figures taken from the latter two sources were converted into GBE sterling at 1 Spanish Dollar $=2.245$ Co. rupees).

Asia and Madras. More important, Singapore did not become a port of long-distance trade for quite a long time. Figure 5.14 suggests that trade within Southeast Asia and with China were large and on the increase, while Europe's share remained relatively small. ${ }^{31}$

Finally, the Dutch East Indies were largely isolated from this emerging network of intra-Asian trade. Java and Madura had limited trade contact with other Asian ports, including Singapore. ${ }^{32}$ There must have been local and regional trade between British and Dutch spheres of influence that are not included in our statistics, but the size of regional trade is unlikely to have been very large, as reports and statistics of Penang and Singapore suggest that in general the authorities appear to have had a good knowledge of regional trade. ${ }^{33}$

31 Wong, "Strategic Significance of Singapore"; Singapore. Tabular Statement of the Commerce and Shipping of Singapore during the Years 1840-41 (Singapore, 1841-42, $1842-43$, and 1843-44).

${ }^{32}$ Altes, Changing Economy in Indonesia.

${ }^{33}$ Wong, "Strategic Significance of Singapore"; C. D. Cowan (ed.), "Early Penang and the Rise of Singapore: A Selection of the Manuscript Records of the East India Company 


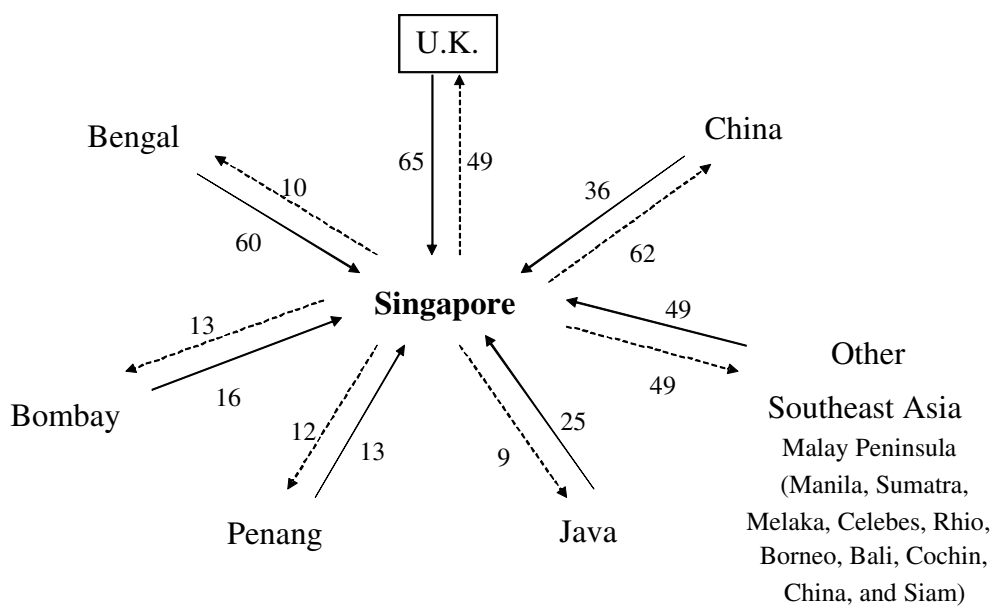

Fig. 5.14. Trade of Singapore, 1840 (in 100,000 Co. Rupees $=£ 10,000$ ). Source: Lin Ken Wong, “The Trade of Singapore, 1819-69", Journal of the Malaysian Branch of the Royal Asiatic Society, 33, 4 (1960), pp. 1-315; Singapore. Tabular Statement of the Commerce and Shipping of Singapore during the Years 1840-41, 1841-42, 1842-43, and 1843-44, Singapore. 1 Spanish Dollar $=2.245$ Co. rupees.

These statistics, combined with information on Chinese junk trade, point to two broad conclusions. First, the size of intra-Asian trade in 1840 probably exceeded that of long-distance export trade. The amount of intra-Asian trade amounted to $£ 14.55$ million sterling. ${ }^{34}$ In addition, there was junk trade. If we are to believe John Crawfurd, one of the best informed Westerners, Chinese junk trade around 1830 amounted to around 80,000 tons, ${ }^{35}$ while the total tonnage of English East India Company's ships entered into Canton was 28,513 tons. The total value of imports and exports carried by the latter amounted to US\$52 million, or approximately $£ 11$ million sterling. ${ }^{36}$ It is likely that junk trade carried commodities of a lower value, but, even if its value per tonnage was worth a third of that of the Canton trade, the total value of junk trade exceeded $£ 10$ million sterling.

over the Period 1805-1832", Journal of the Malayan Branch of the Royal Asiatic Society, 23, 2 (1950), pp. 193-203.

${ }^{34}$ (1) in Table 5.1. This is narrowly defined in the sense that it is the amount taken or estimated directly from recorded statistics. I have included not only trade between countries but trade among major ports, which means that they include a substantial amount of coastal trade, though I have excluded internal land trade.

${ }^{35}$ BPP, 1830 (644) V: "First Report from the Select Committee on the Affairs of the East India Company (China Trade)", p. 299.

${ }^{36}$ Morse, Chronicles of the East India Company. 
The junk trade with Singapore and the Dutch East Indies, part of which is likely to be included in our calculation, took up a very small proportion of this trade around 1830 (Table 5.2). On the other hand, there were other junk trades, conducted by Chinese residents in Southeast Asia, especially in Siam and Cochin-China. ${ }^{37}$ Bangkok remained an important provider of junks. ${ }^{38}$

If we assume that the unrecorded junk trade amounted to $£ 10$ million, and add this amount to the $£ 14.66$ million previously calculated (point (1) Table 5.1), we get $£ 24.55$ million sterling as a figure which might be called the amount of broadly defined intra-Asian trade (point (2) in Table 5.1). In other words, the size of intra-Asian trade may well have exceeded that of total long-distance export trade ( $£ 18.77$ million in Table 5.1) by a wide margin. ${ }^{39}$

The second broad conclusion is that intra-Asian trade is most likely to have steadily grown between 1811 and 1840 . To recapitulate, Figures 5.9 and 5.10 show the growth of India's trade, while Asia's share in India's 'foreign' sea-borne trade ${ }^{40}$ remained at circa 50 percent; Singapore and 'Java and Madura' both showed an increase of Asia's share for the period for which statistics survive; Canton's imports from India increased faster than its trade with Britain. There is no reason to assume that the size of Chinese junk trade decreased during the period either. Although its rate of growth is unknown, ${ }^{41}$ the vigorous entry of Western traders is likely to have stimulated junk trade rather than eliminated it through competition.

\section{Commodity Composition}

Although it is not easy to compile the amount of trade of each commodity, as the classification of goods traded was not always

\footnotetext{
${ }^{37}$ Mazumdar, Sugar and Society in China, p. 112.

38 Sarasin Viraphol, Tribute and Profit: Sino-Siamese Trade, 1652-1853 (Cambridge, Ma: Harvard University Press, 1977).

39 Table 5.1 does not cover the trade of "Other Asian ports" with the West as fully as their intra-Asian trade, so that the estimate made here has a bias towards assigning Asia a larger share in this respect. But its impact is marginal.

${ }^{40}$ A rough equivalent to foreign trade of British India, excluding coastal trade and 'land-frontier trade' see: K. N. Chaudhuri, "Introduction", in K. N. Chaudhuri (ed.), The Economic Development of India under the East India Company, 1814-58 (Cambridge: Cambridge University Press, 1971).

${ }^{41}$ The Junk trade in Southeast Asia showed a clear upward trend. See Reid, "Chinese Trade", p. 30.
} 


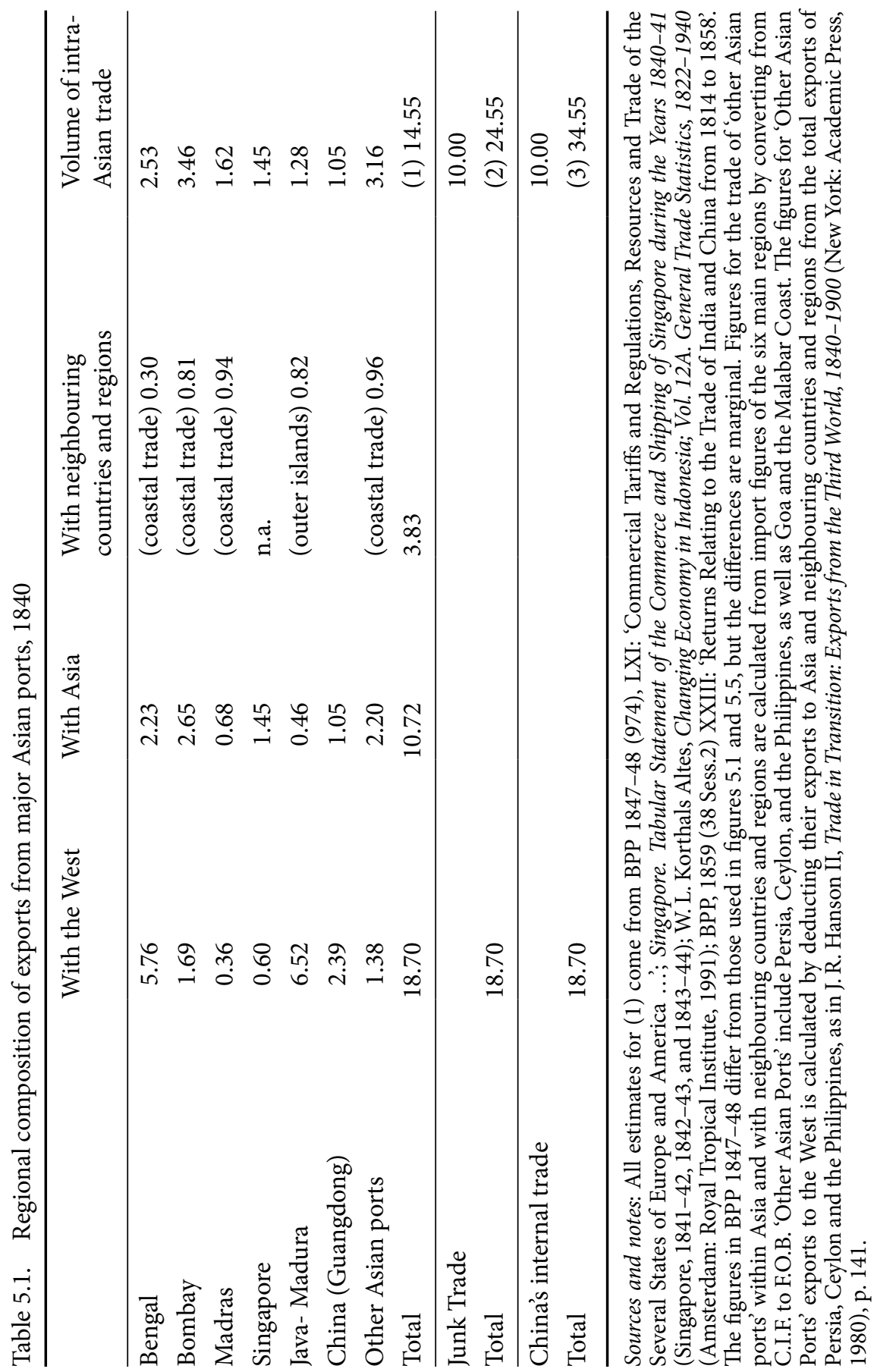


Table 5.2. China's junk trade, c. 1830

Destination

Number of ships ${ }^{*}$

Japan (10 ships over 2 voyages)

20

Philippines

Zoorow Islands

Celebes

Java 13

Sumatra

Singapore

Rhio

East of Malaya Peninsula

Siam

$89(+50)^{\star *}$

Cochin-China

$20(+43)^{* *}$

Cambodia

Tongking

Total

$222(+93)^{\star *}$

Notes: ${ }^{*}$ The average tonnage per ship was 120 to 900 tons including small junks, thus producing a total of c. 80,000 tons.

** Figures in brackets are small junks from the Hainan Islands.

Sources: BPP, 1830 (644), V: 'First Report from the Select Committee on the Affairs of the East India Company (China Trade)', pp. 298-99; Hosea Ballou Morse, The Chronicles of the East India Company Trading to China, 1635-1834 (Oxford: Clarendon Press, 1926), vol. 4; evidence from John Crawfurd, A View of the Present State and Future Prospects of the Free Trade and Colonization of India (London: James Ridgeway, 2nd edn. 1829).

made uniform in this period, it is certainly possible to isolate the main items traded and estimate their relative importance in intra-Asian trade. In 1840 total exports of opium from India were worth $£ 2.28$ million sterling, while exports (largely re-exports) from Singapore to China amounted to $£ 0.46$ million. This compares with the total value of intra-Asian trade of approximately 9 million, which also includes some re-exports. Thus opium trade consisted of about 30 per cent of recorded intra-Asian trade in 1840 . The percentage for this particular year was probably below average, and should be regarded as such. Even so, it should be clear that opium trade hardly constituted the bulk of intra-Asian trade. ${ }^{42}$

${ }^{42}$ In addition, the share of opium in the most broadly defined sum of intra-Asian trade ( $£ 34.55$ million), suggested at the end of this paper, would be much smaller than 
In addition, the flow of precious metals, especially of silver, in connection with intra-Asian trade and settlement were quite substantial, and its significance has been discussed in some detail (see Lin 2006, chapter 2), although this is outside the scope of this chapter. ${ }^{43}$

Apart from opium and silver, the main commodities included grain, raw cotton, cotton cloth, raw silk, silk cloth, sugar, salt and spices. The value of each of these items, especially when sub-varieties are considered, was much smaller than that of opium. Local trade was instead characterised by a wide variety of commodities for everyday consumption. The list of commodities that were part of the internal trade of Madras in 1811, for example, included horse gram, oil seeds, long pepper-root, turmeric, chillies, firewood, coriander seeds, coffee, beetle nut, cocoa nuts, lamp oil, cotton, tortoise shells, arrack, Tricomalee wood, dry ginger, cardamums, coir cordage, iron hoops and camphor, in addition to glassware, stationery goods, copper, copperware of European origin, and spices, tin, and raw silk imported from China and Southeast Asia. ${ }^{44}$ If we look at other minor ports, much of the same kind of items appears in the local and regional trade handled by Asian merchants.

The commodity composition of Singapore's trade in 1840 (Table 5.3) shows relatively high shares of European produce and opium in major port trade. The share of various grains and other local produce tended to be smaller in these ports. Bengal is perhaps the most extreme case of Western domination: local trade hardly featured in this table, although it certainly did not mean a lack of growth of local and regional trade centring around the lesser ports and cities of the Bengal Presidency. ${ }^{45}$ But the bulk of this trade was also closely connected to the growth of longdistance trade.

$30 \%$. The reasoning behind this speculation is that the share of opium in China's internal trade was probably smaller. Although there is no direct estimate for this, opium trade showed a fairly strong growth during the second half of the nineteenth century, and at the early twentieth century it is thought to have consisted of about one-sixth of China's internal trade by value. Man-Houng Lin, "China's "Dual Economy" in International Trade Relations, 1842-1949", in Sugihara (ed.), Japan, pp. 182-87. Around 1840 opium was undoubtedly the single largest commodity in intra-Asian trade, and it was rapidly growing. Nevertheless, seen against the whole structure of intra-Asian trade, primarily made up of a wide variety of food grains and other food stuff, as well as of textiles, it was a relatively minor element.

${ }^{43}$ Id., China Upside Down: Currency, Society and Ideologies, 1808-56 (Cambridge, Ma: Harvard University Press, 2006), ch. 2.

${ }_{44}$ BPP, 1813-14 (46) IX: "Reports on External Commerce in Bengal, Madras, and Bombay, relating to Private Trade".

${ }^{45}$ See Figure 5.7 for a large size of internal trade. I was unable to obtain figures for internal trade in 1840 . 
Table 5.3. Commodity composition of Singapore’s trade, 1840 ( in $£ 10,000$ )

\begin{tabular}{lrr}
\hline & Imports & Exports \\
\hline Opium $^{*}$ & 55.3 & 45.9 \\
European cotton cloth $^{*}$ & 43.3 & 16.5 \\
Asian cotton cloth & 17.0 & 10.4 \\
Tin & 12.5 & 12.1 \\
Raw cotton & 12.4 & 9.0 \\
Tea & 11.0 & 15.2 \\
Raw silk & 9.6 & 7.7 \\
Coffe & 9.0 & 6.5 \\
Rice & 8.1 & 4.7 \\
Sugar & 7.9 & 11.2 \\
Pepper & 6.5 & 10.1 \\
Cotton yarn & 5.5 & 4.7 \\
Total & 220.7 & 181.7 \\
\hline
\end{tabular}

${ }^{*}$ Items mainly produced and consumed in Asia.

Sources: Singapore. Tabular Statement of the Commerce and Shipping of Singapore during the Years 1840-41 (Singapore, 1841-42, 1842-43, and 1843-44).

One can conclude that there were two kinds of forces operating in the growth of intra-Asian trade: an autonomous force linking local trades through improved trading opportunities; and the direct impact of long-distance trade. In line with conventional wisdom, the majority of intra-Asian trade consisted of goods (mostly necessities) relating to food and clothing of the Asian population. However, it would be incorrect to emphasise the autonomy of this trade, as the trade of 'traditional' goods was also indirectly related to long-distance trade. For example, the impact of long-distance trade induced a rise in the purchasing power of both European and Europeanised populations in cities and indigenous populations in the countryside, but their consumer demand included items drawn from local and regional trade. Thus European cloth and liquor were frequently redistributed from port to port for the consumption of urban inhabitants, while the export of primary produce from a locality induced the import of grains, India cotton cloth and other necessities to that place, from other regions within Asia. The English East India Company's ban on trade with ships below 350 tons helped small Indian traders and 
shippers. ${ }^{46}$ British and other Western merchants conducted trade, assuming that local merchants would redistribute certain commodities and procure locally produced food and other necessities for them. Although Southeast Asia's trade was severely disrupted during the period of Anglo-Dutch rivalry and there were changes in the careers of local and regional traders (especially from Southeast Asian to Chinese trade), these complementary relationships between longdistance trade and intra-regional trade were to be found in most Asian waters. In fact they became the basic structure of Asian trade, as long-distance trade expanded in volume as well as geographically to the Far East.

Let us also consider the trade of cotton, since the influx of British cotton textiles to India and other parts of Asia has featured largely in the historiography. ${ }^{47}$ In 1811 Bengal was a major exporter of cotton cloth to both American continents and the Indian Ocean, and imports from Britain were not yet substantial. By 1840 the situation had changed dramatically, with a great influx of Lancashire goods and the well-noted decline of the cotton textile industry in the Bengal Presidency. Britain's share in imports of cotton cloth to Bengal (Calcutta) increased from 25 percent in 1811 to 93 percent in $1840 . .^{48} \mathrm{~A}$ similar change occurred in Bombay: Britain's share in imports of cotton cloth to the city increased from 4 percent in 1811 to 80 percent in 1840 , even if records for this latter date show some imports of Indian cotton cloth from the hinterland to Bombay. ${ }^{49}$ By contrast, Madras cotton trade was less affected by the import of British cotton cloth. Indeed, if we include all kinds of cotton cloth, even in 1840 Madras' exports to Britain were much greater than its imports from Britain. Clearly Madras imported large quantities of Indian cotton cloth from other parts of the Presidency and beyond, and exported a sizable amount to Bombay, a fact that is not recorded in the Bombay statistics. Britain's share in imports of cotton cloth to

${ }^{46}$ N. Benjamin, "Bombay's "Country Trade" with China (1765-1865)", Indian Historical Review, 1, 2 (1974), pp. 298-300 and 330; Arasaratnam, "Coromandel's Bay", pp. 327-28.

${ }^{47}$ A. K. Bagchi, "Deindustrialization in India in the Nineteenth Century: Some Theoretical Implications”, Journal of Development Studies, 12, 2 (1976), pp. 135-64; Tirthankar Roy, Rethinking Economic Change in India: Labour and Livelihood (London: Routledge, 2005), ch. 5.

${ }_{48}$ Bengal. Commercial Annual for the years 1840-41 and 1841-42, Calcutta.

49 Bombay. Commercial Report, 1811 and 1840, Bombay; Trade and Navigation Annual Statement, 1848-49, Bombay. 
Madras and its neighbouring ports remained as low as 12 percent, increasing to circa 20 percent if we include imports of British cloth via Bombay and Bengal. ${ }^{50}$ Figures 5.15 confirms the dominance of Madras cotton cloth in both India's export and coastal trade. ${ }^{51}$ Turning to Southeast Asia, Table 5.4 shows that British cotton cloth imports dominated the Singapore trade in 1840, although Indian, Chinese and Malay cloths were also traded.

The proportion of British cotton cloth in the Asian cotton cloth market was clearly on the rise. At the same time, both India and Singaporean figures suggest a relatively modest decline of Asian cotton cloth trade in absolute terms during the first half of the nineteenth century. If we consider the growth of population at this time, it is unlikely that the proportion of local consumption (that is, home consumption plus local, not regional, sales) in total native cloth production decreased.

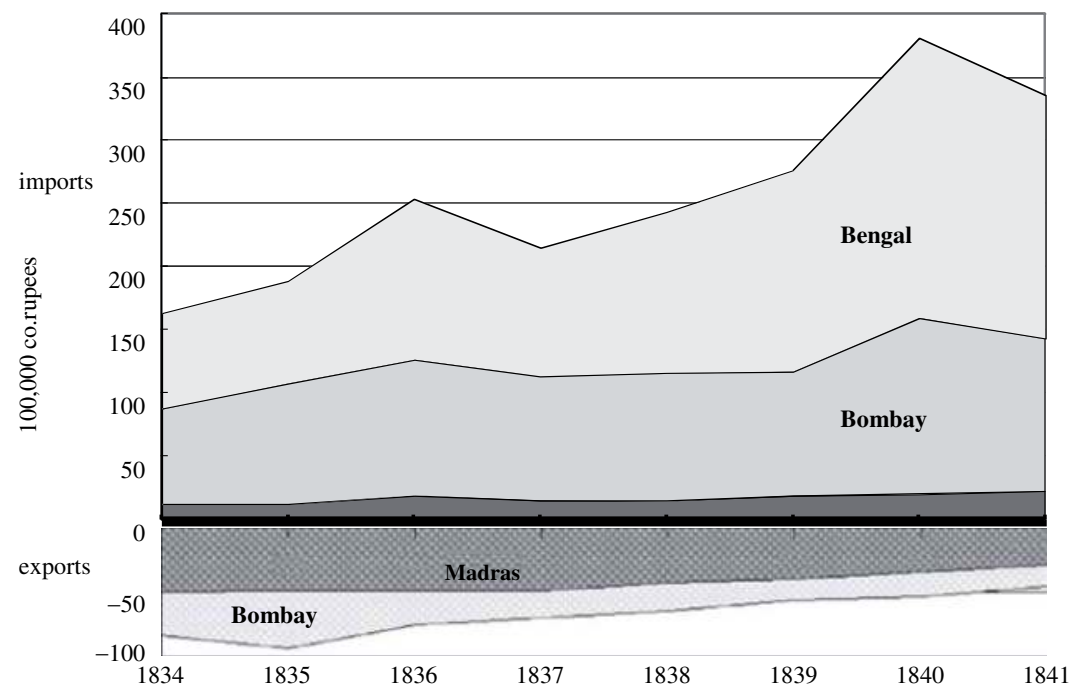

Fig. 5.15. Imports and exports of cotton goods of India, 1834-41 (in 100,000 Co. rupees). Source: BPP, 1847-48 (974) LXI: 'Commercial Tariffs and Regulations, Resources and Trade of the several States of Europe and America ....

${ }^{50}$ Madras. Tabular Statement of the External and Internal Commerce of the Madras Territories during the year 1841-42, Madras.

51 BPP, 1847-48 (974) LXI: “Commercial Tariffs and Regulations”. 
Table 5.4. Singapore’s cotton cloth trade, 1840 (in $£ 1,000)$

\begin{tabular}{lccr}
\hline \multicolumn{1}{c}{ Imports } & \multicolumn{2}{c}{ Exports } \\
\hline Country of import & value & Country of export & value \\
\hline \multicolumn{4}{c}{ British Cotton Cloth } \\
From UK & 396 & To Southeast Asia & 139 \\
From Continental & 13 & To China & 22 \\
$\quad$ Europe and USA & & & \\
From Southeast Asia & 8 & Total & 176 \\
Total & 433 & To Southeast Asia & 69 \\
& Indian Cotton Cloth & \\
From Calcutta & 31 & Total & 69 \\
From Madras & 36 & To Southeast Asia & 5 \\
Total & 93 & Total & 10 \\
& Chinese Cotton Cloth & \\
From China & 24 & To Southeast Asia & 24 \\
Total & 24 & & 25 \\
& \multicolumn{2}{c}{ Malay Cotton Cloth } & \\
From Celebes & 29 & Total & \\
From Java & 14 & 46 & \\
Total & & &
\end{tabular}

Sources: Singapore. Tabular Statement of the Commerce and Shipping of Singapore during the Years 1840-41 (Singapore, 1841-42, 1842-43, and 1843-44).

The shift in the demand from Asian to British cotton cloth did occur, but it did not result in the dominance of long-distance trade over regional trade. The increase of British cloth imports was compensated for by both the rapid increase of opium trade and re-exports of Western goods within Asia, so that the rate of growth of intra-Asian trade remained comparable to that of long-distance trade. Meanwhile, the bulk of other necessities trade, not directly linked to long-distance trade, grew steadily.

\section{Asia and Global Trade}

How important were Asian and intra-Asian trade in world trade? A first issue to address is the relative size of the phenomenon considered. So far, the best attempt to calculate Asia's share in world trade is 
Hanson's work, which suggests that Asia’s exports amounted to $£ 29$ million sterling in $1840 .{ }^{52}$ According to his data, Asia's share in world exports was circa 12 percent. ${ }^{53}$

Our calculation in Table 5.1 suggests that Asia's exports to the west amounted to $£ 18.7$ million sterling, while the amount of intra-Asian trade including coastal trade and Chinese junk trade was $£ 24.55$ million sterling. The total amount of Asia’s exports was $£ 43.25$ million sterling. In addition, Table 5.5 shows the very large size of China's internal trade (in the order of a little more than $£ 100$ million), some of which surely qualify as intra-Asian trade as defined in this paper. This is consistent with some British commercial reports, which record the very large size of intra-regional trade in inland Chinese ports, including substantial long-distance trade. Thus, even if we take 10 percent of the total figure ( $£ 10$ million) in Table 5.5 as intra-regional trade, we arrive at the total intra-Asian trade figure of $£ 53.25$ million, which implies that Asia accounted for more than 20 percent of world trade. It is worth noting that, if we deduct $£ 18.70$ million from this figure and consider the rest

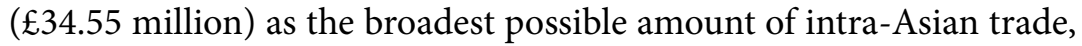
it would have consisted of nearly two-thirds of Asia's overall trade. Since Asia's exports to Europe greatly exceeded its imports from there, it means that the amount of intra-Asian trade would have been comparable to that of Asia's long-distance (exports and imports) trade.

${ }^{52}$ J. R. Hanson II, Trade in Transition: Exports from the Third World, 1840-1900 (New York: Academic Press, 1980), pp. 138 and 141.

${ }^{53}$ Ibid. Frequently cited world trade statistics tend to give the impression that nineteenth century world trade was dominated by the West. Mulhall's data showed that Europe took $71 \%$ of world trade, while India took 3\%, although other Asian countries were included in the category of "Others". Michael G. Mulhall, The Dictionary of Statistics (London: George Routledge, 4th ed. [1898] 1909), p. 128. Rostow does not seem to have cared too much about non-European trade. His estimate of Asia's share in world trade in 1840 is 3\%. Walt Whitman Rostow, The World Economy: History and Prospect (London: Macmillan, 1978), p. 71, Appendix B. However, these figures represent the value of "international trade" recognised by the customs officials. They do not represent, and usually do not claim to represent, the long-distance trade and regional trade that existed around the world. From this perspective, one can argue that there has been no attempt to estimate the "real" amount of world trade, recorded or unrecorded, for the period under review. More recently, Maddison included more data in the calculation of world trade, according to which Europe's share was $74 \%$, while Asia's was $12 \%$ in 1870. Angus Maddison, The World Economy: A Millennial Perspective (Paris: Development Centre, OECD, 2001), p. 77 Appendix F and p. 361. This is certainly closer to the estimates suggested in this paper, especially in view of the fact that Maddison refers to "foreign trade" only, and his estimate of Asia's share in world GDP significantly declined from 59 percent in 1820 to 38 percent in 1870. Id., The World Economy: Historical Statistics (Paris: Development Centre, OECD, 2003). 
Table 5.5. An estimate of China's internal trade, 1840

\begin{tabular}{|c|c|c|c|c|}
\hline & Quantity & $\begin{array}{l}\text { Value (in } \\
10,000 \text { taels) }\end{array}$ & $\begin{array}{l}\% \text { of total } \\
\text { value }\end{array}$ & $\begin{array}{l}\text { Ration of } \\
\text { commoditisation }\end{array}$ \\
\hline Grain & $\begin{array}{l}24.5 \text { billion } \\
\text { (jin) }\end{array}$ & $16,333.3$ & 42 & 11 \\
\hline Raw cotton & $\begin{array}{l}1.56 \text { million } \\
\text { (dan) }\end{array}$ & $1,277.5$ & 3 & 26 \\
\hline $\begin{array}{r}\text { Cotton } \\
\text { cloth }\end{array}$ & $\begin{array}{l}315.18 \\
\quad \text { million (pi) }\end{array}$ & $9,455.3$ & 24 & 53 \\
\hline Raw silk & 70,000 (dan) & $1,202.3$ & 3 & 92 \\
\hline Silk cloth & $50,000($ dan $)$ & 1455.0 & 4 & \\
\hline Tea & $\begin{array}{l}2.61 \text { million } \\
\quad(\text { dan })\end{array}$ & $3,186.1$ & 8 & \\
\hline Salt & $\begin{array}{l}3.2 \text { billion } \\
\text { (jin) }\end{array}$ & $5,852.9$ & 15 & \\
\hline Total & & $\star 38,762.4$ & 100 & \\
\hline
\end{tabular}

* Equal to just over $\mathrm{GB} £ 100$ million sterling.

1 jin $=604$ grams; 1 dan $=100$ jin; 1 pi $=3,633$ square yards.

Sources: Xu Dixin and Wu Chengming, Chinese Capitalism, 15221840 (New York: St. Martin's Press, 2000), p. 174.

Set against Maddison's estimate that Asia's share in world GDP was 59 percent in 1820 and went down to 38 percent by $1870,{ }^{54}$ the suggestion that just over 20 percent of world trade was conducted in Asia in 1840 seems rather conservative. Intra-Asian trade figures would increase substantially if we revised upward the size of China's internal trade (especially of grains), include India's internal (land) trade (which suffered from the impositions of transit and town duties but must have increased as these barriers were gradually withdrawn in the $1830 \mathrm{~s}$ and the $1840 \mathrm{~s},{ }^{55}$ include land-frontier trade, and further refine the categories of regional trade to include the figures we have disregarded

${ }^{54}$ Id., The World Economy.

55 Jitendra G. Borpujari, "The Impact of the Transit Duty System in British India", Indian Economic and Social History Review, 10, 3 (1973), pp. 218-41; Debdas Banerjee, " "Regional Specialization and Market Convergence" Revisited: India's Internal Commodity Trade, c.1850-1920", Occasional Paper, Centre for Studies in Social Sciences, Calcutta, 137 (1992), p. 2. 
in this paper. ${ }^{56}$ If research makes progress in this direction and this sort of speculation is turned into an estimate on the basis of more solid evidence, the share of intra-Asian trade in Asia's trade is likely to increase further, and become much more than two-thirds, making long-distance trade with the West a relatively minor component of the continent's trade. ${ }^{57}$

\section{Conclusion}

A speculation of this kind without further evidence does not amount to anything particularly useful in deepening our understanding of the region, but it serves as a reminder that global trade historians should not ignore intra-regional trade in Asia and other parts of the nonEuropean world, when discussing the evolution of world trade. An important implication of this statement is that the growth of world trade cannot simply be interpreted as one emanating from the West and spreading to the rest of the world, even at a time of the industrial revolution in England and Western expansion to Asia. The growth of intra-Asian trade occurred under the regime of 'forced free trade. The trade restrictions imposed both by Dutch and English East India companies and by the Chinese government were relaxed, and the opportunities for country traders and Asian merchants to engage in local and regional trade increased, first around India, then rapidly spreading to Southeast Asia and China. Part of regional trade gradually became independent from long-distance trade, creating the Asian international market of necessity goods. It was a development which went well beyond the needs of the colonial rulers or the necessity for the settlement of long-distance trade. It also vitally depended on the response to trade opportunities by producers (farmers and artisans), as well as by merchants.

Furthermore, intra-Asian trade not recorded in our statistics is likely to have been even less directly connected to Western impact: in the sense that these activities were of a traditional kind, largely unaffected

\footnotetext{
${ }^{56}$ We have little information on the trend of China's internal trade. If there was a significant decline of this trade during the first half of the nineteenth century, which I think is unlikely, part of the general conclusion of this paper must be qualified.

${ }^{57}$ On the other hand, a further investigation on regional trade in other parts of the world, especially in the non-European world, is likely to increase the total value of world trade, thus decreasing Asia's share to some extent.
} 
by Western technology and organisations. The Asian (East, Southeast and South Asian) paths of economic development continued to underpin the growth of trade, even under the presence of a powerful Western impact and colonialism. ${ }^{58}$ In this respect the standard view, which emphasises a sharp discontinuity in Asian trade history around the nineteenth century must be qualified. The survival and the revitalisation of regional trade in Asia suggest the need for a fundamental rethinking of our understanding of the prime movers of world trade.

${ }^{58}$ Kaoru Sugihara, "The East Asian Path of Economic Development: A Long-term Perspective", in Giovanni Arrighi, Takeshi Hamashita and Mark Selden (eds.), The Resurgence of East Asia: 500, 150 and 50 Year Perspectives (London: Routledge, 2003), pp. 78-123. 
$-978-90-47-42997-5$ 
PART II

REGIONS OF PRODUCTION: TEXTILES IN SOUTH ASIA 
$-978-90-47-42997-5$ 


\title{
THE TEXTILE INDUSTRY AND THE ECONOMY OF SOUTH INDIA, 1500-1800
}

\author{
David Washbrook
}

Between the sixteenth and the eighteenth centuries, India's textile industry made it one of the key centres of the then-emerging world economy. Of course, India's textiles had traded beyond its shores long before this, comprising (along with spices) the principal items in an Indian Ocean commerce, which stretched back into the mists of time. ${ }^{1}$ But the volume of transactions taking place from the sixteenth century appears of a wholly different order. The expansion was brought about, in part, by the addition of European demand to long-established Asian trade routes. However, and even more, it was facilitated by new inflows of specie metal from the Americas and Japan, which in turn stimulated trade and consumption in many parts of the world. When complaints could be heard in seventeenth-century Mexico that Indian textiles were threatening to 'de-industrialize' the local economy, the dawn of a new age in 'global economics' might be thought to have arrived.'

Some of the effects of this transition on the economy (or economies) of India have been charted. Most notably, the impact of increased bullion flows on the monetary, fiscal and commercial systems has been the focus of concern. ${ }^{3}$ By common agreement, they led to the conversion of a copper- to a silver-based coinage, symbolised by the minting of

\footnotetext{
${ }^{1}$ See K. N. Chaudhuri, Trade and Civilisation in the Indian Ocean: An Economic History from the Rise of Islam to 1750 (Cambridge: Cambridge University Press, 1985); Sanjay Subrahmanyam, The Political Economy of Commerce: Southern India, 1500-1650 (Cambridge: Cambridge University Press, 1990); Om Prakash, The New Cambridge History of India; Vol. II.5. European Commercial Enterprise in Pre-colonial India (Cambridge: Cambridge University Press, 1998).

2 Joseph M. Fradera, "The Historical Origins of the Philippine Economy", Australian Economic History Review, 44, 3 (2004), pp. 307-20.

${ }^{3}$ John F. Richards (ed.), The Imperial Monetary System of Mughal India (Delhi: Oxford University Press, 1987); Sanjay Subrahmanyam (ed.), Money and the Market in India, 1100-1700 (Delhi: Oxford University Press, 1994).
} 
Akbar's rupee; they also promoted increased demands for monetary payments within the revenue system, which in turn promoted a wider commercialisation of economic relationships. Old forms of credit and transfer-note expanded their usage and were joined by new forms, often derived either from Europe, on the one side, or contact with Chinese merchants, on the other. New financial services, such as insurance and the raising of joint-capital (beyond the bounds of caste and kinship), came to develop. The sophistication of India's monetary and financial systems, which underpinned its central role in world trade, is well-attested in the historical literature.

But of much less concern has been the impact on India's own 'productive' economy: how the relations of production, consumption and social reproduction may themselves have changed and 'developed' in relation to expanding trade and commercialisation. Om Prakash's pioneering studies of the Dutch in Bengal apart, there have been few attempts even to measure the likely quantitative consequences of the growth of the textile industry in any region during this period. ${ }^{4}$ And 'qualitative' studies of the way that economic institutions and organisations changed to accommodate increased bullion flows and trade demands have been almost wholly neglected - at least before the eighteenth century when they become part of another history (the 'prehistory' of colonialism). ${ }^{5}$

Indeed, shadows (or premonitions) of the colonial future have tended to lie heavily over most interpretations of India's 'early modern' history, making it difficult for Indian historians of 'the nationalist age' to consider that anything positive can have come out of increasing contacts with the external world, especially where Europeans were involved. Sushil Chaudhury has sought to deny the expansionary influence of European trade on Bengal, seeing it as parasitic on internal commerce. ${ }^{6}$ And Irfan Habib has cast doubt on whether rising bullion flows contributed so much to expanded production as rampant inflation. ${ }^{7}$

${ }^{4}$ Om Prakash, The Dutch East India Company and the Economy of Bengal, 16301720 (Princeton: Princeton University Press, 1985).

${ }^{5}$ An exception is Sanjay Subrahmanyam, "Rural Industry and Commercial Agriculture in Late Seventeenth-Century South India", Past and Present, 126 (1990), pp. 76-114.

${ }^{6}$ Sushil Chaudhury, From Prosperity to Decline (Delhi: Oxford University Press, 1995).

7 Irfan Habib, "Monetary System and Prices", in Tapan Raychaudhuri and Irfan Habib (eds.), The Cambridge Economic History of India; Vol. I: 1200-1750 (Cambridge: Cambridge University Press, 1982), pp. 360-81. 
We may not have come far in the fifty years since K. M. Panikkar proclaimed India's own history dead from the day that Vasco da Gama set foot on Indian soil.

Of course, Habib's perspectives are informed by very much more than post-colonial angst. Rather, they reflect, on the one side, a proper respect for the northern origins and connections of 'Mughal' state and society; and, on the other, a Marxist interest in the possibilities of the future. Thus he takes the influence of the Persian wheel and Persian loom on the economy as more significant than anything brought by sea from east or west. Thus, too, he is principally concerned with the 'potentialities for capitalistic development' to be found in the Mughal era. However, both of these perspectives lead him to negative conclusions. On the one side, he sees the Mughal Empire as a revenue-hungry machine, sucking up most of the available surplus to feed the greed of an aristocratic nobility. Commercialisation here is 'forced' on peasants and artisans, who gain very little from it. And, on the other side, whatever productive 'developments' may have been facilitated by this commercialisation (and he has never denied that there were some), they did not lead to capitalist industrialization - and thus represented a cul-de-sac. As a result, the overall impression which he offers of the 'early modern' Indian economy is one of stagnation: where very little changes for the better and, certainly during the eighteenth century, a great deal for the worse. ${ }^{8}$

In recent years, Habib's once-canonical interpretation has come to be questioned from many different angles and sources. The model of unilinear (and immanently universal) capitalist industrialization, by which he judges India's relative 'failure', no longer commands the status which once it did. Britain's industrial revolution would now be seen as something historically unique rather than as a general standard against which the rest of the world's economic history ought to be evaluated - and inevitably found wanting. Also, the causes of that revolution (even if it was a 'revolution') are now much at issue, making it harder to decide what may (or may not) have been significantly 'missing' in India's case. ${ }^{9}$ The corollary to not being Britain need not necessarily be written off as 'stagnant'.

${ }^{8}$ Irfan Habib, "Potentialities of Capitalistic Development in the Economy of Mughal India", Journal of Economic History, 29, 1 (1969), pp. 32-78; Id., "The Technology and Economy of Mughal India”, Indian Economic and Social History Review, 17, 1 (1980), pp. 1-34; Id., The Agrarian System of Mughal India, 1556-1707 (Bombay: Asia, 1963).

9 David Washbrook, "The British Empire and the Indian Economy", in N. Gooptu and D. M. Peers (eds.), The Oxford History of the British Empire: India (Oxford: Oxford University Press, forthcoming). 
Equally, the idea of an 'over-determining' Mughal (Oriental Despotic) state has come under serious challenge. More attention in recent years has been paid to its intermediary levels (Rajput clans, zemindars, mercantile mahajan, etc.), which would seem to have enjoyed a high measure of autonomy. According to Alam and Subrahmanyam, it was here, particularly, that the impact of deepening commercialisation might be seen - in expanding pockets of high farming and artisanal production, in trading profits which did not only line the pockets of the aristocracy and in the buying and selling of taxation (i.e. property) 'rights. ${ }^{10}$ Following John Richards, it would now seem possible to argue that, at least during the sixteenth and seventeenth centuries, the Indian economy enjoyed a long period of relative prosperity and growth. ${ }^{11}$ Moreover, as Guha and Desai have suggested, population levels may not have been as stagnant as Habib supposed ('fixed' at c. 140-160 million after 1600), but increased from c. 95 million in 1500 to perhaps 160 million by the end of the eighteenth century. In pre-modern terms, population growth of 70 percent, even over three centuries, is not to be regarded as negligible. ${ }^{12}$

Admittedly, during the eighteenth century, some of these 'advances' may have had problematic consequences and have reached awkward conclusions. The increasing wealth and prosperity of those occupying the intermediary levels of the Mughal Empire led to political challenges to central authority, especially in the maritime regions, which eventually broke its power - giving rise to attempts to construct new regional states in a context of escalating warfare. ${ }^{13}$ In its turn, these regional states fell dependent on the European powers controlling their flows of trade and specie. India's commercial revolution of the sixteenth and seventeenth centuries ended in colonial conquest in the eighteenth in circumstances which scarcely bespeak of economic growth. Severe

${ }^{10}$ Muzaffar Alam and Sanjay Subrahmanyam (eds.), The Mughal State 1526-1750 (Delhi: Oxford University Press, 1998).

${ }^{11}$ John F. Richards, The New Cambridge History of India; Vol. 1, Part 5. The Mughal Empire (Cambridge: Cambridge University Press, 1993).

${ }_{12}$ Ashok V. Desai, "Population and Standards of Living in Akbar's Time", Indian Economic and Social History Review, 9, 1 (1972), pp. 43-62; and Id., "Population and Standards of Living in Akbar's Time: A Second Look", Indian Economic and Social History Review, 15, 1 (1978), pp. 1-19; Sumit Guha, Health and Population in India: From the Earliest Times to the Present (London: Hurst, 2001).

${ }^{13}$ Frank Perlin, "Of White Whale and Countrymen in the 18th Century Maratha Deccan", Journal of Peasant Studies, 5, 2 (1978), pp. 172-237; Muzaffar Alam, The Crisis of Empire in Mughal North India, 1707-48 (Delhi: Oxford University Press, 1986). 
disruptions due to warfare and famine swept many parts of the country, especially in the second half of the century, and Guha may well be right that population growth was not only checked, but fell back - before picking up again at the turn of the nineteenth century. ${ }^{14}$ Christopher Bayly is 'over-read' if he is taken to be saying more than that eighteenthcentury 'decline' in north India was not as severe as once supposed, and that pockets of high production survived and re-constituted themselves - rather than that 'decline' did not happen at all. ${ }^{15}$

However, problems at the end of a period are no reason for ignoring or downplaying what may have gone on in its earlier phases. The economy(-ies) of India did experience growth and expansion in the early modern era and it largely remains to be explained how this took place and what impact it made on the relations of production, consumption and social reproduction. Indeed, this side of the issue appears almost entirely unexplored. With the exception of Om Prakash's work on Bengal, we have little idea what increases in productive capacity may have followed from the expansion of trade - and Prakash only concentrates on Dutch and English trade, which were but part of the 'global' whole. Nonetheless, Prakash's statistics suggest that the question may have huge dimensions. He notes that, at one point in the late seventeenth century, 11 percent of the labour force of Bengal may have been working for the English and Dutch alone and, from the midseventeenth to early eighteenth centuries, foreign trade may have been responsible for a 40 percent growth in the region's economy. ${ }^{16}$ If trade with other 'factors' is taken into account (including that for inland markets, which Sushil Chaudhury holds to have been greater than that with Europeans), the scale of Bengal's commercial economy becomes truly remarkable. It helps to explain why Adam Smith should have placed Bengal alongside Britain as a 'commercial society' at the highest level in his stadial theory of civilization. Admittedly, even by the later seventeenth century, Bengal had become by far India's largest single manufacturing centre and entrepot for world trade. No other region could match its scale. But several others tried and commercial production also played a very major role in the economies of Coromandel and Gujarat/Maharashtra, as well as being dispersed through many points

\footnotetext{
14 Guha, Health and Population.

15 C. A. Bayly, Rulers, Townsmen and Bazaars: North India Society in the Age of British Expansion, 1770-1870 (Cambridge: Cambridge University Press, 1983).

16 Prakash, Dutch East India Company.
} 
in hinterland north India. ${ }^{17}$ Statistical information on these other regions is less available, or at least has been less worked through, but we can surmise that commerce was highly influential on their production regimes.

But how was it accommodated to those regimes? Here, more ghosts from past historiographies may stand in the way of finding answers. The idea of the self-sufficient 'village community' articulated by nonmonetary jajmani relations has proved very difficult to dispel. Any commercial relations which its members entered into (i.e. production for exchange) must be seen as 'forced' upon the 'village', principally by the taxation system, but also by moneylenders. Otherwise, it could have no use for 'the market' and monetary exchange. In this context, commercial production has sometimes been seen as grafted onto the village economy at the side; or else as reflecting principles of dualism in which peasants and artisans devoted part of their time to it (to pay dues and taxes) and part to feeding themselves or servicing their jajman. The two spheres existed side-by-side and did not impinge on each other. Chicherov conceived the village economy of sixteenth-century south India very much in this way: especially with weavers working part-time for commercial agents. ${ }^{18}$

However, intellectual history has not been kind to the concept of 'the village community' which, certainly so far as self-subsistence is concerned, may largely have been a colonial invention: born of Europe's recovery of its medieval past, bred to support imperialist theories of evolution and raised, certainly in the Indian context, to serve a very specific purpose. ${ }^{19}$ The idea of village self-sufficiency enabled British neo-Ricardian taxation theorists to claim the right to extract all village 'surplus' in revenue without theoretically damaging the village's ability to 'satisfice' and reproduce itself. ${ }^{20}$ That Indian nationalists (specifically Gandhi) then took the idea on and romanticised it - to provide a model of 'indigeneity', free from all external influence - hardly makes it any more useful an analytical tool.

\footnotetext{
${ }^{17}$ Subrahmanyam, Political Economy.

18 A. I. Chicherov, India: Economic Development in the 16th-18th Centuries (Moscow: Moscow Publishing House, 1971).

${ }^{19}$ Clive Dewey, "Images of the Village Community: A Study in Anglo-Indian Ideology", Modern Asian Studies, 6, 3 (1972), pp. 291-328.

${ }^{20}$ Eric Stokes, The English Utilitarian and India (Oxford: Clarendon Press, 1959).
} 
It is not necessary to look very hard at the shape of the early modern Indian economy (certainly in the maritime regions) to appreciate that it cannot just have been the product of the marginal expansion of a series of subsistence-oriented village economies. Specialisation in many areas was highly marked. ${ }^{21}$ The finest textiles were woven in villages largely consisting of artisans (and sometimes assorted washers, painters and even spinners) who did very little else. The cotton they wove was brought to them from hundreds, sometimes thousands, of miles away - in Bengal's case, even from Gujarat on the other side of the sub-continent. Not infrequently, the food that they ate had made a similarly long journey - in the case of central Coromandel, sometimes from Bengal. ${ }^{22}$ These extensive transactions were made possible by the development of a vast transport infrastructure - of boats around the coastline (and, in Bengal, up the rivers) and of banjara cattle caravans inland - whose very existence is difficult to reconcile with notions of self-subsisting villages.

Nor were extended relations of exchange confined just to artisanal villages and the major commercial centres. They reached into the heart of the 'village' itself. By far the largest capital item in farming was cattle. But cattle did not breed in the lowland deltas which had the richest agricultural land. They had to be brought in from upland areas and were sold to local farmers. Equally, salt represents one of the most essential and basic items of diet, especially in tropical climates. However, it was produced mostly in specific coastal areas and traded throughout the hinterland. Similarly, iron, hardwoods (for the better sorts of village housing), refined textiles (silks) and various foodstuffs (not least areca nut for key ceremonials) were obtainable in most parts of the country only through trade. ${ }^{23}$ This was hardly an economy which had to be 'forced' into relations of exchange: it was to a large extent reproduced through them. But we know precious little about how those relations of exchange not immediately involved in the export trades were organised; nor how they related to the export economy; nor how they affected relations of production.

${ }^{21}$ Frank Perlin, "Proto-Industrialization and Pre-Colonial South Asia", Past and Present, 98 (1983), pp. 30-95.

${ }^{22}$ Prakash, Dutch East India Company; Subrahmanyam, "Rural Industry”; Josepth J. Brennig, "Textile Producers and Production in Late Seventeenth Century Coromandel", Indian Economic and Social History Review, 23, 4 (1986), pp. 333-55.

${ }^{23}$ Chaudhuri, Trade and Civilisation; Sanjay Subrahmanyam (ed.), Merchants, Markets and the State in Early Modern India. (Delhi: Oxford University Press, 1990). 
This, in turn, makes it very difficult to understand the wider impact made by the intensification of commercialisation from the sixteenth century. Did it slip into pre-existing 'non-market' channels of exchange or did it cut new channels, shaping new kinds of relationships? Did it rely on established institutions for its regulation and security or did it forge new ones? Did it open out new possibilities for economic growth or was it constrained by old ones? Perhaps most centrally, how did an economy apparently structured around rigid principles (of caste, kinship, fixed residence) accommodate itself to expanding volumes of commercial production? What follows is an attempt to sketch a few answers for southern India.

\section{South India}

For most of the early modern period, southern India lay outside the boundaries of the Mughal Empire. This makes its experience somewhat atypical of the rest of India - but, in several respects, perhaps usefully so. Its history was not 'over-determined' by the institutions of the Empire; nor recovery of that history dominated by vast caches of imperial documentation. This makes it possible to examine more locallevel institutions and relations, relevant to the economy, which elsewhere seem to be smothered by Mughal experience, both in fact and in archival resources. It also makes it possible to ask questions about the significance of the Mughal experience for the development of commerce and trade since the South possessed few of the structural attributes associated with Mughal rule. For example, it never accepted Akbar's silver rupee but remained, essentially, on a gold standard symbolised by the 'pagoda. However, as it never standardised minting, its currency system may better be seen as based on bullion exchange where, in fact, it also made use of silver and copper. Also, its taxation systems were not so dominated by demands for land revenue. While Burton Stein may have gone too far in supposing that land revenue was insignificant - especially in the rice-producing river valleys where it remained collected in kind - it does seem clear that taxes on commerce played a more prominent role in the finances of its states, such as they were. $^{24}$ These states were predominantly small 'Nayak' or 'Sultanate'

${ }^{24}$ Burton Stein, The New Cambridge History of India; Vol. 1.II. Vijayanagara (Cambridge: Cambridge University press, 1989). 
principalities - the Vijayanagar Empire, which in any event 'fell' in 1565 , being more in the nature of an overlordship than a centralised, bureaucratic regime. Lack of an 'imperial' state also may be seen to have impacted on issues of infrastructure. By repute, there were no metalled roads in the south and hence very little in the way of wheeled transport. There were also no inter-riverine canals and most of the rivers were not navigable far into their reaches. ${ }^{25}$

All this might seem to make the south an unpropitious area for the development of a globally-significant commerce. However, this was not the case. Coromandel textiles and Malabar spices were known in the Roman world and to Sung and Ming China. Both played a crucial role in Indian Ocean trade throughout the medieval period and were the focus of attraction for the first European traders at the turn of the sixteenth century. ${ }^{26}$ Lack of land-transport infrastructure may have been overcome by the extensive use of coastal shipping around the peninsula (none of which is very far from the sea) and, on the eastern side, by a broad coastal plain which is relatively easy for pack bullocks to traverse. ${ }^{27}$ Pack-bullock caravans driven by lambadis (the southern equivalent of banjaras) were the ubiquitous means of land transport bringing raw cotton, dry grains, iron and rough cloth from the interior to the coast and taking back salt, rice and fine cloth.

Vijaya Ramaswamy has argued that the principal centres of fine textile production in the medieval period lay in the environs of the major temples, which also would seem to have provided regulatory mechanisms (arbitration, 'licensing', etc.) over the trade. ${ }^{28}$ Here, as in many other areas, the temples supplemented or stood in for 'the state' in the organisation of society. Temples played a key role in validating property rights (usually defined in terms of discrete 'shares' in community assets). They were also engines of trade and investment, re-cycling 'donations' into irrigation works and cattle herds 'shared' among the donors. Indeed, their ritual forms patterned most species of economic transaction. ${ }^{29}$ While evidence of effective land 'sales' (i.e. sale of 'share

25 Jean Deloche, Transport and Communications in India prior to Steam Locomotion. (Delhi: Oxford University Press, 1993).

${ }^{26}$ Kenneth Hall, Maritime Diasporas in the Indian Ocean and East and South-East Asia (Leiden: E.J. Brill, 2006).

${ }_{27}$ Subrahmanyam, Political Economy.

28 Vijaya Ramaswamy, Textiles and Weavers in Medieval South India. (Delhi: Oxford University Press, 1985).

${ }^{29}$ Burton Stein, Peasant State and Society in Medieval South India (Delhi: Oxford University Press, 1980). 
rights' to land) dates back to the eleventh century, technically they took the form of 'gifts' of land to a god, who then 'gifted' them to a third party in return for a 'donation' of money - which, in turn, was then 'gifted' to the first party. The gods stood at the centre of life in south India in every sense and their presence is an obvious reminder that 'exchange' can be driven by a logic, and depend on institutional arrangements, quite other than that supplied by 'the market'. Early commercialisation here penetrated a set of institutions established to supply the needs of communities of local worshippers and, for a very long time, remained dependent on them.

However, as Ramaswamy argues, the explosion of commercial activity taking place from the sixteenth century may well have begun to put a strain on these institutions. The most visible sign of this was the progressive shift of 'fine' textile production away from the environs (and protection) of the temples and towards the coastal settlements of the merchant traders - not only European but also Hindu and Muslim (Chulia or Marrakayar merchants, who commanded south-east Asian and some Gulf trade, were at least as important as Europeans into the eighteenth century). Certainly, by the later seventeenth century, it was the coastal settlements which dominated fine cotton textile production (if not necessarily silk) - opening out questions about the 'new' organisation and regulation of the trade. ${ }^{30}$ However, from what can be made of their records, the Europeans were not eager to take on these responsibilities. Although endlessly 'petitioned' to arbitrate disputes and settle trade boundaries, they prevaricated: appealing to traditions of a state (which here did not exist) or to a religion which they misunderstood. The result may be seen as something of a 'bastardisation' of custom, which made the socio-political relations of the weaving settlements notoriously unstable. On the one hand, principles of caste hardened their edges - eschewing forms of hierarchical integration supervised by the temple to become more openly competitive. On the other, the traditional division between castes of the Left and Right Hand became swept up - as Arjun Appadurai has seen - into the struggle for market place between different merchant groups. ${ }^{31}$ Weaving villages could become extremely turbulent places: which, later in the eighteenth

\footnotetext{
${ }^{30}$ Brennig, "Textile Producers".

31 Arjun Appadurai, "Right and Left Hand castes in South India", Indian Economic and Social History Review, 11, 2-3 (1974), pp. 183-215. See also Niels Brimnes, Constructing the Colonial Encounter (Richmond: Curzon Press, 1999).
} 
century, the Europeans (especially the English) would use as an excuse to try to enforce control over production.

The shift towards new coastal settlements and forms of organisation also raised other issues. One concerned means of expanding production in an industry which was, if anything, becoming more caste-bound and rigid. The volume of demand increased rapidly and various expedients were tried to meet it. Looms were worked by more than one family across twenty-four hour periods. Possibilities of 'adoption' meant that discrete caste groups could increase their numbers faster than by biological reproduction. In some extreme cases, paraiyans were drafted in at night to produce secondary rough cloths on the looms used by 'clean' caste weavers in the day - this latter necessitating purification rituals before day-work could begin and Komati cloth merchants wearing special gloves to touch 'paraiyan' cloth. ${ }^{32}$ As ever in India, expedients could be found to overcome structural difficulties. But the strains were unmistakable - and merchants, faced with ships to load before the winds changed, were long and vociferous in their complaints. One consequence was that, through much of this period, there was intense competition for skilled labour between different settlements and merchant groups - and labour moved regularly to where it was most wanted or better paid. Telugu-, Kannada- and Tamil-speaking weavers shifted through and across each other's territories, leaving their distinctive marks behind them. But competitively-driven movement did not come without costs: from the mid-seventeenth century, there is a strong case that the price of Coromandel cloth was tending to rise. ${ }^{33}$

The second set of issues raised by the expansion of the Coromandel textile industry concerns its supplies of both food and raw materials. Most of the major south Indian temples (certainly those which had large attached weaving industries) were in zones of 'mixed' (dry/wet) agriculture near to supplies of both rice and cotton. These zones experienced very considerable agricultural growth in the late medieval period, particularly in response to the urbanisation process associated with the temple towns. Cotton production on 'dry' soils especially

${ }^{32}$ David Washbrook, "Land and Labour in South India: the Golden Age of the Pariah?", in Peter Robb (ed.), Dalit Movements and the Meanings of Labous in India (Delhi: Oxford University Press, 1993), pp. 68-86.

${ }_{33}$ K. N. Chaudhuri, The Trading World of Asia and the English East India Company (Cambridge: Cambridge University Press, 1976); Prasannan Parthasarathi, The Transition to a Colonial Economy: Weavers, Merchants and Kings in South India 17201800 (Cambridge: Cambridge University Press, 2001). 
increased - driven by the spread of Telugu specialist cotton farmers throughout the south. Indeed, it was these mixed-zone farming regions which also gained from early commercial contacts with the Portuguese. They benefited most from the 'American' crops introduced at this time, which spread rapidly through the southern hinterland. Tobacco, chilli, tomato, papaya transformed southern dietary habits. They also contributed to commercialisation where - especially in Andhra - chilli and tobacco became major cash crops. ${ }^{34}$

However, the shift of the weaving industry towards the coasts cut across these developments. For the most part, it meant that textile production centres became far removed from the regions in the hinterland producing raw cotton. This, in turn, necessitated a substantial increase in lambadi traffic to make the connection - which may have had certain beneficial effects. The lambadis off-loaded raw cotton as they passed through the rice-growing river valleys and picked up spun-yarn along the way. They helped to spread cotton-spinning through the agrarian economies even of regions which did not produce the raw material, making spinning a ubiquitous by-employment which was useful in supplementing agricultural earnings. But there were also problematic consequences. ${ }^{35}$ Textile production became more dependent on extended transport routes, which were at risk of disruption; it also became dependent on market factors which were anything but reliable. Agriculturists tended to spin when agricultural work was low. There was a tendency, therefore, for thread to become short in supply when harvests were good and food cheap and plentiful; and, conversely, for thread to become cheap and plentiful when harvests were bad and food prices high. This made it difficult to co-ordinate and sustain production schedules. Also, this agrarian-industrial cycle did not necessarily coincide with the shifting wind patterns enabling ships to sail in and out of harbours. ${ }^{36}$

The second - and what could be an acute - problem came from security of food supplies. This was relatively easily handled in the weaving centres which backed onto rice-producing river deltas - classically, the Kaveri in the south and the Godaveri in the north. But elsewhere, there were perennial problems of food supply. These were especially

\footnotetext{
${ }^{34}$ Subrahmanyam, Political Economy.

${ }^{35}$ Brennig, "Textile Producers".

36 Sinnappah Arasaratnam, Merchants, Companies and Commerce on the Coromandel Coast, 1650-1740 (Delhi: Oxford University Press, 1986).
} 
acute in central Coromandel around the English centre of Madras. By the early eighteenth century, the English regularly had to import 15-20,000 tons of rice a year, mostly from Bengal. Indeed, the need for food proved a strong imperative for further and deeper commercialisation. As Tsukasa Mizushima has seen, the entire agricultural hinterland of Madras became devoted to supplying its markets with food (especially rice) and, at least by the mid-eighteenth century, priceconsciousness deeply informed agricultural strategies. ${ }^{37}$ This extended even into the 'lower reaches' of agrarian society. Lambadi caravans brought dry grains from the interior, which were the preferred foods of paraiyans and low castes. The latter, who were mostly paid in 'shares' of the harvest, would sell their paddy to buy ragi and cholum - deepening the grip of the price mechanism over the economy. ${ }^{38}$

Nonetheless and in spite of these efforts, food insecurity remained a major difficulty for all those weaving centres not adjacent to stable sources of supply, which was most of them. The spectre of famine was a constant threat and it became noticeably more acute in the eighteenth century - when, for example, major famines hit central Coromandel in 1718-19, 1728-36, 1747, 1769, 1781-83, 1789, 1792 and $1798 .^{39}$ These even precipitated something of a move back into the hinterland - towards the upper Kaveri 'Sultanate' created around Mysore by Hyder Ali and Tipu Sultan. For a time 'Salem blues' became the favoured cloth of textile exporters. But by then, the best days of the southern weaving industry were already gone. From the lateseventeenth century, the Europeans at least had begun to turn their attention north towards Bengal where food was cheaper (and its security greater) and where caste was less an issue in the organisation of society. The south's initial and strong response to the new forces of commercialisation in the end somewhat petered out - in rising prices, declining foreign markets and bitter experiences of famine. Of course, a weaving industry certainly carried on into the early nineteenth century. But even by the 1730s, it was becoming a shadow of its former self.

\footnotetext{
37 Tsukasa Mizushima, Nattar and Socio-Economic Change in South India in 18th and 19th Centuries (Tokyo: Tokyo University Press, 1986).

${ }^{38}$ Washbrook, "Land and Labour".

39 Ravi Ahuja, "Labour Relations in an early Colonial Context: Madras c. 1750-1800", Modern Asian Studies, 36, 4 (2002), pp. 793-826.
} 


\section{Conclusion}

What conclusions might be drawn from this (all too) brief inquiry into the relationship of the southern textile industry to its wider economy? A first set of questions, perhaps, concerns the character of commercialisation. Was it 'forced' or was it 'induced'? The absence of pressures from a Mughal-style revenue system make it very difficult to see that it can have been forced. Southern peasants and artisans had long been involved in an exchange economy, albeit one which was not entirely 'market' based. Increasing flows of specie slipped into this system, progressively expanding but, before the later eighteenth century, not institutionally transforming it. Weavers had long worked simultaneously for money and for the gods and, at least in form, continued initially to do so - their 'donations' to temples indicating their cultural orientations.

However, there is a puzzling feature in their eventual drift away from temple centres and towards the coasts. There cannot be much doubt that they did so in order to earn increased cash wages from merchants and companies becoming frenzied in their competition for scarce skilled labour. But what did money mean in an economy where the market had only a limited remit? One possibility is that it meant 'freedom', both economically and socially. In the coastal settlements, strong opportunities for accumulation arose with certain weavers able to acquire several looms and become 'heads' in negotiations with merchants, if not merchant-entrepreneurs themselves. Also, as the turbulence of caste relations indicates, opportunities existed to challenge social hierarchies, more firmly-fixed in the ancient temple towns. But a second, and perhaps more plausible explanation is - ironically - that money represented a passport to greater security. Indian economic history may not have given full due to the chronic instabilities of monsoon agriculture in a late medieval/early modern context marked by lack of control of river floods and of adequate water-storage facilities. In the south, local variations in annual production levels could be very high: in villages on the Krishna river system in the 1780s, for example, they could be of the order to 70 percent in the same village. Local societies coped with this, in part, by being highly mobile - with labour and capital 'chasing' water supplies. ${ }^{40}$ But also, they coped with it by developing

40 David Washbrook, "India in the Early Modern World Economy", Journal of Global History, 2, 1 (2007), pp. 87-112. 
extended exchange economies - so that supplies could be brought to drought areas from those enjoying 'plenty'. In the south, monetary relations, which facilitated exchange, were noticeably more highly developed in the 'dry' areas of cultivation - associated with the highest risks - than the more secure 'wet' areas ${ }^{41}$ Money here, then, was meant to buy security: a chance to buy in, not least, to the thousands of tons of grain shipped to places like Madras in times of trouble. Commercial and subsistence-orientations were not necessarily juxtaposed in this context - and India's notorious propensity to 'hoard' bullion, in part, may have reflected an attempt to develop insurance mechanisms.

Ultimately, the south's insurance mechanisms did not work too well. What seem to have been expansionary sixteenth and seventeenth centuries gave way to a distinctly unfortunate eighteenth century. If failure to secure food supplies was one cause of this, attention needs to be paid to the links between 'industrial' wealth and agricultural investment, which may have been weak (in spite of efforts to improve them around weaving and urban areas). In Mizushima's Chingleput, for example, while some merchant-entrepreneurs bought share-rights and privileges in some villages, the agricultural context was by no means transformed. ${ }^{42}$ Most land continued to lie in the hands of near-rentier 'mirasidars' who invested little in the expansion of a production, which plainly did not keep pace with demand. The interface between the 'industrial' and agricultural economies remained far from smooth.

But could it have been that the sheer scale on which exchange relations now became extended made them increasingly vulnerable to risks and escalating transaction costs? South Indian weavers were at the centre of - and therefore dependent on - networks stretching from markets in south-east Asia, the Gulf and Europe to deltaic rice-producing villages and upland cotton-producing villages; and also on a vast transport infrastructure linking them together. Problems at any point in this extended chain could have serious repercussions - and problems certainly began to arise from the later seventeenth century. Sanjay Subrahmanyam has been inclined to date the beginning of the decline of the southern textile industry from the 1680s when the 'Persian' merchants who ran a major trade to the Gulf out of Masulipatam cut their purchases and began to move out. ${ }^{43}$ They did so partly in response to

\footnotetext{
41 Washbrook, "Land and Labour".

42 Mizushima, Nattar.

43 Subrahmanyam, Political Economy.
} 
a sharp decline in their Gulf market; and partly in response to Aurangzeb's invasion of Golconda - which itself unleashed a cycle of instability and warfare across the south, which lasted for most of the next century.

Instabilities in foreign markets became increasingly chronic - with Dutch 'interference' squeezing the trade to south-east Asia and then tariff barriers going up in Europe. Domestically, post-Aurangzeb succession wars spread across the south, which could severely disrupt trade. Yarn and cloth were prized items of 'loot', lambadis were commandeered to move armies rather than cotton and grain, delicate irrigation systems were broken down by shifting political authority. If the records of the Maratha regime in Thanjavur can be believed, paddy production levels in the Kaveri delta (the south's great rice bowl) fell by 25 percent between 1720 and 1740 and by 25 percent again between 1740 and 1782 - when Hyder Ali's deliberately destructive invasion broke up the residual irrigation works. ${ }^{44}$ The cause of the longer-term problem appears to have been silting up of the Grand Anicut and the point of erstwhile division of the Kaveri and Coleroon at Tiruchirapalle, which was being besieged and exchanged between would-be potentates on a regular basis for almost half-a-century. The textile industry attempted to cope with all this as best it could - particularly, by becoming even more mobile. The principal weaving centres moved from north to central Coromandel, then inland, then farther south - wherever food and relative security were available. ${ }^{45}$ But prospects of expansion gave way more to the search for sheer survival. The extended exchange relations on which the industry depended made it highly vulnerable to changing political circumstances within India as much as without.

But could the effects of this, in some way, have been avoided or mitigated? As Karl Marx once put it, albeit in relation to the sensibilities of another age: "A nation and a woman are not forgiven for allowing the first available adventurer to violate them" ${ }^{46}$ Given its dependence on extended exchange relations, the southern textile industry appears extraordinarily exposed to 'violation'. As noted earlier, there is little

\footnotetext{
${ }^{44}$ Kathleen Gough, Rural Society in South-east India (Cambridge: Cambridge University Press, 1981).

${ }^{45}$ David Washbrook, "South India 1770-1840: The Colonial Transition", Modern Asian Studies, 38, 3 (2004), pp. 479-516.

${ }^{46}$ Karl Marx, 18th Brumaire of Louis Bonaparte (London, 1852).
} 
sign that its institutional relations had been transformed by the experience of 'advanced' commercialisation. Also, dependent on sea-borne commerce, it is striking that none of its political powers (apart from a few small rajas on the west coast) should have sought to develop a navy and to contest a sea-power that fell easily into the hands of 'foreign' Europeans - who had little interest in using it for the benefit of southern society per se. ${ }^{47}$ It is equally striking that its relations of property and wealth should have continued to be expressed in the traditional terms of 'share rights' and temple endowments - albeit now in increasingly bastardised form. Eighteenth-century south India bears strict comparison to ancien régime France in that everything was for sale and offices, powers and honours were procured by people in ways which made nonsense of their derivation and supposed social meaning. An Idayan shepherd, such as the dubash to the French East India Company, Ananda Ranga Pillai, could 'buy' local chiefship rights in villages adjacent to Madras and even a mansabdarship in the Mughal Empire $^{48}$; Christian and Muslims could buy land rights in villages dedicated to local gods, whom they then had to propitiate at regular festivals; low castes and even paraiyans could buy kaniachi privileges alongside the upper castes. ${ }^{49}$

The consequence of this institutional continuity was that no effort was made to build new state and economic institutions, which might respond better to the circumstances of the times and provide greater security and stability to the economy - or almost no effort. There was the extremely valiant effort of Hyder Ali and Tipu Sultan to build a major commercial state centred inland on Mysore. This involved, once more, reconnecting the textile industry to 'protectable' supplies of food and cotton: by developing the headwaters of the Kaveri for grain production, while simultaneously drawing in weavers from across the south to centres close to cotton fields. Hyder even saw the necessity of naval power and developed plans to build a fleet, and his own fortified port at Mangalore..$^{50}$ But he and Tipu were eventually undone not only by the power of the English, but also by the reaction of all their neighbours (Hyderabad, Travancore and the Marathas), who feared such an

\footnotetext{
47 Sanjay Subrahmanyam, Improvising Empire (Delhi: Oxford University Press, 1990).

48 Washbrook, "South India".

49 Ibid.

${ }^{50}$ Ibid.
} 
expansionary state on their doorsteps and ganged up with the English to bring Mysore to defeat. There was a serious lack of vision and understanding of the new times brought by extended commercialisation to south India, which, with the fall of Tipu, left the future in European hands.

And something of a limited future it proved to be for the southern textile industry. With the rise of the British Industrial Revolution, longstanding overseas markets were lost. ${ }^{51}$ The English were interested more in their own profits than the necessary development of the local economy and, as Prasannan Parthasarathi has seen, resorted to force and monopoly to reduce the residual industry to their needs - eliminating competition, lowering wages, controlling production schedules. ${ }^{52}$ As their political power spread across the south, they also cut off possibilities of the mobility, which once had been the response of weavers to hardship and oppression. There was a long period of dislocation into the middle of the nineteenth century, which, if not entirely marked by de-industrialization, saw trade stagnate and profitability reduced to very low levels..$^{53}$

Admittedly, in the second half of the nineteenth century, there was a revival in southern textile production. As Pax Britannica re-secured internal trade routes and new overseas opportunities opened out, weaving became expansionary once again. It was also helped by the increasing availability of industrially-spun thread (much of it imported) and of new technologies (such as the flying shuttle), which reduced costs of production. ${ }^{54}$ However, the arrival of industrially-spun thread meant the decline of hand-spinning and the possibility of valuable supplements to agricultural earnings. ${ }^{55}$ As this was further accompanied by declining opportunities for physical mobility, in the face of economic adversity, it may be no surprise that the last decades of the nineteenth century were also accompanied by deepening threats of famine.

${ }^{51}$ K. N. Chaudhuri, The Economic Development of India under the East India Company 1814-58. (Cambridge: Cambridge University Press, 1971).

${ }_{52}$ Parthasarathi, Transition.

53 A. Sarada Raju, Economic Conditions in the Madras Presidency 1800-50 (Madras: University of Madras, 1941).

${ }^{54}$ C. J. Baker, An Indian Rural Economy 1880-1955 (Oxford: Clarendon Press, 1984).

${ }^{55}$ Parthasarathi, Transition to a Colonial Economy. 
The southern textile industry lived something of a shadow existence for much of the colonial period: never wholly eliminated but not playing the same key role in the economy, which it had done before the nineteenth century. It was only with the emergence of locally-based industrial thread-spinning, mostly from the 1920s, that it was put back in a position to flourish - which it began to do noticeably from the 1940 s with the addition of industrial weaving. ${ }^{56}$ It took the new technologies, food securities and opportunities created by national market integration, which were characteristic of the twentieth century, to put the southern textile industry back into the position of local economic pre-eminence, which it had enjoyed two centuries earlier.

\footnotetext{
${ }^{56}$ Baker, Rural Economy.
} 
$-978-90-47-42997-5$ 


\title{
FOUR CENTURIES OF DECLINE? UNDERSTANDING THE CHANGING STRUCTURE OF THE SOUTH INDIAN TEXTILE INDUSTRY ${ }^{1}$
}

\author{
Ian C. Wendt
}

The textile industry occupies a central position in the social and economic history of modern South Asia. Few historical themes are viewed with as much simultaneous excitement and pessimism as the textile industry in India. Generations of historians have been at pains to argue both that the textile industry in South Asia made major contributions to the world economy and that it suffered massive decline in the face of European corporate and colonial exploitation. The central protagonists of this history have been hand-loom weavers and cloth merchants. Their productivity and profits are celebrated, and their retrenchment in the face of colonialism and foreign competition are examined as archetypes for the colonized, de-industrialized nation. The story of the former success and later decline of the textile industry thus forms an important part of a broad 'declensionist' South Asian historical narrative.

This narrative, however, misses several crucial points. First, the argument can be made that India has experienced greater continuity of hand-loom cloth production and commerce than any other region in Asia. Indian weavers continued to participate in the 'mixed' mechanized textile industry through the nineteenth and into the twentieth and twenty-first centuries. Mixed industrialization in India resulted in small and middle sized workshops and factories that contained combinations of hand looms and power looms. Secondly, by focusing largely on professional artisans like weavers, merchants and dyers, historians have failed to see the major transitions and disruptions experienced by spinners, cotton cleaners, and other agrarian labourers, who constituted the

\footnotetext{
${ }^{1} \mathrm{I}$ am indebted to the participants in the GEHN Conference in Padua for valuable feedback on this paper. In particular, I thank Prasannan Parthasarathi, Om Prakash, Ulrich Pfister, Masayuki Tanimoto, Kaoru Sugihara and Maureen Mazzaoui.
} 
bulk of the textile industry's workforce. While weavers and merchants experienced remarkable continuity from the early modern period through the nineteenth century, spinners and cotton cleaners were replaced by machines. This transition radically altered the structure of the textile industry as a whole, with broad implications for the South Asian economy.

This paper begins by outlining the modern transitions in the textile industry across South Asia, noting the major themes of historical analysis and debate about its decline. The second section examines recurring themes in the historiography of decline in the specific region of South India. The third section examines the structure of the South Indian textile industry, from commercial agriculture, to spinning, weaving, finishing, and commerce. The paper thus analyses the nineteenth-century structural changes of the textile industry brought about by industrialization. This analysis reframes the story of industrialization and de-industrialization, with attention to continuity, change and survival.

\section{Textile Industry in Modern South Asia}

The first key element in the historical narrative of the Indian textile industry is that the subcontinent was formerly a rich, highly-specialized, differentiated producer and exporter of numerous manufactures, especially cloth. The second element of this narrative is that India's textile industry declined, both in economic and social terms, with regard to the independence, and agency of its artisan and merchant communities. But what caused such a decline? The two key forces at play are deemed to be respectively Western economic and political exploitation - particularly British colonialism - and internal social structures and technological stagnation. The nationalist narrative expressed this story nearly a century ago. Even with revisions that roundly criticize the nation as well as the colonial state, the narrative remains fundamentally unaltered.

While there is general agreement that the textile industry declined, there is some debate among historians about the nature of this decline, its chronologies, and ultimate causes. Was it the late eighteenth or nineteenth century or later? Was the decline absolute or only relative to the broader economy? And did it affect all sectors of the economy or all regions of the subcontinent in the same way? The most wellknown argument posits that de-industrialization resulted from the combined effects of colonial tax policies, imperial malice or ineptitude, 
machine-made cloth imports, maritime market replacement, and the unwillingness or inability of a conservative caste society to adapt to changing conditions. The argument concludes that this brought about large-scale agrarianization and the impoverishment of artisan producers.

The vicissitudes of the textile industry across South Asia present significant regional and temporal variations. The early modern period is usually described in very positive terms. Between 1500 and 1750 South Asian textile production and exports clothed a substantial portion of the world's population. In this period, large textile manufacturing and trading regions such as Gujarat, South India and Bengal produced and exported cloths for consumers from around the world. Indeed South Asia's maritime markets, which in the medieval period included the entire Indian Ocean, expanded in the sixteenth and seventeenth centuries to incorporate parts of East Asia, the Atlantic, and Europe. The most prominent debate among historians is over the relative strength of indigenous versus foreign factors in commerce and industry, particularly the relationships between European and Indian merchants. ${ }^{2}$

Significant debate has focused on the relative economic, political and social vitality of the eighteenth century - which witnessed both the decline of the Mughals and the rise of British colonialism. Some scholars are quite pessimistic about the early influences of British conquest; ${ }^{3}$ while others shift the chronologies and pattern of decline into the nineteenth century. ${ }^{4}$ During the eighteenth century the regional economy

\footnotetext{
${ }^{2}$ See Sushil Chaudhuri and Michel Morineau (eds.), Merchants, Companies and Trade: Europe and Asia in the Early Modern Era (Cambridge: Cambridge University Press, 1999); Sushil Chaudhuri, "International Trade in Bengal Silk and The Comparative Role of Asians and Europeans, c. 1700-57", Modern Asian Studies, 29, 2 (1995), pp. 373-86; Sinnappah Arasaratnam, "The Chulia Muslim Merchants on Southeast Asia, 1650-1800", in Sanjay Subrahmanyam (ed.), Merchant Networks in the Early Modern World (Aldershot and Brookfield, VT: Variourum, 1996), pp. 159-77.

${ }^{3}$ For example: A. K. Sinha, Transition in Textile Industry: A History of Textile Industry in Bihar, 1783-1833 (Delhi: Capitol Publishing House, 1984), pp. 134-53; Ashin Das Gupta, "The Merchants of Surat, c. 1700-50", in Edmund Leach and S. N. Mukherjee (eds.), Elites of South Asia (Cambridge, Cambridge University Press, 1970), pp. 201-22; Prasannan Parthasarathi, "Weavers, Merchants and States: The South Indian textile industry, 1680-1800" (Unpublished Ph.D. Thesis, Harvard University, 1992), pp. 259-62; Hameeda Hossain, "The Alienation of Weavers: Impact of Conflict between Revenue and Commercial Interests of the East India Company, 1750-1800", Indian Economic and Social History Review, 16, 3 (1979), pp. 341 and 345.

${ }^{4}$ Burton Stein, "Arrested Development: But When and Where?", in Clive Dewey (ed.), Arrested Development in India: The Historical Dimension (New Delhi: Manohar, 1988), pp. 50-51, 56-57; P. Sudhir and P. Swarnalatha, "Textile Traders and Territorial
} 
of Gujarat experienced marked decline. South India was badly affected by significant disruptions following the contraction of the Mughal Empire, the convulsions of successor states like the Marathas and Mysore, and conquest by the East India Company. Yet, throughout these conflicts South India continued to produce and export large volumes of textiles. By contrast, politics notwithstanding, Bengal grew markedly during the eighteenth century to become India's richest production region.

Interestingly, while there is general agreement on the fact that the handicraft textile industry experienced significant decline in the course of the nineteenth century - and especially in the colonial period starting in 1858 - still the nature and timing of such decline is hotly debated. Scholars have examined the quantitative data - such as numbers of looms, numbers of weavers, pounds of cloth, or value of exports - in order to estimate the condition of the internal market for textiles. ${ }^{5}$ For, while it seems clear that India exported less textiles during the nineteenth century, it is not at all clear how internal production and consumption markets responded to British manufactured goods. Some have argued for a relative decline, meaning that the actual size of the industry remained about the same size while the larger economy grew. ${ }^{6}$ Others have seen an absolute decline in the industry's size and vitality. ${ }^{7}$

The late nineteenth century also witnessed the rise of machine textile mills, particularly in Bombay. Scholars generally agree that by this date the textile industry of India had radically changed from its early modern organization and structure. Independent textile artisans were no longer ubiquitous; and the flexible commercial structure of diverse merchants had been dismantled. Proponents of de-industrialization argue that the remnants of the artisan and mercantile communities had been subsumed within an agrarian order that appears to have been

Imperatives: Masulipatnam, 1750-1850", Indian Economic and Social History Review, 29, 2 (1992), pp. 168-69.

${ }^{5}$ Michael J. Twomey, "Employment in Nineteenth Century Indian Textiles", Explorations in Economic History, 20 (1983), pp. 40-47; Konrad Specker, "DeIndustrialisation' in Nineteenth century India: The Textile Industry in the Madras Presidency, 1810-70", in Dewey (ed.), Arrested Development, p. 341.

${ }^{6}$ Specker., "Madras Handlooms", p. 342.

7 J. Krishnamurty, "Handicrafts in the Indian Economy: A Study of the Handloom Industry from 1800", in Aparna Basu (ed.), Imperialism, Nationalism and Regionalism in Canadian and Modern Indian History (New Delhi: Manohar, 1989), pp. 138-9; Twomey, "Employment", p. 55. 
more rigid than at any previous period. The growth of a mechanized textile industry did not replace the economic size or significance of the previous handicraft industry. In many cases, it does not even seem to have drawn from the same pools of labour. For example, the agrarian migrants who populated the Bombay mills had little connection to the textile tradition that once supplied all of the Indian Ocean. ${ }^{8}$ There is significant criticism of this de-industrialization thesis as much recent research examines broad continuities in handicraft weaving traditions through the nineteenth century. It is argued that there was significant 'mixed' industrialization, which combined handicraft and power loom production in small factories and workshops.'

It is in such a context that the overall structure of the 'declensionist' Indian economic narrative takes shape. Industrialization was characterized as foreign and often disruptive. Continuity has been preferred, particularly the continuity of the hand-loom industry. Weavers and merchants are central characters of textile industry narratives. Interestingly, the scholarship also decries India's failure to fully industrialize. There are historical analyses of industrialization and larger scale firms in the nineteenth century, and their failure to bring about a complete transition to an industrialized economy. But studies on the decline or stagnation of handicrafts are more prominent.

Finally, scholarship that focuses entirely on the national historiographies in South Asia, particularly India, misses the striking contrast between the South Asian experience and the history of much of the rest of Asia. By contrast to other regions in Asia, the textile industries of India experienced marked continuities from the early modern period through the nineteenth and twentieth centuries. Japan quickly

\footnotetext{
${ }^{8}$ Richard Newman, "The Recruitment of an Industrial Labour Force through Intermediaries: A Comparative Study of the Cotton Textile Industry", in Dewey (ed.), Arrested Development, pp. 349, 351-52 and 356; D. Mazumdar, "Labour Supply in Early Industrialization: the Case of the Bombay Textile Industry", Economic History Review, 26, 3 (1973), pp. 477-96.

${ }_{9}$ Douglas Haynes' work on continuity and change in nineteenth and twentieth century weaving firms in western India is particularly striking. See Douglas Haynes, "The Logic of the Artisan Firm in a Capitalist Economy: Handloom Weavers and Technological Change in Western India, 1880-1947", in Burton Stein and Sanjay Subrahmanyam (eds.), Institutions and Economic Change in South Asia (Delhi: Oxford University Press, 1996), pp. 173-205, esp. 195-203; Douglas Haynes, “The Dynamics of Continuity in Indian Domestic Industry: Jari Manufacture in Surat, 1900-47”, in Tirthankar Roy (ed.), Cloth and Commerce: Textiles in Colonial India (London: Sage Publications, 1996), pp. 299-325. Roy also emphasizes continuity amidst change in the modern textile industry.
} 
industrialized in the late nineteenth century. The historiography of Japanese industrialization celebrates the success of technological adoption, entrepreneurship, and rapid internal political, economic and social transformation. Within its textile industry, hybridization of external technologies to Japanese social and economic structures as well as the survival of high-culture handicraft production is crucial. Southeast Asian textile production suffered major disruptions in the face of expanding cash crop economies under colonialism. Nevertheless, throughout the painful vicissitudes experienced by textile industries in Indonesia, Thailand or the Philippines, regional design motifs and production cultures survived. Because cloth is a great carrier of cultural meaning in Southeast Asia, the survival of autochthonous traditions is considered as an example of the area's adoption and adaptation of external influences and of its cultural autonomy. The hand-loom weavers and merchants of South Asia experienced unparalleled continuities in comparison to Southeast Asia or Japan. But India's historians continue to analyze decline.

\section{Four Centuries of Decline? The Historiography of the South Indian Textile Industry}

The historiography of the South Indian textile industry demonstrates the power of the predominant 'declensionist' argument in South Asian history. Almost without exception, historians' overarching analyses begin with wealth and end with decline. Some have detected evidence of decline as early as the seventeenth century. In fairness few, if any, of the historians below would accept that the textile industry declined over a long period of four centuries. Most scholars agree instead that the early modern period witnessed significant growth in South Indian textile production and commerce, especially from 1600 to 1750 . But as historians analyze the eighteenth and nineteenth century, they generally identify decline, though there is debate about when the industry declined and to what degree. The most common story - regardless of the opening or closing dates - remains one of early prosperity and ultimate decline.

Historians identify decline in various terms. Economic decline can be observed in terms of lowering numbers of weavers and looms, lessening textile exports, closing markets, slackening demand for cloth, falling wages, and rising taxes. Some scholars argue for absolute economic decline, whereas others see only relative decline compared to 
the broader economy. Stagnation too can be viewed as decline. With regard to quality of life, historians make strong arguments that weavers' opportunities and overall agency were curtailed by the East India companies and the colonial state - limiting producers' choices of markets and consumers, increasing Company monopoly powers, reducing textile varieties and demanding homogenous quality, prohibiting physical or social mobility, and interfering in community leadership and governance. Finally in political terms, many scholars identify increasing colonial state power, surveillance, oppression, and the eventual loss of Indian artisans' liberties. This section analyzes the historiography of the South Indian textile industry chronologically through the sixteenth, seventeenth, eighteenth and nineteenth centuries, attending to each of these themes.

We begin with the early modern period. Vijaya Ramaswamy's insightful analysis of the medieval textile industry in South India concluded with the sixteenth and seventeenth century. The bulk of her work utilized inscriptions to piece together a fascinating social history of medieval weavers. But her concluding chapters on the rise of the East India companies are quite pessimistic. Central to her thesis is the role of the state and she described the Chola and Vijayanagara states as enlightened patrons of weaver prosperity for the sake of state revenue. ${ }^{10}$ Thus, in her view, decline dated from the fall of the Vijayanagara Empire in the later sixteenth century. But her greatest criticism is reserved for the arrival of the Dutch and English East India Companies, which she credited with limiting weaver creativity and mobility, contributing to the decline of guilds, forcing the production of standardized export cloths, and the constructing of proto-colonial black towns. ${ }^{11}$ Ramaswamy concludes that:

It must be noted that the East India Company had a demoralizing effect not only on the weavers but on the majority of artisan castes ... The position of weavers in the seventeenth century reflects what can be regarded as the beginning of an eclipse for South Indian handlooms and weavers which lasted over two hundred years. ${ }^{12}$

To date the decline of the textile industry to such an early date is remarkable, since 1600 marks the beginning of the South Indian textile

\footnotetext{
10 Vijaya Ramaswamy, Textiles and Weavers in Medieval South India (Delhi: Oxford University Press, 1985), pp. 35-62, 94-116.

11 Ibid., pp. 150-66, 169-70.

12 Ibid., p. 166.
} 
industry's major expansion wherein its production would reach markets in East Asia, Africa, Europe and even the Americas.

Studies of seventeenth-century South Indian textile industry tend to be optimistic and celebratory, though most historians still end by noting decline. Tapan Raychaudhuri examines textile trade in some detail within his analysis of the Dutch Jan Company in the Coromandel. He lauds the vitality of textile production and trade in seventeenth century. However he notes a clear sense of decline dating from the late seventeenth century, when political disruptions in the northern Coromandel convinced the Dutch to shift their procurement from Pulicat in the north to Nagapattinam in the south. ${ }^{13} \mathrm{~J}$. J. Brennig expresses a more limited sense of decline in the same period. His analysis of seventeenth-century textile production and trade in the northern Coromandel clearly identifies important dynamism in textile manufacturing in the course of the century and well into the eighteenth century. Nevertheless, he views the conquest of southern India by the Mughals as marking a major decline in the history of textile production and trade in the Krishna-Godavari Deltas:

From 1686 to 1689 Golconda experienced the consequences of invasion, famine and epidemic. All of these disasters affected the northern Coromandel ... But despite renewed European trade, northern Coromandel's export trade never again reached the levels attained in the first half of the 1680s ... The Mughal Conquest of Golconda was thus a disaster for the commercial life of northern Coromandel, ending an era of continued expansion derived from the growth in European trade. ${ }^{14}$

Elsewhere Brennig describes the complex interactions between diverse, specialized merchant and weaver communities, emphasizing the agency and power of weavers in these relations. However, it is this same agency that leads him to conclude, pessimistically, that the weakness of mercantile intermediaries blocked the reorganization of the textile industry and "the emergence of even a primitive industrial capitalism". ${ }^{15}$ In The Cambridge Economic History of India, Alaev reached a similar conclusion in his analysis of artisan production in early modern South

\footnotetext{
${ }^{13}$ See conclusion of Tapan Raychaudhuri, Jan Company in Coromandel, 1605-90 (The Hague: Martinus Nijhoff, 1962).

${ }^{14}$ Joseph Jerome Brennig, "The Textile Trade of Seventeenth-Century Northern Coromandel: A Study of a Pre-Modern Asian Export Industry" (Unpublished Ph.D. Thesis, University of Wisconsin - Madison, 1975), p. 276.

${ }^{15}$ Joseph Jerome Brennig, "Textile Producers and Production in Late SeventeenthCentury Coromandel”, Indian Economic and Social History Review, 23, 4 (1986), p. 353.
} 
India. He described both social continuity and economic growth in production and commerce during the early modern period in South India. But, he argues, this continuity led to stagnation rather than growth. ${ }^{16}$

Historians of the eighteenth century are still generally enthusiastic about the economic and social vitality of early modern India, but are also markedly pessimistic about the overall trajectory of its textile industry. Sinnappah Arasaratnam, for example, strongly critiques the extension of British colonial power into South India during the eighteenth century. He argues that such an expansion was accompanied by monopolistic commercial goals, exploitation of South Indian weavers and merchants, and gradual economic and social decline of the textile industry:

As far as the development of the handloom industry is concerned, there is a historical inevitability to the change of the period ... Under the Company, weavers had virtually become wage workers on terms and conditions over which they had no control. ${ }^{17}$

Kanakalatha Mukund examines the textile trade in South India between 1650 and 1750 in the context of her research on Tamil merchant society. She describes great prosperity and activity during the period as well as evidence of a positive transition toward capitalism that brought the "gradual subjection of the producer by the merchant capitalist". ${ }^{18}$ Unfortunately, this endogenous capitalist transformation was halted after 1725, when textile commerce experienced a marked decline, and Tamil merchants became impoverished and sometimes bankrupt. ${ }^{19}$ She describes the efforts of communities of merchant capitalists to achieve social and economic status in eighteenth-century Coromandel, but concludes that:

The irony was that even as the merchant capitalists were achieving the desired social standing, their economic status which was the foundation

\footnotetext{
16 Tapan Raychaudhuri and Irfan Habib (eds.), The Cambridge Economic History of India; Vol. 1. c. 1200-c.1750 (Cambridge: Cambridge University Press, 1982), p. 324.

${ }_{17}$ Sinnappah Arasaratnam, "Weavers, Merchants and Company: The Handloom Industry in Southeastern India in 1750-90", Indian Economic and Social History Review, 17, 3 (1978), pp. 276-77. See also S. Arasaratnam, Maritime Commerce and English Power: Southeast India, 1750-1800 (New Delhi: Variorum, 1996).

${ }^{18}$ Kanakalatha Mukund, The Trading World of the Tamil Merchant: Evolution of Merchant Capitalism in the Coromandel (Hyderabad: Orient Longman, 1999), p. 169.

${ }^{19}$ Ibid., pp. 100-102 and 141-43.
} 
of their social goals was already beginning to show the first signs of disintegration. ${ }^{20}$

Prasannan Parthasarathi's work makes a compelling argument that the textile industry was the first portion of South Indian society to endure the real power of colonialism during the eighteenth century, and that it was the harbinger of things to come in the nineteenth century. Prior to 1760, weavers enjoyed a powerful bargaining position in negotiations with merchants and brokers; similarly, labourers in artisan and agrarian production enjoyed prosperity and protection in pre-colonial states, which enriched the entire society. But with the English Company's conquest of significant and growing portions of South India, the Companystate exerted increasing colonial powers on textile weavers and merchants. It drastically weakened the bargaining power of weavers, cut out merchant brokers, mitigated any benefits from labour mobility, and defeated all weaver protest. The decline of the textile industry after 1760 brought about negative social and economic effects:

The rise of English rule in South India meant the demise of a way of life for laborers. The rights which they possessed - in contract, in property, in community - were eroded and eliminated as the Company state had no respect for them. The Company state's [geographic] fixing of laborers, in particular, had devastating consequences. ${ }^{21}$

Parthasarathi adds that, "Colonialism in South India had devastating consequences not only for the standard of living of labourers but also for the dynamism of the economy as a whole".22

In an examination of mid-eighteenth century South India, Tapan Raychaudhuri identifies evidence of continued commercial and productive vitality accompanied by growth in international trade. But as he looks forward toward the late eighteenth and nineteenth centuries he saw little evidence of transformations of commercial capital relationships, labour structures or technology. Indeed in comparison to Europe, China and Japan, India lacked innovation and adaptation. ${ }^{23}$ For Raychaudhuri this stagnation and failure to industrialize or evolve marked economic and social decline.

${ }^{20}$ Ibid., p. 182.

${ }^{21}$ Prasannan Parthasarathi, The Transition to a Colonial Economy: Weavers, Merchants and Kings in South India, 1720-1800 (Cambridge: Cambridge University Press, 2001), p. 147.

22 Ibid., p. 6.

${ }^{23}$ Dharma Kumar (ed.), The Cambridge Economic History of India; Vol. 2. c .1757c. 1970 (Cambridge: Cambridge University Press, 1983), pp. 7-35. 
In the early 1990s, Potkuchi Swarnalatha wrote a thoroughly researched dissertation on weaver society in the northern Coromandel between 1750 and 1850. Swarnalatha's research analyzes the world of the weaver from numerous perspectives - political, social, productive, and commercial - emphasizing the growing influence of the East India Company and colonialism on weavers. She concludes that weavers struggled in the face of a wide range of challenges throughout this period, as the Company initiated a wide range of new intrusive managerial and administrative systems. Various indigenous agents of the Companies - copdars, senapatis, gumastahs, careerdars - as well as commercial residents and revenue collectors combined to circumscribe weaver production choices, mobility, markets, and quality of life. ${ }^{24}$ Swarnalatha notes that colonial initiatives were often haphazard and short lived, with varied long-term effects. Weavers responded with organized agitations and survived. ${ }^{25}$ Nevertheless, these cumulative challenges had effects. Swarnalatha describes a loss of weaver agency:

The weavers in the Coromandel were thus affected by a multitude of factors, thereby demonstrating the way in which they were locked into a wider world which, in fact, shaped their destinies. ${ }^{26}$

Swarnalatha dates major decline from the beginning of the nineteenth century. The South Indian weaver society experienced significant economic, political and quality of life decline in the face of competing and often conflicting colonial bureaucratic measures enacted by the commercial residents and revenue collectors of the English East India Company. Among South Indians, weavers in particular were squeezed between the uncoordinated and competing claims of colonial commercial agents and revenue officials. ${ }^{27}$ Even more disastrous was the 1830 cessation of Company trade in the South Indian cloth, which cut off weavers from Company markets and left many weavers underemployed. ${ }^{28}$ Thus the Company worked against weavers for well over a

\footnotetext{
${ }^{24}$ Potkuchi Swarnalatha, "The World of the Weaver in the Northern Coromandel, 1750-1850" (Unpublished Ph.D. Thesis, University of Hyderabad, 1991), pp. 193-237.

${ }^{25}$ Ibid., pp. 338-84.

${ }^{26}$ Ibid., p. 464.

${ }^{27}$ Sudhir and Swarnalatha, "Textile Traders", pp. 145-69.

${ }^{28}$ Swarnalatha, "World of the Weaver", pp. 440-52 and 530-33. This conclusion is strongly corroborated by later observers. F. R. Hemingway, Madras District Gazetteers: Godavari (Madras, 1915), vol. 1, p. 103; H. R. Pate, Madras District Gazetteers: Tinnevelly (Madras, 1917), vol. 1, pp. 215-16.
} 
century, bringing them into increasing subjugation, until the Company disbanded its trade and left weavers bereft of their markets and needed capital.

Interestingly, it is in scholarship on the nineteenth century that significant debate on the existence or size of decline arises. Konrad Specker collected substantial data on the numbers of weavers and looms in early-nineteenth-century South India. He argued that the early nineteenth century did not witness a marked decline in weavers:

The number of looms, in general, tended to increase over the period from 1820 to $1870 \ldots$ In quantitative terms there was no 'destruction' of the traditional textile industry ... To talk about destruction of a flourishing textile industry and about deindustrialization however is too simple to render justice to the complexity of changes that occurred in Indian economic life..$^{29}$

This is striking because by broad accounts of the merchants and markets for South Indian cloth, the seventeenth and eighteenth centuries were periods of growth, whereas the nineteenth century was a period of decline in the external demand for South Indian cloth. Nevertheless, the data on weaver populations is ambiguous enough to call into question an overall decline in weaving. Perhaps it was only a decline relative to the broader economy, and not an absolute decline. Dharma Kumar has also expresses a mixed set of conclusions about continuity and decline from the late eighteenth to the nineteenth century. Kumar cautiously interprets data showing a decline in the number of weavers and looms. Weavers transitioned to producing coarse cloth, and the value per unit of cloth produced declined sharply. ${ }^{30}$ Then Kumar identified significant difficulties for weavers in terms of demand for their goods, competition and increased taxation:

But from the second decade in the nineteenth century the Company, faced with competition from British mills and the loss of its monopoly of the Indian trade, began to contract its investment in Indian textiles and its commercial establishments. In addition to the lack of protection from foreign competition from which weavers all over India suffered, the Madras weaver had an additional and very heavy tax burden to bear in the form of the motarfa tax. ${ }^{31}$

${ }^{29}$ Konrad Specker, "Madras Handlooms in the Nineteenth Century", Indian Economic and Social History Review, 26, 2 (1989), pp. 164-66.

${ }^{30}$ Kumar (ed.), Cambridge Economic History of India. Vol. 2, pp. 368-70.

${ }^{31}$ Ibid., p. 369. 
All of these histories tell very similar stories, whether they analyze the seventeenth, eighteenth or nineteenth century. The textile industry began as a successful, competitive producing and trading society, and the industry experienced economic, social or political decline in the end of each study. In optimistic terms, the reader can identify signs of growth and dynamism throughout the early modern period and into the nineteenth century. Without exception, each of these historians has emphasized the size, scope and vitality of textile production and trade during their period of analysis. Their analyses begin with real enthusiasm for the society that produced and marketed cotton cloth for vast areas of Asia, Africa and even Europe. On the other hand, most authors felt obliged to address the poverty of India by detecting and even foreseeing decline. Some historians focus heavily on examining decline and on explaining its causes; others note decline as an epilogue.

\section{Transitions in the Structure of the South Indian Textile Industry}

The historiography of the South Indian textile industry, focusing on hand-loom weavers, identifies and analyzes various kinds of negative changes in modern textile production and commerce. Yet, in contrast to East Asia and Southeast Asia, India's weavers experienced remarkable continuity. For example, South India's weavers continue to manufacture, market and export handloom cloth and traditionally patterned and printed fabrics into the twenty-first century. How did the South Indian textile industry actually change during the crucial eighteenth and nineteenth centuries? What are the major transitions and continuities across the entire textile industry, including commercial agriculture, spinning, weaving and finishing?

By examining continuity and change across the entire textile industry, a very different set of transitions become apparent. Spinners, women, and part-time or agrarian labourers become major protagonists in the textile industry; and it becomes clear that they experienced much greater disruptions than weavers and merchants. This analysis enables us to begin to reshape and partly disaggregate the story of decline and de-industrialization that pre-occupies much scholarship.

Research on the textile industry across India has focused heavily on weavers and cloth merchants. Historians agree that the structure of the textile industry was highly specialized and diversified, with spinning, weaving, washing, dyeing and trade performed by different professional 
groups. In the past, scholars have characterized textile producers and merchants as largely male, professional, full-time, and specialized. Of course, historians have long been aware that spinners, cotton pickers and cleaners, and warpers were mostly female and constituted a large proportion of textile labourers. However, their role in the historiography of textile production has been limited when compared with vast literature on male weavers and merchants. One must notice how this is a peculiarity of South Asian historiography that stands in stark contrast to regions like Southeast Asia where female part-time labour characterized textile spinning as well as weaving, with women occasionally active even in the sphere of commerce. Recent scholarship has acknowledged its gender bias by emphasizing the family or household as a unit of production that combined both male and female labour (Fig. 7.1). ${ }^{32}$

The data and tables in this section are based on the detailed analysis of textile production in early modern South India in my dissertation. By carefully examining the rich archival data on the labour, productivity, input costs, wages and profits for each stage of production, a highly detailed view of textile production and the overall structure of the textile industry can be constructed. Unfortunately, the methodology, sources and fine analysis used to construct these cumulative tables cannot be reproduced here. ${ }^{33}$

Table 7.1 illustrates the structure of labour and the value-added contributed to the production and trade of coarse and medium-quality plain textile varieties for export such as salampuris, long cloths, Guinea cloths, muris, and bethilles in South India. ${ }^{34}$ Such cloths dominated textile exports and constituted a significant portion of the internal market for textiles. Very coarse and fine cloths were produced through different production structures, although with broadly common features. Patterned, printed and painted cloths required significant additional labour and raw materials (dyes and mordants) to perform a series of finishing stages carried out by weavers, dyers and painters; thus, a table describing value added for patterned cloth is quite different. My analysis of seventeenth- and eighteenth-century sources in Dutch and English East India Company archives demonstrates that the social and economic

${ }^{32}$ Parthasarathi, “Transition”, pp. 10-17; Haynes, "Logic”, p. 182.

${ }_{33}$ The primary archives used were the Tamil Nadu Archive, the Andhra Pradesh State Archive, and the National Archives in the Netherlands. See Ian C. Wendt, "The Social Fabric: Textile Industry and Community in Early Modern South India" (Unpublished PhD. Thesis, University of Wisconsin - Madison, 2005).

${ }_{34}$ These included both white and single coloured cloths with thread counts between 40 and 80 threads per inch. 


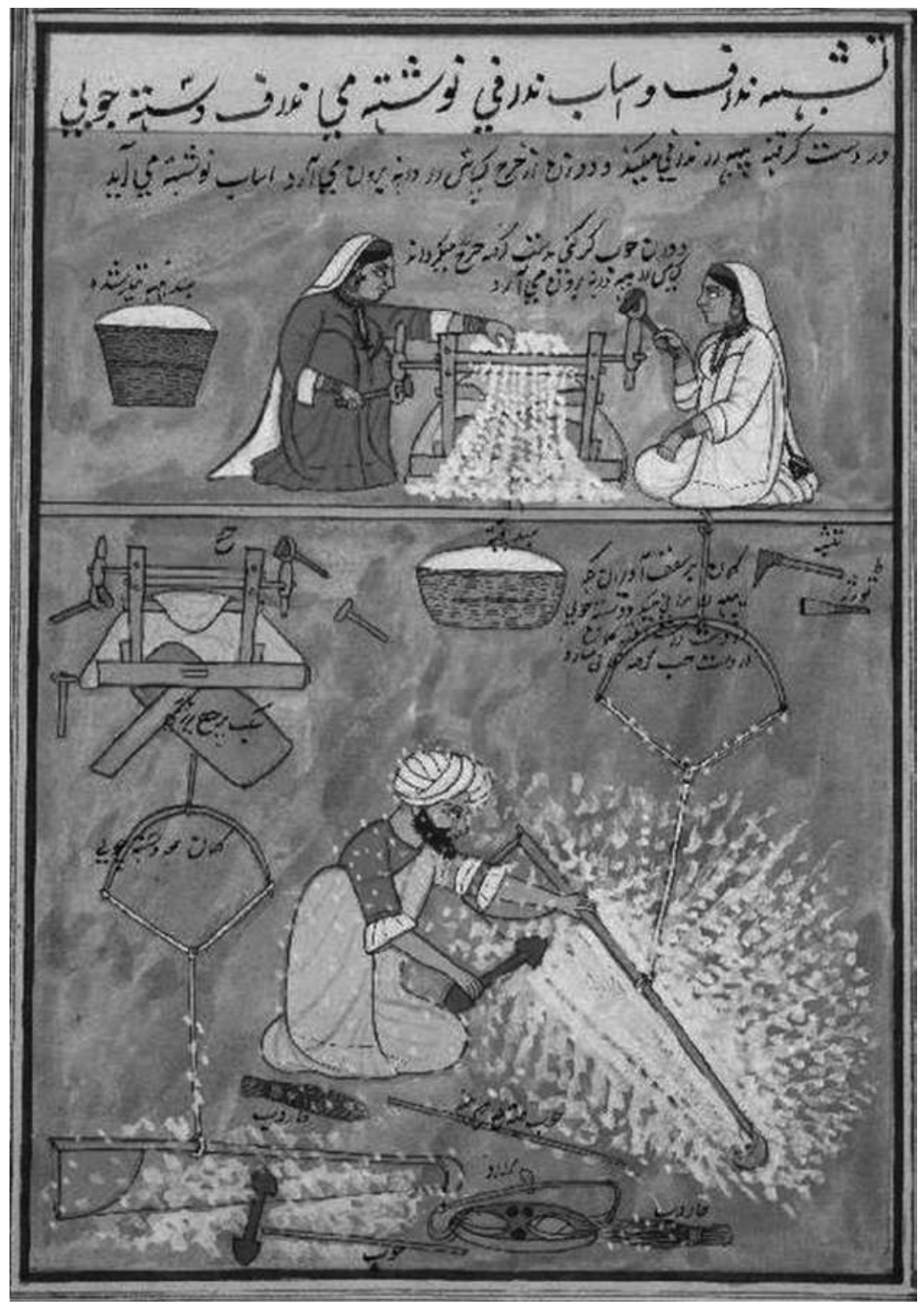

Fig. 7.1. Two women ginning cotton; man carding cotton, opaque watercolour. India, 1850-60. Reproduced by kind permission of the British Library, Add.Or.1727.

structure of textile production did not fundamentally alter across the early modern period. However, the commercial and political relationships between weavers, merchants, companies and states did, through necessity, change during the late eighteenth century. 


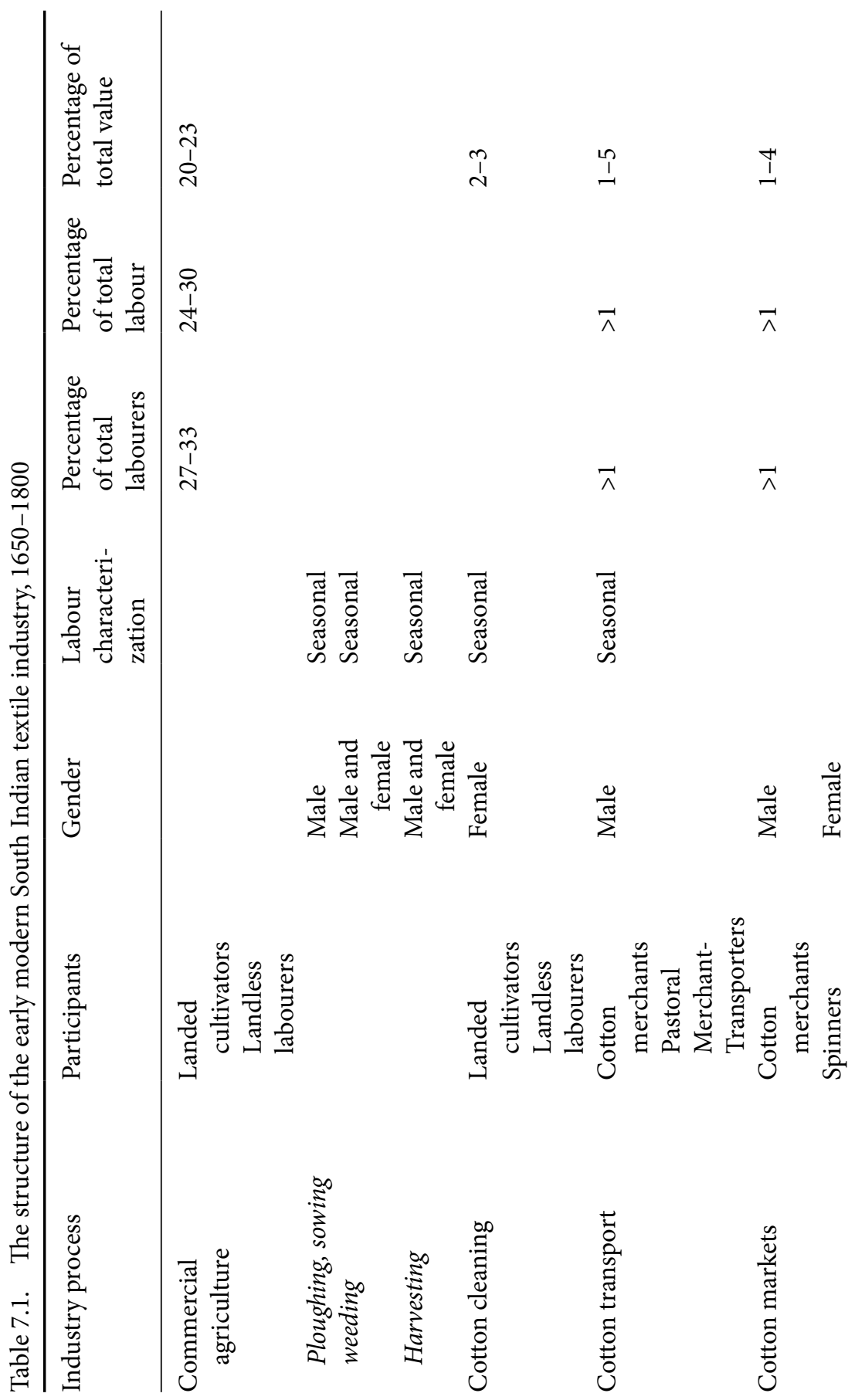


CHANGING STRUCTURE OF THE SOUTH INDIAN TEXTILE INDUSTRY 209

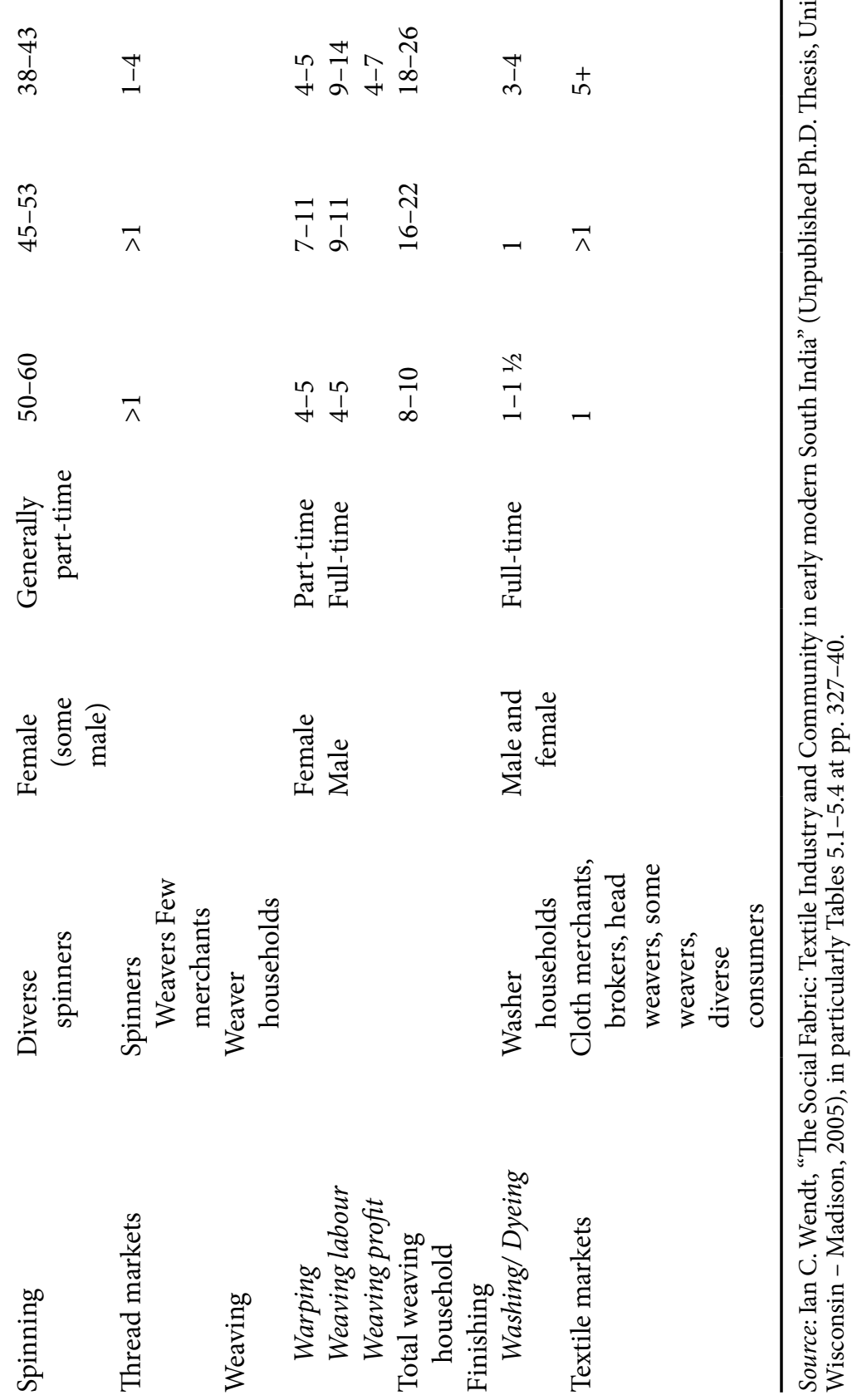


In South India, agrarian and female labour constituted the majority of total labourers, total labour volume, and even total value added on virtually all plain cloths in the early modern period. This was largely part-time, seasonal, and non-professional labour. Spinning with circa 55 percent of total labourers and circa 40 percent of total labour accounted for the largest part of all labour and the highest value added to plain cloth. Agrarian households which included cotton cultivators, cleaners, and the majority of spinners constituted about 75 percent of all labourers and more than 65 percent of total labour. Female labour composed up to 65 percent of all labourers and circa 60 percent of total labour in the textile industry as a whole. All remaining processes of production and commerce accounted for a much smaller percentage of labour and value added. Weaving households were just 10 percent of all textile industry households and contributed 20 percent of the total labour. The combination of all professional labourers, including weavers, washers, dyers and merchants composed only about 12 percent of all households and 22 percent of the total labour (Table 7.2). ${ }^{35}$

Table 7.2. Summary of the structure of the early modern south Indian textile industry

\begin{tabular}{llll}
\hline & $\begin{array}{l}\text { Percentage of } \\
\text { total labourers }\end{array}$ & $\begin{array}{l}\text { Percentage } \\
\text { of total labour }\end{array}$ & $\begin{array}{l}\text { Percentage } \\
\text { of total value }\end{array}$ \\
\hline $\begin{array}{l}\text { Agrarian } \\
\text { household labour }\end{array}$ & $>77$ & $>69$ & $60-70$ \\
$\begin{array}{l}\text { Part-time or } \\
\text { seasonal labour }\end{array}$ & $>80$ & $>75$ & $65-75$ \\
$\begin{array}{l}\text { Professional, } \\
\text { full-time labour }\end{array}$ & $8-10$ & $12-15$ & $>20$ \\
$\begin{array}{l}\text { Commercial } \\
\text { household labour }\end{array}$ & $1-3$ & $1-2$ & $>8$ \\
$\begin{array}{l}\text { Female labour } \\
\text { Male labour }\end{array}$ & $>60$ & $>60$ & $50-57$ \\
\hline
\end{tabular}

Source: Ian C. Wendt, "The Social Fabric: Textile Industry and Community in early modern South India" (Unpublished Ph.D. Thesis, University of Wisconsin - Madison, 2005), in particularly tables 5.1-5.4 at pp. 327-40.

${ }^{35}$ Interestingly, this structure in South India closely correlates to the structure of textile industry in late-eighteenth-century Bengal, as reported by the English East India Company in 1783. K. N. Chaudhuri, "The Structure of Indian Industry in the Seventeenth and Eighteenth Centuries", Indian Economic and Social History Review, 9, 2-3 (1974), pp. 162-63. 
Because the textile industry was highly monetized and commercial, it enabled women in artisan and agrarian households to earn cash. In textile-producing households, female producers - who picked, cleaned and spun cotton into thread, prepared the warp for the loom, and assisted in washing and dyeing - contributed money to their household income. Table 7.3 lists several kinds of agrarian, weaver and spinner households, denominating moderate incomes for both the male and female members. ${ }^{36}$

In addition to forming a large proportion of the value of the overall textile industry, female labour also contributed to the household income of many kinds of families in early modern South India. Female labour contributed circa 5.5 pagodas or 20 rupees annually to many households, which accounted for between one third and one half of many households' total income. Women without male support, particularly widows, could earn a modest living wage for themselves and dependent children by spinning.

How does this alter our historical narrative about continuity and change, decline and de-industrialization? To answer this question we must first answer the basic question of how the structure of this textile industry changed over the course of the nineteenth century. One point that must be emphasised is that the diffusion of mechanized processes for cotton cleaning, spinning, warping, weaving and dyeing was partial, halting and gradual. ${ }^{37}$ But late-nineteenth- and early-twentieth-century sources clearly document the gradual spread and adoption of mechanized processes for cotton cleaning and spinning. Railway transport of cotton and the diffusion of cotton gins gradually replaced the bulk of hand cotton cleaning labour. It is unclear how many spinners and cotton cleaners lost work. But decline in spinning was much more marked than the decline in weaving. In 1906 the Coimbatore District Manual reported that cotton cleaners and spinners constituted barely 20 percent of total textile production, a significant fall from early modern levels. ${ }^{38}$

\footnotetext{
${ }^{36}$ For full ranges of wages, sources and analysis, see Wendt, "Social Fabric", pp. $325-49$, in particular p. 343.

37 English East India Company, Reports and Documents Connected with the Proceedings of the East India Company in Regard to the Culture and Manufacture of Cotton-wool, Raw Silk and Indigo in India (London, 1836), pp. 238-47; Talboys Wheeler, Hand-book to the Cotton Cultivation in the Madras Presidency (Madras: Higginbotham and Pharoah and Co., 1862), pp. 37, 57 and 94-95.

${ }^{38}$ F. A. Nicholson, Madras District Manuals: Coimbatore (Madras: Government Press, 1906), vol. 2, p. 162.
} 


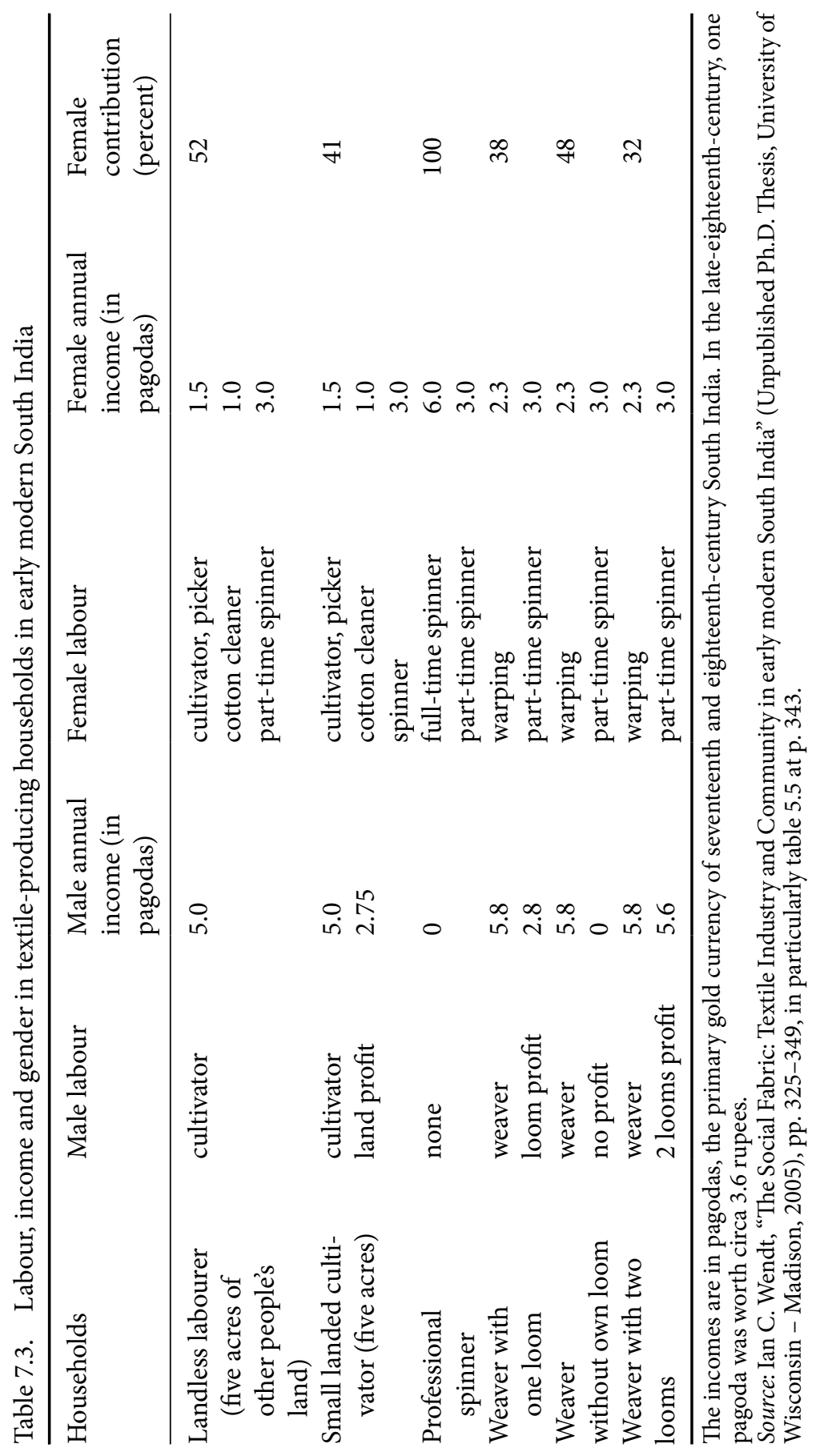


Based on surveys of weavers during the 1890 s, it is clear that many weavers in the Madras Presidency were using machine-spun yarn from Madras, Madurai, Coimbatore, Bombay and elsewhere. ${ }^{39}$ The number of weavers was more stable during the nineteenth century than one might expect. Weavers were still considered to be the most important nonagrarian segment of the economy in the late nineteenth and early twentieth century. ${ }^{40}$

Cotton cleaning and spinning were dominated by agrarian and female labour. Thus the result of nineteenth-century industrialization was the gradual replacement of female and agrarian labourers. Even within the weaving process, warping machines were in use in large weaving centres in South India long before mechanized weaving became an important factor. ${ }^{41}$ Once again, female labour was replaced first.

By the late-nineteenth-century, weavers adopted synthetic aniline dyes and purchased synthetically-dyed thread. Synthetic dyes imported from Europe - particularly Germany - were not just similar in quality to vegetable dyes, but were also cheaper and simpler to use. ${ }^{42}$ The adoption of synthetic dyes by weavers eliminated many dyeing activities, previously performed by specialized dyers and painters. Thus nineteenth-century industrialization contributed to declining professional specialization in handicraft textile production. But instead of eliminating weavers, it reduced demand for dyers and painters and combined their labour with weaving.

The mechanisation of cotton cleaning, spinning and warping, the import of synthetic dyes, and the transport of cotton by rail all severed the ties between agrarian and artisan communities. Agrarian labourers were excluded from the textile industry. Cotton transport and trade shifted from a rural to an urban-based distribution system supported

${ }^{39}$ Edgar Thurston, Monograph on the Cotton Fabric Industry of the Madras Presidency (Madras: Government Press, 1897), p. 8; W. Francis, Madras District Gazetteers: South Arcot (Madras: Government Press, 1906), p. 156; Nicholson, Coimbatore Manual, 16062; C. F. Brackenbury, Madras District Gazetteers: Cuddapah (Madras: Government Press, 1915), vol. 1, pp. 61 and 109; Pate, Tinnevelly Gazetteer, pp. 162-63 and 211-13.

${ }^{40}$ F. R. Hemingway, Madras District Gazetteers: Tanjore (Madras: Government Press, 1906), vol. 1, pp. 122-3; W. Francis, Madras District Gazetteers: Bellary (Madras: Government Press, 1916), vol. 1, p. 110.

${ }^{41}$ F. J. Richards, Madras District Gazetteers: Salem (Madras: Government Press, 1918), vol. 1, part 1, pp. 267-68.

${ }^{42}$ Edwin Holder, Monograph on Dyes \& Dyeing in the Madras Presidency (Madras: Government Press, 1896), p. 1; Edgar Thurston, Monograph on the Cotton Fabric, pp. $4-8$. 
by new rail infrastructures. Rather than buying thread from agrarian spinners, weavers bought it from urban markets or received it from merchants as an advance. Instead of purchasing vegetable dyes from commercial crop producers, weavers and dyers purchased mineral dyes in urban markets.

We can conclude that rather than the agrarianization or de-industrialization of a major portion of the professional textile industry, the nineteenth-century transitions in South India brought about the masculinization (or de-feminization), urbanization (or de-agrarianization), professionalization, and the elimination of much seasonal and parttime labour in what can be defined as a 'modern' textile industry. Indeed, the characterizations of the handicraft textile industry as male, professional and full time date from the late nineteenth and early twentieth centuries.

\section{Conclusion: Mixed Industrialization and Survival}

Historians have correctly identified various kinds of decline experienced by South Asian weavers and merchants in economic terms, standards of living, politics and agency. Weavers and textile merchants were challenged by lowering demand and wages, increasing competition and taxes, limitations on their mobility and professional choices, and increased state power. Nevertheless, weavers and cloth merchants survived through the nineteenth and twentieth century. By contrast, the processes of cotton picking, cleaning, transport, spinning and warping have been almost entirely industrialized. In comparison to the lateeighteenth century, this represents the elimination of at least 60 percent of all labourers from the textile industry. Those labourers, who were primarily female, agrarian and employed part-time, contributed no less than fifty percent of the value of a piece of hand-loom cloth in the seventeenth and eighteenth centuries. As noted above, the very same women contributed between one third and one half of the income for many households. The loss of that income undoubtedly had broad economic and social consequences for many agrarian and artisan families.

This represents a partial or mixed industrialization of textile production in South Asia. The expansion of mixed hand-loom and mechanized loom production - combined in numerous small weaver-owned 
workshops and factories through late nineteenth and twentieth centuries - has continued this process. ${ }^{43}$ And of course fully mechanized, factory textile production in South Asia has grown throughout the same period. This mixed industrialization of the South Asian textile industry, reoriented the ties between the agrarian, the urban and the artisan spheres of South Asian society; it eliminated major avenues of paid labour for millions of Indian women across the subcontinent, accounting for no less than fifty percent of the total value of textile production; and yet despite all of their travails, hand-loom weavers survived. This transition was a process of de-agrarianization and urbanization of production relations, not the agrarianization or de-industrialization of professional artisans. Industrialization in South Asia was a complex process that resulted in mixed handicraft-mechanized industries that are in many ways unique to the history of South Asia.

Scholarship on the wide array of challenges, abuses and difficulties experienced by South Asia's weavers since the beginning of colonialism tell vital stories. But the neglected story of spinners and other female or part-time agrarian labour must also be added to the history of the textile industry. Their decline has been nearly absolute and total. In addition, the survival of South Asia's weaving traditions, communities, methods and heirloom cloths merits some celebration. In comparison to handicraft textile traditions elsewhere in Asia, continuity and survival of handicrafts in India is remarkable. Clearly, weavers and other artisans have struggled and continue to struggle painfully, and have lost much. But their communities and their textile traditions have survived, which suggests that their labour, protests and continuing adaptations had real power.

${ }^{43}$ Haynes, "Logic", pp. 195-203. 
$-978-90-47-42997-5$ 


\title{
FROM MARKET-DETERMINED TO COERCION-BASED: TEXTILE MANUFACTURING IN EIGHTEENTH- CENTURY BENGAL
}

\author{
Om Prakash
}

For many centuries prior to the nineteenth, India had been a major producer and provider of textiles of all kinds. Textiles were manufactured in large quantities all over the subcontinent to provide for consumption in the domestic, the Indian Ocean as well as the world market. While an overwhelming proportion of the total domestic demand for this basic consumption good was obviously met through local village level production involving very little, if at all any, trade, the proportion of total output entering regional or sub-continental trade was by no means entirely insignificant. This was particularly true of trade in luxury textiles where the element of regional specialization was of particular importance. One might also note the large-scale long-distance trade in textile raw materials as in the case of the dependence of the Bengal cotton textile sector on the import of cotton from Gujarat which, in turn, depended for its silk textile sector mainly on the raw silk imported from Bengal.

Beyond the subcontinent, in the west, Indian textiles were traditionally a familiar item in the markets of the Middle East, and via these markets, to a limited extent in the markets of the Mediterranean. The fifth century AD cotton fragments discovered at Berenike, a harbour site on the Egyptian side of the Red Sea, are the earliest patterned textiles of Indian origin so far recovered from an archaeological context. ${ }^{1}$ In the east, Indian textiles were traded on a much more substantial scale in mainland and island Southeast Asia. A number of Indian textiles acquired from Sulawesi in Indonesia, for example, have been carbon-dated to the fourteenth and fifteenth century. Textiles have

${ }^{1}$ John Peter Wild and Felicity Wild, "Rome and India: Early Indian Cotton Textiles from Berenike, Red Sea Coast of Egypt”, in Ruth Barnes (ed.), Textiles in Indian Ocean Societies (London and New York: Routledge, 2005), pp. 11-16. 
reigned as a dominant aesthetic in Indonesia for centuries and have played an important role in various ceremonies in the islands. Indian textiles were quickly assimilated to fit local taste and subsequently were encoded with indigenous meaning. ${ }^{2}$

The first section of this paper focuses on the geography and the structure of textile manufacturing in Bengal in the seventeenth and the first half of the eighteenth century. In the sections we analyse in some detail the situation in the second half of the eighteenth century when a fundamental alteration in textile manufacturing and procurement occurred. This was a direct outcome of the availability of substantive political leverage to the English East India Company in Bengal following the battle of Plassey in 1757 and the grant of diwani rights to the Company in the province in $1765 .^{3}$

\section{Textile Manufacturing and Procurement in Bengal}

With the rise of an early modern world economy, there was a significant increase in the volume and value of trade in Indian textiles both in the markets of the Indian Ocean as well as of those in Europe and the New World. The unquestioned domination of Indian textiles in the Indian Ocean trade has to be understood essentially in terms of the subcontinent's capacity to put on the market a wide range of textiles at highly cost-competitive terms making it in some sense the 'industrial' hub of the region surrounded by west Asia on one side and Southeast Asia on the other. As far as the European market was concerned, the quantum jump in the volume and value of the Indian textiles exported by the European corporate enterprises, mainly the Dutch and the English East India Companies, took place from the last quarter of the seventeenth century onward. This was an outcome of a revolutionary change in European fashion, putting Indian fine cotton and silk textiles

\footnotetext{
${ }^{2}$ Himanshu Prabha Ray, "Far-flung Fabrics - Indian Textiles in Ancient Maritime Trade", in Ibid., pp. 17-37.

${ }^{3}$ From the second half of the century, we are somewhat better informed about variables such as the cost structure of the industry, the level of profitability, etc. This information is contained in extensive documentation available in the archives of the Dutch East India Company. Documentation pertains essentially to the correspondence between the Dutch and the English East India Companies regarding the alleged hindrances being placed in the textile procurement of the former by the latter. The report of the Dutch factor on a joint English-Dutch-French mission of 1767 will be the main source of this paper.
} 
right at the top of the fashion ladder. These textiles suddenly found favour with the European nobility and aristocracy, reportedly including even the English queen. ${ }^{4}$

Regional specialization in the subcontinent in the manufacturing of textiles was an important element in the history of the textile sector over the centuries. Coromandel on the southeast coast of India had traditionally been the leading manufacturer of relatively inexpensive cotton textiles which were either plain or patterned on the loom. They were often dyed in bright colours with vegetable dyes. While both inferior and superior grade cotton textiles were manufactured in large quantities in Gujarat, the region also provided high-grade silk and mixed fabrics. Bengal was the other major textile producing region in the subcontinent specializing in the production of luxury cotton, silk and mixed fabrics. Given this pattern of specialization, it is not surprising that the relative share of Bengal textiles in the Indian Ocean trade - which was largely a low-cost market - was only of limited significance. But since the European market was essentially a luxury textile market, it became increasingly dominated by the textiles woven in Bengal. At the turn of the eighteenth century, as much as 40 percent of the total cargo exported to Europe from Asia by the Dutch as well as the English East India Company originated in Bengal and consisted in a large measure of textiles and raw silk. ${ }^{5}$

The European corporate enterprises procured cotton, silk, mixed cotton and silk textiles in Bengal. Among the cotton textiles, the principal division was between the muslins and the calicoes. Of the two, muslins were more loosely woven and, on an average, were made of finer yarn. The best quality muslins were produced in the district of Dhaka, where a particularly well-known centre of production was Sonargaon, situated at a distance of about fifteen miles east of the city of Dhaka. The names of some of the Dhaka muslins were shab-nam (evening dew), ab-i-rawan (running water) and bakt-hawa (webs of woven wind). According to Tavernier, muslins "are made so fine, you can hardly feel them in your hand, and the thread, when spun, is scarce discernible". ${ }^{6}$

\footnotetext{
${ }^{4}$ See the paper by Beverly Lemire in this volume.

${ }^{5} \mathrm{Om}$ Prakash, The New Cambridge History of India; Vol. 2, Part 5. European Commercial Enterprise in Pre-colonial India (Cambridge: Cambridge University Press, 1998), ch. 4.

${ }^{6}$ Quoted in Edward Baines, History of the Cotton Manufacture in Great Britain (London: Fischer, 1835), p. 57. The emphasis is mine.
} 
The staple varieties of muslins procured by the Europeans were khasa and malmal, both plain muslins of good quality. However, quite a few of the pieces procured were brocaded in gold, silver, or silk threads, usually in floral patterns. Many of the pieces also had their borders woven in gold threads.

Textile production was without any doubt the premier manufacturing industry in early modern Bengal as indeed it was in many other parts of the subcontinent. What is it that we know about the way it was organized, the methods of procurement for purposes of trade, the volume and value of trade by the Indian and the European merchants, the scale of the industry's output, its cost structure and the profitability level and so on? Briefly, what we do know in great detail is the volume and value of the Bengal textiles procured by the European corporate enterprises for export to Europe and other parts of Asia. As far as Indian and other Asian merchants involved in trade in Bengal textiles are concerned, such information is available only on an extremely casual and sporadic basis. What we also know in great detail is the way the manufacturing and procurement were organized. However, we know little about the volume and value of textile output in the region, the cost structure of the industry or the level of its profitability.

Working on the basis of the cotton yarn procured from the spinner, the basic unit of production in the manufacturing of textiles was the weaver operating as an independent artisan. To a certain extent, the production of standardized varieties of textiles for traditional markets was carried out on the basis of the weavers' own resources and at their own risk. There is evidence, for example, that several varieties of comparatively coarse cloth were produced on this basis in the district of Malda in north Bengal for eventual sale to merchants engaged in trade with Pegu, north India (Hindustan) and Persia, which had traditionally been important markets for these varieties. The bulk of the marketed output, however, was produced on the basis of an agreement between merchants - many of whom were intermediary merchants known in Bengal as paikars - and weavers specifying details such as the quantity to be produced, the price and the date of delivery. A part - often a substantial part - of the final value of the contract was given in advance to enable the weaver to buy the necessary raw materials as well as to sustain himself and his family during the period of production.

The three key elements in this system were the weavers' need of finance, their relatively limited access to the market, and a desire on their part to avoid risks arising out of their inability to forecast 
correctly the behaviour of the demand for a given variety of textiles. This structure, which could be described as the contract system, was essentially a variant of the standard European putting-out system. Unlike in the European case, the Indian weaver bought his own raw material and exercised formal control over his output. Of course, the merchant who had given the advance had first claim on the output, and debt obligations often rendered the artisans subject to coercive control by the merchants. ${ }^{7}$

Though grossly inadequate and perhaps not entirely representative, the available evidence on the weavers' costs and the merchants' markup enables us to form some idea of the magnitudes involved. A 1670 report on Malda in north Bengal suggested that standardized textiles worth Indian Rupees (Rs.) 800,000 to Rs. 1 million were sold in the district annually for export to places such as Pegu, Agra, Surat and Persia. If these were bought for cash directly from the producers - who brought them into Malda rather than from the intermediary merchants - the saving in cost would be between 12 and 15 percent. The mark-up by the merchant would, of course, be substantially greater under the contract system to compensate him for the additional risks borne. These risks were not inconsiderable. For example, a sudden rise in the cost of living in the wake of a famine, or the appointment of a particularly tyrannical official in a given area, might lead to a mass migration of the poor weavers to a more convenient location, to the great loss of the merchants. Some data relating to $1686-7$ in respect of khasas, a staple variety of muslin procured by the Dutch East India Company (VOC) in fairly large quantities in Bengal, suggests that about two thirds of the price obtained by the weaver covered the costs of the raw material, the remainder being the reward for his labour. The mark-up by the intermediary merchant (calculated on the basis of the price agreed upon at the time of the contract between the Company and the merchant) was 35 percent in the case of grade one, 55 percent in that of grade two, and as much as 142 percent in that of grade three. ${ }^{8}$

The European corporate enterprises made use of the existing procurement organization, though in the course of time they did indeed introduce modifications and innovations with varying degrees of success in a variety of directions aimed at solving specific problems that

7 Om Prakash, The Dutch East India Company and the Economy of Bengal 16301720 (Princeton: Princeton University Press, 1985), pp. 98-99.

8 Ibid., pp. 99-100. 
they encountered. An important functionary made use of by the Europeans was the dalal (broker), an Indian employee with an intimate knowledge of both the local market and the intermediary merchants. He was ordinarily a salaried employee, and his duties included collecting information about the market price of various goods as well as identifying merchants with a good reputation for honouring contractual obligations. These merchants were brought by the dalal to the relevant company and agreements were concluded between the company and each of the merchants willing to supply at mutually agreed terms. In the case of textiles, the agreement specified the quantity to be supplied, the period of delivery, and the price per piece of each of the different varieties contracted for.

The merchants had the goods manufactured mainly on the basis of the contract system which, as we have seen, obliged them to give a part of the value of the contract to the producers in advance. The merchants, therefore, insisted that the company similarly give them an advance, which in the case of Bengal was ordinarily between 50 and 65 percent. The intermediary merchants who did business with the Europeans were an extremely heterogeneous group. In the case of the VOC in Bengal, at one end it included merchants such as Khem Chand Shah, who engaged in large-scale domestic and overseas trade and who owned several ships. At the other end, there were marginal merchants who genuinely could not have operated except on the basis of the advances received from the Company. Once the goods were delivered into the Company's warehouses, the deviation from the samples was worked out and the price finally paid to the merchants was adjusted accordingly. ${ }^{9}$

There were occasional deviations from this broad structure of procurement. At places such as Dhaka and Pipli, for example, the VOC is known to have used the services of commission agents (also called dalals) to procure export goods. The agent was given a certain amount of money, which he invested among the weavers on behalf of the Company and at the Company's risk. After the goods had been delivered, the agent was entitled to a two percent commission (arhat) on the total value of the transaction. Another interesting functionary is the head weaver (hoofd wever). His precise status is not clear, but he acted as an intermediary between the weavers and the buyers of their produce.

9 Ibid., pp. 102-7. 
He appears to have exercised some authority over the members of his community, ensuring a certain amount of regularity in the supplies. His services were often utilized by the intermediary merchants, who would enter into a contract with him and give him an advance. On the limited occasions on which it was able to do so, the Company dealt directly with the head weavers and saved on the margin of the intermediary merchants. Thus, in 1670, a head weaver of Hughli agreed to supply fotas - an ordinary calico - at Rs. 70 per twenty pieces, whereas the merchants were asking for a price of Rs. 90 . Such deals, however, had to be made very discreetly because the intermediary merchants were always on the lookout to undermine the position of head weavers.

By far the most important problem the corporate enterprises faced in the procurement of textiles was the presence of bad debts. The intermediary merchants almost always supplied less than they had agreed to, either because the producers had not fully honoured their obligations toward them or because they themselves had chosen to divert part of the goods procured to third parties at better terms. Second, of all the goods received by the companies, a part was usually found unacceptable because of its poor quality. Finally, even in respect of goods accepted, for reasons of quality deviation, the final price paid to the merchants was ordinarily lower than that originally agreed upon. The result was that quite often the value of the goods accepted by a company from a particular intermediary merchant was less than the sum of money given to him in advance. The balance constituted a bad debt. Preventive measures taken by the VOC in Bengal included a closer investigation into the credentials of the intermediary merchants before contracts were given out to them, and a denial of fresh contracts to those of them who owed money to it. But since the Company did not want to lose the bulk of its suppliers to its rivals, the latter measure was invoked only in the case of habitual offenders. The others were simply required to clear at least a part of their earlier obligations simultaneously with the new ones.

The emergence of bad debts was not the only problem the companies faced. Another serious problem was the receipt of goods from the intermediary merchants much later than the date mutually agreed upon. Part of the explanation lay in non-adherence to the schedule by the artisans, but in some cases the delay was deliberate. The delivery of goods only a few days prior to the scheduled departure of the ships left very little time for the factors to carefully examine the goods received, thereby increasing the chances not only that substandard items would 
be accepted, but also that they would fetch relatively high prices. The fact that the quality of the goods received was usually poorer than that of the samples given to the intermediary merchants had important consequences other than contributing to the emergence of bad debts.

Various measures were taken at different points in time by the companies to solve these problems to the extent possible. But given that the rate of growth of European demand for Indian goods far exceeded the rate of growth of their supply, the companies were not in a position to impose punitive measures on the suppliers with any degree of success. Indeed, in 1709 a number of textile suppliers dealing with the VOC refused to accept fresh contracts unless the Company gave them an assurance that henceforth in the event of only a limited variation between the quality of the sample given out and that of the pieces actually supplied by them, there would be no deduction made from the price mutually agreed upon at the time of the contract. The suppliers even insisted upon a refund of the price deduction made on textiles supplied during the preceding season. A similar distinct improvement would also seem to have taken place in the bargaining strength of the weavers $v i s-\grave{a}$-vis the textile suppliers. Writing in 1700 , for example, the Dutch factors at Hughli made the following observation:

The merchants inform us (and on investigation we find that they are speaking the truth) that because of the large number of buyers in the weaving centres and the large sale of textiles, the weavers can no longer be coerced. They weave what is most profitable for them. If one does not accommodate oneself to this situation, then one is not able to procure very much and the supplies go to one's competitors. ${ }^{10}$

\section{The Aftermath of Plassey}

The principal casualty of the gaining of political authority by the English East India Company in Bengal following the battle of Plassey in 1757, was the freedom hitherto enjoyed by the intermediary merchants and weavers to decide who to do business with and on what terms. They were now coerced into working for the Company alone at unilaterally determined conditions which were substantially below the market level. This made it impossible for the European rivals of the

10 "Explanation by the Dutch factors of why the orders were not supplied in full, 1700": Nationaal Archief, The Hague (hereafter NA), VOC 1638, ff. 17-19, II Section. 
EIC - mainly the Dutch and, to a smaller extent, the French - to procure adequate quantities of textiles. Within a few months of Plassey, the English factors were reported to be forcibly taking away pieces woven for the Dutch. In October 1758, when the Dutch protested against the English highhandedness, the English promised redress, but nothing was actually done. In the early 1760s, the commercial residents at Malda and Midnapur were instructed to ensure that the best weavers of Jagannathpur, Olmara and the neighbouring aurungs worked exclusively for the English.

The public posture adopted by the English was, however, quite different. A Fort William public notification dated 28 April 1775 asserted unambiguously that:

the weavers of the province of Bengal and Bihar should enjoy a perfect and entire liberty to deal with any persons whom they pleased and that no person should use force of any kind to oblige the weavers or other manufacturers to receive advances of money or to engage in contracts for the provision of clothes against their will, and that all persons offending against this order should suffer severe punishment. ${ }^{11}$

It was against this background that the Dutch proposed to the English in 1767 that they should be assigned weavers in the various aurungs who would then be allowed to work for them without hindrance. The result was the setting up of a joint investigative mission of the English, the Dutch and the French East India Companies. It is the report of the Dutch representative on this mission that together with several other documents for this period constitutes the core of the material analysed in this paper. ${ }^{12}$

The mission was formally set up on 4 March 1767 with Johannes Mathias Ross as the Dutch representative along with his deputy Martinus Koning. The English representatives were John Bitter and Claude de la Porte, while the French East India Company was represented by Roeland and Des Granges. Ross's instructions stipulated that he along with Koning would report to English governor Harry Verelst

${ }_{11}$ NA, The Notification was signed by J. P. Auriol, Assistant Secretary, Appendices to the memoir of Director Johannes Bacheracht for his successor, Johannes Mathias Ross, dated 31 July 1776, Hooge Regering Batavia (hereafter HRB) 246 (unfoliated).

${ }_{12}$ The Report is entitled, "Bericht van den koopman Johannes Mathias Ross wegens de commissie in de Arrengs [met bylagen] 1767". It was submitted to Director George Louis Vernet at Hughli on 26 December 1767. It is available at the NA, under No. 66 in the series Nederlandse Bezittingen in Voor-Indie (hereafter NBVI). The report is not foliated. The access code is 1.04.19. 
at Calcutta wherefrom they would proceed together with the English and the French representatives to the textile aurungs (a localized centre of textile manufacturing) to:

investigate the best procedures to be followed to put out the contracts so that each of the three nations was served satisfactorily. Towards that end, you would make an accurate estimate of the amount of land in each aurung which was used for planting cotton as well as of the average annual output of cotton in each aurung. You would also find out the number of weavers and classify them as being of excellent, middling or poor quality. ${ }^{13}$

The mission was also directed to find out the number of pieces of a specified fineness that a weaver could be expected to weave in a month. Ross was also asked to find out if there were persons available locally for appointment as head-dalals of the Company to whom funds could be entrusted safely.

Since textiles of different quality were produced and bleached in different hamlets of each aurung, a precise investigation was to be carried out behind the reasons accounting for this phenomenon. Was it due to inherent differences in the workmanship of the weavers belonging to different hamlets or was this a function of the differing quality of water used for bleaching purposes? It was known that textiles woven in one aurung were often bleached in another for good results. Finally, Ross was told that with a view to deriving the maximum benefit from a mission such as this, he was to collect precise information regarding the varieties of textiles produced in each aurung, the prices at which these were available there, and the varieties that could be bought or sold there at a profit. Any differences with regard to weights and measures used in these aurungs as compared to Hughli were also to be recorded. ${ }^{14}$

Ross and Koning travelled to Calcutta on the 11 April but were told by Bitter and La Porte that they would not be ready for the trip for another two weeks. A message was subsequently received at Hughli from La Porte that the mission would start on the 4 May and that they would expect the Dutch representatives to join them at Duarhatta, an aurung under the Haripal factory of the English. The team would

\footnotetext{
${ }^{13}$ Instructions by Vernet for Ross at Hughli dated 22 April 1767: Appendix A, Report by Ross, NVBI, 66.

${ }^{14}$ Instructions by Vernet for Ross at Hughli dated 22 April 1767: Appendix A, Report by Ross, NBVI, 66.
} 
start with the aurungs of Haripal and Dhaniakhali and then go on to Chandrakona. The English would then return to Calcutta while the Dutch and the French could continue with the mission to Santipur and other places. This violated the agreement between the English governor and the Dutch director finalized in February 1767 that all aurungs where textiles were manufactured would be visited by the full team.

The Dutch team left on the 23 April for Calcutta where the French had already arrived two days earlier. When the question of the number of aurungs to be visited was raised with governor Verelst, he replied that it was John Bitter who had questioned the advisability of doing all the aurungs in one trip. Verelst reiterated that the basic purpose of the mission was to form an accurate estimate of the total number of weavers available in the aurungs. This was necessary before the number of weavers assigned to each company could be worked out.

When the representatives of the three companies met at Bitter's house at Calcutta, Ross suggested that in order to save on time and expenses, it would be optimal to begin at Chandrakona, go on to Santipur, Kasimbazar and Bhagwangola, then cross the river and visit the aurungs at Malda, Buddaul, Jagannathpur, Handiaal, Dhaka, Bhusna and Bureng before returning home. But the English insisted that they could not be away from Calcutta for so long and would, therefore, insist on visiting Haripal and Dhaniakhali first. The Dutch and the French had no option but to agree. That is what explains the fact that the detailed quantitative information presented later in the paper pertains to these two aurungs. The only other aurung for which detailed information is available is that of Chandrakona. Having agreed to meet at Duarhatta on the 4 May, the group dispersed.

Ross and Koning reached Haripal on the 28 April. The Dutch gumashtas, however, called on them only on the 1 May. By way of an explanation, it was pointed out that the fear of the English was such that all dalals and head weavers had been busy greeting Bitter at Duarhatta with fruit and other gifts. The Dutch intermediary merchant Samram who had been sent from Calcutta to Khattorah (under the Haripal factory of the English) with instructions to join Ross at Duarhatta also joined him on the 1 May. He reported that there were about 400 weavers at Khattorah each capable of producing on average two pieces of yarn rumals each month making a total of 9,600 pieces per annum. All the weavers were obliged to work exclusively for the English. The French had put out some contracts last year but all the pieces being 
manufactured for them were cut off the looms and the weavers concerned meted out both bodily and monetary punishment. ${ }^{15}$

Samram was asked to send a circular letter to all the Dutch gumashtas and merchants to visit Ross together with their dalals. When asked why there were serious shortfalls in the supplies against the contracts of the preceding year, the unanimous explanation offered was the highhanded behaviour of the gumashtas of the English Company and the private English traders. The English Company had reportedly forced fresh contracts on the 28 April on the best weavers in this aurung worth 155,000 sicca rupees. This amounted to each weaver being made to accept advances in respect of the maximum amount of production that he could expect to achieve in a year's time. The private English traders were equally aggressive. Amounting to 37 in number, these individuals were completely indifferent to what they contracted for and what price they had to pay as long as they could earn a return of 9 percent per annum on their investment. They had brought in as much as 350,000 sicca rupees for investment in the aurung. The deadly combination of the violence resorted to by the English Company and of the substantially higher prices offered by the private English traders worked towards the utter ruin of the Dutch Company.

A visitor to Ross told him under a guarantee of his name being kept secret that the English had expressly prohibited all dalals and weavers from declaring that they ever impeded the work of procurement by the Dutch. When they were asked to present themselves at Duarhatta, they were to take the position that they served the Dutch as faithfully as they did the English. Ross was surprised that the head-gumashta of the English had even considered it necessary to recommend such a course of action to them. The fear of the English among the gumashtas and the weavers was so all-pervasive that "an English peon or an employee of equal rank was held in greater esteem by them than he (Ross) himself". ${ }^{16}$ There was thus no real risk of their ever declaring that they were made to discriminate against the Dutch.

On receiving information that the English had reached Duarhatta, Ross and his deputy joined them and the French there. The purpose of the English alerting the gumashtas and the dalals as previously described became clear to Ross when he found that Bitter and La Porte were

15 Ibid.

16 Ibid. 
interpreting the purpose of the mission as being an investigation into the complaints of the Dutch regarding textile procurement. The Dutch were thus the complainants, the gumashtas and the weavers the persons against whom the complaints had been made, and the English the judges. This was completely contrary to the assurances given to Ross by governor Verelst at Calcutta on 24 April when he had reiterated that the purpose of the mission was to make an accurate estimate of the number of weavers and the scale of production. The French supported Ross's stand but Bitter stuck to his position. He suggested that in order to prevent future disputes, all the pieces produced in the aurungs should be appropriated and then divided among the three companies according to their requirements. Any pieces left over were to be made available to the English private traders. When Ross pointed out that this plan was completely impractical, he was told that he was not genuinely interested in the redressal of the Dutch grievances. At this point the Dutch and the French left the meeting in protest. That is how the mission started its work.

On the 6 May, Bitter ordered the arrest and despatch to Calcutta of the six weavers who had been complaining and agitating over the preceding two months about the excesses of the English gumashtas and of the low prices paid by them. The effect of this was the spread of terror among the artisans so much so that the dalals and weavers of Haripal who had earlier promised to Ross that they would jointly and publicly protest against the excesses of the English gumashtas lost their nerve and backed out of their commitment. ${ }^{17}$

At a dinner hosted by Ross for his English and French colleagues on the 12 May, the deputy English representative La Porte, who had arrived before Bitter, was told that the Dutch had been unable to put out any contracts at all. This was due to the fact that an English order of the 9 May had established that over the following three months, on pain of the severest punishment, all weavers would work only for the English. The weavers still owing nearly half of the advances given by the VOC in the preceding year were even offering to return them. This was because they were complaining that the English gumashtas had forced upon them contracts and advances worth more than what they could expect to produce in the course of a whole year. The weavers to whom the English had put out their contracts were precisely the ones who had

17 Ibid. 
always worked for the Dutch and still owed them supplies against the advances of the preceding year. All that La Porte did by way of a response was simply to shrug his shoulders saying that this could not be helped.

The next day Ross told Bitter that his belief that the aurung of Haripal was capable of producing annually only 48,000 to 50,000 pieces of textiles was misplaced and that the actual production capacity was between 90,000 and 100,000 pieces. He added that even the latter number could be enhanced considerably "only if the English desisted from using violence and force on the weavers and restored their freedom completely". ${ }^{8}$ In the meantime, an order had arrived from governor Verelst for Bitter saying that "the procurement of textiles for the English Company was to be regulated in such a manner as to cause the least hindrance to the procurement by the Dutch". ${ }^{19}$ Bitter also admitted that the aurung could probably produce 60,000 pieces annually and that the English had put out contracts for 36,000 pieces. That left 24,000 pieces for the Dutch whose duty it was to ensure that their gumashtas got hold of the necessary number of weavers. Ross wondered that if the entire lot of 24,000 pieces was to be treated as available to the Dutch, how would the French and the English private traders, who had already sent in as many as 350,000 sicca rupees for investment in the aurung, be able to procure anything. ${ }^{20}$

The English involvement in the mission came to an end on the 11 June, when Bitter was instructed to proceed to Chandrakona. Ross and his deputy decided to continue on the mission and left for Dhaniakhali in the same aurung on the 19 June with the intention of continuing southwards in the direction of Khirpai and Chandrakona. As for the French, Roeland excused himself from the mission thus paving the way for Des Granges to become the leader of the French assisted by one Nicolai de Faranse. The curtailed mission decided to begin with Haripal and Dhaniakhali.

\section{The Aurungs of Haripal and Dhaniakhali}

Addressing the issue of the cultivation of cotton first, Ross pointed out that the local term used for the product was kapas and that it was grown

18 Ibid.

19 Ibid.

20 Ibid. 
in shrubs two to four feet high in three or four cornered balls with three kernels each. The variety grown locally was called kali which yielded a thinner yarn than the baga and the muri varieties. The muri kapas, yielding the finest yarn was grown in the areas surrounding Dhaka which were either stony and sandy, or had dense forests. This yarn was used for the manufacturing of the fine Dhaka varieties.

The kapas grown in and around the aurungs of Haripal, Dhaniakhali and Chandrakona was of a similar variety and the number of fields planted was strictly regulated in accordance with the amount likely to be consumed locally. There was thus no trade in the locally grown cotton. A bad crop then involved a rise in the price. In 1767, which was marked by an average crop, the price ranged between $81 \frac{1}{2}$ to $7 \frac{1}{2}$ ceers per sicca rupee. ${ }^{21}$ Once the cotton had been cleaned of the kernels and other impurities, the yarn obtained was around $1 \frac{1}{2}$ ceers. It was indeed not so much a rise or fall in the price of cotton that led to fluctuations in the price of the textiles as the wages of the spinners. Spinning cost at least five times the cost of the raw material. ${ }^{22}$

Ross's report contains a fair amount of information on the process of the weaving of many varieties of cotton, cotton and silk mixed, as well as silk textiles, manufactured in the aurungs of Haripal, Dhaniakhali and Chandrakona in the year 1767. The survey was carried out in these aurungs because being under direct English control, the collection of information was that much easier. Information pertains to variables such as the number of weavers, the number of looms and the number of houses (grouped in three categories of first, second and third quality) from which the weaver households operated. This information is available for each of the hamlets and villages covered by each of the sub-aurungs of the aurung (Table 8.1).

According to Table 8.1, the two aurungs of Haripal and Dhaniakhali had between themselves as many as 164 weaving villages containing 2,745 weaver houses of which around a quarter (26.7 percent) were first quality, about a third (32.1 percent) second quality and the remaining 41.2 percent of third quality. Of the total of 164 villages covered by the two aurungs, while 87 fell in the 8 sub-aurungs of the Haripal aurung, the Dhaniakhali aurung contained the remaining 77 villages spread over three sub-aurungs. 72 of the 87 villages of Haripal aurung

${ }^{21}$ The equivalent of 8 ceers was $11^{1 / 2}$ lbs.

${ }^{22}$ Report by Ross, NBVI, 66. 


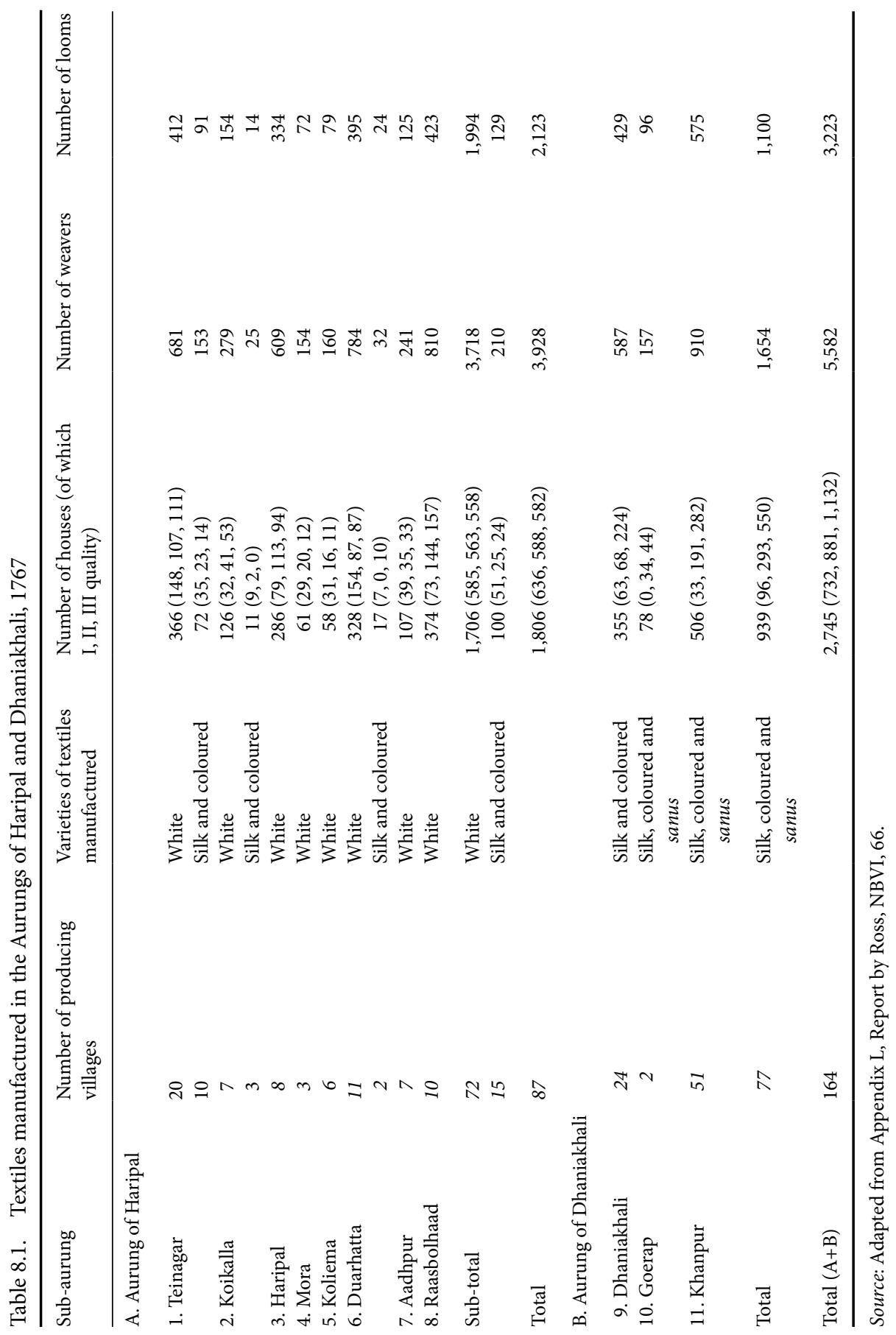


specialized in the production of white cotton textiles, the remaining 15 produced silk and coloured textiles. All 77 villages of the Dhaniakhali aurung specialized in the production of silk and coloured textiles, the only exception being sanus, a cotton calico piece-good.

According to Table 8.1, the total number of looms in the two aurungs was found to have been 3,223 not taking into account broken and otherwise unuseable ones. On the assumption of four weavers (one master-weaver assisted by three assistants) per loom, the number of weavers ought to have been 12,892 . The survey, however, listed only 5,582 weavers suggesting a short fall of as many as 7,310 weavers. Ross attributed this immense discrepancy essentially to three factors. The first was the frequent disturbances the area had suffered from over the preceding years. Secondly, Ross mentioned the exceedingly 'violent' and 'self-centred' procurement procedures followed by the English Company obliging a large number of weavers to turn to farming and other occupations. A contributing circumstance was the large scale "recruitment by the English Company of soldiers and coolies for their army as also of labour to carry out large scale construction activity in Calcutta." ${ }^{23}$ Thirdly, "unlike in an aurung such as Chandrakona where practically all farmers and artisans including smiths were also weavers", weaving in the Haripal and Dhaniakhali aurungs was a full-time activity. ${ }^{24}$

Table 8.2 provides a breakdown of the cost of manufacturing different varieties of cotton and cotton and silk mixed textiles between the cost of the yarn used and the wages bill of the weavers. This information is available for three varieties of cotton textiles and two varieties of cotton and silk mixed textiles. The cotton textiles include four kinds of dorias (a fine quality calico) of the standard size of 40 covid length and $21 / 4$ covid width (the covid was an indigenous measure equalling half a yard) containing 1,100 to 1,700 threads, two kinds of terrindams (a fine quality muslin), again of the standard size of 40 covid length and $2^{1 / 4}$ covid width and containing 1,100 threads, and rumals (a fine quality calico) of 35 covid length and 13/4 covid width containing 1,300 threads. The cotton and silk mixed varieties are sirsick of 30 covid length and 2 covid width containing 1,800 threads and karraderry of the same size and containing 1,600 threads.

What Table 8.2 establishes quite explicitly is that cotton yarn of different qualities went into different varieties of the same textile.

23 Ibid.

24 Ibid. 


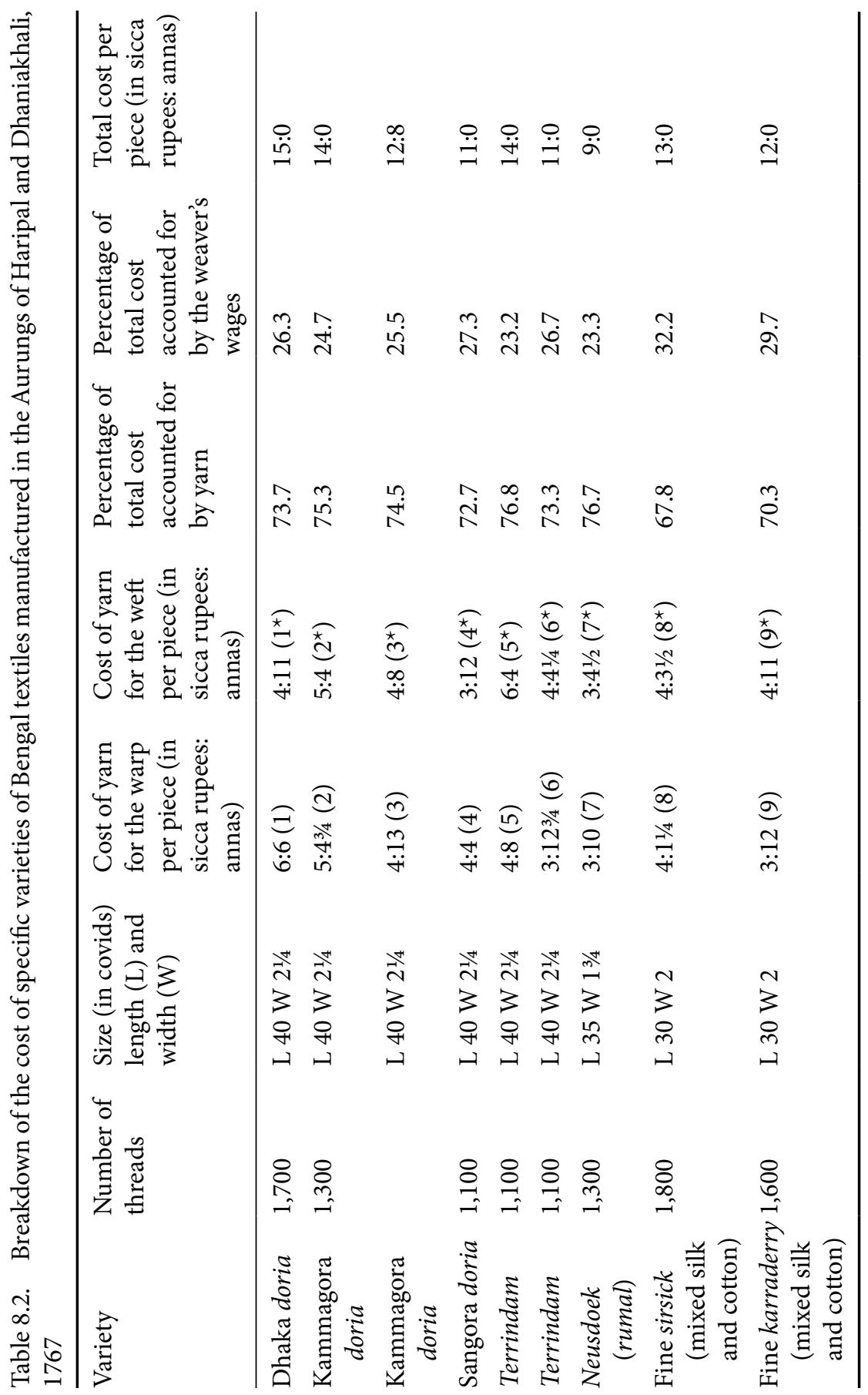




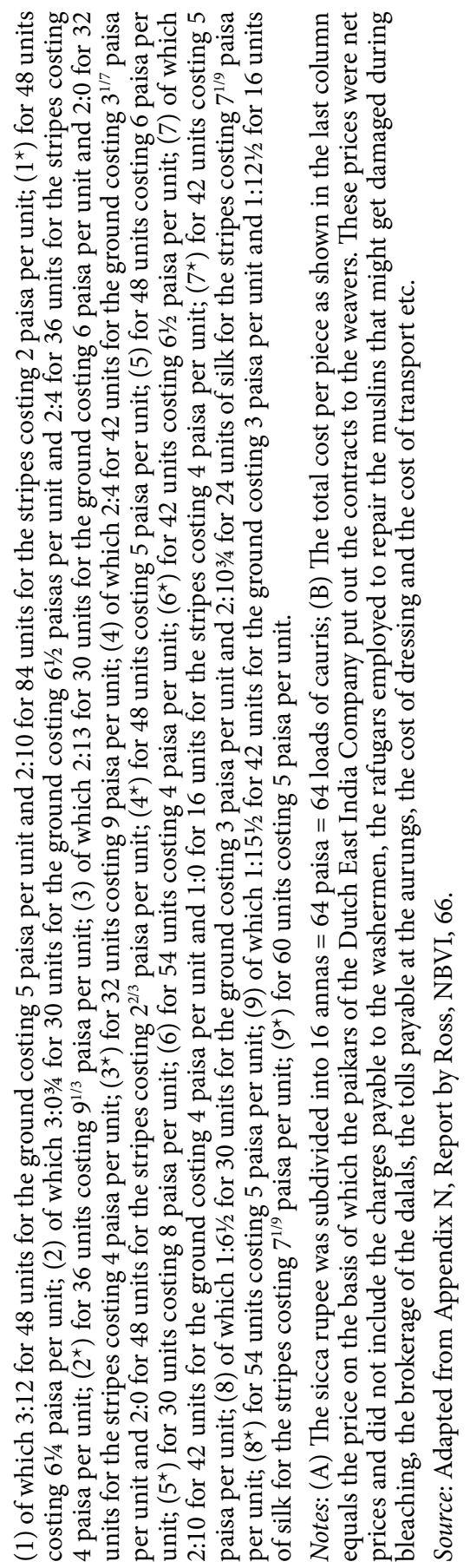


Thus while the yarn that went into the warp of the Dhaka doria cost 5 paisa per unit for the ground and 2 paisa per unit for the stripe, the corresponding figures for the yarn used for the Kammagora doria were $6^{1 / 2}$ paisa per unit and 4 paisa per unit respectively. The difference was even greater in the quality and price of the yarn used for the weft in these two varieties of dorias. While the yarn used for the Dhaka variety cost $6^{1 / 4}$ paisa, the one used for the Kammagora variety cost as much as $91 / 3$ paisa per unit. The same was true of the terrindams even though both the varieties had the same number of threads. The relative share of the cost of the yarn and of the weavers' wages bill in the total cost, however, did not differ very much across the different varieties of textiles. The share of the wages bill thus fluctuated roughly between a quarter and one-third of the total cost, being generally higher in the case of mixed cotton and silk textiles than in that of cotton textiles.

As for the factors contributing to fluctuations in the price of cotton yarn, in addition to the obvious one of fluctuations in the size of the crop, Ross drew attention to two other circumstances. One was fluctuations in the numbers of women spinners available at a point in time depending on what other employment opportunities happened to be available. By far the most important circumstance governing the price of yarn, however, was the volume and value of the contracts being put out at that point in time by buyers other than the English Company. In respect of each variety of yarn, the English Company fixed the price at which the weavers working for it had to be provided with the yarn, obliging the yarn producers to make up for their losses by increasing the price charged to the weavers of the other buyers to the maximum extent possible. ${ }^{25}$

A broadly similar situation prevailed in respect of the wage rate of the weavers. The current high rate was attributable in the first place to the large quantity of contracts being put out. But the more important factor at work was that the weavers working for the English essentially got practically nothing by way of wages. As a result, in order to earn their minimum subsistence, the weavers were forced to ask the Dutch and others - competing for their services but not in a position to dictate terms to them - to pay substantially higher wage rates. In the words of Johannes Mathias Ross, "We are thus obliged to pay for the English

${ }^{25}$ Appendix N, Report by Ross, NBVI, 66. 
not only in respect of the weavers' wages but also the cost of the yarn, in addition to the aurung tolls etc. that the English charge us" ${ }^{26}$

Table 8.3 conveys a broad idea of the average monthly output per loom for different varieties of textiles in the cotton textiles as well as the cotton and silk mixed textiles categories. The table assumes steady employment of the loom employing one master-weaver together with three assistants, further assisted by an unspecified amount of female and child labour in the family. As for the size of the pieces produced, unfortunately only the length is indicated which by and large conformed to the standard length of the pieces manufactured. As one would expect, the output was inversely related to quality (thus $5 \frac{1}{2}$ pieces of ordinary quality dorias being manufactured in a month as against 4 pieces of fine quality).

An unweighted average across cotton as well as cotton and silk mixed varieties of all qualities of the standard size suggests a figure of $52 / 3$ pieces per loom per month giving an annual average of 68 pieces. But considering that, on an average, across each variety, a substantially larger number of ordinary quality textiles than fine or superfine quality textiles were manufactured, Ross put the average figure at 6 per month or 72 per annum. A further adjustment of this figure was necessitated, Ross pointed out, by the fact that sickness and a multiplicity of festivals often kept the weavers away from the looms. An average figure of 60 pieces per annum was, therefore, more realistic. On that basis, the figure of 3,223 looms specified in Table 8.1 would have yielded an annual output of 193,380 pieces across all varieties of textiles. But considering that the number of weavers and their assistants was no higher than a total of 5,582, the number of looms that could be put to use on the assumption of four persons to a loom would have been no higher than 1,395 yielding a total of 83,730 pieces. Finally, Ross pointed out, that if one went by the considered opinion of the knowledgeable persons in the area, the number of weavers and assistants could safely be put at 7,200 providing employment to 1,800 looms. On this basis, the average annual output in the two aurungs could be assumed to be around 108,000 pieces across all varieties of textiles. $^{27}$

${ }^{26}$ Ibid.

${ }^{27}$ Report by Ross, NBVI, 66. 


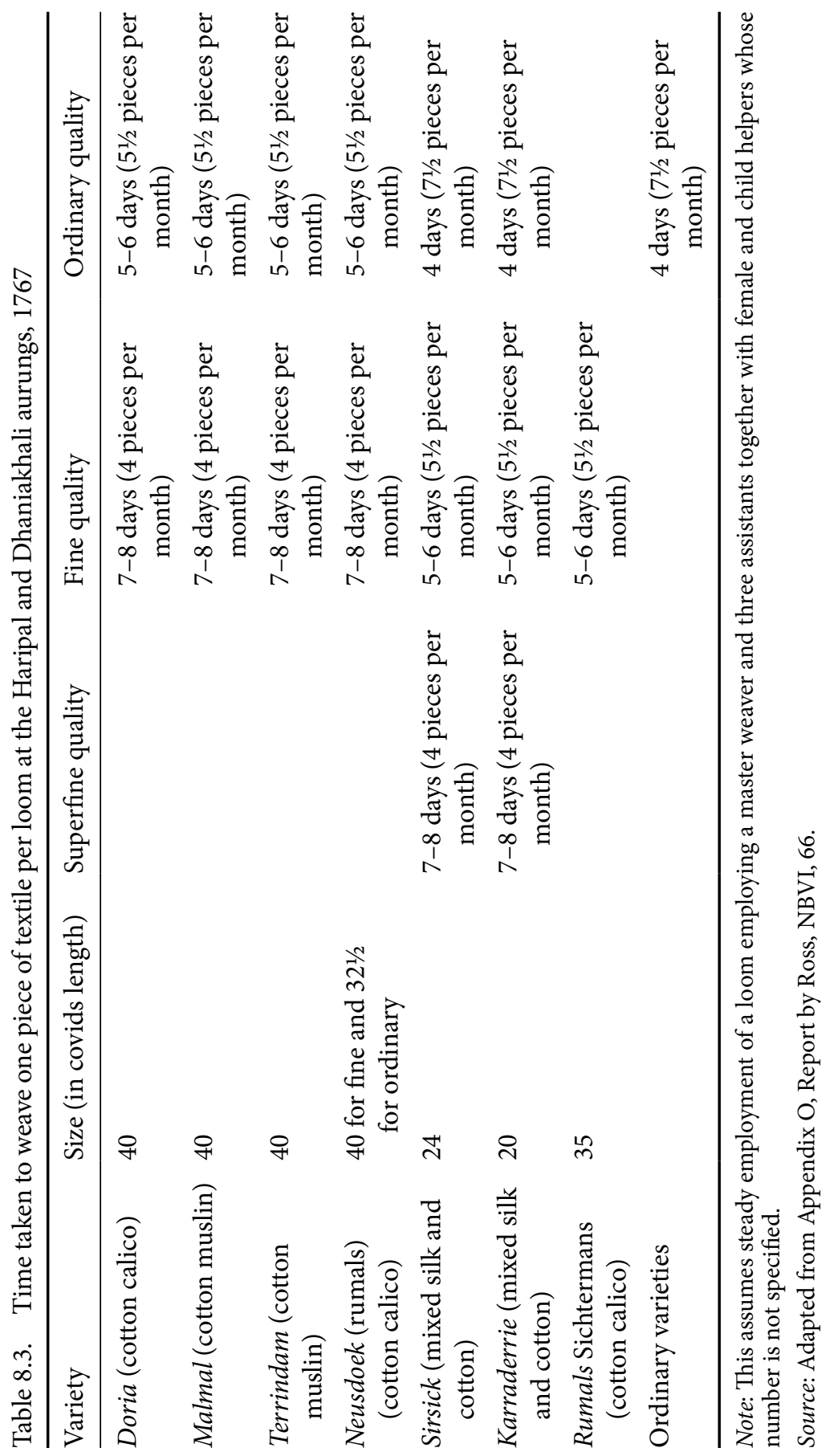




\section{Chandrakona and Adjacent Aurungs}

Another group of aurungs in the area for which quantitative information regarding the number of looms at work is available was that of Chandrakona and other aurungs in the vicinity. This information is summarized in Table 8.4. This group of aurungs lay to the south of those at Haripal and Dhaniakhali. While the Dutch carried out their procurement mainly at Chandrakona, the English trading station in the area was located at Khirpai. Similarly, the counterpart of the Dutch procurement station at Narrasjoul was the village of Sammraat. All these centres including Haripal and Dhaniakhali were under the jurisdiction of Bardwan. Khirpai was part of the jagir of the Jagatseth family. Under the rubric of textile producing centres in this region, one could add Kasisjora which was under a minor raja. Legend has it that this centre was a major producer of textiles before bad management had drawn the producers to areas such as Chandrakona under the jurisdiction of Bardwan. At one point as many as 500 weavers used to operate there producing mainly for domestic consumption. Some of these weavers continued to operate there and transported their output clandestinely to the markets of Narrasjoul,

Table 8.4. Number of looms at work in the aurungs of Chandrakona etc., 1767

\begin{tabular}{lccl}
\hline Name of aurung & $\begin{array}{l}\text { Number of } \\
\text { looms reserved } \\
\text { for the English }\end{array}$ & $\begin{array}{l}\text { Effective } \\
\text { number of } \\
\text { looms available }\end{array}$ & $\begin{array}{l}\text { Number of } \\
\text { looms reportedly } \\
\text { hidden }\end{array}$ \\
\hline Chandrakona & 903 & 896 & 200 \\
Narrasjoul & 231 & 300 & 50 \\
Khirpai & 350 & 350 & 50 \\
Radhanagar & 253 & 250 & 50 \\
Ghatal & 60 & 100 & 25 \\
Udinaspur & 50 & 50 & 10 \\
Hajipur & 50 & 60 & 10 \\
Kolmisoor & 0 & 15 & 0 \\
Total & 1,897 & 2,021 & 395 \\
\hline
\end{tabular}

Source: Adapted from Appendix T, Report by Ross, NBVI, 66. 
Chandrakona and Khirpai. No gumashta or dalal operated from that centre any more. ${ }^{28}$

The aurung of Narrasjoul where the Dutch bought their textiles was adjacent to Kasisjora while the English procurement centre of Sammraat was next to the border of Bardwan. There were seven weaver villages in the neighbourhood accounting for around 300 looms. In addition to the local output, these two centres received a substantial amount of textiles from neighbouring areas. The Jagatseth family got its textiles manufactured in the area through special gumashtas. The bulk of the remaining output was acquired by the English leaving very little for the Dutch and the others.

In addition to manufacturing textiles for the Companies, this region also had about 500 looms catering exclusively to the markets of Mocha, Basra and Jidda in respect of textiles of varying length, width and prices. Each loom produced on an average, four pieces per month. So in principle the number of pieces supplied to these markets could be 24,000 per annum but the actual number was smaller because many of the weavers did not work full-time. ${ }^{29}$

Coming next to the aurung of Chandrakona, Ross reported that the villages and hamlets under this aurung amounted to 47 accounting for about 1,100 looms producing cotton textiles and 200 looms producing silk textiles. About 3 miles northward was Khirpai with 350 to 400 weavers. The nine paikars operating at Khirpai had many weavers also working for them at Radhanagar, Udairajpur, Duanghons, Kajipur etc. with 27 weavers even in Chandrakona. Radhanagar was about an hour's distance in the south and southeast of Khirpai. It had about a 1,000 looms and had traditionally been a major procurement centre for silk and mixed textiles produced in this entire region. It also had about 100 looms producing cotton textiles. It was well-known that the only major item procured by the Europeans in Radhanagar was soosies, a high quality silk textile. Other varieties produced there were mainly for sale in Surat, Mocha and Jidda etc. According to Ross's calculations, there were about 5,000 looms in Radhanagar producing silk and mixed textiles. At an average of four pieces per month, this would involve an annual output of 240,000 pieces worth around 15 lakhs of rupees at an average price of $6 \frac{1 / 4}{\text { rupees per piece. }}{ }^{30}$

28 Ibid.

29 Report by Ross, NBVI, 66.

30 Ibid. 
The English East India Company had declared raw silk produced in Bardwan, Medinipur and Kasisjora as a monopsony item. It bought raw silk from the farmers at 16 tolas per rupee and sold it to the weavers at seven to nine tolas per rupee. The large scale production of silk textiles had cut into the number of cotton textiles available to buyers who could not practice violence on the producers the way the English Company could. ${ }^{31}$

While all the European corporate enterprises - the Dutch, the English and the French - operated in the textile aurungs discussed above, by virtue of the political power enjoyed by it, the English East India Company (and by extension, the private English traders enjoying its protection) was in a category by itself. Before we go into the details of the manner in which the English grossly misused their position of authority and coerced the intermediary merchants and the weavers into working for them at terms substantially below the market, let us look at some quantitative data regarding English Company procurement available for the aurungs of Chandrakona, Khirpai and Radhanagar etc. Table 8.5 sets out the details of the contracts put out by the English Company at the aurungs of Chandrakona and Radhanagar etc. in the year 1767.

According to Table 8.5, the total number of pieces contracted for by the Company at the aurungs of Chandrakona, Khirpai and Radhanagar etc. in 1767 amounted to 28,700 pieces consisting of 15,450 pieces of malmals, 9,300 pieces of dorias, 250 pieces of dassies and 3,700 pieces of soosies. The malmals contracted for included 300 pieces of the usual length of 40 covids but a highly unusually large width of 3 covids. The prices for 1767 were, on an average, higher by 16 percent than the ones for 1766 . These prices were the net prices payable to the weavers and did not include the payment for the services of the washermen etc. It was stipulated in the contract that the prices indicated were in each case in respect of the first quality. Once the goods had been supplied they were sorted into five qualities, each lower quality being evaluated at $6^{1 / 4}$ percent lower than the price of the quality immediately above it. Thus in the case of the wide muslins, against the price of Rs. 24 for the first quality, the price paid would be Rs. 22:8 annas for the second, Rs. 21 for the third, Rs. 19:8 annas for the fourth, and Rs.18 per piece for the fifth quality respectively. Pieces not found good enough to qualify

31 Ibid. 
Table 8.5. Textiles contracted for by the English East India Company together with their prices at the aurungs of Chandrakona, Khirpai and Radhanagar etc., 1767

\begin{tabular}{|c|c|c|c|c|c|c|}
\hline & \multirow{2}{*}{$\begin{array}{l}\text { Quantity } \\
\text { (number } \\
\text { of pieces) }\end{array}$} & \multirow[t]{2}{*}{ Quality } & \multirow{2}{*}{$\begin{array}{l}\text { Size } \\
\text { (length } \\
\text { and } \\
\text { width in } \\
\text { covids) }\end{array}$} & \multicolumn{2}{|c|}{$\begin{array}{l}\text { Price per piece } \\
\text { (in sicca rupees) }\end{array}$} & \multirow{2}{*}{$\begin{array}{l}\text { Value of } \\
\text { current } \\
\text { year's } \\
\text { contract }\end{array}$} \\
\hline & & & & $\begin{array}{l}\text { Previous } \\
\text { year }\end{array}$ & $\begin{array}{l}\text { Current } \\
\text { year }\end{array}$ & \\
\hline \multicolumn{7}{|c|}{ Malmals (fine cotton muslin) } \\
\hline & 300 & fine & 40,3 & 21 & 24 & 7,250 \\
\hline & 1,000 & fine & $40,2^{1 / 4}$ & 16 & 18 & 18,000 \\
\hline & 4,000 & fine & 40,2 & 12 & 14 & 56,000 \\
\hline & 750 & fine & 40,2 & 13 & 15 & 11,250 \\
\hline & 7,000 & ordinary & 40,2 & $81 / 2$ & 11 & 77,000 \\
\hline & 1,600 & superfine & 40,2 & $16^{1 / 4}$ & 18 & 28,800 \\
\hline & 800 & Rasballabhpuria & 40,2 & 13 & 15 & 12,000 \\
\hline Total & 15,450 & & & & & 210,300 \\
\hline \multicolumn{7}{|c|}{ Dorias (fine cotton calico) } \\
\hline & 3,000 & fine broad stripes & 40,2 & 12 & 14 & 42,000 \\
\hline & 300 & $\begin{array}{c}\text { fine embroidered } \\
\text { broad stripes }\end{array}$ & 40,2 & 13 & 15 & 4,500 \\
\hline & 1,000 & small chequered & 40,2 & 16 & 17 & 17,000 \\
\hline & 2,000 & big chequered & 40,2 & 12 & 14 & 28,000 \\
\hline & 3,000 & ordinary & 40,2 & $8^{1 / 2}$ & 11 & 33,000 \\
\hline Total & 9,300 & & & & & 124,500 \\
\hline \multicolumn{7}{|c|}{ Dassies (coarse cotton calico) } \\
\hline & 250 & small & $40,{ }^{1 / 4}$ & 11 & 13 & 3,250 \\
\hline Total & 250 & & & & & 3,250 \\
\hline \multicolumn{7}{|c|}{ Soosies (fine quality silk textile) } \\
\hline & 1,850 & diverse & 40,2 & 8 & 10 & 18,500 \\
\hline & 1,850 & diverse & $50,1^{5 / 8}$ & 8 & 10 & 18,500 \\
\hline Total & 3,700 & & & & & 37,000 \\
\hline \multicolumn{3}{|c|}{ Grand total 28,700} & & & & 375,050 \\
\hline
\end{tabular}

Source: Adapted from Appendix S, Report by Ross, NBVI, 66. 
even for the fifth quality would be designated as 'firty' (ferretted) and would be priced at the discretion of the Company. ${ }^{32}$

The contracts were distributed over a total of 41 paikars whose details are summarized in Table 8.6. The number of pieces contracted for in the aurungs (or sub-aurungs) of Chandrakona, Khirpai, Radhanagar, Ghatal, Udairajpur, Ramjibanpur and Sammraat for the year 1766 was 23,946 (or 1,995 $1 \frac{12}{2}$ per month) and for $1767,31,429$ pieces (or $2,619^{3 / 32}$ pieces per month). The number of looms assigned for the purpose in 1766 was 1,644 as against 1,761 in 1767 . What is very striking is the fact that these numbers suggest an obligation of providing, on an average, only 1.21 pieces per month per loom in 1766 and 1.48 pieces per month per loom in 1767 . This is way below the average output of 5 pieces per month per loom suggested by Tables 8.1 and 8.3 above. Did this imply a tacit understanding between the Company and its paikars that in return for their overall cooperation in the matter of the supply of the Company's textile requirements, they would be allotted a loom capacity substantially in excess of that needed for meeting the Company's requirements? Could this excess capacity then be diverted to meet the textile requirements of other buyers and markets substantially enhancing the overall business and the profit margin of these paikars? In the absence of firm information, however, this must remain only a speculative hypothesis.

What Table 8.6 also suggests is a considerable variation in the number of pieces/looms allotted to individual paikars both across aurungs as well as within an aurung. Thus while in the aurung of Chandrakona, a total of 900 pieces per month was allotted to 26 paikars giving an average of 34.61 pieces per paikar, the corresponding numbers in the aurung of Khirpai were 667 pieces to only 9 paikars giving an average of as many as 74.11 pieces or more than twice the average of Chandrakona. There were also considerable variations across individuals. The person to whom the biggest contract (225 pieces per month and 205 looms) was awarded was one Sarveshwar Pahari at Khirpai. The smallest contract was for 17 pieces with 9 looms at Chandrakona. It is not entirely clear why the contract at the aurung of Sammraat was given to a sarkar (or gumashta) of the Company rather than to a paikar with a substantially enhanced number of looms being assigned to him. Finally, an analysis of the names of the paikars to whom the contracts were given

\footnotetext{
32 Appendix N, Report by Ross, NBVI, 66.
} 
Table 8.6. Distribution of English East India Company contracts at Chandrakona etc. among different paikars, 1767

\begin{tabular}{llll}
\hline $\begin{array}{l}\text { Name of } \\
\text { paikar }\end{array}$ & $\begin{array}{l}\text { Number of } \\
\text { pieces per } \\
\text { month } \\
\text { contracted } \\
\text { for in 1766 }\end{array}$ & $\begin{array}{l}\text { Number of } \\
\text { looms assigned } \\
\text { to the paikar }\end{array}$ & $\begin{array}{l}\text { Number of } \\
\text { in } 1766\end{array}$ \\
& & $\begin{array}{l}\text { looms } \\
\text { assigned to } \\
\text { the paikar } \\
\text { in } 1767\end{array}$ \\
\hline
\end{tabular}

A. At the aurung of Chandrakona (26 paikars)

\begin{tabular}{|c|c|c|c|}
\hline Kamdev Thakur & 66 & 49 & 48 \\
\hline Raghudev Thakur & 15 & 19 & 16 \\
\hline Janki Thakur & 27 & 22 & 21 \\
\hline Gangaram Thakur & 27 & 27 & 24 \\
\hline Hari Ghosal & 21 & 18 & 18 \\
\hline Udit Thakur & 18 & 19 & 19 \\
\hline Sadhu Kar & 90 & 77 & 70 \\
\hline Jugal Poddar & 75 & 57 & 60 \\
\hline Kaliram Hai & 51 & 38 & 38 \\
\hline Gaurang Dutt & 45 & 41 & 41 \\
\hline Govardhan Sarkar & 45 & 40 & 40 \\
\hline Raghu Sarkar & 24 & 25 & 27 \\
\hline Bhagirath Das & 24 & 19 & 29 \\
\hline Motiram Poddar & 24 & 21 & 21 \\
\hline Uknitjan Teli & 30 & 20 & 22 \\
\hline Trilok Chaudhuri & 45 & 28 & 30 \\
\hline Titu Sarkar & 54 & 49 & 50 \\
\hline Trilok Sarkar & 27 & 18 & 23 \\
\hline $\begin{array}{l}\text { Lokicharan } \\
\text { Chaudhuri }\end{array}$ & 27 & 22 & 20 \\
\hline Jagannath Das & 40 & 35 & 35 \\
\hline Sani Sarkar & 30 & 29 & 29 \\
\hline Hit Kar & 18 & 15 & 15 \\
\hline Ganesh Poddar & 18 & 10 & 12 \\
\hline Jagannath Bairagi & 15 & 70 & 12 \\
\hline Jugal Bari & 17 & 8 & 9 \\
\hline Bairagidas Korni & 27 & 26 & 26 \\
\hline Total & 900 & 739 & 755 \\
\hline \multicolumn{4}{|c|}{ B. At the aurung of Khirpai (9 paikars) } \\
\hline Sarveshwar Pahari & 225 & 180 & 205 \\
\hline Kirparam Teli & 90 & 72 & 70 \\
\hline
\end{tabular}


Table 8.6. Cont.

\begin{tabular}{|c|c|c|c|}
\hline $\begin{array}{l}\text { Name of } \\
\text { paikar }\end{array}$ & $\begin{array}{l}\text { Number of } \\
\text { pieces per } \\
\text { month } \\
\text { contracted } \\
\text { for in } 1766\end{array}$ & $\begin{array}{l}\text { Number of } \\
\text { looms assigned } \\
\text { to the paikar } \\
\text { in } 1766\end{array}$ & $\begin{array}{l}\text { Number of } \\
\text { looms } \\
\text { assigned to } \\
\text { the paikar in } \\
1767\end{array}$ \\
\hline Panju Datt & 30 & 24 & 40 \\
\hline Sitaram Pal & 30 & 24 & 25 \\
\hline Sunder Mahi & 90 & 72 & 70 \\
\hline Manik Mondal & 60 & 48 & 46 \\
\hline Baburam Poddar & 60 & 48 & 50 \\
\hline Kashi Pal & 30 & 24 & 25 \\
\hline Gokul Das & $52 \frac{1}{2}$ & 42 & 40 \\
\hline Total & $6671 / 2$ & 534 & 571 \\
\hline \multicolumn{4}{|c|}{ C. At the aurung of Radhanagar (2 paikars) } \\
\hline Jugal Chaudhuri & 60 & 48 & 46 \\
\hline Motiram Dutt & 30 & 22 & 25 \\
\hline Total & 90 & 70 & 71 \\
\hline \multicolumn{4}{|c|}{ D. At the aurung of Ghatal (1 paikar) } \\
\hline Dukhiram Doba & 100 & 80 & 60 \\
\hline \multicolumn{4}{|c|}{ E. At the aurung of Udairajpur (1 paikar) } \\
\hline Sarbjot Thakur & 28 & 23 & 23 \\
\hline \multicolumn{4}{|c|}{ F. At the aurung of Ramjibanpur and Hajipur (1 paikar) } \\
\hline Hiranand Chaudhuri & 60 & 48 & 50 \\
\hline \multicolumn{4}{|c|}{$\begin{array}{l}\text { G. At the aurung of Sammraat ( } 1 \text { sarkar or gumashta being an employee of } \\
\text { the English Company) }\end{array}$} \\
\hline (Name not given) & 150 & 150 & 231 \\
\hline Grand Total & $1,995 \frac{1}{2}$ & 1,644 & 1,761 \\
\hline
\end{tabular}

For the current year (1767), the figure is $2,619^{3 / 32}$ pieces per month (or $31,429^{1 / 8}$ pieces per annum) representing an increase, on an average, of little over 31 percent.

Source: Adapted from Appendix U, Report by Ross, NBVI, 66. 
shows that all of them were Hindus, mostly ethnic Bengalis but also including the names of some Marwaris who had migrated from Rajasthan at some point. Persons carrying the last name of Poddar, figured in the list of paikars for both Chandrakona and Khirpai. As we noted earlier, Khirpai was part of the jagir of the Jagatseth family, also a Marwari immigrant to Bengal.

\section{Procurement by the English East India Company}

The English East India Company's procurement of textiles in the aforementioned aurungs was coordinated by John Bitter, the Company's Commercial Resident at Khirpai. The first thing that he ordered after arriving at the Residency was a survey of the weavers and the looms available in the area and the number of pieces of textiles manufactured in a year. He also ordered an estimate of the number of pieces contracted for and received the previous year by the Dutch and the French East India Companies, the English, Dutch and French private traders as well as the Indian traders. Finally, he asked for an estimate of the contracts already put out by each of these entities during the current year and the funds already invested. ${ }^{33}$

He next ordered all the paikars supplying the English Company to appear before him to explain why the quality of the pieces delivered the previous year had been not as good as of those supplied to the Dutch Company. The suppliers simply pointed out that the Dutch paid a 25 percent higher price. They also pointed out that it would be impossible to supply the same number of pieces (namely 21,590) as last year. The total output in the area was no higher than 42,500 pieces per annum and Bitter could expect to secure most of it only if he ordered the rival companies, their private traders and the Indian traders to leave the area. The 41 paikars listed in Table 8.6 were then held in detention and asked to provide the quantity listed against each in the table.

Against the total requirement of 25,000 pieces, the paikars were obliged to provide a total of 31,429 pieces, the excess of 6,429 pieces

${ }^{33}$ Letter from Ross at Khirpai to Vernet at Hughli dated 18 July 1767, Appendix P, Report by Ross, NBVI, 66. This letter is also available in the "Memorandum concerning the principal reasons why the Dutch East India Company's trade in Bengal, particularly in textiles, has not been proceeding satisfactorily" prepared by George Louis Vernet and presented to the English governor Harry Verelst dated 10 May 1768, NA, HRB 247, Appendix D. The volume is not foliated. 
being reserved for the poor-quality 'firty' pieces. Each paikar was ordered to sign a paper agreeing to supply the number of pieces recorded against his name. On refusal, each was administered ten canes on his naked skin and put in jail. They were told that if they did not sign the paper, Bitter knew of other ways to deal with them. Ross was shocked at this kind of treatment being meted out to paikars of stature, and social and financial wealth. After the lapse of a few days, these people came round and signed the papers.

Before leaving for Sonamukhi, Bitter appointed Motiram Mohan Basak, the brother of head gumashta Radha Mohan Basak, as the first gumashta of the aurung and instructed him to ensure that each of the paikars scrupulously kept to the supply schedule agreed to by him. Ross described this man as "a rogue and a scroundrel". ${ }^{34}$ He treated the paikars with extreme harshness and had even whipped a paikar to death. Ross detailed two other instances of Basak's behaviour towards the paikars. When a paikar brought his three pieces of textiles which he was obliged to deliver daily to Basak, while two of the pieces were found to be of passable quality, the third was found to be short of its supposed width of $2^{1 / 4}$ covids. The punishment inflicted on him was to make him rub his nose on the ground several times for a distance of $2 \frac{1}{4}$ covids. He was told that he was being let off with this minor punishment because this was his first offence. The piece was returned to him with the instruction that a replacement be provided the same day before sunset. The man was obliged to buy the replacement piece from another paikar at a price four rupees higher than what he was due to receive from the English Company. ${ }^{35}$

The behaviour of the paikars towards the weavers was no better. In one instance, three weavers had reportedly brought to a paikar one piece each of a quality that the latter dared not deliver to the English head-gumashta. The pieces were then tied around the necks of the weavers who were told to provide immediate replacements by buying them from others. They were escorted to their respective homes with the pieces tied around their necks by peons whose costs also they were made to reimburse. ${ }^{36}$

\footnotetext{
${ }^{34}$ Ross to Vernet, 18 July 1767, Appendix P, Report by Ross, NBVI, 66; HRB 247, Appendix D.

${ }^{35}$ Ibid.

${ }^{36}$ Ibid.
} 
The terms and conditions the English East India Company imposed on its paikars were substantially below market. The extent of such exploitation is conveyed by the fact that for a piece of cotton textile for which the Dutch East India Company would have offered Rs. 16, the average price paid by the English East India Company was no higher than Rs. 12. The terms of supply and evaluation were equally harsh. The pieces received from the paikars were subjected to an initial sorting from quality one to five and sent to the washermen, engaged by the Company's gumashta, for bleaching. They were then subjected to a second sorting before being sent on to the rafugars (the artisans engaged to repair any damage caused in the process of bleaching). The pieces were then subjected to yet another bleach before being sorted a third time. At this point, the pieces were sent on to Khirpai, chief factory of the region where the fourth round of sorting was carried out. The fifth and final round of sorting was reserved for Calcutta. ${ }^{37}$

The quality requirements imposed by the East India Company were quite strict. Pieces classified as third quality by the English would gladly have been accepted by the Dutch Company as first quality, thus fetching a considerably higher price. It is remarkable that even the pieces rejected by the Company as 'firty' had a profitable market. This margin was shared clandestinely between the Commercial Resident, the chief gumashta, and the paikars. In 1767 Resident John Bitter rejected 896 pieces of textiles as 'firty'. Many of these pieces were eventually sold by the paikars in the open market at between Rs. $6 \frac{1}{2}$ and Rs. 7 per piece higher than the price at which they had been evaluated by Company's factors before being rejected. Bitter had returned the pieces to the paikars after keeping a margin of Rs. 3 per piece for himself and Rs. $1 / 2$ per piece for the chief gumashta Radha Mohan Basak. But even after paying Rs. $3 \frac{1 / 2}{2}$ extra, the paikars managed to earn a net profit of Rs. 3 to Rs. $3 \frac{1}{2}$ per piece in the market for themselves. ${ }^{38}$

The suppliers of textiles at Khirpai estimated that the maximum that the group of aurungs under this English trading station could supply in the course of a year was around 50,000 pieces. The contracts put out by the English Company in 1767 amounted to 31,429 pieces (Table 8.6). The Dutch East India Company's contracts for the year were estimated at 8,100 pieces and of the French Company at 2,000 pieces,

\footnotetext{
37 Ibid.
}

38 Ibid. 
making a total of 41,529 pieces. That left a total of 8,471 pieces for all the private European traders, the Armenians as well as the Indian merchants put together. The English Company was likely to get the number of pieces that it had given out contracts for. The next group with political muscle was that of the private English traders enjoying the protection of the Company. As pointed out earlier, the cause of this group was further helped by the fact that they were quite indifferent to the quality of the pieces received as well as the cost of those pieces as long as they were able to earn a return of 9 percent per annum on their investment. These traders, whose number was estimated at 37 , were reported to have brought in as much as Rs. 350,000 for investment in textiles in the area. This represented only half of the total of Rs. 700,000 worth of textiles that they aimed to procure during the year. At an average cost of Rs. 12 per piece, this would amount to 59,000 pieces. According to Ross's calculations, for a piece for which the English Company would pay Rs. 10 and the Dutch East India Company Rs. 12:7 annas, the private English traders would be willing to pay as much as Rs.14. It was, therefore, not surprising that these traders were the most preferred buyers for any clandestine supplies available with the paikars. ${ }^{39}$

The supplies left for the Dutch and the French East India Companies and others including the Indian traders were, therefore, quite meagre. Indeed, Ross suspected that the best that they could do was to receive between one-eighth and one-fourth of the total that they had intended to buy and in fact had given out contracts for during the year. In view of this situation, the paikars dealing with the intermediary merchants who had accepted the Dutch contracts indeed offered to return the money taken in advance because they believed that the weavers could still be persuaded to return the advances given to them. Given the way the English were dealing with the paikars and the weavers, the latter were likely to be ruined. They claimed that on the pieces prepared for the English, not only did they get no recompense for their efforts, but in fact lost one to two rupees on the cost of the yarn that went into each piece.

A delegation of weavers proceeded to Calcutta with a petition (arzi) requesting that the prices offered to them be increased by at least so much as to meet their costs and afford them a subsistence wage. They

${ }^{39}$ Ibid. 
did manage to obtain an order directing John Bitter to do the needful. But this evidently was no more than a eyewash because Bitter not only openly disregarded the order but indeed threatened to have the weavers arrested in the event that they continued with their efforts. The phenomenon of the weavers running away from their looms and villages was, therefore, increasingly becoming a grim reality. According to a letter from Ross at Khirpai to his superiors at Hughli written on 18 July 1767, already 26 weavers had fled from their looms over the preceding eight days while the flight of another 23 was imminent. When the administrator of the Jagatseth's jagir in the area sought the banker's intervention in the matter, the latter pleaded total inability to do anything about the English oppression. ${ }^{40}$

\section{Conclusion}

The English conquest of Bengal in the second half of the eighteenth century was clearly a circumstance of great importance from the point of view of the textile industry of the province. The replacement of a market-determined by a coercion-based system of production and procurement dealt a heavy blow to the fortunes of the industry. The artisans and the intermediary merchants associated with the industry no longer received their due in the value of the total output of the industry. Without any doubt this caused a certain amount of distortion in the incentive structure in the sector with adverse consequences for total output.

It is, however, critically important to distinguish between the impact of the change in the system of production and procurement on output, and the share of different groups in the value of that output. There can be no question that the artisanal and the intermediary merchant groups suffered a substantive shrinkage in their share while the English East India Company and the private English traders were distinctly better off. But when it came to actual output, while a certain amount of dislocation did almost certainly take place in the short run, the long-term implications were evidently not particularly harmful. The system by and large was resilient enough to continue to deliver as would be evident from the continued high and indeed growing levels of trade, both intra-Asian as well as inter-continental.

40 Ibid. 
The picture of a ruined textile industry in the region does not conform to the evidence available. It was only in the nineteenth century, particularly in the second half, that the impact of the British cotton textile industry was felt with its full force by the Indian handloom sector. But even for that period, the desirability of keeping an open mind on the precise turn of events is strongly suggested by research done over the last few decades. 
$-978-90-47-42997-5$ 


\title{
THE POLITICAL ECONOMY OF TEXTILES IN WESTERN INDIA: WEAVERS, MERCHANTS AND THE TRANSITION TO A COLONIAL ECONOMY
}

\author{
Lakshmi Subramanian
}

In 1800, local merchants working for the English East India Company's contracting brokers and the Commercial Board in Surat complained that

people employed by one Vamal the broker are continually growing into every quarter where the workmen reside and by offer of a higher price are clandestinely carrying away from them all the cloths. They also carry away cloths giving ready money. Thus unless checked, (this) will hamper Company investment. ${ }^{1}$

This complaint was forwarded along with the declaration of one of Vamal's men, Bhagawandas Nanabhai, who confessed that he had been employed to go to the house of Hussein Mohammed, to receive charge of a designated consignment and to send it on to a local broker Rasikdas; and that he had been in this business for some time.

The Company authorities were not entirely taken aback at this admission - their own private operations had rendered them complicit with a range of commercial activities that deflected the official requirements of the English Company, which at the same time had been struggling since the late 1770s to affect major changes in the structure of the procurement business of textiles. The result was the generation of a huge corpus of archival material, which when carefully read, facilitates an enquiry into the political economy of textile manufacture in western India, the linkages between political power, ritual status and commercial developments that configured the structure of the manufacturing sector, and the strategies that merchants and manufacturers adopted

\footnotetext{
${ }^{1}$ Public Department Diary of the Bombay Government (thereafter PDD), no. 147 of 1800, pp. 627-30: "Letter and enclosures from Surat read by the Bombay Council on 2 April 1800".
} 
during the century of transition to colonial rule. It is in this context that the paper attempts to analyze the structure of textile production in late eighteenth century western India, to understand the responses of merchants and manufacturers to the disciplining weight of the early colonial state and its consequences for the region's commercial society.

Scholarship on weavers and artisans of early modern India has tended by and large to fit into the larger context of political and economic change that accompanied early colonial rule in India. Predictably, there were regional variations in the story, the Bengal weavers remaining the most visible subjects of ethnographic and historical attention. ${ }^{2}$ Subsequently, we have the writings of Prasannan Parthasarathi who looks at the Coromandel and the weavers of South India and attempts to link the decline of the weavers and artisanal activity with the structural changes that the English East India Company introduced in their relations with labour. ${ }^{3}$ The more interesting aspect of Parthasarathi's work relates to the greater bargaining power that weavers enjoyed in pre-modern South India and how this diminished with the introduction of Company rule. For western India, specific studies on weaving and artisanal activity in the eighteenth century are missing but there is always an implicit assumption that the region accommodated a greater level of merchant and manufacturing autonomy that resisted the early colonial regime. ${ }^{4}$

Following Parthasarathi, this paper attempts to examine the nature of relations between labour and capital in the half century of transition to colonial rule. It identifies the strategies that both merchants and manufacturers deployed to deal with the changing situation and analyses the way in which these reflected the inherent anxieties of transitional politics. This paper concentrates on Surat and its immediate vicinity in south Gujarat, the principal manufacturing centre for cotton textiles and an area which escaped the direct subjugation of British rule until the beginning of the nineteenth century. The fragmented authority of the English Company within the power structure of the region allowed manufacturers, and to a certain extent also merchants, to retain

${ }^{2}$ Hameeda Hossain, The Company Weavers of Bengal: The English East India Company and the Organization of Textile production in Bengal 1750-1813 (Delhi: Oxford University Press, 1998).

${ }^{3}$ Prasannan Parthasarathi, The Transition to a Colonial Economy: Weavers, Merchants and Kings in South India 1720-1800 (Cambridge: Cambridge University Press, 2001).

4 The contributions of Douglas Haynes on the emergence and organization of power loom manufacture in the nineteenth century deserve special mention here. 
their autonomy over time. The latter appear to have succeeded in benefiting from the asymmetrical nature of the textile contracts that transferred at least partially the risks to the merchant-broker. ${ }^{5}$

\section{Commercial Society in Western India}

Western India or more specifically the suba of Gujarat was for the greater part of the seventeenth and eighteenth century the most well developed commercial region of Mughal India. The region commanded a distinct maritime profile with Surat, its principal port dominating the overseas trade of Mughal India in the seventeenth and early eighteenth centuries. A number of commercial, and manufacturing centres turned out an impressive array of export goods, the most significant of these being textiles of different assortments and varieties catering to diverse markets both domestic and international. West Asia in particular was the most sought after market for Gujarati textiles.

Commercial society in Gujarat was a multi-tiered one, accommodating a miscellany of castes and ethnic groups. The business of shipping and seafaring was by and large restricted to Muslim groups including Bohras, Sunnis, and Muslims of Turkish and Persian extraction. Shippers and export merchants functioned closely with shore based brokers and bankers located in market towns and major centres like Surat and Ahmedabad, Broach, Baroda, Jambuser and Navsari (see Map 9.1). Brokers were both Parsi and Hindu and were, in terms of strength and capital outlay, of different categories. The business of brokerage was stratified and operated through dense networks of kin relations and commercial intelligence.

Ashin Dasgupta referred in his study on Surat to the general broker who worked through a network of commodity brokers who specialized in specific commodities and who in turn worked through sub brokers or under-dealers (as they are described in Company documentation). These under-dealers were located in primary production centres and were in close proximity to the producers and supplied them with the necessary advances. The strength of the under-dealers would appear to

\footnotetext{
${ }^{5}$ Some of these issues have been explored in my essay "Power and the Weave: Weavers, Merchants and Rulers in Eighteenth Century Surat", in Rudrangshu Mukherjee and Lakshmi Subramanian (eds.), Politics and Trade in the Indian Ocean. Essays in Honour of Ashin Dasgupta (Delhi: Oxford University Press, 1998), pp. 52-79.
} 


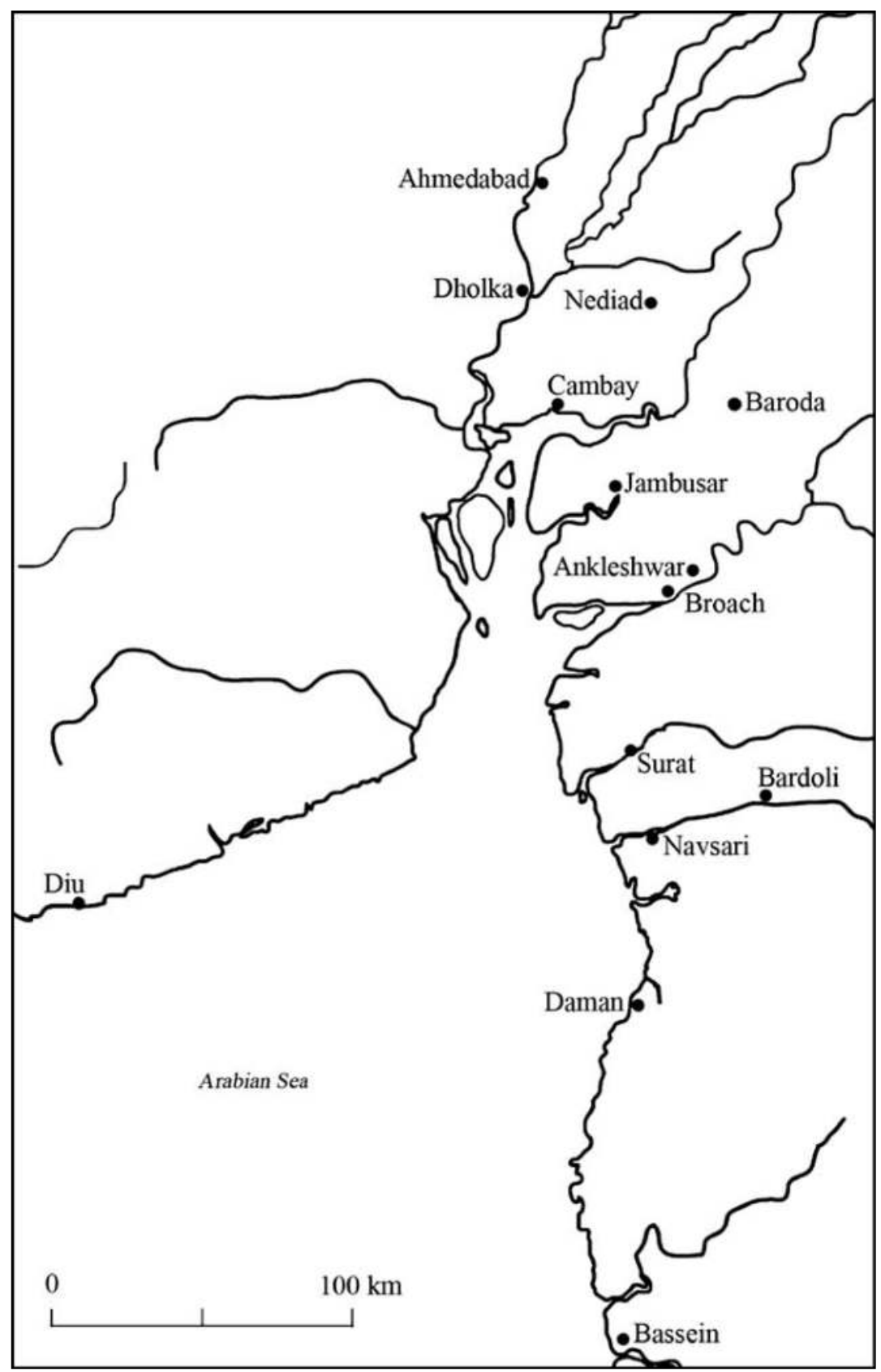

Map 9.1. Western India in the eighteenth century. 
have derived from their ability to supply weavers with regular advances and not so much to enslave them in permanent debt obligations. Company documentation suggests that these men were men of small means and it was their proximity to the weavers and their quotidian life that made them so central in the textile procurement business. Weavers were dependent on the advances, which they used as working capital to buy raw material (yarn) and to support themselves during the manufacturing season. ${ }^{6}$ Weavers in Gujarat were largely urban based, weaving on a full time basis and able to move quickly and migrate along the familial axis. Surat for example was the metropolitan market of three small weaving towns within a distance of twenty miles - Bardoli, Navsari and Gundavie. The same was the case with the other major centres of Gujarat, such as Ankleshwar, Braoch, Dabhoi, Baroda, Nediad, Dholka and Ahmedabad.

The organization of the weaving industry in eighteenth-century western India was characterized by an unusual degree of specialization that followed caste and community lines. A miscellany of castes and communities - Hindu, Muslim and Parsi - were involved in the actual manufacture of textiles and were known to guard their reserve quite fiercely. As the Surat factors commented to their superiors, "each branch of the manufactures of this place is confined to one set of people who by tradition and religious custom can never be persuaded to change their occupation". The weavers would appear to have been owners of their looms and worked along with members of the family (Fig. 9.1). One does hear occasionally of master weavers who worked with subordinate labour but this by and large seems to have been the exception rather than the rule. Among the Muslim castes, the Momnas, Boras and Bhandarrahs were the most visible occupational groups engaged in the production and manufacture of both coarse cloths for domestic consumption as well as pieces that involved gold embroidery or zari. Khatris, a Hindu weaving caste on the other hand seem to have specialized in the manufacture of fine piece goods - the red variety was especially prized - while the Koombees, another Hindu weaving caste manufactured musroo of different kinds, patolas and chaders with silk borders. ${ }^{8}$

${ }^{6}$ Commercial Department Diary of the Bombay Government (hereafter CDD), no. 9 of 1794, pp. 132: "Report of the Committee appointed to enquire into the failure of the provision of piece goods or the Surat investment. 18 March 1794".

7 CDD, No. 9 of 1792, pp. 92-93: "Report of John Griffith dated 14 April 1792".

${ }^{8}$ Lakshmi Subramanian, Indigenous Capital and Imperial Expansion (New Delhi: Oxford University Press, 1996), pp. 206-31. 


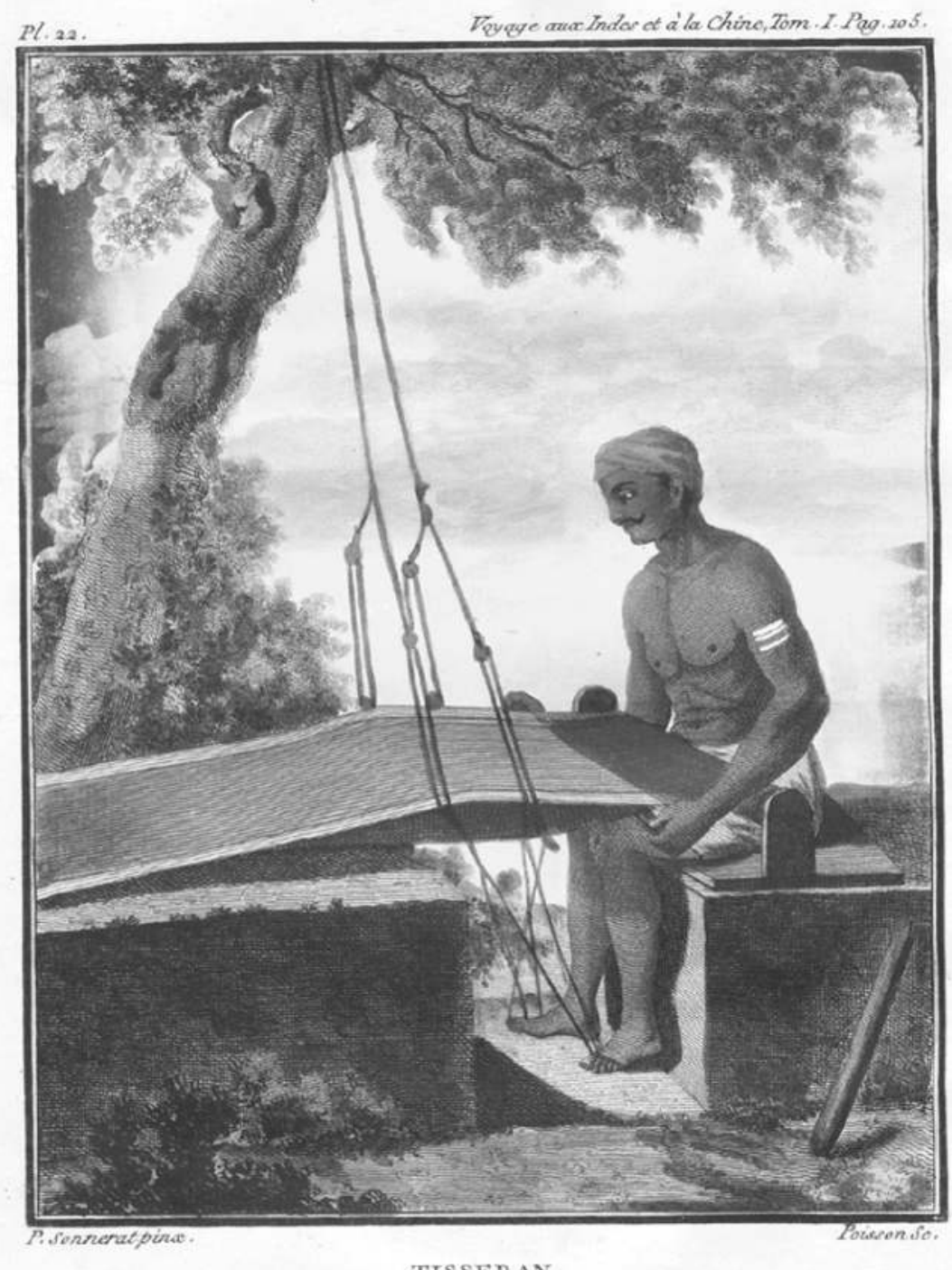

Fig. 9.1. Indian Weaver, engraving from Pierre Sonnerat's Voyage aux Indes Orientales et a la Chine, fait par ordre du roi, depuis 1774, jusquien 1781 (1782).

The manufacturing process began not in the loom but in the cotton marts where raw cotton was first cleaned. This was done by the pirijarrahs referred to as an indigent and depressed group who purchased the cotton in small lots and frequently on credit from merchants paying 
a price generally higher than the market price. The cotton bales, once cleaned were purchased by the spinners, mostly women who sold the spun thread at the town gates to the sootreah. The sootreahs as the name implies were dealers in thread or cotton yarn. The thread was twisted and divided into the requisite length and dimensions by workers of the Deerah caste and subsequently sent out for dyeing. Rates varied depending on the colour - late eighteenth century references talk of Rupees (Rs) 7 per maund if the thread had to be dyed blue and Rs. 10 if the desired colour was red. This was followed by the pasting process, or tahnee making the yarn ready for the loom. ${ }^{9}$

Weaving followed its own rhythm - determined largely by the timing of the export trade as well as that of the domestic market - and partly by seasonal conditions that facilitated certain stages in the manufacturing process. The best variety of necanees, for instance was manufactured in Surat and were worked early in the year and wholly finished before the dry winds of November. Blue and red chelloes on the other hand, were best manufactured in the rainy season, just after having been coloured in April. ${ }^{10}$ Placing orders for these goods therefore had to take into consideration these factors. ${ }^{11}$

The impressive levels of Western India's overseas trade reinforced the strength of indigenous commercial society in the seventeenth and eighteenth centuries. The benefits of political security enabled merchants to draw on the resources of the hinterland and operate a vigorous trade in textiles, sugar and indigo with West Asia. If Muslim ship-owning merchants were able to use their personal connections and religious affiliations with the local Mughal administration to good effect, Parsis and Banias were no less resourceful in developing a measure of leverage with the ruling system. The Mughal administration did not for the most part, coerce traders and barring occasional instances of personal caprice by individual governors, they oversaw a century of vibrant commerce.

The profitability of Indian export trade was thus reflected in the strength of brokers and merchants as well as in the greater bargaining strength of weavers who were able to command high prices for their

\footnotetext{
${ }^{9}$ CDD, no. 12 of 1796, pp. 17-18: "Report of the Committee on the outlines of textile manufacture dated 24 December 1795 ".

${ }^{10}$ CDD, no. 7 of 1792, pp. 87-91 for a tabular representation of the species of goods, place of manufacture and time when best made.

${ }^{11}$ Ibid.
} 
produce. A concrete indication of artisanal strength and solidarity was their sustained capacity to work the asymmetrical contract ${ }^{12}$ to their advantage as well as to work effectively within the existing system of custom and privilege. What this meant on the ground was that technically the weaver was free to cancel his contract with the under contractor and could detach himself from it by paying back the advance. This was in marked contrast to the contract the merchant or Company entered into with the broker who had to pay a penalty if he failed to fulfil his obligation. In fact the so-called debt factor which subordinated the weaver to the under-broker does not seem to have deterred weavers from reneging on their agreements or even from abandoning their centres and migrating to other urban centres. The contracting merchants too at least in Surat were able to put off the persistent demands of the Company to make good the penalty, which remained more of a token provision than anything else.

\section{The Crisis of Mughal decline in Western India}

The eighteenth century crisis assumed in western India the typical features of administrative collapse and political insecurity that exposed the regime to a series of damaging Maratha incursions. By the mid 1720 s, the Maratha presence in Gujarat crystallized into a formal physical occupation of the Athavisis or twenty-eight villages adjacent to Surat and the establishment of revenue collection centres in Baroda, Ahmedabad in South Gujarat. For the merchants, this development had serious implications: the unsettled nature of the countryside as a consequence of Mughal Maratha skirmishes meant that trading networks were seriously disturbed. Additionally, the pecuniary demands of the Marathas on the ruling administration compelled the latter to tap sources of mercantile wealth and thereby to tax the local merchant society at a time when their commercial operations were on the wane and they were facing the competition of European private trade. ${ }^{13}$

Merchants and manufacturers were forced to devise strategies of survival in a complex and fluid situation in which different interests remained ambiguous and often contradictory. For the Muslim

\footnotetext{
12 Parthasarathi, Transition to a Colonial Economy.

13 Ashin Das Gupta, Indian Merchants and the decline of Surat, c.1700-50 (New Delhi: Manohar, 1994).
} 
merchants, the choice was limited as they found themselves hemmed between a besieged and revenue-hungry administration and an aggressive and expanding European presence. The English East India Company by the 1730s and 1740s began to articulate a definite, if limited, political agenda, coveting in particular the office of the Admiralty and Qiladar, which was expected to augment their control over the region's trade with West Asia. This jeopardized the operations of the Muslim merchants who unlike their Bania and Parsi counterparts, found it difficult to arrive at any compromise with the Europeans. The community of Hindu merchants, brokers and bankers did not remain unaffected either. An increasing number of bankruptcies were reported by the Europeans; interest rates rose while the disruption of links with the heartland inevitably contracted the scale of trading operations. As an immediate solution to safeguard whatever remained, sections of the Hindu commercial population approached the English Company for protection and utilized their connection to ward off the demands of the declining Muslim administration in Surat city. The result of the changing political balance in Surat city was the Castle Revolution of 1759 that introduced the English company as joint rulers of the city and more significantly, as a major interlocutor for political negotiations with the Marathas in the larger region of Gujarat. This had important implications for merchants and manufacturers. ${ }^{14}$

\section{Merchants, Manufacturers and Diarchy}

The functioning of the dual government in Surat did not deflect the course of decline that had set in in the city's trading economy. The Company showed itself singularly uninterested in taking direct responsibility. At the same time, it used its political clout to monopolize the carrying trade with the Gulfs of Persia and Arabia. This threw the city's Muslim shippers out of business, while for the remaining players small time merchants and Hindu banias who freighted their goods on English vessels, the new arrangement was a limited means to salvaging some of their trading operations. Others maintained their connections with the ruling administration as well as with the Marathas. The result was a complex and fluid system of power equations that determined the political economy of trade and manufacture. The play of power

${ }^{14}$ Subramanian, Indigenous Capital. 
directly derived from the compulsions of transitional politics: the transfer of power from the court to the castle strained existing social and economic relationships and unlike the situation in the Coromandel, the Company was only one among many players to affect a disjunction in existing practices and labour relationships. It took a longer time for labour in western India to come under the disciplining apparatus of the Company, and even when it did, the consequences were not entirely anticipated.

In terms of actual trading patterns, the second half of the eighteenth century registered earlier trends of decline between western India and West Asia as well as between Surat and Bengal. Bombay's coastal trade under the protection of the English East India Company increased significantly but the Surat Bengal trade never quite recovered. Available figures on the value of imports from Bengal that entered Surat through the Latty or English Custom house from 1730 to 1770 reflect a sharp drop in value from Rs. 11 to 3 million. The trade with the Gulfs demonstrated comparable figures - about Rs. 2 million per annum from a high level of Rs. 16 million. The decline claimed several casualties but the traffic itself did not cease altogether, and remained the mainstay of the region's manufacturing economy. ${ }^{15}$

The trade in textiles with West Asia along with a substantial domestic traffic in cloth constituted the most important line of business for the merchants and manufacturers of Gujarat in the decades after the Castle Revolution. Until the 1790s, the official trade of the English East India Company in calicoes remained of marginal importance in both value and volume. The Company merchants often complained of the unwillingness of the local intermediaries to negotiate contracts for the Company before they had completed their transactions for the gulf markets. To instantiate this point further, let us look at some of the correspondence. The Surat factors in their letter of 17 October 1764 notified their superiors in Bombay that the provision of the Company's investment depended greatly on the demand of other markets, principally the Gulf markets. ${ }^{16}$ The following decades saw similar admissions and even as late as 1792, the Company's official contractor expressed his inability to honour his obligations on time. In his defense, he pointed out that piece goods from the region to the amount of

15 Ibid.

16 PDD, of 1764: "Letter from Surat dated 17 October and read by the Bombay Council on 21 October 1764". 
Rs. 20 lakhs every year were bought for exports to the Gulf. ${ }^{17}$ Three years later, the factors once again brought attention to the fact that after "October, ships arrive from Europe and the Gulfs, the demand for these markets became known, and then there begins an occupation for all classes of manufacturers and demand for all sorts of goods which occasion a increase". 18

The level of Gulf demand was, however, only one of the principal determinants of the textile trade in the eighteenth century. Political factors were equally or even more important - the declining power of the ruling administration, the limited and fractured authority of the English company and the competing claims of the Marathas in the region meant that the textile business and its operating merchants and manufacturers became subject to a range of pressures that in the long run affected the organization of the industry and the status of the labouring artisan. The pressures of the political situation were compounded by the frequent bouts of famine in Gujarat and the rising prices of yarn and rice and the resultant desertion of spinners and weavers.

What were the strategies available for merchants and manufacturers to manoeuvre effectively? Merchants and traders who were not as yet aligned to the Company preferred to work through traditional channels of patronage that were still available. In 1772, we come across a petition by Ramkisan Khatri, a Surat based merchant who complained of having suffered "some hard treatment from the Nawab and of being plundered of a sum of money by him at the instigation of Dhanji Shah, the principal broker of the English Company". ${ }^{19}$ Ramkisan's petition was revealing: it exposed the bitter rivalries of the local merchants and coastal inhabitants who sought to deploy their respective connections with the Durbar and the English Company to their individual advantage. The Khatri merchant stated that Framji Jeta, a local Parsi, was indebted to Ramkisan and had mortgaged his house for a year. However, he had not

${ }_{17}$ CDD, no. 7 of 1792, p. 93: "Representation from Mayaram Atmaram included in the enclosures from Surat read by the Bombay Council on 23 April 1792".

${ }_{18}$ CDD, no. 11 of 1795, p. 884: "Enclosures from Surat read by the Bombay Council on 27 November 1795 ".

${ }^{19}$ For details of this affair, see PDD, no. 61a of 1772, p. 188: "Consultation Meeting of the Bombay council dated 30 June 1772"; p. 203 for the petition of Ramkisan Khatri; p. 208 for Consultation meeting of the Bombay Council dated 6 July 1772, where the letter from Surat dated 28 June 1772 was read and reviewed. See p. 306 for Consultation Meeting of the Bombay Council of 31 July 1772; and p. 409 for Consultation Meeting of the Bombay Council of 10 September 1772. 
paid back his debts thereby forcing Ramkisan to approach his patron Chota Khan, the ruling Nawab's younger brother to intervene on his behalf and get back the loan. No sooner was this done, than Hirjee Parsi, servant of the Nawab stepped in, abused Ramkisan and released Framji Jeta. Thereafter, Chota Khan took up the matter with his brother, the Nawab who reprimanded Hirjee but to no avail. Hirjee on his part approached Dhanji Shah, the Company's marufteah who threatened Ramkisan with dire consequences. This was not an empty threat, for Dhanji proceeded to persuade some fishing Coolies to complain against Ramkisan and the unfair means that he had deployed against them to realize some outstanding dues. The strategy worked; the Nawab lost no time in restraining Ramkisan, torturing him and extracting from him Rs. 7,000 for his release.

Meanwhile, Ramkisan tried to retrieve his position and cut his losses short by approaching the English factory at Surat for redress, but here too, he found himself stymied by Dhanji Shah's manoeuvres. He decided, therefore, to approach the Company's authorities in Bombay directly in the hope that they would intervene on his behalf and enable him to recover his dues and the sum of Rs. 7,000 that he had made over to the Nawab. The Bombay authorities, in line with their rhetoric on protection of the fair trader, looked into the matter and requested the Nawab to state his version. In a letter that the Bombay Council received and read on 15 June 1772, the Nawab outlined the details of the contretemps as follows. Some time ago, fishing men or Machhees had complained to Mr. Price that the Khatri merchants Ramkisan and Dharma Chand, demanded money at interest from them unfairly for they had already made good their previous dues. The Nawab taking up their case ordered the city's Khatri merchants to examine and scrutinize all accounts and instituted an enquiry committee for this purpose. The enquiry, according to the Nawab revealed that all accounts had been satisfactorily settled and that Ramkisan was guilty of misrepresenting evidence. The Bombay authorities were not entirely convinced and suspected Dhanji of having doctored the evidence. For a while, they toyed with the idea of dismissing Dhanji Shah from his position.

Their anxieties were not without basis for almost immediately, after the Ramkisan affair, they confronted the accusations of Siad Hussein, a Surat merchant who alleged that Dhanji Shah misused his influence quite openly and intercepted justice. On 31 July 1772, the Bombay Council reviewed the petition from Siad Hussein who set forth that he had legitimate grievances against Agha Qadil Khan but that he had been 
denied access to the English chief for redress by a small clique headed by Dhanji Shah and his servant Sooley. The Surat factors hotly denied these allegations and stated in their letter that the complaint was:

very unjust, malicious and that no charge advanced against any person mentioned therein, had been proved, that Ramkisan had in many respects, willfully perjured himself, instances of which they produced, and that his accusation against Dhanji and Sooley were in no respect proved. ${ }^{20}$

As regards Siad Hussein, a proper enquiry into this depended on a careful examination of many persons. This would have taken up too much time and it could not be carried out without the presence of the Siad who, according to the factors, was a man of "infamous character". The Bombay Council let the matter pass and continued to retain Dhanji Shah as their marufteah. The incident revealed all too clearly the linkages between the local merchants and the English East India Company, the Durbar, and the private trade dealings of Company servants in Surat. The linkages enabled individual merchants like Dhanji Shah Manji Shah to pursue their commercial interests. It also exposed the fragility of small time local merchants who pinned their faith on existing channels of patronage like that of the Durbar, thereby complicating the general tendency to gravitate towards the Company dispensation.

It took a considerable time for the Company to utilize its political clout to alter conditions of business or to dominate channels of procurement, which happened to be the most pressing consideration. The official investment of the Company did not amount to very much until the closing decades of the century - it was valued between Rs. 300,000 and Rs. 500,000 and accounted for a very small portion of the region's trade. The investment typically consisted of necanees (large and small), tapseils (large), bejutapauts (blue), Guinea (red and blue), byrampauts (blue) and chellos (red and blue). Until the 1760s these were procured from a number of Gujarati towns and manufacturing centres such as Cambay, Broach, Baroda, Navsari and Surat. The investment was organized around the basis of a contract that the Company entered into with principal contract merchants of the city. The latter agreed to supply at the port of shipment a specified number of pieces by a certain date. The system had one obvious advantage in that it drew on the immense experience and resources of the local merchants and thus economized

20 Ibid.

21 Ibid. 
on transaction costs. Also the advantages of the system were evident in a situation where the investment had to be carefully and closely planned and set in motion at different times of the year depending on the items in question. For example the best varieties of necanees (large) were available in Surat and the goods were best worked early in the year and finished before the dry winds set in November. Likewise, large blue and red calicoes were of a superior quality in Surat and Cambay, and had to be coloured in the hot month of April, while byrampauts were available in Broach and had to be contracted for early in the year. All this meant that the investment had to be planned well in advance and had to be entrusted to local merchants who knew the season and its cadences and were, in principle at least, capable of pumping in the necessary funds for different stages of the manufacturing process.

The contract system and the procurement business operated in accordance with certain conventions both written and unwritten. The contract merchants resisted alterations proposed by the Company and steadfastly refused to admit major changes in the provisions of the contract. In fact even the penalty provision for non-performance of any part of the contract could rarely be enforced. The Company authorities failed to insist on any special marks being affixed on pieces that were rejected on grounds of deficiency. In November 1766, the Surat factors informed their superiors at Bombay that the contractors had refused to "admit of a particular mark or chhap as it was called being affixed to such goods of the investment as were rejected". ${ }^{22}$ They also brought attention to the fact that the prices of late had decreased considerably with the contractors, and that these had persuaded weavers and merchants in general to lower the standards in order to be able to supply at the prices fixed by the Company contractors. In other words, the subbrokers were responding to the situation by turning out sub-standard goods. At any rate the question of defective goods related more to the problem of measurements than to quality and had a reasonable market among private European traders and local Bania merchants trading with East Africa.

The commercial depression of the region's trade with West Asia was responsible for a general shortage of specie in the region, a fact that hampered the early efforts of the English Company in procuring a comprehensive and satisfactory investment for Europe. The under-contractors

22 PDD, no. 47 of 1766, p. 295: "Letter from Surat dated 18 November and read in the Council meeting of 20 November 1766". 
who were hard up for funds tended to delay advances to workmen and weavers, a fact that came up periodically in the representation of the Company's contracting brokers. In 1779, the Surat factors in their letter dated 16 April stated that their contractors had pointed out that their failure to deal with the Company investment on time was caused by the large number of bankruptcies among the brokers and agents and a scarcity of weavers. ${ }^{23}$ The Surat Council maintained that these were lame excuses and that "far from there having been a scarcity of weavers this season or a difficulty in providing goods, the Dutch had dispatched two ships with complete cargoes, that the Portuguese had made a large investment and that the export to the Gulf had been very great upon which they gave it as their opinion that the only effectual method of obtaining goods in time would be to oblige the contractors to pay the penalty in case of failure of their agreement". ${ }^{24}$ Eventually, however, the penalty was not enforced, the Surat Council backing out saying that the "levying of the penalty would be a step most prejudicial to the merchants". 25 The fact was, that through out the 1770s and early part of the 1780s, the Company did not feel confident about altering the procurement system. This was partly a consequence of the limited nature of the English Company's political authority and partly on account of the Maratha presence in the region. Maratha presence and policies were unpredictable and although the Marathas occasionally hampered free movement of trade, the Company did not as yet feel confident about provoking a confrontation with them.

The decline of the Gulf markets, the tentative efforts of the English Company to control textile supplies along with conditions of political insecurity, and the rising prices of yarn and foodstuffs put extreme pressure on the smaller merchants and manufacturers. It was in this context that the ruling administration devised a policy of mercantile taxation primarily to to pay off the Marathas. One such measure was the introduction of the Mokat that originated in 1759 and was imposed on the manufactures of the city as well as those coming into the city from outside. Mokat rates varied and generated the necessary revenue

\footnotetext{
${ }^{23}$ PDD, no. 47 of 1766, p. 295: "Letter from Surat dated 18 November and read in the meeting of 20 November 1766 ".

${ }^{24}$ PDD, no. 75a of 1779, pp. 221-26: "Consultation Meeting of the Bombay Council of 7 April 1779. Letter from Surat dated 16 April 1779 and discussed by the Bombay Council on 21 April 1779".

${ }^{25}$ Ibid.; PDD, no. 76 of 1779, pp. 294-95: "Letter from Surat dated 18 December and read by the Bombay Council on 23 December 1779".
} 
but predictably strained the weavers, many of whom tried to avoid the imposition if they could. They were by no means impervious to the changing balance of power or to the deployment of their bargaining skills with the local administration, the Marathas and the English Company to extract whatever leverage was possible.

It is in this context that we may attempt to raise the larger issue of the location of artisans in the pre-colonial trading economy. What seems apparent from the survival strategies of weavers and artisans, is the importance that customary arrangements endorsing the skills and status of artisanal activity assumed in the political structure of the local regimes. The Khatri weavers for instance enjoyed a special status on account of their skills and monopoly control over the manufacture of red cloth, that in itself enjoyed a special status in court and religious ritual. Consequently, they were particularly successful in negotiating with the ruling administration in securing remission of the Mokat. Instead they undertook to pay an annual contribution of Rs. 5 to the Mokat farmer and Rs. 50 to the Nawab and to supply the Durbar and its dependents with coloured threads and other articles as required. ${ }^{26}$ At the same time, their traditional rivals, the Koombis who were producers of blue cloth attempted to exploit the fluidity of the situation by soliciting the intervention of the Company in order to cut into the monopoly of the Khatris in the production of red cloth. The KhatriKoombi dispute reflected in a microcosm the tensions that accompanied the dissolution of the existing social balance among manufacturing groups in Surat city. In fact, the intervention of the English East India Company and their efforts to detach Khatri and Koombee manufacturers to work exclusively on the Company investment reinforced preexisting tensions.

\section{The Emergence of Surat as a Centre of Manufacture}

It was in the 1780s that Surat began to emerge as a major centre of production of textiles. The benefits of relative political security guaranteed by diarchy encouraged artisan groups to settle down in the city and

\footnotetext{
${ }^{26}$ For details on the Mokat, see PDD, no. 120 of 1796, pp. 2232-42. See account on "An estimate of His Highness, the Nawab of the losses of a remission of his Moucats on the probable investment of the following year". The report traces the antecedents of the Moucats, the rates at which these were levied and the exemptions enjoyed by certain manufacturing communities of Surat.
} 
turn out their manufactures for the local market as well as for the European trading groups. The expanding trade of private Portuguese traders from about the 1780s in textiles of the coarser variety, or what the English company designated as the 'inferior sortment' generated opportunities for the weavers and put pressure on the English factors in Surat. The factors repeatedly emphasized to their superiors in Bombay that a very small proportion of the weavers in Surat could manufacture the kind of goods that the company specified, and that there was an enormous demand for "piece goods of quality ever so inferior" and that "only the young and strong could reach the excellence of the Company's fabric whereas old men, women and children can make such goods as foreigners and native merchants will purchase" ${ }^{27}$ As mentioned before, the manufacture of piece goods was highly specialized and characterized by an unusual degree of specialization and division of labour. A number of communities - Parsi, Hindu and Muslim - were involved in the production process and were known to guard their skills and preserve quite them fiercely. Manufacturers with specific skills - like the Khatris who specialized in the manufacture of red cloth and gummed silk goods - strenuously opposed any other manufacturing group engaging in the business and they often used their influence with the higher authorities to stake their claims to a monopoly over certain branches of the manufacturing. By the 1790s the city boasted of a total of 15,777 looms worked by specific weaving groups who turned out particular varieties of cloth. We have for example references to 849 looms worked by the Boras who manufactured pachoras, putkahs, Turbans and doria of various sorts for immediate consumption in the city while other varieties like salloes, seylas and dhotis also turned out by the same looms were exported to Muscat and Malabar. The Koombees and Khatris dominated the business of manufacture and worked on a large number of looms and turned out cloth specifically for the export market. The introduction of the mokat, according to the Enquiry Committee (instituted in 1795 to examine the textile manufacturing business) affected the trade and manufacture of piece goods. Piece goods were under this arrangement subjected to a duty of one and half percent. It was collected from the under-dealers who constituted the vital link between the weavers and the merchants.

${ }_{27}$ CDD, no. 9 of 1794, pp. 134-35: "Results of the Enquiry Committee instituted by the Surat Council to examine the problems of investment". 
The earnings of the weavers varied according to their skill and the kind of cloths they undertook to manufacture. The committee of enquiry estimated the actual net cost of a piece of each sort of cloth included in the Company's investment and stated that the weavers payments were determined by the measurements of the cloth being produced as well as the levels of skill commanded. To this was added the costs of raw material and commission charges of under-dealers. Weavers working on bejutapauts blue and white of 10 vees and $24 \mathrm{guz}$ dimensions were given 3 quarter and 50 reas while the finished product cost Rs. $4 .^{28}$ Skilled weavers like the Koombees were on the look out for improving their material status by encroaching into the manufacture of goods that were in greater demand or fetched higher prices. This was only to be expected in a situation of extreme pressure when the underdealers were sparing with advances and the English Company imposed inflexible standards of fineness. As it happened, the raw materials for weaving were provided by the under-dealers themselves who in most cases in this period prepared the looms. Weavers who operated their looms independently and bought their own raw materials were few and far between. In fact the Enquiry Committee suggested in 1796 that more weavers ought to be encouraged by the Company to work their own looms, admitting that this was a difficult thing to achieve. Most weavers pointed out that they were critically dependent on the undercontractors on whose advances they were dependent upon to buy grain and support their families.

\section{The English East India Company and the Problems of Procurement}

It was in the latter decades of the eighteenth century, that the English East India Company began to seriously consider the possibility of altering the procurement system. Scarcity of capital, the inadequacy of advances and the increasing tendency of the under-contractors to withhold advances to workmen had combined to aggravate the problems of procurement. This combined with the expanding trade of Europeans, notably private Portuguese merchants encouraged the weavers to deliberately turn out inferior cloth and sell them to the highest bidder.

${ }^{28}$ CDD, no.12 of 1796, pp. 17-18, 29-30: "Report of the Committee on the outlines of textile manufacture in Surat dated 24 December 1795". Also see p. 40 for point made on the weavers' dependence on the under dealers. 
Deficiencies in quality and measurement thus became a major and recurrent problem in the 1780 s and 1790 s, forcing the contract merchants to put pressure on the under-dealers and weavers, forcibly collecting their goods and maintaining tighter controls over the advances.

In 1790, Mayaram Atmaram, the Company's contract merchant complained that the Surat factors had been tardy about advances and that this was creating problems. He had tried to salvage the situation by advancing some money from his pocket but this was not sufficient. Also he pointed out that the Company had on very flimsy grounds rejected substantial portions of the investment forgetting that it was not possible to secure identical pieces from so many hundred different workmen, some of whom would naturally be inferior to others. Other purchasers, Mayaram mentioned, had enthusiastically bought up the rejected pieces, the number of which was equal to that of workmen:

You cannot be ignorant of the great encouragement given by foreign nations, the Dutch, French and the Portuguese as well as native merchants to workmen to fail in their engagements with the Company for pieces inferior in every respect and particularly in point of dimension, where the Company are very strict, they will give 4 p.c. more than Company prices by which it become the weavers' advantages to have the pieces rejected. ${ }^{29}$

These complaints were repeated time and again even as the Company authorities failed to alter the system, or punish the contracting merchant for non-performance. The strategies they came up with were half hearted and ad hoc; for instance in 1790-91, the Company attempted to retain the rejected goods so as to intimidate the weavers but to little effect. The contract merchant, on his part urged the Company to remain flexible in its approach and allow delays in the contract. ${ }^{30}$

The situation took a turn for the worse in the following year when cotton production was badly hit by lack of rain. Cotton and indigo was not procurable at any price. Mayaram mentioned in his petition that the general failure of rain had caused untold misery among the poor and that thousands had perished. The mortality among weavers had assumed serious proportions with thousands dying daily. The under-contractors frequently absconded with advances causing great ruin to Atmaram and his colleagues and at the same time, depriving the indigent weavers

${ }^{29}$ CDD, no. 5 of 1790, p. 97: "Letter from Mayaram Atmaram".

${ }^{30}$ Ibid. 
of their habitual occupation. ${ }^{31}$ In 1792, the Company authorities in Surat had once again occasion to comment on the subterfuge of the weavers and on their clandestine trade with foreign merchants, notably the Portuguese and other European private traders who bought up extensive quantities for the African markets. Their brokers employed a good number of Surat weavers to work on this, while at the same time, the rejected pieces of the Company investment found their way into the hands of the brokers working for the foreign traders. The factors were duly cognizant of the fact that manufactures for the African markets constituted only a small proportion of the total manufactures and that the goods of the finer variety for the Gulf markets and those for the Europe investment accounted for the bulk of the city's production.

What was difficult was to persuade local artisans to work on specific goods exclusively for the Company. In 1792, John Griffith, the chief commercial representative in Surat suggested that the only way out of the impasse was for the Company to make use of its political influence. The Company had to insist on being given preference and thus compel a set of weavers to work for the Company on account of the special influence it enjoyed. This was, however, easier said than done as the Surat factors realized. Even extreme pressure failed to persuade weavers to change their branch of specialization. Occasionally weavers responded violently to the growing controls by the Company. This was evident during the riots of 1788 and 1795, when weavers targeted contract merchants working for the Company.

Our evidence does not say much about the linkages between underdealers and weavers in organizing resistance but in 1795, disaffected weavers rallied around dissident elements in the lower echelons of the administration and attacked the houses of the city's bania merchants. ${ }^{32}$ The 1795 riots jolted the Company out of its complacency and forced the authorities to reconsider the situation, to consider alternative modes of procurement and to detach weavers in order to work for the Company manufacture on new terms. During the riots and their immediate aftermath, the Company had failed to get a single weaver to work for almost twelve days not to speak of the Muslim weavers who struck work for even longer. ${ }^{33}$ This in fact was the turning point - the target

${ }^{31}$ CDD, no. 6 of 1792, p. 268: Petition of Mayaram Atmaram.

${ }^{32}$ Lakshmi Subramanian, Indigenous Capital, pp. 206-31. See also Id., "The Eighteenth Century Social Order in Surat: A Reply and an Excursus on the Riots of 1788 and 1795", Modern Asian Studies, 25, 2 (1991).

${ }^{33}$ CDD, no. 11 of 1795 , p. 1006: "The Contractors reply to the Chief's Minute". 
was no longer the contract merchant and the penalty provision. Instead the drive was towards the elimination of the undercontractors and the subjugation of the weavers to the judicial authority of the English East India Company.

The intention of the Company was now clear but the implementation would take more time. In October 1795, the Surat factors pointed out that they had tried through their contracting merchant to secure exclusively for the Company the labour of the resident Khatri weavers in Surat who were skilled in the manufacture of the finest assortment of goods. ${ }^{34}$ Engaging their skills for the Company's investment was not easy as they specialized in making silk goods, which earned them better prices. The factors tried to assure the Khatris that if they had consented to work for the Company, they would enjoy the benefits of Company protection and would suffer no oppression. It was also suggested that after entrusting them with the manufacture of a certain quantity of the Company's investment, they would be permitted to take up the silk business and no further demands made on their labour. Accordingly on 5 October 1795, the Patels or headmen of the Khatri weavers presented an arzee, or a memorandum of understanding, that announced their intention of working exclusively for the Company until they had completed their orders. ${ }^{35}$

The apparent success of this negotiation encouraged the factors to approach other weavers. The following year, on the 8 April 1796, an agreement was signed between manufacturers and under-dealers and the Company's contract merchants wherein the former agreed to accept Company protection and promised not to work for any other party. ${ }^{36}$ This agreement became a sore point with the other buyers in Surat who approached the Nawab and complained of Company intimidation of weavers. The Company dismissed these charges as baseless and accused the Portuguese brokers of interfering with their weavers and of even taking goods from the looms on false pretensions. The authorities held their own as they persuaded the Nawab to waive the the Mokat or extra duties on those piece goods making up the Company's investment.

${ }^{34}$ Ibid., p. 778: "Letter and enclosures from Surat read by the Bombay Council on 27 October 1795 ".

${ }^{35}$ Ibid.

${ }^{36}$ PDD, no. 127 of 1797, p. 181: "Letter and enclosures from Surat discussed by the Bombay Council on 3 November 1797". These enclosures included the agreement signed on 8 April 1796 by the principal manufacturers and merchants working for the Company. 
To facilitate this, they proposed a system, under which the investment was divided into several categories of standard and inferior assortments. This new taxonomy was expected to prevent weavers from deliberately turning out substandard goods and selling them to other foreign merchants. The Company also engaged brokers who were attached to the office of the Commercial Resident who was allowed to depute his peons to collect goods from the manufacturers. The Company justified these new arrangements to the Governor General in Council arguing that the system was not unduly restrictive.

In September 1797, answering the Portuguese charges, the Commercial Resident argued that it was an invariable practice for the Company to use peons to collect goods and that the mixed nature of the government in the city enabled anyone to assume authority to the extent of his means to employ peons in the transaction of business. ${ }^{37}$ On another occasion, he maintained that the company could not afford to dispense with the peons at the height of the season when the chances of clandestine trading increased. Under-contractors tended to hoard up quantities to dispose of at higher prices and it was considered necessary to intercept them by collecting the produce directly from the weavers. On the other hand, the new brokers working for the Commercial Resident were in a better position both in relation to the manufacturers as well as to the local administration. ${ }^{38}$

The new system aimed at binding the weavers to their engagements with the Company and preventing them from entering into fresh engagements until they had discharged all their debt obligations to the Company. All engagements were henceforth to be made in writing attested by two creditable witnesses. Weavers under engagements to the Company and who did not wish to avail themselves of fresh advances in the future had to give a fortnight's notice of their intentions. In cases of weavers failing to deliver by the stipulated period the cloths for which they had been engaged, the Commercial Resident was given the liberty to unleash his peons upon the erring manufacturers. Weavers guilty of clandestine transactions were liable to prosecution and could have their produce confiscated by the Company. Those in the Company's employ who were found guilty of changing Company cloth or accepting

${ }^{37}$ Ibid.: "Letter from the Commercial Resident to the Chief of Surat dated 20 August 1797". Also see CDD, of 1797, p. 111: "Letter and enclosures from the Commercial board at Surat read on 3 February 1797".

38 Ibid. 
advances were also liable to forfeit double the amount of the value of the property or money that they may have embezzled. At the same time, the regulations endorsed the primacy of the Commercial Resident in the business of procuring the standard investment. The system was perceived as an important beginning in paving the way for the abolition of a contractor or any intermediary. For the rest, the investment was to be subdivided into distinct branches and let out by public advertisement to contract merchants. ${ }^{39}$

In practice, these regulations do not seem to have eased the Company's situation. The problem of clandestine purchases continued unabated particularly in the last years of the century, when there was a marked expansion of Portuguese trade. The use of peons was not restricted to the Company servants as the practice seems to have been well established among other traders. The Commercial Resident found it impossible to bypass the medium of local contract merchants who had the necessary access to under-brokers and producers and their headmen. The merchants on their part continued to vigorously resist the penalty clause, and while there is every reason to suppose that they were operating amidst conditions of insecurity and rising yarn prices, it is also important to consider their reserves in holding their own in the negotiations with the company. ${ }^{40}$ It was not before 1802 that the Company was able to move decisively into the supply market and undermine the position of intermediaries. By that time the trade in textiles was already on the wane.

\section{The Working of the New System: Merchants and Manufacturers}

Where did the new system leave the merchants and manufacturers? The division of the investment into various categories of "Standard" and "Inferior", the organization of separate contracts for these varieties, the provision of the Standard Investment remaining with the Commercial Resident who was expected to deal directly with the manufacturers, the imposition on paper of a higher rate of penalty on the contracting brokers, and the permission to use armed peons to retrieve goods from the artisans who were obliged to commit their produce to the Company exclusively until the completion of the investment, were

39 CDD, no. 16 of 1797, pp. 932 and 942.

40 Subramanian, "Power and the Weave", pp. 64-75. 
significant alterations and expected to produce favourable results for the Company.

As yet, however, there was no attempt to dislodge the under contractors who continued to liaise between the contract merchants and the manufacturers. The penalty clause continued to be resolutely opposed while on the ground the Company's demand did not absorb the bulk of the city's supplies. The Surat factors insisted repeatedly that the Company investment did not engross all the labour of Surat and that a very considerable body of manufacturers was required to furnish goods for the yearly trade to the Gulfs. As far as the under-brokers were concerned, the new regulations were irksome, but not impossible to get around. Indeed, the fragmented and fractured nature of Company authority in Gujarat, and the expanding demand for piece goods among foreign and native merchants enabled under contractors to evade the tyranny of Company schedules and to continue exploiting the artisans. In 1797, the proceedings of a prolonged dispute with the Portuguese Resident over the use of armed peons revealed that brokers working for the Portuguese were guilty of corrupting the "weavers and under brokers supplying the company", inducing them "to sell them goods they finish in which they allow prices for inferior quantities equal to the standard of Company investments and needless for me to repeat, they are successful". ${ }^{41}$ It was much later that the English Company's attention was drawn to the oppression of the under-dealers and to the necessity of restraining then.

The Company was soon forced to act when it discovered that the Khatris were shirking their obligations and ignoring the earlier agreement. The brokers confessed their inability to persuade other manufacturing communities to turn their looms over to the manufacture of fabrics required by the Company. They had tried to procure large supplies from areas where the Khatris could not exercise their influence, but the quantity received had been inadequate. A long spell of rain and following floods had resulted in large-scale destruction of looms and weavers' dwellings. This, along with rising yarn prices, once again raised doubts about the annual investment. The contracting brokers stressed, in their representation to the Surat Council in 1798, the recalcitrance of the Khatris, "who were an untractable set of people and act as they

${ }^{41}$ PDD, no. 127 of 1797, p. 1811: "Representation by the English Commercial Resident as part of enclosures from Surat received by the Bombay Council on 3 November 1797". 
please from knowing the dread in which all others stand of their revengeful and too generally successful malice". ${ }^{42}$ Moreover the headmen of the Khatris who had been responsible for the contract with the company had died and the brokers found themselves helpless in exercising any control over the weavers. Closer investigations revealed that the Khatris were exploiting the position vis-à-vis the Company in forcing an old and outstanding dispute with their traditional rivals the Koombees. ${ }^{43}$

The Khatri-Koombee dispute reflected all too clearly the ramifications of the eighteenth-century crisis and the range of responses it generated from artisan groups in Surat. Rioting and violence was but one aspect of their response to a situation where Company controls threatened to erode their autonomy. Another option was to deploy existing political connections with rival contenders, notably the English company, the Durbar and even the Maratha power on the fringe. The Khatris and Koombees were especially adept at these negotiations and used their status and customary location to extract privileges over the city's looms. The Koombees appear to have taken advantage as early as 1759 , when they appealed to the ruling authorities seeking permission to work on the manufacture of silk cloth which traditionally remained the Khatris prerogative. The dispute was resolved ultimately to the satisfaction of both parties, with the Kumbees agreeing to pay Rs. 45 annually to the Khatris and, in return, secure their consent in working a limited number of looms for the manufacture of silk goods.

Relations between the two groups, however, remained strained especially in the wake of the Company's efforts to control the manufacture of fine goods that made up a proportion of the Company's investment. The Khatris raked up the dispute in 1798 when they refused to honour their contractual obligations to the Company and demanded absolute control over the manufacture of all silk goods and a revocation of the privilege granted to the Koombees. ${ }^{44}$ The Commercial Board admitted in 1800 that:

experience of the past ten years having shown that to provide the red goods required by the Company without the Khatris is impracticable,

${ }^{42}$ CDD, no. 17(I) of 1798, p. 134: "Representation of the Contracting Brokers".

43 Ibid.

${ }^{44}$ PDD, no. 147 of 1800 , p. 627: "Letter and enclosures from Surat read by the Bombay Council on 2 April 1800". 
that no other caste of weavers, whatever will work them through fear of the Katrees, the Coolmbess wish to avoid working them and that the Katrees will not work them otherwise than on being restored the paper by which they are, as they say, unjustly deprived of a part of their privilege to work exclusively the piece goods called Deryaye, a kind of silk cloth prepared with gum and that this paper is no more than said to have been obtained some years back too manufacture all silk goods in which they have included the profitable kind Deryaye to that time exclusively wrought by the Katrees. ${ }^{45}$

The Commercial Board also agreed that depriving the Koombees of the manufacture of Deryaye would not prejudice their interests as through "all other kinds of silk goods, musroo, kincobs, cora reshmi etc they are known still to gain a livelihood in great measure and besides, agriculture is still their main profession". 46

The following years did not see a marked improvement in the Company's investment position. The activities of the Portuguese traders and their brokers and under-dealers continued to skim a considerable portion of the city's manufactures. Clandestine trading was the order of the day and peons were hopelessly inadequate to intercept the traffic. Weavers and under-brokers employed innovative means for this: for instance eight or nine people went out together with four or five of them fastening a piece of cloth around each leg and the others fastening a price list around their waists. They were escorted by a small party of Parsis armed with sticks. They sang and danced thereby drawing public attention and eluding the Company's peons in the bargain. ${ }^{47}$ Among the under-dealers who took an active role in such clandestine sales, was Vamalchand Bania who drove a thriving trade in supplying textiles to the Portuguese. In 1800, the Contracting Brokers stated that the agents of the Portuguese had for the past five years carried a traffic not less than " 25 to 40 lakhs of rupees per annum". ${ }^{48}$ What was necessary, therefore, was to exercise judicial authority over weavers committed to manufacturing for the Company, a course of action that was facilitated by the annexation of Surat by the English East India Company. Under the new regulations, defaulting weavers and manufacturers were

${ }^{45}$ Ibid., p. 628.

46 Ibid., p. 630.

${ }^{47}$ CDD, no. 25 of 1800 , pp. 125-26 (pp. 1150-51): "Representation from the Contracting Brokers dated 10 November 1799".

${ }^{48}$ CDD, no. 27 of 1800: pp. 558-59: "Letter in reply to the Commercial Board dated 26 December $1800 "$. 
liable to prosecution at the Adalat in Surat. ${ }^{49}$ At the same time, the Company successfully detached large sections of weavers and persuaded them to work on parts of the Company investment. The Khatri resistance was broken while the Commercial Resident was given greater powers of surveillance over weavers. The numbers of superintendents was increased to go daily around different streets and visit houses of merchants and manufacturers, to keep regular accounts of the time when "each weaver placed in his loom a new piece of good and when it was taken up and carried to the company's warehouse". ${ }^{50}$

The new regulations however did not extend to the under-dealers. As the Commercial board observed in 1802, the new regulations could not be of much efficacy "when applied to Banyan merchants who neither weave nor have looms in their houses and can consequently be under no check were peons to be placed over them". ${ }^{11}$ It was therefore essential to introduce a more direct system of procurement modelled on what had already been introduced in Bengal. "Some means", it was argued, "had to be devised of breaking the claims these intermediate agents have upon the weavers from the debts they nearly one and all are involved in for advances made to them a different times". ${ }^{2}$ The Company now emerged as the champion of the oppressed weaver who had to be rescued from the clutches of the rapacious bania. If the weaver instead of the bania received the advance, he would be able to save a portion, liquidate his previous debts and improve his material position. Weavers were, therefore, approached to come forward to accept company advances and work on the investment.

The benefits of the system do not appear to have convinced all manufacturers. We come across instances of weavers deserting their looms in search of alternative employment in the Company's army, which was perceived as a more stable occupation. The declining importance of textiles for the Company in the first quarter of the nineteenth century rendered much of the new system redundant. If anything the crisis had turned full circle as weaver and merchant, principal and intermediary 
were reduced to the position of disfranchised dependents under Company sovereignty.

\section{Conclusion}

Revisionist historiography on the eighteenth century has tended to foreground the merchant-financier in the political economy of the successor states. The experience of the merchant groups in Western India certainly endorses this position: here, intermediary merchants and brokers were able for some time to resist the attempts of the Company to introduce structural adjustments in the existing system of procurement and commerce. This did not, however, mean that merchants and manufacturers were operating from a vantage position. Conditions of political insecurity, shortage of money, rising prices of yarn combined with the Company's policy of trying to restrict the mobility of weavers, constituted major obstacles that was reflected in frequent bankruptcies, resistance and desertion by weavers. What little remained of their bargaining power was predicated on the limited and fractured nature of Company authority in the region. Once that changed, and Surat was annexed and the region came under the authority of the English East India Company, political equations underwent a complete change, leaving merchant, banker and artisan exposed to the full weight of Company hegemony. 


\title{
COMPETITION AND CONTROL IN THE MARKET FOR TEXTILES: INDIAN WEAVERS AND THE ENGLISH EAST INDIA COMPANY IN THE EIGHTEENTH CENTURY ${ }^{1}$
}

\author{
Bishnupriya Gupta
}

\section{Introduction}

The changes in the international textile market have been a central issue in explaining the rise of Britain as the industrial power and the relative decline of the Indian economy under colonial rule. India dominated the textile market before the industrial revolution in Britain. Indian textile products of different varieties flooded the British market in the seventeenth and the eighteenth centuries, reaching a peak in the mid eighteenth century. Indian calicoes were in great demand and muslins became synonymous of high fashion. A considerable share of these products brought to the British shores by the English East India Company (EIC) was re-exported to other parts of the world. The EIC supplied not just the British market, but also acted as the entrepot for world textile trade. Protests by textile lobbies in Britain (mostly woollen and silk manufacturers) in the late seventeenth century led to the so-called Calico Act of 1701 which banned the import of printed calico for the home market, but allowed its re-export. The policy encouraged a rapid growth of the printing industry in Britain, which provided a continuing and growing demand for white calicos. Further legislation in 1721 banned the import of white calicos for the home market, but allowed re-export. ${ }^{2}$ There are no precise estimates of the extent to which

1 This paper was presented at the GEHN conference in Pune in 2005. I would like to thank all participants, and in particular Prasannan Parthasarathi, for their comments. I am grateful to Jan Luiten Van Zanden for the data on textile prices from Dutch sources and to Lakshmi Subramanian for getting me started on this project. Any remaining errors are mine.

${ }^{2}$ Patrick K. O'Brien, Trevor Griffith and Phillip Hunt, "Political Components of the Industrial Revolution: Parliament and the English Cotton Textile Industry, 1660-1774", Economic History Review, 44, 3 (1991), pp. 395-423. 
the ban was circumvented, although there were indications that this was the case. Calicoes continued to be imported in large volume for re-export. The share of Indian textiles in the world market began to decline in the late eighteenth century; by the early nineteenth century Indian exports to Britain started to dwindle, by the middle of the nineteenth century, India had become a net importer of British textiles. ${ }^{3}$

These changes in the international textile trade coincided with two major developments: the political domination of the Indian subcontinent by the EIC and the industrial revolution in Britain. The literature on India sees the political factors as central to the decline in the textile trade and has focused on the interactions between the weavers and the EIC. The political dominance and monopolist position of the Company are seen as the decisive factors in the textile trade in India. As the EIC acquired revenue rights in Bengal and gained political and legal control, the exploitation of weavers increased and prices paid to the producers decreased. Limited attention has been paid to changes in the international market conditions as British producers began to substitute imports of cotton textiles using more capital intensive technologies. The increasing output per worker reduced textile prices in Britain and the international market price of textiles faced by the Indian exporters had started to decline.

European demand had been at the centre of the analysis of the international textile market in the seventeenth and eighteenth centuries. ${ }^{4}$ Rising demand for Indian textiles in the European market had a significant effect on the industry in certain regions in India. The analysis of the superiority of Indian products is based mainly on supply-side factors, such as cheapness of labour and skills in weaving and design. Considering available technology, Indian products enjoyed a competitive advantage in the world market. As the technological frontier of this industry changed with the industrial revolution, its impact on the world market was dramatic. The competitive advantage in cotton textiles shifted from India to Britain. Imports from India had provided the impetus for import substitution in Britain using a more capital intensive

\footnotetext{
${ }^{3}$ Stephen N. Broadberry and Bishnupriya Gupta, "Lancashire, India and Shifting Comparative Advantage in Cotton Textiles, 1700-1850: The Neglected Role of Factor Prices", Economic History Review, 62, 2 (2009), pp. 279-305.

4 This view is questioned by Sushil Chaudhury, who sees the Asia trade to have a larger share of the market. See Sushil Chaudhury, From Prosperity to Decline: Eighteenth Century Bengal (New Delhi: Manohar, 1995).
} 
technology. The higher labour productivity in Britain compensated for the wage differential and tilted the balance away from Indian producers. ${ }^{5}$

This paper looks at the implications of the changes in the world market on the fortunes of the Indian weavers and raises two issues: firstly, the monopoly position of the EIC was not as important as has been argued. Although in specific segments the company exercised monopoly, the textile market in India must be seen as a competitive market. The weavers had substantial bargaining strength in this market, which was reflected in the failure of the Company in meeting its procurement targets all through this period. In the last decades of the eighteenth century, the Company agents found it increasingly difficult to meet the export targets, suggesting that weavers could sell to other buyers. Secondly, the developments in the Indian textile industry must be seen in the context of the developments in world markets, in particular, the British one, which was the hub of international trade. The EIC was a price taker in this market. The absence of an increasing trend in textile prices in the European market from the middle of the eighteenth century and the eventual decline in nominal and real terms can explain the failure on the part of the EIC to increase procurement prices.

\section{Organization of the Textile Industry}

Supply-side explanations have focused on regional developments in the textile industry in India. ${ }^{6}$ This literature has reconstructed the history of textile production in the different regions of the Indian subcontinent and has explored the channels through which the output was

\footnotetext{
${ }^{5}$ Broadberry and Gupta, "Lancashire, India, and shifting competitive advantage in cotton textiles, 1700-1850: the neglected role of factor prices".

${ }^{6}$ See for instance on Bengal: Debendra B. Mitra, The Cotton Weavers of Bengal 1757-1833 (Calcutta: Firma KLM, 1978); K.N. Chaudhuri, The Trading World of Asia and the English East India Company, 1660-1760 (Cambridge: Cambridge University Press, 1978); Om Prakash, The Dutch East India Company and the Economy of Bengal (Princeton: Princeton University Press, 1985); H. Hossain, The Company Weavers of Bengal (Delhi: Oxford University Press, 1988). On the Coromandel Coast see: Kanakalatha Mukund, The Trading World of the Tamil Merchant: Evolution of Merchant Capitalism in the Coromandel (Hyderabad: Orient Longman, 1999); Prasannan Parthasarathi, The Transition to a Colonial Economy: Weavers, Merchants and Kings in South India, 1720-1800 (Cambridge: Cambridge University Press, 2001).
} 
traded in international markets. K. N. Chaudhuri's classic work on the EIC brings together a picture of the Indian industry combining evidence from the West, South and the East. This is a comprehensive narrative of the shift in production centres from Surat to the Coromandel and finally to Bengal in the eighteenth century. This work presents empirical evidence on the volume of trade from the three major exporting regions. However, Chaudhuri's work stops at 1760 and therefore does not touch on the decline of India as a primary textile producer. ${ }^{7}$

The low labour costs in India were the key to the comparative advantage enjoyed by the subcontinent in textile manufacturing as Indian wages were circa one-fifth the British level between 1680 and $1820 .{ }^{8}$ In 1701, for instance, labour that cost one shilling in England cost two pence in India. ${ }^{9}$ This advantage in wage cost gave Indian producers a competitive edge as long as labour productivity remained unchanged in the two countries. Technical skills were important both in the processing of raw materials and in weaving. These skills were passed down the generations within the family and tended to remain within caste groups. However, the technology used was labour intensive.

The cost of fixed capital has been estimated to be between one to three month's wages. ${ }^{10}$ Habib argues that until the invention of the flying shuttle, there was no scope for any development of the ordinary loom used for the simple weave. ${ }^{11}$ Consequently, labour productivity remained unaltered. However, innovations took place through the centuries through the introduction of patterned and draw looms which allowed weaving of designs, and through new materials and methods for dyeing and printing cloth. ${ }^{12}$ Chaudhuri sees the constraints on increase in labour productivity through the development of craft skills and specialization of labour in eighteenth-century textile manufacturing. ${ }^{13}$

${ }^{7}$ Chaudhuri, Trading World, Appendix 5, Tables 20-22.

${ }^{8}$ Stephen N. Broadberry and Bishnupriya Gupta, "The Early Modern Great Divergence: Wages, Prices and Economic Development in Europe and Asia, 1500-1800", Economic History Review, 59, 1 (2006), pp. 2-31.

9 J. R. MacCullock (ed.), Early English Tracts on Commerce (Cambridge: Cambridge University Press, 1954), p. 549.

10 This is observed for South India by Parthasarathi, Transition to a Colonial Economy, p. 12, and for Bengal by Mitra, Cotton Weavers of Bengal, p. 174.

${ }^{11}$ Irfan Habib, "The Technology and Economy of Mughal India", Indian Economic and Social History Review, 17 (1980), pp. 1-34.

12 Vijaya Ramaswamy, Textiles and Weavers in Medieval South India (Delhi: Oxford University Press, 1985), pp. 126-27.

${ }^{13}$ Chaudhuri, Trading World, pp. 273-75. 
The export trade of Indian cotton textiles has been estimated to be 10 percent of total output of the subcontinent. ${ }^{14}$ Although relatively small, the export trade had a significant effect on the economy of the producing regions. There was a qualitative difference between production for local markets and inter-regional/international markets. Production for local markets was dispersed across the country. Production for export was concentrated in four major centres in Gujarat, Bengal, Madras and Punjab. ${ }^{15}$ Local fairs met the needs of intra regional exchange, but long-distance trade led to greater specialization and the growth of weaving centres. The concentration of textile production in certain regions can only partly be explained by availability of hereditary craft skills and particular raw materials. Centres of textile production also developed in response to demand from the export market.

The main source of external trade moved from the West to the South and finally to Bengal in the East in the course of the seventeenth and eighteenth centuries. Surat in western India was the centre of the early textile trade. The Coromandel Coast in southern India became important from the middle of the seventeenth century as the European companies established trading posts along the coast. The share of this region in the EIC trade declined after 1690 as political conflict disrupted supply. As trade recovered in the early eighteenth century, Bengal rose in importance in the export trade to Europe and remained the main centre until the turn of the century. This region bore the brunt of the decline in India's share of the world market. The industry in this region enjoyed the advantage of skilled labour, cheap agricultural products and cheap transport along waterways. Weavers in many instances combined textile production with agricultural work. Spinning as in other parts of India was a part-time occupation done by women across different castes. ${ }^{16}$

Different social groups were involved in local and long-distance trade. Indian merchants were involved in the long-distance trade to South East Asia, Central Asia and Africa, but did not have a presence in the European trade except as middlemen. The latter was dominated by

\footnotetext{
${ }^{14}$ See Sinnappah Arasaratnam, Merchants, Companies and Commerce on the Coromandel Coast, 1650-1740 (Delhi: Oxford University Press, 1986) for South India; and Prakash, Dutch East India Company for Bengal.

${ }_{15}$ Chaudhuri, Trading World, passim.

${ }^{16}$ Hossain, Company Weavers of Bengal, p. 47.
} 
the European companies, in particular, the Dutch and the English trading companies. The EIC carried the bulk of the textile trade to Europe. There was intense competition in the product market and the Dutch were willing to pay higher prices in many instances. ${ }^{17}$ Mitra suggests that the European rivals were prepared to pay 20-30 percent more for the same product. ${ }^{18}$ The Dutch were involved in the Asian trade and the officials were instructed to give priority to the Asian market over the European one. ${ }^{19}$ Hossain documents the complex market structure in Bengal in the middle of the eighteenth century. ${ }^{20}$ There were many buyers in the market: European trading companies, Asian merchants and private traders. The employees of the EIC undertook their own trade and sold to different European companies. In one instance of sales from the Dhaka arangs in 1786 only 13 percent was accounted for by investments of the EIC. Individual merchants (Indians and foreigners as well as the servants of the Company) accounted for the bulk of the sales. ${ }^{21}$ This indicates that the EIC did not by any means enjoy a monopoly in the market. However, this interpretation appears to be inconsistent with trends in European markets. Prices of Indian goods in different European markets stayed roughly constant or declined. There was competition in European markets among the European companies as documented by Chaudhuri. Prices charged by different Companies could not have been very different in the same market.

The textile production of India consisted of hundreds of varieties of cloth. Different products were sold in different markets. A great variety of textiles were exported from the different regions in India. These included medium coarse varieties such as longcloth and calicos and also fine varieties such as muslins. ${ }^{22}$ The Asian markets were concerned about the colours and paid little attention to the length and width of the woven cloth. By the early seventeenth century, textile trade with South East Asia was well established. The Europeans wanted standardization. Adjustments were made to the looms to make this possible. If it is possible to make some generalization, then we can state

\footnotetext{
17 See in particular Prakash, Dutch East India Company; Hossain, Company Weavers of Bengal; Mukund, Trading World of the Tamil Merchant.

${ }_{18}$ Mitra, Cotton Weavers of Bengal, p. 62.

19 Arasaratnam, Merchants, Companies and Commerce, pp. 179-80.

${ }^{20}$ Hossain, Company Weavers of Bengal, ch. 3.

${ }^{21}$ Hossain, Company Weavers of Bengal, p. 75.

${ }^{22}$ See Giorgio Riello's paper in this volume.
} 
Table 10.1. Percentage shares of different categories of textiles traded by the Dutch and English East India Companies, 1730-59

\begin{tabular}{lcccccc}
\hline & \multicolumn{3}{c}{$\begin{array}{l}\text { Dutch East India } \\
\text { Company }\end{array}$} & \multicolumn{4}{c}{$\begin{array}{c}\text { English East India } \\
\text { Company }\end{array}$} \\
\cline { 2 - 7 } & $1730-39$ & $1740-49$ & $1750-59$ & $1730-39$ & $1740-49$ & $1750-59$ \\
\hline Ordinary Calico & 46 & 40 & 56 & 46 & 31 & 31 \\
Fine calico & 15 & 20 & 13 & 20 & 22 & 19 \\
$\begin{array}{l}\text { Muslin } \\
\text { Silk }\end{array}$ & 20 & 26 & 18 & 24 & 34 & 39 \\
$\begin{array}{l}\text { Thousands of } \\
\text { pieces per year } \\
\text { on average }\end{array}$ & 10 & 10 & 11 & 3 & 5 & 6 \\
\hline
\end{tabular}

Source: Sushil Chaudhury From Prosperity to Decline: Eighteenth Century Bengal (New Delhi: Manohar, 1995), table 7.3, p. 184; K. N. Chaudhuri, The Trading World of Asia and the English East India Company, 1660-1760 (Cambridge: Cambridge University Press, 1978), pp. 547-48; Femme S. Gaastra, "The Textile Trade of the VOC: The Dutch Response to the English Challenge”, South Asia, 19, Special Issue (1996), pp. 85-95.

the following: European demand was concentrated on relatively better quality goods. Other markets absorbed cheaper and lower quality products. Table 10.1 shows the trade share of the English and the Dutch companies in the textile trade in Bengal. In eighteenth century Bengal, the share of the English Company continued to rise at the expense of the Dutch. While Muslins became more important than Calico in the English trade, the Dutch trade showed the opposite trend.

\section{Price and Quantity Trends in Different Markets}

Chaudhuri documents the development of the market for Indian cottons in Europe and beyond. ${ }^{23}$ The domination of the English Company was challenged in Europe by the Dutch and by the 1670 s there was keen competition between the two in the European markets, making demand sensitive to price. ${ }^{24}$ Chaudhuri estimates the price elasticity of demand in the different regions and suggests that price was an important determinant of demand. ${ }^{25}$ Tables 10.2 show the rise in exports

\footnotetext{
${ }^{23}$ Chaudhuri, Trading World, ch. 12.

24 Ibid, pp. 291-92.

25 Ibid., p. 283.
} 
Table 10.2a. Indian exports of textiles to Europe by the VOC and EIC, $1665-1759$ (in thousand pieces per year)

\begin{tabular}{lrrrll}
\hline \multicolumn{5}{c}{ By the EIC from } & \multirow{2}{*}{ By the VOC } \\
\cline { 1 - 4 } & Bombay & Madras & Bengal & Total EIC & \\
\hline $1665-69$ & 96 & 37 & 7 & 140 & 127 \\
$1670-74$ & 295 & 169 & 47 & 511 & 258 \\
$1675-79$ & 310 & 193 & 67 & 570 & 127 \\
$1680-84$ & 452 & 408 & 108 & 968 & 283 \\
$1685-89$ & 201 & 244 & 169 & 614 & 316 \\
$1690-94$ & 90 & 23 & 59 & 172 & 157 \\
$1695-99$ & 149 & 108 & 131 & 388 & 365 \\
$1700-04$ & 296 & 105 & 197 & 598 & 311 \\
$1705-09$ & 34 & 99 & 71 & 204 & 295 \\
$1710-14$ & 165 & 150 & 260 & 575 & 373 \\
$1715-19$ & 82 & 200 & 252 & 534 & 436 \\
$1720-24$ & 185 & 269 & 342 & 796 & 476 \\
$1725-29$ & 120 & 142 & 559 & 821 & 399 \\
$1730-34$ & 57 & 87 & 584 & 728 & 241 \\
$1735-39$ & 67 & 137 & 581 & 785 & 316 \\
$1740-44$ & 95 & 98 & 619 & 812 & 288 \\
$1745-49$ & 60 & 144 & 480 & 684 & 262 \\
$1750-54$ & 55 & 170 & 407 & 632 & 533 \\
$1755-59$ & 56 & 106 & 308 & 470 & 321 \\
\hline $504 r c 5: 1665$ & $1759:$ & & &
\end{tabular}

Sources: 1665-1759: K. N. Chaudhuri, The Trading World of Asia and the English East India Company, 1660-1760 (Cambridge: Cambridge University Press, 1978), pp. 54045; Michel Morineau, “The Indian Challenge: Seventeenth and Eighteenth Centuries", in Chaudhury, Sushil and Michel Morineau (eds.), Merchants, Companies and Trade: Europe and Asia in the Early Modern Era (Cambridge: Cambridge University Press, 1999), pp. 273-74. 1771-94.

to Europe from the middle of the seventeenth century. The trend was punctuated by sharp downturns due to wars and political upheavals. The downturn in the early eighteenth century reflects the introduction of protection in Great Britain, but trade bounced back as protection was circumvented. The regional balance changed over time. Bengal emerged as the primary exporter in the eighteenth century: export volumes showed fluctuations, but did not show a sustained decline until the 1790 s, when there was a sharp decline in Indian exports.

Chaudhuri's data on unit price from the three major producing centres show a slight upward trend in all regions from 1660 to 1750 (Fig. 10.1). Thereafter, prices stayed stable for a variety of textiles. 
Table 10.2b. Indian exports of cotton textiles, 1790-1859 (thousand pieces per year)

\begin{tabular}{lcclll}
\hline & \multicolumn{2}{c}{ Exports to Britain } & & \multicolumn{2}{c}{ Total exports } \\
\cline { 2 - 3 } \cline { 5 - 6 } & Bengal & Total India & & Bengal & Total India \\
\hline $1790-99$ & 787 & 2,200 & & & 4,500 \\
$1800-09$ & 1,331 & 1,824 & & & \\
$1810-19$ & & 1,358 & & \\
$1820-29$ & & 431 & & & \\
$1830-39$ & 6 & 271 & & & \\
$1840-49$ & & 304 & & & 2,600 \\
$1850-59$ & & & & & 278 \\
\hline
\end{tabular}

Source: Michael J. Twomey, "Employment in Nineteenth Century Indian Textiles", Explorations in Economic History, 20 (1983), pp. 42-44.

Parthasarathis's data on longcloth prices from Cuddalore in the Coromandel from 1698 to 1790 show a similar trend: they rose until the first years of the 1730s and thereafter they remained stationary (Fig. 10.2).

In the Coromnadel, the trade in woven piece goods included three main varieties of cotton cloth: longcloth, salampores and moris. Figure 10.3 shows the price trend in the first two varieties. Prices show a slight upward trend up to 1705, there after staying relatively flat. Mukund argues that European demand increased sharply after 1710 and pushed up prices. There were two distinct periods of price rise: 1696 to 1702 , followed by a decline and another from 1732 to 1750 , similar to that observed by Chaudhuri.

There are no long term price series for Bengal. What we can find are short term series of prices from different regions and for specific products which makes systematic comparison difficult. Sushil Chaudhury finds that the prices of finer varieties of textiles tended to decline between 1730 and 1750, where as prices of coarse varieties rose. This is attributed partly to the Maratha invasions, which affected mostly those regions that produced coarse cloth, and partly to greater competition in the market for coarse textiles. Hossain's data for a later period also suggests little change in the prices of several varieties of cloth (Fig. 10.4). This difference in the price trends of coarse and fine varieties is an important aspect of the textile market and suggests that the market for fine textiles was mainly European; whereas private traders bought more coarse goods and created more competition in this market. 


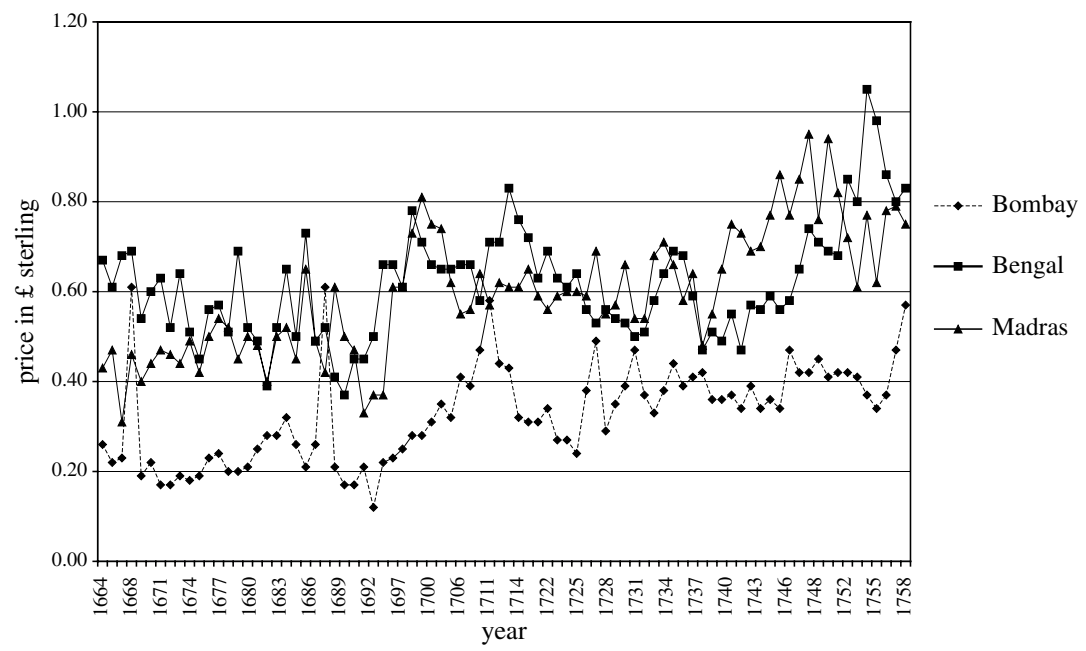

Fig. 10.1. Regional textile prices, 1664-1764. Source: K. N. Chaudhuri, The Trading World of Asia and the English East India Company 1660-1760 (Cambridge: Cambridge University Press, 1978), Appendix 5, tables C 20-22.

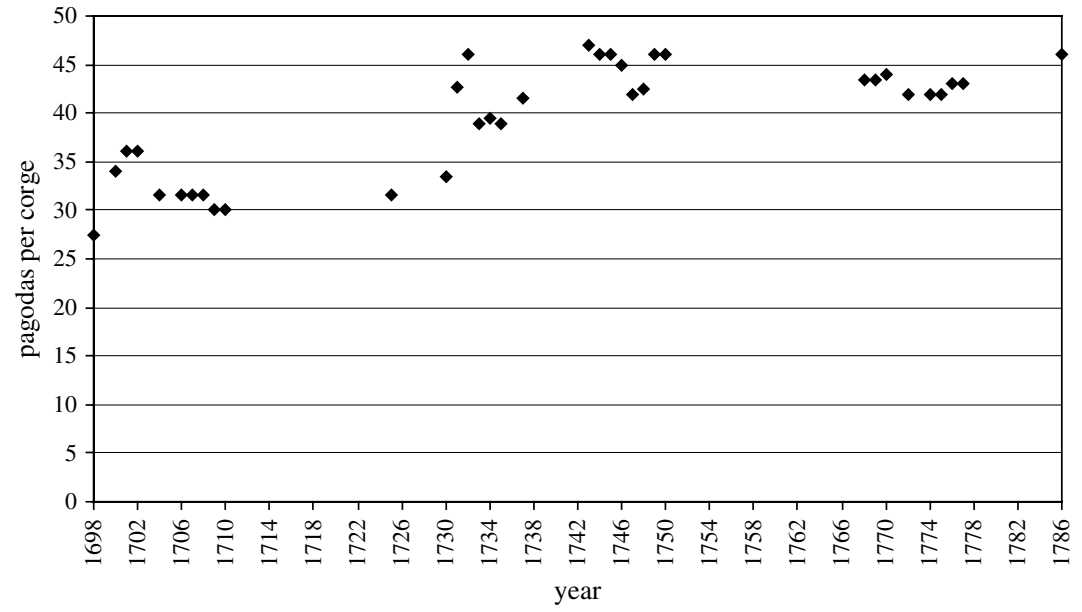

Fig. 10.2. Prices of longcloth at Cuddalore, 1698-1786. Source: Prasannan Parthasarathi, The Transition to a Colonial Economy: Weavers, Merchants and Kings in South India 1720-1800 (Cambridge: Cambridge University Press, 2001), p. 40. 


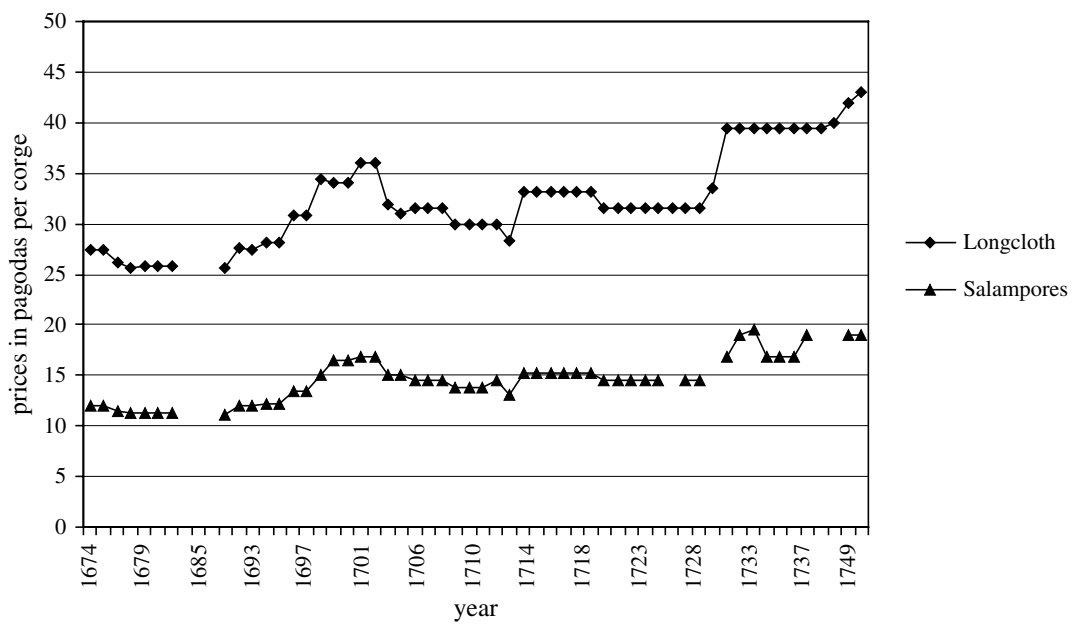

Fig. 10.3. Textile prices in Coromandel, 1674-1752. Source: Kanakalatha Mukund, The Trading World of the Tamil Merchant: Evolution of Merchant Capitalism in the Coromandel (Hyderabad: Orient Longman, 1999), pp. 81-2.
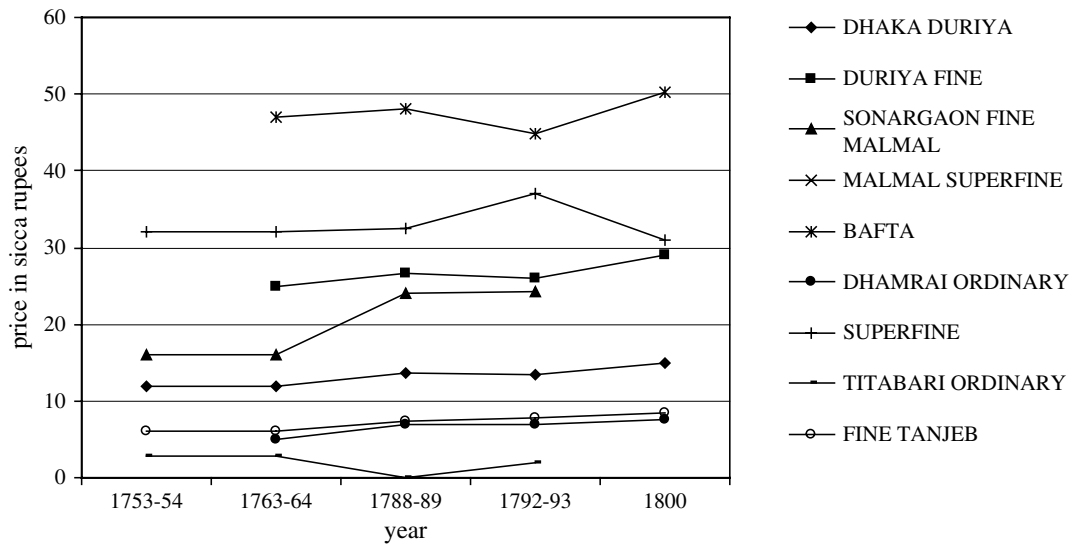

Fig. 10.4. Prices of different varieties of textiles in Bengal, 1753-1800. Source: Hameeda Hossain, The Company Weavers of Bengal: The East India Company and the Organization of Textile Production in Bengal 1750-1813 (Delhi: Oxford University Press, 1988), pp. 53-4. 


\section{Weavers, Merchants and the Company}

The European companies bought textile goods through a network of intermediaries. Commissioning of cloth by a middleman merchant on behalf of the company was a common practice. The weavers undertook production on the basis of advances made by merchants as done in Europe. The significant difference with the European puttingout-system was that the advance consisted of cash and not raw materials. The system of cash advance gave specific characteristics to the production of textiles. It allowed the weavers to purchase raw materials for production and food for the family. It also allowed the weaver to juggle sales between the English company and alternative buyers. The system of purchase therefore conferred some advantage to the weaver.

The cash advance from the company was based on contracts that specified what was to be supplied and when. Typically the contract was made a year before the delivery date. Contracts between the weaver and the merchant decided on the advance and the type and price of products and the date of delivery. The price of cloth was determined by a process of bargaining between the weaver and the merchant. Potential for dispute arose when the intermediary collected the product. Disputes over price and quality were endemic. By suggesting that the quality had not met the required standard, the Company intermediary could pay a lower price. Goods were confiscated if they did not meet the quality standard. But there was also the threat that the Company would not be able to fulfil its export target. Despite the problem of being locked into a system of advances it offered interest free credit when the going rate of interest in urban areas was $12-15$ percent and 7-8 percent in rural areas. ${ }^{26}$ This was potentially another advantage to the weaver.

There is little indication that there was a monopsony in the market. Instead there was fierce competition between the European companies, Asian merchants and local trade. Cash advances were paid to weavers through the intermediaries. The weaver was cash constrained and the cash advance provided a loan at a lower than the market rate of interest, which could be used not just to buy raw materials, but also food and other necessities. It also allowed the weaver to produce for other buyers before meeting the requirement of the European companies. Contracts normally established a rather long delivery date that allowed weavers

${ }^{26}$ Mitra, Cotton Weavers of Bengal, p. 61. 
flexibility in the timing of production. Moreover, since the European market demanded superior quality cloth, anything which failed the quality test could be sold in other markets.

Yarn purchases gave control over choice of raw materials. When the price of yarn rose, the weaver could buy lower quality yarn to maintain their income or use less yarn in the weave, thereby affecting the quality of the output. The expense on thread was three quarters of the total cost for finer varieties of cloth and two thirds for cloth sold in local markets. ${ }^{27}$ If the product did not satisfy the agents of the company, the cloth could be sold to other buyers. The cash advance was important for the weavers who did not have enough working capital to buy thread and the system of contracts provided a certain flexibility and an advantage to the weavers.

Parthasarathi argues in the context of the trade in the Coromandel that the weavers had a stronger position in this bargaining process before 1750 so that a rise in the cost of yarn and food was passed on to the merchants, keeping the weavers' shares fixed. The way in which the contracts affected procurement has been documented by Mukund. When cloth price increases did not keep pace with increases in the price of raw cotton and food grains, there was a shortage of supply of cloth to the company. Often the merchants agreed to supply only half of what the company demanded. The weavers' response to the low price was to weave thinner cloth using less yarn leading to complaints from the Company. There was a downturn in cloth procurement after 1684. The contracted quantity was only 54 percent of the previous year. In 1692 the English increased the price by 8 percent and by a further 10 percent in 1694. The following year marked an all time low in procurement: the Company contracted only 15 percent of its requirements. ${ }^{28}$

Chaudhuri documents a similar bargaining advantage enjoyed by the weavers in Gujarat and Madras in the late seventeenth century. The rise in input prices caused a decline in quality and the rejected cloth was sold to alternative buyers. Chaudhuri argues that since the cloth demanded by the EIC had little demand elsewhere, the weavers protected themselves by producing cheaper and inferior cloth, which could be sold in other markets if these were rejected by the Company. ${ }^{29}$

\footnotetext{
${ }^{27}$ Francis Buchanan, An Account of the District of Purnea in 1809-10 (Patna: The Bihar and Orissa Research Society, 1928), p. 542.

${ }_{28}$ Mukund, Trading World of the Tamil Merchant, pp. 93-4.

${ }^{29}$ Chaudhuri, Trading World, pp. 258-59.
} 
Evidence from different regions suggests that it was not unusual for weavers to renege on contracts and to sell to the highest bidder. Weavers could sell coarser qualities of cloth more easily to different buyers instead of just finer varieties, and during the latter part of the seventeenth and all through the eighteenth century they sold their output to buyers other than the East India Company.

Parthasarathi argues that the bargaining advantage enjoyed by the weavers in the early eighteenth century, disappeared as the EIC gained economic and political power. ${ }^{30}$ Weavers' distress in other parts of India has also been seen to coincide with the political domination of the Company. ${ }^{31}$ After 1770, the EIC brought in a series of legal sanctions to make the contracts more binding. These in effect reduced the bargaining power of the weaver and strengthened the power of the company. For delays in production, incomplete orders and clandestine sales, the weavers could be prosecuted and fined. Towards the close of the eighteenth century, as cotton prices rose in Bengal, weavers often lacked adequate resources to buy yarn and consequently economized on this input, producing inferior quality cloth. These goods failed to meet the company's quality standard. At the time of sorting, the cloth was given a lower grade and a lower price and some were rejected. The share of "ferreted cloth", as these were known, increased. The weavers found it increasingly difficult to sell this in another market due to the legal restriction introduced by the company on such sales. Moreover, the rejects had to be replaced, which led to further indebtedness.

There is much evidence that suggest that weavers received harsh treatment in the hands of the Company agents. ${ }^{32}$ However, at the same time, some of the bargaining advantages enjoyed by weavers, which Parthasarathi discusses in the context of early eighteenth century Coromandel, continued to be a feature of the late eighteenth century Bengal. What was missing was the buoyancy of the European demand. The response of the weavers documented for southern India in the late seventeenth and early eighteenth century was also seen in Bengal in the late eighteenth century. The rising prices of food and raw material led to supply shortfalls. The increasing problems in fulfilling company's orders in Bengal can be documented for the 1770s. Despite the legal

\footnotetext{
30 Parthasarathi, Transition to a Colonial Economy, pp. 83-93.

${ }^{31}$ Hossain, Company Weavers of Bengal, ch. 4; Mitra, Cotton Weavers of Bengal, pp. $132-50$.

32 Ibid.
} 
backing and confiscations of products delivered by the weavers and the use of force in many instances, the company found it difficult to meet its export target. This was particularly true for finer varieties of cloth. The procurement problems dominate the correspondence between the Company agents in Bengal and the higher authorities. There was increasing dissatisfaction with the gumasthas (an intermediary) for failing to meet procurement targets. The Company resident withheld further advances until the shortfalls or confiscated orders could be replaced.

The gumashtas, on the other hand, complained of their inability to procure goods from the weavers unless the advances could be made. In January 1776, the persons in charge at different arangs wrote to the Residents in Patna, Dacca, Cossimbazar and elsewhere that if goods from a subordinate factory were found to be unsatisfactory, the resident by whom they were provided should pay for the difference at which they were rated and their actual value. ${ }^{33}$ The contracts with the chief at Patna specified a penalty of 10 percent over and above the money advanced. ${ }^{34}$ In many instances money for further investment was raised by the sale of confiscated goods. There is evidence for seventeenthcentury Surat that a penalty of 9 percent was specified for non-fulfilment of a contract, though such a penalty was rarely imposed. ${ }^{35}$

One case reported in May 1776 refers to the purchase of thread with the advance received for 10,800 pieces from the gumashta. As the price of thread was high, the advance was not adequate to pay for the appropriate quantity and the quality of the cloth failed to meet the required standard. The weavers claimed that the money was inadequate to purchase the right amount of yarn. The local resident placed the blame on the agent for his failure to ensure quality. 600 pieces met the quality standard and 900 were rejected. ${ }^{36}$

The Board of Trade frequently discussed the inferior quality of the cloth delivered and the consequent effect on the colours on the woven cloth. ${ }^{37}$ Table 10.3 reports on the loss made by the company on the sale of ferreted cloth. The Board stated the recovery of outstanding

\footnotetext{
${ }^{33}$ West Bengal State Archives (thereafter WBSA), "Letter to Board of Trade", 2 Jan. 1776.

${ }^{34}$ WBSA, "Letter to P. M. Dacres", 17 Jan. 1776.

${ }^{35}$ WBSA, "Public Department Diary of the Bombay Government", No. 24B of 1751, pp. 238-467.

${ }^{36}$ WBSA, Board of Trade, Fort William, 14 May 1776.

37 WBSA, Board of Trade, Fort William, 17 May 1776.
} 
balances of $1774 / 75$ and $1775 / 76$ as the primary objective. Advances were to be denied to weavers who had not settled their balances. Resolving disputes in the legal system was also mentioned. ${ }^{38}$ However, further advances continued to be made in response to the demand by weavers that they would not be able to supply the contracted quantity. During the same period, weavers from two arangs returned the advances paid to them and refused to work for the company. ${ }^{39}$

The chief of Luckipore wrote to the Board of Trade in April of 1776 that the prices paid by the Company were below the "real cost of cloth to the weavers" and the loss made on sales to the Company were made up by clandestine sales to private traders. He warned about the problems with procurement unless the weavers were paid the right price. The chief of Dacca, on the other hand, had a much less compassionate view and argued that the weavers made use of the advance paid by the Company to produce cloth and then sold to the best bidder. When the

Table 10.3. A comparative statement of the profit and loss on the following goods sold at outcry, the 15 May 1776 (in rupees)

\begin{tabular}{lrrrrr}
\hline & Pieces & Prime cost & Outcry price & Profit & \multicolumn{1}{c}{ Loss } \\
\hline Baflaes Tugdea & 240 & 797.7 .3 & 731.4 & & 66.3 .3 \\
D.Luckypore & 480 & 1794.4 & 1725 & & 69.4 \\
D.Fine & 1200 & 5869.15 .3 & 5298.12 & & 571.3 .3 \\
D.Callipatties & 960 & 5271.7 .6 & 4477.8 & & 793.15 .6 \\
Cossaes & 400 & 3275.8 & 2690.10 & & 584.14 \\
Ditto & 100 & 922 & 737.8 & & 184.8 \\
Ditto & 100 & 666 & 715.10 & 40.10 & - \\
& $\mathrm{ms}$. & & & & \\
Raw silk & 39.4 .4 & $19,343.10 .3$ & 8630.11 .3 & & $10,712.15$ \\
Ditto & 3.8 .8 & 1336.6 .3 & 739.4 & & 597.2 .3 \\
Ditto & 38.39 .4 & 18696.15 .6 & $8,790.12 .3$ & & $9,906.3 .3$ \\
Charges & & $57,943.10$ & $34,536.15 .6$ & 40.10 & $23,486.4 .6$ \\
Wrappers \& & & & 172.12 & & 49.10 deduct \\
$\quad$ wax cloths & & & & & \\
Total & & & 34.709 .11 .6 & & 23436.10 .6 \\
\hline
\end{tabular}

Source: WBSA, Board of Trade, 21 May 1776.

${ }^{38}$ WBSA, Board of Trade, Fort William, 7 June 1776.

39 WBSA, Board of Trade, Fort William, 14 May 1776. 
weavers were put under pressure to deliver the goods or when they were in need of further monetary advances, they hastily produced cloth of inferior quality with several defects. Upon delivery these goods were rejected by the Company for not having met the quality standard specified in the contract. The spot or 'ready money purchases' as they were known, were seen to be the only option left to procure the right quality cloth. ${ }^{40}$ However, with this the Company could never be sure of meeting its procurement target and stood to loose any control it had on the weavers. The existing system of contracts allowed the Company to use substantial threats against the weavers as output was confiscated and sold to local buyers. The Company appropriated the sum of the sale and the weaver continued to remain indebted to the Company and worked to pay off the loan. ${ }^{41}$ Table 10.3 shows the losses that were sustained by the Company on these sales. Mukund discusses a similar phenomenon for the Coromandel..$^{42}$ Archival evidence from Surat suggests a similar response by the weavers. ${ }^{43}$ The response of the weavers to changes in the price of inputs was similar even when the political context differed. There is no evidence to suggest that monopoly in the market for textiles and the political power of the EIC brought about crucial changes.

The textile market after 1760 was characterized by the shortfalls in supply to the EIC. The story of weavers' impoverishment is one of increasing debt to the company, harassment in the hands of the agents and increased legal penalties as the EIC gained political power in Bengal. Although the balance of power titled heavily in their favour, the agents of the company failed to meet the export targets. This puzzle can be explained if we look at the market for textiles in Britain.

\section{Indian Textiles and the World Market}

The economic distress of the Indian weavers coincided with the stability of textile prices in the British market. It also coincided with the rise in prices of agricultural products in the Indian market. These included the price of raw cotton and food. As the cost of production rose the weaver's profit margin became increasingly smaller. Yarn accounted for

\footnotetext{
${ }^{40}$ WBSA, Board of Trade, Fort William, 10 May 1776

${ }^{41}$ WBSA, Board of Trade, Fort William, 1 April 1776.

${ }^{42}$ Mukund, Trading World of the Tamil Merchant, p. 93.

${ }^{43}$ WBSA, "Public Department Diary of the Bombay Government, Consultation", 1751 , various letters.
} 
approximately 70 percent of the cost of production. Therefore an agricultural crisis which might increase the cost of cotton had profound effects on the cost of production. At the same time an agricultural shortage also increased food prices and the weavers demanded higher prices for the cloth they supplied. The prices offered by the company showed little upward trend. Table 10.4 shows the gap between the weaver's asking price and the Company's offer price. Between the $1760 \mathrm{~s}$ and 1790 the offer price increased by circa 50 percent for fine cloth varieties, but the coarser qualities showed no price change. The price acceptable to the weaver for fine cloth had doubled, and for coarser varieties it was 50 percent higher. While the Company was prepared to increase the offer price for finer textiles, it was reluctant to do so for inferior quality cloth as the price gap in different varieties suggest. This reflects the demand and supply situation in the market. The imbalance between demand and supply was much more significant in the market for fine cloth. The main shortfall was in fine quality textiles.

The gap between the Company's demand price and the weavers' asking price reflected the ceiling imposed by changes in the British market. Weavers adopted the same defense mechanism as earlier in the century: they economized on the use of yarn and produced inferior quality cloth which could be sold to other buyers in the local market. A compelling explanation of the weavers' response is that there was more competition in coarse and medium varieties due to private trade. This also explains why the supply shortfall was primarily in the market for fine quality cloth, where demand was mostly from the European markets.

Table 10.4. Difference in company's price and the price acceptable to the weaver (in rupees)

\begin{tabular}{lllll}
\hline Type of good & $\begin{array}{l}\text { Average price } \\
(1764-66)\end{array}$ & $\begin{array}{l}\text { Offer price } \\
\text { in } 1790\end{array}$ & $\begin{array}{l}\text { Price } \\
\text { acceptable to } \\
\text { the weaver }\end{array}$ & $\begin{array}{l}\text { Price gap in } \\
\text { percentage }\end{array}$ \\
\hline $\begin{array}{l}\text { Midling } \\
\quad \text { Malmal }\end{array}$ & 9.2 .6 & 9.13 .0 & 13.8 .0 & 40 \\
$\begin{array}{l}\text { Fine Malmal } \\
\text { Superfine }\end{array}$ & 12.7 .11 & 16.0 .0 & 18.0 .0 & 12 \\
$\quad 17.8 .5$ & 28.4 .0 & 35.0 .0 & 25 \\
\hline
\end{tabular}

Source: Hameeda Hossain, The Company Weavers of Bengal: The East India Company and the Organization of Textile Production in Bengal 1750-1813 (Delhi: Oxford University Press, 1988), Table 2.4, p. 55. 
Hossain argues that it is not necessarily true that aggregate output declined. It is likely that weavers switched to private trade. Weavers, particularly of coarse varieties of cloth, produced for both export and home markets. They used advances from the Company to produce for domestic demand that once fulfilled - sometimes surreptitiously provided funds to complete Company's orders. A differential pattern of production developed: the first part of the season was spent on part of the Company's orders and part of the time on the cheaper warp that was laid for private trade. Money earned from the sale to private traders was then spent on completing the Company's orders. ${ }^{44}$ Mitra argues that the export market for Indian goods was shrinking as a consequence of changes in demand in Britain with the onset of the industrial revolution and the technological changes in cotton textile production. ${ }^{45}$

There is evidence of competition in the textile market, although it is difficult to find reliable quantitative estimates. The changing market shares of the Dutch Company and the English Company have been documented for Bengal. ${ }^{46}$ It has been suggested that only one third of the estimated output was under the English EIC's control. The prices offered by the company were invariably lower than that offered by its rivals. The price difference between private traders and the EIC on comparable varieties of cloth, though not the same, ranged from 4 to 83 percent. ${ }^{47}$

If competition in this market was so intense, then clearly the Asian merchants had an important role. However, in the absence of quantitative estimates of Asian trade, more precise statements are difficult to make. Chaudhury presents some patchy information from specific centres. One estimate puts the volume of textiles exports from Dhaka in 1747 by Asian merchants (including Armenians) at two thirds, and by European merchants (including private trade) at one third of the total. Dutch sources estimate the investment by non Dutch merchants (Asians and Europeans) to be twice as high as the share of the English Company. Chaudhury's estimates are in line with these figures. ${ }^{48}$

Despite the lack of precise estimates of the European and the intraAsian trade, all the evidence from the competition in the textile market

\footnotetext{
44 Hossain, Company Weavers of Bengal, p. 59.

45 Mitra, Cotton Weavers of Bengal, pp. 3-4. However, Mitra does not discuss how the market for textiles was changing.

46 Chaudhury, From Prosperity to Decline, pp. 188-95.

47 Mitra, Cotton Weavers of Bengal, pp. 3-4.

48 Chaudhury, From Prosperity to Decline, p. 210.
} 
indicates a significant presence of alternative buyers. Qualitative estimates from the correspondence of the company officials to the court of directors indicate a high volume of intra-Asian trade carried out by Asian merchants. Therefore the idea of a monopsonistic market in textiles is not a realistic one.

\section{An Alternative Framework of Analysis}

Why did the weavers face a squeeze in earnings in the EIC trade? We have already shown the trends in the prices of Indian exports from different regions. Now let us consider the prices at which they were sold in the European market. Prices in London and Amsterdam showed similar trends over the eighteenth century (Figs 10.5 and 10.6). Prices fetched by the EIC's textiles in London declined both in nominal and real terms. Calico prices in Amsterdam show a similar picture. The price trends reflect the technological changes and the rising labour productivity in Britain.

What about the cost of production in the Indian textile industry? Here the picture suggests an increase after 1760. Agricultural crises raised the prices of cotton and food. The weavers demanded higher prices for the final product. However, given the general price levels in international markets (especially the European ones), it is not surprising that the procurement prices in India did not compensate for the rising cost of production. Although there is little evidence on the price of yarn, we can take the price of cotton textiles as an indicator. Evidence from the Coromandel Coast suggests that the price of raw cotton was substantially higher during the first half of the eighteenth century than half a century earlier ${ }^{49}$ This coincided with the periods of supply shortfall in the Coromandel. Mukund's econometric estimates show that the rise in textile prices cannot be totally explained by changes in food or raw cotton prices, even if food prices had a great impact on the cotton prices. Demand factors appear more important.

There is evidence of a rise in cotton prices in all regions of Bengal after the 1740s. In Dhaka the price of cotton increased from Rs. 2 per maund in 1738 to Rs. 10 in 1752, to Rs. 24 in 1762. In Lakhipore cotton prices increased 25 percent between 1788 and 1789. Some varieties of cotton became 50-100 percent more expensive. Such a rise in prices

\footnotetext{
${ }^{49}$ Mukund, Trading World of the Tamil Merchant, p. 84.
} 


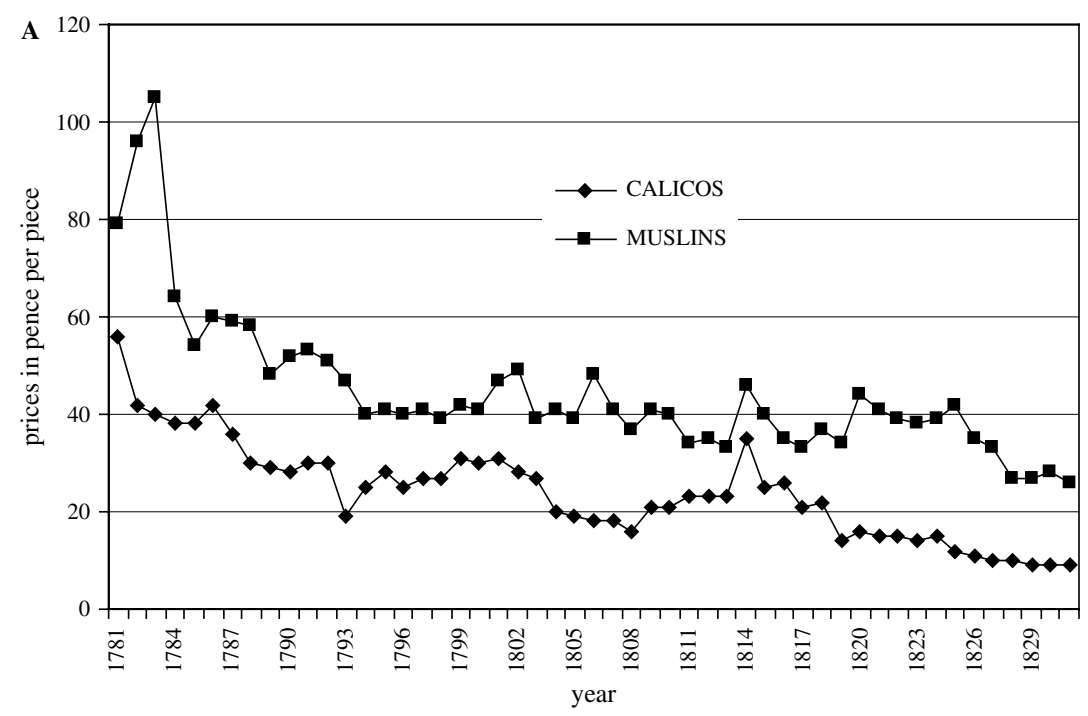

Fig. 10.5a. Current textile prices, 1781-1832. Source: Javier Cuenca Esteban, "British Textile Prices, 1770-1831: A Comment on the Crafts-Harley View of the Industrial Revolution”, Economic History Review, 46, 1 (1994), pp. 66-105.

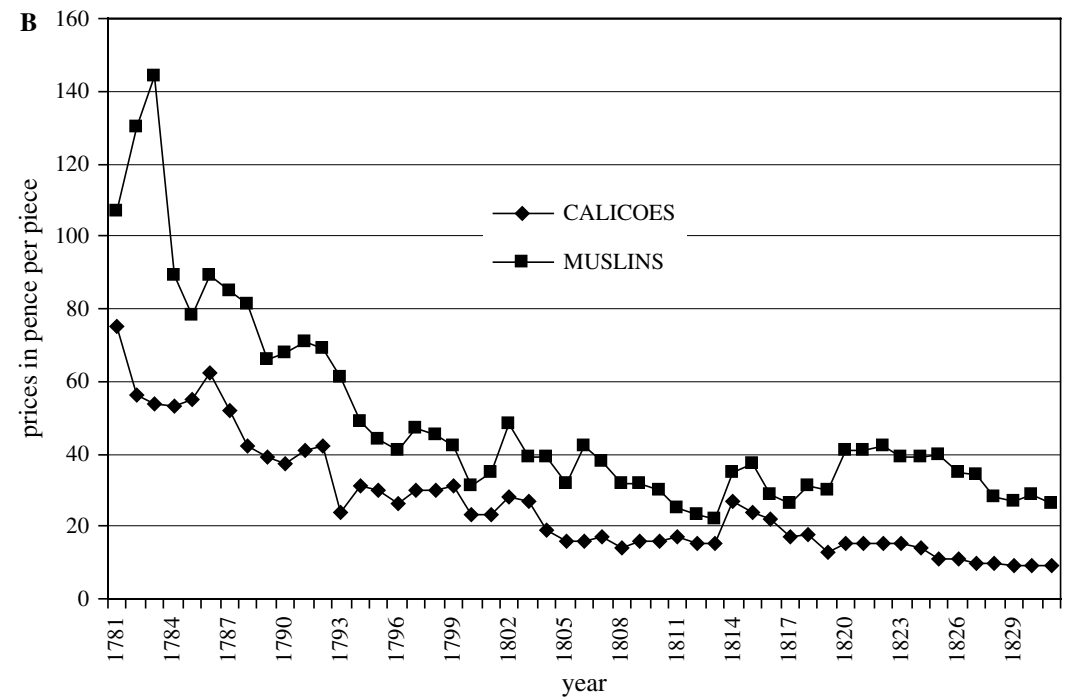

Fig. 10.5b. Deflated textile prices, 1781-1832. Source: Javier Cuenca Esteban, "British Textile Prices, 1770-1831: A Comment on the Crafts-Harley View of the Industrial Revolution", Economic History Review, 46, 1 (1994), pp. 66-105. 


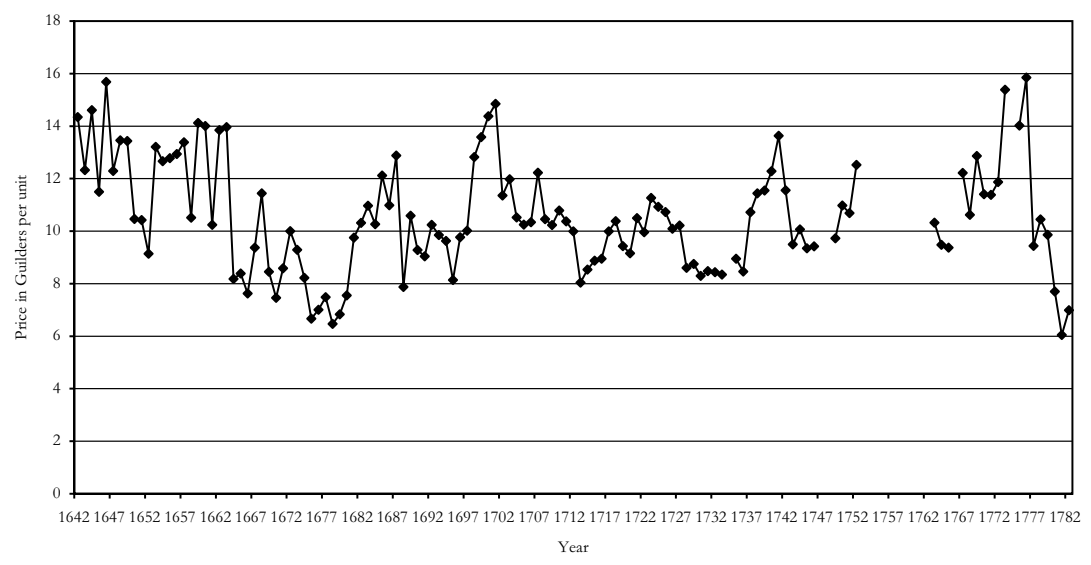

Fig. 10.6. Calico Prices in Amsterdam, 1642-1783. Source: Data made available by J.L. van Zanden from Dutch sources.

was caused partly by political conflicts and partly by weather conditions. The price of rice increased by 30 percent between 1738 and 1751 . Similarly the price of cleaned cotton doubled in the last few years of the century, confirming a trend that was already visible in the 1750 s. High cotton prices reflected shortages of the raw material. Bengal, for instance, produced just over 7 million pounds of cotton and had to import over 43 million. Periods of high cotton prices clearly coincided with periods of procurement problems. Towards the end of the seventeenth century in the Coromandel and after the mid-eighteenth century in Bengal, the EIC frequently failed to meet its procurement target.

By analyzing the demand and supply of cotton textiles within a competitive international product market, we can explain the shortfall in output. The EIC can be seen as facing a perfectly elastic demand curve, given by the British price $\left(\mathrm{P}_{\mathrm{B}}\right)$ (Fig. 10.7). This represents the EIC's marginal revenue curve (MR). The supply curve (S) of Indian textiles is upward sloping. Let us first consider a market with many buyers. Now consider the situation where the supply curve in an Indian region shifts upwards because of an increase in local costs, while costs and prices in Britain are unaffected. There are two likely reasons why the supply curve may have shifted to the left: first, a rise in the cost of yarn or raw cotton; and second, an increase in the cost of labour. Region-specific movements in raw cotton costs and in labour costs can thus be seen as affecting 


\section{A: Monopsony}

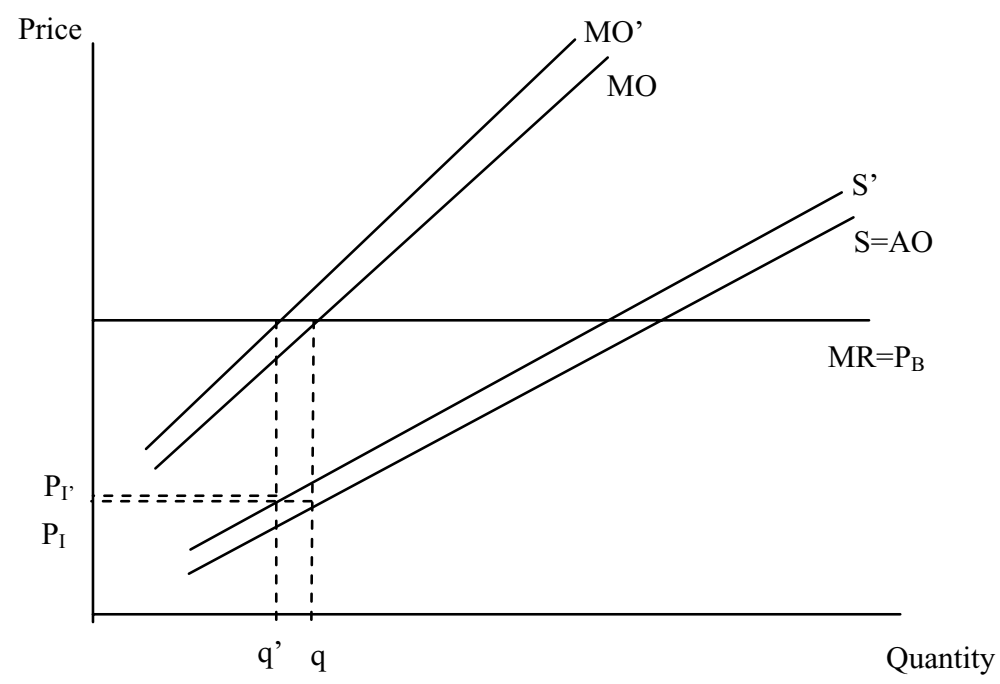

\section{B: Perfect competition}

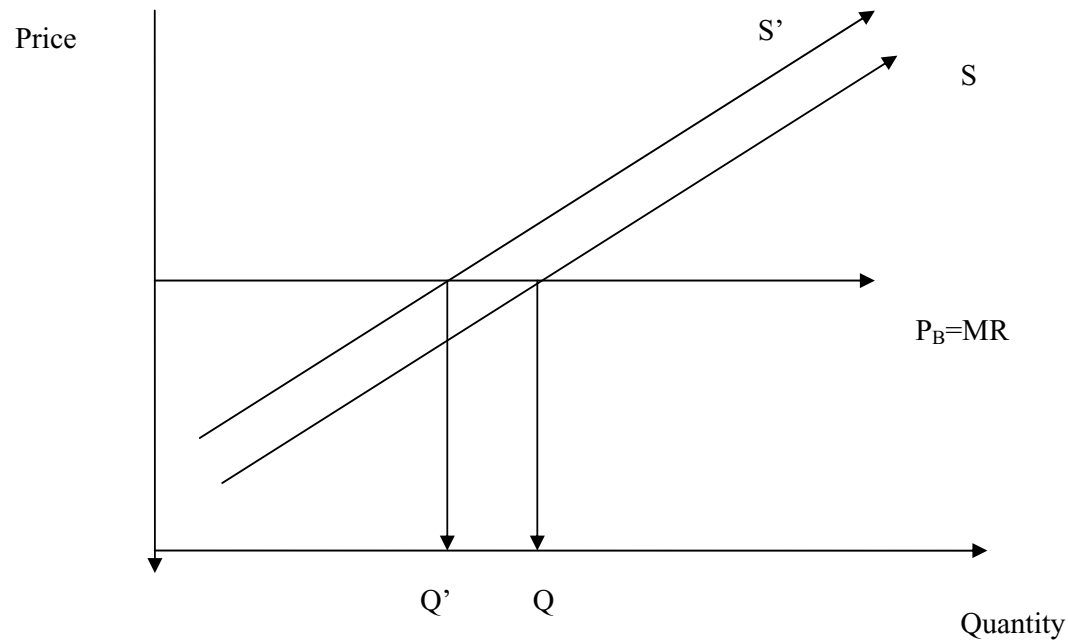

Fig. 10.7A-B. The English East India Company and the market for textiles. 
the regional balance of supply. As the supply curve shifts upwards, the new equilibrium will be found at a reduced volume of output.

We can also consider a situation where the EIC enjoyed monopsony power, its marginal outlay curve (MO) lies above the supply curve. The supply curve $(\mathrm{S})$ of Indian textiles is upward sloping, and determines the average outlay $(\mathrm{AO})$ of the EIC. The EIC equates marginal revenue to marginal outlay to determine the quantity of cloth purchased (q), while the price paid to the Indian supplier $\left(\mathrm{P}_{\mathrm{I}}\right)$ is read off the supply curve. The new supply curve is $S^{\prime}$ and the new marginal outlay curve is MO'. The response of the EIC is to raise the procurement price to $\mathrm{P}_{\mathrm{I}}$, but by less than the shift in supply resulting from the cost increase. Hence the quantity procured falls from q to q' (Fig. 10.7).

Note also that the framework can be adapted to deal with oligopsonistic competition between the EIC and the VOC, with the two companies having different strengths in different regions of India. Even with cotton cloth fetching similar prices in the Netherlands and Britain, relative procurement prices would be expected to vary inversely with the extent of regional market dominance. Hence the EIC would be expected to offer higher procurement prices in regions of Dutch dominance and vice versa. This would be consistent with Mukund's claim that the Dutch offered 10 per cent higher prices than the British in the Coromandel Coast region during $1672-83 .^{50}$

Therefore in both scenarios, there would be a procurement failure if the cost of production increased. The essential condition here is that the EIC was a price taker in the international market. Prices in this market reflected gains in labour productivity in Britain. Therefore bringing in the world market resolves the puzzle of procurement failure in the market for textiles despite the political domination of the EIC.

\section{Conclusion}

This paper has offered an alternative framework for analyzing the decline of the Indian textile trade. The existing literature is rich in detail and analyzes the rise and fall of the textile trade in different regions in India. By bringing the developments in the international market for textiles

${ }^{50}$ Ibid., p. 93. 
and the industrial revolution in Britain into the story, we can get a new perspective on the changes in the textile market. The textile trade in India was characterized by competition among many buyers that included European companies as well as local traders. Consequently the political control exercised by the EIC could only lead to limited economic control. The decline in this trade can be best understood by bringing the developments in the international textile market into the story. 
$-978-90-47-42997-5$ 
PART III

REGIONS OF CHANGE: INDIAN TEXTILES

AND EUROPEAN DEVELOPMENT 
$-978-90-47-42997-5$ 


\title{
THE INDIAN APPRENTICESHIP: THE TRADE OF INDIAN TEXTILES AND THE MAKING OF EUROPEAN COTTONS
}

\author{
Giorgio Riello
}

There is no doubt that in the 1760s the Indian subcontinent was the major producer and trader of cotton textiles in the world. Fifty years later, in the 1810s, this was no longer the case. ${ }^{1}$ Europe or, to be more precise, the north-western corner of the continent called England, was fast overtaking India in the production of cotton textiles thanks to the use of machinery and the consequent reduction of the cost of production. This is a classic narrative that we succinctly call 'The Industrial Revolution'. It is complemented by explanations of how Europe rose to world dominance in the production of cotton textiles and how, as a consequence, the strong trading position of Britain became increasingly evident. Europe, as India had done for centuries, was now not just the core of manufacturing but also the main carrier of cotton textiles across the globe. ${ }^{2}$

This narrative of European achievement is the result of generations of economic historians painstakingly collecting data, analysing documents and creating hypotheses on the modalities, causes and effects of a process that has been mostly seen as European in nature and characterised by a certain northern English accent. The very concept of a revolutionary event implies a break or discontinuity with the past, and more precisely with the long tradition of cotton textile manufacturing and trade that for centuries had characterised India.

1 Stephen Broadberry and Bishnupriya Gupta, "The Early Modern Great Divergence: Wages, Prices and Economic Development in Europe and Asia, 1500-1800", Economic History Review, 59, 1 (2006), pp. 2-31.

${ }^{2}$ For a revisionary analysis see Patrick K. O'Brien, “The Geopolitics of a Global Industry: Eurasian Divergence and the Mechanisation of Cotton Textile Production in England", in Giorgio Riello and Prasannan Parthasarathi (eds.), The Spinning World: A Global History of Cotton Textiles, 1200-1850 (Oxford: Oxford University Press, 2009), pp. 367-85. 
The Indian subcontinent plays no part in the story of a process of European industrialisation, although it can be argued that the subcontinent later became a victim of competition or prey to political imperialism. The lack of Indian agency can be contrasted with some rather exaggerated European confidence and boisterousness. What seems to be often forgotten is that Europe did not suddenly acquire the skills, knowledge and 'outlook' to produce and sell cotton textiles and that even when it did, they were not the simple result of technological innovation. It was a long process of learning that started back in the 1500s that eventually led, a couple of centuries later, to Europe becoming one of the world's leading cotton manufacturing areas.

It is here argued that the intercontinental trade in cotton textiles was key to creating the conditions for the later development of a European cotton industry. It is the relationship between India and Europe, mediated as it were through the so-called East India companies (in particular the Dutch (VOC) and the English (EIC) companies), not European exceptionalism that explains the mechanisation, industrialization and re-location of the cotton industry from India to Europe at the end of the eighteenth century.

The question that this paper raises is why Europe started producing cotton textiles, when India was the undisputed global leader in their manufacturing and trade. I confine my reply to the analysis of trade and the types of commodities exchanged. By necessity, this paper will not discuss two important issues such as the comparative role of technology and organisation of labour, or the different wage levels and productivity in Europe and India. ${ }^{3}$ The first section contextualises the ways in which the interaction between trade and industry has been explained by historians. My argument is that the specific relationship between the import into Europe of Indian textiles and the subsequent development of a European cotton industry must give due consideration to the accumulation of knowledge regarding products and markets in the period between 1600 and the late eighteenth century. The role of the European chartered companies is considered in the following two sections.

${ }^{3}$ Broadberry and Gupta, "Early Modern Great Divergence"; Stephen Broadberry and Bishnupriya Gupta, "Cotton Textiles and the Great Divergence: Lancashire, India and Shifting Comparative Advantage, 1600-1850" (Unpublished paper, July 2004). See also Gupta's paper in this volume. 
The first section discusses the early trade with India by the Portuguese, and by the EIC and VOC after 1600. The concluding section examines the issue of knowledge and information by focusing on the overall pattern of trade in textiles between India and Europe and the complex range of products exchanged.

\section{What is the Relationship between Trade and Industry?}

The connection between trade and industry is a topic that has drawn the attention of generations of economic historians interested in understanding the relevance of 'endogenous' and 'exogenous' causes in relation to the economic growth of specific locations, be they towns, cities, countries and even continents. As one might expect, consensus has never emerged on the ultimate formula that combines trade and manufacturing as different historical experiences show a variety of conditions and outcomes. What might be more important for the purpose of the present analysis is the idea that the very connection between trade and industry has been explained by economic historians (and in particular by textile historians) in very different ways. Allow me to briefly summarise these positions.

Perhaps the strongest conceptual model that links trade and industry is based on the idea of capital accumulation. Capital acts as a catalyst between the two with trade producing resources that can be later invested in industry. This is a theoretical framework that can be applied throughout the world, although its main application has been the process of industrialization in the British Isles. Rostow, fifty years ago, suggested that one of the features of the British Industrial Revolution was to be capital intensive and that conditio sine qua non for entering the industrial age was the accumulation of minimal levels of capital. ${ }^{4}$ In the case of India, a similar model has been used in reverse. India deindustrialized because of a lack of capital and the declining position of a merchant community that for centuries had provided support and markets for Indian products, including textiles. Some historians have also seen a connection between these European and Indian mirror stories and have explained European industrialization as the result of a continuous and efficient exploitation of India, or a disruption of

${ }^{4}$ Walt Whitman Rostow, The Stages of Economic Growth: A Non-Communist Manifesto (Cambridge: Cambridge University Press, 1960). 
established productive structures by European demand. ${ }^{5}$ A second position, that complements but also revises the capital accumulation one, has been recently emphasised by Douglas Farnie. He claims that the relationship between trade and industry is based on an implicit understanding that whilst industry is wealth-producing, trade is wealth-allocating. ${ }^{6}$

A second position is based instead on the commodities themselves that were traded between Europe and Asia and in particular on their key attributes: exoticism and imitation. According to Maxine Berg, trade - especially trade between China and India, and Europe - was key in familiarizing European consumers with Asian products, and in particular cotton textiles. ${ }^{7}$ As demand surged, Europe became increasingly keen to substitute exotic imported products with home-produced wares. ${ }^{8}$ This position combines trade and industrialization through the medium of consumption. Import substitution is the process through which trade, commodities and manufacturing are linked with innovation and the creation of new products within Europe.

A third explanation sees the success of Indian cotton textiles not confined just to European markets. Joseph Inikori in his Africans and the Industrial Revolution (2002) suggests the existence of a triple link between import, manufacturing and export. ${ }^{9}$ Imported cotton textiles

\footnotetext{
${ }^{5}$ Not all historians agree. For instance, Steensgaard states that "The Indians weavers were able to deliver without fundamental changes in technique or organization". Other historians are less categorical and suggest a complex - and long-term - restructuring of the entire productive system. Niels Steensgaard, "The Growth and Composition of the Long-Distance Trade of England and the Dutch Republic before 1750", in James D. Tracy (ed.), The Rise of Merchant Empires: Long-Distance Trade in the Early Modern World, 1350-1750 (Cambridge: Cambridge University Press, 1990), p. 125. See also Ian Wendt's paper in this volume.

${ }^{6}$ Douglas A. Farnie, "The Role of Merchants as Prime Movers in the Expansion of the Cotton Industry, 1760-1990", in Douglas A. Farnie and David J. Jeremy (eds.), The Fibre that Changed the World: The Cotton Industry in International Perspective, 16001990s (Oxford: Oxford University Press, 2004), pp. 15-55.

7 Maxine Berg, "Asian Luxuries and the Making of the European Consumer Revolution", in Maxine Berg and Elizabeth Eger (eds.), Luxury in the Eighteenth Century: Debates, Desires and Delectable Goods (London: Palgrave, 2003), pp. 228-244; Id. "In Pursuit of Luxury: Global History and British Consumer Goods in the Eighteenth Century", Past and Present, 82 (2004), pp. 85-142.

${ }_{8}$ Beverly Lemire and Giorgio Riello, "East and West: Textiles and Fashion in Early Modern Europe", Journal of Social History, 41, 4 (2008), pp. 887-916.

${ }_{9}$ Joseph E. Inikori, Africans and the Industrial Revolution in England: A Study of International Trade and Economic Development (Cambridge: Cambridge University Press, 2002); Id., "Slavery and the Revolution in Cotton Textile Production in England", Social Science History, 13, 4 (1989), pp. 343-79. See also Maxine Berg, "Africans and the
} 
into Europe were printed on (and eventually entirely manufactured in the Old Continent) to be sold to consumers on both sides of the Atlantic. Inikori emphasises in particular the role of African markets in consuming textiles imported from India (via Europe) or directly from Europe. He claims that Europeans went through an 'apprenticeship' by selling cottons imported from India to African consumers. Such an apprenticeship consisted of learning how to capture markets, to diversify product ranges and exchange with profitable returns. Inikori juxtaposes this free market of Western Africa with the privileged and protected position of the European companies engaged in monopolistic trade within Asia and between Asia and Europe.

This brief overview is not designed to be comprehensive. Rather it shows how historians' explanations of the role of global markets and trade and their impact on European (and Indian manufacturing) varies greatly. There is however a certain degree of uneasiness (surfacing in particular in Inikori) about an innate capacity of European entrepreneurs to seize opportunities when presented with them. We know far more about European cotton producers than about their Indian counterparts and by consequence we imply the existence of a high degree of agency for Europeans: this seems to be the case in explaining their ability to accumulate capital, to allocate it, to shape products, to successfully achieve product substitution or to assess the potential of global markets. But is this really the case? I would like to argue in this paper that Europeans could only appreciate the potential of cotton textiles by looking at the extensive and complex network of traders exchanging cotton goods on enormous distances from the horn of Africa to Japan. The commerce of cotton textiles in Asia can be seen as a preliminary and largely necessary condition - for Europe to fully engage with a fibre previously little known. Central to these are the accumulation not of capital - but of experience in trading and information on commodities and consumers. This is the 'Indian apprenticeship' that Europe had to complete in order to become in its own right a new centre of manufacturing and trade.

Industrial Revolution: Roundtable", International Journal of Maritime History, 15, 2 (2003), pp. 291-300; Giorgio Riello "Cotton before the Revolution: A European Perspective, c. 1200-1800" (Unpublished paper presented at the Economic History Seminar, London School of Economics, May 2004). 


\section{Europes Early Participation in Textile Trade}

It was only after the opening of the Cape of Good Hope route at the very end of the fifteenth century that European traders reached India and China via the sea - a journey that was long and perilous but still preferable to the difficult land route over much of Continental Asia along what is traditionally known as the silk road. This new route by sea, a 'cotton road', became the backbone of trade between India and Europe over the next three centuries. Asian tea, china, lacquer, but also printed and painted calicoes and chintzes, occupy a familiar place in the construction of what is commonly defined as a 'consumer revolution' in early modern Europe. ${ }^{10}$

Quantitative historians are, however, highly sceptical about the economic importance of the commercial relationship between Europe and Asia before the age of industrialization. Recent estimates by de Vries show how between 1500 and 1800, just over ten thousand voyages connected Europe and Asia: on average two ships a month. ${ }^{11}$ European economic historians dispute the scale and ultimate effects of such trade on the economic development of the European continent. ${ }^{12}$ Nevertheless, the European trade within Asia (the so-called 'country trade') and trade between Asia and Europe were certainly part of the trajectory that one specific commodity (namely cotton textiles) experienced as the industry evolved in the Eurasian continent.

${ }^{10}$ Beverly Lemire, Fashion's Favourite: The Cotton Trade and the Consumer in Britain, 1660-1800 (Oxford: Oxford University Press, 1991).

${ }^{11}$ Jan de Vries, "Connecting Europe and Asia: A Quantitative Analysis of the Cape-Route Trade, 1497-1795", in Dennis O'Flynn, Arturo Giràldez and Richard von Glahn (eds.), Global Connections and Monetary History, 1470-1800 (Aldeshot: Ashgate, 2003), pp. 35-106. As Pieter Emmer observes, the entire quantity of goods traded from Asia to Europe between 1500 and 1800 could fit within just five present-day super-tankers. Pieter Emmer, "The Myth of Early Globalization: The Atlantic Economy, 1500-1800", European Review, 11, 1 (2003), p. 38. Further figures about the overall size of the Eurasian trade are provided by Om Prakash, The New Cambridge History of India; Vol. 2, Part 5. European Commercial Enterprise in Pre-colonial India (Cambridge: Cambridge University Press, 1998), p. 32; and Id., "Financing the European Trade with Asia in the Early Modern Period: Dutch Initiatives and Innovations", Journal of European Economic History, 27, 2 (1998), p. 354.

12 Berg, although supporting the idea of Asia's impact on European taste and consumption, admits that imported commodities accounted no more than $1 \%$ of Europe's total industrial output. Maxine Berg, "Manufacturing the Orient. Asian Commodities and European Industry 1500-1800", in Simonetta Cavaciocchi (ed.), Prodotti e tecniche d'oltremare nelle economie europee. Secc. XIII-XVIII. Atti della ventinovesima settimana di studi, 14-19 aprile 1997 (Florence: Le Monnier, 1998), p. 395. 
The first European nation to trade with Asia by sea was Portugal. The discovery of the Cape route had been financed and backed by the Portuguese crown and regular trade was organised by the Carreira da India. This was the first European chartered company to trade with Asia, and served as a model for the later Dutch, English, French, Danish and Swedish trade in the Indian Ocean from the early seventeenth century onwards. These companies were large organisations whose activities in Asia were secured by monopolies granted by their respective governments and the control of trading posts (the so-called "factories") secured by permits from local South and South-east Asian rulers. The Carreira became a model not only in organisational terms, but also for its trade pattern. By 1510 the Portuguese had secured the port of Goa from which they engaged in coastal trade, especially with Cambay where several varieties of textiles could be bought for sale back in Portugal. In 1514 the Carreira shipped to Lisbon more than 1.5 tons of silk mostly coming from China through the ports of Malabar. In 1518 the cargo included also 2.4 tons of other cloth, probably cotton. ${ }^{13}$ If in the early sixteenth century textiles accounted for less than one percent of all commodities transported to Portugal, their share increased to circa ten percent in the second half of the century when 1,200 tons of cotton textiles reached Lisbon in the year 1587-88 alone (Fig. 11.1). ${ }^{14}$

Spices from Southeast Asia, rather than cotton textiles from India, were considered by the Portuguese to be the most desirable commodities for the European market. ${ }^{15}$ However, the problem of how to pay for Asian commodities soon emerged. Merchants in Melaka or Java had for centuries exchanged spices for textiles with Gujarati and other Indian merchants. When Portuguese traders arrived in Southeast Asia, Gujarati merchants dominated the trade to Melaka from the port of Cambay. According to the Portuguese Pires, Melaka could not "live without Cambay, nor Cambay without Malacca". ${ }^{16}$ As for most of the

\footnotetext{
${ }^{13}$ K. S. Mathew, Portuguese Trade with India in the Sixteenth Century (New Delhi: Manohar, 1983), p. 133.

${ }^{14} \mathrm{Om}$ Prakash, New Cambridge History of India, p. 36, table 2.3; Sanjay Subrahmanyam, The Portuguese Empire in Asia. 1500-1700: A Political and Economic History (Harlow: Longman, 1993), p. 63, 142, 166.

${ }^{15}$ George Bryan Souza, The Survival of Empire: Portuguese Trade and Society in China and the South China Sea, 1630-1754 (Cambridge: Cambridge University Press, 1986), p. 76.

${ }^{16}$ Tomé Pires, The Suma Oriental of Tomé Pires: An Account of the East, from the Red Sea to Japan, Written in Malacca and India in 1512-15, ed. Armando Cortesaõ (London: Hakluyt Society Publications, 1944), vol. 1, p. 45.
} 


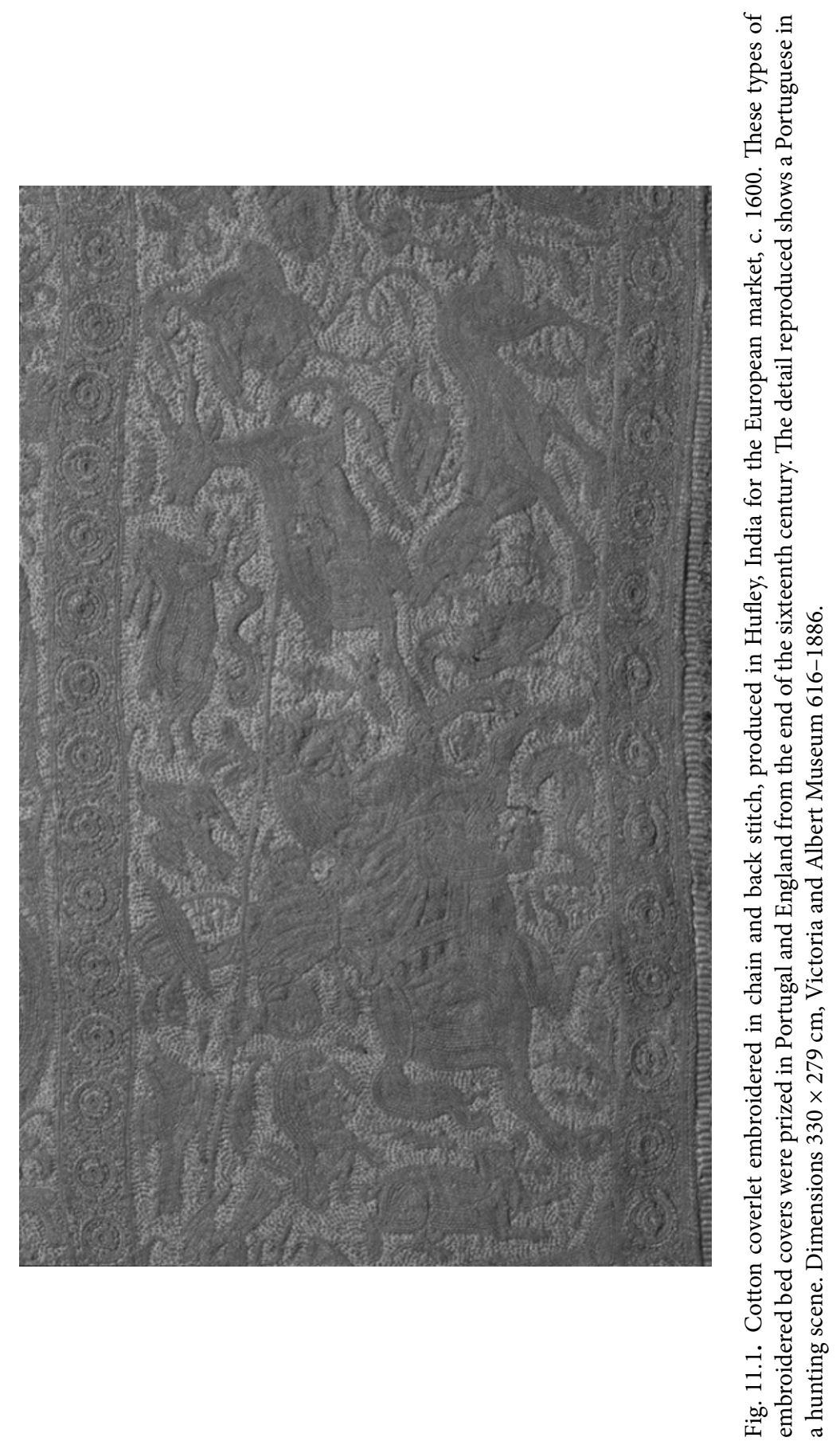


trade in the Indian Ocean, spices could only be bought by exchanging cotton textiles as the locals "want nothing but the cloths of Cambay". ${ }^{17}$ As observed by John Guy, cotton textiles simply lubricated "the wheels of the Southeast Asia spice trade". ${ }^{18}$

The Portuguese expanded this pattern of trade throughout the eastern part of Eurasia: they reached Japan in 1542; in 1557 they leased Macao from the Chinese; and they arrived in Formosa in $1590 .{ }^{19}$ The following expansion of trade with Cambodia and Cochin-China made textiles even more central to their trade as such commodities were in high demand. In the late sixteenth century, cotton textiles were not yet key commodities for the Portuguese trade to Europe, but they were by now indispensable in the intra-Asian trade. Cotton textiles were the currency that permitted exchange of all goods across thousands of miles. Javanese and Malays, for instance, would not accept any other product, apart from textiles in exchange for foodstuffs and spices. ${ }^{20}$

Cotton textiles did not immediately become key trade goods for European consumers. The initial engagement of Europeans with cotton textiles had more to do with exchanges within the Indian Ocean than any upsurge in demand for such textiles back in Europe. ${ }^{21}$ Furthermore, commerce in cotton textiles was not easy to enter and remained in the hands of Indian merchants. The rather slow growth of cotton textile imports into Europe can perhaps be explained by inelastic supplies from India before the first half of the seventeenth century. ${ }^{22}$

${ }_{17}$ Quoted in Micheal N. Pearson, Merchants and Rulers in Gujarat: The Response to the Portuguese in the Sixteenth Century (Berkeley and London: University of California Press, 1976), p. 12.

${ }^{18}$ John Guy, "Sarasa and Patola: Indian Textiles in Indonesia", Orientations, 20, 1 (1989), p. 48.

19 Prithvish Nag, "The Indian Ocean, India and Africa: Historical and Geographical Perspectives", in Satish Chandra (ed.), The Indian Ocean: Explorations in History, Commerce and Politics (New Delhi: Sage, 1987), p. 159, footnote 25.

${ }^{20}$ Marie Antoinette Petronella Meilink-Roelofsz, Asian Trade and European Influence in the Indonesian Archipelago: Between 1500 and About 1630 (The Hague: M. Nijhoff, 1962), p. 189.

${ }^{21}$ Moreland suggests that the low quantities of Indian textiles imported into Europe before 1660 are due to very low European demand. W. H. Moreland, From Akbar to Aurangzeb: A Study in Indian Economic History (London: Macmillan, 1923), p. 123. This position has been recently challenged by Lemire and others who argue that the Euro-Indian textile trade before 1660 was much larger than what figures show. Beverly Lemire, "Domesticating the Exotic: Floral Culture and the East India Calico Trade with England, c. 1600-1800", Textile: A Journal of Cloth and Culture, 1, 1 (2003), pp. 65-85.

${ }^{22}$ O. P. Singh, Surat and its Trade in the Second Half of the 17th Century (Delhi: University of Delhi, 1977), p. 137. 
Notwithstanding these obstacles, textile trade developed into an increasing component of Portuguese commerce both within Asia and towards Europe. According to van Linschoten, by the end of the sixteenth century the amounts of cottons exported were "not to be numbered, which are yearely carried into India, Portigall, Nova Spaignia, and other waies". ${ }^{23}$ Afzal Ahmad details the wide variety of textiles traded by the Portuguese in the early seventeenth century: they included expensive taffetas, satins, semians, chintz, percalcos, sarja, salampura and roupas da seda (silk cloth), but also middle-range baftas, beatilha, arganizes and berame. ${ }^{24}$

Portuguese textile trade expanded enormously in the 1610s and 1620s. In 1630 the Carreira traded 265,000 pieces of cloth of different types. A few years later it sent an impressive 40,000 pieces to Mozambique. ${ }^{25}$ By then their trade was not just confined to the routes opened by Gujarati merchants within Asia or the export trade back to the mother country. The Portuguese also sold Indian cotton textiles in West Africa. Cotton textiles were in high demand in ports such as São Jorge da Mina where slaves were exchanged for cotton textiles and grain. ${ }^{26}$ Portuguese trade also reached the New World and Brazil became an important market for Indian cottons, as did Manila where cotton textiles of Indian origin where exchanged for American silver. ${ }^{27}$ By the mid seventeenth century the Portuguese influence in the Indian Ocean, and especially in Southeast Asia, started to dwindle. ${ }^{28}$ In 1658 the strategically important port of Nagapatam on the Coromandel Coast was captured by the Dutch, signalling the coming of new and powerful European traders in Asia. ${ }^{29}$

${ }^{23}$ Jan Huygen van Linschoten, The Voyage of John Huyghen van Linschoten to the East Indies, from the English Translation of 1598, ed. Pieter Anton Tiele (London: Hakluyt Society, 1885), vol. 1, p. 129.

${ }^{24}$ Afzal Ahmad, "Indian Textiles and the Portuguese Trade in the Seventeenth Century (1600-43)", Studia, 48 (1989), pp. 215-20.

25 Ibid., pp. 230-34.

${ }^{26}$ Ibid., p. 214; José Roberto do Amaral Lapa, "Domensões do Comercio Colonial o Brasil e o Oriente”, Studia, 49 (1989), pp. 391-92.

${ }_{27}$ Anthony R. Disney, Twilight of the Pepper Empire: Portuguese Trade in Southwest India in the Early Seventeenth Century (Cambridge, Ma.: Harvard University Press, 1978), pp. 118-19; Souza, Survival of Empire, p. 78.

${ }^{28}$ Kenneth McPherson, "Anglo-Portuguese Commercial Relations in the Eastern Indian Ocean from the Seventeenth to the Eighteenth Centuries", South Asia, 19, Special Issue (1996), pp. 41-57.

${ }_{29}$ Kristof Glamann, Dutch-Asiatic Trade, 1620-1740 (The Hague: Martinus Nijhoff, 1958), p. 133. See also Sanjay Subrahmanyam, "The South Coromandel Portuguese in the late 17th century: A Study of the Porto Novo - Nagapattinam Complex", Studia, 49 (1989), p. 341. 


\section{The European Chartered Companies}

European traders were attracted to Asia by the availability of goods that were in high demand in the Old Continent and yielded high profit margins. In the sixteenth century, the Portuguese profited by selling back to Europe products that had previously been transported via land, changing hands several times and increasing their cost as they moved East to West. This was a very risky business: illness, distance and perpetual violence made trade difficult to undertake. Furthermore information remained scarce and European companies spent years in search of efficient business practices to deploy in the unknown environment of Asia. ${ }^{30}$ Letters from European rulers and gifts could ease initial contacts between Europeans and the Indian governmental and commercial classes, but this was just the first step upon a long and complicated learning curve. The copious correspondence and memoranda sent by factors to their headquarters in Lisbon, London, Amsterdam, Copenhagen and Lorient testify both to the need to monitor business going on thousands of miles away and the accumulation of knowledge required to do business around the Indian Ocean. ${ }^{31}$

The period from 1600 to 1800 was characterised by three interrelated developments in the context of Eurasian commerce. Firstly, competition increased. In 1601 the English Government awarded a charter to a company to trade with Asia. The English East India Company (EIC) was followed just one year later by a similar initiative by the Dutch with the foundation of the Vereenigde Oost-Indische Compagnie (VOC). Later in the century other companies such as the Danish (1616), French (1664) and Swedish (1732) East India companies joined their larger rivals. Secondly, this new group of trading companies routinised and lowered transaction costs for trade within Asia and between Asia and Europe by accumulating information concerning complex connections between production and purchasing in India as well as on consumer markets in Europe. Thirdly, in the course of the seventeenth

${ }^{30}$ Miles Ogborn, "Writing Travels: Power, Knowledge and Ritual on the English East India Company's Early Voyages", Transactions of the Institute of British Geographers, 27, 2 (2002), pp. 155-71.

${ }_{31}$ See for instance: William Foster (ed.), English Factories in India, 13 vols. (Oxford: Clarendon, 1906-27) on the period 1618-69; Sir Charles Fawcett (ed.), English Factories in India, New Series, 4 vols. (Oxford: Clarendon, 1936-55) on the period 1670-84; Ethel Bruce Sainsbury (ed.), A Calendar of the Court Minutes of the East India Company 1635-79, 11 vols. (Oxford: Clarendon Press, 1907-38) covering the period 1635-79. 
century cotton textiles became the most important commodity traded by the chartered companies between Asia and Europe.

The VOC and EIC enjoyed diverging success in the European and Asian markets. The VOC's trade in cotton textiles in Europe never reached the levels of the EIC. Dutch linen interests seemed to have prevented the diffusion of cottons to a level comparable with England or France. ${ }^{32}$ By contrast the EIC was able to become the major trader in Indian cotton textiles imported to Europe as early as the $1660 \mathrm{~s}^{33}$ Competition in the Indian Ocean instead was very different: for all of the seventeenth and the first part of the eighteenth century the VOC remained the dominant European trading company in Asia. It was successful not only in securing strongholds in India, but also in engaging in the remunerative trade in spices and luxury goods with China and Japan. However, between the 1680s and the 1740s the VOC's supremacy came under increasing threat from the EIC and the Dutch company lost even more ground in the trade back to Europe. ${ }^{34}$ Cotton textiles (and some modest quantities of silk) were key commodities in ensuring the success of the EIC in European markets and, by the early part of the eighteenth century, also in the Atlantic markets of the American colonies and West Africa. ${ }^{35}$

When the EIC and the VOC began to trade in textiles early in the seventeenth century, quantities were small, although the two companies already specialised in different types of fabrics. The VOC traded cheap Guinea cloth, normally striped, that was probably re-exported to

${ }^{32}$ Glamann, Dutch-Asiatic Trade, p. 138.

${ }^{33}$ On the early engagement by the EIC with cotton textiles see: K. N. Chaudhuri, The English East India Company: The Study of an Early Joint-Stock Company 1600-40 (London: Frank Cass, 1965), pp. 190-203.

${ }^{34}$ For a summary see: Michael N. Pearson, The Indian Ocean (London and New York: Routledge, 2003), p. 150. See also Femme S. Gaastra, "War, Competition and Collaboration: Relations between the English and Dutch East India Company in the Seventeenth and Eighteenth Centuries", in Huw V. Bowen, Margarette Lincoln, and Nigel Rigby (eds.), The Worlds of the East India Company (Woodbridge: Boydell Press, 2002), pp. 49-68.

${ }^{35}$ On the American market see: Robert DuPlessis, "Cottons Consumption in the Seventeenth- and Eighteenth-Century North Atlantic", in Riello and Parthasarathi (eds.), Spinning World; and for the late eighteenth century Bean, Susan S., "The American Market for Indian Textiles, 1785-1820: in the Twilight of Traditional Cloth Manufacture", in Textiles in Trade (Washington: Proceedings of the Textile Society of America Biennial Symposium, 1990), pp. 43-52. For the African market see Inikori, Africans and the Industrial Revolution; Id., "Slavery and the Revolution". See also Id., "Africa and the Globalization Process: Western Africa, 1450-1850", Journal of Global History, 2, 1 (2007), pp. 63-86. 
Africa, while the EIC brought back to Europe baftas and simians (both white calicoes used for linings), as the company recognised that cotton cloths such as "lighte blewes", semians, chintz and sashes, were "fitt to be sente for England" ${ }^{36}$ During the sixteenth century the VOC acquired a more acute understanding of cotton textiles through engagement in the spice trade of Southeast Asia, an area where they retained a competitive advantage over other European traders:

The Hollanders doth take such extraordinary courses in putting out their cloth to the Chineses.......we cannot sell any of ours because it is not so vendible in the country, for they giveth them choice of commodities, that which is fitting for the country, whereof we have little store. ${ }^{37}$

Thus the EIC looked for opportunities in the western part of the Indian ocean and for trade back to Europe. In 1612, the Company established a factory at Surat, followed a few years later by another in Bombay. ${ }^{38}$ As early as 1619 it started sending white and striped sashes and chintzes from Ahmedabad to Agra and Burhanpur. "Factories" were central to their trade in textiles both within Asia and with Europe. They functioned as co-ordinating centres for the supply of a wide range of manufactured goods and natural produce and were the reference point for middlemen who outsourced products for the European companies. Servants of the Dutch, French and English East India companies, portrayed these middlemen as 'perfidious' and so selfish as to "have their throats cut if one reduces the least among from what they demand. They do nothing for anybody unless paid in advance and (even) when thus paid, serve you as badly as they can" ${ }^{40}$ Yet, the role of middlemen

\footnotetext{
${ }^{36}$ Nicholas Downton, The Voyage of Nicholas Downton to the East Indies 1614-15: As Recorded in Contemporary Narratives and Letters, ed. William Foster (London: Hakluyt Society, 1938), pp. 95, 102-3.

${ }_{37}$ William Foster (ed.), Letters Received by the East India Company from its Servants in the East; Vol. 2. 1613-15 (London: Sampson Low, Marstron, 1896-1902), p. 269. During the period between 1631 and 1658 the Dutch imported from India into Holland on average 277,000 pieces of calicoes a year at a value of nearly half a million Dutch florins (c. £45,000). Steensgaard, "Growth and Composition", p. 124.

${ }^{38}$ Singh, Surat and its Trade, pp. 55-78. On the EIC's development in India see also: Om Prakash, "The English East India Company and India", in Bowen, Lincoln, and Rigby (eds.), Worlds of the East India Company, pp. 1-17.

39 Sangar, "Export of Indian Textiles", p. 2.

${ }^{40}$ Indrani Ray, "The Trade and Traders in Ahmedabad in Late Seventeenth Century: Extracts from George Roques' MSS", in Lakshmi Subramanian (ed.), The French East India Company and the Trade of the Indian Ocean: A Collection of Essays by Indrani Ray (New Delhi: Munshiram Manoharlal, 1999), p. 66.
} 
as the link between European traders and Indian spinners and weavers is the key to understanding the evolution of the chartered companies' activities in India. The evolution took several decades to complete but by the mid eighteenth century the European companies engaged directly and actively in the co-ordination of textile production in order to secure more efficient control over the qualities and deliveries of textiles supplied. ${ }^{41}$

A new relationship with the large numbers of spinners, weavers and finishers matured, which Indian historians have depicted as one of increasing alien exploitation over the Indian workforce. ${ }^{42}$ The gradual shift from independent producers to waged workers employed by European companies has also been interpreted as the decline of Indian export capacity which started with the Mughal conquest, rather than with European opportunism. ${ }^{43}$

The need for standardised textiles suited to European tastes was also pushed forward by important changes in the market for cotton textiles back in Europe. Although the partial ban on the import of Asian cotton textiles into England of 1701 and the later absolute ban of 1721 did not seriously diminish the overall position of the EIC in the transoceanic trade of textiles, it clearly created barriers for sales in home markets. Similar protectionist measures had already been put in place by France in 1689 and were later enacted by Spain and Prussia and most other European nations in the first two decades of the eighteenth century. One of the few countries to retain freedom of import, sale and consumption of Asian cotton textiles within its borders was the Dutch

${ }^{41}$ Lakshmi Subramanian, "Power and the Weave: Weavers, Merchants and Rules in Eighteenth-Century Surat", in Rudrangshu Mukherjee and Lakshmi Subramanian (eds.), Politics and Trade in the Indian Ocean World: Essays in Honour of Ashin Das Gupta (Delhi: Oxford University Press, 1998), pp. 52-82. See also Hameeda Hossain, The Company Weavers of Bengal: The East India Company and the Organization of Textile Production in Bengal 1750-1813 (Delhi: Oxford University Press, 1988), pp. 76-95; Sinnappah Arasaratnam, "Weavers, Merchants and Company: The Handloom Industry in Southeastern India 1750-90", Indian Economic and Social History Review, 17, 3 (1980), pp. 257-81.

${ }^{42}$ See for instance Om Prakash, "Cooperation and Conflict among European Traders in the Indian Ocean in the Late Eighteenth Century", Indian Economic and Social History Review, 39, 2-3 (2002), p. 133. See also the theoretical discussion by Immanuel Wallerstein, "The Incorporation of the Indian Subcontinent into the Capitalist WorldEconomy", in Satish Chandra (ed.), The Indian Ocean: Explorations in History, Commerce and Politics (New Delhi: Sage Publications, 1987), pp. 222-53.

${ }^{43}$ Sanjay Subramanyam, "Rural Industry and Commercial Agriculture in Late Seventeenth South-Eastern India", Past and Present, 126 (1990), pp. 76-114. See also Ian Wendt's paper in this volume. 
Republic. However, the VOC seems to have been able only to partially benefit from such a market advantage, probably because the core of its trading activities remained in Southeast Asia. Import figures show how the ban on imports into Europe had only a short term impact. The EIC continued to prosper and traded even larger quantities than in previous decades. Its success depended on three interrelated factors: control over purchasing markets; smuggling; and access to European mainland and North American markets. ${ }^{44}$

Resistance to the penetration of European markets by Indian textiles had started in earnest well before total bans on cotton textiles were imposed by most European countries in the late seventeenth and early eighteenth centuries. Initially the French had vacillated before participating directly in the trade, but finally embraced the argument that it was better to buy cotton textiles directly from India rather than paying higher prices for cloth imported through England and the Netherlands..$^{45}$ In 1664 Colbert established the first Compagnie des Indes Orientales followed by the Compagnie de la Chine in $1698^{46}$ The French East India Company never achieved anything comparable to the success of the EIC and VOC. ${ }^{47}$ Overwhelmed with financial problems, the Compagnie's orders were too small to monopolise local textile-producing markets. ${ }^{48}$ Its commerce in cotton textiles was also hindered by a fragile political position beyond the bastion of Pondicherry and the absence of French traders in Bengal - a central area of cotton cloth manufacturing. French mercantilist policies designed to preserve established equilibriums between traditional fabrics made the introduction of Indian cottons particularly difficult. ${ }^{49}$ Nevertheless the company imported c. 100,000 pieces a year of white calicoes and blue and painted muslins at the end

\footnotetext{
${ }^{44}$ Steensgaard, "Growth and Composition", p. 127.

${ }^{45}$ Charles Woolsey Cole, French Mercantilism, 1683-1700 (New York: Columbia University Press, 1943), p. 168.

${ }^{46}$ Philippe Haudrère, "La Compagnie Française des Indes, 1719-95", L'Information Historique, 51 (1989), p. 1.

${ }^{47}$ For an overview of the French trade in India in the eighteenth century see: Paul Butel, "French Traders and India at the End of the Eighteenth Century", in Sushil Chaudhuri and Michel Morineau (eds.), Merchants, Companies and Trade: Europe and Asia in the Early Modern Era (Cambridge: Cambridge University Press, 1999), pp. 28799. See also Rila Mukherjee, “The French East India Company's Trade in East Bengal from 1750 to 1753: A Look at the Chandernagore Letters to Jugdia", Indian Historical Review, 17, 1-2 (1990-91), pp. 122-35.

${ }^{48}$ Indrani Ray, "The French Company and the Merchants of Bengal (1680-1730)", in Subramanian (ed.), French East India Company, p. 84.

${ }^{49}$ Ibid., p. 78.
} 
of the seventeenth century, rising to 300,000 pieces a year in the early years of the following century..$^{50}$ Only for a brief period (1735-60) did the overall imports of the French East India Company rival those of the EIC and VOC. In the 1730s its total imports surpassed 22 million livres tuournois $(£ 900,000)$, although textiles accounted for a small proportion, probably less than 20 percent. ${ }^{51}$

The Danish East India Company was established as early as 1616 and re-founded several times. Its activities could be defined as irregular because in the 30 years between 1640 and 1670 the company sent no ships to Asia. ${ }^{52}$ The Danes followed the same practices of the larger European companies, trading heavily in Bengal from a factory in Tramquebar, especially in pano comprido and salampores, selling them in Copenhagen but also to Germany and as far as the West Indies. ${ }^{53}$

The increasing presence of the European companies in the Indian Ocean should not lead to the false impression that Europe's eventual dominance in the production and trade of cotton textiles at a global level was either ordained or foreseeable. Their monopolistic position in Europe was surely of great advantage, but one must not forget that their success in Asia was circumscribed: the French Company traded little beyond India; the VOC showed weaknesses in European markets; and still in the 1790s the EIC 'country trade' was worth not even half of its $£ 3$ million a year trade to Europe ${ }^{54}$ Although each European company controlled key ports in the Indian Ocean, these were often the target of rival companies and changed hands several times between 1600 and 1800. Moreover, in important centres of textile manufacturing such as Ahmedabad in Gujarat (that Alexander Hamilton believed to be "little inferior to the best towns in Europe ... in magnitude and wealth"), the English, Dutch, French and Portuguese traders were just a small contingent within a wider commercial community formed by Jews, Arabs, Medes, Persians, Turks and Tartars trading not only in cotton textiles,

\footnotetext{
${ }^{50}$ Haudrère, "Compagnie Française des Indes", p. 5; Philippe Haudrère and Gérard Bouëdec, Les Compagnies des Indes (Rennes: Ouest France, 1999), p. 80.

${ }^{51}$ On the types of textiles traded by the French see: Henry Weber, La Compagnie Française des Indes (1604-1875) (Paris: Arthur Rousseau, 1904), pp. 220-37.

52 Ole Feldbæk, "The Danish Trading Companies of the Seventeenth and Eighteenth Centuries", Scandinavian Economic History Review, 34, 3 (1986), pp. 204-6.

${ }_{53}$ Kristof Glamann, "The Danish Asiatic Company, 1732-71", Scandinavian Economic History Review, 8, 2 (1960), pp. 125-49.

${ }_{54}$ Ambroise Marie Arnould, De la balance du commerce et des relations commerciales extérieures de la France... (Paris: Chez Buisson, 1791), p. 285.
} 
but in silks and indigo. ${ }^{55}$ In the eighteenth century the situation was no different in Bengal (the second most important area for cotton textile production in the Indian subcontinent) where the business community was dominated by Arabs, Parsees, Turks and Abyssinians, as well as Indian merchants from Chaul, Dabhol and Goa. ${ }^{56}$

The weakness of the European companies was evident also in their bargaining power over Indian producers. Explanations that see coercion (through the medium of colonial power especially by the EIC after 1757) as a way to control producing markets imply that the European companies' position in securing cheap and reliable supplies of cotton textiles was feeble. Brennig estimates that in the 1680s the English and Dutch companies exported to Europe from 9 to 18 million yards of cloth a year. His calculations suggest that the average yearly production of an Indian weaver ranged from a 1,300 to 1,600 square yards of cloth. This implies that the VOC and the EIC gave work to a minimum of 5,500 and a maximum of 14,000 households, or less than 10 per cent of the total textile workforce of the Coromandel Coast. ${ }^{57}$ By considering the entire chains of production, Om Prakash estimates that in the late seventeenth century Dutch demand provided employment to circa 100,000 people in the textile trade of Bengal. ${ }^{58} \mathrm{~A}$ century later, in the 1770s, the EIC imported from India into Europe 1.6 million pieces of cotton cloth a year from India. Rajat Datta calculates that between this date and 1815, the very apogee of the EIC's trade, the Company gave work to only between a quarter and a third of the weaving population of Bengal..$^{59}$

The relative position enjoyed by the European companies in Indian markets can be better understood simply by looking at trade figures. The overland caravan trade that for centuries had linked India and

${ }^{55}$ Shri Pramod Sangar, "Ahmedabad and Cambay in the Seventeenth Century", Journal of Historical Research, 17, 1 (1974), p. 35.

${ }_{56}$ Meilink-Roelofsz, Asian Trade, p. 68.

${ }^{57}$ Joseph Brennig, "The Textile Trade of Seventeenth Century Northern Coromandel: A Study of a Pre-Modern Asian Export Industry" (Unpublished Ph.D. Thesis, University of Wisconsin at Maddison, 1975), p. 44; John F. Richards, New Cambridge History of India; vol. 1.5. The Mughal Empire (Cambridge: Cambridge University Press, 1993), p. 202; Levi, Indian Diaspora, pp. 74-5.

${ }^{58} \mathrm{Om}$ Prakash, The Dutch East India Company and the Economy of Bengal, 16301720 (Princeton: Princeton University Press, 1985).

59 Rajat Datta, "The Commercial Economy of Eastern India under Early-British Rule: The First Fifty Years" (Unpublished paper, 2006). I am grateful to Rajat Datta for allowing me to read this paper. 
China to Europe via Persia and Turkey was in all probability only marginally affected by competition from the newly-formed European companies using sea routes. In the 1660 s, the VOC reported that 25-30,000 camel loads of cottons from India reached Persia every year and from there Istanbul and various parts of Europe ${ }^{60} \mathrm{~A}$ camel could carry from 400 to 500 pounds of textiles, equal to 5,500-7,200 metric yards of cloth (at 14-15 yards per pound). This implies that at least 70 million yards of cotton textiles were exported from India overland to Turan, Russia, Persia, the Ottoman Empire, North Africa and Europe, compared to an optimistic estimate of 18 million yards for the direct sea trade of the European companies. ${ }^{61}$ The fact that the new maritime connexions did not supersede land routes does not mean that European traders were unimportant in world textile trade. ${ }^{62}$ By the middle of the seventeenth century, as Mantran has shown, Anatolian trade was looking West, rather than East, for its supplies of cotton. A caravan of 300 camels could carry 700-800 tons, less than a medium-size ship. Thus with all probability Aleppo with six caravans a year and Damascus and Izmir with four each, received less cotton textiles from India and Persia than from European traders. ${ }^{63}$ This overland trade via Southern Asia was complemented by the textile trade along the North-South routes to Russia, and from there to Scandinavia, though this trade is more difficult to precisely quantify. ${ }^{64}$

\section{Knowledge and Information}

The heavy engagement in the commerce of cotton textiles by European traders was not the result of a mindset that looked for opportunities of economic development, or the product of an unchallenged success in

${ }^{60}$ Scott C. Levi., The Indian Diaspora in Central Asia and Its Trade, 1550-1900 (Leiden: Brill, 2002), pp. 30-1. See also Scott C. Levi, "India, Russia and the eighteenthcentury transformation of the central Asian caravan trade", Journal of the Economic and Social History of the Orient, 42, 4 (1999), pp. 519-48.

${ }^{61}$ Levi, Indian Diaspora, p. 78. See in particular note 263 on how these amounts were calculated. Paul Masson, Histoire du commerce français dans le Levant au XVIIe siècle (Paris : Hachette \& C., 1896), p. 165.

${ }^{62}$ John F. Richards, "Early Modern India and World History", Journal of World History, 8, 2 (1997), p. 199.

${ }^{63}$ Roger Owen, "Introduction", in Thomas Naff and Roger Owen (eds.), Studies in 18thCentury Islamic History (London and Amsterdam: Ferrer and Simons, 1977), p. 135.

${ }^{64}$ Agnes Geijer, Oriental Textiles in Sweden (Copenhagen: Rosenkilde and Bagger, 1951), pp. 23-4. 
Asian markets. Trade had to be routinized, and based on a solid information system that could secure increasing efficiency, and also a more satisfactory relationship between production and purchasing in India and knowledge of consumer markets in Europe. These were fundamental conditions for the subsequent development of cotton textiles as an industry in Europe. I will focus specifically on: (i) quantities traded and product testing; (ii) variety and quality of the textiles traded; (iii) customization for European markets.

\section{(i) Quantities Traded and Product Testing}

The period between 1660 and the late 1680s coincided with the rise of imports of cotton textiles into Europe (Figure 11.2). If in the early 1660s the VOC and EIC's combined import of textiles just exceeded 100,000 pieces a year, by the late 1680 s this figure reached a peak of 1.3 million pieces. During these two decades the rate of growth and the quantities of cotton textiles brought into Europe by the EIC exceeded that of the VOC by a large margin, although the performances of the EIC were severely tested in the 1690s, making competition between the two companies intense over the following couple of decades. In the late 1720 s the trade reached its zenith and the two companies imported 1.4 million pieces of cotton textiles. The period from the early 1730 s to the late 1750s showed a steady trade of c. 1.0-1.1 million pieces a year, a level that was maintained over the next fifty years. European sources (mostly the EIC's documentation) and the historiography that it has inspired seem to suggest that the problem companies faced was one of supply. Before the beginning of colonial rule in the mid eighteenth century, European traders, and the EIC in particular, was at the mercy of a complex system of provisioning that often resulted in orders being partially fulfilled with cloth that in ordinary circumstances would have been considered of low quality. The importance of controlling production and provisioning in cotton textile production seemed to have been a serious matter well before the mechanisation and industrialization of the sector.

Behind aggregate figures rests a variety of market conditions, including the fact that at the end of the seventeenth century cotton textiles were still a type of commodity little known in Europe. One must underline that this was not the case in the 1770s or 1780s when consumers' demand for cheap cottons (both imported and home produced) seemed to be extremely elastic. What happened in the century preceding 


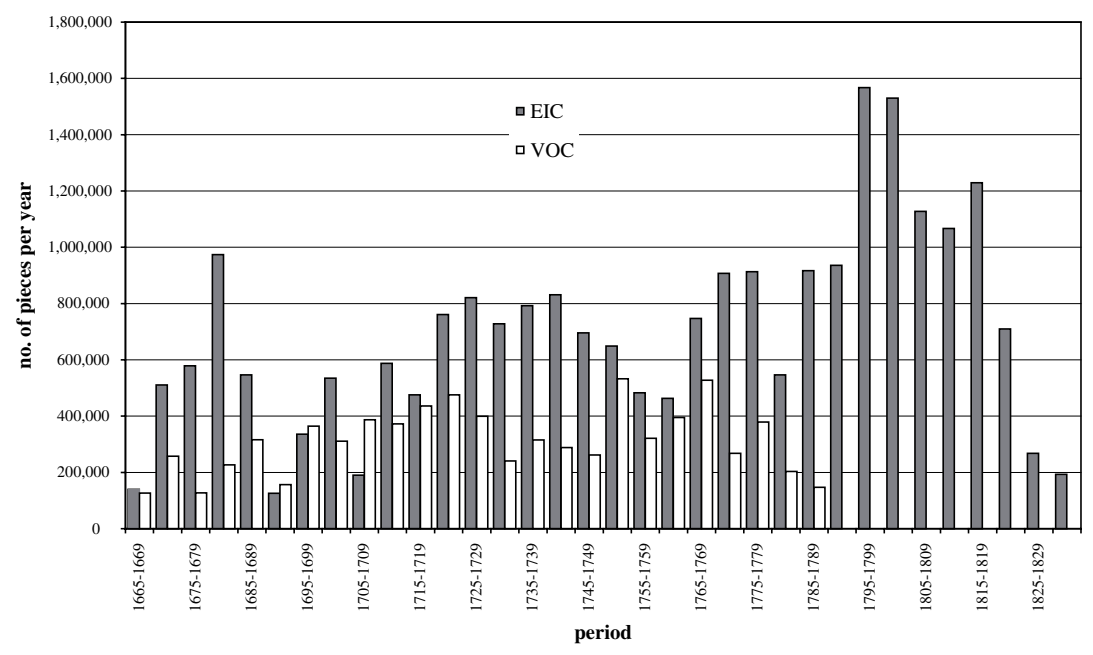

Fig. 11.2. Textiles Imported from Asia into Europe by the EIC and VOC, 1665-1834 (pieces per year on average over 5 -year periods).

Sources: EIC (1665-1760): K. N. Chaudhuri, The Trading World of Asia and the English East India Company 1660-1760 (Cambridge: Cambridge University Press, 1978), pp. 540-41.

EIC (1760-1834): Database "The East India Company: Trade and Domestic Financial Statistics, 1755-1838" compiled by Huw Bowen.

VOC (1665-1760): Femme S. Gaastra, "The Textile Trade of the VOC: The Dutch Response to the English Challenge", South Asia, 19, Special Issue (1996), pp. 85-95; Michel Morineau, "The Indian Challenge: Seventeenth to Eighteenth Centuries", in Sushil Chaudhuri and Michel Morineau (eds.), Merchants, Companies and Trade: Europe and Asia in the Early Modern Era (Cambridge: Cambridge University Press, 1999), pp. 273-275; Niels Steensgaard, “"The Indian Ocean network and the emerging world-economy, c. 1500-1750", in Satish Chandra (ed.), The Indian Ocean: Explorations in History, Commerce and Politics (New Delhi: 1987), pp. 126.

VOC (1760-1789): quantities have been calculated from auction sales (in value) by using an average value per piece calculated for the period 1665-1760.

the European 'take off' in cotton manufacturing was a process of familiarisation and testing of the markets with commodities that were not always successful. Companies had to avoid overstock and be attentive to the trends in demand in home markets. This was a period of 'apprenticeship' in terms of understanding how innovative cotton textiles could be, and how they would eventually sit together with other types of textiles.

The most famous case of this market exploration concerns the EIC and its misconceived understanding of the substitutability of linen with cotton. In 1682 the EIC ordered from their factors in Madras 200,000 ready-made cotton shirts and shifts to "introduce the using of Callicoe 
for that purpose in all these Northern parts of the world" ${ }^{35}$ It was an ambitious scheme as the Company was actively seeking to sell one garment for every two adults in London, or two percent of all clothes sold in Britain in a year according to Gregory King's estimates. ${ }^{66}$ The Company was convinced that such a plan would benefit both its coffers and the nation as it was based on the "more general use ye wearing of Callicoes in stead of French Holland, or Flanders Cloth, which we apprehend to be a National Benefit". ${ }^{67}$ This was an import substitution through another imported commodity, but this time with a less direct political implication of economic dependency than in the case of linen. ${ }^{68}$ Notwithstanding the carefully crafted justification for embarking on such a vast import, the substitution failed. Consumers rejected cottons as substitutes for linen and even when the Company tried to sell off the shirts and shifts at cut prices, results were modest. ${ }^{69}$ Perhaps their rejection was also caused by the fact that they were ready made and considered "strongly sewed for the poor people's wear" ${ }^{70}$

This is the best-known story of failure both in the substitution of an imported commodity and in the integration of an exogenous element into the sartorial order of late seventeenth-century British society. It was not an isolated episode: in 1679 the Company started importing carpets from Ellore. Notwithstanding the rather enthusiastic pitch

${ }^{65}$ K.N. Chaudhuri, The Trading World of Asia and the English East India Company 1660-1760 (Cambridge: Cambridge University Press, 1978), pp. 281-87. Also reported in John E. Wills, "European Consumption and Asian Production in the Seventeenth and Eighteenth Centuries", in John Brewer and Roy Porter (eds.), Consumption and the World of Goods (London and New York: Routledge, 1993), p. 137.

${ }^{66}$ John Styles, "Product Innovation in Early Modern London", Past and Present, 168 (2000), p. 137. See also Audrey W. Douglas, "Cotton Textiles in England: The East India Company's Attempts to Exploit Developments in Fashion 1660-1721", Journal of British Studies, 8, 2 (1969), p. 32; and Lemire, Fashion's Favourite, p. 180.

${ }^{67}$ Quoted in Styles, "Product Innovation", p. 137.

${ }^{68}$ On the issue of the dependence of England on imported linen see: Negley B. Harte, "The Rise of Protection and the English Linen Trade, 1690-1790", in Negley B. Harte and Kenneth G. Ponting (eds.), Textile History and Economic History (Manchester: Manchester University Press, 1973), pp. 75-112; David Ormrod, The Rise of Commercial Empires: England and the Netherlands in the Age of Mercantilism, 16501770 (Cambridge: Cambridge University Press, 2002), ch. 5; and Giorgio Riello, "The Ecology of Cotton in Early Modern Europe: Possibilities and Potentials" (Paper Presented at the GEHN Conference on "A Global History of Cotton Textiles", University of Padua, November 2005).

${ }^{69}$ Styles, "Product Innovation”, pp. 138-39.

${ }^{70}$ Quoted in Douglas, "Cotton Textiles in England", p. 32. See also John Irwin and P. R. Schwartz, Studies in Indo-European Textile History (Ahmedabah: Calico Museum of Textiles, 1966), p. 36. 
made by factors in India and the doubtful reaction of the London directors, it looks like the 100 carpets that were patiently produced according to very precise specifications did not sell at all and a few years later it was stated that they "are now grown much out of use in Europe" and that this trade could be considered terminated. ${ }^{71}$ Both cases show how consumers could exercise choice and dismiss products that were not sufficiently well known, trusted or part of their expectations.

Until recently our understanding of the dynamics of trade of the EIC were profoundly impeded by the lack of precise statistical data for the period after 1760. Ground-breaking research carried out in the 1960s and 1970s by K. N. Chaudhuri on the EIC's trade between Asia and Europe for the period 1660-1760 has been recently expanded by Huw Bowen who has painstakingly gathered the entire set of trade figures for the period 1760 to the demise of the Company in 1834. Contrary to what one might expect, the trade in textiles of the EIC increased substantially during the very period in which Arkwright and Crompton were revolutionising cotton production in England. Figures for the period from 1795 to the 1830s suggest that Indian cottons profited from the expansion of cotton textile consumption at all levels (Figure 11.2). They did well on the back of increasingly cheaper English wares, though the exact varieties of cloth traded are yet to be studied for the period after 1760. An increase of fifty percent of the number of pieces imported into Britain each year in the decade 1795-1805 raised several eyebrows, including those anxious entrepreneurs that feared market saturation. ${ }^{72}$ But over the course of the following three decades Indian cottons lost markets as cheaper, and in many cases better-quality English cottons became available.

The different strategies implemented by the EIC and VOC in the trade of textiles should be considered. The VOC traded widely within Asia and was an important carrier of cotton textiles to Southeast Asia in particular. ${ }^{73}$ Its engagement in the European cotton textile market was rather more limited, not just in comparison with the quantities imported

${ }^{71}$ John Irwin, "Indian Textile Trade in the Seventeenth Century: (2). Coromandel Coast", Journal of Indian Textile History, 2 (1956), pp. 24-42.

${ }^{72}$ See for instance an early discussion of these problems in Observations on the Means of Extending the Consumption of British Calicoes, Muslins, and Other Cotton Goods and of Giving Pecuniary Aids to the Manufacturers ... (London: n.a., 1788).

${ }^{73}$ See the paper by Anthony Reid in this volume. 
by the EIC, but also in terms of its own specialization. Figure 11.3 compares the share of cotton textiles with the overall values of all commodities sold in Europe by the VOC and EIC. The VOC trade in textiles was never superior to 30 percent of its total trade for the entire eighteenth century. By contrast, more than 50 percent of the EIC's textile trade was destined to Europe. ${ }^{74}$ Two elements are striking: the first is that neither of the two companies seems to have either suffered (in the case of the EIC) or benefited (in the case of the VOC) from the protectionist measures put in place against the import of cotton textiles into Europe between 1689 and the 1720s. Secondly, these figures could be upheld as evidence not just of a different merchandise specialisation between the two companies, or their differing ability to appeal to European and international markets, but as proof of a rather peculiar relationship between trade and industry in Britain, a topic I will discuss in the following section.

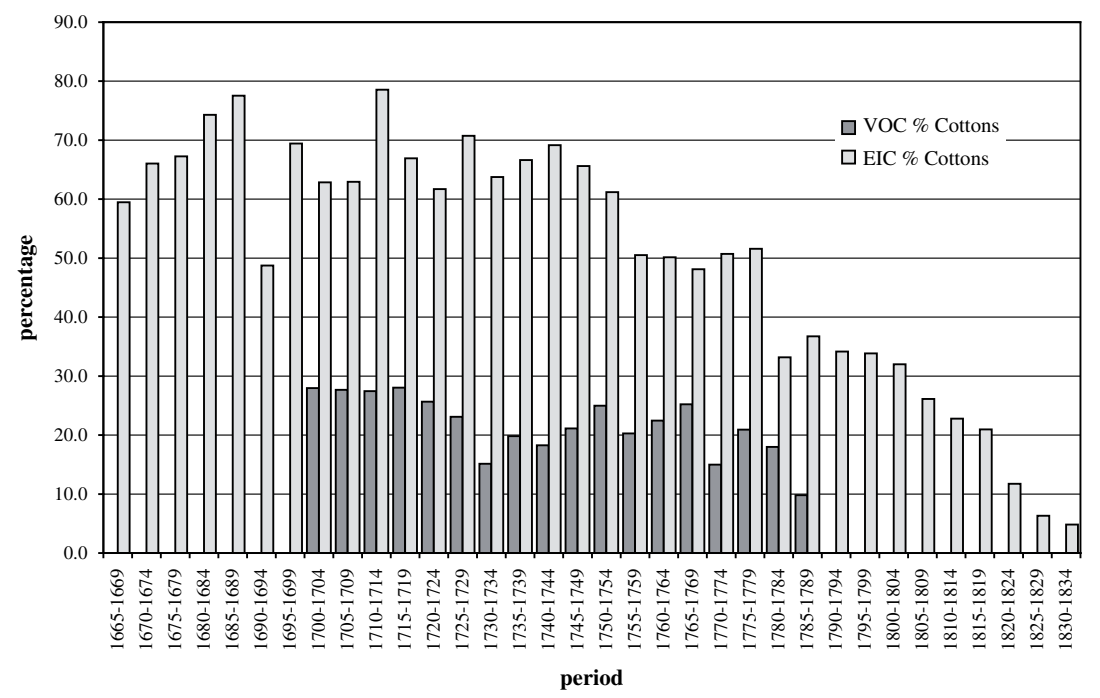

Fig. 11.3. Cotton textiles as percentage of all commodities traded by the VOC (1700-1789) and the EIC (1665-1834). Source: see Figure 11.2.

${ }^{74}$ See also Prakash, New Cambridge History of India, p. 120, table 4.2. 


\section{(ii) Varieties and Quality of Textiles}

Aggregated quantities, either as number of pieces traded or their value, hide the very complex reality of a plethora of different textiles traded by the European companies. The sheer variety of cotton cloth and other seventeenth-century Indian textiles is fully referenced by Satya Prakash Sangar's encyclopaedic survey of historical references to fabrics. He identifies more than 150 different types of cotton cloths produced in seventeenth-century India, excluding quilted fabric, turbans and mixed silk-cotton fabrics. ${ }^{75}$ Over the seventeenth and eighteenth centuries the EIC imported more than fifty varieties of cloth. Most of them were traded for short periods in response to specific demand in Europe or because of inelastic supplies from India. Over the century a smaller number of textiles constituted the bulk of the company's trade (Table 11.1). Baftas, chintzes, cossaes, gurras, Guinea stuff, longcloth, romalls and sallamporees formed from half to five-sixths of imported textiles. ${ }^{76}$

Initially the Company offered consumers a wide range of textiles, but after the slump of the early 1690s, its strategy changed to focus on fewer types of cloth. Well-known varieties such as baftas, chintzes and Guinea stuff did not figure as prominently as one might expect in the Company's trade. Contrary to the widespread idea of a calico craze, it was white Indian cotton textiles (sossaes, gurras, and sallamporees) that dominated imports into London (Figure 11.4). ${ }^{77}$ These textiles were not used for undergarments or in substitution of linen (that happened in the late eighteenth century) but as plain cloth on which English, but also Dutch, French, German, Spanish and Italian calico printers could print an

${ }^{75}$ Satya Prakash Sangar, Indian Textiles in the Seventeenth Century (New Delhi: Reliance Publication House, 1998), in particular pp. 1-28.

${ }^{76}$ Baftas was a type of ordinary cotton cloth. Normally a piece was 15 yards long and 25 inches wide, although a so-called broad baftas had the same length but was 36 inches wide. Singh, Surat and its Trade, p. 130. See also the quantitative analysis in Dietmar Rothermund, "The Changing Pattern of British Trade in Indian Textiles, 1701-57", in Chaudhuri and Morineau (eds.), Merchants, Companies and Trade, pp. 276-86.

77 See the figures in Sergio Aiolfi, Calicos und gedrucktes Zeug: die Entwicklung der englischen Textilveredelung und der Tuchhandel der East India Company, 1650-1750 (Stuttgart: Steiner, 1987), pp. 424-31; and Bala Krishn, Commercial Relations between India and England (1601-1757) (London: Routledge, 1926), pp. 307-17. The same can be said about the import of Indian cottons into France. The figures provided by Haudrère suggest that white cotton cloth and muslin constituted three quarters of all fabrics imported into France from India between 1720 and 1770. Philippe Haudrère, $L a$ Compagnie Française des Indes au XVIIIe Siècle (1719-95) (Paris: Librarie de l'Inde, 1989), vol. 1, p. 467, footnote 222. 


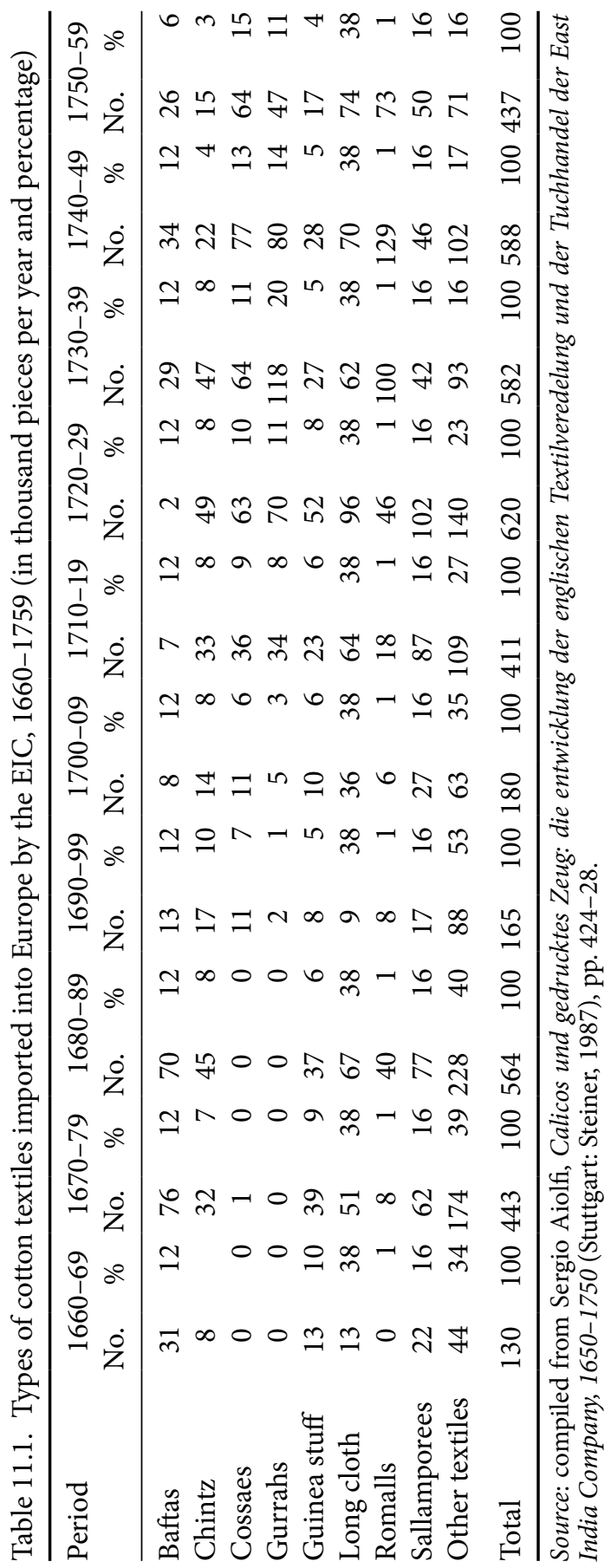




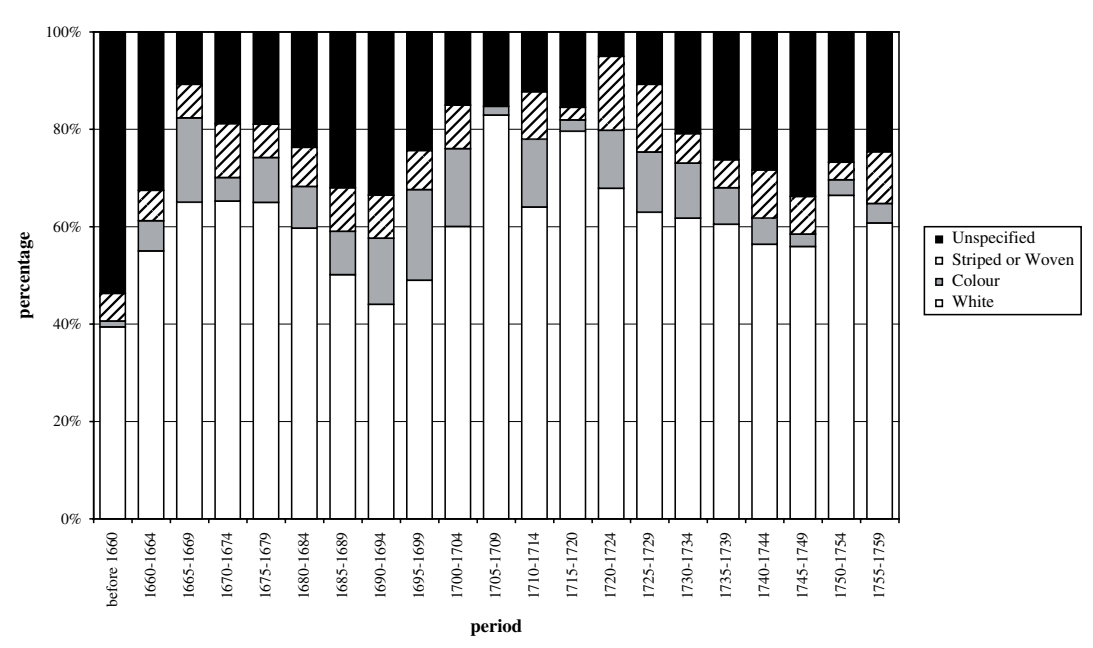

Fig. 11.4. Typology of cotton cloth imported by the EIC, 1630-1759. Source: compiled from Sergio Aiolfi, Calicos und gedrucktes Zeug: die Entwicklung der englischen Textilveredelung und der Tuchhandel der East India Company, 1650-1750 (Stuttgart: Steiner, 1987), pp. 424-28.

increasing variety of designs and colours. The East India company was pursuing its own financial interests, but in doing so was also fostering the establishment of industries such as calico printing - an industry that would have not achieved the same degree of accomplishment if it had confined itself simply to the printing of European fustians (mixed cottons) and linens, both of which were more difficult to print on than cotton. White cloths from India were key commodities not for European consumers, but for European manufacturers who increasingly specialised in the finishing of the cloth.

The EIC purchased precise varieties from specific markets in order to reduce risks associated with a concentration of demand on a restricted number of producers. Taffeta, a woven silk with gold and silver threads was at the top of the range. Slightly less expensive, but still marketed for wealthy consumers, was Gujarat satin that competed with European especially Italian products. Other high- and medium-quality fabrics included chintz (printed cottons), roupas da seda (a silk cloth), tafecira (a striped cotton cloth mostly produced in Sindh), salampuri (cotton cloth produced in Coromandel), sarja (a mixed silk and woollen cloth), pecalcos (a thin cotton cloth commonly known as cambric-muslin) and mermolano (otherwise known as malmal, a thin fabric from Bengal 
and Gujarat). This range of expensive textiles was matched by a similar choice of medium-range fabrics including arganizes (one of the most famous cotton fabrics produced in blue and white in Golconda and Bijapur), beatilha (or Golconda muslin), berame or beirame (a chintz from Cambay), and bertangil (a calico cloth produced in Daman in blue, black and white and mostly exported to South-East Asia). Baftas were also very common calicoes and were produced in the areas of Burhanpur and Machiwara. The list can be continued with exotic names such as montassis, mouris, gamcha, canequin, chandes, chinderis, daryabadi, mantagen, and the generic 'panos' that Portuguese traders sold throughout the Indian and Atlantic oceans and Europe. ${ }^{78}$

This complex variety of unfamiliar textiles created asymmetries of information between European traders and Indian producers that are well recorded in companies' records usually under the heading of the 'quality' of merchandise. In 1704 a French East India Company servant complained that it was as hard to know the final product as it was to control its productive process. Several orders of 1,000 pieces each would be given to middlemen who, in turn, employed 3-4,000 workers each. The final result often turned out to be highly unsatisfactory, "so much so that one will make his piece fine, another will make it thicker (closely woven), others will use a thread which will be round - and which will be of the same quality as the first one even a little finer". ${ }^{9}$ Problems were not just confined to the quality of the weave because "The same workers will differ in length - some will give 1 or sometimes 2 fingers more than that ordered, and others will give less". ${ }^{80}$ The French report concluded that "during the 25 years that we are doing this business we have noticed that it is not possible to have 100 pieces of goods of this country of undoubtedly the same size". ${ }^{81}$

\section{(iii) Product Customization}

Textile historians have investigated the issue of product customization through the analysis of artefacts and written sources. ${ }^{82}$ By customization, I mean the production of specific products to be sold in specific

${ }_{78}$ Ahmad, "Indian Textiles", pp. 214-19.

79 Quoted in Ray, "French Company", p. 78.

${ }^{80}$ Ibid.

${ }^{81}$ Ibid.

${ }^{82}$ See in particular the numerous examples in Ruth Barnes (ed.), Textiles in Indian Ocean Societies (London: Routledge 2005); and Rosemary Crill (ed.), Textiles from India. The Global Trade (Oxford and Calcutta: Seagull, 2006). 
markets. A region like Gujarat produced cotton textiles for a series of different markets, each of which was characterised by precise product specifications ranging from productive techniques, to precise design, patterns and colours of textiles with which consumers often associated not just monetary, but also a social value according to the meaning that such textiles assumed in their respective cultures. We also know that India did not simply act as a passive caterer for other people's aesthetic requirements. The cross-fertilization of cotton textile design across the Indian Ocean is perhaps the best indicator of the agency of Indian producers and merchants in shaping both trade and the commodities that they carried. ${ }^{83}$

The encounter with European consumers was rather different. ${ }^{84}$ Here there was no direct contact; no possibility of finding out consumer preferences by simply observing the final market; there was not even a remote idea of what type of uses fabrics could be subjected to. The impossibility of approaching the final market for Indian traders and their producers was clearly a key advantage for the European companies. The EIC for instance had access to information of distributors, retailers and consumers. The Company's function was to match information moving in opposite directions: from London to Gujarat, Coromandel and Bengal making it clear what would "sell well," and from India to London with information on prices, location of production and the endemic problems of shortages of supply and low quality. Matching supply and demand was key to the success of the EIC and VOC as they could not afford large stocks of unsold stuff, nor subsequent years of what we would now call 'loss leaders'.

The first thing that the companies had to do was to market cottons. As Chudhuri says "The spectacular expansion in the sale of the East India Company's textile imports from India in the 1670s was deliberately accompanied by an attempt to popularise their use in Europe". ${ }^{55}$ Their success, Chaudhuri argues, could not be taken for granted.

\footnotetext{
${ }^{83}$ See for instance the useful papers by Steven Cohen, "The Unusual Textile Trade between India and Sri Lanka: Block-prints and Chintz, 1550-1900", and Ruth Barnes, "Indian Textiles for Island Taste: The Trade to Eastern Indonesia", in Crill (ed.), Textiles from India, pp. 56-80 and 99-116.

${ }^{84}$ This specific topic is analysed in detail in my "The Globalisation of Cotton Textiles: Indian Cottons, Europe and the Atlantic World, 1600-1850", in Riello and Parthasarathi (eds.), Spinning World.

${ }_{85}$ K.N. Chaudhuri, "Some Reflections on the World Trade of the XVIIth and XVIIIth Century: A Reply”, Journal of European Economic History, 7, 1 (1978), p. 224.
} 
The aesthetic and tactile training European consumers needed was as important for the companies as strict control over prices. ${ }^{86}$

It was not sufficient to market what was sent to India. The European companies, and the EIC in particular, found in the Western markets' customization of production an appealing tool to reduce the risk assumed in merchandising. As analysed by Irwin and Styles, more radical forms of customisations were adopted in the second half of the seventeenth century. Patterns detailing what was fashionable in Europe were already sent to India in the 1660 s and even silks were imitated on cotton (Fig. 11.5). The EIC sent also samples of the tree of life - deemed to be from Scandinavian mythos - to be reproduced in India. Back in Europe, large palampores with the tree of life became an instant hit, with customised versions being produced in India (Fig. 11.6) and replicas in Europe. "The floweres must run through the whole piece from end to end", reported one dispatch to India, "whereas, the Flowers have of late been observed to have been begun at each end of the piece, insomuch that in the middle they have, instead of agreeing, been opposite to one another" ${ }^{87}$ A language of customization, precision and exactitude in following specifications was paramount not only in the productive process but also in finishing: "They [calicoes] must be either 13 or 15 yards on a fine calico. Half of fine bunches of four colours, viz., the ground work drawing black, filled up with red and peach blossom color and the twigs or spring green".88

Already in 1643 the EIC directors in London were keen for the factors in India to change the design to suit English taste:

Those [quilts] which thereafter you shall send me we desire may be with more white ground, and the flowers and branch to be in colour in the middle of the quilt as the painter pleases, whereas now most part of your quilts come with red grounds which are not so well accepted here. ${ }^{89}$

Colour was a key matter as the preference accorded by European (and in particular British) consumers to cotton textiles with lighter

\footnotetext{
${ }^{86}$ Ibid.

${ }^{87}$ Quoted in Tamezo Osumi, Printed Cottons of Asia: The Romance of Trade Textiles (Tokyo: Bijutsu Shuppan-sha and Tuttle, 1963), p. 17.

${ }^{88}$ Ibid.

${ }^{89}$ Quoted in Styles, “Product Innovation”, p. 133.
} 


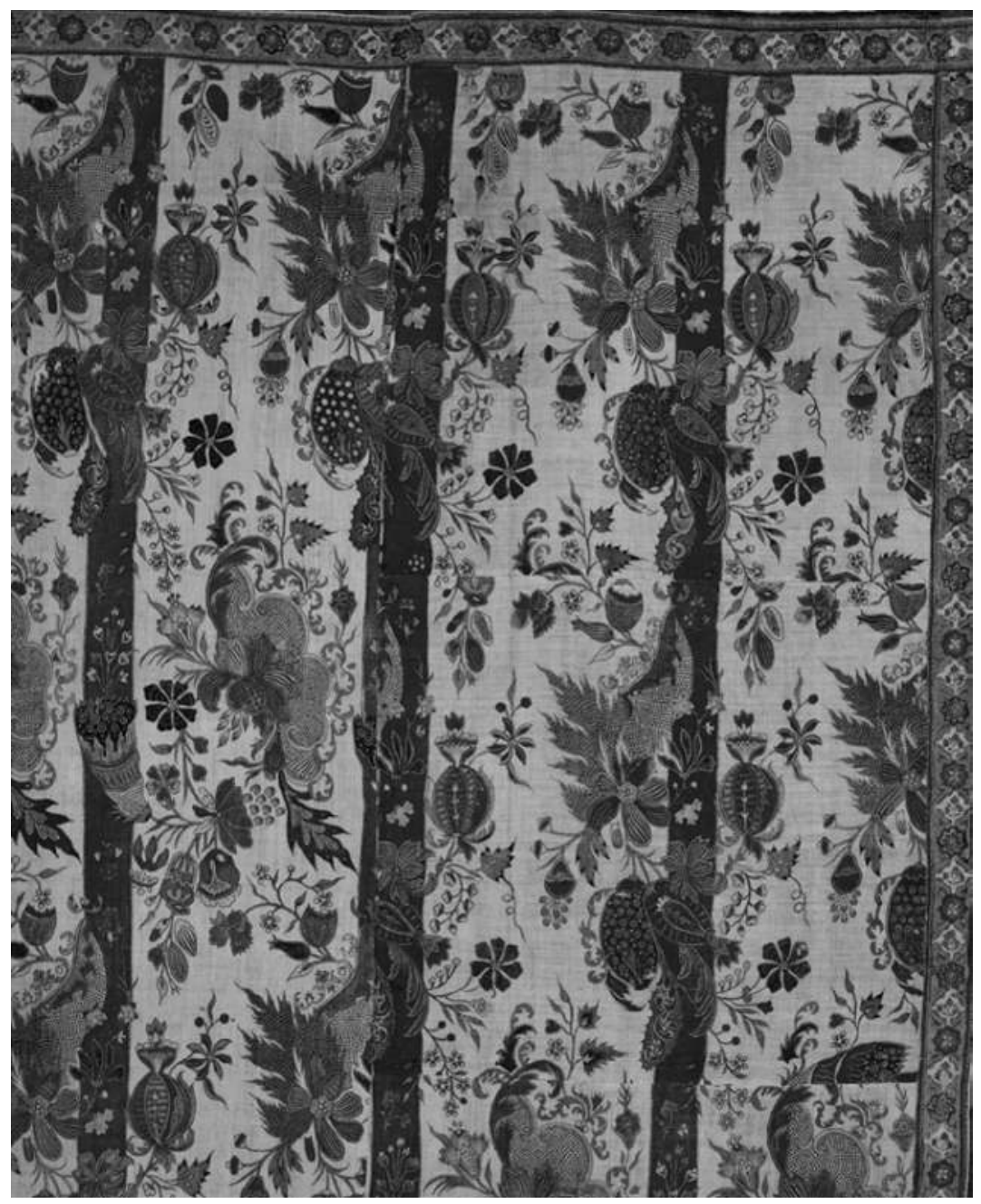

Fig. 11.5. Resist- and mordant-dyed furnishing(?) cotton fabric produced on the Coromandel Coast, c. 1715-25. The motif is strongly influenced by French woven silks popular at the time, especially 'bizarre' silks with linear designs, fruit and exotic objects. Dimensions $218 \times 148 \mathrm{~cm}$. Victoria and Albert Museum, 342.B.1898. 


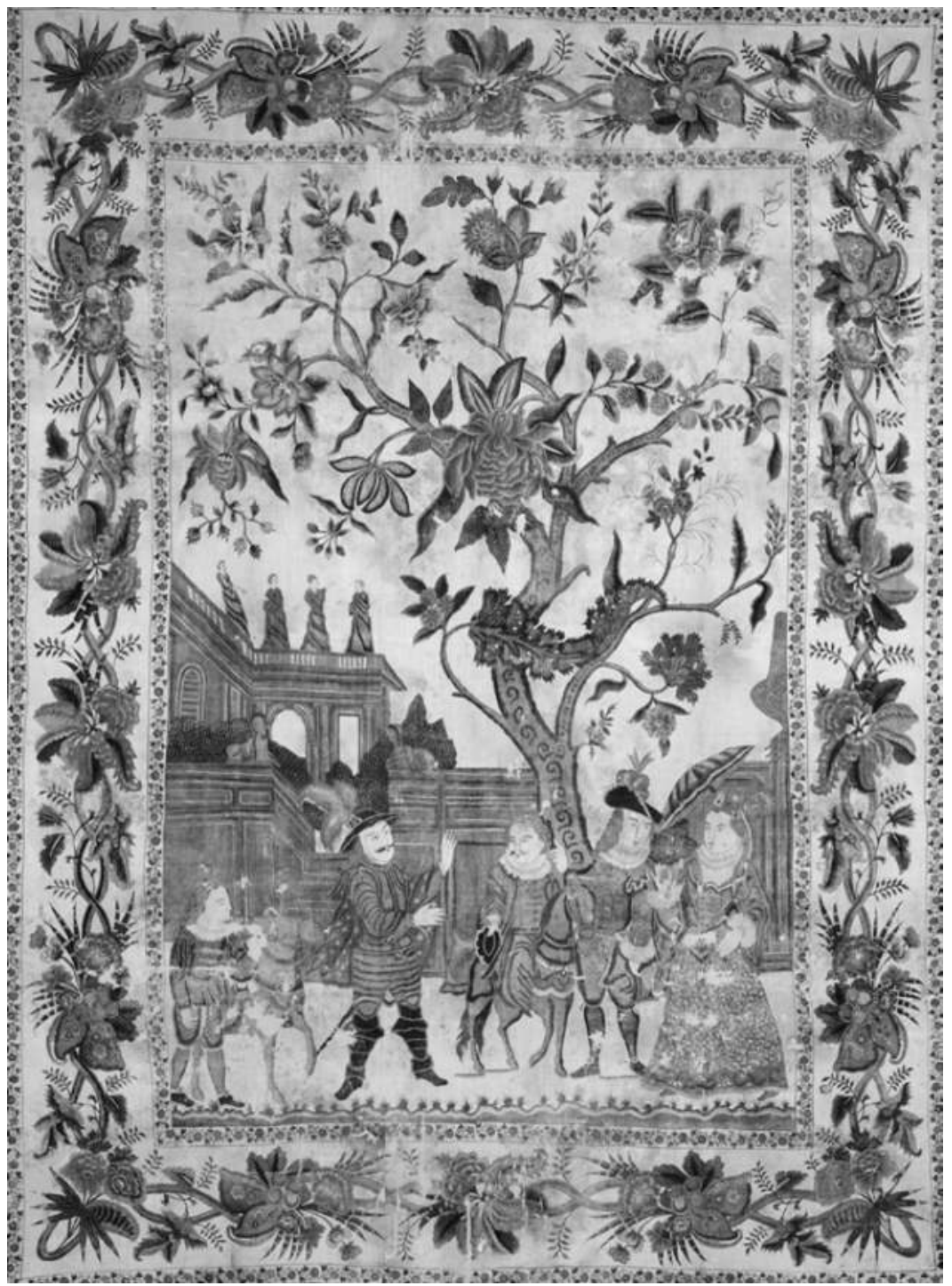

Fig. 11.6. Palampore produced on the Coromandel Coast of India, c. 1740. Victoria and Albert Museum, IS.118-1950. The design is based on a print by J.B.H. Bonnart illustrating an episode from Don Quixote. The tree in the original print has been transformed into the exotic flowering tree typical of export chintzes of the period. 
backgrounds was at odds with most of the Indian production that preferred rich blues and dark reds (Figs 11.7 and 11.8). ${ }^{90}$

What might seem a divergence of taste (alas still largely unexplained) had important effects beyond design: it encouraged the European cotton textile industry to compete with its Indian counterpart by adopting technical solutions that would reduce the expensive process of printing on light backgrounds. As Natalie Rothstein observes, the cottons that Europeans produced at the end of the seventeenth century "have a naïve charm but do not compare in quality with the cottons from India"

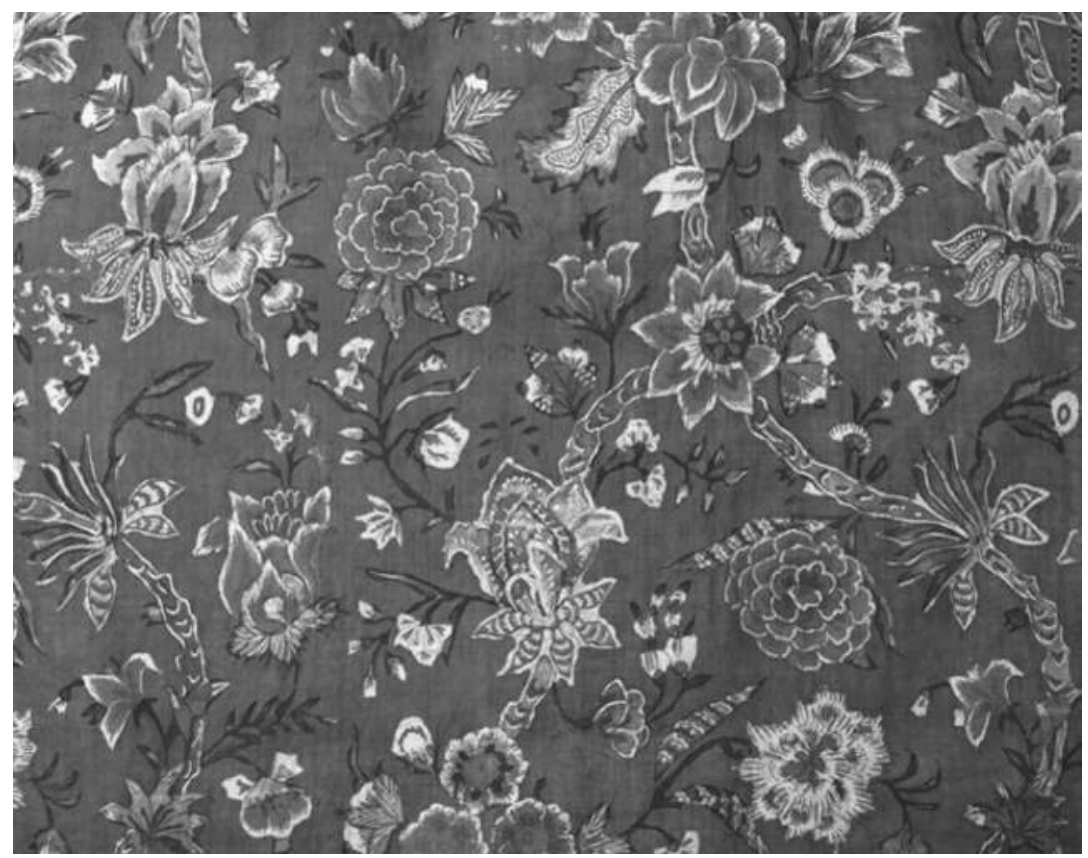

Fig. 11.7. Motif of a cotton banyan. Red background. Cotton, painted and dyed, with printed cotton lining produced on the Coromandel Coast, c. 1750-75. Victoria and Albert Museum, T.215-1992. Although the motif suggests that the cloth was produced for the European market and the garment was in all probability tailored in the Netherlands or in England, dark red backgrounds were not particularly popular in Europe, although they might have been seen as appropriate for men's garments.

${ }^{90}$ Irwin, "Indian Textile Trade"; and Styles, "Product Innovation", pp. 132-40. See also Woodruff D. Smith, Consumption and the Making of Respectability, 1600-1800 (New York and London: Routledge, 2002). 


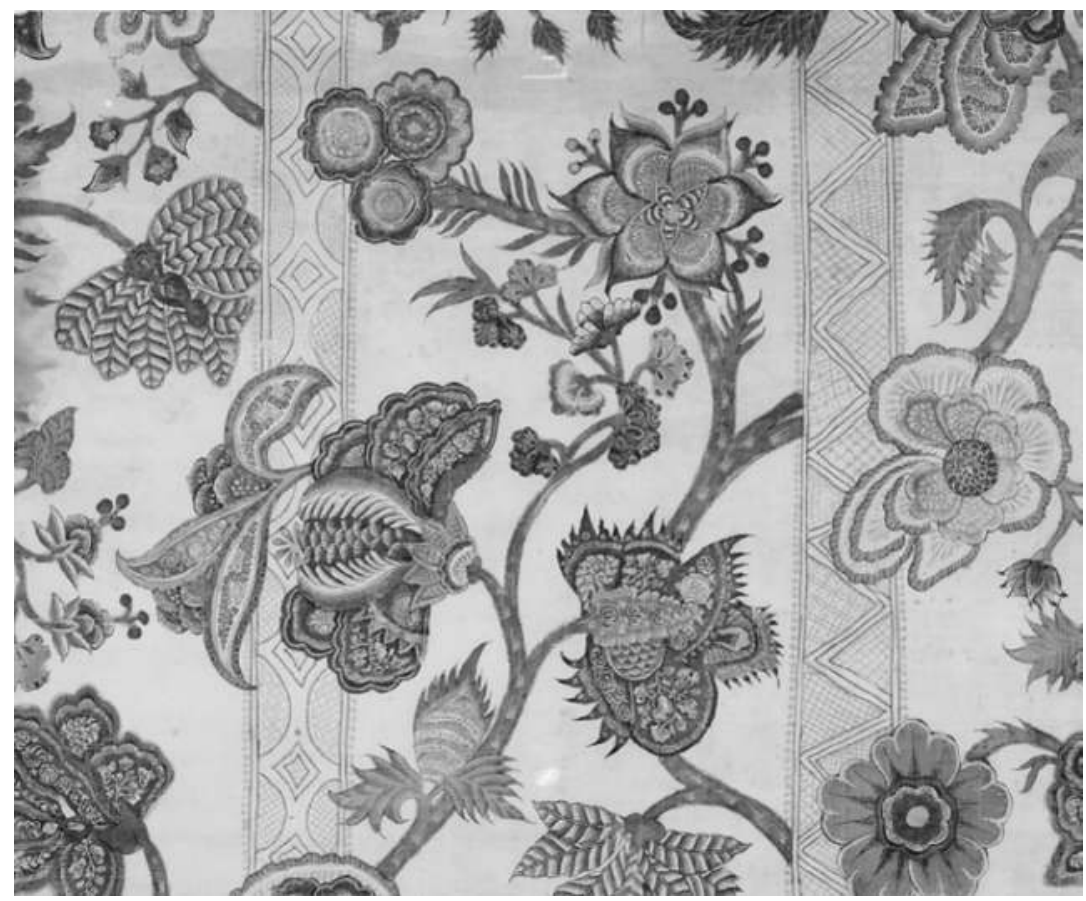

Fig. 11.8. Indian chintz, painted cotton, for the European market with light background. Produced on the Coromandel Coast, c. 1730. Courtesy of the Musée de l'Impression sur Etoffes, Mulhouse, 858.141.1.

(Fig. 11.9). ${ }^{91}$ However, the EIC's championing of established European aesthetic canons (derived from embroidering on white bleached linen) became a source of European dynamism and innovation in printing. By the 1730s the industry had grown considerably and the application of chemistry allowed both the pencilling and printing of blue on white cloth, creating designs reminiscent of blue and white Chinese porcelains that in the 1750s were produced through the use of copper plates (Fig. 11.10). Trade set the basis for the development of a flourishing European cotton printing industry. First in Amsterdam and Marseilles in the 1660s and later in London, Barcelona, Genoa, Basel, Mulhouse and several other European continental cities, calico printing developed as a profitable activity: customization was no

${ }^{91}$ Natalie Rothstein, “Cotton”, in Jane Turner (ed.), The Dictionary of Art (London: Macmillan, 1996), vol. 8, p. 36. 


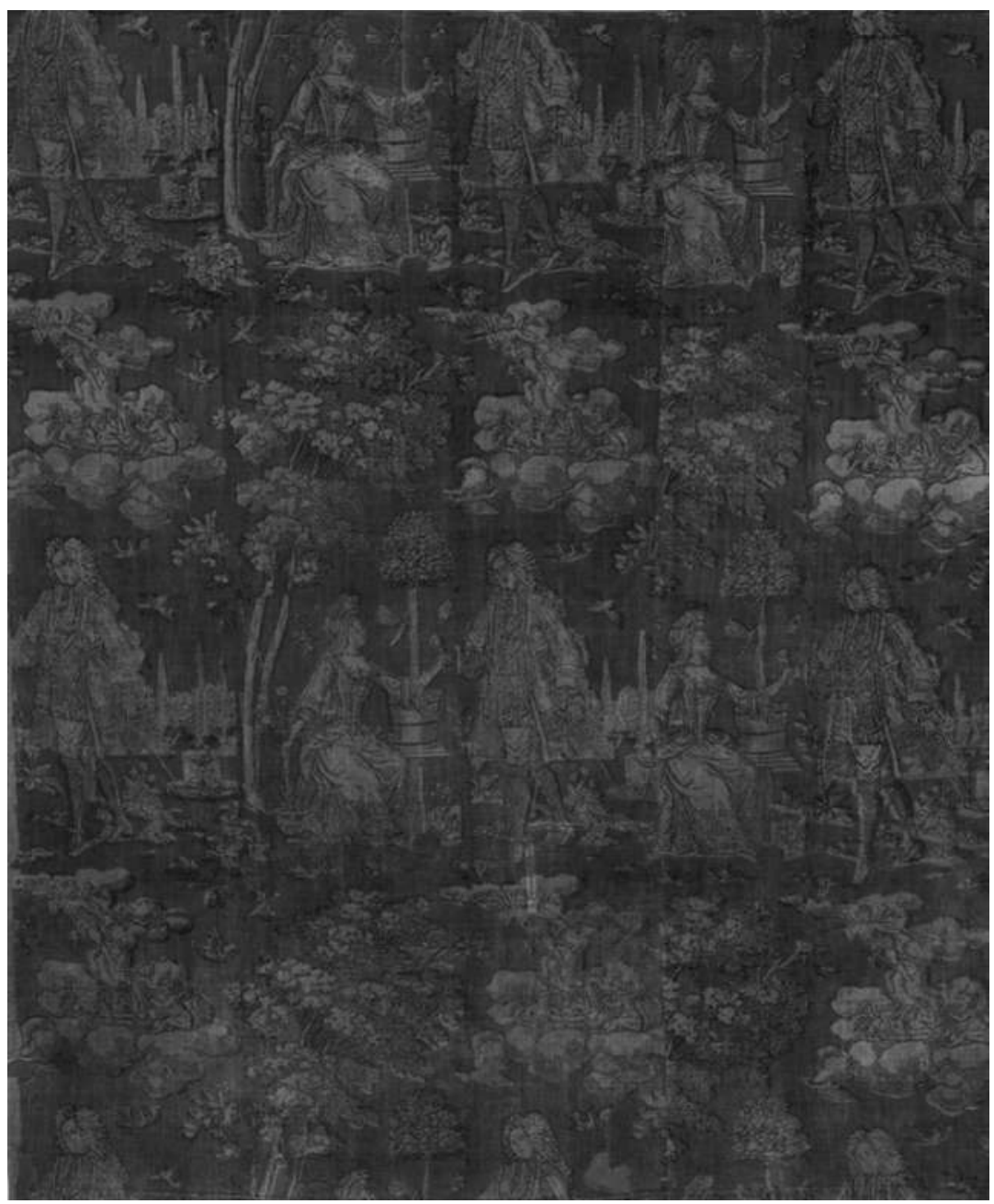

Fig. 11.9. Block-printed cotton textile, printed possibly in England or the Netherlands, c. 1690-1700. The white cotton cloth was in all probability imported by the VOC or the EIC and printed by the newly-established European cotton printing industry. One can notice the low level of precision in the print and the use of a dark red background. Dimension: $99.5 \times 82 \mathrm{~cm}$. Victoria and Albert Museum, T.12.1884. 


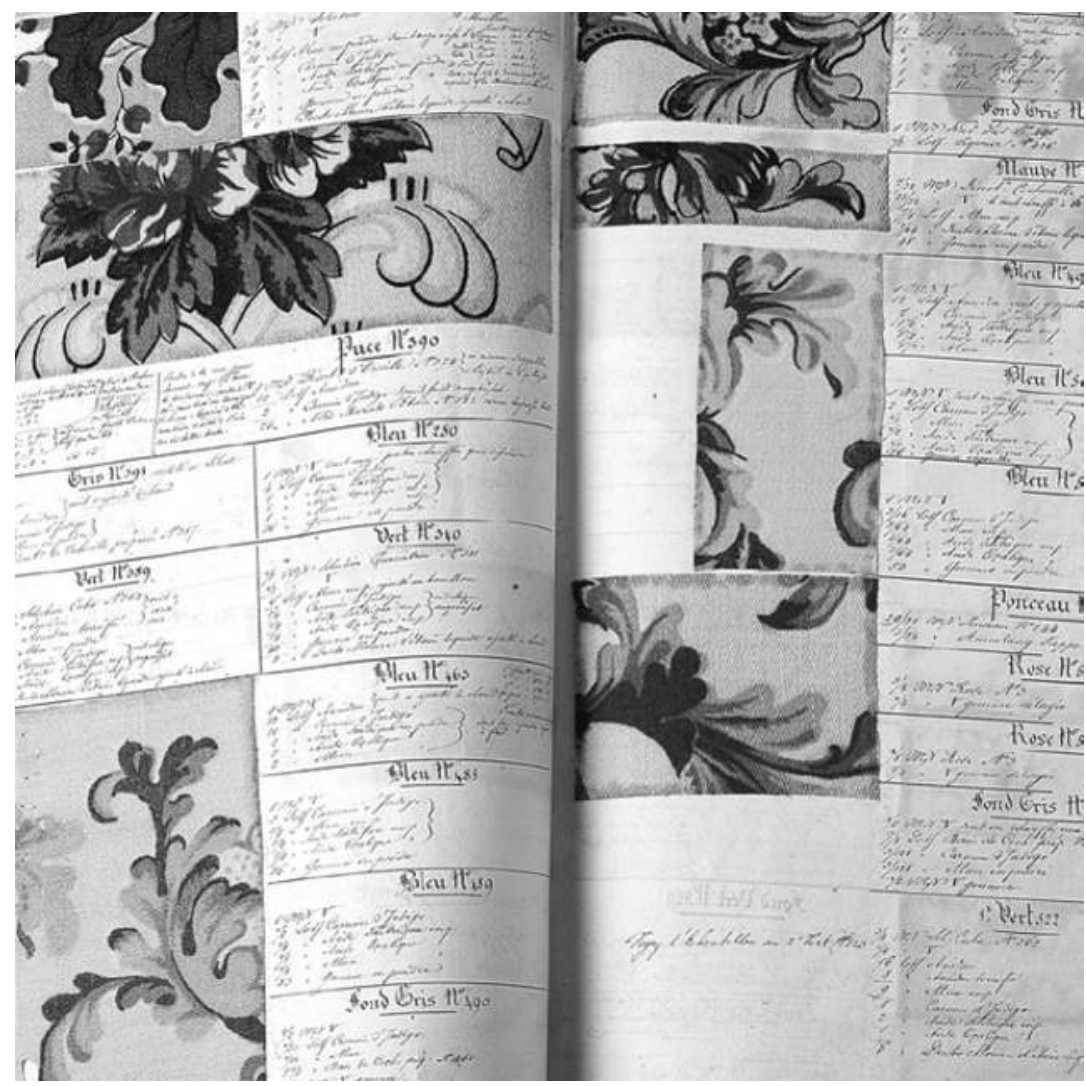

Fig. 11.10. "Livre d'Echantillons" showing the variety of textiles produced by a French cotton printing firm in the second half of the eighteenth century, including blue design on white background and polychrome printing. The qualitative difference with the types of cottons produced three generations earlier (Illustration 11.9) is evident. Courtesy of the Musée de l'Impression sur Etoffes, Mulhouse, Archive.

longer done in India but in Europe, and the import of white cloth from India was essential to it. ${ }^{92}$

The shift from customization to product substitution did not rest only on design or consumer factors. The late seventeenth and early eighteenth centuries were not a period of high price elasticity for cot-

92 Giorgio Riello, "The Rise of European Calico Printing and the Influence of Asia in the 17th- and 18th-centuries" (Paper presented at the GEHN Conference on "Cotton Textiles in the Indian Ocean", Pune, India, December 2005). 
tons. The EIC's employees in India and London knew well that increases in purchasing cost had profound consequences on the retail markets in Europe with consumers shifting back to cambricks, lawns, and other linens and woollens when the competitiveness of cotton prices decreased..$^{93}$ If quality was paramount to the success of cotton textiles in Europe, price competition remained key to the overall ascendancy of cotton textiles. This was a well known fact for the companies that lamented - perhaps overlamented - the high purchasing prices in India and shrinking sale prices in Europe, a fact confirmed by Chaudhuri's price analysis. ${ }^{94}$ However what the EIC's purchasing and selling prices do not show us is that European fustians or the more appealing cotton cloths printed in Europe on imported white Indian cloth faced similar price problems to those affecting cotton cloth imported into Europe from Asia.

Cotton remained over the period here considered a weak competitor in relation to woollen, worsteds and linen..$^{95}$ It was unable to secure a stable market identity (a fact that however had also positive consequences in terms of fashion), it was subject to yearly price fluctuations, and was continuously vituperated by competing fibres and their powerful economic interests. This is a different understanding compared with the triumphal ascendancy of cotton textiles to which we have been accustomed in standard histories of the industrial revolution. The manufacturing of cotton textiles was an area where cost-reducing devices were sought after because of its relative weakness not just in competing with imported Asian cottons, but also with European woollens and linens.

Figure 11.11 illustrates the price trends of linens and cottons sold in the United Kingdom during the period 1660 to 1760 . Figures for fustians, cotton cloth and linen are taken from Beveridge's analysis of prices paid by charitable institutions and therefore tend to be rather constant in time as they were not subject to frequent contract renegotiations. ${ }^{96}$ The price of Indian cotton comes instead from Chaudhuri's

${ }^{33}$ Chaudhuri, "Some Reflections", p. 226

${ }^{94}$ Chaudhuri, Trading World, pp. 540-48.

${ }_{95}$ On this topic see Riello, "Ecology of Cotton".

${ }_{96}$ A precise analysis and the admission of the limitation of this price series can be found in Carole Shammas, "The Decline of Textile Prices in England and British America prior to Industrialization", Economic History Review, 47, 3 (1994), pp. 483-507. 


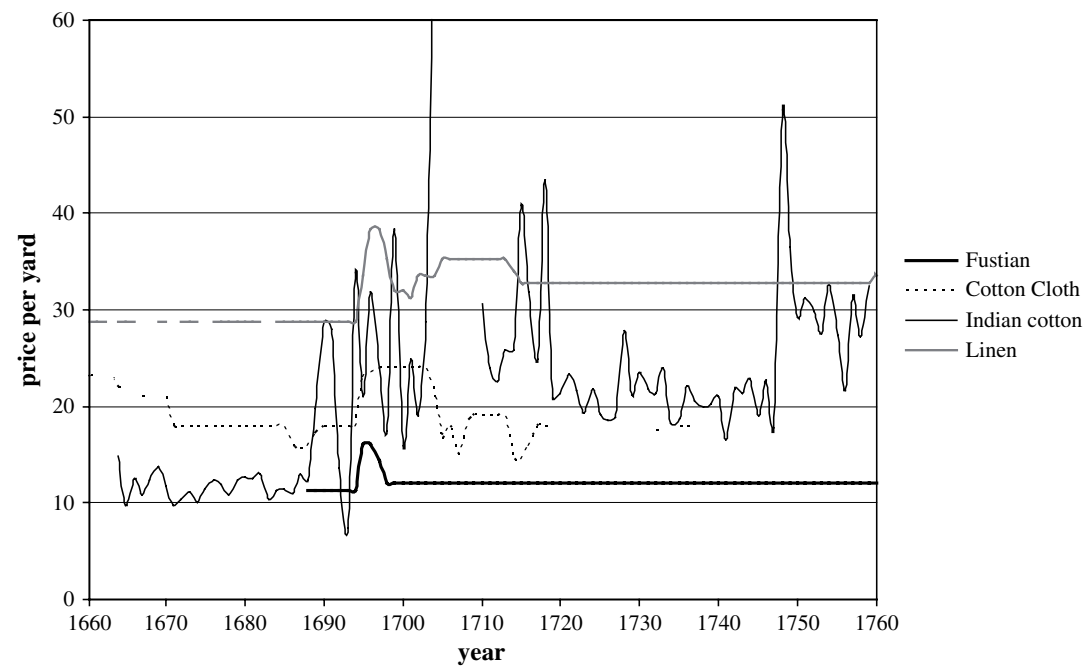

Fig. 11.11. Cotton and linen prices in London, 1660-1760. Source: Sir William Beveridge, Prices and Wages in England from the Twelfth to the Nineteenth Century (London: Macmillan, 1939); K. N. Chaudhuri, The Trading World of Asia and the English East India Company 1660-1760 (Cambridge: Cambridge University Press, 1978), pp. 440-48 and 499-502; Carole Shammas, "The Decline of Textile Prices in England and British America prior to Industrialization," Economic History Review, 47, 3 (1994), pp. 483-507.

quantitative and price analysis. ${ }^{97}$ Imported cotton textiles were more expensive than home produced fustians and cotton cloth, a fact that one might expect as they were the market leaders of the time. However, already by the 1730 s, the price differential seems to have disappeared when compared with home-produced cotton cloth, though this conclusion should be noted with caution due to a lack of complete data. Imported cottons remained cheaper than linen, but again the price gap dramatically shrunk after 1700 . In the period of the prohibition of cotton textiles, high prices - rather than legal zeal - might have hampered the use of Indian chintzes and calicoes in England. The most remarkable feature of this price comparison, however, is that the period of

${ }_{97}$ As quantities are expressed in pieces, I have used the conversion of 1 piece $=15$ yards. This seems to be a plausible measure considering the variety of textiles traded with different measure units per piece: longcloths were up to 40 yards long, baftas 13-18 yards, and romalls just 0.75 yard square handkerchiefs. The resulting value per yard is in line with Shammas's figures. Ibid., pp. 484 and 493. 
expansion of the European cotton industry between the 1680s and the 1720 s coincided with a moment of rocketing prices for imported cottons. Import substitution was clearly a strategy that seemed to have been in action in several sectors of the British economy, but in the case of cotton textiles there was a clear economic incentive.

\section{Conclusion}

How did European trade with Asia shape the European continent's future path of development? European traders who entered Asian commerce became additional competitors in a highly sophisticated and well-integrated pan-Asian market in which cotton textiles had long been the favourite fibre and fabric for clothing, furnishings and other purposes. By contrast Europe had little consumer experience with cottons and no useful knowledge on how to spin, weave or print it. This paper has attempted to highlight the long-lasting process that allowed Europe to learn about cotton textiles as commodities and become a carrier of technologies and taste. This early phase of engagement with cotton textiles within a highly competitive but well developed market system should be seen as an integral part of a narrative of economic development based on cotton that has been far too narrowly focused on wage differentials and the gift of technological innovation. This was for Europe a long 'Indian apprenticeship'. 


\title{
THE FRENCH CONNECTION: INDIAN COTTONS AND THEIR EARLY MODERN TECHNOLOGY
}

\author{
George Bryan Souza
}

A great degree of Asia's success in textile production in the early modern period was derived from the technology employed by the region's artisans in selecting, handling, applying, and incorporating diverse raw materials, especially dyes and mordant, in their crafting of all fibres and in particular with cotton. Regardless of profound differences, textile producers in India and China shared many general and specific textile technologies, especially, in silks and cottons. The technical level was higher in Asia than Europe. This paper examines the comparative superiority of Indian cotton technology in the early modern period by isolating one example of Indian cotton textile production and comparing it with a contemporaneous and an equivalent cotton textile produced in Europe.

Generic terms like 'Indian textiles' and even 'Indian cotton textiles', it is argued, have to be disaggregated and placed within their geographical, technical, and commercial contexts. This examination, therefore, focuses on the French experience with Indian cottons and wood-block printed chintz technology in the last quarter of the seventeenth century and into the first half of the eighteenth century. While similar comparative opportunities between western Indian and other European (English, Dutch, and, possibly, Iberian) wood-block chintz painting producers may exist, the French example was chosen because of the quality and specificity of the documented evidence and written descriptions that permit such an evaluation. This paper also discusses how, for what reasons and which aspects of Indian cotton textile production technology were investigated by the French. It also seeks to establish whether and by what means, the knowledge that the French acquired was diffused and incorporated into their production methods.

While much has been made of Europe's industrial divergence with Asia and the rest of the world in the nineteenth century, it should be remembered that before Europe could diverge technically from 
other parts of the globe, European textile manufacture had to converge through the acquisition and incorporation of new materials and superior technical knowledge or practice from other parts of the globe. Asia, America, and Africa were the sources of supply of new raw materials and India and China were the potential sources of technical knowledge in the area of textile production. Alternatively, and conjointly, Europe (as well as all other regions around the globe) could advance and develop its textile production through new or incremental advances in technical knowledge, production processes, machines, and apparatus. ${ }^{1}$

\section{Indian Cottons and Wood-Block Printed Chintz Technology}

Three Frenchmen investigated and wrote separately long and highly detailed first-hand reports about Indian cotton textile production in general and its technology, especially the methods of printing, painting, and dyeing in particular in the last quarter of the seventeenth century and the first half of the eighteenth century. They dealt geographically with some of the primary port city complexes of India and two of the three centres of Indian textile production: first, western India (Surat - Ahmedabad in Gujarat, including Sironji in Rajputana and Burhanpur in Khandesh); and second, southern India on the Coromandel Coast (including, among the many, Masuilipatam, Pulicat, Tegenapatam, Tranquebar, and Negapatnam). They did not deal with the third, north-east India or Bengal, including Orissa, and the Ganges delta (Hugli - Kasimbazar). ${ }^{2}$

The first two authors (Roques and Beaulieux) were representatives of the French East India Company, respectively, a commercial and the

\footnotetext{
${ }^{1}$ Kenneth Pomeranz, The Great Divergence: China, Europe and the Making of the Modern World Economy (Princeton: Princeton University Press, 2000).

2 See: John Irwin, "Indian Textile Trade in the Seventeenth Century: (1) Western India, (2) Coromandel Coast, (3) Bengal, (4) Foreign Influences", Journal of Indian Textile History, 1 (1955), pp. 15-44; 2 (1956), pp. 24-42; 3 (1957), pp. 19-70; 4 (1959), pp. 57-64; and H. K. Naqvi, "Dyeing of Cotton Goods in the Mughal Hindustan (15561803)", Journal of Indian Textile History, 7 (1967), pp. 45-56. For more general discussions of textile production, see: Prasannan Parthasarathi, The Transition to a Colonial Economy: Weavers and Kings in South India, 1720-1800 (Cambridge: Cambridge University Press, 2001); and Carla M. Sinopoli, The Political Economy ofCraft Production: Crafting Empire in South India, c. 1350-1650 (Cambridge: Cambridge University Press, 2003), pp. 171-90.
} 
other a naval officer. ${ }^{3}$ The third (Coeurdoux) was a Catholic missionary. Roques wrote a report entitled La manière de nègocier dans les Indes Orientales at Ahmedabad in western India from 1678 to 1680, which included details on the wood-block printing of chintz. ${ }^{4}$ Beaulieux in 1737 and Coeurdoux in 1742 and 1747 wrote authoritative letters and reports at Pondicherry, on the Coromandel Coast, about the fabrication of painted cottons in southern India. ${ }^{5}$ The Beaulieux and Coeurdoux reports deal with painted cotton textile production and techniques that were geographically distant and technically distinct from the Roques report.

This paper concentrates on the Roques report and western Indian cotton textile production and techniques for wood-block printed chintz. Salient aspects of the Indian producers' side of the story are identified and interwoven with comparable experience by French producers. ${ }^{6}$ Afterwards, it will be determined whether any of the technological knowledge that was identified was diffused in France. And, if it was not, an explanation will be advanced.

Roques documented that India was an early and a highly proficient proponent of printing "with thickened mordants with the aid of wood

${ }^{3}$ For the French East India Company and its trade in Asia and with Europe, see: Philippe Haudrère, La Compagnie Française des Indes au XVIII Siecle (1719-95) (Paris: Librairie de l'Inde, 1989); Glenn J. Ames, Colbert, Mercantilism, and the French Quest for Asian Trade, (DeKalb, Illinois: Northern Illinois University Press, 1996); and Catherine Manning, Fortunes à faire: The French in Asian Trade, 1719-48 (Aldershot: Variourum/Ashgate, 1996).

${ }^{4}$ Bibliothèque National de France, Paris (hereafter BAF), Fonds Français 14614. Significant segments have been published, see: Paul R. Schwartz, Printing on Cotton at Ahmedabad, India in 1678 (Ahmedabad: Calico Museum of Textiles, 1969); Indrani Ray, "Of Trade and Traders in the Seventeenth-century India: An Unpublished French Memoir by Georges Roques" and Id., "The Trade and Traders in Ahmedabad in Late Seventeenth Century: Extracts from Georges Roques' MSS", in Lakshmi Subramanian (ed.), The French East India Company and the Trade of the Indian Ocean: A Collection of Essays by Indrani Ray (New Delhi: Munchiram Manoharlal Publishers, 1999), pp. 1-62 and 63-76.

${ }^{5}$ See P. R. Schwartz, "French Documents on Indian Cotton Painting: (1) The Beaulieu Mss; (2) New Light on Old Material", Journal of Indian Textile History, 2 (1956), pp. 5-23; 3 (1957), pp.15-44; and Id, "The Roxburgh Account of Indian Cotton Painting: 1795”, Journal of Indian Textile History, 4 (1959), pp. 47-56.

${ }^{6}$ For an overview of French printing and dyeing techniques see: A. Juvet-Michel, "The Controversy over Indian Prints"; Id., "The Great Textile Printing Factories in France"; Id. "The Technique of French Textile Printing"; and Id., "The Patterns of the 'Toiles de Jouy'", pp. 1098-1106; 1109-16; and 1117-22; and H. Wescher, "Dyeing in France before Colbert"; "Great Masters of Dyeing in 18th Century France"; and "The French Dyeing Industry and its Reorganization by Colbert", Ciba Review, 18, February (1939), pp. 618-25; 626-41; and 643-46. 
blocks"7 The principal cotton textile described by Roques was the less expensive wood-block printed chintz as opposed to the more expensive painted chintz from this same region and elsewhere in India. The less expensive wood-block printed chintz was produced at Ahmedabad in Gujarat, Sironji in Rajputana and Burhanpur in Khandesh. Ahmedabad was one of the lowest cost production centres for this textile in western, if not all of India. The use of one or more carved wood blocks was actually "the predominant means of patterning cloth in the west of India", which had spread to the east of India. They "were used to apply the mordant to the prepared cloth". It was a "more mechanical but less timeconsuming technique [that] ultimately robbed the medium of its vitality". In order for the mordant to adhere to the wood-block, it had to be thickened with a resin or a similar substance; "this thickener acted as a contaminant to the mordant and had to be washed out of the cloth before immersion in the dye, or the colour would lack brilliance". Indian producers had confronted and surmounted the drawbacks or limitations in this process. In Europe, printing with wooden blocks was the primary method of cotton textile production. In contrast with their Indian counterparts, contemporary European producers, apparently, had not yet surmounted all the drawbacks or limitations inherent in this process.

Paul R. Schwartz prepared an enlightening detailed technical summary and evaluation of Roques description of wood-block printed chintz processes in western India, which permits us to identify and discuss some of the technical issues and comparisons between western Indian cotton technology and production processes with those of France. Ahmedabad producers used three types of blocks,

one for the outlines of the designs; one for the ground; and a third type for the details, for which up to ten small blocks might be used.... The worker prints first the outlines, then the ground, and then the details and the reserves of wax. Ahmedabad prints seem generally to have had coloured grounds, either red or violet. ... The method by which the colour was obtained is described in a rather confused fashion by Roques, who could not have understood it fully. Fortunately he lists the necessary ingredients: a root to produce the red [saranguy (Morinda citrifolia) or al (Morinda tinctorium)]; alum; iron rust; myrobalan; gall-nuts; pomegranate rinds; terra merita (turmeric); verdigris; copperas; indigo; wheaten flour moistened and become sour; a gum extracted from a tree; wax; and ochre. ${ }^{9}$

7 Schwartz, Printing on Cotton at Ahmedabad, p. 1.

${ }_{8}^{8}$ Mattiebelle Gittinger, Master Dyers to the World: Technique and Trade in Early Indian Dyed Cotton Textiles (Washington, D.C.: The Textile Museum, 1982), p. 27.

${ }_{9}$ Schwartz, Printing on Cotton at Ahmedabad, p. 11. 
Schwartz also comments upon the use of alum (double salt of aluminium and potassium) as mordant for the red colour. Myrobalan and gallnuts, astringents containing tannin, were combined with iron or copperas (sulphate of iron) to produce black. The mordant for black was obtained by discharging an acid (flour soaked and become sour) on iron. The other colours, blue, yellow, and green, were produced, respectively, from indigo, turmeric, and from a superimposition of the yellow of the turmeric on the blue of the indigo.

Roques' observations centred on three areas: raw cotton fibres, aluminous mordant and red dyes, which were integrally, interrelated with western Indian wood-block chintz printing production processes. His observations will serve as a guide for comment and comparison with two contemporaneous French wood-block chintz printing production centres - Marseilles and Rouen. ${ }^{10}$

\section{Raw Cotton Fibres}

The first comparison is the selection, preparation, and use of cotton fibre. Cotton is a vegetable fibre. In the early modern period, it was "one of the most difficult fibers to dye", since "unlike animal fibers such as silk and wool, which can accept most natural dyes with 'comparative' ease, inherent properties of the cotton fiber reject a permanent bonding". ${ }^{11}$ In India, this chintz was woven from raw cotton that was available from local or internal regional Indian market supplies. In outlining the weavers' ability to technically manipulate warp and weft to commercial advantage, Roques raises two speculative and unanswered questions. The first, to what degree did raw cotton quality influence Indian and French producers? In the case of India, cultivation of a perennial (Gossypium arboreum) to an annual variety (Gossypium herbaceum) occurred around the thirteenth century and "India by this time clearly had mastered the difficulties of handling this plant fiber". ${ }^{2}$

${ }^{10}$ For Marseilles see: Olivier Raveux, "Spaces and Technologies in the Cotton Industry in the Seventeenth and Eighteenth Centuries: the Example of Printed Calicoes in Marseilles", Textile History, 36, 2 (2005), pp. 131-45; "Les débuts de l'indiennage dans les Pays d'Aix (1758-70)", Industries en Provence, 4, March (2004), pp. 1-8. For Rouen see: H. Wescher, "Rouen and Its Port in Olden and Modern Times"; Id., "The 'Rouennerie' Trade and Its Entrepreneurs"; Id., "Turkey Red Dyeing"; and Id., "The Normandy Textile Printing Industry of the Eighteenth and Nineteenth Centuries", Ciba Review, 135, December (1959), pp. 2-6; 14-20; 21-26; and 27-32.

${ }^{11}$ Gittinger, Master Dyers, p. 19.

12 Ibid., p. 16. 
In France, in the case of Marseilles, raw cotton was supplied from the Levant; and, in the case of Rouen, it came primarily from the Caribbean. Apparently, there were technical issues caused by the different length of cotton fibres from the different sources of supply that French producers had to identify and resolve technically in order to produce a standard quality product. Another question is whether French producers had reached a level of dexterity, both technically and commercially comparable with their Indian counterparts in handling and manipulating warp and weft.

\section{Aluminous Mordant}

The second comparison concerns Roques' observations on mordant dyeing technology and the comparative status of this practice and process in Asia and Europe. At this time, Europe was effectively using only one of three known dyeing processes, specifically substantive versus vat and mordant dyeing. ${ }^{13}$ Mordant, and in particular alum, was used to fix the colouring matter to form an insoluble coloured compound. Alum is of mineral origin. Aluminous mordant dyeing was and is possible without alum through the use of materials of vegetable origin, bark and leaves, which possess the chemical properties to fast colour to fabric. ${ }^{14}$ Because of the sheer volume of mordant that was required in the aluminous mordant dyeing processes, the use of materials of vegetable origin could not compete with those of mineral origin.

Alum of mineral origin was the principal source of mordant for Asian and European textile producers, until it was chemically manufactured in France in the late eighteenth century. The mining and processing of alum was relatively ubiquitous in China and India and it became known relatively early in the development of textile production processes in Asia. The Chinese had developed a technique for making white alum by the sixth century. ${ }^{15}$ Presumably, the use of alum in the fixation of colour in textile dyeing processes in China dates from that point onwards. Similarly, the use of alum in the fixation of colour

${ }_{13}$ Stuart Robinson, A History of Dyed Textiles (Cambridge, Ma.: MIT Press, 1969), pp. 22-5.

14 A. Bülher, "Dyeing among Primitive Peoples", Ciba Review, 68, June (1948), pp. 2497-98.

${ }_{15}$ Sung Sung Ying-Hsing, Chinese Technology in the Seventeenth Century: T'ienKung K'ai-Wu (New York: Dover Publications, 1997), pp. 206 and 213. 
in textile dyeing processes in India dates from the ninth century, although evidence suggests that it may have occurred at a much earlier date. ${ }^{16}$ In the early modern period, Chinese alum was involved in the intra-Asian maritime trade because it was commercially viable and useful as ballast for shipping purposes. Chinese alum found demand, commercial acceptance, and incorporation in Indian port cities and hinterland textile production centres. ${ }^{17}$

Other global textile production centres were neither ignorant nor was alum insignificant in their processes of textile production. Alum was known in Europe and used in antiquity and in the medieval period. ${ }^{18}$ It was widely traded within and between the Mediterranean and Muslim worlds. ${ }^{19}$ European textile producers were dependent upon supplies from distant locations. From the late Middle Ages, European textile producers were using alum supplied from Chios in the Mediterranean and the Levant and from Tolfa near Rome. The only exception was England, as in 1608 the English began mining deposits of alum and rudimentarily processing it in Yorkshire. It was not until late in the eighteenth century that the applied chemist, Jean Antoine Claude Chaptal, found a solution to this dependence upon foreign supplies of alum for French textile and cotton producers "He discovered the composition of alum, which he manufactured artificially in his factory" in Montpellier. ${ }^{20}$

Dependence upon foreign supplies of alum in France was not the only limitation that French producers had to confront and surmount in the mordant wood-block printing of chintz. A further problem, Roques

${ }^{16}$ Mira Roy, "Dyes in Ancient and Medieval India", Indian Journal of History of Sciences, 13, 2 (1978), pp. 84-85. Using evidence found at Mohenjo Daro, Gittinger suggests that it was much earlier. See Gittinger, Master Dyers, p. 16.

${ }_{17}$ See: George Bryan Souza, "Ballast Goods: Chinese Maritime Trade in Zinc and Sugar in the Seventeenth and Eighteenth Centuries", in Roderick Ptak and Dietmar Rothermund (eds.), Emporia, Commodities and Entrepreneurs in Asian Maritime Trade, c.1400-1750 (Stuttgart: Franz Steiner Verlag, 1991), pp. 291-315; and Id., "Country Trade and Chinese Alum: Raw Material Supply in Asia's Textile Production in the Seventeenth and Eighteenth Centuries", Revista da Cultura, 11 (2004), pp. 136-53.

${ }_{18}$ Pliny the Elder, Natural History (Cambridge, Ma.: Harvard University Press, 1962); and Vannoccio Biringuccio, Pirotechnia (Cambridge, Ma.: Harvard University Press, 1959), pp. $77-8$ and $98-105$.

${ }_{19}$ Peregrine Horden and Nicholas Purcell, The Corrupting Sea: A Study of Mediterranean History (Oxford: Blackwell, 2000), pp. 145, 346, 349, 354, 361 and 611; and Suraiya Faroqhi, "Alum Production and Alum Trade in the Ottoman Empire (About 1560-1830)", Wiener Zeitschrift für die Kunde des Morgenlandes, 71 (1979), pp. 153-75.

20 Wescher, "Great Masters of Dyeing", p. 640. 
observed, was caused by the thickening of the aluminous mordant with a resin (or a similar substance in order for the mordant to adhere to the wood-block and the action of this thickener as a contaminant), which required an additional washing process before immersion in the dye, otherwise the colour would lack brilliance. At present, it has not been determined whether French chintz producers using wood-block printing in places like Marseilles and Rouen in the late seventeenth and early eighteenth century incorporated resins or similar substances to enhance their mordant dyeing technology or whether they incorporated the additional washing process. It appears, however, that initially they did not obtain the same level of brilliance of colour in their cottons in comparison with the western Indian chintz.

\section{Red Dyes}

The third and final comment on Roques' observations deals with colour in general and red dyes and red dyeing technology in particular, and the comparative status of their availability and utilization and their associated technical practices and processes in Asia and Europe. Colour in textile production in general and in cottons in particular was provided by dyes derived from natural organic materials and applied to fabric by different printing, painting or dyeing techniques (Fig. 12.1). ${ }^{21}$ Dyers, globally, were secretive about their recipes and processes. ${ }^{22}$ What exactly was held 'secret' by dyers? Clearly, the observable phenomenon that specific plants, trees, insects, or minerals produced suitable dyes or dye colours was not occulted. What was hidden in their careful guarding of their recipes was the quantity and the manipulation of different dyes or mordant ingredients to produce

${ }^{21}$ For dyeing and dyed textiles see Franco Brunello, The Art of Dyeing in the History of Mankind (Vicenza, 1973) and Robinson, History of Dyed Textiles. For printing and painting techniques see Stuart Robinson, A History of Printed Textiles (Cambridge, MA: MIT Press, 1969); and Serge Chassagne, "Calico Printing in Europe before 1780", in David Jenkins (ed.), The Cambridge History of Western Textiles (Cambridge: Cambridge University Press, 2003), vol. 1, pp. 513-27. For dyeing techniques see B. C. Mohanty, K. V. Chandramouli and H. D. Naik, Natural Dyeing Processes of India (Ahmedadbad: Calico Museum of Textiles and Sarabhai Foundation, 1987).

${ }_{22}$ See Pamela O. Long, Openness, Secrecy, Authorship: Technical Arts and the Culture of Knowledge from Antiquity to the Renaissance (Baltimore and London: Johns Hopkins University Press, 2001). 


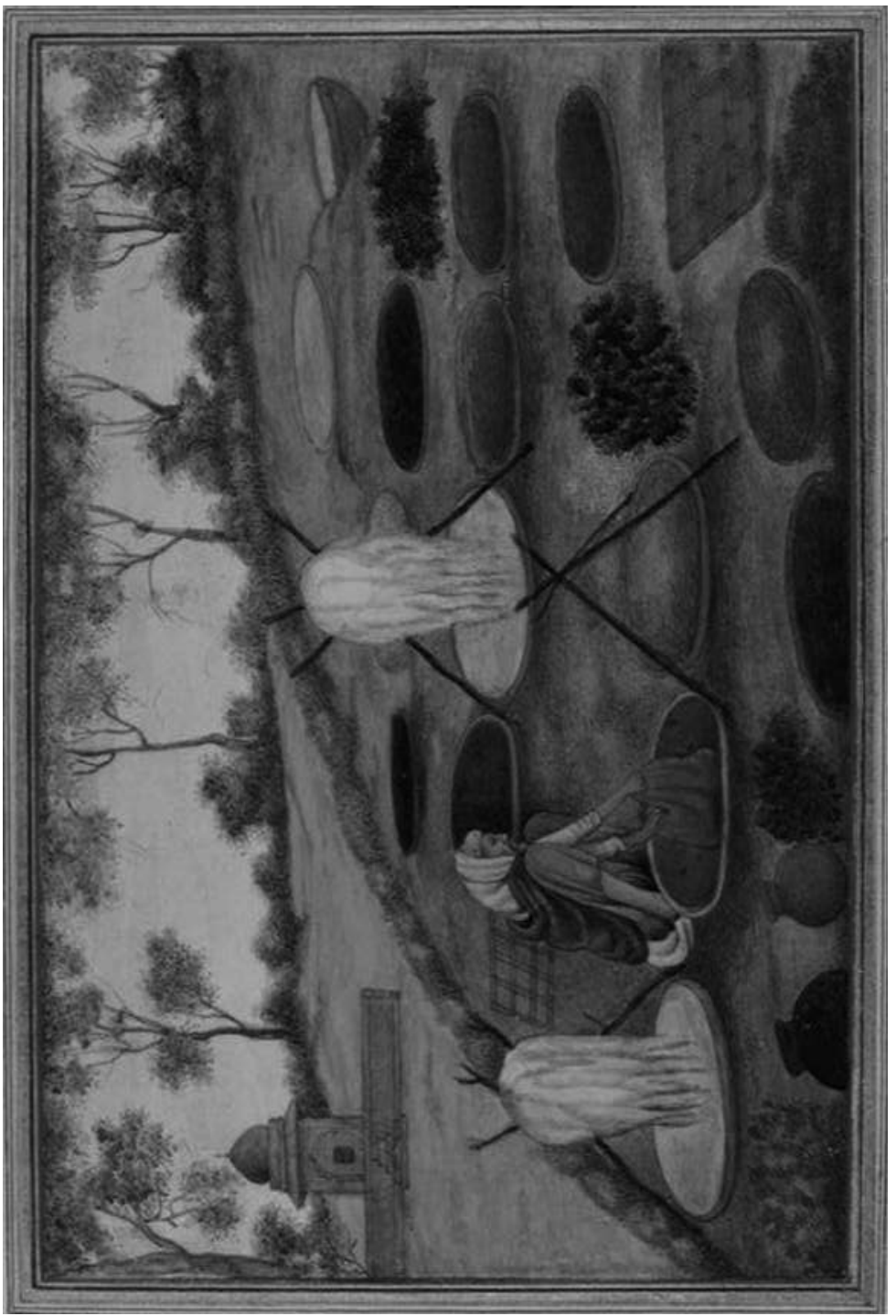

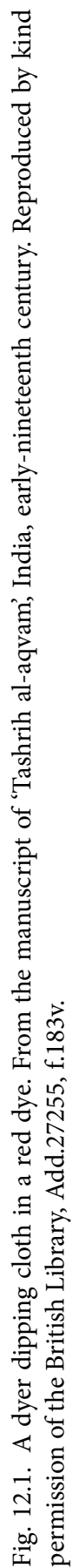


different colours at different costs for different qualities and fibre types for differing production and markets.

Both Asia and Europe possessed internal supplies of natural organic materials that would dye fabric in different colours. The colour red held a powerful symbolic and fashionable attraction for consumers. While European dyers had confronted and resolved how, for example, to dye red fast in woollens, linens, and silks, the search for dyeing fast in red remained an open issue. The global sources for natural materials with the red colouring agent, alizarin or brazilin, were numerous in the early modern period. The principal red dyes that were commercialised globally were from insects (kermes, cochineal), vegetables (madder and other varieties), trees (campeche, brazilwood, and sappanwood), ${ }^{23}$ or their resins (gum and lac). ${ }^{24}$ They were exchanged on a regular and sustained basis between two or more major geographical locations in the emerging early modern global economy. All of these insect or vegetable sources produced red dyes that could be employed alone or used with other dyes to heighten the production of a shade of red in a given woollen, linen, silk or cotton fabric. These red dyes demonstrated a typical commercial and market interrelationship that was dependent upon availability, price, quality, and the technical application of the material vis-à-vis individual market production processes. This interrelationship was not static. Although there were elements of continuity over time, there was also change as knowledge of the chemical traits of the materials and their reaction to different fabrics was increasingly studied. Other red dye materials also competed within different regions and markets. And the application of mercantilist doctrines could limit the importation of a dyeing material from a global or neighbouring source in favour of a material sourced locally or from the colonies.

${ }^{23}$ For the brazilwood cycle in the Atlantic world see C. Furtado, Formação Económica do Brasil (17 ed., São Paulo, 1980). For sappanwood see George Bryan Souza, "Dyeing Red: S. E. Asian Sappanwood in the Seventeenth and Eighteenth Centuries", O Oriente, 8 (2004), pp. 40-58 and Id., "Tingir de vermelho: o sapão da Ásia do Sueste nos séculos XVII e XVIII", in Jorge M. dos Santos Alves, Claude Guillot, Roderich Ptak (eds.), Mirabilia Asiatica (Wiesbaden and Lisbon: Harrassowitz Verlag and Fundação Oriente, 2005), pp. 21-35.

${ }^{24}$ Brunello, Art of Dyeing, passim. For a general discussion of some red dyes see Gösta Sandberg, The Red Dyes. Cochineal, Madder, and Murex Purple: A World Tour of Textile Techniques (Ashville - NC: Sterling Publishing, 1997) and Robert Chenciner, Madder Red: A History of Luxury and Trade (London: Routledge/Curzon, 2000). 
Roques mentions sappanwood as a source of red dye: it had been re-exported from Surat to Le Havre in France, where it was tested by dyers and found technically and commercially successful for textile production. ${ }^{25}$ The sappanwood that was involved was either from Bima on the island of Sumbawa in the Indonesian Archipelago or from southern Siam (Thailand), and had become a commodity regularly exported to France by the French East India Company or acquired by French textile producers from the Dutch East India Company. ${ }^{26}$

Sappanwood was one of nature's prized sources of red dye. ${ }^{27}$ It was and is found in Sumbawa, in the Indonesian Archipelago, Thailand, the Philippines, and in other parts of South and East Asia. Sappanwood's participation in global - as well as intra-Asian (Indo-Chinese) maritime exchange antedates the arrival of Europeans in Asian waters. Sappanwood from Sumbawa was widely used in making a rich reddishbrown colour in medieval Europe. It arrived "in surprisingly large quantities, for $80 \%$ of the examples of red fabrics surviving from the period from around 1100 to around 1450 that have been analyzed, prove to have been dyed with at least some brazilwood". ${ }^{28}$ At the beginning of the sixteenth century, sappanwood from Sumbawa and Thailand was available at Melaka and was destined for China.

Sappanwood produces a red dye that is not as persistent or vibrant as other redwoods or alternative sources. However, in the medieval period some of these other redwoods were not readily known or available. Later, after brazilwood and the other red wood family members in the New World were found to be superior and richer sources of red dye, dyers in Europe employed Southeast Asian sappanwood in conjunction with other red dye materials. They also developed process improvements such as the immersion of cotton and wool fibres with mordant in red wood solution - thus permitting the continuation and the maximization of the commercial use of the commodity.

${ }^{25}$ Schwartz, Printing on Cotton at Ahmedabad, p. 13.

${ }^{26}$ Donald C. Wellington, French East India Companies: A Historical Account and Record of Trade, (Lanham, Maryland: Hamilton Books, 2006), pp. 142, 153, 164, 175, 186, 190-93, 203, and 205-206.

${ }^{27}$ For a technical description of South East Asian sappanwood see H. H. Zeijlstra, "Looi- en Verfstoffen", in K. W. van Gorkom, Oost-Indische Cultures (Amsterdam: De Bussy, 1913), vol. 3, pp. 699-789.

28 Peter Spufford, Power and Profit: The Merchant in Medieval Europe (London: Thames and Hudson, 2003), pp. 332-34. 


\section{The Supply of Red}

Southeast Asian sappanwood was a profitable and practical commodity for inclusion in global maritime trade and in Eurasian exchange. Despite low prices in Southeast Asia, a good gross profit margin could be made from its sale in Europe and Asia. However, sappanwood prices decreased as quantities traded increased and other competing red dyes became more widely available. This conclusion is supported by the comparative analysis of the wholesale prices of sappanwood, madder, brazilwood and cochineal fetched at Amsterdam from the late sixteenth to the eighteenth century. Such a comparison also provides data on the price differentials between different sources of red dyes. ${ }^{29}$ In Asia, the demand for Southeast Asian sappanwood extended from Japan and China to India and Persia. Surat - a major Indian port city centre for weaving, dyeing and the production of cotton textiles - was one of the intra-Asian markets in which the Dutch profitably sold sappanwood. ${ }^{30}$ The VOC also identified that there was demand for the commodity in other Indian port city markets on the Coromandel Coast, Bengal and the Malabar Coast, as well as in Persia and Japan. ${ }^{31}$

Southeast Asian sappanwood supplies increased throughout the seventeenth and eighteenth centuries, although they were potentially subject to being over-exploited through indiscriminate cutting. The agents responsible for the exploitation of sappanwood over this entire period were a diverse group of merchants and investors: the VOC, foreign traders and Chinese junk operators.

First and of primary importance, the rulers of the pre-colonial state systems on Sumbawa and Thailand were the controllers and the immediate financial beneficiaries from the commercialisation of sappanwood. Sumbawa and Thailand were suppliers to the Dutch and others

${ }^{29}$ N. W. Posthumus, Inquiry into the History of Prices in Holland (Leiden: E.J. Brill, 1946-64); ARA, VOC 1394 to 3947: "Price Current Report"; and George Bryan Souza, "The VOC's Price Current in Asia: A Price History for Asian and European Commodities over the Long Eighteenth Century" (Paper presented at the XIV International Economic History Congress, 20-25 August 2006, Helsinki, Finland).

${ }^{30}$ Ashin Das Gupta, Indian Merchants and the Decline of Surat, c. 1700-50 (New Delhi: Manohar, 1994).

${ }_{31}$ Willem Floor, The Persian Textile Industry in Historical Perspective, 1500-1925 (Paris: L'Harmattan/Société d'Histoire de l'Orient, 1999). For suō or sappanwood in Japanese textiles and dyeing techniques see Betsy Sterling Benjamin, The World of 'Rozome': Wax-Resist Textiles of Japan (Tokyo: Kodansha International, 1996), pp. 82-84, 195 and 206. 
in the seventeenth century. The Dutch exported sappanwood from both areas to Europe and within Asia. There was some slight market preferences for one source or the other, based upon a perceived difference in dye quality. Thai supplies of sappanwood in the seventeenth century, for example, had been preferred in the Japanese and the Dutch market. ${ }^{32}$ There were some labour and environmental limitations and constraints upon the supply of sappanwood on Sumbawa in the eighteenth century. ${ }^{33}$ It was Thailand's increased exploitation of its sappanwood resources that overtook and relegated Sumbawa supplies to a secondary level of importance in the eighteenth century.

Second, through the negotiation of commercial relations with the rulers of the pre-colonial state systems in Sumbawa and Thailand and via trade with Chinese and foreign merchants at Batavia, the VOC was able to purchase and secure adequate supplies of sappanwood for its Europe-bound and its intra-Asian trade. Sufficiency of supply was not always certain and the Company had to implement a variety of strategies during the eighteenth century that included direct contracts with suppliers such as the Sultan of Bima of Sumbawa and negotiations in Thailand, and exchange on free markets with foreign traders at Batavia.

Third, the efforts of European (Portuguese, Spanish) and Asian (Armenians, but primarily, Chinese) merchants' activities in sourcing non-VOC controlled sources of sappanwood in Southeast Asia were of significance and out-paced Dutch activities. ${ }^{34}$ By 1771, the Portuguese were importing annually upwards of 750,000 ponden ${ }^{35}$ of southeast and south Asian sappanwood into China. ${ }^{36}$ This amount of sappanwood was slightly higher than its potential demand in Europe as estimated by the VOC in 1797. This does not include any estimate for the quantity of

${ }^{32}$ George Vinal Smith, The Dutch in Seventeenth-century Thailand (Dekalb, Ill.: Northern Illinois University, Centre for Southeast Asian Studies, 1977), pp. 80, 82 and 88 .

${ }^{33}$ B. de Jong Boers, "Sustainability and Time Perspective in Natural Resource Management: the Exploitation of Sappan Trees in the Forests of Sumbawa, Indonesia, 1500-1875", in Peter Boomgaard, et. al. (eds.), Paper Landscapes: Explorations in the Environmental History of Indonesia, (Leiden: KITLV Press, 1997), pp. 261-80.

${ }^{34}$ Souza, "Dyeing Red", O Oriente, 8 (2004), pp. 40-58.

35 The Dutch ponden was fractionally greater than the English pound; for our purposes, it may be considered roughly equivalent to the English pound.

${ }^{36}$ AHU, Maços de Macao, 6, doc. 28, 10 Nov. 1771. This report has been published in A. M. Martins do Vale, Os Portugueses em Macau (1750-1800) (Macau: Instituto Português do Oriente, 1997), annex 20. The report uses the Chinese picol, which was converted to Dutch ponden. 
sappanwood that was commercialised by Chinese junk operators, which would have been probably of some significant if not similar magnitude. The Spanish in the Philippines were also successful in intensifying the exploitation and commercialisation of sappanwood, which they and others (the Chinese, Portuguese and Armenians) employed in intra-Asian maritime trade. Sappanwood did not figure significantly in the Pacific exchange. Conversely, there were attempts to locate demand, develop markets and increase the consumption of New World cochineal in Asia. ${ }^{37}$

\section{Convergence}

Roques establishes that Indian producers were technically more advanced in employing red dyes, as the ground in wood-block chintz printing. Contemporaneous French producers at Marseilles and Rouen were either using the natural white of the cotton or employing black dyes as the ground. In Europe and France, red dyeing technology for cotton was considered a complex and difficult process. By the $1760 \mathrm{~s}$, European including French dyers had converged or resolved the pending technological issues for all animal and most vegetable fibres. This convergence had occurred through empirical practice and the transfer of knowledge, similar to what occurred in Asia, and the incorporation of scientific inquiry in the age of reason, which was dissimilar to the Asian experience. ${ }^{38}$ European dyers were producing colours in those textiles that were equal to those produced in Asia, with the exception of red dyeing in cotton. Lepileur d'Apligny attempted to address this issue in 1776, but it was not until the early nineteenth century that Chaptal resolved it with the publication of the Lart de la teinture du coton en rouge (1807) and Principe chimiques de l'art du teinturier dègraisseur (1808). ${ }^{39}$

Although in agreement with the evaluation that Roques' report was "neither systematic nor always complete in technical details", ${ }^{40}$ Roques' observations of the late seventeenth century did contain information that could have been of critical importance to French producers of

\footnotetext{
${ }^{37}$ For the trade between the Philippines and Mexico see Carmen Yuste López, El comercio de la Nueva España con Filipinas, 1590-1785 (Mexico, D. F.: INAH, 1977).

${ }^{38}$ See Jean Hellot, Lart de la teinture des laines et des étoffes de laine, en grand et petit teint (Paris, 1750). See also A. Birembaut and G. Thuillier, "Une source inédite: Les cahiers du chimiste Jean Hellot”, Annales, Economies, Civilisations, 21 (1966), pp. 357-64.

39 Wescher, "Great Masters of Dyeing", pp. 636-37 and 640-41.

40 Ray, "Of Trade and Traders", p. 1.
} 
printed chintz. There is no evidence to suggest that this information was diffused. Writing under instructions to provide commercial information for the directors of the French East India Company, Roques' "La manière de nègocier dans les Indes Orientales" was read internally, discussed, and archived. In contrast, Coeurdoux's information on the fabrication of painted cottons in southern India by being published were publicly scrutinized and disseminated.

The consumption of cotton textiles in Europe in the 1660s was shifting from domestic to personal use and was booming. ${ }^{41}$ In France, the Company's exports of low cost western Indian wood-block printed chintz was just beginning and most imported chintzes originated from the Ottoman Empire as copies of Indian goods. Because of their low cost, these imported chintzes were oriented towards the lower-middle classes and competed with inferior qualities of 'indiennes' or 'siamoises' style chintz produced at Marseilles and Rouen. In the latter half of the seventeenth century, Marseille's manufacturing and trade of 'indiennes' was presented as a demonstration of how Asian textile technology could be diffused in France. Driven toward producing cottons that would reduce the importation and the outlay of French treasure for the purchase of cottons from India, it was the dexterity and experience of Armenian merchants from the Levant and not India and their presence in Marseilles that provided expertise and the technical transfer of technique and knowledge in developing this technology. ${ }^{42}$ While this study focuses on the technical obstacles that had to be surmounted by French wood-block cotton painting producers, additional political and economic factors created additional difficulties. These included the mercantilist measures that led to a ban on production and consumption of printed and painted cotton. Mercantilist doctrines predicted the organisation of space and economic resources by the State in order to protect and foster domestic production and increase the wealth of the nation through export. ${ }^{43}$ The state intervened and decreed the

\footnotetext{
${ }^{41}$ Beverly Lemire, "Fashioning Cottons: Asian Trade, Domestic Industry and Consumer Demand, 1660-1780", in Jenkins (ed.), Cambridge History of Western Textiles, vol. 1, pp. 493-512.

${ }_{42}$ Raveux, "Spaces and Technologies"; and Id., "Les débuts de l'indiennage".

${ }^{43}$ On French mercantilism see Charles Woolsey Cole, French Mercantilist Doctrines before Colbert (New York, 1931); Id., French Mercantilism 1683-1700 (New York: Columbia University Press, 1943); and Thomas J. Schaeper, The French Council of Commerce 1700-15: A Study of Mercantilism after Colbert (Columbus, Oh.: Ohio State University Press, 1983).
} 
prohibition of the importation of foreign printed cottons and the production of imitations in France in $1686 .{ }^{44}$

\section{Conclusion}

This paper examines the comparative superiority of Indian to European cotton technology in the early modern period by isolating one example of Indian cotton textile production and comparing it with a contemporaneous and an equivalent cotton textile produced in Europe in the late seventeenth and eighteenth centuries. Using an unusually rich, detailed, and specific report, it concentrates on a specific example of western Indian cotton textile production and techniques: the wood-block printed chintz.

This paper argues that India's clear comparative advantage rested upon knowledge. Indian weavers and dyers possessed extensive knowhow from long-term familiarity and deductive practice with raw materials and from developing techniques in how to manipulate cotton fibre, the use of mordant in fixing colors, and the use of a wide range of red dye materials. Dyers, globally, were secretive of their recipes and how they concocted their dyeing and their fixing of colouring processes. The materials that were involved were not occulted and were subject to regular and growing regional and global commercial exchanges. The cost of raw materials was not the crucial difference, it was knowing how to select, handle, apply, and incorporate diverse raw materials, especially dyes and mordant, in crafting cotton fibres. And, for example, in the specific case of wood-block printed chintz in western India, it was knowing how to maximize the use of low cost red dyes and the handling of aluminous mordant and its residue. Their European counterparts did not lack the apparatus or competitively priced raw materials, they lacked knowledge.

Before early modern Europe could diverge technically from other parts of the globe, European textile manufacture had to converge through the acquisition and incorporation of new materials and technical knowledge from other parts of the globe, especially from India and China or, alternatively, through new or incremental advances in technical knowledge. This paper re-enforces the argument that the

${ }^{44}$ Juvet-Michel, “The Controversy over Indian Prints”, p. 1093. 
local, regional, and global elements of the organization of space, human, as well as natural, technological and commercial resources, and production should be approached individually and holistically, via their inter-connections, and then compared with alternative experiences.

Finally, while the Roques report contained potentially useful information for French producers, the commercial rationale for the acquisition of this information, apparently, impeded the indirect or direct public diffusion of its findings. The practical experience of the Levant helped to resolve the particular issue concerning improving the quality of French chintz production. However, the sources of information that resolved the larger pending technical issues for French cotton producers relating to mordant dyeing and red dyeing in cottons came more from the incorporation of scientific inquiry in the age of reason and less from empirical practice and the transfer of prescriptive knowledge. The Asian experience was dissimilar to the European, in part, possibly, because they were technically more advanced and did not face the necessity that Europe had to expand and develop new or incremental advances in technical or propositional knowledge, production processes, machines, and apparatus. 
$-978-90-47-42997-5$ 


\title{
FASHIONING GLOBAL TRADE: INDIAN TEXTILES, GENDER MEANINGS AND EUROPEAN \\ CONSUMERS, $1500-1800$
}

\author{
Beverly Lemire
}

\section{Introduction}

By 1500, the centuries old trade in Indian cotton textiles represented more than simply an exceptional economic phenomenon, although it was certainly that. The traffic in cottons linked together disparate regions of the world, while the textures and designs of this commodity brought about cultural conversations, multi-party dialogues employing commodities rich in iconic significance and practical value. A 'transmission of culture' through trade, as K. N. Chaudhuri notes, is an adjunct to global exchange; indeed, as Chaudhuri observes, "the power of objects to locate man within the grids of a social space transcend far beyond its immediate economic value". Indian cottons were unmatched by other commodities in terms of their diverse cost and quality, at the same time as they provided a key medium for the global circulation of print imagery. Moreover, the widespread appetite for these textiles made India the source of the most significant global consumer commodity before industrialization. The ambit and chronology of this phenomenon have been confirmed by recent research; ${ }^{2}$ however, the complex factors underlying demand for Indian cottons in world markets remain to be fully explored and their comparative features assessed. This chapter will contribute to the dialogue on cotton's role in global

${ }^{1}$ K. N. Chaudhuri, “Trade as a Cultural Phenomenon”, in Jens Christian V. Johansen, Erling Ladewig Petersen and Henrik Stevnborg (eds.), Clashes of Cultures: Essays in Honour of Niels Steensgaard (Odense: Odense University Press, 1992), p. 210.

2 John Guy, Woven Cargoes: Indian Textiles in the East (London: Thames \& Hudson, 1998); Ruth Barnes, Indian Block-Printed Textiles in Egypt: The Newberry Collection in the Ashmolean Museum, Oxford (Oxford: Clarendon Press, 1997), vol. 1; Stephen Frederic Dale, Indian Merchants and Eurasian Trade, 1600-1750 (Cambridge: Cambridge University Press, 1994). 
trade by exploring our understanding of fashion in economic history and by analysing the long-term influence of Indian cottons on Europe's markets and people. ${ }^{3}$ Fashion's historic trajectory is part of this process, a phenomenon arising in urban centres rooted in trade; its selfsustaining momentum in Europe, from the late Middle Ages, is a critical ingredient in the dynamic of social change. As Chaudhuri notes, "trade is an exchange of object which in turn structure and define social categories, practices and values". ${ }^{4}$ Fashion's genesis and evolution are exemplary of the power of trade.

Choice, selection and variability are requisite components of fashion commodities. Indian painted and printed cottons provided a unique medium for the flow of imagery, carrying the rich and mutable visual language impressed on these fabrics. These goods were part of a discursive cultural interchange among peoples who, while their religious and secular beliefs might vary, shared cultural systems that embraced admixtures of plant and animal symbolism in both high and low cultural forms. In the European context the floral culture of the middle ages and later Renaissance developed out of social interactions between elites and commoners, the passion for flowers and the rich meanings embedded in their uses as evident among one group as the other. ${ }^{5}$ Printed Indian motifs came in an array of decorative styles that included geometric as well as botanic forms, with a flexible symbolic imagery amenable to multiple interpretations. Printing, in particular, provided a mechanism that enabled the broadest array of patterns - with the form itself supporting fashionable articulations - suited to changing tastes. The medium of printing on paper has long been studied as a European development. Chandra Mukerji has made a particular study of the growing market for printed pictures in early modern Europe, as a type of artefact exemplary of the new consumerism of that age. Indeed, Mukerji claims a special place for pictorial prints as "the first form of

\footnotetext{
${ }^{3}$ The phrase 'fashion system' is associated with Roland Barthes, who focused on the twentieth-century interaction between print and fashionable commodities. Its application to earlier periods is more problematic because of very different economic and social contexts. In this instance the fashion system is defined as a self-perpetuating, dynamic force which framed the cultural stimulus to demand and focused the desire for self-definition. Roland Barthes, The Fashion System (New York: Hill and Wang, 1983).

${ }^{4}$ Chaudhuri, "Trade as a Cultural Phenomenon", p. 210.

${ }^{5}$ Jack Goody, The Culture of Flowers (Cambridge: Cambridge University Press, 1993), pp. 163-65.
} 
mass-produced images for popular market ... an early form of mass culture that helped to cultivate consumerism in the lower echelons of

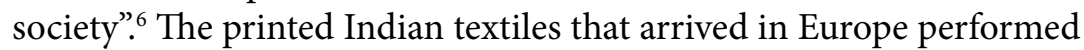
much the same role as Mukerji assigns to the spread of pictorial prints in Europe, which "helped in the geographic spread of consumerism by carrying designs for artefacts over broad areas, shaping international patterns in taste". The imagery carried on Indian cottons fed the burgeoning fashion system in Europe generating a cultural energy across social ranks, in forms accepted by men and women.

While consumerism, luxury and semi-luxury trades have become the focus of considerable historical research, fashion, as a stimulus to demand, a part of the cultural dynamic of global trade, has been too generally neglected by economic historians. ${ }^{8}$ The factors that shape demand need to be more fully assessed: factors such as the temporality of fashion stimuli and the social composition of fashion participants in the evolution to its demotic forms. The chronology of fashion must also be reconsidered. Over the early modern era the expression of fashion educed from an isolated, elite preoccupation to become a fashion system - a self-perpetuating, dynamic force which framed demand and focussed broad-based desires within an evolving form of material selfdefinition. Asian textiles, like silk, were singularly important as expressions of status in late medieval and early modern Europe, a limited and precious fashion commodity. Indian cottons were integral to the fuller development of the fashion system in the Atlantic world, fundamentally affecting patterns of material culture. In cotton textiles, the economic, the cultural and the social are intertwined. In trade history, too, gender is a feature generally ignored in analyses of commerce. But the power and practice of gendered fashions are essential to an

\footnotetext{
${ }^{6}$ Chandra Mukerji, From Graven Images: Patterns of Modern Materialism (New York: Columbia University Press, 1983), p. 38.

7 Ibid., p. 65.

${ }^{8}$ For exceptions see: Maxine Berg, Luxury and Pleasure in Eighteenth-Century Britain (Oxford: Oxford University Press, 2005); Craig Clunas, "Modernity Global and Local: Consumption and the Rise of the West", American Historical Review, 104, 5 (1999), pp. 1497-1511; Id., Superfluous Things: Material Culture and Social Status in Early Modern China (Cambridge: Polity Press, 1991); Jeremy Prestholdt, "On the Global Repercussions of East African Consumerism", American Historical Review, 109, 3 (2004), pp. 755-81; Beverly Lemire, Fashion's Favourite: The Cotton Trade and the Consumer in Britain (Oxford: Oxford University Press, 1991) and Id., "Fashioning Cottons: Asian trade, domestic industry and consumer demand 1660-1780", in David Jenkins (ed.), The Cambridge History of Western Textiles (Cambridge: Cambridge University Press, 2003), vol. 1, pp. 493-512.
} 
understanding of markets and their function. In this chapter I examine the particular consumerism expressed by men from the middling classes through to the elites. The marketplace resounded with the demands of men as consumers and, though they have been less often studied as an explicit driver of commerce, their appetites for Asian wares were instrumental in shaping a new consumerism. ${ }^{9}$ They, along with their wives and mothers, created new commercial forces which fuelled global commerce, even as it redesigned their material lives.

\section{Fashioning Cottons}

Commercial hubs throughout Eurasia, along the Indian Ocean, Red Sea and eastern Mediterranean pumped products from producers to the world's consumers. The wealth amassed in these in-land cities and coastal ports in turn generated an urban population sophisticated in commercial products..$^{10}$ It is now clear that fashion was not restricted to Western locales, despite long-standing claims to the contrary. ${ }^{11}$ Fashion's power affected various Asian communities at periods similar to its appearance in early modern Europe and may well have flourished in other sites yet unstudied. The generative East/West exchange over centuries, the stimulus to urban societies across Eurasia and Africa, and the expressions of fashion which underlay global commerce were

9 Some exceptions include Margot Finn, “Men's Things: Masculine Possession in the Consumer Revolution", Social History, 25, 2 (2000), pp. 133-55; and Brandon Brame Fortune, "Studious Men are Always Painted in Gowns': Charles Wilson Peale's Benjamin Rush and the Question of Banyans in Eighteenth-Century Anglo-American Portraiture", Dress, 29 (2002), pp. 27-40.

${ }^{10}$ For a discussion of the centrality of trade in social development see: Andrew Sherratt, "Reviving the Grand Narrative: Archaeology and Long-Term Change", Journal of European Archaeology, 3, 1 (1995), pp. 1-32.

11 The claim for the Western uniqueness of fashion is offered by Gilles Lipovetsky, The Empire of Fashion: Dressing Modern Democracy (Princeton: Princeton University Press, 1994), pp. 3-8 and 15. A similar perspective is offered by Peter N. Stearns, Consumerism in World History: The Global Transformation of Desire (New York: Routledge, 2001), pp. i and 1. For more extensive evidence of fashion see Peter Burke, "Res et Verba: Conspicuous Consumption in the Early Modern World", in John Brewer and Roy Porter (eds.), Consumption and the World of Goods (London: Routledge, 1993), pp. 148-61; Timothy Brook, The Confusions of Pleasure: Commerce and Culture in Ming China (Berkeley: University of California Press, 1998); Antonia Finnane, "Yangzhou's 'Modernity': Fashion and Consumption in the Early Nineteenth Century", Positions, 11, 2 (2003), pp. 395-425; Jennifer Ball, Byzantine Dress: Representations of Secular Dress in 8th-to 12th-Century Painting (New York and Basingstoke: Palgrave Macmillan, 2005). 
driving forces at critical junctures. Nowhere is this more evident than in the history of Indian cottons in the global market. The Indian trade in cottons - printed, painted and embroidered - was built to suit societies and peoples around the span of the compass, over countless generations. Did fashion figure in this trade? One definition of fashion emphasizes the systematic interchange between producers and consumers, resting on endless shifts in taste; and this definition does not characterize all markets. ${ }^{12}$ From the Classical to the early modern era, empires rose and fell, some cities grew while others withered; but the 'archipelago of towns' ${ }^{13}$ across the globe drew in quantities of Indian textiles for customers high and low. There is no doubt that at some times, in some urban settings, fashion held sway. Great Indian trading cities, like Goa and Cambay, for example, were "famous and opulent ... for ... commerce and traffic" as François Pyrard reported about $1600,{ }^{14}$ and may indeed have supported classes of merchants and traders who had been responsive to shifting styles for centuries. In the absence of fashion's insistent pulse, however, regional and cultural preferences shaped demand and India's artisans were skilled in their response. Mattiebelle Gittinger observes that:

The mastery of the technical aspects of this craft allowed the dyer the freedom to respond to orders for different patterns and designs with assured success. He could meet the demand-in design and, unusually, colour preferences-of virtually any market. Dark maroons, blacks and deep reds-patterned in grids with details worked with 'nervous' white resist lines-went to Thailand. To Southeast Asia went hip wrappers with large saw-toothed borders and fields worked with geometric patterns or small flowers. To Armenia went Christian altar frontals. [And, ultimately,] to Europe went bedhangings with great blossoming trees and dress goods, robes, or vests..$^{15}$

12 Alan Hunt, Governance of the Consuming Passions: A History of Sumptuary Law (Basingstoke: Macmillan, 1996), p. 44.

${ }^{13}$ Janet L. Abu-Lughod, Before European Hegemony: The World System A.D. 12501350 (New York: Oxford University Press, 1989), p. 13. The phrase was coined by Richard Haëpke and also employed by Fernand Braudel.

${ }^{14}$ François Pyrand, The Voyage of François Pyrard of Laval to the East Indies, the Maldives, the Moluccas and Brazil, ed. Albert Gray (London: Hakluyt Society, 1888), vol. 2, part 1, p. 249. Generations of Westerners arriving in India marvelled at the wealth within commercial precincts, including Clive later in the eighteenth century. Jack Goody, The East in the West (Cambridge: Cambridge University Press, 1996), pp. 113-14.

${ }^{15}$ Mattiebelle Gittinger, Master Dyers to the World: Technique and Trade in Early Indian Dyed Cotton Textiles (Washington, DC: The Textile Museum, 1982), pp. 16-17. 
The India trade was, "the backbone of international economy in the Middle Ages in general and the Islamic world in particular". ${ }^{16}$ Over millennia, Indian merchants and producers became skilled in the creation of products suited to various classes of buyers, whether in classical Rome, fourth-century Southeast Asia or the sixteenth-century Mediterranean. Carriers of iconic symbols, imbued with exceptionally vibrant and subtle colours, Indian cottons sustained cross-cultural dialogues where their surface designs, as well as the fabrics' weight and wear, attracted peoples largely illiterate in written text, but deeply trained in the reading of symbols. The printed surface designs were an essential part of their appeal. ${ }^{17}$ Distinctive Indian textiles set new standards within global markets, effects that were particularly dramatic in Europe after 1500.

In the first century of direct trade with India, Europeans marvelled at the decorative imagery and wondered at the extraordinary variety of cottons that appeared in ports and in royal courts. Following direct trade with Portugal, after 1500, printed cottons were absorbed into clerical and secular markets, soon found from Iberia to the North Sea. Design and decorative idioms were transformed within decades of contact with these materials. Before 1600 the unique Southeast Asian iconography was translated by European hands into a wealth of embroideries stitched by amateur and professional needle workers. ${ }^{18}$ Rarities became more commonplace, as testified by mid-sixteenth-century probate inventories from England's south coast and by reference to 'calico'

16 S. D. Goitein, "Letters and Documents on the India Trade in Medieval Times", Islamic Culture, 37, 3 (1963), p. 188. The scope of Indian trade is also considered by Lynda Shaffer, "Southernization", Journal of World History, 5, 1 (1994), p. 2; and G. P. Baker, Calico Printing and Painting in the East Indies in the XVIIth and XVIIIth Centuries (London: Edward Arnold, 1921), pp. 1-3.

17 Goody, East into West, pp. 115-16; R. M. Riefstahl, Persian and Indian Textiles from the Late Sixteenth to the Early Nineteenth Century (New York: E. Weythe, 1923) pp. 7-9; John Irwin and Paul R. Schwartz, Studies in Indo-European Textile History (Ahmedabad: Calico Museum of Textiles, 1966); K. B. Brett, "The Flowering Tree in Indian Chintz", Journal of Indian Textile History, 3 (1957), pp. 45-56; John Irwin, "Indian Textile Trade in the Seventeenth Century: Foreign Influences", Journal of Indian Textile History, 4 (1959), pp. 57-64; K. B. Brett, “The Japanese Style in Indian Chintz Design”, Journal of Indian Textile History, 5 (1960), pp. 42-49.

18 See Beverly Lemire, "Revising the Historical Narrative: India, Europe and the Cotton Trade, c. 1300-1800", in Giorgio Riello and Prasannan Parthasarathi (eds.), The Spinning World: A Global History of Cotton Textiles, 1300-1850 (Oxford: Oxford University Press, 2008), pp. 205-26. 
under categories of trade goods listed in Tudor Books of Rates. ${ }^{19}$ This first century of direct trade profoundly affected the tastes of Europeans, as the domestication of exotics got underway. By 1600, the dramatic response to Asia's manufacturing bounty had long since been accepted as part of the normal course of European material culture, as a natural outcome. In fact, by all criteria, this was one of the most dramatic disjunctures in European history: aesthetically, economically and culturally. The exotic roused an equal measure of official anxiety. After first targeting Asian silks, later in the seventeenth century legislators would take aim at Indian cottons. But along with official resistance was a more widespread process of interrogation, adaptation and adoption, with the fashion process ignited and redefined. Indian cottons brought to Europe a template for popular fashionability: it had both demotic and elite forms; the aesthetic of print and colour were malleable; while the volume of these products available made them eventually accessible to the widest population. Yet, to understand fully the significance of these textiles, we must look more intently at those buying cottons as, over the course of Indo-European trade, these products reconfigured personal appearances and domestic space, ultimately representing far more than their utilitarian value.

\section{Cotton Textiles, Gender and Global Trade}

A close study of markets uncovers not only the variety of goods sold, but the characteristics of the buyers and the uses to which these goods were put. ${ }^{20}$ In this regard, gender is a key element of analysis. Typically, gender concerns have been entirely ignored in the history of global trade, the masculine essence of this endeavour thereby rendered invisible and the gendered markets neutered. A similar scholarly pattern was once the norm in a cognate field, imperial history, but the most recent generation studying the history of empires have employed gender analyses to great effect. This now provides a fuller understanding of

19 Edward Roberts and Karen Parker (eds.), Southampton Probate Inventories, 14971575 (Southampton: Southampton University Press, 1992), vol. 1, pp 65-70; 150-52; 159-62; 165-67; and vol. 2, pp 244-52; 346-47; 358-59.

${ }^{20}$ Beverly Lemire, "Domesticating the Exotic: Floral Culture and the East India Calico Trade with England, c. 1600-1800", Textile: The Journal of Cloth and Culture, 1, 1 (2003), pp. 65-85. 
the functioning of empires, a development that helped revive imperial history. ${ }^{21}$ In economic history, as well, an awareness of gender is required to understand all elements of the trade in textiles, disclosing key patterns in the interaction of fabrics, consumers and markets. Sophie White illustrates this in her study of male slaves' textile preferences in colonial New Orleans, where the "[male] consumerism in the Colony formulated itself as a syncretic amalgam of European and nonEuropean values". 22 The introduction of the 'banyan' into Western male wardrobes provides another telling example of the ways in which new gender consumer priorities figured in the development of trade with India.

One of the distinctive developments of Western European male dress over the fifteenth and sixteenth centuries was the abandonment of floor-length robes for daily wear by elite adult men. The clerical cassock, judges' robes and formal scholastic gown are reminders of what was for generations the typical clothing form for prominent men in and out of the church. Over the fifteenth and sixteenth centuries gentlemen's legs became visible and for young men in particular this part of their anatomy was celebrated with hose, stockings and breeches of various forms. ${ }^{23}$ But the geo-politics of early modern Eurasian trade reformulated the wearing of gowns by men for at least informal occasions, as nobles and merchants, gentlemen and genteel aspirants embraced an Asian hybrid garment with a similar profile to that of generations past. However, in this instance there were no symbolic associations with the venerable, ancient, formal garments of old, despite some apparent similarities. Rather, this new-style robe carried with it an essence distinct to the period, redolent of daring sea voyages, scientific discoveries and the commercial desires tied to these endeavours preoccupations with events such as these were found in both the courts and counting houses of Amsterdam, Paris and London. The robe that

${ }^{21}$ Antoinette Burton (ed.), Gender, Sexuality and Colonial Modernities (London: Routledge, 1999); Catherine Hall, Civilising Subjects: Colony and Metropole in the English Imagination, 1830-67 (Chicago: University of Chicago Press, 2002); Kathleen Wilson (ed.), A New Imperial History: Culture, Identity, and Modernity in Britain and the Empire, 1660-1840 (Cambridge: Cambridge University Press, 2004).

${ }^{22}$ Sophie White, "'Wearing Three or Four Handkerchiefs around his Collar, and Elsewhere about Him': Slaves' Constructions of Masculinity and Ethnicity in French Colonial New Orleans", Gender and History, 15, 3 (2003), p. 541.

${ }^{23}$ For a study of the Venetian case see Stella Mary Newton, The Dress of the Venetians, 1495-1525 (Aldershot: Scolar Press, 1988), pp. 9-47. 
became so much the rage did not originate in India, but in Japan, where once a year in the seventeenth century the Shogun presented a single kimono to a representative of the Dutch United East India Company, the garment folded beautifully and offered on a lacquered wooden tray. This rarity marked the recipient among the European traders in Asia and these garments also attracted immediate notice when worn back in Europe. ${ }^{24}$ The patterned silk gown had an honorific association, as well as being constructed of distinct and sumptuous fabrics. Confirmation of status came with the wearing of this distinguished new piece of clothing. And, as so many European men yearned to adopt this mark of distinction, new sources for the robes and the fabrics were found in India.

The designation of this garment as a 'banyan' in the English-speaking world is an intriguing cross-cultural eliding of terms. Duarte Barbosa employed the word in his 1518 account of his voyage to the subcontinent, observing that there was a "caste of Heathen merchants whom they call Guzarates (but in Cambaya, of which they are natives, they are called Baneanes) ... and trade in goods of every kind from many lands...". He concluded that, " $t \mathrm{t}]$ hey dwell in great houses and streets of their own". 25 The wealth and social prominence of these traders was noteworthy. In François Pyrard's early seventeenth-century description of the East Indies the name banyan was given to all Hindu traders and brokers, that is, all commercial men of substance he encountered in India. ${ }^{26}$ Thus, the term employed for the merchants of India became the English name applied to a garment in vogue among those European men who likewise strived for commercial prominence and social riches. In France, this robe was given an Armenian provenance by one of the artists who recorded this vogue, Armenian traders being long established Eurasian intermediaries for those in Western Europe (Fig. 13.1). ${ }^{27}$ The Dutch employed two names: "Japanese robe" and "Cambay", the second term reflecting the commercial power of that western Indian

\footnotetext{
${ }^{24}$ Bianca M. du Mortier, Aristocratic Attire: The Donation of the Six Family (Amsterdam: Rijksmuseum, 2000), p. 35.

${ }^{25}$ Duarte Barbosa, The Book of Duarte Barbosa. An Account of the Countries Bordering on the Indian Ocean and their Inhabitants, Written by Duarte Barbosa, and Completed about the Year 1518 A.D., ed. Mansel Longworth Dames (London: Hakluyt Society, 1921), vol. 2, p. 73 and footnote 2.

${ }^{26}$ Pyrand, Voyage, p. 364, footnote 2 and p. 365.

${ }^{27}$ Jean Baptiste Bonnart, Recueil des modes de la cour de France (Paris, 1676), described as "robe d'Armenien".
} 


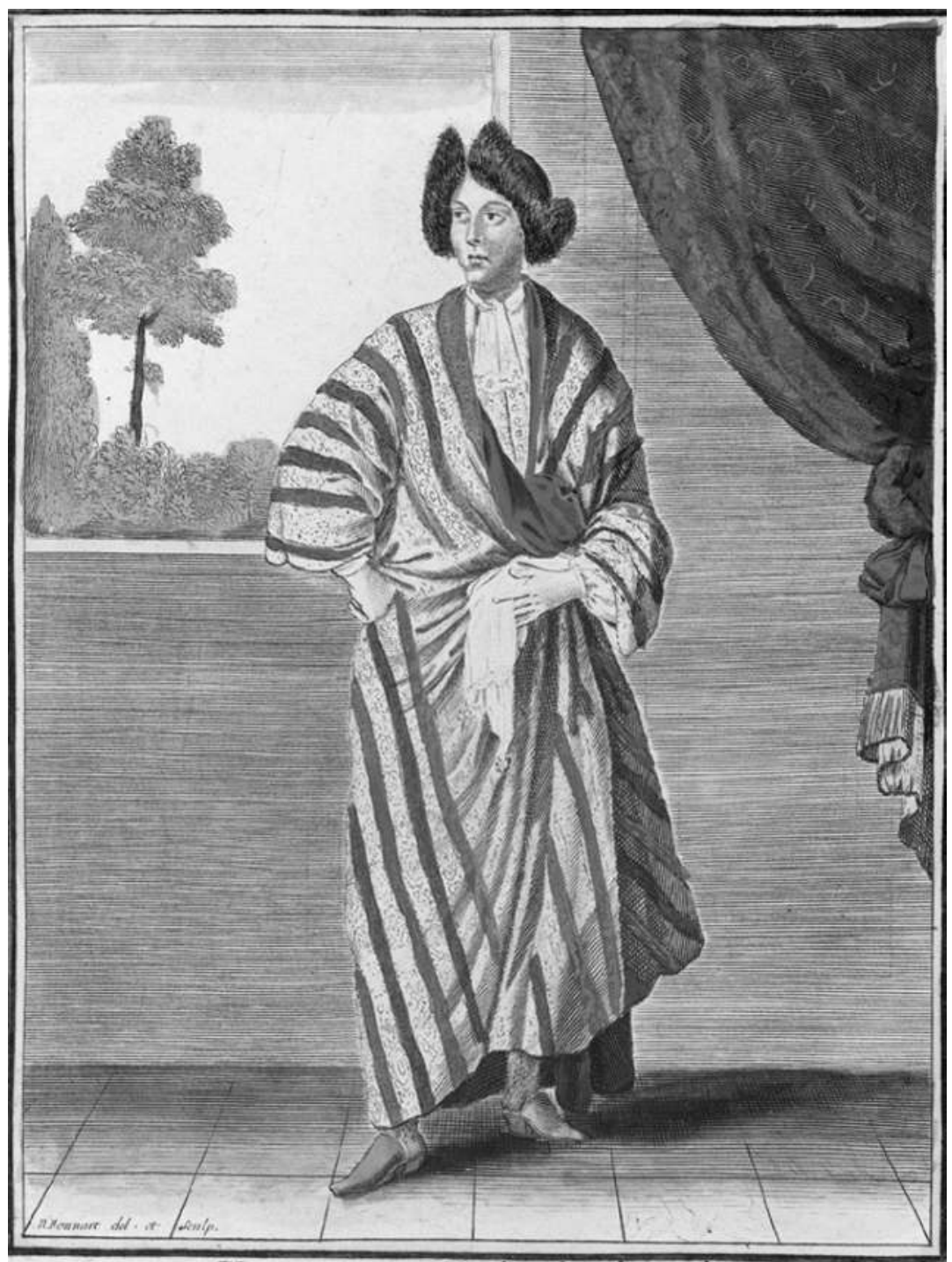

Hom me en Robede Chambre.

Cette robe a'drmenien Et lón ne fraureit trouncr rien

E.st on des babillí com mode. De plus graue et pless a la mode.

Fig. 13.1. "Hommes en Robe de Chambre" in Nicholas Bonnart, Recueil des modes de la cour de France (Paris, 1676). 
port. ${ }^{28}$ Each of these designations called up the wealth of Asia, a lure to commercial and philosophical adventurers.

The name given to this garment varied from country to country: denoting a commercial elite in India (in the English case), the Japanese origins of the robe or a great Indian port (in the case of the Dutch), or the dynamic Armenian trading community (in the case of the French). Regardless of the designation, seventeenth-century elite European males embraced this Asian form of dress. In themselves, the robes carried celebrated associations with mercantile success founded on commerce with Asia and they also alluded to wider cosmopolitan pursuits. Banyans were replete with an amalgam of meanings, defining urbane, successful and erudite masculinity. Samuel Pepys exemplified the ambitious men of this era, determined that his dress would reflect the social position to which he aspired. "I hope I shall not now need to lay out more money a great while", wrote Pepys in his diary in 1663, "I having laid out in clothes for myself and wife ... these two months ... above $110 \mathrm{l}$. But I hope I shall with more comfort labour to get more, and with better successe then when, for want of clothes, I was forced to sneak like a beggar" ${ }^{29}$ Pepys ensured that when his portrait was painted in 1666 he was wearing the requisite banyan, even though he had to borrow this garment, as he did not yet have one in his wardrobe. ${ }^{30}$ Ultimately rising to high office in the Admiralty, a Member of Parliament and elected to the Royal Society, the sartorial emblem Pepys employed in this portrait epitomized his social and professional milieu.

R. W. Connell defines what he calls conventional 'gentry masculinity' as an elite male ethos that "did not emphasize rational calculation ... being tied to lineage and kin networks". The great social and economic movements of the early modern era, of which new global trade networks were a major part, inaugurated a process of change in the dominant expressions of Euro/American masculinity. This era, as Connell notes, "saw the displacement of gentry masculinity by more calculative, rational and regulated masculinities". ${ }^{31}$ The banyan became

${ }^{28}$ Ebeltje Hartkamp-Jonxis, Sitsen uit India (Amsterdam: Rijksmuseum, 1994), p. 70 .

${ }^{29}$ Samuel Pepys, The Diary of Samuel Pepys, eds. Robert Latham and William Matthews (Berkeley: University of California Press, 1970), vol. 4, p. 358.

${ }^{30}$ Lemire, Fashion's Favourite, p. 15.

${ }^{31}$ R. W. Connell, "The Big Picture: Masculinity in Recent World History", Theory and Society, 22, 5 (1993), pp. 608 and 609. 
the material idiom of this manly social ideal. Aspiring males embraced this new mode of informal apparel, redefining the material forms of masculinity through the use and wearing of banyans at home, in their libraries, at their desk, with their cabinets of curiosities or at their ease with friends. ${ }^{32}$ Margot Finn finds that English male diarists from the long eighteenth century were "active both as participants and initiating agents in a range of consumer activities which scholars typically tend to associate with women". ${ }^{33}$ And, among other things, they were keenly interested in the purchase of garments that would construct a socially appropriate figure, while also offering utility. The wealthy Hollander, Jan Six, recalled the use to which he put his Japanese robe, writing in his diary: "June 1689 was so cold we had to don our winter underwear, with braziers at table and Japanese dress coats". ${ }^{34}$

The term virtuoso culture has been coined to define the ethos of the men enamoured with the curiosities brought to Europe from far afield, intellectually intrigued by the rarities of nature or the beautiful manufactures from the East. Science and commerce conjoined in their interests. ${ }^{35}$ An affinity with these intellectual preoccupations marked the incumbent as virtuosi, an association confirmed for some by membership in a scientific or philosophical society, by the adoption of the new coffee drink, or through the deployment of a banyan for private interactions. As Brian Cowan observes, the virtuosi's interests were practical and utilitarian and they "led the way in spurring consumer interest in coffee". ${ }^{36}$ For those men like Pepys who worked successfully to develop or maintain his status, there was a powerful fashion imperative to affirm their standing through the wearing of Indian robes, like the printed calico banyan worn by the much ridiculed bourgeois gentilhomme, Jourdain, in Molière's 1670 play of the same name. Jourdain affected the dress of the elite and was derided for his pains by those courtiers who

${ }^{32}$ François-Hubert Drouais painted an informal family portrait of a prosperous bourgeois family in 1756, with the husband swathed in a banyan of this sort. National Gallery of Art, Washington D.C. 1946.7.4.

${ }^{33}$ Finn, "Men's Things", p. 142.

${ }^{34} \mathrm{Du}$ Mortier, Aristocratic Attire, p. 35.

${ }_{35}$ See, for example, Mark A. Meadow, "Merchants and Marvels: Hans Jacob Fugger and the Origins of the Wunderkammer", in Pamela H. Smith and Paula Findlen (eds.), Merchants and Marvels: Commerce, Science, and Art in Early Modern Europe (London: Routledge, 2002), pp. 182-200.

${ }^{36}$ Brian Cowan, The Social Life of Coffee: The Emergence of the British Coffeehouse (New Haven and London: Yale University Press, 2005) p. 14. 
subscribed to traditional hierarchies. ${ }^{37}$ But whether or not this vogue was approved at Louis XIV's court for all men, it was a potent cultural form that persisted through several centuries-this pattern of material culture likewise represented a distinct and highly profitable segment of the Indian textile trade. Whether made of heavy or lighter fabrics, cotton, silk or a blend, it became a staple of genteel male attire, the stuff of everyday wear. ${ }^{38}$

Brandon Brame Fortune explores the symbolic importance of the costume selected by eighteenth-century Anglo-American Enlightenment gentlemen (scholars and practitioners of science) when they had their portraits painted. As with Pepys, the garb in which these men would be immortalized was of signal importance. Fortune observes that for the members of the American Philosophical Society: "a banyan in eighteenth-century portraiture seems to indicate a body at ease, giving free rein to the mind's work" ${ }^{39}$ This fashion idiom is also reflected in a host of portraits created from the mid seventeenth century onwards throughout the Atlantic world, including, for example, Louis XIV's chief architect, along with a prominent Dutch sculptor at the Sun King's court and a citizen of Utrecht dressed in the latest style-all of which survive in the Louvre. ${ }^{40}$ The Italian, Antonio Verrio, worked for the restored Stuart royal household after 1660 as a fresco and portrait painter and created a self-portrait in 1700 , choosing a sumptuous flowered banyan for the occasion, a mode of dress that transcended borders. ${ }^{41}$ The political aesthetics established for the Indian banyan after 1650 continued for generations and with this the market for Indian fabrics grew. Eighteenth-century painters, like William Hogarth and John Singleton Copley, scientists/inventors, like Isaac Newton and Benjamin Franklin, the East India Company director, Sir Josiah Child, and philosophers Voltaire and John Locke, all of whom wore banyans

\footnotetext{
${ }^{37}$ For a further commentary on this evocative play see Daniel Roche, The Culture of Clothing: Dress and Fashion in the "Ancient Régime" (Cambridge: Cambridge University Press, 1989), pp. 91-93.

${ }^{38}$ Among the household tasks Sir John Mordaunt mentioned in a 1701 letter to his wife was a request that his nightgown [banyan] sleeves be relined. Warwickshire County Record Office, CR 1368 vol.1/12, 5 Aug. 1701.

${ }_{39}$ Brandon Brame Fortune with Deborah J. Warner, Franklin and His Friends: Portraying the Man of Science in Eighteenth-Century America (Philadelphia: University of Philadelphia Press, 1999), p. 53.

${ }_{40}$ Musée du Louvre, Paris, Inv. 7510; Inv. 7511; R.F. 2885.

${ }^{41}$ National Portrait Gallery, London (hereafter NPG), 2890.
} 
in their portraits, articulated their self-image through the patterns and practice of their dress, as surely as through their other creative processes. This style typified male portraits from the commercial and intellectual ranks for a century and a half in all regions of the Atlantic world, a cross-cultural form further exemplified in the portraits of Denis Diderot, the great encyclopaedist, the French financier and connoisseur of gardens, Claude Henri Watelet and the philosophe JeanJacques Rousseau. Publishers, architects, botanists, chemists, clerics, diplomats, geographers, merchants, philosophers, politicians, artists, poets, actors, composers, mathematicians and writers, all were memorialised in the seventeenth and eighteenth centuries wearing banyans of one sort or other. There are many hundreds of portraits of this type in major museums and in small collections as well, wherein the banyan figured as a visible sign of shared interests, a markedly different form from the military, clerical or aristocratic figures painted at the same time. The young James Boswell, on the Grand Tour, had his portrait painted in Rome wearing this attire, telegraphing his aspiration to make a place for himself in erudite circles. Men of position, and many less august males of the age, wore this garment as a habitual practice and were painted swathed in its folds; they clearly saw an association between this informal, hybrid garment and the wider intellectual, physical and commercial worlds with which they were engaged. ${ }^{42}$

Robert Carter Nicholas, a prominent member of Virginia society, wrote to an English supplier in 1768, asking that a "large Wraping Gown for a large Man be sent by the very first Opportunity" ${ }^{43}$ In an exchange of letters in the summer of 1778 between Baron Grantham and his sister, he reminded her of the chintz robes sent for the comfort of the men

${ }^{42}$ Fortune, “'Studious Men”"; Susan Rather, "Benjamin West's Profession Endgame and the Historical Conundrum of William Williams", William and Mary Quarterly, 59, 4 (2002), pp. 13, 16 and figures IV and V. Additional portraits of men in banyans can be found in the National Portrait Gallery collection: NPG, 11, 278, 299, 550, 558, 562, 1045, $1167,1179,1323,1920,2106,2890,3230,3228,5188,5932,6063$ and 6143. Portraits reflecting this style produced for French and Low Countries men held in the Louvre, Paris, include, R.F. 2169, Inv. 27-622, Inv. 4306, R.F. 1991-4, R.F. 1972-14, R.F. 1982-66, R.F. 2002-05. The portrait of a geographer, school of Caravaggio from the seventeenth century, offers another example of this form of dress. Norton Simon Museum, Pasadena, F. 1968.11.03.P.. Rousseau's portrait is held at the National Galleries of Scotland, NG 820, as is James Boswell's P.G. 804, as well as other men in this costume: P.G. 731, P.G. 894, P.G. 629, P.G. 2472. See also Musée des Beaux Arts, Bordeaux, Bx E 204.

${ }^{43}$ Linda Baumgarten, What Clothes Reveal: The Language of Clothing in Colonial and Federal America (New Haven and London: Yale University Press and The Colonial Williamsburg Foundation, 2002), p. 110. 
of the family during the hot summer weather and recollected "Tom laughing the first time he saw them in their Banyans". ${ }^{44}$ Perhaps this was a generational reaction to what was now a traditional form of dress among men past the first flush of youth. Well over a century had passed since the introduction of this garment and despite the occasional amused responses to the loose-flowing wrap, it was a perennial part of the gentleman's wardrobe, widely diffused even in colonial American society where through the customary redistribution of secondhand clothes the Virginia plantation owner, John Ball, gave an old banyan to his slave Israel in the mid-eighteenth century. ${ }^{45}$

East India merchants and local retailers profited from this distinctly masculine fashion, carrying ready-made banyans to Europe's capitals, or making up morning gowns for their clients from a range of fabrics, all with the requisite Asian flavour. Edward Gunn specialized in Indian gowns for men, with a shop in central London which on his death in 1672 included items such as "coloured Indian sattin", "flowered" and more generic "ordinary gowns for men" ${ }^{46}$ At the same time in the Netherlands, the Amsterdam Courant announced the arrival of hundreds of ready-made morning gowns or banyans on ships of the Dutch East India Company, as well as cotton gowns ready-to-sew; 317 such items were advertised in 1686, for example. ${ }^{47}$ Like his Amsterdam contemporaries, the Londoner, Thomas Cole, held considerable stock of Indian textiles in his warehouse and shop in 1667 and most likely organized the making of banyans himself, turning the 'Carnation India Sattin', 'bengale taffety' and 'bengale stuff' into stock like the "38 Indian Gownes, small \& great" that were valued at $£ 11 .{ }^{48}$ Specialist shops selling these garments persisted well into the eighteenth century, such as the Magazin des Robes De Chambre that opened in 1732 in the Temple Exchange in London (Fig. 13.2), the French name of the shop suggesting the trans-national fashion associated with this garment. ${ }^{49}$

${ }^{44}$ Bedforshire and Luton Archives and Record Service: L 30/17/4/205.

${ }^{45}$ Baumgarten, What Clothes Reveal, pp. 110-11 and 134.

${ }^{46}$ London Metropolitan Archives, AM/P1 (1) 1672/33.

${ }^{47}$ Hartkamp-Jonxis, Sitsen uit India, p. 78.

48 Corporation of London Record Office, Court of Orphans, Inventories, 301.

${ }^{49}$ John Johnson Collection, Bodleian Library, Oxford, Trade Cards Box 13. A later eighteenth-century bill head with reference to Indian as well as French textile novelties is noted in Natasha Coquery, "The Language of Success: Marketing and Distributing Semi-Luxury Goods in Eighteenth-Century Paris", Journal of Design History, 17, 1 (2004), p. 79, Fig. 4. 
It advertised "a clean, fresh Stock of Morning Gowns and Banjans of Scotch Pods, Silk Damasks, Stuff Demaks, Flower'd Silks, Thread Sattins, Turkey Mantua's, Floretta, Callimancoes etc". In a neighbouring district, in 1739, a surviving handbill records the sale of goods from a "GownWarehouse" near the Royal Exchange. The list included "Banjans of all Sorts, at as reasonable Rates" ${ }^{50}$ Banyans were sold at least to 1800 , as illustrated in the 1792 receipt from the ready-made linen warehouse of Copwood \& Company, New Bond Street. This business listed products including "Gentleman's Banyans" among their extensive range of readymade goods. Doyley's Warehouse in Covent Garden and Christian's Warehouse in Cavendish Square likewise advertised banyans for sale in various London newspapers. ${ }^{51}$

The longevity of the wearing of banyans in portraits was matched by the ubiquity of these items in the wardrobes of middling and upper class men. Likewise, banyans survive in major museum collections throughout the West, testament to the numbers bought and owned, as well as to the sentiment attached to these garments. ${ }^{52}$ From the outset,

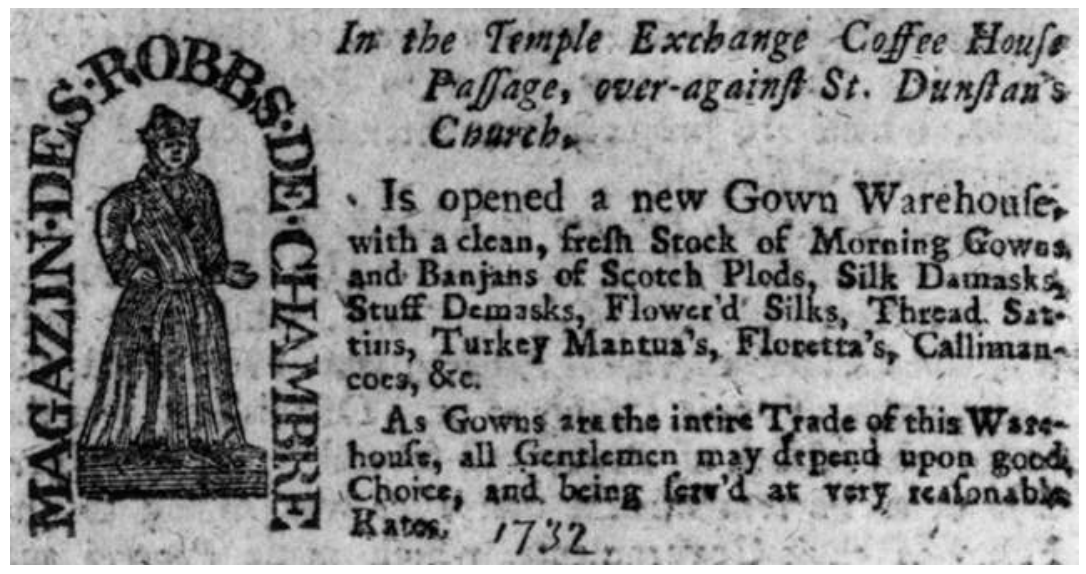

Fig. 13.2. "Magazin des Robes de Chambre”, Trade Card, John Johnson Collection, Box 13, Bodleian Library, Oxford.

${ }^{50}$ John Johnson Collection, Bodleian Library, Oxford: Men's Clothing, Box 6.

${ }_{51}$ Morning Chronicle (London), 18 April 1797; Weekly Register (London), 2 May 1798; Times (London), 30 May 1799.

${ }^{52}$ For example, a banyan which went from daily wear to become a costume worn from at least the late nineteenth century with Turkish slippers on the holiday of St Nicholas. Rijksmuseum, Amsterdam, BK-1982-80. See also BK-NM-5546 and BKNM-8247. 
they redefined male informal attire, framing fashionable European men with an initially exotic form emblematic of new male sensibilities that enriched European material culture..$^{53}$ Figure 13.3 is an example imported to the Netherlands in this period, currently held in the Rijksmuseum. The floral painted fabric is typical of goods from the North-west of India, as is the braid and button fastening applied down the front of the gown, a garment that may in fact have been tailored in India. ${ }^{54}$ Beginning in the seventeenth century with the rare kimono gift to Dutch traders, the banyan developed as a hybrid construction in a category of Indian trade carefully cultivated and widely promoted. Indeed, in 1666 Charles II decided to take up this fashion at court, though this was a short-lived initiative; but for some weeks this "Eastern fashion" took hold under a sort of royal fiat. ${ }^{55}$ More long-lived, the banyan celebrated masculine endeavour, the riches of trade and the exotics of Asia. And only through attention to the interaction of fashion, gender and international trade are these rich material processes revealed.

\section{Domestic Comforts and Global Trade}

The gendered practices of a cross-section of Western men offer an important case study of the reception and significance attached to new goods and the gendered cultural forces that shaped the trade in cottons. However, male consumerism was only one part of a wider material practice which involved women as well as men, the young as well as the old, plebeian as well as elite. The household was the primary site of negotiation where resources, labour and time were allocated and expenditures determined. Margot Finn observes of the eighteenthcentury middle ranked male diarists she studied that they "cultivated their sartorial ambitions alongside a pragmatic understanding of the ways of the domestic market".56 They were doubtless equally aware of the dynamics of household negotiation. In the evolution of the West, Jan de Vries identifies the critical importance of decisions made within the household, which collectively represented a key site enabling a more intensive consumerism. Terming this process the industrious

${ }^{53}$ Lemire, "Domesticating the Exotic".

${ }^{54}$ Hartkampf-Jonxis, Sitsen uit India, p. 70.

${ }_{55}^{5}$ Lemire, Fashion's Favourite, pp. 10-12.

${ }^{56}$ Finn, “Men's Things", p. 142. 


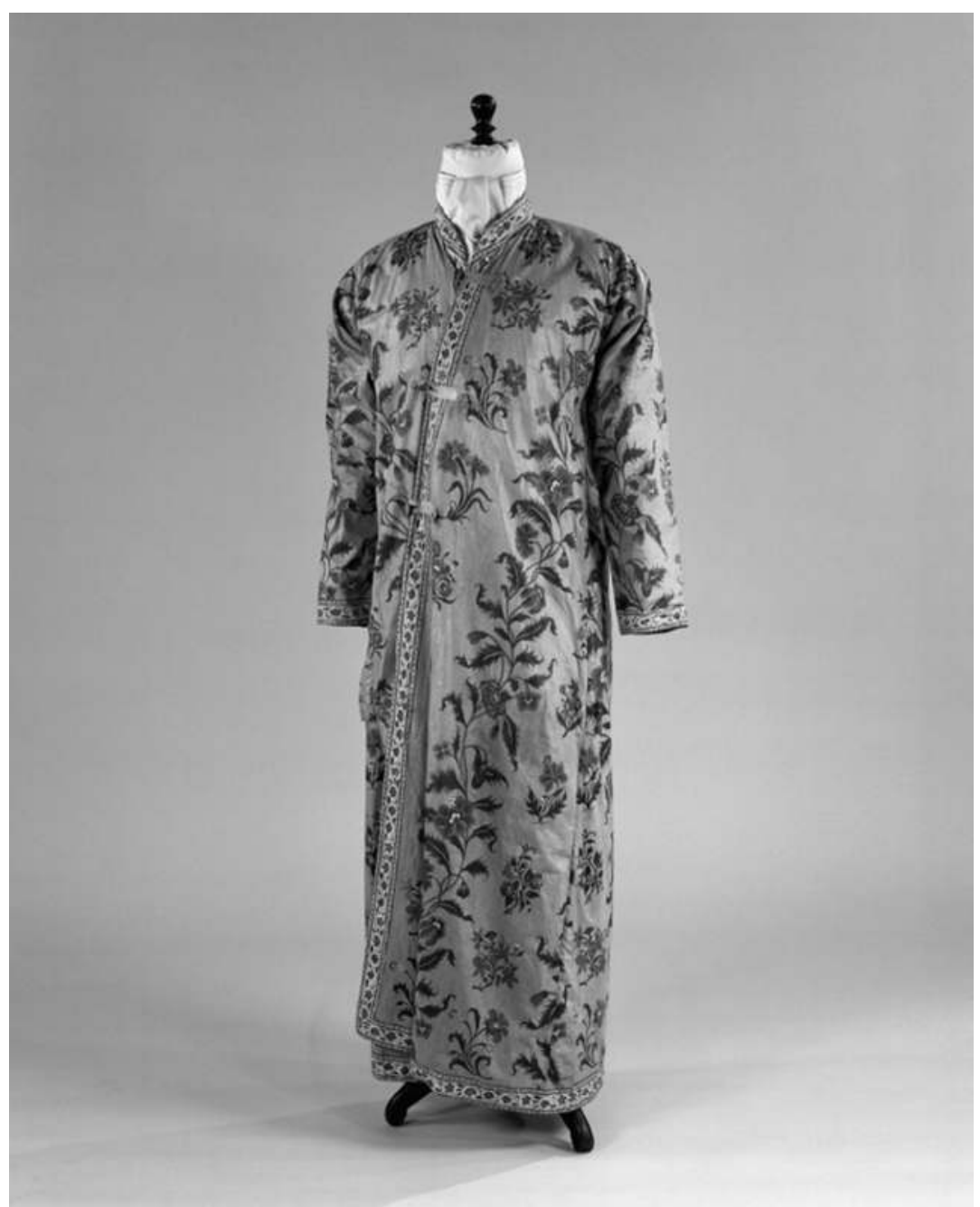

Fig. 13.3. Banyan. Rijksmuseum, Amsterdam: BK-NM-8247.

revolution', de Vries points to the importance of "a major intensification of labour-measurable in labour force participation rate, days worked per year and effort per unit of labour-[which] occurred in many areas in the course of the early modern era". ${ }^{37}$ In the contest between the

${ }^{57}$ Jan de Vries, "Between Purchasing Power and the World of Goods: Understanding the Household Economy in Early Modern Europe", in Brewer and Porter (eds.), Consumption, p. 110. See also Id., The Industrious Revolution: Consumer Behavior and the Household Economy, 1650 to the Present (Cambridge: Cambridge University Press, 2008). 
charms of rest and the delights of new material desires, plebeian family members increasingly chose to work more to satisfy new wants. De Vries emphasizes the importance of the reallocation of time and labour within families as a matter of choice to secure particular goods-goods associated with comfort and enhanced status. His theorizing provides an analytical lynchpin further tying together household strategies, gendered market practices and global trade. In the first instance, gendered patterns among women and men informed the patterns of consumption and the practice of fashion. Fabrics like cotton figured in utilitarian and cultural functions, as we have seen with the banyan's history, where gender-practice directed the kinds of fabric and uses to which materials were put. Women also had important roles in the allocation of resources. In most societies, women directed much of the purchase, use and exchange of household textiles. As a result of these duties, women were directly engaged in determinations of value, in calculations of second-hand markets, in the organization of gifts and the direction of everyday credit, much of which was founded on the manipulation of cloth and clothing. Recognizing women's agency is crucial to an understanding of the long evolution of economic development and is equally central in linking trade patterns with regional development.

Annette Weiner brings a particular acuity to the study of gender and cloth; her observations are rooted in South Pacific communities but have resonance far beyond this geographic locale. "In many societies throughout the world", writes Weiner, "women are the producers and, in part or wholly, the controllers of highly valued possessions - a currency of sorts made from cloth". ${ }^{8}$ Monetization was a gradual and intermittent process over many centuries, also reversible and at times impermanent. Cultural and economic contexts vary from region to region, but in many instances where monetization was imperfectly in place, textiles functioned as one of the most important alternate currencies, as well as gifts of practical and symbolic importance. ${ }^{59}$ The availability of cloth as a key consumer item made it ideal as an alternate currency; commonly pawned, readily exchanged for other goods or

58 Annette Weiner, Inalienable Possessions: The Paradox of Keeping-While-Giving (Berkeley: University of Chicago Press, 1992), p. 3.

${ }^{59}$ In the fifteenth century, by decree, cotton cloth was employed as an alternate currency in Korea, for example, a practice that was revived in specific seventeenth century economic conditions. Heita Kawakatsu, "The Emergence of a Market for Cotton Goods in East Asia in the Early Modern Period", in Anthony J. H. Latham and Heita Kawakatsu (eds.), Japanese Industrialization and the Asian Economy (London: Routledge, 1994), pp. 25-27. 
textiles, value was assigned on the basis of utility and cultural desirability. ${ }^{60}$ Women were central agents in these economic exercises, typically balancing domestic budgets, or managing small trade or craft enterprises ${ }^{61}$ Such exchanges engendered an important flexibility in the marketplace, as well as serving crucial economic and social functions in generations of household economies. In this way consumer goods, like cottons, became important in every market they penetrated, valued for their multiplicity of practical and aesthetic uses.

In 1577 William Harrison wrote that "the furniture of our houses also exceedeth and is grown in manner even to passing delicacy; and herein I do not speak of the nobility and gentry only but likewise of the lowest sort in most places of our South Country". ${ }^{62}$ Sometime earlier the Southampton merchant Thomas Goddard bought calico sheets, items listed in a probate inventory in 1555 and the widow Margaret Pyd enjoyed calico curtains on her windows before she died in $1559 .{ }^{63}$ The vicar of Stoke Gifford, Gloucestershire, owned a painted calico hanging, two calico sheets and four calico pillow covers in $1620 .{ }^{64}$ And although we cannot know who was instrumental in organizing these purchases, this taste for cottons was not unique among their neighbours, numbers of whom owned some of the brilliant but practical fabrics. The appearance of calico pillows, curtains, quilts and yard goods, fine and coarse, within several southern and western regions of England mark a transitional moment in global trade, as material agendas were recast. John Crowleyobserves that "During the eighteenth century, Anglo-Americans

${ }^{60}$ Beverly Lemire, The Business of Everyday Life: Gender, Practice and Social Politics in England, c. 1600-1900 (Manchester: Manchester University Press, 2006), introduction and ch. 4.

${ }^{61}$ Beverly Lemire, Dress, Culture and Commerce: the English Clothing Trade before the Factory (Basingstoke: Macmillan, 1997), chs. 3 and 4; Elizabeth Sanderson, Women and Work in Eighteenth-Century Edinburgh (Basingstoke: Macmillan, 1996), ch. 2; Abdoulaye Kane, "Financial Arrangements Across Borders: Women's Predominant Participation in Popular Finance, from Thilogne and Dakar to Paris. A Senegalese Case Study", in Beverly Lemire, Ruth Pearson and Gail G. Campbell (eds.), Women \& Credit: Researching the Past, Refiguring the Future (Oxford: Berg Publishers, 2002); Lemire, Business of Everyday Life, chs. 2 and 4.

62 William Harrison, The Description of England: The Classic Contemporary Account of Tudor Social Life, ed. Georges Edelen (Ithaca, NY: Cornell University Press, 1968), p. 200.

${ }_{63}$ Roberts and Parker, Southampton Probate Inventories, vol. 1, pp. 70 and 152.

${ }^{64}$ John S. Moore (ed.), The Goods and Chattels of our Forefathers: Frampton Cotterell and District Probate Inventories (London and Chichester: Phillimore \& Co. Ltd., 1976), p. 52 . 
used the word 'comfort' with increasing frequency to express their satisfaction and enjoyment with immediate physical circumstances". ${ }^{65}$ The addition of new forms of Indian cotton bedding, cushions and draperies pre-dated the 1700s, but was certainly part of the careful cultivation of comfort that preoccupied householders for generations.

Exploring the second-hand trade in England provides rich evidence of the mechanisms that allowed labouring and middle ranked men and women to buy the desirable new Indian cottons. One of these consumer devices was the vast confluence of stolen textiles and clothing pouring into the second-hand market, which could be resold at markedly cheaper prices than new goods. Theft of Indian cottons began very shortly after their arrival in England, like the 'Calicut cloth' removed "out of a ship called the Johne Arthur" at Gravesend on the Thames in March $1541 .^{66}$ There is no indication whether the foreign dealer selling 'callacow' on the streets of London in the 1590s was selling new goods or black market wares. ${ }^{67}$ But the informal market was significantly expanded with the growing sales of cottons from this date onwards, goods which often found their way to other owners by way of illicit commerce. Perusing the criminal prosecution one finds two calico quilts pilfered from a London house in 1687 and a single calico quilt lifted by a larcenous lodger in 1695 , a theft quickly noted by his landlady; these and similar cases trace the percolation of Indian fabric furnishings into modest homes. ${ }^{68}$ The seaman Benjamin Cook was lucky to retrieve his quilt, pillows and two cotton shirts in 1732; similarly Eleanor Read, a lodging-house keeper, reclaimed her cotton gown, checked apron and cotton handkerchief in 1745 from a light-fingered thief - many others were not so lucky and other consumers were offered popular cotton goods at bargain prices.

The fashion-inspired shifts and changes within a substantial consumer sector are no longer opaque if one charts the ownerships of goods through the activities of thieves. ${ }^{69}$ Through the circulation of

\footnotetext{
${ }^{65}$ John E. Crowley, “The Sensibility of Comfort”, American Historical Review, 104, 3 (1999), p. 750.

${ }^{66}$ Letters and Papers ... of the Reign of Henry VIII (London: H. M. Stationery Office, 1898), vol. 16, p. 491.

${ }^{67}$ Lien Bich Luu, Immigrants and the Industries of London 1500-1700 (Aldershot: Ashgate, 2005), p. 186.

${ }_{68}$ Proceedings of the Old Bailey Online: www.oldbaileyonline.org/ accessed 20 November 2008, 7 December, 1687, 8 May 1695, 12 October 1715.

${ }^{69}$ Lemire, Fashion's Favourite, pp. 205-6 and Id., Dress, Culture and Commerce, ch. 5 .
} 
alternate currencies and the creative use of second-hand wares the fashion impulse was sustainable at lower levels of society. Subsequent research revealed the tremendous scale of the second-hand trade, nationally and internationally, over many centuries. The pawning of household goods, predominantly cloth and clothing, and the varied uses to which materials were put were crucial to credit functions among non-elites, a phenomenon that persisted for centuries in many regions and cultures. ${ }^{70}$ Women were the principal organizers of material resources, their actions linking household to markets, local to international trade. The strategies employed by women, to meet personal and domestic requirements and to satisfy material desires, reflect the persistence of malleable economic practices even as the foundations for international capitalism were laid. ${ }^{71}$ Fernand Braudel recognized the multi-layered nature of the early modern economy, including what he called a, "shadowy zone, often hard to see for lack of adequate historical documents, lying underneath the market economy: this is the elementary basic activity which went on everywhere and the volume of which is truly fantastic". The importance of this 'shadowy zone' cannot be overstated; while attention to gender practices in this analysis of 'material civilization' is equally important. ${ }^{72}$ The choices made in these markets affected international trade. We must take all these elements into account, just as we also consider the policies of kings and the responses of governments.

\section{Conclusion}

The arrival of Indian cottons in Europe after 1500 introduced a new material agenda to a developing region of the world. Within generations, Indian cottons assumed a place of signal importance in decisions

${ }^{70}$ For a typical example of pawning by the wife of a trader in medieval Cairo see S. D. Goitein, A Mediterranean Society: The Jewish Communities of the Arab World as Portrayed in the Documents of the Cairo Geniza; Vol. IV. Daily Life (Berkeley: University of California Press, 1983), pp. 332-33. For later European and modern non-Western examples see Laurence Fontaine, "Women's Economic Spheres and Credit in Preindustrial Europe"; Jayshree Vyas, "Banking with Poor Self-employed Women"; and Hotze Lont, "Negotiating Financial Autonomy: Women, Income and Credit in Urban Java", all in Lemire, Pearson and Campbell, Women and Credit, pp. 15-32, 145-66, 203-22.

${ }^{71}$ See, Lemire, Business of Everyday Life.

${ }_{72}$ Fernand Braudel, Civilization and Capitalism 15th-18th Century; Vol. 1. The Structures of Everyday Life (New York: Harper \& Row, 1985), pp. 23-24 and 27-29. 
about domestic accessories, in decorative accoutrements and in personal apparel. This was one of many new products to transform the domestic interior, but it was an especially important one, with botanic imagery brought indoor through the designs devised by Indian craftspeople and modified for various global markets. But the figure as well as interior spaces were also changed. The India gown offered a new look and new cultural associations for a wide contingent of men, like the mathematician Brook Taylor. In 1720 he had himself painted wearing a blue and white striped (cotton?) banyan, lined with pink silk (Fig. 13.4). ${ }^{73}$ This vogue reshaped desires and redefined material idioms of male dress, even as the products evolved.

This fashion process and the commercial network it spawned included Indian merchants and craftspeople, European tradesmen and middle ranked housewives, as well as genteel ladies and gentlemen - all were part of this global equation. Husbands and wives negotiated the assigning of resources within the home, assessing the value of colourfast patterned cloth, the wives judging their ease of washing and their capacity to please. Housewives often negotiated the purchase of these goods, or participated in the process, while the preservation of these materials was their everyday concern. In 1663, Samuel Pepys wrote of a shopping expedition with his wife Elizabeth in search of the perfect chintz to line the walls of her study. Pepys penned the account of this shopping foray, but Elizabeth's tastes were also a factor; she, too, was concerned with the practical as well as aesthetic reasons for this choice. After all, it was her study and it was she who oversaw the laundry. ${ }^{74}$ Equally, among those with fewer resources, the advent of cheap Indian printed cottons provided an opportunity to express their aesthetic sensibility, to join with those sharing a similar fashionability. Elizabeth Price was a working woman who prized her printed cotton gown, wearing this emblem of style along with a more traditional hooded wool cloak in $1719 .^{75}$ This gown marked her claim as being among the more avant garde among her social cohort, more in the mode than women conventionally dressed in drab linsey woolsey. By the early eighteenth century, this working woman and "the [other] mean People, the Maid Servants, and indifferently poor Persons ... the meaner Sort playing in

\footnotetext{
3 NPG, 1920, 2890.

${ }_{74}$ Pepys, Diary of Samuel Pepys, vol. 4, p. 299.

75 Proceedings on the King's Commission of the Peace ... for the City of London ... held at ... the Old Bailey, July 1719, p. 7.
} 


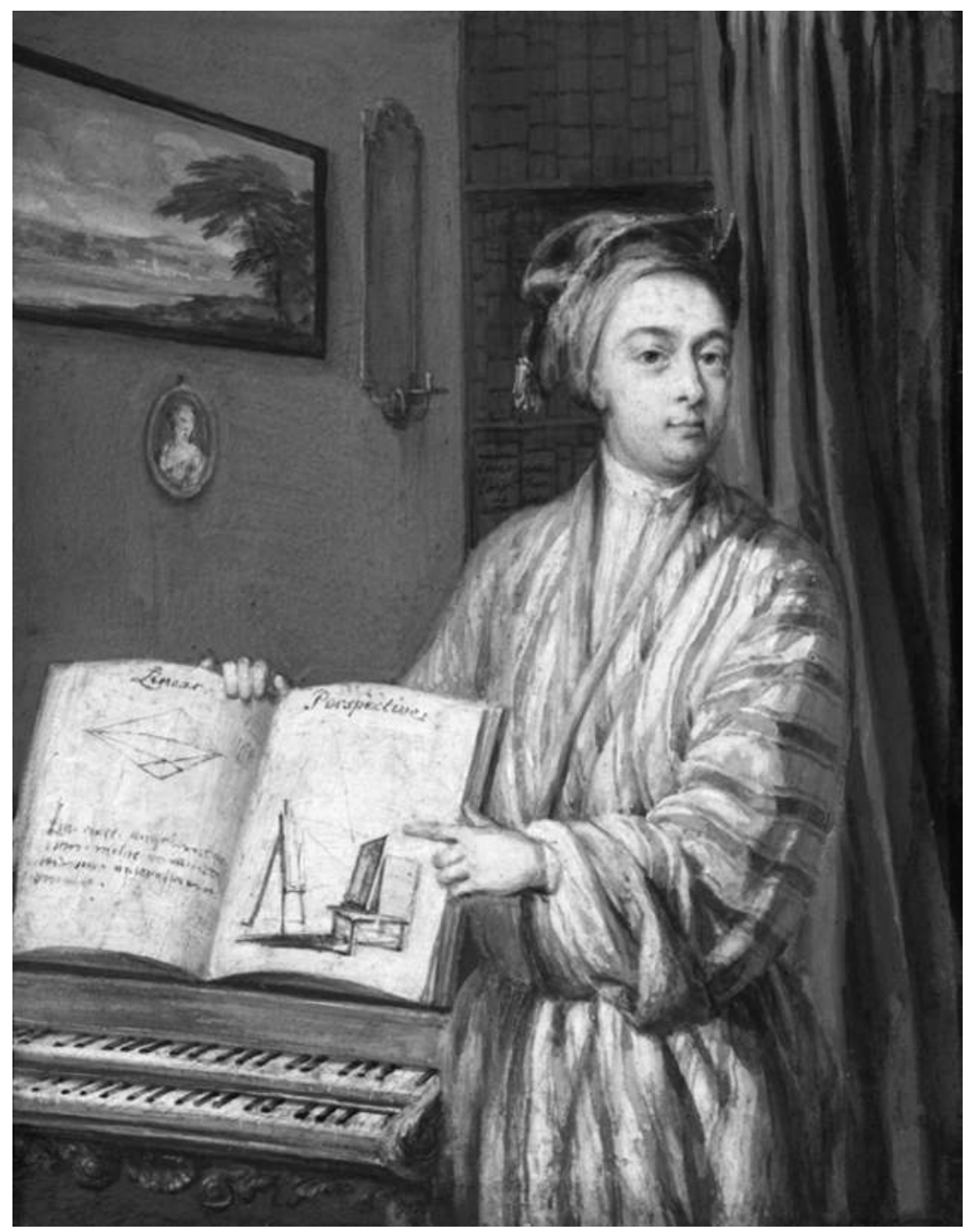

Fig. 13.4. A portrait of Brook Taylor, mathematician wearing a blue and white striped (cotton?) banyan, lined with pink fabric. Painted by Louis Goupy, c. 1720. National Portrait Gallery, London NPG 1920. 
the Street, or ... the better Sort at Boarding School" ${ }^{16}$ had become part of a process of social and economic change and the inspiration for European fashion derived from Asia. By 1799, it was unremarkable that Elizabeth Harris, the wife of a sergeant in the Dragoon Guards, would own "two cotton printed gowns, one calico gown, one striped corded dimity petticoat, one pair of cotton stockings and two cotton handkerchiefs"; $; 7$ the global exchange begun centuries before had by this date transformed British material culture and British industry.

This process was shaped by collective decisions of aspiring men, as well as generations of women; the priorities of both sexes and several social groups fuelled global commerce. The choices they made and the strategies they employed to secure these choices are as much a factor in the meaning of trade as the workings of joint stock companies. In early modern Europe, and probably in other regions at other times, international trade reacted with existing social structures to ignite a system of fashion-driven consumption. Gendered mechanisms shaped this consumption process. Making global economic history a comprehensive exercise is a necessary and laudable aim; creating a global history of textiles requires recognition of the breadth of human motivation as adjuncts to trade - exploring the workings of fashion, as well as function of gender, is an essential part of this project.

76 The Just Complaints of the Poor Weavers Truly Represented, reprinted in John Smith (ed.), Chronicum Rusticum Commerciale (London, 1747), vol. 2, p. 195.

77 Surrey Quarter Sessions Records: year 1799, QS2/6/1799/Mid/. 
$-978-90-47-42997-5$ 


\title{
QUALITY, COTTON AND THE GLOBAL LUXURY TRADE
}

\author{
Maxine Berg
}

\section{Introduction}

The cotton industry occupies the key place in explanations of the industrial revolution. Its mechanization and early adoption of new work organization in the factory system provided the model for other industries. Its rapid increases in supply and productivity made it by the early nineteenth century into Britain's leading manufacturing industry and its leading export sector. How this British industry rose to dominate both a domestic and a global textile sector depends on the making of its markets as much as it does on factors affecting its productivity growth. Cotton's success story, most economic historians have assumed, was based on the mechanical and factory production of cheap, low quality or standardized products enabling a rapid and widespread mass consumer demand.

This chapter will argue, on the contrary, that during the period of the industry's crucial technological and organizational changes inventors, manufacturers and merchants prioritized the quality of their products. They thought carefully about metropolitan fashion markets, and framed their marketing and their aims of technological improvement within a wider global trade in luxury goods. This was a trade in luxury goods from Europe, and also more significantly over the course of the eighteenth century from Asia. The challenge for early British cotton manufacturers was the challenge of a newly fashionable and high-quality product from India. Textile manufacturers and merchants engaged in the same processes of product innovation in response to imports and aspirations for new domestic and export markets that affected ceramics, glass and metal goods producers. Metropolitan market institutions for imported luxury goods also shaped how new British goods would be sold. They shaped perceptions of product types, of potential consumers, and the standards by which goods were judged. These in turn directed technology and the organization of production. 
Cottons until the mid eighteenth century were imported into Europe from India. Their domestic markets had to be made in Britain; they were goods associated with Asian luxury, their trade organized from the metropolis, and in the early stages of attempts at British production, even dyed and printed there. Technological and organizational changes developing soon afterwards in Lancashire, Nottinghamshire and Scotland, responded closely and constantly to the information of metropolitan merchants and markets. The India trade was also at the forefront of thinking on products and markets. The key concept that dominated goals amidst both achievements and uncertainties was 'quality'. The cotton textile industry's road to industrialization was conceived and practiced in these early stages as one part of a more widespread 'quality road of industrialization' across British industry.

John U. Nef's The Cultural Foundations of Industrialization ${ }^{1}$ set out the connections between consumer goods and industrialization. Nef posed that England responded in a particular way to earlier continental achievements. He argued that the goals of continental manufacture in the sixteenth and seventeenth centuries were sumptuousness, surprise and delight, at a time when what the English were known for was using iron and coal fuels. Just when the Dutch were developing new living styles with intimate spaces as settings for beautiful objects, the English pursued their advantages in coal, beer, lumber, iron, copper, brass and metal manufactures, building material and paper. But English manufacturers turned, he reasoned, to producing their own luxuries in the later seventeenth and eighteenth centuries. They used their own materials and technologies, and created an 'economy of quality', which led in turn to increased productivity and inventiveness.

The new and various goods emerging from this 'economy of quality' responded to the luxury and craft products of Britain's European neighbours, but more significantly they responded to a global commodity trade in Asian export-ware. My chapter will first survey recent research on the part played by product innovation and quality improvement as sources of British industrialization in the eighteenth century; and it sets this research within a wider framework of economic theory on quality improvement. The chapter then will argue that global trade, intensifying from the later seventeenth century, pressured merchants

${ }^{1}$ John U. Nef, The Cultural Foundations of Industrialization (Cambridge: Cambridge University Press, 1958). 
and consumers to bypass former limits on the world trade in luxury goods, to invent for quality, and even to refashion the meaning of quality. It will argue that cotton textiles became part of a global story of the making of an export-ware sector. The third section of the chapter discusses the analysis of the cotton industry in debates on the emergence of the 'great divergence'. Just what made this into an industry of global economic change? The fourth and final section of the chapter examines in some depth the part played by issues of product and quality in the early mechanisation and industrial expansion of the cotton industry in Lancashire led by Robert Peel in calico printing and Samuel Oldknow in muslin spinning and weaving. The chapter concludes in pointing out that mechanisation and factory organization were led by these highquality producers, and that the global trade in fine and fashionresponsive fabrics from India shaped the highly competitive market that drove the British industry into industrialization.

\section{Quality, Product Innovation and Product Characteristics}

Histories of the industrial revolution have long provided intensive analysis of technological innovation, focussed on process innovation. They have devoted little discussion to quality and product characteristics, despite the priority given by contemporary merchants and manufacturers to their markets. We have, perhaps, focussed too narrowly on a technology that tells us of process innovation, but too little of the product innovation that went with this. Ian Wendt shows us just what we can achieve through close consideration of cloth dimensions, thread counts, cloth weight and cloth quality. ${ }^{2}$ These are, he argues, the keys to unlocking the labour that produced a textile. Carlo Poni, some years ago set out the wide socio-economic ramifications of silk technologies in sixteenth and eighteenth-century Italy that changed the counts of yarn and the quality of goods. ${ }^{3}$ Products and qualities were likewise central to Britain's industrial revolution. Historians of the British cotton industry connected cotton's mechanisation to attempts to increase quantities of yarn, thereby solving yarn shortages emerging out of the

\footnotetext{
2 Ian C. Wendt, 'Writing the Rich Economic History of the South Asian Textile Industry: Spinners in Early Modern South India' (Paper presented at the GEHN Conference on "Cotton Textiles in the Indian Ocean", Pune, India, December 2005).

${ }^{3}$ Carlo Poni, "Standard, fiducia e conversazione civile: misurare lo spessore e la qualità del filo di seta”, Quarderni Storici, 96 (1997), pp. 717-33.
} 
division of labour in the industry. Parthasarathi argues that these explanations relied on endogenous British sources of technological change; they moved away from the earlier priorities manufacturers, inventors and merchants placed on meeting the challenge of Indian cotton products. ${ }^{4}$ Parthasarathi argues that historians of the cotton industry moved away from their earlier focus on connections between the British cotton industry and questions of global trade, of Indian imports and of products towards a later focus on questions of labour inputs and technology. It is important to return to those early priorities on world trade and Indian imports as they certainly gave a much greater role to the part played by India in the first industrial revolution. But they also provide evidence for a more general point about the importance of products and quality, and the role played by product innovation and quality improvement in the wider history of innovation and industrialization.

We should look first to the wider theoretical framework for analysing product and quality change. Economists and economic historians consider, in the first instance, productivity change. Product innovation brought in its wake productivity gains that we have not yet even tried to estimate. Economists recently have told us that estimates of productivity growth in the last half of the twentieth century are biased downwards because these do not adjust for quality improvements, nor do they count new products. ${ }^{5}$ Some recent economic historians, especially Joel Mokyr, have conceded this, providing examples of productivity growth arising from cotton quality improvements and new varieties in the later eighteenth century, of improvements in oil lamps in the late eighteenth century along with the introduction of gas lighting at the beginning of the nineteenth century, and of new medical interventions, such as the discovery of smallpox inoculation in $1796 .^{6}$

But this leads us on to bigger questions. How we define products and quality? Few economists or economic historians give much thought to this. They acknowledge quality differences as reflected in relative prices, but unless they are focussing specifically on consumer demand, they do

${ }^{4}$ See in particular Prasannan Parthasarathi's chapter in this book and his book Why Europe Grew Rich and Asia did Not: Global Economic Divergence, 1600-1850 (Cambridge: Cambridge University Press, 2011).

5 Timothy F. Bresnahan and Robert J. Gordon (eds.), The Economics of New Goods (Chicago: Chicago University Press, 1997).

${ }^{6}$ Joel Mokyr, "Accounting for the Industrial Revolution", in Roderick Floud and Paul Johnson (eds.), The Cambridge Economic History of Modern Britain; Vol. 1. Industrialisation 1760-1860 (Cambridge: Cambridge University Press, 2004), pp. 12-13. 
not enquire further. Those seeking to analyse the physical properties of goods turn to the economic theory of hedonic indices. Products are bundles of characteristics whose effects can be isolated through hedonic functions, that is to say, relations between prices of heterogeneous goods and the quantities of characteristics contained in them. Quality innovation implies positive demand responses to high-quality products, and willingness to pay for the higher production costs involved in making quality goods. ${ }^{7}$ Behind the search for new and higher quality products lies an 'active consumer' taking part in taste formation, responding to new goods, and combining and recombining goods to create a social identity. ${ }^{8}$ Making better products also frequently required supporting changes in processes; higher qualities or better substitutes could have the same effect as reductions in costs and prices. ${ }^{9}$

What did quality mean to manufacturers, inventors and consumers in the eighteenth century? Did it mean the best or most valuable materials, the finest craftsmanship, the most durable and long-lasting, or did it also include foreign and exotic origins, modern or new designs or techniques, or alternatively reliability, regularity and measurement? Perceptions of world markets affected this definition, and fed into product innovation over the period. So too did the reception of different qualities and products among consumers at home. Class differentiation and incomes played a key part, but choices were also underpinned by urban, metropolitan and indeed imperial identities. Deeply embedded routines of daily life continued to affect choices of products and qualities used in bodily practices, domestic practices of food preparation and eating and drinking and in kin and community connections. Manufacturers and merchants had to convince consumers on these many different levels to buy their new products and diverse qualities. Their product innovation was in some cases about 'indigenising' what they offered; in others it was offering a 'world product', available at home, but also desirable abroad.

Historians considering product innovation have, however, defined this narrowly as import substitution, or domestic replacements for

${ }^{7}$ Kelvin Lancaster, Consumer Demand: A New Approach (New York: Columbia University Press, 1971), pp. 2-12.

${ }_{8}$ Marina Bianchi, "Taste for Novelty and Novel Tastes: the role of Human Agency", in Marina Bianchi (ed.), The Active Consumer: Novelty and Surprise in Human Choice (London: Routledge, 1998), pp. 64-86.

9 Nicholas Von Tunzelmann, Technology and Industrial Progress (Aldershot: Edward Elgar, 1995), pp. 12-13. 
foreign goods. Yet manufacturers at the time pursued patents and projects that show them experimenting and inventing new goods to be sold on world markets. Responding to the fine goods of the global luxury trade led British producers in new and creative directions. What they achieved in the process was not just an 'industrial revolution', but a 'product revolution' of equal significance. The different goods British producers created were quality goods, and goods produced, moreover, by the division of labour and machine methods. If we follow De Marchi's point about the pleasure in artifice, we see that this is also a pleasure taken in invention and ingenuity. 'New-invented' was an advertising trope of the eighteenth century, and manufacturers sought to present an 'ingenious product' associated with scientific thinking. ${ }^{10}$ Quality and ingenuity went together in the appeal of new goods. Patents, projects and invention more generally focussed to a much higher degree than most historians have assumed on the quality and finishing. MacLeod identified an aim of "improving the regularity of the product" as of equal significance to increasing output or saving time among patents for capital-saving inventions between 1660 and 1799. ${ }^{11}$

This product revolution, including attention to improved quality and finishing was not just a domestic event, for it found its context in a global economy. It marked out a 'British pathway' to providing quality consumer goods for rapidly expanding middling-class markets at home and abroad. That pathway was, however, made in the framework of the models, institutions, markets and knowledge networks of the global luxury trade, and especially the trade with Asia.

\section{Luxury Goods and World Trade}

Global trade is not usually considered to be the key stimulus to the industrial revolution, and even less so a global trade in luxury goods. Yet intense investment in long-distance trade from the beginnings of the seventeenth century reflected the rising incomes of certain social classes, and the part played by exotic, non-European and luxury goods

\footnotetext{
${ }^{10}$ Neil De Marchi and H. J. Van Miergroet, "Ingenuity, Preference and the Pricing of Pictures: the Smith-Reynolds Connection", in Neil De Marchi and Craufurd D. W. Goodwin (eds.), Economic Engagements with Art (Durham, NC: Duke University Press, 1999), pp. 405-6.

${ }^{11}$ Christine MacLeod, Inventing the Industrial Revolution: the English Patent System, 1600-1800 (Cambridge: Cambridge University Press, 1988), p. 172.
} 
in European consumer aspirations. The exotic provenance of cottons and porcelain, emanating from an Indian Ocean trade then associated by Europeans with mystique and danger, excited fascination; there was a sense of unknowable technologies, of secret processes, and enhanced value. But at the same time these goods were part of a commodities trade; they were not items of art whose value was created by withdrawing them from circulation.

They entered European markets in rapidly ascending quantities as European trade networks with Asia intensified. Merchants accessing these products through highly sophisticated Indian and Chinese mercantile networks found they could order replicated and standardized goods to any quantity desired; they could also find variety in design and quality; they could design and order the higher quality items that might be consumed in some quantity among the lower ranks to indicate differentiations of higher incomes or status. Fine-quality fabrics, reflecting art, ceremony and tribute might also stimulate their own reflections in Europe.

East India Company merchants trading in Asian export-ware actively participated in creating a product, dictating design sources, colour combinations, lengths and breadths of fabric, and shapes and decoration of porcelain ware. They also carefully cultivated their markets in Europe, and set them firmly within metropolitan luxury markets, relying on the auction houses, galleries, gold and silversmiths, toyshops, marchands-merciers, mercers and china sellers to sell directly to consumers and to other retailers.

Recent theories and strategies of trade and economic development have considered products and their qualities. Theories of export-led growth in the 1980s drew on examples from Taiwan and Korea where productivity grew rapidly in industries targeting world markets. But this was also an enclave-type production of export-ware, separated off from wider domestic capital formation and technology. ${ }^{12}$ Were East India Company merchants in the seventeenth and eighteenth centuries creating or promoting such enclaves in India and China to provide for large potential markets in Europe and the wider Atlantic world? In doing this they clearly attended to the kinds of products they could sell in these wider world markets, and whose sale price would bear the

${ }^{12}$ Alice Amsden, The Rise of "the Rest": Challenges to the West from LateIndustrializing Economies (Oxford: Oxford University Press, 2001), pp. 277-83. 
expenses of long-distance trade. Later manufacture in Europe of such goods had to meet the challenge of such export-ware products in quality, design and price.

\section{Cotton, the Great Divergence and Industrialization}

Cotton is the great industry of global history. The narrative of its transfer from East to West is simultaneously the grand narrative of modernization and industrialization in Britain, in most other European countries and in North America. Was it similar to other Asian exportware industries, likewise connected to metropolitan luxury markets? Did quality and product development play a part in stimulating the rapid phase of technological innovation in the industry that became a paradigm for the Industrial Revolution itself? Parthasarathi argued vigorously that the technological advances of the British cotton industry were prompted by the "need to out-produce Indian textiles."13

The cotton industry, as summed up by Mokyr, was the site of mechanisation, concentration and increasing productivity. ${ }^{14}$ Mokyr asserts that "technology was at the core of everything"; ${ }^{15}$ and adds that the cotton textile industry was, together with energy exploitation, new materials and the production of 'miscellaneous' goods, one of the four key sectors of technological innovation during the British industrial revolution. ${ }^{16}$

Generations of historians have sought to explain this path of technological change. Why cotton? A string of 'brilliant mechanical inventions' between 1765-1779, Kay's flying shuttle, Hargreaves' jenny, Arkwright's water frame, Crompton's mule, were reinforced by chlorine bleaching in 1774 and roller printing in 1785. Most attributed such a unique concentration of innovation to cotton's physical characteristics. Unlike other textiles, this product, as Mokyr sums up the consensus

\footnotetext{
${ }_{13}$ Prasannan Parthasarathi, "The Great Divergence", Past and Present, 176 (2002), p. 288.

${ }^{14}$ Joel Mokyr, "Accounting for the Industrial Revolution", in Roderick Floud and Paul Johnson (eds.), The Cambridge Economic History of Modern Britain (Cambridge: Cambridge University Press, 2004), vol. 1, pp. 18 and 22.

${ }^{15}$ Id., "The Industrial Revolution", in Joel Mokyr (ed.), Oxford Encyclopedia of Economic History (Oxford: Oxford University Press, 2003), p. 50.

${ }^{16}$ Id., "Technological Change, 1700-1830", in Roderick Floud and Donald McCloskey (eds.), The Economic History of Britain since 1700; Vol. 1. 1700-1860 (Cambridge: Cambridge University Press, 2nd ed. 1994), p. 18.
} 
"lent itself uniquely to mechanization and mass production"; and the output of both new technology and work organization was a product of "even quality, attractive, and above all inexpensive". ${ }^{17}$ We know, therefore, that mechanisation worked in this industry, yet it had not been applied before in what we know was a major Asian industry from the medieval period, and one with extensive global markets. The reasons advanced for such innovation when it did occur in Britain focus above all on labour-saving. David Landes saw machines substituting for human skill and effort. The advantages of mechanisation, from Edward Baines' history of the cotton manufacture in 1835 onwards, were always presented as the number of hours needed to spin a hundred pounds of cotton: "The old technology employed an Indian handspinner; who took about 50,000 hours. The mule brought that number down to around 300 hours in the 1790s, and three decades later the self-actor reduced the figure to 135 ".18

Global historians have not specifically addressed connections between innovation in the cotton industry and labour saving. Instead they focussed on wage differentials between China and Europe, or India and Europe, and assumed that labour-saving incentives would follow. Arguments in favour of labour-saving mechanisation, followed by challenge-response explanations of succeeding innovation, do not explain underlying causes or contemporary perceptions of motivations to invention. Von Tunzelmann many years ago pointed out that there was little incentive in terms of input prices, over the whole period of innovation, to substitute capital for labour. Over most of the period real wages did not rise substantially, but there were two periods of sharp wage increases in the north of England - the 1750s and 1760s and at the end of the eighteenth century, coinciding with the French and Napoleonic Wars. These may have prompted efforts to mechanise, but at this stage we have only coincidence rather than evidence to establish this. ${ }^{19}$ Indeed Crompton's mule was not invented with the objective of replacing labour, but rather of extending it. Crompton designed the mules to be adopted in workers' cottages. ${ }^{20}$

17 Id., "Industrial Revolution", vol. 3, p. 51.

${ }_{18}$ Ibid.

19 Nicholas Von Tunzelmann, “Technological and Organizational Change' in Industry during the Industrial Revolution", in Patrick O'Brien and Roland Quinault (eds.), The Industrial Revolution and British Society (Cambridge: Cambridge University Press, 1993), p. 256.

${ }^{20}$ Id., Technology and Industrial Progress, p. 110. 
As argued above, economic historians focus on process innovation; they treat product and quality innovation separately, as an aspect of demand. Their focus on process innovation yields a significant place for cotton in the growth of final output; but even so, their results, ignoring product and quality differences, may well have underestimated productivity change in the industry. Crafts and Harley's estimates of cotton output are built on evidence using low-level counts of yarn, and a basic multiplier on raw cotton inputs for their final output series. ${ }^{21}$ Their estimates have never acknowledged the force of challenges claiming a much greater part in influencing quality differences, in improvements in quality, and in changing mixes of fabrics in exported cotton goods. ${ }^{22}$

Only recently are historians turning to the product yielded by this crucial industry. What counts of yarn were produced; what types of fabrics were made; did quality improve; did questions of product, quality and output drive mechanisation? Thus Griffiths, Hunt and O'Brien, studying the chronology of textile invention, turn to the part played by output quality and to acknowledging the rapidly changing market for fashionable textiles. They tell us that Robert Kay listed quality consideration highly among the benefits to accrue from the use of his father's shuttle. Advocates of machine spinning made much of improvements in quality that would result, and the prospects these offered of entry into lucrative quality-end international markets in North America, Africa and Europe. ${ }^{23}$ Von Tunzelmann recognized that the advantages of the cotton mule were greatest in fine yarns; innovations like the mule allowed higher qualities to be produced by machine methods. But even so Von Tunzelmann regarded the mule as the exception that proved the rule. He argued that mechanisation more generally took place first in lower grade products, and with learning could come to be applied to higher-grade output. Mechanisation was still, in this account, about

${ }^{21}$ C. Knick Harley and N. F. R. Crafts, "Cotton Textiles and Industrial Output Growth during the Industrial Revolution", Economic History Review, 47, 4 (1995), p. 141 .

${ }^{22}$ Javier Cuenca Esteban, "British Textile Prices, 1770-1831: Are British Growth Rates Worth Revising Once Again?", Economic History Review, 46, 1 (1994), p. 78 and Id, "Further Evidence of Falling Prices of Cotton Cloth, 1768-1816", Economic History Review, 47, 1 (1995), p. 148.

${ }^{23}$ Trevor Griffith, Phillip Hunt and Patrick K. O’Brien, "Scottish, Irish, and Imperial Connections: Parliament, the Three Kingdoms, and the Mechanization of Cotton Spinning in Eighteenth-Century Britain", Economic History Review, 61/3 (2008), pp. 625-50. 
standardization and lower and median quality output. ${ }^{24}$ Yet a significant part of the story of mechanisation also claimed by Mokyr was about producing cheaper, better and more versatile products. The cotton industry in Britain mechanised and grew in response to the incentives offered by world import and export markets in cotton textiles, and the real challenge was in producing goods to match their quality and variety. This was a story of product innovation fundamentally integrated into process innovation.

\section{Quality, Innovation and the Lancashire Cotton Trade}

The market for varieties of cotton goods and especially high quality cottons played a key role in fostering innovation in the industry, both in technology and in organization, including the factory system. Cotton needs to be considered within the wider framework of global luxury goods, traded by East India companies, focussed initially on a London entrepot trade. Its regional growth in Lancashire responded to international markets; its formation as an industry was of a piece with other quality British consumer goods honed to compete in highly developed markets for oriental luxury goods. Was cotton, however, different from these other quality goods - its success made in mechanisation, standardization, factories and mass popular markets? This is what the conventional histories convey to us. But cotton textiles were introduced as Asian export-ware; its transformation into a British product like those other quality consumer goods, developed in response to oriental luxury. Quality provided the incentive to mechanisation as well as factory organization.

From its early formation as an English industry, cotton or fustians (cotton and linen mixes) responded to the variety, price differences, and invention which marked out Asian imports from porcelain to silks, muslins and calicoes. Holker, reporting on the Lancashire fustian industry, found 67 different cotton/linen fabrics. Manufacturers from an early stage recognized consumer preferences for variety and quality. ${ }^{25}$

${ }^{24}$ Von Tunzelmann, Technology and Industrial Progress, p. 132.

${ }^{25}$ Joan Thirsk, Economic Policy and Projects: the Development of a Consumer Society in Early Modern England (Oxford: Oxford University Press, 1978), p. 107; Beverly Lemire, "Fashioning Cottons: Asian Trade, Domestic Industry and Consumer Demand, 1660-1780", in David Jenkins (ed.), The Cambridge History of Western Textiles (Cambridge: Cambridge University Press, 2003), vol. 1, p. 506. 
Cotton was an exotic fibre imported from the Levant, then from the West Indies and Brazil through London. The metropolitan base also dictated the diffusion of imported luxury fabrics, including cotton goods, throughout British home markets. The market for imported cotton goods focussed on fashion goods, novelty and quality wares. The cotton goods developed in England also responded to similar markets. Manufacturers sought out quality raw cotton imports; they focussed on finishing processes, and they concentrated their efforts to innovate in the intermediate stages of weaving and spinning at the high end of the market.

In developing this argument, I will turn first to imports of Indian cottons, especially calicoes and the legislation directed to control these. Secondly I will examine connections between spinning innovation and efforts to produce high count yarn to compete with Indian muslin. The calico craze in Europe from the mid seventeenth century brought a luxury good, fine cotton calico fabrics, dyed and printed in colourful designs into wide fashion markets; such fashion markets were previously much more restricted and had been supplied with much more expensive silks, and fine figured woollens and linens. Merchants fostered the high-end market for this fabric, made on its visual and tactile characteristics, but more significantly, its exotic provenance from Asia. The value of cottons imported in the 1660s exceeded that of Chinese silks. Indian calicoes by the end of the seventeenth century accounted for one quarter of all textiles imported into England. ${ }^{26}$

Beverly Lemire and John Styles set out the entry of Indian calicoes into British markets in the seventeenth century first as curiosities and exotics, and subsequently as fashionable luxury goods. Styles recounts a limited entry early in the century as quilts and hangings were displayed as curiosities. But shortly afterwards the company directors sought to develop a market for the materials as domestic furnishings and fine table and bed linens. It was not until the 1640s that the East India Company took charge of directing print designs to appeal to English taste. By the 1660s it was sending sample patterns for Indian printers to adapt. By the 1660s they were developing markets for the cloth within the same framework as the annual fashion change developed by the Lyon silk manufacturers. ${ }^{27}$ Lemire presents a fabric

${ }^{26}$ O’Brien, Griffith and Hunt, "Political Components", p. 396.

${ }^{27}$ John Styles, "Product Innovation in Early Modern London", Past and Present, 168 (2000), pp. 133-35. 
imported within British controlled-trade to challenge the French domination of fashion markets. ${ }^{28}$

What Lemire and Styles recount here is the active construction of the "Calico Craze" by merchants, and the focus on quality fashion markets to do so. Merchants did not treat their fabric as a cheap substitute for expensive European silks and fine French or Flemish linens or "Hollands". Such efforts as there were to do so failed, as in the example cited by Styles of attempts to substitute cheap Indian ready-made shifts and shirts for their fine European linen originals. ${ }^{29}$ Instead they developed new fashions including new interior decoration, the use of palampores or quilts, hangings and curtains, as well as new types of dress from banyans and waistcoats to cuffs, neckcloths, handkerchiefs, headdresses and pockets, overdresses, aprons and petticoats. East India companies from as early as the 1640s directed print designs to appeal to European taste; they sent sample patterns for Indian printers to adapt.

John Styles, in recent writing on these fashion markets for Indian cottons emphasised highly distinctive uses. Prices of chintz cotton were still high in the mid eighteenth century. The cheaper fabrics were monochrome rather than polychrome prints, and dominated the printed cotton fabrics owned by plebeian consumers represented in the Foundling Hospital billet books. Richer women still bought silks, though also multi-coloured printed cottons. ${ }^{30} \mathrm{He}$ argues that plebeian women chose printed cotton as a gown material because of its appearance, not its cheapness. It was never supplied by overseers of the poor to paupers, and plebeian women who might have afforded a printed cotton gown, could not enter easily into new fashions for cotton muslins emerging in the early nineteenth century. "Where appearance was crucial, cotton succeeded". But its spread through more mundane uses such as shirting and shifts was no more than uneven in face of more generally preferred and hard-wearing linen. Cotton was not, he concludes, "a single product, protean and infinitely substitutable for textiles made from other materials ... Adapting cotton to new uses sometimes required radical and difficult reworking of what defined it as a product".31

\footnotetext{
28 Beverley Lemire, Fashion's Favourite: The Cotton Trade and the Consumer in Britain 1660-1800 (Oxford: Oxford University Press, 1991), pp. 11, 15 and 18.

29 Styles, "Product Innovation", pp. 136-37.

${ }^{30}$ John Styles, The Dress of the People. Everyday Fashion in Eighteenth-Century England (London and New Haven: Yale University Press, 2007), p. 12 and 13.

31 Ibid., p. 17.
} 


\section{Technology and Quality}

What distinguished Indian cotton goods in the eyes of European consumers was appearance and quality. Asian technologies were long perceived in Europe as labour and skill-intensive, impenetrable, exotic and secret. European commentators described hereditary spinning and weaving technologies producing yarns and fabrics specialised by district. They marvelled at muslins described as 'linens' "of such fineness, that very long and broad pieces of it may easily be drawn through a small ring". ${ }^{32}$

Technologies developed at home faced enormous challenges to compete with these highly-regarded Asian techniques. Spinning and printing innovation over the course of the eighteenth century prioritised quality goods. The point of spinning innovations over the eighteenth century was to reduce yarn shortages and to enhance the quality and variety of yarn. Better yarn also enhanced the quality and variety of handloom cloth. ${ }^{33}$ Flexible outwork and volatile fashion markets for fine cloth dictated production and demand for handloom cloth and printed goods.

The first determinant of quality was the raw cotton itself. Recent economic indicators of the growth of cotton output in Britain over the eighteenth and early nineteenth century are based on data on raw cotton imports and excise duties. But there was no single type of cotton imported; it came from many parts of the world and in a whole range of qualities. In the late 1780s imports were divided between the French, Spanish, Dutch and Portuguese colonies and the East Indies on the one hand, and the Levant on the other. ${ }^{34}$

Projects and patents for spinning innovations from at least the 1690s sought a quality output to compete with Indian yarn: "to be spun so extraordinarily fine, as to be fit to make such cloths commonly called calicoes ... as well as in the East Indies"; or invention to make "calicoes, muslins and other fine cloths ... to as great perfection as those which are brought over and imported hither from Calicut and other places in

${ }^{32}$ Malachy Postlethwayt, The Universal Dictionary of Trade and Commerce, vol. 1. Mechanical Arts (London: John Knapton, 2nd edn. 1757).

${ }^{33}$ Mary B. Rose, "Introduction: The Rise of the Cotton Industry in Lancashire to 1830", in Mary B. Rose (ed.), The Lancashire Cotton Industry. A History since 1700 (Preston: Lancashire County Books, 1996), pp. 8-9.

${ }^{34}$ R. S. Fitton and A. P. Wadsworth, The Strutts and the Arkwrights 1758-1830 (Manchester: Manchester University Press, 1958), pp. 262-64. 
the East Indies". ${ }^{35}$ Arkwright, defending his 'patent machines' in 1774, and campaigning for an end to the additional excise duty of $3 \mathrm{~d}$ on calicoes, argued that his cotton warps were both cheaper and of higher quality; his patent cotton warp "could answer as well as linen warp for many goods". ${ }^{36}$

British state prohibitions in 1701 on imported printed calicoes from Asia extended from 1722 to plain cottons printed or painted in Britain. Manufacturers instead printed on linen or cotton-linen mixes. But these did not take the dyes so well or the prints so sharply as cotton. They were always less desirable than smuggled Indian printed calicoes. ${ }^{37}$ Arkwright's water frame and the legislative change to allow the fine dyeing and finishing of British cottons made possible a new or improved quality product which might now compete with Indian printed calicoes. And Crompton's mule from 1779 made it possible for Lancashire's manufacturers to compete with India in 'the finer branches'. Manufacturers at the time saw the opportunities opened by Crompton's technological improvement. It made it possible for Samuel Oldknow to envisage a manufacture of "Balasore handkerchiefs, of jaconet and of japanned muslins". The first histories of the cotton manufacture focussed on new yarn qualities produced by machine which now made possible effective competition with India.

The 1812 Committee on Crompton's petition claimed that "in the invention of the mule may be found one of the chief causes of the transference of the seat of an industry to the Western from the Eastern world, where it had been situated from time immemorial". ${ }^{38}$ Kennedy's Brief Memoir of Samuel Crompton stated that Samuel Oldknow "took new ground by copying some of the fabrics imported from India, which at that time supplied this kingdom with all the finer fabrics, and which the mule-spun yarn alone could imitate".39

The Scots extended the manufacture of fine yarns. In Lanarkshire they were "long in the habit of weaving fine cambric from flax yarn, and silk friezes, [and] had also turned their hands to the manufacture of

\footnotetext{
${ }^{35}$ George Daniels, The Early English Cotton Industry (Manchester: Manchester University Press, 1920), p. 17.

${ }^{36}$ Ibid., p. 17.

37 O’Brien, Griffith and Hunt, "Political Components", p. 418; Parthasarathi, "European Response to India Cottons", pp. 7-8. See also Styles, Dress of the People, ch. 7.

38 Daniels, Early English Cotton Industry, p. 129.

39 Ibid., p. 131.
} 
fine cotton fabrics principally from the fine yarns produced by Hargreaves and other subsequent machines." In Nottinghamshire, fine cotton yarn also transformed the lace manufacture. "Twofold fine cotton twisted together was found to answer very well as a substitute [for fine linen]; and as it required the finest yarns, a great impulse was given towards perfecting the production of fine cotton yarn" ${ }^{40}$ Together with these wider experiences, we can turn in some depth to the Lancashire cases of Samuel Oldknow's production of muslin, and to Robert Peel's production of printed calicoes as well as to the French comparison of Oberkampf's producing printed calicoes in his factory in Jouy.

The mule was known as Muslin Wheel. Crompton described it as "that piece of mechanism that has produced and increased one of the first manufactories in Europe, viz, the fine Muslin and Cambric". ${ }^{41}$ Muslin was the generic name given at the time to the finest cotton goods made from counts between 50 and 70 . It was manufactured in all varieties and patterns, and especially in imitation of India goods, which were also given Indian names. Earlier efforts to succeed at muslin had failed to meet the test of Indian competition. Oldknow employed his weavers to use the yarn first on fabrics they were accustomed to making, such as cords and velveteens, but by 1782 he had started a muslin manufacture. His markets, furthermore, were Londonbased. London's fashion trade looking for the "latest novelties in Manchester goods" "found a gold-mine in Oldknow's muslins". His products competed directly with the India product, and faced a "severe burst of competition" whenever East India Company vessels unloaded cargoes of textiles. ${ }^{42}$

Oldknow flung himself into metropolitan fashion markets, facing the challenge of quality and finishing of his Indian competitors. He wrote to one of his London merchants in 1783:

The finishing part is what we have long been striving to master and in this I wish you to say what you think of mine. I do them myself and the people I employ in that department are under an obligation not to disclose the secret ... I take very great delight in the manufacture and shall always to anxious to excel. ${ }^{43}$

${ }^{40}$ Ibid., p. 131.

${ }^{41}$ George Unwin, Samuel Oldknow and the Arkwrights (Manchester: Manchester University Press, 1924), p. 3.

42 Ibid., p. 7.

${ }^{43}$ Ibid. 
By 1784, Oldknow had over 1,000 weavers working for him, and his entire output supplied fashion markets for muslins and calicoes. His London merchants demanded frequent changes in design; they insisted at very frequent intervals, month by month on new fashion, on invention, and high quality. They conveyed a charged competitive atmosphere:

Do not make any Shawls, they are totally unsaleable ... The Striped muslin Cravats are too course $\&$ thick, drop them entirely. Fancy broad Stripes are the fashion \& good Quality from 42/- to 60/- ... The Scotch has sent up many Spotted Muslins, indeed too good \& too cheap - You must make them thinner \& raise the Spot. Different sizes of Spots, Barley corns, little Clubs, and any other ... Figure will vary \& give more choice - they answer for Cloaks as well as aprons \& gowns. ${ }^{44}$

These demanding merchants prepared a history of the rise and progress of the British muslin and calico manufacture for the Lords of the Council for Trade, claiming that "the object they [the inventors] grasped was great indeed - to establish a Manufacture in Britain that should rival in some measure the Fabrics of Bengall". ${ }^{5}$ The muslin and calico manufacturers fashioned their goods in direct competition with Indian cottons. They attended the India Muslin sales in London to see the style and quality of the goods coming in, to watch how they sold, and to take away new ideas for patterns and higher quality: “... there are more India Goods coming into the Market than has been known of these many years in so short a time". ${ }^{46}$ By the spring of 1789 muslins grew to make up nine-tenths of Oldknow's production and even more of his sales. Substantial amounts of these high-quality goods were furthermore figured, and they were highly differentiated. ${ }^{47}$

It was India which also set the terms for producing printed calicoes. Chapman and Chassagne argue, against accepted conventions, that British and French production of printed calicoes addressed highfashion markets, quality goods based in craft-based skills. For a fashion industry, such as calico printing, they argue, consumer demand shifted rapidly, and it was the firms that could respond quickly that did well. With fashion demand for printed calicoes high across Europe, North America and the Caribbean, the big challenge for printers was to

\footnotetext{
${ }^{44}$ Ibid. (5 June 1786).

${ }^{45}$ Cit. in Ibid., p. 63.

46 Salte to Oldknow, 23 May 1786; 18 and 19 Oct. 1787. Cit. in Ibid., pp. 67 and 96.

${ }^{47}$ Cit. in Ibid., pp. 103-5.
} 
compete with oriental qualities and prices. ${ }^{48}$ As Chapman and Chassagne put it, the "essence of Lancashire's problem" was that in India "millions of ingenious and industrious manufacturers ... work for onefifth part of the wages given in England", and moreover the East India Company had successfully geared their Indian labour force to the demands of the European market. ${ }^{49}$

Yet Indian imports were not always of the quality and design demanded, nor could they be depended on. Parthasarathi found Indian merchants in the first half of the eighteenth century facing great difficulties in enforcing quality standards on weavers in South India. The advance contract system used by merchants allowed weavers to select their yarns, to mix good and poor yarn, to conceal defective cloth in sophisticated schemes of embezzlement. They were in a buyer's market; there were always private traders able to give high prices. With the enforcement of European calico acts, prices stagnated for a time. Various parts of India over the whole period between 1744 and 1763 faced war, conflict and insecurities from the Maharatta War to the break up of the Mughal Empire. The East India Company complained of high prices and the bad quality of goods coming through Bombay, Madras and Bengal. Rapidly expanding European demand and the relaxation of import controls on plain and printed cotton goods in France in 1759 and in Britain in 1774 exacerbated pressures; prices rose and quality deteriorated. More European and private traders were keen buyers of even poorly manufactured pieces. Quality control now dictated moves by the East India Company to tighten their hold on markets for cloth in their territories and to exert more control over weavers, the yarn they spun and the looms they worked..$^{50}$

Following the cases of Robert Peel in Lancashire and Oberkampf in Mulhouse between the 1770s and 1790s, Chapman and Chassagne describe a heady atmosphere of fashion markets, the 'calico rage'.

${ }^{48}$ Robert Duplessis, "Cotton Consumption in the Seventeenth and EighteenthCentury Atlantic World", in Giorgio Riello and Prasannan Parthasarathi (eds.), The Spinning World: A Global History of Cotton Textiles, 1200-1850 (Oxford: Oxford University Press 2009), pp. 227-46.

49 Stanley Chapman and Serge Chassagne, European Textile Printers in the Eighteenth Century (London: Heinemann Educational and the Pasold Research Fund, 1981), pp. 198 and 200. See also Serge Chassagne, "Calico Printing in Europe before 1780", in Jenkins (ed.), Cambridge History of Western Textiles, vol. 1, pp. 513-27.

${ }^{50}$ Prasannan Parthasarathi, The Transition to a Colonial Economy: Weavers, Merchants and Kings in South India 1720-1800 (Cambridge: Cambridge, 2001); Id., "Great Divergence", pp. 79-91. 
The real problem for the printers was matching the perceived high quality of Indian imports while extending their markets out to the middling classes. Aikin, in his Description of the Country from Thirty to Forty Miles around Manchester (1795) described Peel's works as a highclass producer: "The articles here made and printed are chiefly the finest kind of the cotton manufactory and they are in high request both in Manchester and London". ${ }^{51}$

Peel's objectives extended beyond the quality of the finishing and printing of fabrics to the cloth itself: he perfected his own production of quality fabrics, seeing out and adopting Crompton's mule for fine spinning as soon as it appeared. He experimented constantly and trained schools of mechanics and artisans. He now competed with London printers using Indian fabrics. The American Quaker merchant, Samuel Rowland Fisher, on his travels around Britain's manufacturing centres in 1783 commented on Peel's success:

Very large quantities are made in the Neighbourhood of Bolton \& Blackburn, their prints are done at Bury \& they appear to me to be the best manufacture, well printed and the cheapest I have ever seen. They have and will command all the trade which used to be carried on near London. ${ }^{52}$

Rowland Fisher's optimistic assessments notwithstanding, the metropolitan printers still led fashion and luxury markets, and their products still needed Indian fabrics. And Lancashire manufacturers, even in 1792 when they petitioned Pitt over renewal of the East India Company charter, knew that they still faced the fierce competition of handpainted Indian textiles, hand-made muslins, calicoes, nankeens and other Oriental specialities. They pressed for total prohibition of sales of Indian textiles in the British home market, for an increase of raw cotton supplies from the Orient and for direct access to the Indian market. But they failed against the interests of London wholesale dealers in Indian piece goods who claimed that the pinnacle of London society still preferred genuine oriental prints. ${ }^{53}$

In contrast to Peel, Oberkampf in Mulhouse did not even try to match the production of Indian fabrics. He concentrated on printing, and imported his fabrics. He dealt in London in the 1770s for his Indian

${ }^{51}$ Chapman and Chassagne, European Textile Printers, p. 58.

${ }^{52}$ Ibid., p. 44.

${ }^{53}$ Ibid., p. 92; British Library, India Office Records, A/2/11; A/1/85a. 
cloth, and in Lorient in the 1790s when prices were much lower than those on the London markets. He always preferred Indian woven fabrics until forced, by the Napoleonic prohibitions on their import, to demand higher standards from local producers in Normandy and Picardy. ${ }^{54}$ Oberkampf focussed on quality, and built a fashion market for his own distinctive designs. He introduced copper plate printing as early as 1769 , by the 1770 s he set about 'the creation of a new taste' and by the early 1780s was using the best-known designer of the day, J. B. Huet to produce topical designs for high-fashion markets. In doing this, he made his printing works at Jouy a celebrated destination; his products were brands even by the 1770 s, so that "in a small village where you would not believe that anyone would have a notion about it, the salesman would be given the price he asked as soon as he showed the trademark". ${ }^{55}$

Again, copper plate printing, aimed at the high end of the market, was a superior art form not a labour-saving device. It was an East India Company merchant who first bought the process in the late 1750s to introduce into his print works in Surrey; the process spread quickly along the networks of the international luxury trade, so that Oberkampf was using it by 1769 . The process allowed large scale prints on fabric: "decorated with elegant pictorial designs with figures, landscapes and architecture, often incorporating mythological, romantic, theatrical or commemorative scenes of a type completely beyond the scope of the humbler wood block printer" ${ }^{56}$ The crossover of print designs from engravings to wallpaper and textiles, and later through transfer printing onto ceramics and japanned ware ${ }^{57}$ was not so very different than the art transfers of Mughal India between Persian miniature painting and kalik cloth..$^{58}$

Peel and Oberkampf knew that the advantage of Indian calicoes and muslins lay in quality and price. Creating a distinctive luxury product

${ }^{54}$ Chapman and Chassagne, European Textile Printers, pp. 157, 159 and 195.

55 Ibid., pp. 133 and 150.

56 Ibid., p. 18.

${ }^{57}$ Katie Scott, "Art and Industry - a Contradictory Union: Authors, Rights and Copyrights during the Consultat", Journal of Design History, 13, 1 (2000), pp. 1-21; Tim Clayton, The English Print 1688-1802 (New Haven: Yale University Press, 1997).

${ }_{58}$ Stewart Gordon (ed.), Robes of Honour. Khil'at in Pre-Colonial and Colonial India (New Delhi,: Oxford University Press, 2003); Natasha Eaton, "Between Mimesis and Alterity: Art, Gift and Diplomacy in Colonial India, 1770-1800", Comparative Studies in Society and History, 46, 4 (2004), pp. 816-44. 
only took them part of the way; their businesses were only to be sustained by opening out to middling and even labouring-class markets. East India Company merchants were already adept at demarcating their consumers. A Nantes calico printer admired the success of the Dutch East India Company that specialized in bringing in fabrics for the common people, while the English brought in those for "more refined taste.". ${ }^{59}$ Oberkampf, like Oldknow, spent long periods each year at the East India Company sales in London or Lorient, studying the varieties of cloth, and buying up all the plain types he could get. And he printed this to suit his different markets. He produced a little less than half his output in copper plate pieces for the luxury and fashion market, and more than half in wood block pieces for the popular market. The Peels chose a similar market division, but also soon realized the potential in pursuing variety and novelty in prints on their own cottons for fashion-conscious popular markets. Peel, like other Lancashire printers, did not hire designers, but pirated the latest designs from London. Rapid turnover, and warehouse selling of the new designs several times a week eventually wrested the initiative from the London printers and East India Company merchants. ${ }^{60}$

The story that has come down to us is one of decline in quality and design. By the 1780s the British had been eclipsed by the French. ${ }^{61}$ Francois de Rochefoucauld said of the Manchester manufacturers: "their dyes are not very high quality and they do not finish them on cotton any better than we do, there are some which lose their colour by exposure to the air". F. A. Wenderborn, travelling to Lancashire in 1790 reported:

It is said that the English manufacturers, particularly those who employ themselves in articles of luxury, do it with less taste than some other nations, particularly their neighbours the French. They show this want of taste much in their drawings, their designs and patterns ... ${ }^{62}$

Their comments echoed the more widespread British debate on design and quality at the time. Whether there had actually been a decline is a moot point. Chapman has argued elsewhere for the ascendancy of London and Dublin in designing, engraving and colouring

\footnotetext{
59 Chapman and Chassagne, European Textile Printers, p. 18.

60 Ibid., pp. 133 and 85.

61 Toshio Kusamitsu, "British Industrialisation and Design before the Great Exhibition”, Textile History, 12 (1981), pp. 77-95.

62 Chapman and Chassagne, European Textile Printers, p. 88.
} 
printed textiles in the third quarter of the eighteenth century; English pattern books at the time demonstrated the quality of floral and pictorial designs. ${ }^{63}$ Certainly, the debate itself as well as the conscious competition with London printers, with the French and with India generated reflection on just what distinguished the Lancashire product from others. Peel, praised in the 1760s for his "precision, exactness and order", saw his firm's essential advantage in its capacity to produce a wide variety of designs, and to respond immediately to changing orders and wider markets. ${ }^{64}$ That responsiveness was especially important in international markets. Long runs and simple designs, along with rapid responses to the take up of new varieties meant productivity and quality, and were more important in these markets than factories and mechani-sation (Fig. 14.1).

The import markets that fuelled fashion in the first instance now turned to export markets. The Lancashire producers could provide demanding North American and West Indian merchants with quality, novelty and competitive prices. Output quality was what mattered in this high-income Atlantic free-trade zone. Inventors and advocates of spinning machinery attested to the improved export-ware they could produce. Mechanisation would provide merchants with the more varied and higher quality product mix they sought. Irish, Scots and even Indian hand-made goods now looked unreliable, and even possibly second-best. ${ }^{65}$ Peel sold directly to these merchants, and wrote of the number calling at his warehouse, always looking for better quality. By 1790 the British were producing 15 or 16 million yards of coloured piece goods; a large proportion went to North American and European markets. At the height of the Napoleonic Wars, buyers at the embargoed Frankfurt fairs wanted muslins and printed calicoes sur les dessins et modèles venus de Londres, though to be sure, they were often produced by Swiss or Alsatian manufacturers. ${ }^{66}$ As Chapman concluded his small book on the cotton industry, "In this period British textile producers were out to win the world market for both cheap mass-produced and quality fabrics, and to a remarkable degree they succeeded". ${ }^{7}$

${ }^{63}$ Stanley Chapman, The Cotton Industry in the Industrial Revolution (London: Macmillan, 1987), p. 57.

${ }^{64}$ Chapman and Chassagne, European Textile Printers, p. 214.

${ }^{65}$ O’Brien, Griffith and Hunt, "Political Origins", p. 24.

${ }^{66}$ Chapman and Chassagne, European Textile Printers, pp. 81, 87, and 93.

${ }^{67}$ Chapman, Cotton Industry, p. 61. 


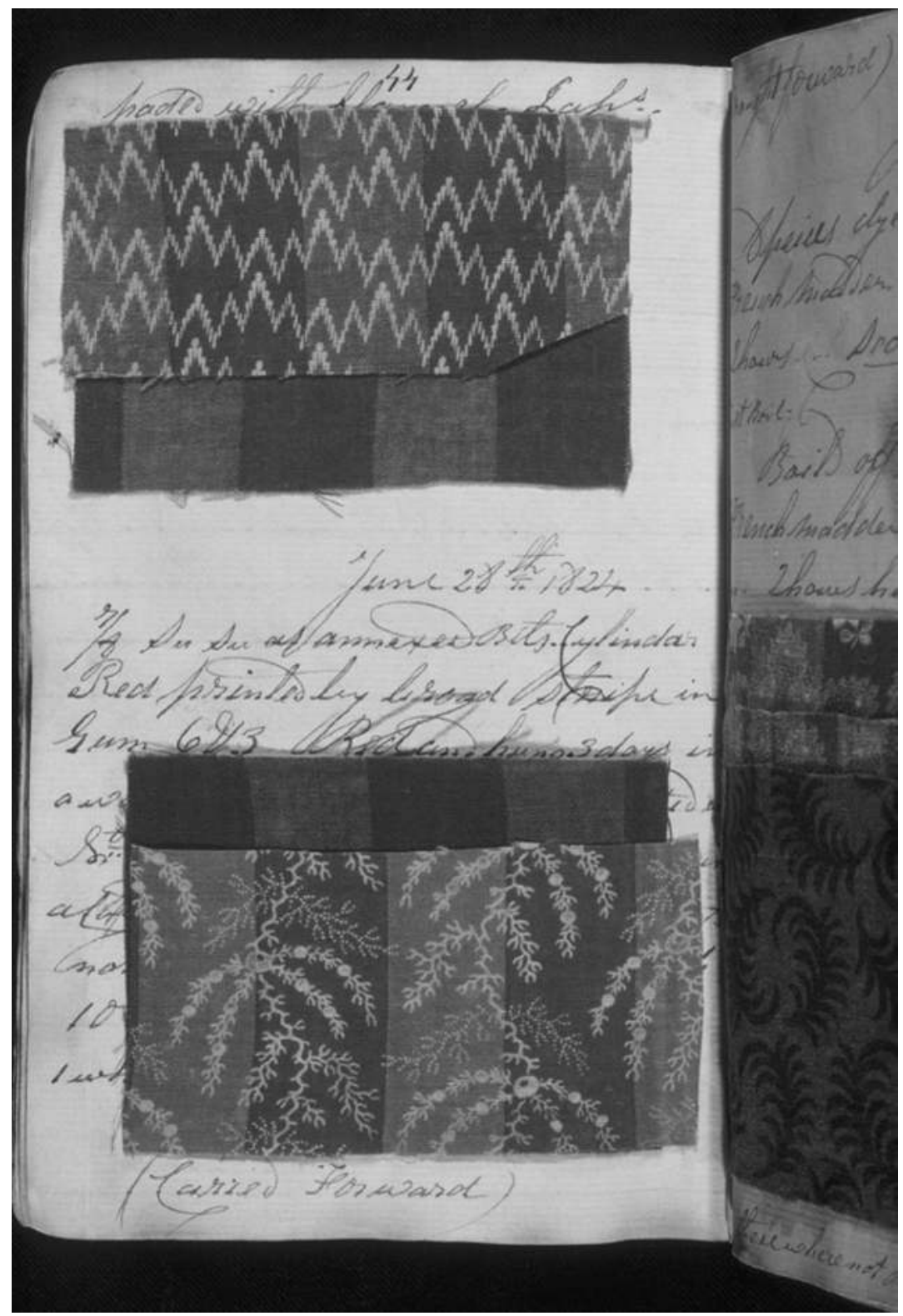

Fig. 14.1. Dye recipe book with printed cotton samples. Probably Henry Fielding Bros., 1824. Books like this show the attention given to colouring agents and design in the production of cottons. Victoria and Albert Museum, T.12-1956. 


\section{Conclusion}

This chapter has argued for a new global historical analysis of the British cotton industry. Like Parthasarathi, I argue for the challenge posed to British manufacturers and merchants by India's world domination of cotton products. That challenge posed by India was, moreover, the quality, distinctiveness and variety of its products. These goods came to British consumers as a part of a wider world trade in luxury goods, and our understanding of the cotton trade leads to questions of product and quality which first drove manufacturers and merchants.

The chapter has developed this case through four stages of argument: first, it argues for the place of product innovation and quality improvement in industrialization; second it places eighteenth-century product development, including cotton textiles in a wider framework of the global luxury trade; thirdly it sets out explanations of cotton innovation in recent economic and global history, and finally, it provides a detailed account of pressures felt by leading cotton manufacturers, Peel, Oberkampf and Oldknow, over products and qualities. Demanding fashion markets which accessed products across the world heightened the stakes of the supercharged competitive atmosphere among producers. The Asian trade in export-ware provided models of production and distribution and the institutions for making markets for cottons as well as other quality consumer goods. It was these that set the terms for the spinning, weaving and printing innovations that gave cotton its place in the 'years of miracles'. 


\title{
HISTORICAL ISSUES OF DEINDUSTRIALIZATION IN NINETEENTH-CENTURY SOUTH INDIA
}

\author{
Prasannan Parthasarathi
}

\section{The Sources of Indian Competitiveness}

In the seventeenth and eighteenth centuries Indian cottons, especially the higher quality varieties, were less expensive than locally made cotton goods in virtually all markets around the globe. Europeans became keenly aware of this fact from the mid-seventeenth century when low priced Indian goods invaded markets in France, England, Spain and other nations. Throughout Europe local textile interests protested against the imported stuff because they were unable to compete against it. In Britain, for example, wool and silk manufacturers took to the streets to oppose the import and use of Indian cotton goods as they were marketed at prices far below what their cloths commanded.

Since the seventeenth century there has been widespread consensus initially among contemporary commentators but then later among professional historians - on why Indian cottons were so cheap. A conventional wisdom emerged which attributed their low prices to the degraded and exploited conditions under which Indian workers laboured. Indian weavers were paid less than a penny a day, suffered harsh treatment from unscrupulous merchants and manufacturers, and taxed mercilessly by Oriental Despots, according to these accounts.

In 1998 an essay appeared which re-evaluated the sources of Indian competitiveness. It argued that the standard of living of Indian workers was far more similar to that of workers in Europe than previous commentators had appreciated. ${ }^{1}$ This assertion was supported with

${ }^{1}$ Prasannan Parthasarathi, "Rethinking Wages and Competitiveness in the Eighteenth Century: Britain and South India", Past and Present, 158 (1998), pp. 79-109. Also see Prasannan Parthasarathi, "Agriculture, Labour, and the Standard of Living in Eighteenth-Century India", in Robert C. Allen, Tommy Bengtsson and Martin Dribe (eds.), Living Standards in the Past: New Perspectives on Well-Being in Asia and Europe (Oxford: Oxford University Press, 2005), pp. 99-111. 
calculations of weekly earnings expressed in terms of grain. These showed that the real earnings of weavers and agriculturalists in Britain and South India were roughly comparable in the mid-eighteenth century. For spinners as well, grain earnings per pound of yarn spun were comparable in Britain and South India. These earnings estimates are summarized in Table 15.1 along with some earnings figures for weavers and spinners in Bengal.

These 'real wage' estimates were buttressed with a comparison of the position of weavers in the South Indian and British political and economic order. Weavers in South India possessed a number of advantages over their counterparts in Britain. First, the structure of contracts with merchants for the production of cloth gave the South Indian weaver several privileges which the British weaver did not have. Weavers in South India were free to cancel a contract at any time. Merchants, on the other hand, could not cancel contracts and they were obligated to take all cloth. In case of defects in manufacture, merchants had to negotiate price abatements with weavers to compensate for the shortfall in quality, but this was no easy matter since weavers could sell their cloth on the open market and cancel the merchant contract. Such a structure of contracts meant weavers could take advantage of favourable fluctuations in the market for cloth.

Second, merchants in South India, in sharp contrast to Britain, had little access to the levers of political power to discipline weavers.

Table 15.1. Earnings in the mid-eighteenth century Britain, South India and Bengal

\begin{tabular}{lccc}
\hline & Britain & South India & Bengal \\
\hline Weaving (lbs per week) & $40-140$ & $65-160$ & $55-135$ \\
Spinning (pence per lb of Yarn) & $4-24$ & $7-24$ & $5-24$ \\
Agriculture (lbs per week) & $30-35$ & $26-30$ & - \\
\hline
\end{tabular}

Sources: For Britain and South India, see Prasannan Parthasarathi, "Rethinking Wages and Competitiveness in the Eighteenth Century: Britain and South India", Past and Present, 158 (1998), pp. 79-109; for Bengal, see Id., "Agriculture, Labour, and the Standard of Living in Eighteenth-Century India", in Robert C. Allen, Tommy Bengtsson and Martin Dribe (eds.), Living Standards in the Past: New Perspectives on Well-Being in Asia and Europe (Oxford: Oxford University Press, 2005), pp. 99-111.

Notes: The wages for weaving and agriculture are given in terms of pounds of grain per week. For spinning they are given in terms of earnings per pound of yarn spun with correction for differences in grain prices. 
As a consequence, South Indian merchants faced difficulties recovering weaver debts and were powerless to prevent weavers from absconding with their advances of capital. In eighteenth-century Britain, by contrast, merchants were using state power to weaken and further subordinate weavers as well as other forms of labour. The eighteenth century British state passed laws making combinations of workers illegal and many of the customary rights of workers to 'waste' products were whittled away.

Finally, and perhaps most critically, weavers in South India suffered from far less unemployment and underemployment. The demand for their services was high since global demand for South Indian cottons was strong. This meant that weavers in South India typically worked their looms to the full extent that they wanted. In Britain, by contrast, weavers found less steady demand for their labour with fluctuations during the year as well as from year to year. The actual levels of employment in the two places cannot be quantified. Nevertheless, the respective states of demand for cloth suggest that weavers in South India received the weekly quantities of grain given in Table 15.1 with far greater regularity than their counterparts in Britain. Therefore, even though weekly earnings were comparable, annual earnings in South India would have been higher. The importance of employment levels for standard of living points to a significant shortcoming of real wage comparisons divorced from the broader economic and even political context.

If the standard of living for weavers was not lower in South India than in Britain, then what accounted for the low prices of Indian cottons in markets around the world? The answer to this question lies in the different general price levels, which was far lower in South India than in Britain. The most important commodity in both places in the eighteenth century was grain and the price of rice, the grain of choice in South India, was half the price of wheat in Britain, the preferred grain in that nation. As a result, South Indian workers received a money wage that was about half of the money wage in Britain. In this way, they were able to simultaneously maintain a high standard of living and produce cloth at extremely competitive terms for the world market.

The reasons for the lower price of food in the Indian subcontinent are not clear. One approach attributes the price difference to differences in the productivity of agriculture. Rice cultivation was far more productive than wheat growing in Britain, both in terms of output per seed and output per acre. The output to seed ratio for rice cultivation 
was about twenty or twenty-five to one and annual rice harvests yielded about 1500 pounds net of rice per acre in South India. By contrast, the comparable figures from Britain were output to seed ratios of eight to one and net output of 900 to 1000 pounds per acre.

In 2006, Stephen Broadberry and Bishnupriya Gupta criticized the above explanation for Indian competitiveness and argued that the economy of eighteenth-century India was far more backward than that of northwestern Europe. "By the eighteenth century the more economically advanced parts of Asia should be seen as on the same level as the more peripheral, rather than the most developed, parts of Europe," they wrote. ${ }^{2}$ According to Broadberry and Gupta, grain wages were comparable between the Indian subcontinent and Britain in the seventeenth century, but Indian grain wages fell precipitously in the eighteenth century to between thirty and forty percent of the British level. They reject the earnings figures given by Parthasarathi for eighteenth century South India on the ground that they are inconstant with other estimates.

In money terms, according to the two writers, the Indian wage was between a tenth and a quarter of the British money wage in the sixteenth, seventeenth and eighteenth centuries. Broadberry and Gupta take the lowness of Indian silver wages as indicative of the low level of economic development in the subcontinent. They draw a parallel between India and southern Europe, where money wages were similarly low and conclude that the economy of the Indian subcontinent was akin to the less developed regions of the European periphery. Drawing upon a the theoretical work of Rudiger Dornbush, Stanley Fisher and Paul Samuelson, they further conclude that the low money wages in India were due to the lower productivity in the subcontinent, specifically in the traded goods sector, which was in this case cotton textiles. $^{3}$

The Broadberry and Gupta arguments are problematic on several counts. Most critically, the empirical and historical foundations for their argument are shallow. Evidence for key claims is not given and much of the historical material that is harnessed is treated in a superficial fashion. As a consequence, the argument for the backwardness of Indian economic life is derived from economic theory, not historical fact.

\footnotetext{
2 Stephen Broadberry and Bishnupriya Gupta, “The Early Modern Great Divergence: Wages, Prices and Economic Development in Europe and Asia, 1500-1800", Economic History Review, 59, 1 (2006), p. 3.

${ }^{3}$ Ibid., pp. 2-31.
} 
Broadberry and Gupta provide several estimates of money and grain wages for South and North India. Almost all of these estimates are obtained from secondary sources, but Broadberry and Gupta do not undertake any analysis of the reliability of the figures or the sources. Even prices and wages obtained from primary sources require critical evaluation and analysis. For instance, Broadberry and Gupta draw upon the A'in-i Akbari for data on prices and wages in Mughal North India in the late sixteenth century, but they do not treat the data with care. Alan Heston has cautioned that "the prices given in the A'in-i Akbari must be some sort of nominal price, not a market price ... and the same is true for wages." Apparently unaware of these problems with the source, Broadberry and Gupta proceed to treat them as representing economic reality in Mughal India, a highly problematic procedure.

The calculation of wages and earnings in the early modern world is fraught with difficulties, but Broadberry and Gupta appear to be completely unaware of these problems. For the vast majority of weavers in the Indian subcontinent, earnings did not consist of a wage for their services. Weaver earnings consisted of the difference between the price they received for the cloth they produced and the cost of materials. And weavers were fully capable of reducing materials in order to maintain their earnings (a South Indian saying ran, "When a merchant reduces his price, the weaver reduces his thread"). Parthasarathi's calculations of weaver earnings appear to stand out, but they were obtained from accounts of costs and prices for weavers. Therefore, they are far more reliable measures of weaver earnings and standards of living then some random number reported in a secondary source.

The widespread use of non-monetary perquisites further complicates the calculation of wages and earnings in the early modern period. Peter Linebaugh has remarked in the case of Britain, "For most workers in the eighteenth century the payments were not made in money, or, when they were, such payments were only one of several forms." Even in cases where workers received a money payment for their services, a part of the compensation would have consisted of goods, including meals, housing, or waste products. These items were a welcome

\footnotetext{
${ }^{4}$ Alan Heston, "Review of Shireen Moosvi, The Economy of the Mughal Empire c. 1595: A Statistical Study," Economic History Review, 41, 4 (1988), p. 671.

${ }^{5}$ Peter Linebaugh, The London Hanged: Crime and Civil Society in the Eighteenth Century (Cambridge: Cambridge University Press, 1992), p. 374.
} 
addition to the monetary payment that the worker received. While British sources typically include both monetary and non-monetary payments when giving a wage figure, sources for India fail to do this. ${ }^{6}$ In his calculation of payments to labourers in agriculture, Parthasarathi included non-monetary perquisites, including meals and housing, but not all of these payments could be identified or "costed," such as a daily allowance of alcoholic drinks which were given in agriculture. Broadberry and Gupta fail to include such perquisites in their measures, but peons, scavengers, and other workers whose earnings they have estimated would have very likely received meals and other supplements to the money they were paid.

Finally, Broadberry and Gupta criticize Parthasarathi's estimates of weaver earnings on the grounds that his figures are too high. Their critique, however, relies upon an inaccurate distinction between skilled and unskilled labour. Broadberry and Gupta treat scavengers as low and calico weavers as unskilled. While it is certainly correct to treat scavengers low skilled, the calico weavers whose earnings Parthasarathi estimated were full-time manufacturers who manufactured cloth for markets in Europe, West Africa and the Middle East. These weavers were skilled workers and in the hierarchy of weaver skill in eighteenthcentury South India they were somewhere in the middle. When the skill distinction are drawn correctly, the Parthasarathi weaver earnings figures may be seen as consistent with the Broadberry and Gupta figures for scavengers as can be seen in Table 15.2. Weaver earnings were higher, but that was due to the skill premium that they received. In addition, the Parthasarathi estimate for what Broadberry and Gupta call a skilled worker is actually for one of the most highly skilled workers in eighteenth-century South India: a manufacturer of fine calicoes and muslins. From this perspective which makes careful distinctions of skill, it is the Broadberry and Gupta figures for weaver earnings in 1779 and 1790 that are anomalous, not Parthasarathi's figures for middling and high skill weavers.

Parthasarathi's data on earnings in agriculture, which Broadberry and Gupta ignore altogether, further suggests that the Broadberry and Gupta weaver figures are anomalous. Parthasarathi's agricultural earnings figures come from the late eighteenth and early nineteenth

${ }^{6}$ In calculating wages in eighteenth-century Britain Arthur Young converted nonmonetary perquisites to their money equivalents and added them to the money wage. 
Table 15.2. Daily grain wages in eighteenth-century South India

\begin{tabular}{llll}
\hline Year & Low skilled & Medium skilled & High skilled \\
\hline $1741-50$ & 2.1 (scavengers) & & \\
1750 & & 4.2 (calico weavers) & 10.5 (fine calico and \\
& & 1.1 (calico weavers) & \\
1779 & & 1.8 (calico weavers) & \\
1790 & & & \\
1795 & 1.95 & (agriculturalists)
\end{tabular}

Source: The numbers in italics are from Stephen Broadberry and Bishnupriya Gupta, "The Early Modern Great Divergence: Wages, Prices and Economic Development in Europe and Asia, 1500-1800", Economic History Review, 59, 1 (2006), pp. 2-31. Others are from Prasannan Parthasarathi, "Rethinking Wages and Competitiveness in the Eighteenth Century: Britain and South India", Past and Present, 158 (1998), pp. 79-109.

centuries and they indicate that labourers in agriculture received about two kilograms of rice per day. As can be seen in Table 15.2, the earnings for these unskilled workers fall in the same neighbourhood as that of scavengers. In the context of these agricultural earnings numbers, the weaver earnings figures that Broadberry and Gupta report for 1779 and 1790, both obtained from Sinnappah Arasaratnam, stand out as far too low. From the perspective of the political changes of those decades, it is not surprising that the 1779 and 1790 wage estimates for weavers are lower than earlier in the century. From the early 1770s the power of the new English East India Company state was deployed to reduce weaver earnings. Parthasarathi himself elsewhere argued that between the late 1760 s and the late 1770 s weaver earnings fell by a third. ${ }^{7}$

In their obsession to quantify, Broadberry and Gupta completely ignore the qualitative evidence that Parthasarathi provided, which buttressed the grain wage estimates. Given the crudeness of the quantitative exercise, and the undeniable fact that price and earnings data for seventeenth and eighteenth century India have to be treated with great caution, it is critical that all the evidence be examined and combined to

\footnotetext{
7 Prasannan Parthasarathi, Transition to a Colonial Economy: Weavers, Merchants and Kings in South India, 1720-1800 (Cambridge: Cambridge University Press, 2001), ch. 3 .
} 
obtain a picture of the standard of living. This is why the qualitative evidence on weavers and their place in the political and economic orders in Britain and South India are crucial as they provide valuable evidence in support of the crude earnings figures.

The weak historical and empirical foundation of the Broadberry and Gupta essay is also evident when they declare that the Indian subcontinent was economically backward. The argument is not based on empirical evidence, or more specifically of a refutation of two decades of research on the economic and commercial sophistication of the subcontinent in the seventeenth and eighteenth centuries, but rather on analogy. Since southern Europe had low silver wages and it was economically less advanced than northern Europe, Broadberry and Gupta conclude that low silver wages in the subcontinent was coupled with a backward economy as well. No historical material is provided in support of such a sweeping claim. The possible economic types in the world are reduced to two: the northern and southern European. Broadberry and Gupta do not seem to have considered the possibility that other combinations of silver wages and economic sophistication could have existed in the vast global economy of the eighteenth century.

The backwardness of eighteenth-century India is supported with the assertion that productivity in the textile sector was lower in India than in Europe. Again, no evidence on productivity is provided in support of this claim. On the face of it, this claim is hard to fathom. In both Europe and India, weavers and spinners worked on technologies that were very similar. Weavers used frame looms with hand thrown shuttles and spinners relied largely on spinning wheels in both places. Given the comparable technologies, why should productivity be vastly different? In the absence of empirical material in support of their argument, Broadberry and Gupta base their conclusion on a famous model of international trade developed by Rudiger Dornbush, Stanley Fisher and Paul Samuelson. ${ }^{8}$ Rather than analyzing the historical record, they assume that the eighteenth century trade between Europe and Asia conformed to this economic model.

The use of this model is problematic. Most critically, it assumes that cloth prices (or more precisely, the price of the traded good) were set by

${ }^{8}$ Rudiger Dornbusch, Stanley Fischer, and Paul A. Samuelson, 'Comparative Advantage, Trade, and Payments in a Ricardian Model with a Continuum of Goods", American Economic Review, 67 (1977), pp. 823-39. 
arbitrage in the world market. However, in the eighteenth century Europe produced very little cotton cloth and the international price for this good was set by the Indian price with mark-ups for trader profits and transport costs. A fundamental condition of the model, that the trade good be produced in both places and the world price set at some intermediate point between the two prices is not met.

\section{The Changing Basis for Competitiveness and Indian Deindustrialization}

From the late eighteenth century, the basis of competitiveness changed as a consequence of technological and institutional changes in British cotton manufacturing. The Indian competitive advantage in the seventeenth and eighteenth centuries rested on lower price levels, but from the late eighteenth century, the cotton manufacturers of Britain dominated markets for cotton yarn and cloth on the basis of superior technology and the extraordinary levels of productivity that machines afforded. As a result, the relative price of Indian cotton manufactures rose enormously, which is evident from Table 15.3. By 1812 British yarn prices were already far below Indian levels and the gap widened even further by 1830 with English prices across the board less than half of Indian prices.

British technological superiority in textiles emerged at the same time that the English East India Company was establishing its political

Table 15.3. Comparative prices of English and Indian cotton yarns, 1812 and 1830

\begin{tabular}{rlll}
\hline Thread count & English prices & English prices & Indian prices \\
\hline & 1812 & 1830 & 1812 and 1830 \\
49 & $1 \frac{3 / 4}{2}$ & $3 / 4$ & $21 / 8$ \\
60 & $13 / 8$ & $3 / 4$ & $23 / 4$ \\
80 & $15 / 16$ & $13 / 16$ & $23 / 4$ \\
100 & $11 / 4$ & $13 / 16$ & 3 \\
120 & $13 / 16$ & 1 & $31 / 4$ \\
150 & $11 / 2$ & $13 / 4$ & $41 / 16$ \\
200 & $23 / 8$ & $23 / 4$ & $53 / 8$ \\
250 & $33 / 8$ & 3 \\
\hline
\end{tabular}

Source: "Appendix to the Report from the Select Committee on East India Produce, 1832", British Parliamentary Papers, repr. in British Parliamentary Papers, East India Company Affairs, Colonies, East India (Shannon, 1970), vol. 6, p. 606. 
dominance over the subcontinent. For more than a century the fate of the Indian textile industry upon the establishment of British rule has been a hotly debated question. For many nineteenth-century commentators, it was an accepted fact that the rise of British rule led to a wiping out of Indian textile manufacturing. Marx's writings on the subject are the most famous of the nineteenth-century accounts, and his image of the bones of the handloom weavers bleaching the plains of India is firmly imprinted in the minds of many. Marx's accounts received widespread assent from other nineteenth-century observers, most importantly nationalist writers who used the decline of the textile industry to criticize British rule in India.

For Marx, the destruction of handloom weaving was a painful but necessary step in the modernization of India. The British were simply the bearers of a historical inevitability, the development of capitalism and with it modern industry. For nationalists, however, the destruction of handloom weaving in India was a vivid example of British misrule and illustrated the disadvantages under which India laboured as a consequence of foreign rule. In nationalist accounts, British rule was further criticized for exploiting the Indian market for British economic benefit, without concern for the state of the Indian economy. The implication is that if Indians had ruled India, industry would have been protected and therefore survived. Furthermore, the decline of Indian industrial activity created the groundwork for widespread Indian poverty. As Romesh Dutt argued in his classic critique of British rule:

India in the eighteenth century was a great manufacturing as well as great agricultural country, and the products of the Indian loom supplied the markets of Asia and of Europe. It is, unfortunately, true that the East India Company and the British Parliament ... discouraged Indian manufactures in the early years of British rule in order to encourage the rising manufactures of England ... millions of Indian artisans lost their earnings; the population of India lost one great source of their wealth. ${ }^{9}$

Although late nineteenth-century commentators wrote with great certainty that Indian industry came to be destroyed, there was actually little examination of the evidence. Only from the 1970s was research undertaken on changes in the size and scale of the textile industry in the subcontinent over the course of the nineteenth century.

${ }^{9}$ Romesh Dutt, The Economic History of India; Vol. 1. Under Early British Rule (London: Routledge, 2nd edn. [1990] 1906), pp. vi-vii. 
In a path-breaking essay, Amiya Kumar Bagchi compared employment figures from 1809-13 and 1901 in spinning as well as other manufactures from several districts in Bihar and concluded that there had been an absolute decline in manufacturing employment. In addition, he argued that the proportion of manufacturing workers in the population fell by more than half. ${ }^{10}$

Bagchi's findings have not gone unchallenged. Marika Vicziany has questioned the reliability of the evidence that Bagchi drew upon, especially for his early nineteenth century employment figures. ${ }^{11}$ Several historians have criticized Bagchi's conclusions on the decline in manufacturing employment on the basis of data from other regions in the subcontinent and on the basis of evidence from the late nineteenth and early twentieth centuries. Most notably, in opposition to Bagchi, Konrad Specker has investigated nineteenth century developments in the Madras Presidency and Tirthankar Roy has analyzed all-India developments in the late nineteenth and early twentieth centuries. According to Specker: "To talk about destruction of a flourishing textile industry and about deindustrialization, however, is too simple to render justice to the complexity of changes that occurred in Indian economic life under the impact of British economic penetration of the Indian market." ${ }^{12}$ And according to Roy, "There is little dispute among historians with the statement that economic contact between India and industrializing Europe had both a destructive and a creative impact on Indian industry. In the most influential view, the destructive impact has tended to be overemphasized. This book, by contrast, considers the creative impact the more important". ${ }^{13}$

Neither Specker nor Roy examined the evolution of the textile industry from its heyday in the late eighteenth century. Not surprisingly, the timeframe over which manufacturing activity is analyzed shapes one's

10 Amiya Kumar Bagchi, "De-industrialization in India in the Nineteenth Century: Some Theoretical Implications", Journal of Development Studies, 12, 2 (1976), pp. 135-64.

${ }^{11}$ Marika Vicziany, "The Deindustrialization of India in the Nineteenth Century: A Methodological Critique of Amiya Kumar Bagchi", Indian Economic and Social History Review, 16, 2 (1979), pp. 105-46. Also see Bagchi's "Reply", Indian Economic and Social History Review, 16, 2 (1979), pp. 147-61.

${ }_{12}$ Konrad Specker, "Madras Handlooms in the Nineteenth Century", in Tirthankar Roy (ed.), Cloth and Commerce: Textiles in Colonial India (New Delhi: Sage, 1996), p. 216.

13 Tirthankar Roy, Traditional Industry in the Economy of Colonial India (Cambridge: Cambridge University Press, 1999), p. 3. 
conclusions on deindustrialization. Specker begins his analysis of South India from the 1820s and 1830s, after a process of deindustrialization had commenced, and ends around 1870, in the middle of a second wave of deindustrialization. Similarly, much of Roy's work has concentrated on the late nineteenth and twentieth centuries after the process of deindustrialization had worked its way through the Indian economy and the indigenous industrialization of the subcontinent was beginning to expand.

From the vantage point of the late eighteenth century, the decline of manufacturing was a long and protracted process and took several decades. To some extent, this decline was reversed from the late nineteenth century, but this later revival of manufacturing must be placed in the context of the protracted contraction that preceded it. Despite an expansion from the late nineteenth century, manufacturing represented a smaller fraction of total economic activity than it had a hundred years earlier.

To examine this process of nineteenth-century change in detail, the following discussion focuses on textile manufacturing in southeastern India. It sees the process of deindustrialization as occurring in two phases. In the first phase, roughly from the late eighteenth century to the mid-nineteenth century, the decline in textile manufacturing was primarily due to the loss of export markets for Indian cloth to British textile producers. In the second, from about 1850 to 1880 , Indian production suffered from imported cloth, which undersold local manufacturers.

The analysis begins with some loom censuses, which much of the literature on deindustrialization has centred upon as a proxy for cloth production. Konrad Specker, for example, argued against the thesis of deindustrialization largely based upon loom counts. This focus on numbers of looms has several serious shortcomings. One of the most critical is the limited data on numbers of looms in the late eighteenth century and the data that does exist is difficult to interpret and compare with that for later years. Nevertheless, this evidence does suggest a decline in looms between the late eighteenth century and the second quarter of the nineteenth.

In 1787, according to a Committee of Circuit Report, the major weaving villages in the region of Rajahmundry contained 7,135 looms. By the 1820s, this figure had dropped to $3,026 .{ }^{14}$ Therefore, between the

${ }^{14}$ Selections from the Records of the Godavari District (Cocanada: Government Press, 1912), p. 20. 
late 1780 s and the 1820 s there was a very substantial decline in weaving activity, at least in the vicinity of Rajahmundry. A similar decline in looms may be shown for other parts of South India. For instance, in 1784 the Cassimcotah Division of the Chiacole Circar, a portion of which became the Vizagapatnam District, had 10,170 looms. In 1819, the whole of the Vizagapatnam District had 11,000 looms. ${ }^{15}$

Certainly, by the mid-nineteenth century textile manufacturing in a number of South Indian centres was in bad straits because of British competition in major export markets. In Vizagapatnam: "The export trade in cloth has however of late years fallen much into decay, from the produce being incapable of competing with cheaper cloth from the English market". ${ }^{16}$ Neelapilly and Ingeram: "Both these towns are now much deteriorated, and the cloth trade which in former days amounted to many lacs a year, has fearfully diminished under the influence of Manchester competition." ${ }^{17}$ Masulipatam: "Fifty years ago the trade with the Persian Gulf was 50 lacs, but Manchester has superseded Masulipatam and the trade is now half a lac." ${ }^{18}$ Cuddalore: "A valuable trade was carried on with the Straits and West Coast of Sumatra in piece goods ... The manufacture and exports of piece goods has been almost superseded by piece goods of European manufacture". ${ }^{19}$

The loss of these export markets had consequences that were far greater than those captured by a simple counting of looms. In the eighteenth century, on average the quality of the cloth produced for export, especially for European buyers, tended to be superior to that produced for local markets. In fact, the coarsest cloth purchased by the English East India Company was finer than much of the cloth found in bazaars in South India. Because of these quality differences, the value-added or income created from production for export was on average greater than that from production for South Indian markets. Therefore, a simple comparison of loom numbers will underestimate the economic loss associated with the decline in weaving.

${ }^{15}$ The figure for 1784 comes from the Report of the Committee of Circuit on the Cassimcotah Division of the Chiacole Circar 11 October 1784 (Madras: Government Press, 1914), p. 22. The 1819 figure is from Specker, "Madras Handlooms in the Nineteenth Century."

${ }_{16}$ A Gazetteer of Southern India with the Tenasserim Provinces and Singapore (Madras: Pharoah and Co., 1855), p. 22.

17 Ibid., p. 42.

${ }_{18}$ Ibid., p. 53.

${ }^{19}$ Ibid., p. 285. 
Table 15.4 gives some figures of value-added for several qualities of longcloth at the end of the eighteenth century. The bulk of the purchases of European traders was in cloth of 18 punjam and higher. Bazaar cloth, or the common variety for local consumption, tended to be around 14 punjam. The table shows that the value added for even the coarsest cloth for European buyers was more than double the value added in cloth made for local markets. Weaver incomes were also higher with higher quality cloths. From 18 punjam cloth to 24 punjam, weaver weekly incomes increased by 50 percent. For manufacturing 36 punjam cloth, weavers received a weekly income that was more than double that for 18 punjam. ${ }^{20}$ Therefore, we may conclude with some confidence that between 1790 and 1820, the average earnings of weavers declined and it is likely that this was the case for later in the nineteenth century as well.

The loss of markets for high quality cloth also meant a decline in demand for high quality yarn. The spinning of this yarn was a valuable source of income in South India, as well as other major textile regions in the subcontinent. Detailed investigations of costs in textile manufacturing, which were conducted in 1790 , indicate that spinning accounted for more of the value added in cloth production than weaving. For the manufacture of salempores in Ganjam, the costs of spinning accounted for 25 percent of the final price of the cloth. Weaving costs accounted for only 13 percent of the final price. ${ }^{21}$ Data on costs of manufacturing

Table 15.4. Weaving costs for longcloth at Ingeram, 1790

\begin{tabular}{lll}
\hline $\begin{array}{l}\text { Quality of longcloth } \\
\text { (in punjam) }\end{array}$ & $\begin{array}{l}\text { Cost of weaving } \\
\text { (pagodas, fanams, cash) }\end{array}$ & $\begin{array}{l}\text { Weaving costs as } \\
\text { percentage of final cloth price }\end{array}$ \\
\hline 14 & $0,12.7$ & 18 \\
16 & $0,20,47$ & 24 \\
18 & $0,28,10$ & 32 \\
20 & $0,34,63$ & 34 \\
22 & $1,0,0$ & 33 \\
24 & $1,1,55$ & 33 \\
36 & $4,15,25$ & 52 \\
\hline
\end{tabular}

Source: British Library, Oriental and India Office Collections: Madras Public Consultations, 1790, vol. P/241/16, p. 343.

${ }^{20}$ See my "Rethinking Wages and Competitiveness in the Eighteenth Century".

${ }^{21}$ British Library, Oriental and India Office Collections: Madras Public Proceedings, 1790, vol. P/241/16, pp. 337-38. 
Table 15.5. Spinning and weaving costs for longcloth at Vizagapatnam, 1790

\begin{tabular}{lllc}
\hline $\begin{array}{l}\text { Quality of } \\
\text { longcloth }\end{array}$ & $\begin{array}{l}\text { Spinning costs } \\
\text { as per cent of } \\
\text { total costs }\end{array}$ & $\begin{array}{l}\text { Weaving costs } \\
\text { as per cent of } \\
\text { total costs }\end{array}$ & $\begin{array}{l}\text { Sum of spinning and } \\
\text { weaving costs } \\
\text { per cent of total costs }\end{array}$ \\
\hline 14 punjam & 24 & 19 & 43 \\
18 punjam & 34 & 24 & 58 \\
20 punjam & 39 & 28 & 67 \\
\hline
\end{tabular}

Source: British Library, Oriental and India Office Collections: Madras Public Consultations, 1790, vol. P/241/16, p. 339.

for longcloth in Vizagapatnam reveal much the same and this material is laid out in Table 15.5. For 14, 18 and 20 punjam longcloth, spinning accounted for a larger fraction of the total costs of production than weaving. Per unit of time the incomes earned from spinning were lower than in weaving, and the incomes earned from spinning were distributed among many more individuals than in weaving, but these facts should not obscure its enormous economic importance.

These figures for value added from spinning shed light on how women could survive economically simply on the basis of spinning full time. Although there is no direct evidence from South India, the following very famous letter written in 1828 by a widow in Bengal most likely describes the situation in several regions of the subcontinent:

I was widowed when I was twenty-two years old. I had given birth to only three daughters ... I began to spin yarn on asana and charkha ... The weavers would come to my doorstep to buy the yarn thus spun ... and they would immediately advance as much cash money as I wanted. As a result we did not have any anxiety about food and clothing ... In this fashion I got three daughters married ... Now for over three years, the mother and daughter-in-law are facing ricelessness again. Not only have the weavers stopped coming to my doorstep to buy my yarn, even when I send it to the hat they will not buy at one-fourth of the former price. I am completely at a loss to understand how this has come to pass. I have made inquiries and have learned that the weavers are using English yarn now being extensively imported ... When I examined the yarn I indeed found it better than mine.

The elimination of spinning would have severely curtailed the economic independence and survival strategies of women. These, in turn, would have weakened the power of women within the family and household. 
From the 1840s imports of British piece goods into the southern India grew very rapidly. From the mid-1850s imports of British yarn also took off, increasing very substantially both in terms of value and in quantity. During this period, export of Indian piece goods went up very slightly, but this increase was insignificant in comparison to the burgeoning import of yarn and cloth. These developments in trade may be seen from Table 15.6 and Figure 15.1.

Table 15.6. Cloth and yarn trade in South India (Madras Presidency), 18551882 (in rupees)

\begin{tabular}{|c|c|c|c|}
\hline Year & Cloth exports & Yarn imports & Cloth imports \\
\hline $1855-56$ & 2145918 & 2268071 & 2785199 \\
\hline $1856-57$ & 2025299 & 2270388 & 2852383 \\
\hline $1857-58$ & 2087224 & 2145307 & 3792992 \\
\hline $1858-59$ & 2367187 & 3546077 & 4427005 \\
\hline $1859-60$ & 2061318 & 4159590 & 4894476 \\
\hline $1860-61$ & 1874689 & 3884960 & 6140183 \\
\hline $1861-62$ & 2075600 & 3805750 & 5238752 \\
\hline $1862-63$ & 1986766 & 2885638 & 6416495 \\
\hline $1863-64$ & 1636131 & 4532792 & 10112573 \\
\hline $1864-65$ & 1560666 & 6176796 & 9587776 \\
\hline $1865-66$ & 2043953 & 7161022 & 11247895 \\
\hline $1866-67$ & 2355722 & 7859122 & 10233102 \\
\hline $1867-68$ & 3368234 & 8336638 & 12026540 \\
\hline $1868-69$ & 2300271 & 9163489 & 13543760 \\
\hline $1869-70$ & 2218106 & 9271945 & 12564225 \\
\hline $1870-71$ & 2162205 & 10427948 & 14966869 \\
\hline $1871-72$ & 2514408 & 9478866 & 15294988 \\
\hline $1872-73$ & 2569696 & 10730337 & 14144953 \\
\hline $1873-74$ & 2808060 & 10408275 & 15698902 \\
\hline $1874-75$ & 2868125 & 10886821 & 13560894 \\
\hline $1875-76$ & 2772173 & 12388399 & 14320756 \\
\hline $1876-77$ & 3255411 & 11340439 & 14345021 \\
\hline $1877-78$ & 2776285 & 9852583 & 11414349 \\
\hline $1878-79$ & 2489407 & 9521614 & 10523407 \\
\hline $1879-80$ & 2222304 & 12033904 & 13260241 \\
\hline $1880-81$ & 2608914 & 14612249 & 16760984 \\
\hline $1881-82$ & 2980167 & 12015663 & 16950690 \\
\hline $1882-83$ & 3312498 & 14958006 & 20166913 \\
\hline
\end{tabular}

Source: Charles Donald Maclean, Manual of the Administration of the Madras Presidency (Madras: Govt. Press, 1885-93), vol. 1, pp. 341, 347 and 348. 

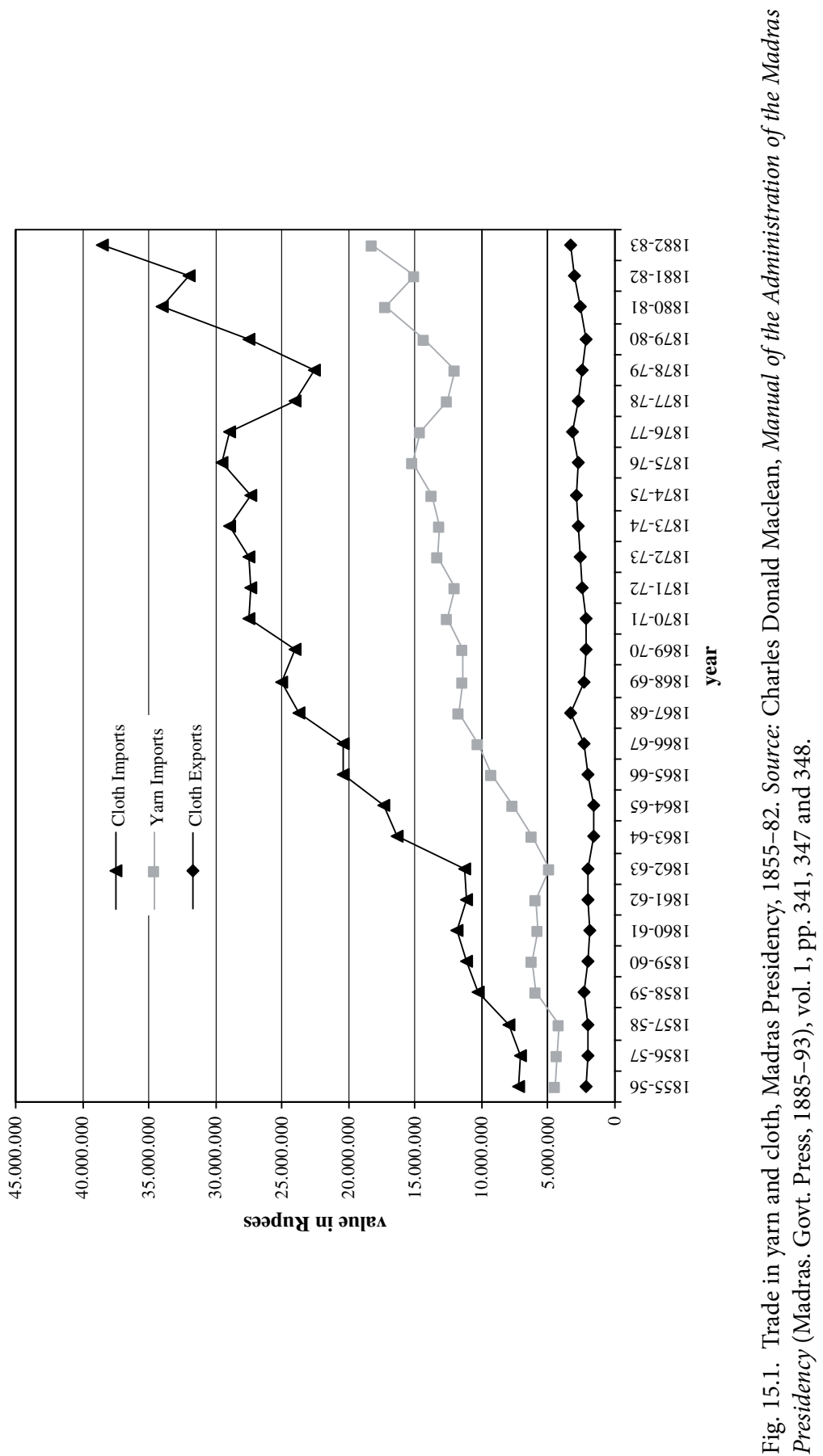
This trade data suggests that southern India was further deindustrialized between 1850 and 1880. No other conclusion seems possible given the fact that cloth exports from Madras were more or less steady in this period. For there not to have been deindustrialization of the Madras Presidency, cloth consumption would have had to increase at fantastic rates. Without this, British imports would have displaced significant quantities of locally manufactured cloth. There is little evidence of increases in cloth consumption that matched the growth in imports. The population of the Madras Presidency grew from 22 million in $1851-52$ to 31 million in 1881, an increase of 40 percent. ${ }^{22}$ Between $1855-6$ and 1881-82, cloth imports increased 600 per cent. And imports of cotton yarn increased 530 percent. Nor were the years between 1850 and 1880 a period of rapid or enormous growth in consumption in general. Between 1860 and 1913 per capita incomes in British India as a whole increased by about a third, so it is likely that there was some income growth between 1850 and 1880 in the South. At the same time devastating famines struck several parts of the Madras Presidency, culminating in the great famine of 1876-78. Although the available data makes it difficult to establish unequivocally, it does strongly suggest that South Indian textile manufacturing activity declined in the third quarter of the nineteenth century.

Census data indicates that the number of looms in the Madras Presidency were more or less steady after 1850 . However, impressionistic evidence suggests a marked decline in the numbers of weavers and in their earnings as well as a drop in handloom output by the $1880 \mathrm{~s}$, which again points to the limitations of loom counts. In the early $1880 \mathrm{~s}$, E. B. Havell, who was serving as the superintendent of the School of Arts in Madras, travelled widely in southeastern India to survey industrial activity. According to Havell, in the Tamil country, specifically the districts of North Arcot, Salem, Tanjore, Trichinopoly and Madurai, weaving had "suffered very considerably from the competition daily growing stronger and stronger of the cheap cotton and woolen goods which are being poured into the country and that many weavers have been forced to abandon their trade for other pursuits is already a wellknown fact". ${ }^{23}$ Havell further reported that low price was the most

${ }^{22}$ Charles Donald Maclean, Manual of the Administration of the Madras Presidency (Madras: Government Press, 1885-93), pp. 490-91.

${ }^{23}$ Ernest Binfield Havell, Reports on the Arts and Industries of Certain districts of the Madras Presidency (Madras: Government Press, 1909), pp. 4-5. 
important advantage that European cloth possessed; "consequently the native manufacturer who supplies the wants of the low caste and poorer classes has suffered most". 24

In cloths made for men, according to Havell, the dhotis made for the dress of the poor had been "almost entirely superseded for general wear by English long cloth, which is cheaper than the native cloth by about one half". ${ }^{25}$ "Still", he added, "the manufacture is carried on throughout the districts on a very small scale, for the native cloth is always worn by those who can afford it on occasions of ceremony and by some it is preferred on account of its superior durability and thicker texture". ${ }^{26}$ The manufacture of cloths for women was still carried on on a "very extensive scale, and has not declined to such an extent as the other, for though the industry has suffered considerably in the inferior kinds by the competition of English and French cheap printed cotton goods, European manufacturers have not hitherto produced anything which can at all compete with the finer cloths". ${ }^{27}$ Havell concluded his survey of the Tamil country on a gloomy note, and declared that "the native manufacture of cloths has nothing to hope for in the future" as European producers were perfecting imitations of Indian cloths, even the fine varieties. Fearing this competition, he reported that almost everywhere weavers "looked upon my inquiries with great suspicion; and in some cases refused to allow me to see their looms." ${ }^{28}$

Although the evidence on the fate of weavers and the decline in weaving is not clear cut, there is wide consensus - even among those who are optimistic about the fortunes of Indian handloom weavers - that hand spinning was wiped out in the second half of the nineteenth century. Tirthankar Roy has concluded that the "gradual extinction of handmade yarn" is a point "on which there is not much disputation today". ${ }^{29}$ The ramifications of the loss of hand spinning, however, have been largely unexplored. The importance of spinning has been pointed to in essays on women's work in colonial India, ${ }^{30}$ but there has been little

${ }^{24}$ Ibid.

${ }^{25}$ Ibid.

26 Ibid.

27 Ibid.

28 Ibid.

${ }^{29}$ Roy, Traditional Industry, p. 22.

${ }^{30}$ See, for instance, Nirmala Banerjee, "Working Women in Colonial Bengal: Modernization and Marginalization", in Kumkum Sangari and Sudesh Vaid (eds.), Recasting Women: Essays in Indian Colonial History (New Brunswick, N. J.: Rutgers University Press, 1990), pp. 269-301. 
analysis of the consequences of the elimination of spinning in the voluminous literature on deindustrialization. Part of the complacence about the death of hand spinning may stem from the fact that it was women's work, and, in common parlance, it represented a by-employment for women. Terms such as by-employment, however, serve to obscure the central position that spinning occupied in South Indian economic life and, in particular, for survival strategies before the nineteenth century.

The debate on deindustrialization, therefore, has had a consistent male bias. As a consequence, one of the most critical developments in manufacturing in the nineteenth century - the elimination of hand spinning - has been neglected. The loss of spinning would have had a major effect on rural life in South India, especially in the dry areas of the subcontinent where agriculture was rain-fed, and thus vulnerable to the vagaries of the monsoon. In these areas spinning - a quintessentially female occupation - had been critical for the weathering of bad years and slack seasons. In the eighteenth century during bad agricultural times the price of yarn would often fall, which suggests that spinning played an important role as a form of insurance and protection against an uncertain agrarian production system. ${ }^{31}$

\section{Conclusion}

There were many dimensions to deindustrialization in nineteenthcentury India. These notes suggest that many of these dimensions have been neglected and the debate on deindustrialization has adopted too narrow a focus on employment and numbers of looms. An analysis of these issues alone can not capture the complex economic changes that colonial rule and competition against machinery wrought in the Indian subcontinent. These notes point to several ways in which the debate and analysis may be broadened.

First, the temporal focus of the analysis of deindustrialization must be expanded. The starting point for analyses of what happened to textile manufacturing must be the late eighteenth century when the industry was still flourishing. To begin a comparison of numbers of looms from the 1820s, as Specker and others have done, is to miss an early phase of decline in textile manufacturing as a consequence of the loss of export markets to the British cotton industry. The scattered data on

${ }^{31}$ See Parthasarathi, Transition to a Colonial Economy, pp. 56-61. 
numbers of looms discussed in this paper shows a dramatic decline between the late eighteenth century and the 1820s.

Second, changes in the quality composition of cloth manufacturing are central to the process of deindustrialization. Even if neither employment nor the number of looms declined in the nineteenth century (of course both of these did decline), there would have been deindustrialization in the nineteenth century because textile manufacturers were making cloth of lower quality. The manufacture of poorer quality cloths translated into lower incomes for spinners and weavers, which meant that industrial activity was generating less income in the economy. This must be considered deindustrialization.

Third, counting looms alone is a poor guide to output of cloth and employment. As E. B. Havell noted in the late nineteenth century, the total number of looms had not changed dramatically in the final decades of the nineteenth century, but the looms were worked less intensively and weavers had less employment. Therefore, the quantity of cloth manufactured locally declined and cheaper machine-made stuff began to be consumed on an ever-larger scale.

Finally, analysis of deindustrialization must move beyond its male focus on weavers and their looms and include female work, which was indispensable for the manufacture of textiles, most critically hand spinning. Accounts of costs in textile production show that spinning contributed more value added than weaving. The loss of hand spinning in the nineteenth century, therefore, represented a seismic economic shift in the major textile centres of the subcontinent. To just note the decline of spinning, as the literature on deindustrialization does - when it notices it at all - does not do justice to the tremendous importance of spinning in the eighteenth-century agrarian order. The loss of spinning transformed the relationship between the agrarian and the manufacturing economies and as a consequence agriculture in the nineteenth century was made more insecure and unstable, especially in the dry areas of the subcontinent which became increasingly filled up with population growth in the nineteenth century.

A multi-dimensional approach suggests that South India did indeed suffer deindustrialization in the nineteenth century. And the decline in textile manufacturing had profound consequences for economic and social life from the early decades of the century, when export markets were lost to European manufacturers, to the closing decades of the century, when the products of European machines flooded the markets of the subcontinent. 
$-978-90-47-42997-5$ 


\section{GLOSSARY}

alum

aluminous
mordant dyeing
ambafis
arang
ardians (ardeas)
arganizes
aso-ado
baftas (bafta, or baffeta)

bark cloth

batik

beatilha (or beetilha, or beter, or bethilles)

'Benin cloth'

berame (or beirame)

bertangil

calico

canequins (cannikin, or kanniekin, or kaniki)
A double sulphate of ammonium or a univalent metal (as sodium or potassium) and of a trivalent metal (as aluminium, iron or chromium)

The use of alum or substances (vegetable, primarily) with similar properties as a mordant in fixing colour

A blue narrow cloth produced in West Africa, of inferior quality compared with Benin Cloth

A place where textile goods were produced and marketed in India

Plain dyed cloths of differing sizes traded in Delagoa Bay in the Zambesi Valley

One of the most famous cotton fabrics produced in blue and white in Golconda

See 'Ikerin'

From the Persian 'bâfta' meaning 'woven' it identifies ordinary calicoes, especially those produced in Broach. Normally a piece was 15 yards long and 25 inches wide, although a so-called broad baftas had the same length but was 36 inches wide

Type of cloth made by processing and beating out pieces of inner bark cut from living trees

A wax-resiste dyeing technique typical of Indonesia

A type of calico that was also called 'Golconda muslin' as it was produced in several centres in Golconda in the seventeenth and eighteenth centuries and was widely exported to Europe. It varied in length from 15 to 25 yards and $1 \frac{1}{2}$ yard wide, with thread counts ranging from 40 to 75 threads per inch. It could be dyed red, striped or flowered with embroidery.

See 'Ikerin'

A chintz from Cambay. It was produced both in fine and course quality

Calico cloth produced in Daman in blue, black and white and mostly exported to South-East Asia

Generic name for cotton cloth. It was normally called 'calicut' in the seventeenth century from the city of Calicut in Kerala

Low-priced, coarse cotton piece dyed blue or black, probably similar to baftas. A thin high-quality variety was produced in Daman and exported to Europe. 
canting

capotins (capperees)

careerdars

chandes

charkha

chello (chela, or chillae)

chintz

copdars

country ships

country trade

daryabadi

direct dyeing

dhotis (dotins, or dutties)

dotins (dutties)

fotas (or 'photas' or

'photaes')

fustian

gondos

Guinea cloth (or Guinea stuff, or Guinea)

gumasthas
Wax-resist technique of cloth printing and dyeing used in Southeast Asia

Blue and white chequered or striped cloths

Indigenous Indian agents employed by the English East India Company for a short period during the early nineteenth century for procuring textiles in South India

A cotton cloth produced in Gujarat and Balaghat and exported by the Portuguese in the sixteenth and seventeenth centuries

A wooden wheel used to spin coarse- or mediumquality yarn

Cotton handkerchief usually striped or chequered blue and white (loom-patterned). It was made in northeast India. The name perhaps derived from Sanskrit chela or chaila, 'a kind of scarf or mantle'. It was exported mainly to the Malay Archipelago

Painted or printed cotton cloth popular in Europe in the seventeenth and eighteenth centuries for bed and pillow covers, tablecloths, waistcoats ad pocketkerchiefs. It was also called 'pintado' in Portuguese Indigenous Indian agents employed by the English East India Company for a short period during the early nineteenth century for procuring textiles in South India

Intra-Asian trading vessels belonging to private merchants

Intra-Asian maritime trade

Cotton textile from Daryabad

See 'substantive dyeing'

From dhoti, a strong coase cotton cloth, probably indigodyed cloth used in particular in east-central Africa

See 'dhotis'

An ordinary cotton calico

Broad category of cotton-linens

Rough utilitarian cotton cloth manufactured in Sofala

General term for a variety of cheap cotton textiles made in western India. They were striped or checked with coloured threads. It was popular on the Guinea Coast during the Atlantic slave trade, hence the name

Indigenous Indian assistants or agents employed by the English East India Company in various localities across South India during the late eighteenth and early nineteenth century for procuring textiles 
ikeji

ikerin

iketa

khasa

longcloth (or long cloth)

machiras

malmal

mantagens

mermolano or merbolano or malmal

mordant

muris

nankeens

nicannee (niccanee, or nickanee, or niquanias)

paikars a two-strip cloth (each strip about two yards by one yard), produced mainly for personal consumption in Ekiti, Akoko, and Igbomina in West Africa

A four-strip cloth (also about three yards by two feet, each strip) produced in Ekiti, Akoko, and Igbomina in West Africa. Ikerin cloth was designed for the Benin market and the producers referred to it as aso-Ado, meaning 'Benin cloth' or 'cloth for Benin'

A three-strip cloth (each strip about three yards by two feet) produced in Ekiti, Akoko, and Igbomina in West Africa

Cotton cloth widely produced in Bengal and the Coromandel Coast. The production of Dacca and Hugli was popular in England

A piece of plain cotton cloth up to 37 yards long and more than a yard wide, with thread counts ranging from 40 to 70 threads per inch. This was a measure unknown in India and was produced especially for the European market and given a European name. These cloths were among the most common cloths exported from South India by the English Company during the seventeenth and eighteenth century

roughly woven undyed cotton cloths manufactured in the Zambezi Valley

A generic name for muslin of different qualities

Cambay cloth that was produced in large (grande) and small sizes (pequeno)

A thin cotton cloth of Bengal and originally produced in Dacca

A substance used in dyeing to fix the colouring matter, especially a metallic compound, as an oxide or hydroxide that combines with the organic dye and forms an insoluble colour compound or lake in the fibre

Plain cotton cloths about 8 to 9 meters long and about 1.3 meters wide, with thread counts ranging from 70 to 90 threads per inch and sometimes as high as 130 thread per inch for very fine cloth

An off-white cotton cloth manufactured in Jiangnan in the Yangzi River Delta and exported from Canton to Britain where it was used in the manufacture of trousers, breeches, etc. A single piece of nankeen measured 16 yards in length and one yard in width

Low-priced striped cotton cloth (loom-patterned). It was produced in western India and bought by British merchants mainly for the Guinea trade

Intermediary merchants in Bengal 


palampores
panos
patolas
percalcos (percalços, or
percale)
photas (photaes)
picul (picol)
pond (ponden)
private traders
quaqua cloth

romalls (rumals)

roupas da seda taffeta (taffatie, or taffety)

Satin (satim)

Salampura (salampoory, or salampuris)

samateres

sanus

sarja
A kind of chintz bedcover

A general term for a medium-quality linen, cotton, wool or silk cloth

Gujarati patolu, was a well known type of silk-cloth, the warp and the weft being tie-dyed before weaving according to the pre-determined pattern. Patolas were exported mainly to the Malay Archipelago, the measurements varying according to the needs of different markets. The chief centre of patola weaving was Patan, north-east of Ahmedabad in Western Gujarat

A thin cotton cloth commonly known as cambricmuslin

See 'fotas'

A unit of Chinese weight measurement equivalent to 133.5 pounds

Dutch unit of weight, equivalent to 1.09 pounds; 125 ponden was equivalent to one picul

Non-East India Company traders who were engaged in intra-Asian maritime trade on their own account

Cotton cloth brought to the Ivory Coast from the West African interior in exchange for salt and overseas products during the Atlantic slave trade. It was traded in units based on standard wrapper sizes that were made of plain or loom-patterned strips woven on the treadle loom and sewn together

Small cloth squares, woven of cotton or silk, usually decorated with painting, printing, or embroidery. Made in India for use as a covering or for wrapping gifts silk cloth

General trade term for silk piece-goods made in India and elsewhere. The name is derived from the Persian word tafta, 'a glossy twist'

An expensive variety of silk velvet woven in Persia, Gujarat and Bengal

A broad cotton cloth produced in the Coromandel Coast, usually white or blue, between 14 and 16 metres long and about 1 metre wide, with thread counts ranging from 50 to 90 threads per inch. These cloths were among the most common cloths exported from South India by the English, Dutch and French companies during the seventeenth and eighteenth century

Narrow white cotton cloths that was traded extensively in Manyika in the Zambezi Valley

A cotton cloth manufactured in Soro, Mohanpur, and Hariharpur in Bengal and sold in England

A mixed silk and woollen cloth 
savagagins
semians (simians)
senapatis
soosies
substantive dyeing (direct
dyeing)

teal

tafecira

tapseils (tapsell, or tapseel, or tafficila)

terrindams

vat dyeing
Cured cloths

A chintz produced in the areas of Semana, near Delhi Head weavers and other professional or caste community heads that the English East India Company utilized to standardise production of cloth and demand regular deliveries of cloth from weavers

Striped of chequered fabric of silk or mix silk-and-cotton, woven in the Malda-Kasimbazar area and other areas of India. They were usually 1 yard in width and 10-20 yards in length

Dyeing process carried out in a neutral or slightly alkaline dyebath, at or near boiling point, with the addition of either sodium chloride or sodium sulfate

A unit of Chinese currency equivalent to $8 \mathrm{~s} 6 \mathrm{~d}$ (£0.425)

A striped cotton cloth mostly produced in Sindh

Low-price striped (loom-patterned) cloth of mixed silk and cotton, woven in western India. Much in demand on the Guinea Coast during the Atlantic slave trade

Bengal plain muslins of superior quality, woven in the Dacca district

Dyeing in a bucket or vat and may be performed whenever a solid, even shade over the entire garment is desired. Takes dyes that are essentially insoluble in water and incapable of dyeing fibers directly and reduces them in alkaline liquor producing water soluble alkali metal salt of the dye, which has an affinity for the textile fiber and subsequent oxidation reforms the original insoluble dye

Indigo-dyed cloths traded in the Zambezi Valley 
$-978-90-47-42997-5$ 


\section{BIBLIOGRAPHY}

\section{Primary Sources and Pre-1900 Publications}

Agricola, Georgius, De Re Metallica, trans. Herbert Clark Hoover and Lou Henry Hoover (New York: Dover, 1950).

Arnould, Ambroise Marie, De la balance du commerce et des relations commerciales extérieures de la France..., 3 vols. (Paris: Chez Buisson, 1791).

Auber, Peter, China. An Outline of its Government, Laws, and Policy: and of the British and Foreign Embassies to, and intercourse with, that Empire (London: Parbury Allen \& Co., 1834).

Baines, Edward, History of the Cotton Manufacture in Great Britain (London: Fischer, 1835).

Barbosa, Duarte, The Book of Duarte Barbosa. An Account of the Countries Bordering on the Indian Ocean and their Inhabitants, Written by Duarte Barbosa, and Completed about the Year 1518 A.D., ed. Mansel Longworth Dames, 2 vols. (London: Hakluyt Society, 1921).

Barbot, John, A Description of the Coasts of North and South-Guinea, and of Ethiopia Inferior, Vulgarly Angola ... (London: A. \& J. Churchill, 1732).

Biringuccio, Vannoccio, Pirotechnia, trans. C. S. Smith and M. T. Gnudi (Cambridge, Ma.: MIT Press, 1959).

Bonnart, Jean Baptiste, Recueil des modes de la cour de France (Paris: n.a., 1676).

Brackenbury, C. F., Madras District Gazetteers: Cuddapah, 2 vols. (Madras: Government Press, 1915).

Briggs, John, The Cities of Gujarashtra: Their Topography and History Illustrated, in the Journal of a Recent Tour, with Accompanying Documents (Bombay: Times' Press, 1849).

Buchanan, Francis, An Account of the District of Purnea in 1809-10 (Patna: Bihar and Orissa Research Society, 1928).

Buchanan, Francis, An Account of the District of Bhagalpur in 1810-11 (Patna: Bihar and Orissa Research Society, 1939).

Buchanan Hamilton, F., Geographical, Statistical and Historical Description of the District of Dinajpur (Calcutta: Baptist Mission Press, 1833).

Burton, Richard, The Lake Regions of Central Africa: A Picture of Exploration, 2 vols. (London: Longman, Green, Longman and Roberts, 1860).

Caldeira, Carlos José, Apontamentos d'uma viagem de Lisboa a China e da China a Lisboa. Tomo Segundo, 2 vols. (Lisbon: J. P. M. Lavado, 1853).

Chaudhuri, K. N. (ed.), The Economic Development of India under the East India Company 1814-58 (Cambridge: Cambridge University Press, 1971).

Coolhaas, W. Ph. (ed.), Generale Missiven van Gouverneurs-Generaal en Raden aan Heren XVII der Verenigde Oostindische Compagnie; Vol. 5 (1686-97) (The Hague: Nijhoff, 1975).

Crawfurd, John, A View of the Present State and Future Prospects of the Free Trade and Colonization of India (London: James Ridgeway, 2nd edn. 1829).

Crawfurd, John, History of the Indian Archipelago, 3 vols. (Edinburgh: Constable, 1820). da Silva, João Julião, "Memoria Respectiva á Villa de Sofalla, seo Continente e Antiguidades mais notaveis ... no anno de 1790..., in José Fialho Feliciano and 
Victor Hugo Nicolau (eds.), Memórias de Sofala: Etnografia e História das Identidades e da Violência entre os diferentes Poderes no Centro de Moçambique Séculos XVIII e XIX (Lisbon: Comissão Nacional para as Comemorações dos Descobrimentos Portugueses, 1998), pp. 137-205.

Dantzig, A. van, The Dutch and the Guinea Coast, 1674-1742: A Collection of Documents from the General State Archive at The Hague, Compiled and Translated (Accra: GAAS, 1978).

Downton, Nicholas, The Voyage of Nicholas Downton to the East Indies 1614-15: As Recorded in Contemporary Narratives and Letters, ed. William Foster (London: Hakluyt Society, 1938).

English East India Company, Reports and Documents Connected with the Proceedings of the East India Company in Regard to the Culture and Manufacture of Cotton-wool, Raw Silk and Indigo in India (London, 1836).

Fawcett, Sir Charles (ed.), English Factories in India, New Series, 4 vols. (Oxford: Clarendon, 1936-55).

Foster, William (ed.), Letters Received by the East India Company from its Servants in the East, 6 vols. (London: Sampson Low, Marston, 1896-1902).

Foster, William (ed.), The English Factories in India. A Calendar of Documents in the India Office, British Museum and Public Record Office, 13 vols. (Oxford: Oxford University Press, 1906-27).

Francis, W., Madras District Gazetteers: South Arcot (Madras: Government Press, 1906).

Francis, W., Madras District Gazetteers: Bellary, 2 vols. (Madras: Government Press, 1916).

Gamitto, A. C. P., King Kazembe, trans. Ian Cunnison, 2 vols. (Lisbon: Junta de Investigações do Ultramar, 1960).

A Gazetteer of Southern India with the Tenasserim Provinces and Singapore (Madras: Pharoah and Co., 1855).

Gazetteer of the Bombay Presidency; Vol. II. Gujarat: Surat and Broach (Bombay: Government Central Press, 1877).

Harrison, William, The Description of England: The Classic Contemporary Account of Tudor Social Life, ed. Georges Edelen (Ithaca, NY: Cornell University Press, 1968).

Havell, Ernest Binfield, Reports on the Arts and Industries of Certain districts of the Madras Presidency (Madras: Government Press, 1909).

Hellot, Jean, L'Art de la teinture des laines et des étoffes de laine, en grand et petit teint (Paris: La Veuve Pissot, Jean-Thomas Hérissant, Pissot, fils, 1750).

Hemingway, F. R., Madras District Gazetteers: Tanjore, 2 vols. (Madras: Government Press, 1906).

Hemingway, F. R., Madras District Gazetteers: Godavari, 2 vols. (Madras: Government Press, 1915).

Holder, Edwin, Monograph on Dyes \& Dyeing in the Madras Presidency (Madras: Government Press, 1896).

Hove, Anton Pantaleon, Tours for Scientific and Economic Research, made in GuzeratKattiwar, and the Conkuns, in 1787-88, by Dr Hove (Bombay: Bombay Education Society Press, 1855).

Liesegang, Gerhard (ed.), "Resposta das Questoens sobre os Cafres" ou Notícias Etnográficas sobre Sofala do Fim do Século XVIII (Lisbon: Junta de Investigações do Ultramar/Centro de Estudos de Antropologia Cultural, 1966).

Livingstone, David, Missionary Travels and Researches in South Africa (New York: Harper, 1858).

Macartney, George, An Embassy to China, being the Journal kept by Lord Macartney during his Embassy to the Emperor Ch'ien-lung 1793-94, ed. J. L. Cranmer-Byng (London: Longmans, 1962).

MacCullock, J. R. (ed.), Early English Tracts on Commerce (Cambridge: Cambridge University Press, 1954).

Manucci, Niccolao, Mogul India, 1653-1708: or, Storia do Mogor, ed. William Irvine, 4 vols. (Delhi: Low Price Publications, 1990-96). 
Martin, François, India in the 17th Century (Social, Economic and Political): Memoirs of François Martin (1670-94), ed. Lotika Varadarajan, 4 vols (New Delhi: Munchiram Manoharlal Publishers, 1981-5).

Marx, Karl, 18th Brumaire of Louis Bonaparte (London, 1852).

Masson, Paul, Histoire du commerce français dans le Levant au XVIIe siècle (Paris: Hachette \& C., 1896).

Maclean, Charles Donald, Manual of the Administration of the Madras Presidency (Madras: Government Press, 1885-93).

Mendes de Vasconcellos e Cirne, Manuel Joaquim, Memória sobre a Provincia de Moçambique, ed. José Capela (Maputo: Arquivo Histórico de Moçambique, 1990).

Milburn, William, Oriental Commerce: Containing a Geographical Description of the Principal Places in The East Indies, China, and Japan with their Produce, Manufactures, and Trade, including the Coasting or Country Trade from Port to Port, 2 vols. (London: Black, 1813).

Montaury, João Baptista de, "Moçambique, Ilhas Querimbas, Rios de Sena, Villa de Tete, Villa de Zumbo, Manica, Villa de Luabo, Inhambane (C. de 1788)", in António Alberto de Andra (ed.), Relações de Moçambique Setecentista (Lisbon: Agência Geral do Ultramar, 1955), pp. 339-73.

Morice, Monsieur, "Observation on the List of Trade Goods from another Point of View" in G. S. P. Freeman-Grenville (ed.), The French at Kilwa Island: An Episode in Eighteenth-Century East African History (Oxford: Clarendon Press, 1965), pp. 144-45.

Morse, Hosea B., The Chronicles of the East India Company Trading to China, 16351834, 5 vols. (Oxford: Clarendon Press, 1926-29).

Montez, Caetano, "Plano e relação da Bahia..., in Descobrimento e Fundação de Lourenço Marques, 1500-1800 (Lourenço Marques: Minerva Central Editora, 1948), pp. $138-45$.

Nicholson, F. A., Madras District Manuals: Coimbatore, 2 vols. (Madras: Government Press, 1906).

Observations on the Means of Extending the Consumption of British Calicoes, Muslins, and Other Cotton Goods and of Giving Pecuniary Aids to the Manufacturers ... (London: n.a., 1788).

Pate, H. R., Madras District Gazetteers: Tinnevelly, 2 vols. (Madras: Government Press, 1917).

Pepys, Samuel, The Diary of Samuel Pepys, eds. Robert Latham and William Matthews (Berkeley: University of California Press, 1970).

Pires, Tomé, The Suma Oriental of Tomé Pires: An Account of the East, from the Red Sea to Japan, Written in Malacca and India in 1512-15, ed. Armando Cortesão, 2 vols. (London: Hakluyt Society Publications, 1944).

Pliny the Elder, Natural History, trans. H. Rackham (Cambridge, Ma.: Harvard University Press, 1962).

Postlethwayt, Malachy, The Universal Dictionary of Trade and Commerce, 2nd edition, 2 vols. (London: John Knapton, 1757).

Prinsep, George Alexander, "Remarks on the External Commerce and Exchanges of Bengal, with Appendix of Accounts and Estimates [1823]", in K. N. Chaudhuri (ed.), The Economic Development of India under the East India Company, 1814-58 (Cambridge: Cambridge University Press, 1971), pp. 51-167.

Pyrand, François, The Voyage of François Pyrard of Laval to the East Indies, the Maldives, the Moluccas and Brazil, ed. Albert Gray, 2 vols. (London: Hakluyt Society, 1888).

Report of the Committee of Circuit on the Cassimcotah Division of the Chiacole Circar 11 October 1784 (Madras: Government Press, 1914).

Richards, F. J., Madras District Gazetteers: Salem, 2 vols. (Madras: Government Press, 1918).

Rossetti, G., The Plictho, trans. S. M. Edelstein and H. C. Gorghettey (Cambridge, Ma.: Harvard University Press, 1962). 
Sainsbury, Ethel Bruce (ed.), A Calendar of the Court Minutes of the East India Company 1635-79, 11 vols. (Oxford: Clarendon Press, 1907-38).

van Linschoten, Jan Huygen, The Voyage of John Huyghen van Linschoten to the East Indies, from the English Translation of 1598, ed. Pieter Anton Tiele, 2 vols. (London: Hakluyt Society, 1885).

Santana, Francisco (ed.), Documentação Avulsa Moçambicana do Arquivo Histórico Ultramarino, 3 vols. (Lisbon: Centro de Estudos Históricos Ultramarinos, 1964-74).

Selections from the Records of the Godavari District (Cocanada: Government Press, 1912).

Strandes, Justus, The Portuguese Period in East Africa, trans. Jean F. Wallwork (Nairobi: East African Literature Bureau, 4th edn. 1989).

Teixeira Pinto, Gonçalo de Magalhães, Memoria sobre as Possessos Portuguezas na Asia, escriptas no anno de 1823 (Nova Goa: Imprensa Nacional, 1859).

Temple, Sir Richard Carnac, Lavinia M. Anstey and Bernard P. Scattergood (eds.), The Scattergoods and the East India Company: Being a Selection from the Private Letters and Business Correspondence of John Scattergood, East India Merchant 1681-1723 (Bombay: British India Press, 1921-33; reprinted Harpenden: D. J. Jeffrey, 1935).

The Just Complaints of the Poor Weavers Truly Represented, reprinted in John Smith (ed.), Chronicum Rusticum Commerciale, 2 vols. (London, 1747).

Thurston, Edgar, Monograph on the Cotton Fabric Industry of the Madras Presidency (Madras: Government Press 1897).

Wheeler, J. Talboys, Hand-book to the Cotton Cultivation in the Madras Presidency (Madras: Higginbotham and Pharoah and Co., 1862).

Ying-Hsing Sung, Chinese Technology in the Seventeenth Century: T'ien-Kung K'ai-Wu, trans. E-Tu Sen Sun and Shiou-Chuan Sun (New York: Dover Publications, 1997).

\section{Published Secondary Literature}

Abu-Lughod, Janet L., Before European Hegemony: The World System A.D. 1250-1350 (New York: Oxford University Press, 1989).

Adamu, Mahdi, The Hausa Factor in West African History (Zaria: Ahmadu Bello University Press, 1978).

Adenaike Carolyn Keyes, "West African Textiles, 1500-1800", in Maureen Fennell Mazzaoui (ed.), Textiles: Production, Trade and Demand (Aldershot: Ashgate/ Variorum, 1998), pp. 251-61.

Afigbo, A. E., "Pre-colonial Trade Links Between Southeastern Nigeria and the Benue Valley", Journal of African Studies, 4, 2 (1977), pp. 119-39.

Afigbo, A. E., "The Spell of Oral History: A Case Study of Northern Igboland", History in Africa, 33 (2006), pp. 39-52.

Ahmed, Afzal, "Indian Textiles and the Portuguese Trade in the Seventeenth Century (1600-1643)", Studia, 48 (1989), pp. 213-36.

Ahmed, Afzal, Indo-Portuguese Trade in the Seventeenth Century (1600-63) (New Delhi: Gian, 1991).

Ahuja, Ravi, "Labour Relations in an Early Colonial Context: Madras c. 1750-1800", Modern Asian Studies, 36, 4 (2002), pp. 793-826.

Aiolfi, Sergio, Calicos und gedrucktes Zeug: die Entwicklung der englischen Textilveredelung und der Tuchhandel der East India Company, 1650-1750 (Stuttgart: Steiner, 1987).

Akintoye, S. A., "The North-Eastern Yoruba Districts and the Benin Kingdom", Journal of the Historical Society of Nigeria, 4, 4 (1965), pp. 539-53.

Alagoa, E. J., "Long-Distance Trade and States in the Niger Delta", Journal of African History, 11, 3 (1970), pp. 319-29.

Alam, Muzaffar, The Crisis of Empire in Mughal North India, 1707-48 (Delhi: Oxford University Press, 1986). 
Alam, Muzaffar and Sanjay Subrahmanyam (eds.), The Mughal State, 1526-1750 (Delhi: Oxford University Press, 1998).

Allen, Robert, "The Great Divergence in European Wages and Prices from the Middle Ages to the First World War", Explorations in Economic History, 38, 4 (2001), pp. 1-26.

Alpers, Edward A., Ivory \& Slaves in East Central Africa: Changing Pattern of International Trade to the Later Nineteenth Century (London: Heinemann, 1975).

Altes, W. L. Korthals, Changing Economy in Indonesia; Vol. 12A. General Trade Statistics, 1822-1940 (Amsterdam: Royal Tropical Institute, 1991).

Ames, Glenn J., Colbert, Mercantilism, and the French Quest for Asian Trade (DeKalb, Il.: Northern Illinois University Press, 1996).

Amsden, Alice, The Rise of "the Rest": Challenges to the West from Late-Industrializing Economies (Oxford: Oxford University Press, 2001).

Andaya, Barbara, "The Cloth Trade in Jambi and Palembang Society during the Seventeenth and Eighteenth Centuries", Indonesia, 48 (1989), pp. 27-47.

Appadurai, Arjun, "Right and Left Hand Castes in South India", Indian Economic and Social History Review, 11, 2-3 (1974), pp. 183-215.

Arasaratnam, Sinnappah, "Weavers, Merchants and Company: The Handloom Industry in Southeastern India 1750-90", Indian Economic and Social History Review, 17, 3 (1980), pp. 257-81.

Arasaratnam, Sinnappah, Merchants, Companies and Commerce on the Coromandel Coast, 1650-1740 (Delhi: Oxford University Press, 1986).

Arasaratnam, Sinnappah, Maritime Commerce and English Power: Southeast India, 1750-1800 (New Delhi: Variorum, 1996).

Arasaratnam, Sinnappah, "Coromandel's Bay of Bengal Trade, 1740-1800", in Om Prakash and Denys Lombard (eds.), Commerce and Culture in the Bay of Bengal, 1500-1800 (New Delhi: Manohar, 1999), pp. 307-328.

Austen, Ralph A. and Dennis D. Cordell, "Trade, Transportation, and Expanding Economic Networks: Saharan Caravan Commerce in the Era of European Expansion, 1500-1900", in Alusine Jalloh and Toyin Falola (eds.), Black Business and Economic Power (Rochester: University of Rochester Press, 2002), pp. 80-113.

Bagchi, Amiya Kumar, "De-industrialization in India in the Nineteenth Century: Some Theoretical Implications", Journal of Development Studies, 12, 2 (1976), pp. 135-164.

Bagchi, Amiya Kumar, "The Deindustrialization of India in the Nineteenth Century: Reply”, Indian Economic and Social History Review, 16, 2 (1979), pp. 147-61.

Bairoch, Paul, "European Foreign Trade in the XIX Century: The Development of the Value and Volume of Exports (Preliminary Results)", Journal of European Economic History, 2, 1 (1973), pp. 5-36.

Bairoch, Paul, "Geographical Structure and Trade Balance of European Foreign Trade from 1800 to 1970", Journal of European Economic History, 3, 1 (1974), pp. 557-607.

Baker, C. J., An Indian Rural Economy 1880-1955 (Oxford: Clarendon Press, 1984).

Baker, G. P., Calico Painting and Printing in the East Indies in the 17th and 18th Centuries, 2 vols. (London: Edwin Arnold, 1921).

Ball, Jennifer, Byzantine Dress: Representations of Secular Dress in 8th-to 12th-Century Painting (New York and Basingstoke: Palgrave Macmillan, 2005).

Banerjee, Debdas, " 'Regional Specialization and Market Convergence' Revisited: India's Internal Commodity Trade, c.1850-1920", Occasional Paper, Centre for Studies in Social Sciences, Calcutta, 137 (1992).

Banerjee, Nirmala, "Working Women in Colonial Bengal: Modernization and Marginalization", in Kumkum Sangari and Sudesh Vaid (eds.), Recasting Women: Essays in Indian Colonial History (New Brunswick, N. J.: Rutgers University Press, 1990), pp. 269-301.

Banga, I., Ports and their Hinterlands in India, 1700-1970 (New Delhi: Manohar, 1992).

Benjamin, N., "Bombay's 'Country Trade' with China (1765-1865)", Indian Historical Review, 1, 2 (1974), pp. 295-303. 
Barendse, R. J., "Reflections on the Arabian Seas in the Eighteenth Century", Itinerario, 25, 1 (2001), pp. 25-49.

Barnes, Ruth, Indian Block-Printed Textiles in Egypt: The Newberry Collection in the Ashmolean Museum, Oxford, 2 vols. (Oxford: Clarendon Press, 1997).

Barnes, Ruth (ed.), Textiles in Indian Ocean Societies (London: Routledge, 2005).

Barnes, Ruth, "Indian Textiles for Island Taste: The Trade to Eastern Indonesia", in Rosemary Crill (ed.), Textiles from India. The Global Trade (Oxford and Calcutta: Seagull, 2006), pp. 99-116.

Barthes, Roland, The Fashion System, trans. Matthew Ward and Richard Howard (New York: Hill and Wang, 1983).

Baskes, Jeremy, Indians, Merchants, and Markets: A Reinterpretation of the 'Repartimiento' and Spanish-Indian Economic Relations in Colonial Oaxaca, 1750-1821 (Stanford, Ca.: Stanford University Press, 2000).

Basu, D. K., (ed.), The Rise and Growth of the Colonial Port Cities in Asia (Berkeley, Ca.: Lanham, University Press of America, 1985).

Baumgarten, Linda, What Clothes Reveal: The Language of Clothing in Colonial and Federal America (New Haven and London: Yale University Press and The Colonial Williamsburg Foundation, 2002).

Bauss, Rudy, "A Legacy of British Free Trade Policies: The End of the Trade and Commerce between India and the Portuguese Empire, 1780-1830", Calcutta Historical Journal, 6, 2 (1982), pp. 81-115.

Bayly, C. A., Rulers, Townsmen and Bazaars. North Indian Society in the Age of British Expansion, 1770-1870 (Cambridge: Cambridge University Press, 1983).

Bayly, C. A., Indian Society and the Making of the British Empire (Cambridge: Cambridge University Press, 1988).

Bayly, C. A., Sven Beckert, Matthew Connelly, Isabel Hofmeyr, Wendy Kozol, and Patricia Seed, "Conversation: On Transnational History", American Historical Review, 111, 5 (2006), pp. 1141-64.

Bean, Susan S., "The American Market for Indian Textiles, 1785-1820: in the Twilight of Traditional Cloth Manufacture", in Textiles in Trade (Washington, D.C.: Proceedings of the Textile Society of America Biennial Symposium, 1990), pp. $43-52$.

Benjamin, B. S., The World of 'Rozome': Wax-Resist Textiles of Japan (Tokyo: Kodansha International, 1996).

Bennison, Amira K., "Muslim Universalism and Western Globalization", in A. G. Hopkins (ed.), Globalization in World History (London: Pimlico, 2002), pp. $74-97$.

Berg, Maxine, "Manufacturing the Orient. Asian Commodities and European Industry, 1500-1800", in Simonetta Cavaciocchi (ed.), Prodotti e tecniche d'oltremare nelle economie europee. Secc. XIII-XVIII. Atti della ventinovesima settimana di studi, 14-19 aprile 1997 (Florence: Le Monnier, 1998), pp. 385-419.

Berg, Maxine, "From Imitation to Invention: Creating Commodities in EighteenthCentury Britain", Economic History Review, 55, 1 (2002), pp. 1-30.

Berg, Maxine, "Asian Luxuries and the Making of the European Consumer Revolution", in Maxine Berg and Elizabeth Eger (eds.), Luxury in the Eighteenth Century: Debates, Desires and Delectable Goods (London: Palgrave, 2003), pp. 228-244.

Berg, Maxine, "Africans and the Industrial Revolution: Roundtable", International Journal of Maritime History, 15, 2 (2003), pp. 291-300.

Berg, Maxine, "In Pursuit of Luxury: Global History and British Consumer Goods in the Eighteenth Century", Past and Present, 82 (2004), pp. 85-142.

Berg, Maxine, Luxury and Pleasure in Eighteenth-Century Britain (Oxford: Oxford University Press, 2005).

Berg, Maxine, "Britain, Industry and Perceptions of China: Matthew Boulton, 'Useful Knowledge' and the Macartney Embassy to China, 1792-94", Journal of Global History, 1, 2 (2006), pp. 269-88. 
Beveridge, Sir William, Prices and Wages in England from the Twelfth to the Nineteenth Century (London: Macmillan, 1939).

Bhattacharya, Bhaswati, "The Chulia Merchants of Southern Coromandel in the Eighteenth Century: A Case for Continuity", in Om Prakash and Denys Lombard (eds.), Commerce and Culture in the Bay of Bengal, 1500-1800 (New Delhi: Manohar, 1999), pp. 285-305.

Bhila, H. H. K., Trade and Politics in a Shona Kingdom (Essex: Longman, 1982).

Bianchi, Marina (ed.), The Active Consumer: Novelty and Surprise in Human Choice (London: Routledge, 1998), pp. 64-86.

Birembaut, A., and G. Thuillier, "Une source inédite: Les cahiers du chimiste Jean Hellot”, Annales, Economies, Civilizations, 21 (1966), pp. 357-64.

Boomgaard, Peter, "Forest Management and Exploitation in Colonial Java, 1677-1897", in Helen Wheatley (ed.), Agriculture, Resource Exploitation, and Environmental Change (Aldershot and Brookfield, Vt.: Variorum, 1997), pp. 291-311.

Borpujari, Jitendra G., "The Impact of the Transit Duty System in British India", Indian Economic and Social History Review, 10, 3 (1973), pp. 218-41, reprinted in Asiya Siddiqi (ed.), Trade and Finance in Colonial India, 1750-1860 (Delhi: Oxford University Press, 1995), pp. 321-44.

Bose, Sugata, "Space and Time on the Indian Ocean Rim", in Leila Tarazi Fawaz and C. A. Bayly (eds.), Modernity \& Culture: From the Mediterranean to the Indian Ocean (New York: Columbia University Press, 2002), pp. 365-88.

Bose, Sugata, A Hundred Horizons: The Indian Ocean in the Age of Global Empire (Cambridge, Ma.: Harvard University Press, 2006).

Bowen, H. V., The Business of Empire: The East India Company and Imperial Britain, 1756-1833 (Cambridge: Cambridge University Press, 2006).

Boxer, Charles R., The Portuguese Seaborne Empire, 1415-1825 (London: Hutchinson, 1969).

Braudel, Fernand, The Mediterranean and the Mediterranean World in the Age of Philip II, trans. Siân Reynolds (New York: Harper \& Row, 1972).

Braudel, Fernand, Civilization and Capitalism 15th-18th Century; Vol. 1. The Structures of Everyday Life, trans. Siân Reynolds (New York: Harper \& Row, 1985).

Brennig, Josepth J., "Textile Producers and Production in Late Seventeenth Century Coromandel", Indian Economic and Social History Review, 23, 4 (1986), pp. 333-55, reprinted in Sanjay Subrahmanyam (ed.), Merchants, Markets and the State in Early Modern India (Delhi: Oxford University Press, 1990), pp. 66-89.

Bresnahan, Timothy F. and Robert J. Gordon (eds.), The Economics of New Goods (Chicago: Chicago Press, 1997).

Broadberry, Stephen and Bishnupriya Gupta, "The Early Modern Great Divergence: Wages, Prices and Economic Development in Europe and Asia, 1500-1800", Economic History Review, 59, 1 (2006), pp. 2-31.

Broadberry, Stephen and Bishnupriya Gupta, "Lancashire, India and Shifting Comparative Advantage in Cotton Textiles, 1700-1850: The Neglected Role of Factor Prices," Economic History Review, 62, 2 (2009), pp. 279-305.

Brett, K. B., "The Flowering Tree in Indian Chintz", Journal of Indian Textile History, 3 (1957), pp. 45-56.

Brett, K. B., "The Japanese Style in Indian Chintz Design", Journal of Indian Textile History, 5 (1960), pp. 42-49.

Brimnes, Niels, Constructing the Colonial Encounter (Richmond: Curzon Press, 1999).

Broeze, Frank (ed.), Brides of the Sea: Port Cities of Asia from the Sixteenth to the Twentieth Centuries (Honolulu: University of Hawaii Press, 1989).

Broeze, Frank (ed.), Gateways of Asia: Port Cities of Asia in the 13th-20th Centuries (London and New York: Kegan Paul International, 1996).

Brook, Timothy, The Confusions of Pleasure: Commerce and Culture in Ming China (Berkeley: University of California Press, 1998). 
Brunello, Franco, The Art of Dyeing in the History of Mankind, trans. B. Hickey (Vicenza: Neri Pozza, 1973).

Bulbeck, David, Anthony Reid, Lay-Cheng Tan and Yiqi Wu, Southeast Asian Exports since the 14th Century: Cloves, Pepper, Coffee and Sugar (Singapore: ISEAS for ECHOSEA 1998).

Bülher, Alfred, "Dyeing among Primitive Peoples", Ciba Review, 68 (1948), pp. 2497-535.

Bulley, Anne, The Bombay Country Ships, 1790-1833 (Richmond: Curzon, 2000).

Burke, Peter, "Res et Verba: Conspicuous Consumption in the Early Modern World", in John Brewer and Roy Porter (eds.), Consumption and the World of Goods (London: Routledge, 1993), pp. 148-61.

Burton, Antoinette (ed.), Gender, Sexuality and Colonial Modernities (London: Routledge, 1999).

Butel, Paul, "French Traders and India at the End of the Eighteenth Century", in Sushil Chaudhuri and Michel Morineau (eds.), Merchants, Companies and Trade: Europe and Asia in the Early Modern Era (Cambridge: Cambridge University Press and Maison des Sciences de l'Homme, 1999), pp. 287-99.

Carreira, Ernestine (ed.), Sources européennes sur le Gujarat (Paris: Société d'Histoire de l'Orient \& L'Harmattan, 1998).

Chandavarkar, Raj, The Origins of Industrial Capitalism in India: Business Strategies and the Working Classes in Bombay, 1900-40 (New York: Cambridge University Press, 1994).

Chao, Kang, The Development of Cotton Textile Production in China (Cambridge, Ma.: Harvard University Press, 1977).

Chapman, Stanley D., The Cotton Industry in the Industrial Revolution (London: Macmillan, 1972).

Chapman, Stanley D., "Quality versus Quantity in the Industrial Revolution: The Case of Textile Printing", Northern History, 21 (1985), pp. 175-92.

Chapman, Stanley D. and Serge Chassagne, European Textile Printers in the Eighteenth Century (London: Heinemann Educational and the Pasold Research Fund, 1981).

Chassagne, Serge, "Calico Printing in Europe before 1780", in David Jenkins (ed.), The Cambridge History of Western Textiles, 2 vols. (Cambridge: Cambridge University Press, 2003), vol. 1, pp. 513-27.

Chaudhuri, K. N., The English East India Company: The Study of an Early Joint-Stock Company 1600-40 (London: Frank Cass, 1965).

Chaudhuri, K. N., "Introduction", in K. N. Chaudhuri (ed.), The Economic Development of India under the East India Company, 1814-58 (Cambridge: Cambridge University Press, 1971).

Chaudhuri, K. N., "The Structure of Indian Industry in the Seventeenth and Eighteenth Centuries", Indian Economic and Social History Review, 9, 2-3 (1974), pp. 127-82.

Chaudhuri, K. N., The Trading World of Asia and the English East India Company 1660-1760 (Cambridge: Cambridge University Press, 1978).

Chaudhuri, K. N., "Some Reflections on the World Trade of the XVIIth and XVIIIth Century: A Reply", Journal of European Economic History, 7, 1 (1978), pp. 223-31.

Chaudhuri, K. N., Trade and Civilisation in the Indian Ocean: An Economic History from the Rise of Islam to 1750 (Cambridge: Cambridge University Press, 1985).

Chaudhuri, K. N., Asia Before Europe. Economy and Civilisation of the India Ocean from the Rise of Islam to 1750 (Cambridge: Cambridge University Press, 1990).

Chaudhuri, K. N., "The Structure of Indian Textile Industry in the Seventeenth and Eighteenth Centuries", in Tirthankar Roy (ed.), Cloth and Commerce: Textiles in Colonial India (New Delhi: Sage, 1996), pp. 33-84.

Chaudhury Sushil, From Prosperity to Decline: Eighteenth Century Bengal (New Delhi: Manohar, 1995).

Chaudhuri, Sushil, "International Trade in Bengal Silk and The Comparative Role of Asians and Europeans, c. 1700-57", Modern Asian Studies, 29, 2 (1995), pp. 373-86. 
Chaudhuri, Sushil and Michel Morineau (eds.), Merchants, Companies and Trade: Europe and Asia in the Early Modern Era (Cambridge: Cambridge University Press, 1999).

Cheong, Weng Eang, The Hong Merchants of Canton: Chinese Merchants in Sino-Western Trade (Richmond: Curzon, 1997).

Chenciner, Robert, Madder Red: A History of Luxury and Trade (London: Routledge/ Curzon, 2000).

Chicherov, A. I., India: Economic Development in the 16th-18th Centuries (Moscow: Moscow Publishing House, 1971).

Chittick, Neville H., "East African Trade with the Orient", in Donald S. Richards (ed.), Islam and the Trade of Asia. A Colloquium (Oxford: Bruno Cassirer, 1970), pp. 97-104.

Chung, Tan, "The British-China-India Trade Triangle (1771-1840)", Indian Economic and Social History Review, 11, 4 (1974), pp. 411-31.

Cissoko, S. M., "The Songhay from the 12th to the 16th Century", in Djibril Tamsir Niane (ed.), General History of Africa; IV. Africa from the Twelfth to the Sixteenth Century (London, Berkeley and Paris: Henemann, University of California Press and Unesco, 1984), pp. 187-210.

Clayton, Tim, The English Print 1688-1802 (New Haven: Yale University Press, 1997).

Clodd, H. P., Malaya's First British Pioneer: The Life of Francis Light (London: Luzac \& Co, 1948).

Clunas, Craig, Superfluous Things: Material Culture and Social Status in Early Modern China (Cambridge: Polity Press, 1991).

Clunas, Craig, "Modernity Global and Local: Consumption and the Rise of the West", American Historical Review, 104, 5 (1999), pp. 1497-1511.

Cohen, Steven, "The Unusual Textile Trade between India and Sri Lanka: Block-prints and Chintz, 1550-1900", in Rosemary Crill (ed.), Textiles from India. The Global Trade (Oxford and Calcutta: Seagull, 2006), pp. 56-80.

Cole, Charles Woolsey, French Mercantilist Doctrines before Colbert (New York: Richard R. Smith Inc., 1931).

Cole, Charles Woolsey, Colbert and a Century of French Mercantilism, 2 vols. (New York: Colombia University Press, 1939).

Cole, Charles Woolsey, French Mercantilism 1683-1700 (New York: Colombia University Press, 1943).

Coleman, Donald. C., "Proto-Industrialization: A Concept too Many", Economic History Review, 36, 3 (1983) pp. 435-48.

Connell, R. W., "The Big Picture: Masculinity in Recent World History", Theory and Society, 22, 5 (1993), pp. 597-623.

Coquery, Natacha, "The Language of Success: Marketing and Distributing Semi-luxury Goods in Eighteenth-Century Paris", Journal of Design History, 17, 1 (2004), pp. 71-89.

Cowan, Brian, The Social Life of Coffee: The Emergence of the British Coffeehouse (New Haven and London: Yale University Press, 2005).

Cowan, C. D. (ed.), "Early Penang and the Rise of Singapore: A Selection of the Manuscript Records of the East India Company over the Period 1805-32", Journal of the Malayan Branch of the Royal Asiatic Society, 23, 2 (1950), pp. 193-203.

Crafts, N. F. R., British Growth during the Industrial Revolution (Oxford: Clarendon, 1985).

Crafts, N. F. R. and C. Knick Harley, "Output Growth and the British Industrial Revolution: A Restatement of the Crafts-Harley View", Economic History Review, 45, 4 (1992), pp. 703-30.

Crill, Rosemary (ed.), Textiles from India. The Global Trade (Oxford and Calcutta: Seagull, 2006).

Crowley, John E., "The Sensibility of Comfort", American Historical Review, 104, 3 (1999), pp. 749-82. 
Cuenca Esteban, Javier, "British Textile Prices, 1770-1831: A Comment on the CraftsHarley View of the Industrial Revolution", Economic History Review, 46, 1 (1994), pp. 66-105.

Cuenca Esteban, Javier, "Further Evidence of Falling Prices of Cotton Cloth, 17681816", Economic History Review, 47, 1 (1995), pp. 145-50.

Curtin, Philip, Cross-cultural Trade in World History (Cambridge: Cambridge University Press, 1984).

Daaku, Kwame Yeboa, Trade and Politics on the Gold Coast, 1600-1720: A Study of the African Reaction to European Trade (Oxford: Clarendon Press, 1970).

Dale, Stephen Frederic, Indian Merchants and Eurasian trade, 1600-1750 (Cambridge: Cambridge University Press, 1994).

Daniels, George, The Early English Cotton Industry (Manchester: Manchester University Press, 1920).

Das Gupta, Ashin, "The Merchants of Surat, c. 1700-50", in Edmund Leach and S. N. Mukherjee (eds.), Elites of South Asia (Cambridge: Cambridge University Press, 1970), pp. 201-22.

Das Gupta, Ashin, Indian Merchants and the Decline of Surat, c.1700-50 (Wiesbaden: Franz Steiner Verlag, 1979).

Das Gupta, Ashin, "Gujarati Merchants and the Red Sea Trade, 1700-25", in Blair B. Kling, and M. N. Pearson (eds.), The Age of Partnership: Europeans in Asia before Domination (Honolulu: The University of Hawaii, 1979), pp. 123-58.

Das Gupta, Ashin, and Michael N. Pearson (eds.), India and the Indian Ocean 15001800 (Calcutta: Oxford University Press, 1987).

Das Gupta, Uma (ed.), The World of the Indian Ocean Merchant, 1500-1800: Collected Essays of Ashin Das Gupta (New Delhi: Oxford University Press, 2001).

Davison, Patricia and Patrick Harries, "Cotton Weaving in South-East Africa: Its History and Technology", in Dale Idiens and K. G. Ponting (eds.), Textiles of Africa (Bath: Pasold Research Fund, 1980), pp. 175-92.

Dean, Warren, With Broadax and Firebrand: The Destruction of the Brazilian Atlantic Forest (Berkeley: University of California Press, 1995).

Deloche, Jean, Transport and Communications in India prior to Steam Locomotion (Delhi: Oxford University Press, 1993).

De Marchi, Neil and Craufurd D. W. Goodwin (eds.), Economic Engagements with Art (Durham, NC: Duke University Press, 1999), pp. 379-412.

Desai, Ashok V., "Population and Standards of Living in Akbar's Time", Indian Economic and Social History Review, 9, 1 (1972), pp. 43-62.

Desai, Ashok V., "Population and Standards of Living in Akbar's Time: A Second Look", Indian Economic and Social History Review, 15, 1 (1978), pp. 1-19.

Dewey, Clive, "Images of the Village Community: A Study in Anglo-Indian Ideology", Modern Asian Studies, 6, 3 (1972), pp. 291-328.

Dewey, Clive (ed.), Arrested Development in India: The Historical Dimension (New Delhi: Manohar, 1988).

Deyan, Guo, "The Study of Parsee Merchants in Canton, Hong Kong, and Macao", Review of Culture (International Edition), 8 (2003), pp. 51-69.

Dike, Kenneth Onwuka, and Felicia Ekejiuba, The Aro of South-eastern Nigeria, 16501980: A Study of Socio-Economic Formation and Transformation in Nigeria (Ibadan: University Press, 1990).

Disney, Anthony R., Twilight of the Pepper Empire: Portuguese Trade in Southwest India in the Early Seventeenth Century (Cambridge, Ma.: Harvard University Press, 1978).

do Amaral Lapa, José Roberto, "Dimensões do Comercio Colonial o Brasil e o Oriente", Studia, 49 (1989), pp. 379-96.

Dornbusch, Rudiger, Stanley Fischer, and Paul A. Samuelson, "Comparative Advantage, Trade, and Payments in a Ricardian Model with a Continuum of Goods", American Economic Review, 67 (1977), pp. 823-39. 
dos Santos Alves, Jorge M., Claude Guillot, and Roderich Ptak (eds.), Mirabilia Asiatica, 2 vols. (Wiesbaden and Lisbon: Harrassowitz Verlag and Fundação Oriente, 2005).

Douglas, Audrey W., "Cotton Textiles in England: The East India Company's Attempts to Exploit Developments in Fashion 1660-1721", Journal of British Studies, 8, 2 (1969), pp. 28-43.

DuPlessis, Robert, "Cottons Consumption in the Seventeenth- and Eighteenth-Century North Atlantic", in Giorgio Riello and Prasannan Parthasarathi (eds.), The Spinning World: A Global History of Cotton Textiles, 1200-1850 (Oxford: Oxford University Press, 2009), pp. 227-46.

Dutt, Romesh, The Economic History of India; Vol. 1. Under Early British Rule (London: Routledge, 2nd edn. [1990] 1906).

Eaton, Natasha, "Between Mimesis and Alterity: Art, Gift and Diplomacy in Colonial India, 1770-1800", Comparative Studies in Society and History 46, 4 (2004), pp. 816-44.

Edmonds, John, The History and Practice of Eighteenth Century Dyeing (Little Chalfont: John Edmunds, 2002).

Edwards, Michael, M., The Growth of the British Cotton Trade 1780-1815 (Manchester: Manchester University Press, 1969).

Eltis, David, and Lawrence C. Jennings, "The Trade between Western Africa and the Atlantic World in the Pre-colonial Era", American Historical Review, 93, 4 (1988), pp. 936-59.

Eltis, David, "Trade between Western Africa and the Atlantic World Before 1870: Estimates of Trends in Value, Composition and Direction", Research in Economic History, 12 (1989), pp. 197-239.

Eltis, David, The Rise of African Slavery in the Americas (Cambridge: Cambridge University Press, 2000).

Emmer, Pieter, "The Myth of Early Globalization: The Atlantic Economy, 1500-1800", European Review, 11, 1 (2003), pp. 37-47.

Fage, John D., "Some Remarks on Beads and Trade in Lower Guinea in the 16th and 17th Centuries", Journal of African History, 3, 2 (1962), pp. 343-47.

Fage, John D., A History of Africa (London: Hutchinson 1978).

Fair, Laura, "Dressing Up: Clothing, Class and Gender in Post-Abolition Zanzibar", Journal of African History, 39, 1 (1998), pp. 63-94.

Faroqhi, Suraiya, "Alum Production and Alum Trade in the Ottoman Empire (About 1560-1830)", Wiener Zeitschrift für die Kunde des Morgenlandes, 71 (1979), pp. $153-75$.

Farnie, Douglas A. and David J. Jeremy (eds.), The Fibre that Changed the World: The Cotton Industry in International Perspective, 1600-1990s (Oxford and New York: Oxford University Press, 2004).

Farnie, Douglas A., "The Role of Merchants as Prime Movers in the Expansion of the Cotton Industry, 1760-1990", in Douglas A. Farnie and David J. Jeremy (eds.), The Fibre that Changed the World: The Cotton Industry in International Perspective, 1600-1990s (Oxford and New York: Oxford University Press, 2004), pp. 15-55.

Farrington, Farrington (ed.), Catalogue of East India Company Ships' Journals and Logs (London: British Library, 1999).

Feldbæk, Ole, "The Danish Trading Companies of the Seventeenth and Eighteenth Centuries", Scandinavian Economic History Review, 34, 3 (1986), pp. 204-18.

Ferrier, R. W., "The Trade between India and the Persian Gulf and the East India Company in the 17th Century", Bengal Past and Present, 89, 1 (1970), pp. 189-98.

Fine, Ben and Ellen Leopold, The World of Consumption (London: Routledge, 1993).

Finn, Margot, "Men's Things: Masculine Possession in the Consumer Revolution", Social History, 25, 2 (2000), pp. 133-55.

Finnane, Antonia, "What Should Chinese Women Wear? A National Problem", Modern China, 22, 2 (1996), pp. 99-131. 
Finnane, Antonia, "Yangzhou's 'Modernity': Fashion and Consumption in the Early Nineteenth Century", Positions, 11, 2 (2003), pp. 395-425.

Fitton, R. S. and A. P. Wadsworth, The Strutts and the Arkwrights 1758-1830 (Manchester: Manchester University Press, 1958).

Fleet, Kate, European and Islamic Trade in the Early Ottoman State: The merchants of Genoa and Turkey (Cambridge: Cambridge University Press, 1999).

Floor, Willem, The Persian Textile Industry in Historical Perspective, 1500-1925 (Paris: L'Harmattan and Société d'Histoire de l'Orient, 1999).

Fortune, Brandon Brame with Deborah J. Warner, Franklin and His Friends: Portraying the Man of Science in Eighteenth-Century America (Philadelphia: University of Philadelphia Press, 1999).

Fox, Robert (ed.), Technological Change: Methods and Themes in the History of Technology (Amsterdam and London: Harwood Academic, 1996).

Fox, Robert and Augusti Nieto-Galan (eds.), Natural Dyestuffs and Industrial Culture in Europe, 1750-1880 (Canton, Ma.: Science History Publications, 1999).

Furber, Holden, John Company at Work (Cambridge, Ma: Harvard University Press, 1948).

Furtado, C., Formação Económica do Brasil (São Paulo, Brazil: Companhia Editora Nacional, 1980).

Fortune, Brandon Brame, “Studious Men are Always Painted in Gowns': Charles Wilson Peale's Benjamin Rush and the Question of Banyans in Eighteenth-Century Anglo-American Portraiture", Dress, 29 (2002), pp. 27-40.

Fradera, Joseph M., "The Historical Origins of the Philippine Economy", Australian Economic History Review, 44, 3 (2004), pp. 307-20.

Furuta, Kazuko, "Kobe Seen as Part of the Shanghai Trading Network: The Role of Chinese Merchants in the Re-export of Cotton Manufactures to Japan", in Kaoru Sugihara (ed.), Japan, China and the Growth of the Asian International Economy, 1850-1949 (Oxford: Oxford University Press, 2005), pp. 23-48.

Fynn, John Kofi, Asante and its Neighbours 1700-1807 (Evanston, Il.: Northwestern University Press, 1971).

Gaastra, Femme S., "The Textile Trade of the VOC: The Dutch Response to the English Challenge", South Asia, 19, Special Issue (1996), pp. 85-95.

Gaastra, Femme S., "War, Competition and Collaboration: Relations between the English and Dutch East India Company in the Seventeenth and Eighteenth Centuries", in Huw V. Bowen, Margarette Lincoln, and Nigel Rigby (eds.), The Worlds of the East India Company (Woodbridge: Boydell Press, 2002), pp. 49-68.

Gabaccia, Donna, "A Long Atlantic in a Wider World", Atlantic Studies, 1, 1 (2004), pp. 1-27.

Gemery, Henry A. and Jan S. Hogendorn, "Technological Change, Slavery, and the Slave Trade," in Clive Dewey and A. G. Hopkins (eds.), The Imperial Impact: Studies in the Economic History of Africa and India (London: The Athlone Press, 1978), pp. 243-58.

Geijer, Agnes, Oriental Textiles in Sweden (Copenhagen: Rosenkilde and Bagger, 1951).

Gittinger, Mattiebelle, Master Dyers to the World: Technique and Trade in Early Indian Dyed Cotton Textiles (Washington, D.C.: The Textile Museum, 1982).

Glamann, Kristof, Dutch-Asiatic Trade, 1620-1740 (The Hague: Martinus Nijhoff, 1958).

Glamann, Kristof, “The Danish Asiatic Company, 1732-71”, Scandinavian Economic History Review, 8, 2 (1960), pp. 125-49.

Glassman, Jonathan, Feasts and Riot: Revelry, Rebellion, and Popular Consciousness on the Swahili Coast, 1856-1888 (Portsmouth, NH: Heinemann, 1995).

Goitein, S. D., "Letters and Documents on the India Trade in Medieval Times", Islamic Culture, 37, 3 (1963), pp. 188-205. 
Goitein, S. D., A Mediterranean Society: The Jewish Communities of the Arab World as Portrayed in the Documents of the Cairo Geniza; Vol. IV. Daily Life (Berkeley, Ca.: University of California Press, 1983).

Goody, Jack, The Culture of Flowers (Cambridge: Cambridge University Press, 1993).

Goody, Jack, The East in the West (Cambridge: Cambridge University Press, 1996).

Gopal, Surendra, Commerce and Crafts in Gujarat, 16th and 17th Centuries: A Study in the Impact of European Expansion on a Pre-capitalist Economy (New Delhi: People's Publishing House, 1975).

Gordon, Stewart (ed.), Robes of Honour. Khil'at in Pre-Colonial and Colonial India (New Delhi: Oxford University Press, 2003).

Gough, Kathleen, Rural Society in South-east India (Cambridge: Cambridge University Press, 1981).

Greenberg, Michael, British Trade and the Opening of China, 1800-42 (Cambridge: Cambridge University Press, 1951).

Greenfield, Kent Roberts, Sumptuary Law in Nürmberg: A Study in Paternal Government (Baltimore: Johns Hopkins University, 1918).

Griffith, Trevor, Phillip Hunt and Patrick K. O'Brien, "Scottish, Irish, and Imperial Connections: Parliament, the Three Kingdoms, and the Mechanization of Cotton Spinning in Eighteenth-Century Britain," Economic History Review, 61/3 (2008), pp. 625-50.

Guha, Sumit, "Potentates, Traders and Peasants: Western India, c.1700-1870", in Burton Stein and Sanjay Subrahmanyam (eds.), Institutions and Economic Change in South Asia (Oxford: Oxford University Press, 1996), pp. 71-84.

Guha, Sumit, Health and Population in India: From the Earliest Times to the Present (London: Hurst, 2001).

Gunder Frank, André, ReOrient: Global Economy in the Asian Age (Berkeley and Los Angeles: University of California Press, 1998).

Guy, John, "Sarasa and Patola: Indian Textiles in Indonesia", Orientations, 20, 1 (1989), pp. 48-60.

Guy, John, Woven Cargoes: Indian Textiles in the East (London: Thames and Hudson, 1998).

Habib, Irfan, The Agrarian System of Mughal India, 1556-1707 (Bombay: Asia, 1963).

Habib, Irfan, "Potentialities of Capitalistic Development in the Economy of Mughal India", Journal of Economic History, 29, 1 (1969), pp. 32-78.

Habib, Irfan, "The Technology and Economy of Mughal India", Indian Economic and Social History Review, 17, 1 (1980), pp. 1-34.

Habib, Irfan, "Monetary System and Prices", in Tapan Raychaudhuri and Irfan Habib (eds.), The Cambridge Economic History of India; Vol. I. 1200-1750 (Cambridge: Cambridge University Press, 1982), pp. 360-81.

Hall, Catherine, Civilising Subjects: Colony and Metropole in the English Imagination, 1830-67 (Chicago: University of Chicago Press, 2002).

Hall, Kenneth, Maritime Diasporas in the Indian Ocean and East and South-East Asia (Leiden: Brill, 2006).

Harley, C. Knick, "Cotton Textile Prices and the Industrial Revolution", Economic History Review, 51, 1 (1998), pp. 49-83.

Harley, C. Knick and N. R. F. Crafts, "Cotton Textiles and Industrial Output Growth during the Industrial Revolution", Economic History Review, 48, 1 (1995), pp. 134-44.

Haller, R., "The Chemistry and Technique of Turkey Red Dyeing", Ciba Review, 39 (1941), pp. 1417-21.

Haller, R., "Turkey Red Dyeing in South and South East Asia", Ciba Review, 39 (1941), pp. 1423-26.

Hanson, J. R. II, Trade in Transition: Exports from the Third World, 1840-1900 (New York: Academic Press, 1980). 
Harte, Negley B., "The Rise of Protection and the English Linen Trade, 1690-1790", in Negley B. Harte and Kenneth G. Ponting (eds.), Textile History and Economic History (Manchester: Manchester University Press, 1973), pp. 75-112.

Hartkamp-Jonxis, Ebeltje (ed.), SITS: Oost-West Relaties in Textiel (Zwolle: Waanders, 1987).

Hartkamp-Jonxis, Ebeltje, Sitsen uit India (Amsterdam: Rijksmuseum, 1994).

Haudrère, Philippe, La Compagnie française des Indes au XVIIIe siècle (1719-95), 4 vols. (Paris: Librarie de l'Inde, 1989).

Haudrère, Philippe, "La Compagnie française des Indes, 1719-95", L'Information Historique, 51 (1989), pp. 1-11.

Haudrère, Philippe and Gérard Bouëdec, Les compagnies des Indes (Rennes: Ouest France, 1999).

Heston, Alan, "Review of Shireen Moosvi, The Economy of the Mughal Empire c. 1595: A Statistical Study", Economic History Review, 41, 4 (1988), p. 671.

Heston, Alan, "Review of Shireen Moosvi, The Economy of the Mughal Empire c. 1595: A Statistical Study", Economic History Review, 41, 4 (1988), pp. 671-72.

Hofenk de Graaff, J. H., "De techniek van sits en katoendruk", in E. Hartkamp-Jonxis (ed.), SITS: Oost-West Relaties in Textiel (Zwolle: Waanders, 1987), pp. 30-41.

Hopkins, Anthony G., An Economic History of West Africa (Harlow, Essex: Longman, 1973).

Hopkins, D., The Art of the Dyer 1500-1700 (Bristol: Stuart Press, 2000).

Hoppe, Fritz, A África Oriental Portuguesa no Tempo do Marquês de Pombal (1750-77) (Lisbon: Agência-Geral do Ultramar, 1970).

Horton, Mark and John Middleton, The Swahili (Oxford: Blackwell, 2001).

Horden, Peregrine and Nicholas Purcell, The Corrupting Sea: A Study of Mediterranean History (Oxford: Blackwell, 2000).

Hossain, Hameeda, "The Alienation of Weavers: Impact of Conflict between Revenue and Commerical Interests of the East India Company, 1750-1800", Indian Economic and Social History Review, 16, 3 (1979), pp. 323-45.

Hossain, Hameeda, The Company Weavers of Bengal: The East India Company and the Organization of Textile Production in Bengal 1750-1813 (Delhi: Oxford University Press, 1988).

Hunt, Alan, Governance of the Consuming Passions: A History of Sumptuary Law (Basingstoke: Macmillan, 1996).

Hunwick, John O., Timbuktu and the Songhay Empire: Al-Sadi's Ta'rikh al-sudan down to 1613 and other Contemporary Documents (Leiden: Brill, 1999).

Hussin, Nordin, Trade and Society: Dutch Melaka and English Penang, 1780-1830 (Singapore: NUS Press, 2007).

Iliffe, John, The Emergence of African Capitalism (Minneapolis: University of Minnesota Press, 1983).

Inikori, Joseph E. (ed.), Forced Migration: The Impact of the Export Slave Trade on African Societies (London and New York: Hutchinson and Africana, 1982).

Inikori, Joseph E., "West Africa’s Seaborne Trade, 1750-1850: Volume, Structure and Implications," in Gerhard Liesegang, Helma Pasch and Adam Jones (eds.), Figuring African Trade: Proceedings of the Symposium on the Quantification and Structure of the Import and Export and Long Distance Trade in Africa, 1800-1913 (Berlin: Dietrich Reimer Verlag, 1986), pp. 49-88.

Inikori, Joseph E., "Slavery and the Revolution in Cotton Textile Production in England", Social Science History, 13, 4 (1989), pp. 343-79.

Inikori, Joseph E., "Export Versus Domestic Demand: The Determinants of Sex Ratios in the Transatlantic Slave Trade", Research in Economic History, 14 (1992), pp. 111-59.

Inikori, Joseph E., Africans and the Industrial Revolution in England: A Study in International Trade and Economic Development (Cambridge: Cambridge University Press, 2002). 
Inikori, Joseph E., "The Development of Entrepreneurship in Africa: Southeastern Nigeria during the Era of the Trans-Atlantic Slave Trade", in Alusine Jalloh and Toyin Falola (eds.), Black Business and Economic Power (Rochester, NY: University of Rochester Press, 2002), pp. 41-79.

Inikori, Joseph E., "Africa and the Globalization Process: Western Africa, 1450-1850", Journal of Global History, 2, 1 (2007), pp. 63-86.

Inikori, Joseph E., "Transatlantic Slaving and Market Development in the Atlantic World: West Africa, 1450-1850", in David Eltis and Stanley L. Engerman (eds.), The Cambridge World History of Slavery; Vol. 3. AD 1420-AD 1804 (Cambridge: Cambridge University Press, forthcoming 2009).

Irwin, John, "Indian Textile Trade in the Seventeenth Century: (1) Western India", Journal of Indian Textile History, 1 (1955), pp. 5-33.

Irwin, John, "Indian Textile Trade in the Seventeenth Century: (2) Coromandel Coast", Journal of Indian Textile History, 2 (1956), pp. 24-42.

Irwin, John, "Indian Textile Trade in the Seventeenth Century: (3) Bengal", Journal of Indian Textile History, 3 (1957), pp. 59-74.

Irwin, John, "Indian Textile Trade in the Seventeenth Century: (4) Foreign Influences", Journal of Indian Textile History, 4 (1959), pp. 69-76.

Irwin, John, and Paul R. Schwartz, Studies in Indo-European Textile History (Ahmedabah: Calico Museum of Textiles, 1966).

Isaacman, Allen F., Mozambique: The Africanization of a European Institution (Madison: University of Wisconsin Press, 1972).

Jenkins, David (ed.), The Cambridge History of Western Textiles, 2 vols. (Cambridge: Cambridge University Press, 2003).

Jeremy, David J., Transatlantic Industrial Revolution: The Diffusion of Textile Technologies between Britain and America, 1790-1830s (Cambridge, Ma.: MIT Press, 1981).

Johansen, Jens Christian V., Erling Ladewig Petersen and Henrik Stevnborg (eds.), Clashes of Cultures: Essays in Honour of Niels Steensgaard (Odense: Odense University Press, 1992).

Johnson, Marion, "The Cowrie Currencies of West Africa: Part I", Journal of African History, 11, 1 (1970), pp. 17-49.

Johnson, Marion, "The Cowrie Currencies of West Africa: Part II", Journal of African History, 11, 3 (1970), pp. 331-53.

Johnson, Marion, "Technology, Competition, and African Crafts", in Clive Dewey and Anthony G. Hopkins (eds.), The Imperial Impact: Studies in the Economic History of Africa and India (London: The Athlone Press, 1978), pp. 259-69.

Jong Boers, B. de, "Sustainability and Time Perspective in Natural Resource Management: The Exploitation of Sappan Trees in the Forests of Sumbawa, Indonesia, 1500-1875”, in Peter Boomgaard, Freek Colombijn and David Henley (eds.), Paper landscapes: Explorations in the Environmental History of Indonesia (Leiden: KITLV Press, 1997), pp. 261-80.

Juvet-Michel, A., "The Controversy over Indian Prints", Ciba Review, 31 (1940), pp. 1090-97.

Juvet-Michel, A., "The Great Textile Printing Factories in France", Ciba Review, 31 (1940), pp. 1098-1106.

Juvet-Michel, A., “The Technique of French Textile Printing”, Ciba Review, 31 (1940), pp. 1109-16.

Juvet-Michel, A., “The Patterns of the 'Toiles de Jouy”, Ciba Review, 31 (1940), pp. 1117-22.

Kaeppelin, Paul, La Compagnie des Indes Orientales et François Martin (Paris: Agustín Challamel, 1908).

Kathirithamby-Wells, Jeyamalar and John Villiers (eds.), Southeast Asian Port and Policy: Rise and Demise (Singapore: Singapore University Press, 1990).

Kato, Yuzo, "Shokuminchi Indo no Ahen Seisan, 1773-1830-nen" [Opium Production in Colonial India, 1773-1830], Toyo Bunka, 83 (1981), pp. 53-109. 
Kea, Ray A., Settlements, Trade, and Polities in the Seventeenth-Century Gold Coast (Baltimore: Johns Hopkins University Press, 1982).

Klein, Herbert S., The Atlantic Slave Trade (Cambridge: Cambridge University Press, 1999).

Kose, Hajime, "Foreign Trade, Internal Trade and Industrialization: A Statistical Analysis of Regional Commodity Flows in China, 1914-31", in Kaoru Sugihara (ed.), Japan, China and the Growth of the Asian International Economy, 1850-1949 (Oxford: Oxford University Press, 2005), pp. 198-213.

Kraan, Alfons van der, Contest for the Java Cotton Trade, 1811-40: An Episode in Anglo-Dutch Rivalry (Hull: Center for Southeast Asian Studies, University of Hull, 1998).

Kriedte, Peter, Peasants, Landlords and Merchant Capitalists: Europe and the World Economy, 1500-1800 (Leamington Spa, Warwickshire: Berg, 1983).

Kriger, Colleen E., "Textile Production in the Lower Niger Basin: New Evidence from the 1841 Niger Expedition Collection", Textile History, 21, 1 (1990), pp. 31-56.

Kriger, Colleen E., "Textile Production and Gender in the Sokoto Caliphate", Journal of African History, 34 (1993), pp. 361-401.

Kriger, Colleen E., Cloth in West African History (Lanham, MD: Altamira Press, 2006).

Krishn, Bala, Commercial Relations between India and England (1601-1757) (London: Routledge, 1926).

Krishnamurty, J., "Handicrafts in the Indian Economy: A Study of the Handloom Industry from 1800", in Aparna Basu (ed.), Imperialism, Nationalism and Regionalism in Canadian and Modern Indian History (New Delhi: Manohar, 1989), pp. 133-45.

Kumar, Dharma (ed.), The Cambridge Economic History of India; Vol. 2. c.1757-c.1970 (Cambridge: Cambridge University Press, 1983).

Kusamitsu, Toshio, "British Industrialisation and Design before the Great Exhibition", Textile History, 12 (1981), pp. 77-95.

Lancaster, Kelvin, Consumer Demand: A New Approach (New York: Columbia University Press, 1971).

Landes, David, The Unbound Prometheus: Technical Change and Industrial Development in Western Europe from 1750 to Present (Cambridge: Cambridge University Press, 1969).

Larson, Pier, History and Memory in the Age of Enslavement: Becoming Merina in Highland Madagascar, 1770-1822 (Portsmouth, NH: Heinemann, 2000).

Latham, Anthony J. H., "Currency, Credit and Capitalism on the Cross River in the Pre-colonial Era", Journal of African History, 12, 4 (1971), pp. 599-605.

Latham, Anthony J. H. and Kawakatsu, Heita (eds.), Japanese Industrialization and the Asian Economy (London: Routledge, 1994).

Law, Robin, "Trade and Politics behind the Slave Coast: The Lagoon Traffic and the Rise of Lagos, 1500-1800", Journal of African History, 24, 3 (1983), pp. 321-48.

Lemire, Beverly, Fashion's Favourite: The Cotton Trade and the Consumer in Britain, 1660-1800 (Oxford: Oxford University Press, 1991).

Lemire, Beverly, Dress, Culture and Commerce: the English Clothing Trade before the Factory (Basingstoke: Macmillan, 1997).

Lemire, Beverly, Ruth Pearson and Gail C. Campbell, (eds.), Women \& Credit: Researching the Past, Refiguring the Future (Oxford: Berg Publishers, 2002).

Lemire, Beverly, "Fashioning Cottons: Asian trade, Domestic Industry and Consumer Demand 1660-1780", in David Jenkins (ed.), The Cambridge History of Western Textiles (Cambridge University Press, Cambridge, 2003), vol. 1, pp. 493-512.

Lemire, Beverly, "Domesticating the Exotic: Floral Culture and the East India Calico Trade with England, c. 1600-1800", Textile: The Journal of Cloth and Culture, 1, 1 (2003), pp. 65-85.

Lemire, Beverly, The Business of Everyday Life: Gender, Practice and Social Politics in England, c. 1600-1900 (Manchester: Manchester University Press, 2006). 
Lemire, Beverly, "Revising the Historical Narrative: India, Europe and the Cotton Trade, c. 1300-1800", in Giorgio Riello and Prasannan Parthasarathi (eds.), The Spinning World: A Global History of Cotton Textiles, 1300-1850 (Oxford: Oxford University Press, 2009), pp. 205-26.

Lemire, Beverly and Giorgio Riello, "East and West: Textiles and Fashion in Early Modern Europe", Journal of Social History, 41, 4 (2008), pp. 887-916.

Levi, Scott C., "India, Russia and the Eighteenth-Century Transformation of the Central Asian Caravan Trade", Journal of the Economic and Social History of the Orient, 42, 4 (1999), pp. 519-48.

Levi, Scott C., The Indian Diaspora in Central Asia and Its Trade, 1550-1900 (Leiden: Brill, 2002).

Lieberman, Victor, Strange Parallels: Southeast Asia in Global Context, c.800-1830 (Cambridge: Cambridge University Press, 2003).

Liesegang, Gerhard, Helma Pasch and Adam Jones (eds.), Figuring African Trade: Proceedings of the Symposium on the Quantification and Structure of the Import and Export Long Distance Trade in Africa, 1800-1913 (Berlin: Dietrich Reimer Verlag, 1986).

Lin, Man-Houng, "China’s "Dual Economy" in International Trade Relations, 18421949", in Kaoru Sugihara (ed.), Japan, China and the Growth of the Asian International Economy, 1850-1949 (Oxford: Oxford University Press, 2005), pp. 179-97.

Lin, Man-Houng, China Upside Down: Currency, Society and Ideologies, 1808-56 (Cambridge, Ma.: Harvard University Press, 2006).

Linebaugh, Peter, The London Hanged: Crime and Civil Society in the Eighteenth Century (Cambridge: Cambridge University Press, 1992).

Lipovetsky, Gilles, The Empire of Fashion: Dressing Modern Democracy, trans. Catherine Porter (Princeton, N.J.: Princeton University Press, 1994).

Lobato, Alexandre, Evolução administrativa e economica de Moçambique 1752-63 (Lisbon: Agência Geral do Ultramar, 1957).

Lobato, Alexandre, História do Presídio de Lourenço Marques (1787-99), 2 vols. (Lisbon: Tipografia Minerva, 1960).

Lobato, Alexandre, A expansão Portuguêsa em Moçambique de 1498 a 1530, 3 vols. (Lisbon: Gráfica Boa Nova, 1960).

Lombard, Denys, "The Indian World as seen from Acheh in the Seventeenth Century", in Om Prakash and Denys Lombard (eds.), Commerce and Culture in the Bay of Bengal, 1500-1800 (New Delhi: Manohar, 1999), pp. 183-96.

Lombard, Denys and Jean Aubin (eds.), Asian Merchants and Businessmen in the Indian Ocean and the China Sea (New Delhi: Oxford University Press, 2000).

Long, Pamela O., Openness, Secrecy, Authorship: Technical Arts and the Culture of Knowledge from Antiquity to the Renaissance (Baltimore and London: Johns Hopkins University Press, 2001).

Lovejoy, Paul E., Caravans of Kola: The Hausa Kola Trade, 1700-1900 (Zaria: Ahmadu Bello University Press, 1980).

Ludden, David, "Presidential Address: Maps in the Mind and the Mobility of Asia", Journal of Asian Studies, 62, 4 (2003), pp. 1057-78.

Luu, Lien Bich, Immigrants and the Industries of London, 1500-1700 (Aldershot: Ashgate, 2005).

Machado, Pedro, "A Forgotten Corner of the Indian Ocean: Gujarati Merchants, Portuguese India and the Mozambique Slave Trade, c. 1730-1830", in Gwyn Campbell (ed.), The Structure of Slavery in Indian Ocean Africa and Asia (London: Frank Cass, 2004), pp. 17-32.

Machado, Pedro, "Awash in a Sea of Cloth: Gujarat, Africa and the Western Indian Ocean, 1300-1800", in Giorgio Riello and Prasannan Parthasarathi (eds.), The Spinning World: A Global History of Cotton Textiles, 1200-1850 (Oxford: Oxford University Press, 2009), pp. 161-79. 
MacLeod, Christine, Inventing the Industrial Revolution: The English Patent System, 1600-1800 (Cambridge: Cambridge University Press, 1988).

Maddison, Angus, The World Economy: A Millennial Perspective (Paris: Development Centre, OECD, 2001).

Maddison, Angus, The World Economy: Historical Statistics (Paris: Development Centre, OECD, 2003).

Manning, Catherine, Fortunes à Faire: The French in Asian Trade, 1719-48 (Aldershot: Variorum Publishing Ltd., 1996).

Manning, Patrick, Slavery and African Life: Occidental, Oriental, and African Slave Trades (Cambridge: Cambridge University Press, 1990).

Markovits, Claude, The Global World of Indian Merchants, 1750-1947: Traders of Sind from Bukhara to Panama (Cambridge: Cambridge University Press, 2000).

Martins do Vale, A.M., Os Portugueses em Macau (1750-1800) (Macau: Instituto Português do Oriente, 1997).

Martin, Phyllis, "Power, Cloth and Currency on the Loango Coast", African Economic History, 15 (1986), pp. 1-12.

Marshall, Peter J., "Economic and Political Expansion: The Case of Oudh", Modern Asian Studies, 9 (1975), pp. 465-82.

Marshall, Peter J., East Indian Fortunes. The British in Bengal in the Eighteenth Century (Oxford: Clarendon Press, 1976).

Marshall, Peter J., "Debate: Early British Imperialism in India", Past and Present, 106 (1985), pp. 164-69.

Marshall, Peter J., Bengal: The British Bridgehead. Eastern India 1740-1828 (Cambridge: Cambridge University Press, 1987).

Marks, Robert B., Tigers, Rice, Silk, and Silt: Environment and Economy in Late-Imperial South China (Cambridge: Cambridge University Press, 1998).

Mathew, K. S., Portuguese Trade with India in the Sixteenth Century (New Delhi: Manohar, 1983).

Matsumoto, Mutsuki, "Bengaru ni okeru Ejenshi Hausu no Keisei: Igirisu-kei Shiteki Shihon no Keisei Katei to Higashi Indo Kaisha, 1757-1800-nen" [The Formation of Agency Houses in Bengal: The Emergence of British and British-related Private Capital and the East India Company, 1757-1800], Keizaigaku Ronso, 32 (1983), pp. 156-218.

Maxwell, Robyn, Textiles of Southeast Asia: Tradition, Trade and Transformation (Melbourne: Oxford University Press, 1990).

Mazumdar, D., "Labour Supply in Early Industrialization: The Case of the Bombay Textile Industry", Economic History Review, 26, 3 (1973), pp. 477-96.

Mazumdar, Sucheta, Sugar and Society in China. Peasants, Technology, and the World Market (Cambridge, Ma.: Harvard University Asia Center, 1998).

McPherson, Kenneth, "Anglo-Portuguese Commercial Relations in the Eastern Indian Ocean from the Seventeenth to the Eighteenth Centuries", South Asia, 19, Special Issue (1996), pp. 41-57.

McPherson, Kenneth, The Indian Ocean: A History of People and the Sea (Delhi and Oxford: Oxford University Press, 1998).

Meilink-Roelofsz, Marie Antoinette Petronella, Asian Trade and European Influence in the Indonesian Archipelago: Between 1500 and About 1630 (The Hague: M. Nijhoff, 1962).

Mendels, Franklin, "Proto-industrialisation: Theory and Reality, General Report", in Eighth International Economic History Congress, Budapest, 1982, "A" Themes (Budapest: Akadémiai Kiadó, 1982), pp. 69-107.

Miller, Joseph C., Way of Death: Merchant Capitalism and the Angolan Slave Trade, 1730-1830 (Madison: University of Wisconsin Press, 1988).

Miller, Joseph C., "Imports at Luanda, Angola 1785-1823", in Gerhard Liesegang, Helma Pasch and Adam Jones (eds.), Figuring African Trade: Proceedings of the Symposium on the Quantification and Structure of the Import and Export Long 
Distance Trade in Africa, 1800-1913 (Berlin: Dietrich Reimer Verlag, 1986), pp. 163-246.

Mitra, Debendra B., The Cotton Weavers of Bengal 1757-1833 (Calcutta: Firma KLM, 1978).

Mizushima, Tsukasa, Nattar and Socio-Economic Change in South India in 18th and 19th Centuries (Tokyo: Tokyo University Press, 1986).

Mohanty, Bijoy Chandra, K. V. Chandramouli and H. D. Naik, Natural Dyeing Processes of India (Ahmedabad: Calico Museum of Textiles and Sarabhai Foundation, 1987).

Mokyr, Joel, "Technological Change, 1700-1830", in Roderick Floud and Donald McCloskey (eds.), The Economic History of Britain since 1700. Vol. 1, 1700-1860 (Cambridge: Cambridge University Press, 1981), pp. 12-44.

Mokyr, Joel, The Gifts of Athena: Historical Origins of the Knowledge Economy (Princeton: Princeton University Press, 2002).

Mokyr, Joel, "The Industrial Revolution", in Oxford Encyclopedia of Economic History, ed. Joel Mokyr (Oxford: Oxford University Press, 2003), vol. 3, pp. 49-56.

Mokyr, Joel, "Accounting for the Industrial Revolution", in Roderick Floud and Paul Johnson (eds.), The Cambridge Economic History of Modern Britain; Vol. 1. Industrialization 1760-1860 (Cambridge: Cambridge University Press, 2004), pp. 1-27.

Moore, John S. (ed.), The Goods and Chattels of our Forefathers: Frampton Cotterell and District Probate Inventories (London and Chichester: Phillimore and Co. Ltd., 1976).

Moreland, W.H., From Akbar to Aurangzeb: A Study in Indian Economic History (London: Macmillan, 1923).

Morineau, Michel, "The Indian Challenge: Seventeenth and Eighteenth Centuries", in Chaudhury, Sushil and Michel Morineau (eds.), Merchants, Companies and Trade: Europe and Asia in the Early Modern Era (Cambridge: Cambridge University Press, 1999), pp. 243-75.

Morse, Hosea Ballou, The Chronicles of the East India Company Trading to China, 1635-1834, 5 vols. (Oxford: Clarendon Press, 1926-29).

Mortier, Bianca M. du, Aristocratic Attire: The Donation of the Six Family (Rijksmuseum, Amsterdam, 2000).

Mudenge, S. I. G., A Political History of Munhumutapa (Harare: Zimbabwe Publishing Co., 1986).

Mui, Hoh-cheung and Lorna H. Mui, The Management of Monopoly: A Study of the English East India Company's Conduct of its Tea Trade, 1784-1833 (Vancouver: University of British Columbia Press, 1984).

Mukerji, Chandra, From Graven Images: Patterns of Modern Materialism (New York: Columbia University Press, 1983).

Mukherjee, Rila, "The French East India Company's Trade in East Bengal from 1750 to 1753: A Look at the Chandernagore Letters to Jugdia", Indian Historical Review, 17, 1-2 (1990-91), pp. 122-35.

Mukherjee, Rudrangshu, "Trade and Empire in Awadh, 1765-1804", Past and Present, 94 (1982), pp. 85-102.

Mukherjee, Rudrangshu, “[Early British Imperialism in India:] A Rejoinder”, Past and Present, 106 (1985), pp. 169-73.

Mukheyee, Rudrangshu and Lakshmi Subramanian (eds.), Politics and Trade in the Indian Ocean World: Essays in Honour of Ashin Das Gupta (New Delhi: Oxford University Press, 1998).

Mukund, Kanakalatha, The Trading World of the Tamil Merchant: Evolution of Merchant Capitalism in the Coromandel (Hyderabad: Orient Longman, 1999).

Mukund, Kanakalatha and B. Syama Sundari, Traditional Industry in the New Market Economy: The Cotton Handlooms of Andhra Pradesh (New Delhi: Sage Publications, 2001).

Mulhall, Michael G., The Dictionary of Statistics (London: George Routledge, 4th ed. [1898] 1909). 
Muller, Hendrik (ed.), De Oost-Indische Compagnie in Cambodia en Laos: Verzameling van bescheiden van 1636 tot 1670 (The Hague: Linschoten-Vereniging, 1917).

Murakami, Ei, "Binetsu Enganmin no Katsudo to Shincho: 19 seiki Zenhan no Ahen Boeki Katsudo o Chushinni" [Activities of Merchants and Fishermen of Fujian and Guandong and the Qing Government: With Special Reference to Opium Trade in the First Half of the Nineteenth Century], Toho Gakuho, 75 (2003), pp. 201-71.

Murphey, R., "Traditionalism and Colonialism: Changing Urban Roles in Asia”, Journal of Asian Studies, 29 (1969), pp. 67-84.

Mazumdar, Sucheta, Sugar and Society in China: Peasants, Technology, and the World Market (Cambridge, Ma.: Harvard University Press, 1998).

Nag, Prithvish, "The Indian Ocean, India and Africa: Historical and Geographical Perspective", in Satish Chandra (ed.), The Indian Ocean: Explorations in History, Commerce and Politics (New Delhi: Sage, 1987), pp. 151-73.

Nakazato, Nariaki, "Bengaru Ai-ikki o megutte (1): Igirisu Shokuminchi-shugi to Bengaru Nomin" [On the Indigo Strikes in Bengal (1): British Colonialism and Bengal Farmers)], Toyo Bunka Kenkyusho Kiyo, 83 (1981), pp. 61-151.

Naqvi, H. K., "Dyeing of Cotton Goods in the Mughal Hindustan (1556-1803)", Journal of Indian Textile History, 7 (1967), pp. 45-56.

Nef, John U., Cultural Foundations of Industrial Civilization (Cambridge: Cambridge University Press, 1958).

Newitt, Malyn, A History of Mozambique (Bloomington and Indianapolis: Indiana University Press, 1995).

Newton, Stella Mary, The Dress of the Venetians, 1495-1525 (Aldershot: Scolar Press, 1988).

Niane, Djibril Tamsir, "Mali and the Second Mandingo Expansion", in D. T. Niane (ed.), General History of Africa; Vol. 4. Africa from the Twelfth to the Sixteenth Century (London, Berkeley and Paris: Henemann, University of California Press and Unesco, 1984), pp. 117-71.

Nightingale, Pamela, Trade and Empire in Western India 1784-1806 (Cambridge: Cambridge University Press, 1970).

Northrup, David, "The Growth of Trade Among the Igbo before 1800", Journal of African History, 13, 2 (1972), pp. 217-36.

Northrup, David, Trade without Rulers: Pre-Colonial Economic Development in SouthEastern Nigeria (Oxford: Clarendon Press, 1978).

O'Brien, Patrick K., "The Precocious Mechanization of a Global Industry: Invention and Innovation in Cotton Textile Manufacturing", in Giorgio Riello and Prasannan Parthasarathi (eds.), The Spinning World: A Global History of Cotton Textiles, 12001850 (Oxford: Oxford University Press, 2009), pp. 351-65.

O’Brien, Patrick K., Trevor Griffith and Phillip Hunt, "Political Components of the Industrial Revolution: Parliament and the English Cotton Textile Industry, 16601774", Economic History Review, 44, 3 (1991), pp. 395-423.

O'Brien, Patrick K., Trevor Griffiths and Philip Hunt, "Technological Change during the First Industrial Revolution: the Paradigm Case of Textiles, 1688-1846," in Robert Fox (ed.), Technological Change: Methods and Themes in the History of Technology (Amsterdam: Harwood Academic, 1996), pp. 155-76.

Ogborn, Miles, "Writing Travels: Power, Knowledge and Ritual on the English East India Company's Early Voyages", Transactions of the Institute of British Geographers, 27, 2 (2002), pp. 155-71.

Ormrod, David, The Rise of Commercial Empires: England and the Netherlands in the Age of Mercantilism, 1650-1770 (Cambridge: Cambridge University Press, 2002).

Osumi, Tamezo, Printed Cottons of Asia: the Romance of Trade Textiles (Tokyo: Bijutsu Shuppansha and Tuttle, 1963). 
Owen, Roger, "Introduction", in Thomas Naff and Roger Owen (eds.), Studies in 18thCentury Islamic History (London and Amsterdam: Ferrer and Simons, 1977), pp. 133-51.

Parthasarathi, Prasannan, "Merchants and the Rise of Colonialism", in Burton Stein and Sanjay Subrahmanyam (eds.), Institutions and Economic Change in South Asia (Delhi: Oxford University Press, 1996), pp. 85-104.

Parthasarathi, Prasannan, "Rethinking Wages and Competitiveness in the Eighteenth Century: Britain and South India", Past and Present, 158 (1998), pp. 79-109.

Parthasarathi, Prasannan, The Transition to a Colonial Economy: Weavers, Merchants and Kings in South India 1720-1800 (Cambridge: Cambridge University Press, 2001).

Parthasarathi, Prasannan, "The Great Divergence", Past and Present, 176 (2002), pp. 275-93.

Parthasarathi, Prasannan, "Agriculture, Labour, and the Standard of Living in Eighteenth-Century India", in Robert C. Allen, Tommy Bengtsson and Martin Dribe (eds.), Living Standards in the Past: New Perspectives on Well-Being in Asia and Europe (Oxford: Oxford University Press, 2005), pp. 99-111.

Parthasarathi, Prasannan, "Cotton Textiles in the Indian Subcontinent, 1200-1800", in Giorgio Riello and Prasannan Parthasarathi (eds.), The Spinning World: A Global History of Cotton Textiles, 1200-1850 (Oxford: Oxford University Press, 2009), pp. 17-41.

Parthasarathi, Prasannan, Why Europe Grew Rich and Asia Did Not: Global Economic Divergence, 1600-1850 (Cambridge: Cambridge University Press, 2011).

Pearson, Michael N., Merchants and Rulers in Gujarat: The Response to the Portuguese in the Sixteenth Century (Berkeley and London: University of California Press, 1976).

Pearson, Michael N., "Brokers in Western Indian Port Cities: Their Role in Servicing Foreign Merchants", Modern Asian Studies, 22, 3 (1988), pp. 455-72.

Pearson, Michael N., Port Cities and Intruders: The Swahili Coast, India, and Portugal in the Early Modern Era (Baltimore \& London: The Johns Hopkins University Press, 1998).

Pearson, Michael N., The Indian Ocean (London and New York: Routledge, 2003).

Perlin, Frank, "Of White Whale and Countrymen in the 18th Century Maratha Deccan", Journal of Peasant Studies, 5, 2 (1978), pp. 172-237.

Perlin, Frank, "Proto-Industrialization and Pre-Colonial South Asia", Past and Present, 98 (1983), pp. 30-95.

Pollard, Sidney, Peaceful Conquest: The Industrialization of Europe 1760-1970 (Oxford: Oxford University Press, 1981).

Pomeranz, Kenneth, The Great Divergence: China, Europe and the Making of the Modern World Economy (Princeton and Oxford: Princeton University Press, 2000).

Poni, Carlo, "Standard, fiducia e conversazione civile: misurare lo spessore e la qualità del filo di seta", Quaderni Storici, 96 (1997), pp. 717-33.

Posthumus, N. W., Inquiry into the History of Prices in Holland (Leiden: E. J. Brill, 1946-64).

Prakash, Om, The Dutch East India Company and the Economy of Bengal, 1630-1720 (Princeton: Princeton University Press, 1985).

Prakash, Om, The New Cambridge History of India; Vol. II.5. European Commercial Enterprise in Pre-colonial India (Cambridge: Cambridge University Press, 1998).

Prakash, Om, "Financing the European Trade with Asia in the Early Modern Period: Dutch Initiatives and Innovations", Journal of European Economic History, 27, 2 (1998), pp. 331-56.

Prakash, Om, "The English East India Company and India", in Huw V. Bowen, Margarette Lincoln and Nigel Rigby (eds.), The Worlds of the East India Company (Woodbridge: Boydell Press, 2002), pp. 1-17. 
Prakash, Om, "Cooperation and Conflict among European Traders in the Indian Ocean in the Late Eighteenth Century", Indian Economic and Social History Review, 39, 2-3 (2002), pp. 131-48.

Prestholdt, Jeremy, "On the Global Repercussions of East African Consumerism", American Historical Review, 109, 3 (2004), pp. 755-81.

Prestholdt, Jeremy, Domesticating the World: African Consumerism and the Genealogies of Globalization (Berkeley: University of California Press, 2008).

Pritchard, Earl H., The Crucial Years of Early Anglo-Chinese Relations, 1750-1800. Research Studies of the State College of Washington, 4 vols. (Washington: Pullman, 1936; rep. Octagon Books, 1970).

Pritchard, Earl H., "Private Trade between England and China in the Eighteenth Century (1680-1833)", Journal of the Economic and Social History of the Orient, 1 (1958), pp. 108-44.

Ptak, Roderich and Rothermund Dietmar (eds.), Emporia, Commodities and Entrepreneurs in Asian Maritime Trade, c.1400-1750 (Stuttgart: Franz Steiner Verlag, 1991).

Raju, A. Sarada, Economic Conditions in the Madras Presidency, 1800-1850 (Madras: University of Madras, 1941).

Ramaswamy, Vijaya, "The Genesis and Historical Role of the Masterweavers in South Indian Textile Production", Journal of Economic and Social History of the Orient, 28 (1983), pp. 294-325.

Ramaswamy, Vijaya, Textiles and Weavers in Medieval South India (Delhi: Oxford University Press, 1985).

Rather, Susan, "Benjamin West's Profession Endgame and the Historical Conundrum of William Williams", William and Mary Quarterly, 59, 4 (2002), pp. 821-64.

Raveux, Olivier, "Espaces et technologies dans la France méridionale d’ancien régime: l'example de l'indiennage marseillais (1648-1793)", Annales du Midi, 116, 246 (2004), pp. 155-70.

Raveux, Olivier, "Les débuts de l'indiennage dans les pays d'Aix (1758-70)", Industries en Provence, 4 (2004), pp. 1-8.

Raveux, Olivier, "Spaces and Technologies in the Cotton Industry in the Seventeenth and Eighteenth Centuries: The Example of Printed Calicoes in Marseilles", Textile History, 36, 2 (2005), pp. 131-45.

Ray, Himanshu Prabha, "Far-flung Fabrics - Indian Textiles in Ancient Maritime Trade", in Ruth Barnes (ed.), Textiles in Indian Ocean Societies (London and New York: Routledge, 2005), pp. 17-37.

Ray, Indrani, "The Trade and Traders in Ahmedabad in Late Seventeenth Century: Extracts from George Roques' MSS”, in Lakshmi Subramanian (ed.), The French East India Company and the Trade of the Indian Ocean: A Collection of Essays by Indrani Ray (New Delhi: Munshiram Manoharlal, 1999), pp. 63-76.

Raychaudhuri, Tapan and Irfan Habib (eds.), The Cambridge Economic History of India; Vol. I. 1200-1750 (Cambridge: Cambridge University Press, 1982).

Raychaudhuri, Tapan, Jan Company in Coromandel, 1600-90: A Study in the Interrelations of European Commerce and Traditional Economies (The Hague: Martunus Nijhoff, 1962).

Raychaudhuri, Tapan, "Some Patterns of Economic Organization and Activity in Seventeenth Century India", in International Conference on Economic History (Paris: Mouton and Co., 1962), pp. 751-60.

Reid, Anthony, Southeast Asia in the Age of Commerce, c.1450-1680, 2 vols. (New Haven: Yale University Press, 1988-93).

Reid, Anthony, "A New Phase of Commercial Expansion in Southeast Asia, 1760-1840", in Anthony Reid (ed.), The Last Stand of Asian Autonomies: Responses to Modernity in the Diverse States of Southeast Asia and Korea, 1750-1900 (Basingstoke: Macmillan, 1997), pp. 57-82. 
Reid, Anthony, "Introduction: Four Key Exports and the Trade Cycle of Southeast Asia", in David Bulbeck, Anthony Reid, Lay Cheng Tan and Yiqi Wu (comp.), Southeast Asian Exports since the 14th Century: Cloves, Pepper, Coffee and Sugar (Leiden: KITLV Press, 1998), pp. 1-16.

Reid, Anthony, "Chinese Trade and Southeast Asian Economic Expansion in the Later Eighteenth and Early Nineteenth Centuries: An Overview", in Nola Cooke and Li Tana (eds.), Water Frontier: Commerce and the Chinese in the Lower Mekong Region, 1750-1880 (London: Lowman and Littlefield, 2004), pp. 21-34.

Richards, John F. (ed.), The Imperial Monetary System of Mughal India (Delhi: Oxford University Press, 1987).

Richards, John F., New Cambridge History of India; Vol. 1, Part 5. The Mughal Empire (Cambridge: Cambridge University Press, 1993).

Richards, John F., "Early Modern India and World History", Journal of World History, 8, 2 (1997), pp. 197-209.

Riefstahl, R. M., Persian and Indian Textiles from the late Sixteenth to the Early Nineteenth Century (New York: E. Weythe, 1923).

Riello, Giorgio and Prasannan Parthasarathi (eds.), The Spinning World: A Global History of Cotton Textiles, 1200-1850 (Oxford: Oxford University Press, 2009).

Riello, Giorgio, "The Globalization of Cotton Textiles: Indian Cottons, Europe and the Atlantic World, 1600-1850", in Giorgio Riello and Prasannan Parthasarathi (eds.), The Spinning World: A Global History of Cotton Textiles, 1200-1850 (Oxford: Oxford University Press, 2009), pp. 261-87.

Rita-Ferreira, A., African Kingdoms and Alien Settlements in Central Mozambique (c. 15th-17th Cent.) (Coimbra: Departamento de Antropologia, Universidade de Coimbra, 1999).

Roberts, Richard, "Guinee Cloth: Linked Transformations within France's Empire in the Nineteenth Century", Cahiers d'études africaines, 32, 4, (1992), pp. 597-627.

Roberts, Richard, Two Worlds of Cotton: Colonialism and the Regional Economy in the French Soudan, 1800-1946 (Stanford, Ca.: Stanford University Press, 1996).

Roberts, Edward, and Karen Parker (eds.), Southampton Probate Inventories, 14971575, 2 vols. (Southampton: Southampton University Press, 1992).

Robinson, Stuart, A History of Dyed Textiles (Cambridge, Ma.: MIT Press, 1969).

Robinson, Stuart, A History of Printed Textiles (Cambridge, Ma.: MIT Press, 1969).

Roche, Daniel, The Culture of Clothing: Dress and Fashion in the "Ancient Régime", trans. by Jean Birrell (Cambridge: Cambridge University Press, 1989).

Rockel, Stephen J., Carriers of Culture: Labor on the Road in Nineteenth-Century East Africa (Portsmouth, NH: Heinemann, 2006).

Rose, Mary B. (ed.), The Lancashire Cotton Industry. A History since 1700 (Preston: Lancashire County Books, 1996).

Rostow, Walt Whitman, The Stages of Economic Growth: A Non-Communist Manifesto (Cambridge: Cambridge University Press, 1960).

Rostow, Walt Whitman, The World Economy: History and Prospect (London: Macmillan, 1978).

Rothermund, Dietmar, "The Changing Pattern of British Trade in Indian Textiles, 1701-57", in Sushil Chaudhuri and Michel Morineau (eds.), Merchants, Companies and Trade: Europe and Asia in the Early Modern Era (Cambridge: Cambridge University Press, 1999), pp. 276-86.

Rothstein, Natalie, "Cotton", in Jane Turner (ed.), The Dictionary of Art (London: Macmillan, 1996), vol. 8, pp. 34-38.

Rouffaer, G. P. and H. H. Juynboll, De Batikkunst in Nederlandsch-Indië en haar geschiedenis (Utrecht: Oosthoek, 1914).

Roy, Mira, "Dyes in Ancient and Medieval India", Indian Journal of History of Sciences, 13, 2, (1978), pp. 83-113.

Roy, Tirthankar (ed.), Cloth and Commerce: Textiles in Colonial India (London: Sage, 1996). 
Roy, Tirthankar, Traditional Industry in the Economy of Colonial India (Cambridge: Cambridge University Press, 1999).

Roy, Tirthankar, Rethinking Economic Change in India: Labour and Livelihood (London: Routledge, 2005).

Rush, James R., Opium to Java: Revenue Farming and Chinese Enterprise in Colonial Indonesia, 1860-1910 (Ithaca: Cornell University Press, 1990).

Ryder, A. F. C., "Dutch Trade on the Nigerian Coast during the Seventeenth Century", Journal of the Historical Society of Nigeria, 3, 2 (1965), pp. 195-210.

Salvucci, Richard J., Textiles and Capitalism in Mexico: An Economic History of the 'Obrajes', 1539-1840 (Princeton: Princeton University Press, 1987).

Sandberg, G., The Red Dyes. Cochineal, Madder, and Murex Purple: A World Tour of Textile Techniques (Ashville, N. C.: Sterling Publishing, 1997).

Sanderson, Elizabeth, Women and Work in Eighteenth-Century Edinburgh (Basingstoke: Macmillan, 1996).

Sangar, Shri Pramod, "Ahmedabad and Cambay in the Seventeenth Century", Journal of Historical Research, 17, 1 (1974), pp. 34-40.

Sangar, Shri Pramod, "Export of Indian textiles to Middle East and Africa in the Seventeenth Century", Journal of Historical Research, 17, 1 (1974), pp. 1-5.

Sangar, Satya Prakash, Indian Textiles in the Seventeenth Century (New Delhi: Reliance Publication House, 1998).

Sarabia Viejo, María Justina, La grana y el añil: técnicas tintóreas en México y América Central Sevilla: CSIC, 1994).

Schaefer, G., “The Cultivation of Madder", Ciba Review, 39 (1941), pp. 1398-1406.

Schaefer, G., "The History of Turkey Red Dyeing", Ciba Review, 39 (1941), pp. 1407-16.

Schaeper, Thomas J., The French Council of Commerce 1700-15: A Study of Mercantilism after Colbert (Columbus, Oh.: Ohio State University Press, 1983).

Schumpeter, Elizabeth B., English Overseas Trade Statistics, 1697-1808 (Oxford: Clarendon Press, 1960).

Schwartz, Paul R., "French Documents on Indian Cotton Painting: (1) The Beaulieu mss", Journal of Indian Textile History, 2 (1956), pp. 5-23.

Schwartz, Paul R., "French Documents on Indian Cotton Painting: (2) New Light on Old Material", Journal of Indian Textile History, 3 (1957), pp. 15-44.

Schwartz, Paul R., "The Roxburgh Account of Indian Cotton Painting: 1795”, Journal of Indian Textile History, 4 (1959), pp. 47-56.

Schwartz, Paul R., Printing on Cotton at Ahmedabad, India in 1678 (Ahmedabad: Calico Museum of Textiles, 1969).

Scott, Katie "Art and Industry - A Contradictory Union: Authors, Rights and Copyrights during the Consultat", Journal of Design History, 13, 1 (2000), pp. 1-21.

Shaffer, Lynda, "Southernization", Journal of World History, 5, 1 (1994), pp. 1-21.

Shammas, Carole, "The Decline of Textile Prices in England and British America prior to Industrialization", Economic History Review, 47, 3 (1994), pp. 483-507.

Shaw, Thurstan, Igbo-Ukwu: An Account of Archaeological Discoveries in Eastern Nigeria, 2 vols. (Evanston, Il.: Northwestern University Press, 1970).

Shaw, Thurstan, "Archaeological Discoveries: The Example of Igbo-Ukwu", in Thurstan Shaw (ed.), Discovering Nigeria's Past (Ibadan: Oxford University Press, 1975), pp. 47-57.

Shaw, Thurstan, Unearthing Igbo-Ukwu: Archaeological Discoveries in Eastern Nigeria (Ibadan: Oxford University Press, 1977).

Shea, Philip James, "Economies of Scale and the Indigo Dyeing Industry of Pre-colonial Kano", Kano Studies, 1, 2 (1974), pp. 55-61.

Sheriff, Abdul, Spices \& Ivory in Zanzibar: Integration of an East African Commercial Empire into the World Economy, 1770-1873 (London: James Currey, 1987).

Sherratt, Andrew, "Reviving the Grand Narrative: Archaeology and Long-Term Change", Journal of European Archaeology, 3, 1 (1995), pp. 1-32. 
Short, Brian, "The De-industrialisation Process: A Case Study of the Weald, 16001850", in Pat Hudson (ed.), Regions and Industries: A Perspective on the Industrial Revolution in Britain (Cambridge: Cambridge University Press, 1989) pp. 156-74.

Siddiqi, Asiya, "Introduction", in Asiya Siddiqi (ed.), Trade and Finance in Colonial India, 1750-1860 (Delhi: Oxford University Press, 1995), pp. 1-60.

Simonsen, Roberto Cochrane, História Económica do Brasil, 1500-1820 (São Paulo: Companhia Editora Nacional, 1962).

Singer, Charles, The Earliest Chemical Industry: An Essay in the Historical Relations of Economics and Technology Illustrated from the Alum Trade (London: Folio Society, 1948).

Singh, O. P., Surat and its Trade in the Second Half of the 17th Century (Delhi: University of Delhi, 1977).

Sinha, A. K., Transition in Textile Industry: A History of Textile Industry in Bihar, 17831833 (Delhi: Capital Publishing House, 1984).

Sinopoli, Carla M., The Political Economy of Craft Production: Crafting Empire in South India, c. 1350-1650 (Cambridge: Cambridge University Press, 2003).

Smith, Carl T., "Parsee Merchants in the Pearl River Delta", Review of Culture (International Edition), 10 (2004), pp. 6-15.

Smith, Carl T. and Paul A. Van Dyke, "Muslims in the Pearl River Delta, 1700 to 1930", Review of Culture (International Edition), 10 (2004), pp. 6-15.

Smith, G. V., The Dutch in Seventeenth-Century Thailand (Dekalb, Il.: Northern Illinois University, Centre for Southeast Asian Studies, 1977).

Smith, Pamela H. and Findlen, Paula (eds.), Merchants and Marvels: Commerce, Science, and Art in Early Modern Europe (London: Routledge, 2002).

Smith, Woodruff D., Consumption and the Making of Respectability, 1600-1800 (New York and London: Routledge, 2002).

Souza, George Bryan, The Survival of Empire: Portuguese Trade and Society in China and the South China Sea, 1630-1754 (Cambridge: Cambridge University Press, 1986).

Souza, George Bryan, "Country Trade and Chinese Alum: Raw Material Supply in Asia's Textile Production in the Seventeenth and Eighteenth Centuries", Revista da Cultura, 11 (2004), pp. 136-53.

Souza, George Bryan, "Dyeing Red: S.E. Asian Sappanwood in the Seventeenth and Eighteenth Centuries", O Oriente, 8 (2004), pp. 40-58.

Souza, George Bryan, "Convergence before Divergence: Global Maritime Economic History and Material Culture", The International Journal of Maritime History, 17, 1 (2005), pp. 17-27.

Specker, Konrad, "Madras Handlooms in the Nineteenth Century", Indian Economic and Social History Review, 26, 2 (1989), pp. 131-66, reprinted in Tirthankar Roy (ed.), Cloth and Commerce: Textiles in Colonial India (New Delhi: Sage, 1996)].

Spufford, Peter, Power and Profit: The Merchant in Medieval Europe (London: Thames and Hudson, 2003).

Steensgaard, Niels, "The Indian Ocean Network and the Emerging World-Economy, c. 1500-1750", in Satish Chandra (ed.), The Indian Ocean: Explorations in History, Commerce and Politics (New Delhi: Sage Publications, 1987), pp. 125-50.

Steensgaard, Niels, "The Growth and Composition of the Long-distance Trade of England and the Dutch Republic before 1750", in James D. Tracy (ed.), The Rise of Merchant Empires: Long-Distance Trade in the Early Modern World, 1350-1750 (Cambridge: Cambridge University Press, 1990), pp. 102-52.

Stein, Burton, Peasant State and Society in Medieval South India (Delhi: Oxford University Press, 1980).

Stein, Burton, The New Cambridge History of India; Vol. 1.2. Vijayanagara (Cambridge: Cambridge University Press, 1989).

Stein, Burton and Sanjay Subrahmanyam (eds.), Institutions and Economic Change in South Asia (Delhi: Oxford University Press, 1996). 
Stokes, Eric, The English Utilitarian and India (Oxford: Clarendon Press, 1959).

Styles, John, "Product Innovation in Early Modern London", Past and Present, 168 (2000), pp. 124-69.

Styles, John, The Dress of the People: Everyday Fashion in Eighteenth-Century England (New Haven: Yale University Press, 2007).

Styles, John and Amanda Vickery (eds.), Gender, Taste and Material Culture in Britain and North America 1700-1830 (New Have: Yale University Press, 2006).

Subramanian, Lakshmi, "The Eighteenth Century Social order in Surat: A Reply and an excursus on the Riots of 1788 and 1795", Modern Asian Studies, 25, 2 (1991), pp. 321-65.

Subramanian, Lakshmi, Indigenous Capital and Imperial Expansion: Bombay, Surat and the West Coast (Delhi: Oxford University Press, 1996).

Subramanian, Lakshmi, "Power and the Weave: Weavers, Merchants and Rules in Eighteenth-Century Surat", in Rudrangshu Mukherjee and Lakshmi Subramanian (eds.), Politics and Trade in the Indian Ocean World: Essays in Honour of Ashin Das Gupta (Delhi: Oxford University Press, 1998), pp. 52-82.

Subramanian, Lakshmi (ed.), The French East India Company and the Trade of the Indian Ocean: A Collection of Essays by Indrani Ray (New Delhi: Munshiram Manoharlal, 1999).

Subramanian, Lakshmi, "A Trial in Transition: Courts, Merchants and Identities in Western India, circa 1800", Indian Economic and Social History Review, 41, 3 (2004), pp. 269-92.

Subrahmanyam, Sanjay, "Notes on the Sixteenth Century Bengal Trade", Indian Economic and Social History Review, 24, 3 (1987), pp. 267-71.

Subrahmanyam, Sanjay, "The South Coromandel Portuguese in the Late 17th Century: A Study of the Porto Novo - Nagapattinam Complex", Studia, 49 (1989), pp. 341-74.

Subrahmanyam, Sanjay, The Political Economy of Commerce: Southern India 1500-1650 (Cambridge: Cambridge University Press, 1990).

Subrahmanyam, Sanjay, Improvising Empire: Portuguese Trade and Settlement in the Bay of Bengal, 1500-1700 (Delhi: Oxford University Press, 1990).

Sanjay Subrahmanyam (ed.), Merchants, Markets and the State in Early Modern India (Delhi: Oxford University Press, 1990).

Subramanyam, Sanjay, "Rural Industry and Commercial Agriculture in Late Seventeenth South-Eastern India", Past and Present, 126 (1990), pp. 76-114.

Subrahmanyam, Sanjay (ed.), Money and the Market in India, 1100-1700 (Delhi: Oxford University Press, 1994).

Subrahmanyam, Sanjay, The Portuguese Empire in Asia. 1500-1700: A Political and Economic History (Harlow: Longman, 1993).

Subrahmanyam, Sanjay, "Of Imârat and Tijârat", Comparative Studies in Society and History, 37, 4 (1995), pp. 750-80.

Subrahmanyam, Sanjay (ed.), Merchant Networks in the Early Modern World (Aldershot and Brookfield, Vt.: Variourum, 1996).

Subrahmanyam, Sanjay, Explorations in Connected History (New Delhi: Oxford University Press, 2005).

Sudhir, P. and P. Swarnalatha, "Textile Traders and Territorial Imperatives: Masulipatnam, 1750-1850", Indian Economic and Social History Review, 29, 2 (1992), pp. 145-69.

Sugihara, Kaoru, Ajiakan Boeki no Keisei to Kozo [Patterns and Development of IntraAsian Trade] (Kyoto, Mineruva Shobou, 1996).

Sugihara, Kaoru, "Indo Kindaishi ni okeru Enkakuchi Boeki to Chiiki Koeki, 18681938 nen" [Long-distance Trade and Regional Trade in Modern Indian History, 1868-1938], Toyo Bunka, 82 (2002), pp. 1-46.

Sugihara, Kaoru, "The East Asian Path of Economic Development: A Long-term Perspective", in Giovanni Arrighi, Takeshi Hamashita and Mark Selden (eds.), The 
Resurgence of East Asia: 500, 150 and 50 Year Perspectives (London: Routledge, 2003), pp. 78-123.

Sugihara, Kaoru (ed.), Japan, China and the Growth of the Asian International Economy, 1850-1949 (Oxford: Oxford University Press, Oxford, 2005).

Tarling, Nicholas, Anglo-Dutch Rivalry in the Malay World, 1780-1824 (Sydney: Halsted Press, 1962).

Thampi, Madhavi, "Parsis in the China Trade", Review of Culture (International Edition), 10 (2004), pp. 16-25.

Tchitcherov, Alexander I., India: Changing Economic Structure in the Sixteenth-Eighteenth Centuries. Outline History of Crafts and Trade (New Delhi: Manohar, 1998).

Thirsk, Joan, Economic Policy and Projects: the Development of a Consumer Society in Early Modern England (Oxford: Clarendon, 1978).

Thomas, P. J. and B. Natarajan, "Economic Depression in the Madras Presidency (1825-54)", Economic History Review, 7, 1 (1936), pp. 67-75.

Thornton, John, Africa and Africans in the Making of the Atlantic World, 1400-1680 (Cambridge: Cambridge University Press, 1992).

Tomlinson, B. R., The Economy of Modern India, 1860-1970 (Cambridge: Cambridge University Press, 1993).

Tregonning, Kennedy Gordon Phillip, The British in Malaya: The First Forty Years 1786-1826 (Tucson, Az.: University of Arizona Press, 1965).

Trocki, Carl A., Opium and Empire: Chinese Society in Colonial Singapore, 1800-1910 (Ithaca: Cornell University Press, 1990).

Twomey, Michael J., "Employment in Nineteenth Century Indian Textiles", Explorations in Economic History, 20, 1 (1983), pp. 37-57.

Unwin, George, Samuel Oldknow and the Arkwrights (Manchester: Manchester University Press, 1924).

Van Dyke, Paul A., "The Yan Family: Merchants of Canton, 1734-80s", Review of Culture (International Edition), 9 (2004), pp. 30-85.

Van Dyke, Paul A., "The Ye Merchants of Canton, 1720-1804", Review of Culture (International Edition), 13 (2005), pp. 6-47.

Van Dyke, Paul A., "Cai and Qui Enterprises: Merchants of Canton, 1730-84", Review of Culture (International Edition), 15 (2005), pp. 60-101.

Van Dyke, Paul A., The Canton Trade. Life and Enterprise on the China Coast, 17001845 (Hong Kong: Hong Kong University Press, 2005).

Varadarajan, Lotika, South Indian Traditions of Kalamkari (Ahmedabad, India: National Institute of Design, 1982).

Varadarajan, Lotika, Ajrakh and Related Techniques: Traditions of Textile Printing in Kutch (Bombay: The New Order Book Co., 1983).

Varadarajan, Lotika, "Syncretic Symbolism and Textiles: Indo-Thai Expressions", in Om Prakash and Denys Lombard (eds.), Commerce and Culture in the Bay of Bengal, 1500-1800 (New Delhi: Manohar 1999), pp. 361-81.

Vicziany, Marika, "The Deindustrialization of India in the Nineteenth Century: A Methodological Critique of Amiya Kumar Bagchi”, Indian Economic and Social History Review, 16, 2 (1979), pp. 105-46.

Viraphol, Sarasin, Tribute and Profit: Sino-Siamese Trade, 1652-1853 (Cambridge, Ma.: Harvard University Press, 1977).

Von Tunzelmann, Nicholas, "Technological and Organizational Change in Industry during the Industrial Revolution", in Patrick O'Brien and Roland Quinault (eds.), The Industrial Revolution and British Society (Cambridge: Cambridge University Press, 1993), pp. 254-82.

Von Tunzelmann, Nicholas, Technology and Industrial Progress (Aldershot: Edward Elgar, 1995).

Vogt, John, "Portuguese Gold Trade: An Account Ledger from Elmina, 1529-31", Transactions of the Historical Society of Ghana, 14, 1 (1973), pp. 93-103. 
Vries, Jan de, "Between Purchasing Power and the World of Goods: Understanding the Household Economy in Early Modern Europe", in John Brewer and Roy Porter (eds.), Consumption and the World of Goods (London: Routledge, 1993), pp. 85-132.

Vries, Jan de, "Connecting Europe and Asia: A Quantitative analysis of the Cape-route Trade, 1497-1795”, in Dennis O'Flynn, Arturo Giràldez and Richard von Glahn (eds.), Global Connections and Monetary History, 1470-1800 (Aldershot: Ashgate, 2003), pp. 35-106.

Vries, Jan de, The Industrious Revolution: Consumer Behavior and the Household Economy, 1650 to the Present (Cambridge: Cambridge University Press, 2008).

Wadsworth, A. P. and Julia De Lacy Mann, The Cotton Trade and Industrial Lancashire 1600-1780 (Manchester: Manchester University Press, 1931).

Wallerstein, Immanuel, The Capitalist World-Economy: Essays (Cambridge: Cambridge University Press, 1979).

Wallerstein, Immanuel, "The Incorporation of the Indian Subcontinent into the Capitalist World-Economy", in Satish Chandra (ed.), The Indian Ocean: Explorations in History, Commerce and Politics (New Delhi: Sage Publications, 1987), pp. 222-53.

Washbrook, David, "Land and Labour in Late Eighteenth Century South India: The Golden Age of the Pariah?", in Peter Robb (ed.), Dalit Movements and the Meanings of Labour in India (Delhi: Oxford University Press, 1993), pp. 68-86.

Washbrook, David, "Economic Depression and the Making of Traditional Society in Colonial India, 1820-55", Transactions of the Royal Historical Society, 3 (1993), pp. 237-63.

Washbrook, David, “South India 1770-1840: The Colonial Transition”, Modern Asian Studies, 38, 3 (2004), pp. 479-516.

Washbrook, David, "India in the Early Modern World Economy", Journal of Global History, 2, 1 (2007), pp. 87-112.

Washbrook, David, "The British Empire and the Indian Economy", in N. Gooptu and D. M. Peers (eds.), The Oxford History of the British Empire: India (Oxford: Oxford University Press, forthcoming).

Weber, Henry, La Compagnie Française des Indes (1604-1875) (Paris: Arthur Rousseau, 1904).

Webster, Anthony, “The Political Economy of Trade Liberalization: the East India Company Charter Act of 1813", Economic History Review, 43, 3 (1990), pp. 404-19.

Webster, Anthony, Gentlemen Capitalists: British Imperialism in South East Asia, 17701890 (London: I. B. Tauris, 1998).

Wescher, H., "Dyeing in France before Colbert: Great Masters of Dyeing in 18th Century France", Ciba Review, 18 (1939), pp. 618-25.

Wescher, H., "The French Dyeing Industry and its Reorganization by Colbert", Ciba Review, 18 (1939), pp. 626-41.

Wescher, H., "Rouen and Its Port in Olden and Modern Times", Ciba Review, 135 (1959), pp. 2-6.

Wescher, H., "The Medieval Cloth Trade", Ciba Review, 135 (1959), pp. 7-9.

Wescher, H., "John Holker, a Promoter of the French Textile Industry", Ciba Review, 135 (1959), pp. 10-13.

Wescher, H., "The 'Rouennerie' Trade and Its Entrepreneurs", Ciba Review, 135 (1959), pp. 14-20.

Wescher, H., “Turkey Red Dyeing”, Ciba Review, 135 (1959), pp. 21-26.

Wescher, H., "The Normandy Textile Printing Industry of the Eighteenth and Nineteenth Centuries", Ciba Review, 135 (1959), pp. 27-32.

Weiner, Annette, Inalienable Possessions: The Paradox of Keeping-While-Giving (Berkeley, Ca.: University of Chicago Press, 1992).

Weiner, Annette B and Jane Schneider, "Introduction", in Weiner and Schneider (eds.), Cloth and Human Experience (Washington and London: Smithsonian Institution Press, 1989), pp. 1-29. 
White, Sophie, "'Wearing Three or Four Handkerchiefs around his Collar, and Elsewhere about Him': Slaves' Constructions of Masculinity and Ethnicity in French Colonial New Orleans", Gender and History, 15, 3 (2003), pp. 528-49.

Wild, John Peter and Felicity Wild, "Rome and India: Early Indian Cotton Textiles from Berenike, Red Sea Coast of Egypt", in Ruth Barnes (ed.), Textiles in Indian Ocean Societies (London and New York: Routledge, 2005), pp. 11-16.

Wills, John E., "European Consumption and Asian Production in the Seventeenth and Eighteenth Centuries", in John Brewer and Roy Porter (eds.), Consumption and the World of Goods (London and New York: Routledge, 1993), p. 133-47.

Wilks, Ivor, "A Medieval Trade Route from the Niger to the Gulf of Guinea", Journal of African History, 3, 2 (1962), pp. 337-41.

Wilks, Ivor, "Land, Labour, Capital and the Forest Kingdom of Asante: A Model of Early Change", in J. Friedman and Michael John Rowlands (eds.), The Evolution of Social Systems (London: Duckworth, 1977), pp. 487-534.

Wilks, Ivor, Forests of Gold: Essays on the Akan Kingdom of Asante (Athens: Ohio University Press, 1993).

Wilson, Kathleen (ed.), A New Imperial History: Culture, Identity, and Modernity in Britain and the Empire, 1660-1840 (Cambridge: Cambridge University Press, 2004).

Wong, Lin Ken, "The Trade of Singapore, 1819-69", Journal of the Malaysian Branch of the Royal Asiatic Society, 33, 4 (1960), pp. 1-315.

Wong Lin Ken, "The Strategic Significance of Singapore in Modern History", in Ernest C. T. Chew and Edwin Lee (eds.), A History of Singapore (Singapore: Oxford University Press, 1991), pp. 17-35.

Wright, Harold R. C., East Indian Economic Problems of the Age of Cornwallis and Raffles (London: Luzac \& Co., 1961).

Yule, Henry, and A. C. Burnell, Hobson-Jobson: A Glossary of Anglo-Indian Colloquial Words and Phrases (London: Routledge \& Kegan Paul, 1968).

Yuste López, C., El comercio de la Nueva España con Filipinas, 1590-1785, (Mexico, D.F.: INAH, 1977).

Zeijlstra, H. H., "Looi- en Verfstoffen", in K. W. van Gorkom (ed.), Oost-Indische Cultures (Amsterdam: De Bussy, 1913), vol. 3, pp. 699-789.

\section{Unpublished Theses and Papers}

Brennig, Joseph, "The Textile Trade of Seventeenth Century Northern Coromandel: A Study of a Pre-Modern Asian Export Industry" (Unpublished Ph.D. Thesis, University of Wisconsin at Maddison, 1975).

Broadberry, Stephen and Bishnupriya Gupta, "Cotton Textiles and the Great Divergence: Lancashire, India and Shifting Comparative Advantage, 1600-1850" (Unpublished Paper, July 2004).

Datta, Rajat, "The Commercial Economy of Eastern India under Early-British Rule: The First Fifty Years" (Unpublished Paper, 2006).

Hedges, David William, "Trade and Politics in Southern Mozambique and Zululand in the Eighteenth and Nineteenth Centuries" (Unpublished Ph.D. Thesis, School of Oriental and African Studies, University of London, 1978).

Kriger, Colleen E., "'Guinea Cloth': Production and Consumption of Cotton Textiles in West Africa before and during the Atlantic Slave Trade" (Paper presented at the GEHN conference, "Cotton Textile as a Global Industry", University of Padua, Italy, 17-19 November, 2005).

Laarhoven, Ruurdje, "The Power of Cloth: The Textile Trade of the Dutch East India Company (VOC) 1600-1780" (Unpublished Ph.D. Thesis, Australian National University, 1994).

Ludden, David, "History Along the Coastal Zones of Southern Asia" (Paper presented at the South Asia Seminar, Columbia University, 18 October, 1999). 
Machado, Pedro, "Gujarati Indian Merchant Networks in Mozambique, 1777-c.1830" (Unpublished Ph.D. Thesis, School of Oriental and African Studies, University of London, 2005).

Miki, Sayako, "Merchants, Markets and the Monopoly of the East India Company: The Salt Trade in Bengal under Colonial Control, c.1790-1826" (Unpublished Ph.D. Thesis, School of Oriental and African Studies, University of London, 2005).

Parthasarathi, Prasannan, "Global Trade and Textile Workers, 1650-2000" (Paper presented at Globalization and Trade Conference, International Institute of Social History, November 2004).

Parthasarathi, Prasannan, "The European Response to India Cottons" (Paper presented at the GEHN Conference on "Cotton Textiles in the Indian Ocean", Pune, India, December 2005).

Prestholdt, Jeremy, "As Artistry Permits and Custom May Ordain" (Program of African Studies Working Papers, Number 3, Northwestern University, 1998).

Prestholdt, Jeremy, "East African Consumerism and the Genealogies of Globalization" (Unpublished Ph.D. Thesis, Northwestern University, 2003).

Smith, Alan, "The Struggle for Control of Southern Mozambique, 1720-1835" (Unpublished Ph.D. Thesis, University of California, Los Angeles, 1970).

Riello, Giorgio, "Cotton Before the Revolution: A European Perspective, c. 1200-1800" (Unpublished paper presented at the Economic History Seminar, London School of Economics, May 2004).

Riello, Giorgio, "The Ecology of Cotton in Early Modern Europe: Possibilities and Potentials" (Paper Presented at the GEHN Conference on "A Global History of Cotton Textiles", University of Padua, Italy, November 2005).

Riello, Giorgio, "The Rise of European Calico Printing and the Influence of Asia in the 17th- and 18th-centuries" (Paper presented at the GEHN Conference on "Cotton Textiles in the Indian Ocean", Pune, India, December 2005).

Shea, Philip James, "The Development of an Export Oriented Dyed Cloth Industry in Kano Emirate in the Nineteenth Century" (Unpublished Ph.D. Dissertation, University of Wisconsin, Madison, 1975).

Swarnalatha, Potukuchi, "The World of the Weaver in the Northern Coromandel, 1750-1850" (Unpublished Ph.D. Thesis, University of Hyderabad, 1991).

Wendt, Ian C., "The Social Fabric: Textile Industry and Community in Early Modern South India" (Unpublished Ph.D. Thesis., University of Wisconsin - Madison, 2005).

Wendt, Ian C., "Writing the Rich Economic History of the South Asian Textile Industry: Spinners in Early Modern South India" (Paper presented at the GEHN Conference on "Cotton Textiles in the Indian Ocean", Pune, India, December 2005).

Zimba, Benigna de Jesus Lurdina Mateus Lisboa, “Overseas Trade, Regional Politics, and Gender Roles: Southern Mozambique, ca. 1720 to ca. 1830" (Unpublished Ph.D. Thesis, University of Michigan, 1999). 


\section{NOTES ON CONTRIBUTORS}

Maxine Berg (FBA, Professor of History, University of Warwick) teaches and researches on the history of consumption and material culture in Europe and Asia in the eighteenth century. She is the Founding Director of The Warwick Centre for Global History and Culture and a Fellow of the British Academy. Among her publications are Luxury and Pleasure in Eighteenth-Century Britain (OUP, 2005); The Age of Manufactures (1985; Routledge, 1994), three edited books and several articles.

H. V. Bowen (Professor of History at Swansea University) has written on the East India Company, British trade and imperialism in Asia between 1700 and 1850, and researches on war, finance, and the British state in the eighteenth century. He is the author of The Business of Empire: The East India Company and Imperial Britain, 1756-1833 (CUP, 2005); Revenue and Reform: The Indian Problem in British Politics, 1757-73 (CUP, 1991, 2002); and War and British Society, 1688-1815 (CUP, 1998).

Bishnupriya Gupta (Associate Professor, Department of Economics, University of Warwick) has a D.Phil from the University of Oxford and has taught at the London School of Economics, University of St. Andrews and the Delhi School of Economics. Her major work has been on the industrial organization in colonial India, in particular on cartels in tea and jute. Recently she has contributed to the debate of the Great Divergence in a series of papers with Stephen Broadberry. Her publications include papers in the Journal of Economic History, the Economic History Review, Explorations in Economic History and Business History.

Joseph E. Inikori (Professor of History at the University of Rochester, New York) researches and teaches on the evolution of the current global economic order from the sixteenth century and in particular on the global impact of the Atlantic slave economy. He is the author of Africans and the Industrial Revolution in England (CUP, 2002) (winner of the American Historical Association 2003 Leo Gershoy Award); The Chaining of a Continent: Export Demand for Captives and the History of Africa 
South of the Sahara, 1450-1870 (University of the West Indies, 1992) as well as other edited volumes and major articles.

Beverly Lemire (Professor of History and Henry Marshall Tory Chair at the University of Alberta, Canada). Her publications include Fashion's Favourite: The Cotton Trade and the Consumer in Britain, 1660-1800 (OUP, 1991); Dress, Culture and Commerce: the English Clothing Trade before the Factory (Palgrave, 1997); and most recently The Business of Everyday Life: Gender, Practice and Social Politics in England, c. 16001900 (Manchester, 2005). She co-edited Women \& Credit: Researching the Past, Refiguring the Future (Berg, 2002), an interdisciplinary initiative that gave her a taste for globally comparative projects. In 2011 she published a book entitled Cotton as part of the Berg series 'Textiles that Changed the World'.

Pedro Machado (USE Assistant Professor of World History at Indiana University, Bloomington) completed his $\mathrm{PhD}$ at the School of Oriental and African Studies (SOAS), University of London, and was a Fellow at the Institute of Commonwealth Studies in London, and Assistant Professor in Global History at New York University in 2005-7. At Indiana he teaches courses in global history, slavery, South Asia, the Oceans, and the Indian Ocean. He specializes in eighteenth and nineteenth-century Indian Ocean social, cultural and economic networks. $\mathrm{He}$ is interested in the Indian Ocean both as a site of interrelation and as a space of overlapping and intersecting webs of 'connected histories'.

Prasannan Parthasarathi (Professor of History at Boston College). He is the author of The Transition to a Colonial Economy: Weavers, Merchants and Kings in South India, 1720-1800 (CUP, 2001) as well as several articles in comparative and global economic history. He has recently co-edited (with Giorgio Riello), The Spinning World: A Global History of Cotton Textiles, 1200-1850 (OUP, 2009). His Why Europe Grew Rich and Asia Did Not was published in 2011.

Om Prakash (Professor of Economic History, Delhi School of Economics) has written extensively on Indian Ocean trade in the seventeenth and eighteenth centuries. His publications include The Dutch East India Company and the Economy of Bengal 1630-1720 (Princeton UP, 1985); Precious Metals and Commerce, The Dutch East India Company in the Indian Ocean Trade (Variorum, 1994); European 
Commercial Enterprise in Pre-colonial India (CUP, 1998); and Bullion for Goods: European and Indian Merchants in the Indian Ocean Trade, 1500-1800 (Manohar, 2004).

Anthony Reid (Emeritus Professor, Australian National University) is a historian of Southeast Asia, who has at different times worked on political, economic, social and intellectual history. His books include Southeast Asia in the Age of Commerce, 1450-1680 (Yale, 1988-93); Charting the Shape of Early Modern Southeast Asia (Silkworm, 1999); and An Indonesian Frontier: Acehnese and Other Histories of Sumatra (Singapore University Press, 2004).

Giorgio Riello (Professor of Global History, Global History and Culture Centre, University of Warwick) has written on early modern textiles, dress and fashion in Europe and Asia. He is a graduate of the University of Venice and holds a doctorate from University College London. He is the author of $A$ Foot in the Past: Consumers, Producers and Footwear in the Long Eighteenth Century (OUP, 2006) and has recently co-edited (with Prasannan Parthasarathi), The Spinning World: A Global History of Cotton Textiles, 1200-1850 (OUP, 2009). His new book Cotton: The Fabric that Made the Modern World (CUP) was published in 2013.

Tirthankar Roy (Professor of Economic History, London School of Economics) specializes in the economic history of colonial and postcolonial South Asia with special reference to the artisan industries and textiles. He holds a doctorate from the Jawaharlal Nehru University, New Delhi. He has taught at the Jawaharlal Nehru University, the Gokhale Institute of Politics and Economics, Pune, India and has been Visiting Professor at the Economic Growth Centre, Yale University in 2004-5. He is the author of Artisans and Industrialization. Indian Weaving in the Twentieth Century (OUP, 1993); (ed.) Cloth and Commerce: Textiles in Colonial India (AltaMira Press, 1996); Traditional Industry in the Economy of Colonial India (CUP, 1999); Rethinking Economic Change in India: Labour and Livelihood (Routledge, 2005), The Economic History of India 1857-1947 (OUP, 2000, 2006).

George Bryan Souza (Mercator Guest Professor, Seminar für Sinologie und Koreanistik, Universität Tübingen) teaches on and researches global maritime economic history and European expansion in the early modern period. He is the author of The Survival of Empire: Portuguese 
Trade and Society in China and the South China Sea, c. 16301754 (CUP, 1986, 2004) and numerous articles.

Lakshmi Subramanian (Professor, Centre for Studies in Social Sciences, Calcutta) has worked on the Indian Ocean in the eighteenth and the nineteenth centuries, diasporic cultures, and on music. She has published extensively on these topics, including New Mansions for Music (Social Science Press - Orient Longmans, 2008) and Veene Dhanammal (Routledge, 2009). She is currently working on Indian Ocean journalism and merchant networks.

Kaoru Sugihara (Professor, Graduate School of Economics, University of Tokyo) works on the history of intra-Asian trade as a historian of the modern international economy. Since 1978 he has taught at Osaka City University, SOAS, and Osaka University. He has published in Japanese: Patterns and Development of Intra-Asian Trade (Mineruva Shobou, 1996); The Rise of the Asia-Pacific Economy (Osaka Daigaku Shuppankai, 2003) and edited three volumes. He has also published five books in English, among which (with P. Robb and H. Yanagisawa) Local Agrarian Societies in Colonial India: Japanese Perspectives (Curzon, 1996) and (ed.) Japan, China, and the Growth of the Asian International Economy, 1850-1949 (OUP, 2005).

David Washbrook (Professorial Fellow, Trinity College Cambridge) specializes in the history of Southern India between the eighteenth and twentieth centuries and has written on political, social, and economic and cultural themes. His publications include The Emergence of Provincial Politics: the Madras Presidency 18701920 (CUP, 1976); and (with C. J. Baker), South India: Political Institutions and Political Change (Holmes \& Meier, 1976).

Ian C. Wendt (Assistant Professor of History, Moravian College in Pennsylvania). His research and teaching focus is on the regions of South and Southeast Asia, the Indian Ocean, as well as the Islamic World in Asia. His is currently investigating the social and economic history of textile production and trade in early modern South India. Several of his papers are soon to appear in edited volumes on Indian and global economic history. 


\section{INDEX}

Aboh 92, 97

Aceh 33, 35, 36, 39, 42, 47

'Active consumer' 391

Africa $6,10,12,20,21,25,44,53-84$, 85-114, 198, 203, 283, 309, 317, $344,364,396$

Agra 221, 321

Agriculture

Commercial 190, 205, 208, 214

in Africa 89, 91, 93, 111

in China $21,116,124$

in India $179,183,184-6,194,205$, $208,298,416,420-1,434,435$

in Southeast Asia 31

labourers in 420-1

mixed 183

productivity of $416,417,420$

Ahmad, Afzal 318

Ahmedabad 73, 225, 257, 260, 321, 324, $348-9,350,440$

Aikin, J. 409

A'in-i Akbari 419

Akan forest 95

Akoko 96, 439

Akure 96

Alaev, L. 200

Alam, Muzaffar 176

Alcohol 104, 420

Alizarin 356

Allada 92, 99, 108

Alum 350, 351-4, 437

America 15, 42, 44, 55, 86, 103, 105, $153,173,200,348$

Amoy 119

Amsterdam 300, 319, 341, 358, 372, 379,382

Andhra 184

Angoche 60

Aniline dyes 213

Anlo 109

Apomu 96

Appadurai, Arjun 182

Aprons 385, 403, 407

Arabic sources 93

Arasaratnam, Sinnappah 74, 201, 421
Arbitration 181

Archeological excavations 91

Areca nut 179

Arganizes 318, 335, 437

Aristocracy 175, 176, 219, 378

Arkwright, Richard 330, 405

Artisans 23, 24, 60, 73, 75, 169, 175, 176, $178,179,186,193,194-5,196,199$, $200,202,211,213,214,215,220-1$, $223,229,233,248,250,254,263$, $268,272,275-6,277,280,347,369$, 409,424

Asana 429

Asante empire 95, 102

Ashmolean Museum, Oxford 4

Asia $6,7,9,13,14,16,17,21,24,25,27$, $44,86,119,121,137,139-69,197$, $219,220,312,313,314,315,318$, $319,320,321,324,326,330,344$, $346,347,348,352,354,357,358$, $359,360,371,373,375,381,389$, $396,397,402,405,418,422$

Asian merchants - see 'Merchants, Asian' Aso-ado 97, 100, 437, 439

Astringents 351

Atlantic coasts 20, 92, 93, 97-8, 112,113

Atlantic Ocean 8, 20, 25, 86, 93, 118, 195, $313,320,335,367,377,378,397,412$

Aurangzeb (Mughal Emperor) 188

Austen, Ralph 86

Awadh 118, 132, 133

Awka 101, 109

Awka Igbo 91

Ayutthaya 33, 37

Backwardness 418, 422

Baftas 291

Baghdad 4

Baines, Edward 399

Bali 31, 156, 157

Ball, John 379

Ban on cotton textiles $322-3$

in England 281-2, 322-3

in Europe $322-3,361$ 
in France 322

in the Dutch Republic 322-3

Banda 36, 38

Bandar Addas 4

Banjaras 181

Banten (West Java) 33

Banyan (garment) 365-90

Barbosa, Duarte 373

Barcelona 341

Barbot, John 97

Barnes, Ruth 4

Baroda 72, 255, 257, 260, 265

Basel 341

Basra 4, 240

Batavia 10, 38, 42, 45, 48, 154, 159

Bayly, Christopher 177

Beads 4, 96, 102, 110

Beatilha 206, 318, 335, 437

Beaulieux, M. de 36, 348-9

Beer 392

Begho 95

Bencoolen (Bengkulu), Sumatra 33, 34, $37,40,41,44,47,48,152,153,156$, $157,160,427$

Bengal $1,6,23,24,33,35,36,58,71,72$, $79,118,122,128,132,134,136,137$, $141,143,146,151,152-7,159,161$, $162,163,164,174,177,179,185$, $195,196,217-51,254,262,279,282$, 284-7, 288, 289, 290, 294, 295, 298, $299,302,323,324,325,334,336$, $348,358,408,416,425,429,439$, 440,441

Benin 92, 96-102, 104, 108, 437, 439

Benin cloth 97, 98, 100, 437, 439

Berame 318, 335

Berenike 217

Berg, Maxine 26, 312, 391-414

Beveridge, William 344-5

Bhavnagar 76, 79-80

Biafra 101-4

Bijapur 335

Bima 357, 359

Blackburn 409

Bolton 409

Bombay $67,73,76,118,120,123-37$, $141,143,151,152-60,163-64,196$, $197,213,262,264-5,269,288,290$, 321,408

merchants in $123,124,125,135-6$

trade of $118,123-4,125,132,143,151$, $154,155,156,157,159,163-4,262$

trade in raw cotton 126-31, 133, $163-4,288$
Bonny 110

Borneo 33, 47-8, 156-7

Boswell, James 378

Bowen, H. V. 20-1, 115-137, 328, 330

Boxer, Charles 7

Brass 96, 97, 102, 110, 392

Braudel, Fernand 8, 386

Brazil 44, 152, 318, 402

Brazilin 356

Brennig, Joseph 200, 325

Britain 13, 16, 25, 42, 43, 46, 49, 102, $103,104,107,116,118,122,126$, $137,148,149,152,155,158$, $163-4,175,281-3,289,298,299$, $300,303,305,309,329,331,391-2$, 398-9, 401, 404, 405, 408, 409, $415-18,422$

British Industrial Revolution - see 'Industrial Revolution'

Broadberry, Stephen 418-23

Brokers 23, 58, 74-6, 83, 202, 209, 222, $235,253,255,259-61,263,266$, $267,272-80,373$

Brunei 39

Bugis 39, 40, 45, 47, 48

Bullion 123, 173, 174, 180, 187

Bundelkhand 132

Burhanpur 321, 335, 348, 350

Burke, Edmund 122

Burma 5, 31-33, 37, 39, 45, 156

Burton, Richard 68

By-employment 184, 434

Calcutta 118, 120, 123, 126-7, 131-6, $143,146,156,163,165,226,227,229$, 233, 248, 249

Caldeira, Carlos José 82

Calico craze 25, 332, 402, 403

Calico printing $10,25,59,281,284,334$, $340,341,348-51,353-4,366,393$, $398,404,407,409-10,414$

Calicoes 26, 45, 68, 219, 223, 233, 238, $242,262,266,281-2,286-7,300-2$, $314,321,323,332-5,337,341,346$, $370-1,384,385,289,401-12$, $420-1,437,438$

Cambay 4, 72, 73, 129, 135, 265, 266, $315-7,335,369,373,437,439$

Cambodia $31,37,40,160,317$

Cambric 46, 334, 344, 405, 406, 440

Camphor 5, 31, 161

Canals 181

Canton 21, 115-37, 143-44, 148, 157, 158,439 
Cape of Good Hope $314-5$

Capital 43, 75, 83, 84, 202, 204, 254, 257, $270,284,293,311,312,397,417$

Capital accumulation 311, 312

'Capitalistic development' 175

Captives 104, 105, 108, 111

Caravans 4, 6, 65, 325, 326

Caribbean 352, 407-8

Carpets 329-30

Carreira da India 315, 318

Carter Nicholas, Robert 378

Cassimcotah Division 427

Castes 174, 180, 182-3, 185, 186, 195, $199,255,257-9,278,284,285,433$

Cattle 179,181

Celebes - see 'Sulawesi'

Censuses 426, 432

Ceramics - see also 'Porcelain' 391, 410

Chamberpots 102

Chaptal, Jean Antoine Claude 353, 360

Charkha 429, 438

Charles II (King of Britain) 381

Chaudhuri, K. N. 8, 72, 146, 284, 286-90, 294, 328, 330, 336, 344-5, 365,367

Chaudhuri, Sushil 174, 177, 287, 288, 292,328

Chaul 325

Chemistry 341

Chiacole Circar 427

Chicherov, A. I. 178

Child, Sir Josiah $377-8$

Chillies 161, 184

China $6,8,15,16,17,20,21,25,31,40$, $42,43,44,45,47,50,77,115-37$, $139,143,144,145,148-61,165$, $166,167,168,181,202,312,314$, $315,317,320,326,347,348,352$, $357,358,359,362,397,399$

consumption and use of cotton in 77 , 116,120

cotton-growing in 115,120

imports of raw cotton into $31,115-38$

Chintzes $45,46,110,314,318,321$, $332-5$, 339, 341, 345, 347-54, 360-3, $378,387,403,437,438$, 440,441

Chios 353

Cholum 385

Chulia (traders) 39, 44, 50, 182

Clans 176

Cloth - see 'textile' and 'textiles'

Coal 17, 89, 97, 392

Coeurdoux, Pére 349, 361
Coimbatore 211, 213

Coinage 173, 180, 241

copper 173

pagoda 180

rupee 180,241

silver $173,180,241$

Colbert, Jean-Baptiste 323

Cole, Thomas 379

Coleroon 188

Colonial rule 21, 23, 168, 254, 281, 327,434

Colonialism 18, 140, 169, 174, 193, 194, $195,198,202,215$

Commercial activities 130, 133, 182,259

Commercial agents 178, 203

Commercial agriculture - see 'Agriculture, commercial'

Commercial centres 179, 253, 258, 277-9, 368

Commercial competition $13,18,19,34$, $38,77-83,128,204,260,281-305$, $319,320,326$

Commercial concessions 119

Commercial depression 265

Commercial economy 176

Commercial factors 128, 166

Commercial information 255, 361

Commercial law 19

Commercial networks $6,9,10,14,20$, $22,53-84,121,136,137,145,156$, $187,260,313,387,397,410$

Commercial policies 73

Commercial practices 74

Commercial production 109, 176, 178,180

Commercial records 127

Commercial relations $4,9,20,21,36,58$, $178,184,202,207,314,356,359$

Commercial Resident 134, 205, 225, $146,248,274-5$

Commercial revolution 176

Commercial society 176, 219, 254, 255

Commercial systems 55, 117, 173

Commercial treaties 139

Commercialisation $100,112,114,119$, $174,175-6,180,182,184-6$, $189-90,211,356,358,369$

Commodification 19

Compagnie des Indes Orientales - see 'East India Companies, French'

Companies - see 'East India Companies'

Competition - see 'Commercial competition,' 'Textile procurement' 
Congo 4

Connell, R. W. 375

Consumer demand $6,10,41,43,45,46$, $56-8,60-73,81,99,105,108,114$, $116,121,126,130,163,165,173$, $217,224,282,295,299,302,312$, $319,368,369,391,394,400,407$

Consumer revolution 314

Consumer taste $25,57,60,65-7,68,70$, $72,75,80-2,218,322,337,340$, $347,366-7,369,371,384,387,395$, $402,403,410,411$

Consumers 19, 55-7, 60, 65, 67, 70, 72, $75,78,83,195,199,209,312,313$, $317,329-30,332,334,336-7,344$, $356,365-89,393,395,397,403$, $404,411,414$

Consumption - see 'Consumer demand'

Convergence 25, 360-2

Convergence/divergence debate - see 'Great divergence'

Cooking pots 102

Copenhagen 319, 324

Copper 4, 91, 97, 101, 102, 103, $110,161,173,180,341,350,392$, 410,411

Coral beads 96

Cordell, Dennis 86

Coromandel Coast 1, 6, 11, 33, 34, 35, $36,38,39,46,58,71,72,118,152$, $177,179,181,183,185,188,200$, $201,203,219,254,262,284,285$, $289,291,293,295,297,300-2,303$, $318,325,334,336,338,339,340$, $341,348,349,358,439,440$

Cossaes 296, 332-3

Constantinople 4,326

Cotton - see 'Cotton fibre'

Cotton fibre 21, 25, 31, 44, 46, 72, 77, 88-9, 97, 109, 115-37, 150, 161-2, $167,181,183-4,206,217,220,221$, $237,258,270,284-5,292-3,298$, $300-3,347,351-2,362,400,402$, 404, 409

Cotton industry 391, 393

in Africa 85-114

in Asia 121-2

in Britain 116, 393-414, 434

in China 21, 116

in Europe 310, 346

relocation of 310,394

technology - see 'Technology'

Cotton textiles

ban on $281-2,322-3,361$ colours of $12,259,334,337,350-7$, $369,397,411$

design of $4,12,60,282,336-40,343$, $369,370,397-8,407-11$

in India $4,6,7,9,10,12,19,20,21$, 25-6, 31-51, 78, 85-114, 203, 204, $265,285-7,312,318,330,332,336$, $344-5,347-50,362,365-89,394$, $403,404,407,415,417,423,426$

in South India 22, 33, 118, 173-91, 192-215, 254, 408, 415-35

innovative nature of 328

Lancashire 50, 105, 113, 163, 392, 393, 401-3, 406, 408-9, 411-12

painting of 347-61, 410

prices of - see 'prices'

printing of $10,25,59,281,284,334$, 340-3, 348-60, 366, 393, 398, 404, 407, 409-10, 414

production of comparative advantages 25,56 , 136,284

control of $16,112,130,136,183$, 201, 221, 231, 261, 267-8, 277, 281-305, 322, 325, 335, 402 supplies 267

quality of - see 'Quality'

standardization of 286, 401

technological innovation $16,109,194$, 198, 282, 299, 300, 310, 346, 349, $360,391-94,398,405,423$

Cotton trade $108,131,133,135,163$, 401-3, 414

Intra-Asian 108, 121, 125

'Country trade' 16, 21, 35, 39, 118, 119, $123,288,314,324,438$

Cowan, Brian 376

Cowries 102-5, 109

Crawfurd, John 42-6, 157, 160

Credit 23, 75, 99, 128, 174, 258, 292-3, 383, 386

Crompton, Samuel 44, 330, 405, 406

Crompton's mule - see 'Mule'

Crops 41, 43, 91, 130, 132, 184, 198, 214, 231,236

Cuddalore 39, 289, 290, 427

Custom duties 80, 262

Customs 182, 257, 260

Customisation 327, 335-44

Cutch $135,153,154$

d'Apligny, Lepileur 360

Dabhol 325

Dahomean coast 101, 103, 104 
Daman $56,62,68,74,76,79,80,81,82$, $83,335,437$

Das Gupta, Ashin 13, 119

Datta, Rajat 325

De Marchi, Neil 396

de Vries, Jan 314, 381-3

De-industrialisation 173

in India 23, 190, 193-97, 204, 205, $211,214-15,311,415-35$

Delagoa Bay 60, 66, 69, 437

Demand - see 'consumer demand'

Desai, Ashok V. 176

Design 4, 12, 34, 60, 65, 96-7, 99, 198, $282,284,334,336-8,340-3,350$, $365,367-70,387,395,397-8$, $402-3,407,408,410-12$

Development theory 12

Dhaka 219, 222, 227, 231, 234, 236, 286, 300,302

Dhaniakhali 227, 230-46

Diderot, Denis 378

Dike, Kenneth Onwuka 91

Diu 55, 65, 68, 71, 74, 76-83

Divergence - see 'Great divergence'

Division of labour 14, 95, 100, 269, 394, 396

Dornbush, Rudiger 418, 422

Dutch East India Company - see 'East India Companies, Dutch'

Dutch trade - see 'East India Companies'

Dutt, Romesh 424

Dyers 113, 193, 206, 210, 214, 354-7, $360,362,369$

Dyes 25, 59, 206, 213-14, 219, 347, 351, $354-60,362,405,411$

Dyeing $40,96,112,205,209,211,259$, $284,348,352-4,360,362-3$, 405,437

Earthenware 4, 26, 31

East Africa 4, 8, 10, 20, 21, 55-84, 144,266

East India Companies $7,16,21,24-5$, $38,98,163,168,177,186,199$, $203,206,218,219,223-4,225$, $227,229,240-1,246,249,271$, 285-7, 292-3, 303, 305, 310, 313, $315,319,320-6,327-8,331-2$, $335-7,344,401,403$

Danish 38, 146, 225, 315, 319, 324

Dutch (VOC) 16, 21, 31-52, 61, 98, 99, 109-10, 121, 143, 144, 145, 146, $148,163,168,174,187,188,199$, 200, 206, 218, 219, 221-30, 235,
239-41, 246, 248, 249, 267, 271, 286-8, 299, 300, 303, 310, 311, 315, $318,319-21,323-4,325,326-8$, $331,332,336,342,357,358-9,373$, $379,381,392,400,411$

English 21, 23, 42, 43, 44, 45, 76, 107, $117-18,121,122,125,127,128$, $137,141,145,146,147,148,150$, $152,157,160,163,168,196,199$, 203, 206, 218, 219, 224, 235, 241, 242, 244, 246-50, 253-80, 281-305, $310,319,321,328,332,334,336$, $345,357,377,392,397,401,402$, 403, 406, 408, 409, 410, 411, 421, 423,427

French $24,38,189,225-30,246,248$, $249,271,315,319,321,323-4,335$, $348,357,361$

Swedish 24, 315, 319

Economic decline - see also 'De-industrialization' 9, 13, 15-6, $17,22-4,26,27,38-41,73,79,81$, $103,137,177,187-88,190,193-215$, 254, 260-1, 262, 267, 281-92, 294, $305,322,424-35$

Economic growth $12,17,20,22,41,53$, 86-7, 89-92, 101, 105, 113, 140, 176, 180, 197, 201, 204, 205, 281, $311,397,401,432$

'Economy of quality' 392

Egypt 1, 4, 44

Ekiti 96,439

Ellore 329

Eltis, David 86

Embeddedness 56

Empires 56, 92, 369, 371-2

Asante 95, 102,

Mughal 18, 175, 176, 180, 186, 189, $196,200,255,259,260-1,408$

Ottoman 6, 326, 361

Vijayanagar 181,199

England 13, 16, 26, 42, 45, 79, 88, 101, $103,105-7,108,168,284,305,320-3$, $329,330,340,345,353,370,384$, 387, 392, 399, 402, 408, 415, 424

English East India Company - see East India Companies, English'

Esteban, J. C 301

Etawah 132

Ethiopia 1,4

Eurasia $4,16,314,317,319,358,368$, 372,373

Europe 6, 9, 10, 12, 13, 14, 15, 16, 17, 20, $24,25,26,27,42,44,47,53,59,86$, 
$88,95,101,105,108,109,113,116$, $17,188,119,148,152,165,167,174$, $187,188,195,200,202,205,213$, $218,219,220,263,265,272,284$, $285,286,287,288,289,292,309-46$, 347-63, 365-89, 391-414, 415, 418, 420, 421, 422, 423, 424, 425

European companies - see 'East India Companies'

'European expansion' 7

Excise 404, 405

Exoticism 312, 335, 338, 339, 371, 381, $395,396-7,402,404$

'Factories' 44, 63, 98, 226, 227, 248, 257, 262-76, 295, 315, 321, 324, 330, 337

Fage, John 85, 86

Famine $80-1,125,177,185,190,200$, $221,263,432$

Farmers 45, 120, 179, 184, 233, 241, 268

Farming 176, 179, 184, 233

Farnie, Douglas 312

Fashion 12, 24, 25-6, 27, 57, 72, 144, 218-19, 281, 344, 350, 365-89, 391, 393, 402-12, 414, 429

Fashionability 17, 25, 337, 356

Finishing 209

Finn, Margot 376, 381

Firearms 102, 103, 104

Fisher, Samuel Roland 409

Fisher, Stanley 418, 422

Flying shuttle 190, 284, 398

Foodstuff

prices of $417,298,302$

supplies of $22,111,124,183,184-9$, $191,267,292-5$

preparation of 395

trade of $1,5,21,162,163,179,317$

Formosa 317

Fortune, Brandon Brame 377

Foundling Hospital 403

Franklin, Benjamin 377

Fujian Province 120

Furber, Holden 7

Furniture 384

Fustians 334, 344-5, 401, 438

Gamitto, A. C. P. 82,83

Ganges valley 348

Gao 92

Gas lighting 394

Gender 367, 206, 208, 371-81, 313-14, 336,339

Genoa 341
Germany 213, 324

Ghana 93, 100

Gifts 4, 70, 182, 227, 319, 346, 381, 383,440

Gittinger, Mattiebelle 369

Glass 4, 26, 161, 391

Global trade 26, 166-7, 168, 365-89, 391-6

Globalization 9, 84

Gloucestershire 384

Goa 315, 325, 369

Godaveri 184

Golconda 188, 200, 335, 437

Gold Coast 93-108, 113

Gowns 46, 372, 373, 378, 379-81, 385, $387-9,403,407$

Grains 21, 124, 161, 163, 167, 181, 185, 187, 188, 189, 270, 293, 318, 416-421

Great divergence 9, 13, 15-17, 25, 27, $347,393,398$

Guangdong province 117, 120, 159

Guha, Sumit 176-77

Guinea cloth 206, 265, 320, 332, 333,438

Guinea coast 92, 94, 438, 441

Gujarat 1, 5, 6, 20, 33, 35, 36, 55-84, $118,120,124,128,132,135,177$, $179,195,196,217,219,254-80,285$, $294,324,334,335,336,348,350$, 438,440

Gum 10, 278, 350, 356

Gumashtas 228-30, 240, 243, 245, 247, 248, 295

Gunder Frank, Andre 14

Gunn, Edward 379

Gunpowder 111

Gupta, Bishnupriya 16, 24, 281-305, 418-422

Gurras 332

Guy, John 317

Habib, Irfan 174, 176, 284

Hamilton, Alexander 324

Handicraft 23, 59, 82, 83, 87, 196-8, 213-4, 215

Handkerchiefs 385, 389, 403, 405, 438

Handloom 199, 201, 205, 215, 251, 404, $424,432,433$

Handloom cloth 205, 404

Hand-spinning - see 'spinning'

Hangings 369, 402, 403

Hanson, J. R. 166

Hardwoods 179 
Hargreaves, James 406

Haripal 226-39

Harley, Knick 301, 400

Hausaland 95, 108

Havell, E. B. 432-5

Headdresses 403

Heston, Alan 419

Heyd, Wilhelm 8

Historians $7,8,19,22,67,83,194$, $198,309,314,393,394,398$, 399,415

economic 85, 91, 116, 311, 367, 391, 394,400

nationalist 174

Historiography $7,22,23,27,139,163$, $178,194,197-9,205-6,280,327$

Hogarth, William 377

Holker, John 401

Hollands 403

Hong Kong 139, 143

Hong merchants - see 'Merchants, Hong'

Hossain, H. 286, 291-2, 298-9

Huet, J. B. 410

Hugli 348, 439

Hunt, Phillip 400

Hyder Ali 185, 188, 189

Hyderabad 189

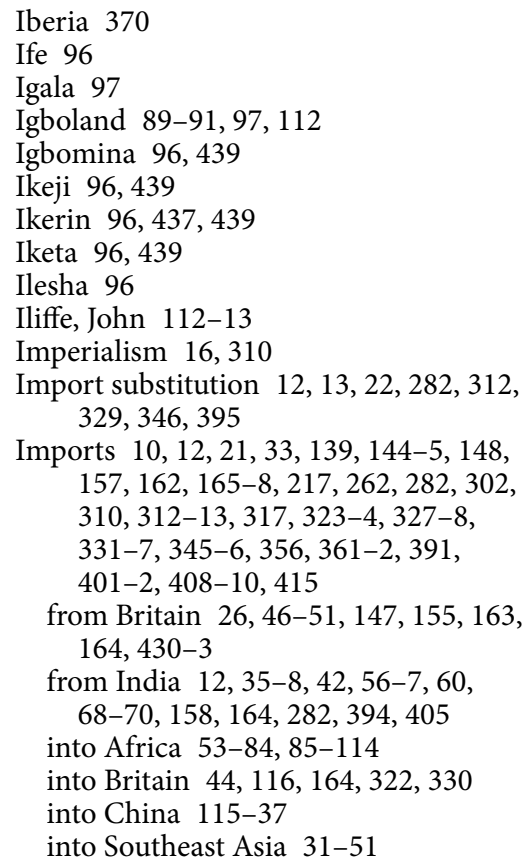

India

and Britain 13, 42, 149, 152, 177, 281-305, 416-21

wage comparisons $416-17$

and the world economy $1,22-3$, 173,193

colonial rule in $18,23,118,176,191$, 193, 196, 199, 201, 203, 254, 281, 325,434

decline of 13,15-17, 22, 24, 26-7, 177, 187-8, 190, 193-201, 260-1, 262, 181-305, 424-8, 432-5

population of $37,176-7,195,425,432$, 435

productivity in $43,193,206,284,310$, 422,423

standards of living in 26, 202, 214, 415-22

'Indian apprenticeship' 25, 309, 324, 341

Indian cotton textiles - see 'Cotton textiles, in India'

Indian subcontinent - see 'India'

Indiennes 361

Indigo $10,59,68,72,152,259,271,325$, $350-1,438,441$

Indonesia $1,8,12,36,40,45,121,198$, $217,218,357,437$

Industrial Revolution 18, 87-8, 168, $175,190,281,282,299,305,309$, $311,312,344,391,393-4,396,398$

Industrialization $9,12,13,16-8,24,26$, $27,87,140,175,193,194,197,198$, $213,214-5,311,312,314,327,365$, $392-4,398-401,414$

Ingeram $427-8$

Inikori, Joseph 12, 20, 85-114, 312-13

Inventions 16, 26, 44, 284, 396-407

Iron $43,89,91,96,97,101-3,110,161$, $179,181,350,351,392$

Irrigation 181,188

Istanbul 326

Italy 393

Ivory $10,57,63,66,77,78,100$

Ivory Coast 92, 99, 101, 108, 440

Iyagba 96

Jajmani 178

Jakarta - see 'Batavia'

Jambusar 57, 62, 72-7, 79-81

Japan $1,8,139,160,173,197,198,202$, $313,317,320,358,373$

Java $31,33,35,40,41,45-50,143,148$, $151-60,165,315$

Jenne 92,95 
Jennings, Lawrence 86

Jenny - see 'Spinning jenny'

Jiangnan 117, 439

Johor 39

Jones, Eric 17

Jouy 406,410

Junkceylon - see 'Phuket'

Kachchh 80, 83

Kalik cloth 410

Kanem-Borno 93

Kasimbazar 227, 348, 441

Kathiawar 55, 71, 79, 135

Kaveri 184, 185, 188, 189

Kay, Robert 400

Kerimba archipelago 60

Keta 109

Khandesh 348, 350

Khorah 132

Kilwa 60

King, Gregory 329

Kinship 174, 180

Klein, Herbert 86

Knowledge 15, 17, 24, 25, 27, 65, 66, $77,81,115,131,156,222,310$, $311,319,326,327,346,347,348$, $349,360,361,362,363,396$

Kola nuts 95, 100

Korea 35, 139, 397

Kraan, Alphons van der 40, 48

Kriedte, Peter 113

Kumar Bagchi, Amiya 425

Kumar, Dharma 204

Kumasi 100

Laarhoven, Ruurdje 35, 36, 38, 40

Labour 14, 16, 23, 26, 40, 44, 46, 59, $60,72,97,102,103,112,129,177$, $183,186,197,202,206,208-9$, $210,211,212-14,215,221,233$, $237,254,257,262,273,276,282-5$, $300,303-5,310,359,375,381$, $382,393,394,399,404,408,410$, 417,420

mobility of $102,202,383$

division of $14,95,100,269$, 394, 396

Lake Chad 93

Lakhipore 302

Lambadis $181,184,188$

Land $55,88,97,100,179,180,181,182$, $187,189,212,226,314$

Landes, David 17, 399

Laos 37
Lawns 344

Le Havre 357

Leather 95

Lemire, Beverly $12,25,365-89,402-3$

Levant 352, 353, 361, 363, 402, 404

Lin Ken Wong 35, 47, 48, 156, 157

Linebaugh, Peter 419

Lisbon 315,319

Locke, John 377

London $21,46,118,119,120,122,125$, $126,128,152-4,300,319,329,330$, $336,337,341,344,345,372,379$, $380,385,401,402,406,407$, 409-10, 411-12

Longcloth 286, 289-91, 332, 428-9, 439

Looms $1,57,175,183,186,196,198$, 204, 211, 212, 219, 228, 231-3, 237-8, 239-40, 243-6, 250-1, 257, $258,259,269-70,273,276,277-9$, $284,286,408,417,422,424,426-7$, $432-3,434-5$

back-strap $33,40-1$

hand 23, 193, 197, 198, 199, 201, 205, 214, 215, 224, 404, 432, 433

Persian 175

power 193, 197, 214

purification of 183

wooden 33,41

Lorient 319, 410, 411

Lumber 392

Luxury 4, 26, 86, 217, 219, 320, 367, 391-414

Luzon 31

Macao 317

Macartney, George, Earl 124

Machado, Pedro 53-84

MacLeod, Christine 396

Madras 10, 11, 35, 41, 118, 120, 123, 126, $127,143,151-6,159,161,163-5$, $185,187,189,204,213,285,288$, $294,328,408,425,430,432$

Madurai 213, 432

Maharashtra 177

Maharatta war 408

Malabar Coast 134, 151-4, 181, 269, 315, 358

Malacca - see 'Melaka'

Malay (traders) 45, 47, 48

Malda 220, 221, 225, 227, 441

malmal 220, 238, 291, 298, 334, 439

Manchester 406, 409, 411, 427 
Mandvi 80, 83

Mangalore 189

Manila 10, 35, 121, 152-7, 318

Mantran, Robert 326

Maratha Confederacy 129, 188

Marathas 73, 189, 196, 260, 261, 263, 267-8

Marchands-merciers 397

Marseilles 341, 351-2, 354, 360, 361

Marx, Karl 188, 424

Marxism 175

Masekesa (Manyika) $66,68,70$

Masulipatam 39, 187, 427

Material culture $367,371,377,381,389$

Mechanization 112, 213, 305, 310, 327, 391, 393, 398-401, 412

Mediterranean 8, 55, 93, 217, 353, 368,370

Melaka 1, 4, 10, 33, 35, 39, 48, 121, 148, $153-7,315,357$

Mercantile networks - see 'commercial networks'

Mercantilism 141

Merchants

American 41, 82, 126, 139, 148, 149, 152,412

Armenians 249, 300, 359-61, 373, 375

Asante 100

Asian 21, 79, 80, 84, 141, 161, 168, $220,286,293,299,300$

Bengali 6

Bhātiyā 80,83

Chinese 34, 40, 125, 131, 174, 359, 397

Chulia 39, 44, 50

Communities of 125, 130, 137, 194, 311

Gujarati 4, 6, 39, 53-84, 121, 315, 318

Gujarati Vāniyā 53-84

Hindu 56, 182, 261, 269, 373

Hong 124, 130

Komati 183

Mahajan 176

Marrakayar 182

Portuguese $4,24,39,59,62-7,76$, $79-82,95,98,99,121,184,267$, $269,270,271,272,275,276,278$, $311,315-19,324,335,359-60$

Spanish 359-60

Mermolano 334, 439

Metal goods 5, 26, 31, 97, 99, 102, 104, $161,173,391$

Mexico 173

Mirasidars 187

Mirzapur 132
Mitra, D. B 286, 299

Mizushima, Tsukasa 185, 187

Mogadishu 60

Mokyr, Joel 394, 398, 401

Moliere 376

Monetary payments 174,420

Monopolies 20, 38, 41, 42-3, 45, 49, 64, $119,147,190,199,201,204,261,268$, $269,282-3,286,297,313,315,324$

Mordants 33, 206, 347-63, 437

Morse, Hosea Ballou 127, 144, 150, 160

Mozambique 20,62-84, 318

Mudenge, S. I. 69

Mughal Empire 18, 175, 176, 180, 186, $189,196,200,255,259,260-61,408$

Mukerji, Chandra 366-67

Mukund, Kanakalatha 201, 291-93, 297

Mule (for spinning) 44, 398, 399, 400, 405,406

Mulhouse 341, 343, 408, 409

'Muslin wheel' 406

Muslins 26, 219-20, 235, 241, 281, 286, $287,301,323,401,403,404-12$, 420,441

Mysore 185, 189-90, 196

Nankeen cloth 117, 439

Nantes 411

Nanyang, The 121

Napoleonic wars 399, 412

Natural resources $17,93,94-5$

Neckcloth 403

Neelapilly 427

Nef, John U. 392

Negapatnam 1, 348

Networks - see 'Commercial networks'

Newton, Isaac 377

Niani 92

Niger River 90, 92-3, 95, 97, 108

Nigeria 89, 91-8, 101-113

Normandy 410

North America 323, 412, 398, 400, 407

North Arcot 432

North Sea 370

Nottinghamshire 392, 406

Novelties 402, 406, 411-12

Nri 89, 91

Nsenga Chewa 69

Nsukka Igbo 91

Nupe 92, 96-7, 99, 108

Oba 96, 99

Oberkampf, Christiphe-Philippe 406, 408, 409-11, 414 
O’Brien, Patrick K. 400

Okeluse 96

Oldknow, Samuel 393, 405-7, 411, 414

Opium 21, 118, 126, 139, 140, 145-51, $152,155,160-2,165$

Orissa 348

Ottoman Empire 6, 326, 361

Outwork 404

Overdresses 403

Owo 96

Oyo 96

Pagoda (coin) 180, 212

Palampores 337, 339, 403, 440

Pannikar, K. M. 174-75

Pano comprido 323

Parsis 125, 134, 225, 257, 261, 263, 264, 269

Parthasarathi, Prasannan 18, 26, 190, 202, 254, 289, 290, 293, 294, 295, $394,398,408,414,415-35$

Patamares 65, 67

Patents 396, 404-5

Patna 295

Pax Britannica 190

Peel, Robert 393, 406, 408-14

Pegu 1, 6, 33, 39, 152-5, 220, 221

Penang 44-50, 143-4, 152-7

Peons 228, 247, 274-9, 420

Pepper 5, 34, 36, 38, 41, 43, 100-1, 120, 161,162

Pepys, Elizabeth 387

Pepys, Samuel 375-7, 387

Percalcos 318, 440

Persia 4, 6, 44, 159, 220, 221, 261, 326, 358

Persian Gulf 59, 152-55, 427

Persian loom 175

Persian wheel 175

Petticoats 389, 403

Phuket $49-50$

Picardy 410

Pillai, Ananda Ranga 189

Pirenne, Henri 8

Pires, Tomé 4, 33-4, 315

Pitt, William the Younger 126, 409

Plassey 18, 218, 224-25

Political power 21, 190, 241, 253, 294, 297-8, 416

Pomeranz, Kenneth 16-17

Pondicherry 323, 349

Poni, Carlo 393

Population 89-91, 92, 93, 97, 100, 112, $116,163,165,176-7,368,424-5$, 432-5
Porcelain 4, 5, 341, 397, 401

Port cities 115, 117, 118, 348, 353, 358

Portugal 315, 316, 370

Prakash Sangar, Satya 332

Prakash, Om 16, 23, 174, 177, 217-51, 325

Prices 22, 24, 34, 36, 38, 40, 44, 55, 74, $106-7,124,129,184,185,224,226$, $228,229,240,249,270,273,276$, 282, 283, 286, 289-92, 294, 295, 297, 298, 300-5, 323, 329, 336, 337, 344-6, 358, 385, 394, 395, 399, $408,410,412,415,417,419$

Private trade $6,44,64,119,120,122,128$, $139,141,145-7,148,152-4,229$, $230,246,260,265,272,286,292$, $297,299,300,408,440$

Product innovation 391-5, 401, 402, 414

Production

artisanal 77, 86, 176, 254, 268

specialisation of $96,101,213,219$, $257,285,331$

Productivity $33,43,55,193,206,283-4$, $300,304-5,310,391,392,394,397$, $398,400,412,417,418,422,423$

Prohibitions 345, 362, 405, 409

Napoleonic 410

Property rights 181

Proto-industrialization $20,87,88,91$, $100,105,108,112-14$

Pulicat 200, 348

Punjab 59, 71, 285

Putting-out system 99, 112, 221

Quality $12,17,24,25,26,33,66,72$, $91,124,129,134,136,220,224,226$, 231-43, 246, 247, 248, 249, 266, $269,271,287,292-7,298-9,227$, 232-44, 363, 365, 391-414, 415, 416, $427,428,429,435$

Quelimane 63,78

Quilts 134, 337, 384, 385, 402, 403

Ragi 185

Railway transport 114, 211

Rajahmundry 426-7

Rajput clans 176

Rajputana 348, 350

Ramaswamy, Vijaya 181-2, 199

Ray, Aniruddha 73

Raychaudhuri, Tapan 7, 200, 202

Real wages 399

Red (colour) 46, 257, 259, 265, 266, 268, $269,277,337,340,342,350$ 
Red (colouring agent) 351, 354-63

Red Sea 59, 217, 368

Reid, Anthony 19-20, 31-51, 140

Revenue 24, 73, 174, 175, 178, 180, 186, 199, 203, 260, 261, 267, 282, 303

Ricardo, David 85

Rice 5, 6, 31, 125, 162, 180, 181, 183, $184-5,187-8,263,302,417-18$, 421

Richards, John 176

Riello, Giorgio 1-27, 309-46

Rochefaucauld, Frencois de 441

Romalls 332, 333, 440

Rome 353, 370, 378

Roques, Georges 348-63

Rostow, W. W. 311

Rothstein, Natalie 340

Rouen 351, 352, 354, 360, 361

Rousseau, Jean-Jacques 378

Rowland Fisher, Samuel 409

Roy, Tirthankar 1-27, 425, 433

Royal African Company 104, 108

Rozvi empire 68

Rupee 174, 180

Russia 326

Ryder, A. F. C. 99

Salampores 206, 289, 291, 318, 324, 334,440

Salem 432

'Salem Blues' 185

Samuelson, Paul 418, 422

Sandalwood 5, 31, 120

São Jorge da Mina 318

Sappanwood 356-60

Sarja 318, 334, 440

Satins $318,334,440$

Savannah $89,92-7,104,113$

Scandinavia 326, 337

Schwartz, Paul R. 350-1

Scotland 392

Segu 93

Semarang (Java) 46

Semians $318,321,441$

Sena $61,63,65,66$

Senegal River valley 92

Senegambia 89,100

Shire Valley $69-70$

Shirts 328-9, 385, 403

Shona 69

Shuttle - see 'Flying shuttle'

Siam - see also 'Ayutthaya' 33, 39, 45, $47,48,50,51,144,156,157,158$, 160,357
Siamoises 361

Silk 1, 5, 10, 50, 58, 69, 108, 124, 150, $152,161,167,179,207,218$, 219-20, 231-8, 240-2, 258, 269, 273, 277-8, 281, 287, 315, 318, 320, $325,332,334,337-8,347,351,356$, $367,371,373,377,380,387,393$, $401-5,415$

raw $120,161,162,167,211,217,219$, 241,296

Silver coinage - see 'Coinage, silver'

Silver wages - see 'Wages'

Silversmiths 397

Sind $59,153,154$

Singapore $35,42,46-51,143,144,148$, $151-62,164-5$

Singleton Copley, John 377

Sironji 348, 350

Six, Jan 376

Slave trade $77-83,85-114,438$, 440,441

Slaves $1,20,57,78,80,318,372$

Smallpox 394

Smith, Adam 177

Smuggling 323, 405

Sofala $60,69,70,438$

South India 22, 33, 118, 173-91, 193-215, 254, 408, 415-35, 438, 439, 440

South Sulawesi 31, 40

Southeast Asia 4, 10, 12, 19, 21, 31-51, $55,140,141,142,144,148,152-161$, 164-5, 168, 198, 205, 206, 217, 218, $315,317,318,321,323,330,358,359$, $369,370,438$

Southern Lunda 69

Souza, George 25, 347-63

Specker, Konrad 204, 425, 425-6, 434

Spices $1,5,6,19,31,36,161,173,181$, $315,317,320,321$

Spinners 75, 116, 179, 193, 194, 205, 206, 208-11, 212, 214, 215, 231, $236,259,263,322,416,422,435$

Spinning wheel $40,406,422,438$

Persian 175

Muslim 406

Spinning jenny 398

Stagnation 175, 194, 197, 199, 201, 202

Stalpaert, Augustijn 36

Standards of living 202, 414-17, 422

Stein, Burton 180

Styles, John 337, 402-3

Subramaniam, Lakshmi 23, 253-80, 281 
Subsistence 51, 111, 178, 179, 187, 236, 249

Sugar 5, 41, 43, 120, 161, 162, 259

Sugihara, Kaoru 21-2, 139-70

Sulawesi (Celebes) - see also 'South Sulawesi' $37,40,46,47,48,156$, $157,160,165,217$

Sultan of Bima 359

Sumatra $33,34,37,40,41,47,48$, $152-60,427$

Sumbawa $31,357,358,359$

Surat $24,36,39,56,71,76,77,79,118$, $119,120,121,124,127,129,133$, $135,221,240,253-80,284,285$, 295, 297, 321, 348, 357, 358

Swarnalatha, Potkuchi 203

Syria 4

Taffetas 334, 379, 440, 441

Taiwan 397

'Take off' 17, 328

Tamil (merchants) 201

Tanjore 432

Taxation 43, 118, 176, 178, 180, 194, $198,204,214,260,267,415$

Taylor, Brook 387-8

Tea trade $21,118-19,120,122-3,125-6$, $137,139,150,162,167$

Technological invention 16, 109, 194, 198, 282, 299, 300, 310, 346, 349, $360,391-94,398,405,423$

Technology 17, 24, 25, 42, 86, 89, 169, $202,282,283,284,310,347,362$, 391, 393-4, 397, 398-401, 404-13

Tegenapatam 348

Telugu farmers 183-4

Tennasserim (Siam) 37

Tete 64

Textiles

as currency $10,56-7,64,317,383$ weight of $370,393,440$

Textile consumption - see 'Consumer Demand'

Textile manufacturing - see 'Cotton industry' and 'Cotton textiles'

Textile procurement $23-4,57,61,70-1$ $74-6,80,200,218-33,239-41$, 246-50, 256, 257, 265-80, 283, 293-7, 300-5

Textile trade - see 'Trade'

Thanjavur 188

Thread 40, 59, 117, 184, 190, 191, 211, 213-14, 219, 220, 233, 234, 236, 259, 268, 293, 295-6, 334, 335, 419
Thread count 206, 293

Timbuktu 92

Tipu Sultan 185, 189-90

Tiruchirapalle 188

Tobacco 43, 184

Tolfa 353

Tomatoes 184

Trade

Dutch - see also 'East India Companies, Dutch' 148, 287, 381

English - see also 'East India Companies, English' 44, 79, 99, $101,119,134,141,148,177,228$, 241, 249-50, 287

intra-Asian 5, 7, 16, 21, 37, 44, 115-38, 139-69, 250, 300, 314, 317, $324,353,357-60$

land 1, 4, 145, 152-5, 167, 319, 326

Portuguese $4,16,24,39,53-84,98$, $99,121,184,267,269,270,271-6$, 278, 311, 315-19, 359

Traders - see 'Merchants'

Tranquebar 348

Transportation 93, 134, 136, 179, $181,184,187,208,211,213-14$, 285,423

Travancore 189

Trichinopoly 432

Tudor Book of Rates 371

Turan 326

Turkey 326

Underemployment 203, 417

Unemployment 417

United Kingdom 48, 150, 344

United States 44

Urbanisation $83,214-15$

van Leur, J. C. 7, 13

Van Linschoten, Jan Huygen 1, 318

Van Zanden, Jan Luiten 302

Vāniyā - see 'Merchants, Gujarati Vāniyā'

Vashambadzi 65, 67, 68

Velvet 440

Velveteens 406

Verelst, Harry 225, 227, 229, 230

Verenigde Oost-Indische Compagnies see 'East India Companies, Dutch'

Verrio, Antonio 377

Vicziany, Marika 425

Vietnam 31, 48, 50

Vijayanagar Empire 181, 199

'Village community' 187 
Villages 178-9, 186, 187, 189, 217, 231,410

weaving $74,182,231-33,240,250$, 260,426

Virginia 378, 379

Virtuosi - see 'Banyan'

Vizagapatnam District 427, 429

VOC - see 'East India Companies, Dutch'

Volta rivers 106-9

Voltaire 377

Von Tunzelmann, Nicholas 399-400

Wages $26,87,112,113,186,190,198$, 284, 346, 399

in Britain 283, 408, 416-22

in India $26,189,190,198,206,214$, 231, 232, 234, 236-7, 249, 283, 284, 408, 416-22

Wallerstein, Immanuel 15

Wallick, Dr Nathaniel 136

Warfare $39,103,111,139,148,412$ in India $129,188,289,406$

Warping 209, 211-14

Washbrook, David 22, 173-191

Washing 205, 209, 211, 354, 387

Watelet, Claude Henri 378

Weavers - see 'Weaving'

Weaving 26, 42, 59, 112, 134, 182, 187, 190, 194, 197, 204-15, 231, 254, $257,259,269,393,404,405,414$, $416,424,428-9$

as a household activity $33,40,83$, 204-15, 257

centres of - see also 'Villages' 19, 31, $71,74-5,182,185,188,224,231$, $285,358,426$ decline of $204-5,427,432-5$

industry $60,72,96,183-5,191$

Weiner, Annette 383

Wellesley, Richard Colley, Marquis 132-33

Wenderborn, F. A. 411

Wendt, Ian 22-23, 193-215, 393

West Africa 1, 10, 15, 17, 20, 53-84, $85-114,318,320,420,438,439$, 440

Wheel - see 'Spinning wheel'

Wholesale 73, 358, 409

Women 60, 206, 267, 376, 381, 383-6, 389,403

in the household 40, 211, 214-15, 429-30

labour 33, 96, 205, 207, 211, 236, 259, $269,285,429,433-4$

Wool 351, 357, 387, 415

Woollens 45, 51, 108, 282, 334, 344, 356,402

'World product' 395

Yarn $23,26,44,74,91,117,137,162$, $184,188,213,219,220,227,231,233$, $234,236,237,249,257,263,267,275$, 276, 280, 293-4, 296, 297, 299, 300, $303,305,393,400,402,404-6,408$, $416-23,428,429-34$

Yoruba 90, 92, 96, 99, 100, 108, 112

Yunnan 31

Zambesi Valley $60,61,66,69,70,78,82$, 437, 439, 440, 441

Zanzibar 68

Zemindars 176

Zimbabwe 69 